\title{
Copper-Catalyzed Propargylation of Nitroalkanes
}

Raphael S. Kim, Linh V. Dinh-Nguyen, Kirk W. Shimkin, and Donald A. Watson

Department of Chemistry and Biochemistry, University of Delaware,

Newark, Delaware, 19716, United States

\section{Supporting Information}

Index

Page

1. General Experimental Details

S2

2. Instrumentation and Chromatography

S2

3. Additional Optimization Details

4. Synthesis and Structure Elucidation of the Allene Byproduct $\mathbf{5 b}$

5. Preparation of Diamine Ligands

6. Preparation of Propargyl Bromides

7. Preparation of Starting Nitroalkanes

8. Synthesis of Homopropargylic Nitroalkanes via Cu-catalysis

9. Downstream Functionalization of Homopropargylic Nitroalkanes to Pyrroles

10. Downstream Functionalization of Homopropargylic Nitroalkanes to 2-Pyrrolines

11. References

12. Spectroscopic Data 


\section{General Experimental Details}

Diethyl ether $\left(\mathrm{Et}_{2} \mathrm{O}\right)$, dichloromethane (DCM), 1,4-dioxane (dioxane), toluene (PhMe), methyl tertbutyl ether (MTBE), and tetrahydrofuran (THF) were dried on alumina according to a published procedure. ${ }^{1}$ Copper bromide $(\mathrm{CuBr})$ and potassium tert-butoxide $\left(\mathrm{KO} \mathrm{B}^{t} \mathrm{Bu}\right)$ were purchased commercially and stored in a $\mathrm{N}_{2}$-filled glovebox. $N, N$-diisopropylethylenediamine was purchased commercially, distilled, and de-gassed with $\mathrm{N}_{2}$ for 15 mins prior to storing in a $\mathrm{N}_{2}$-filled glovebox. $N$-((2Z,4E)-4-((2,6-dimethylphenyl)imino)pent-2-en-2-yl)-2,6-dimethylaniline, ${ }^{2} \quad(1 R, 2 R)-N^{1}, N^{2}-$ dibenzyl cyclohexane-1,2-diamine, ${ }^{3}$ (+/-)- $N^{1}, N^{2}$-bis(3,5-bis(trifluoromethyl)benzyl)cyclohexane1,2-diamine, ${ }^{3} \quad(1 R, 2 R)-N^{1}, N^{2}$-bis(3,5-dimethylbenzyl)cyclohexane-1,2-diamine, ${ }^{3} \quad(+/-)-N^{1}, N^{2}-$ bis(4-methoxybenzyl)cyclohexane-1,2-diamine, ${ }^{3} N^{1}, N^{2}$-dibenzhydrylethane-1,2-diimide, ${ }^{4}$ Ethyl 4nitrobutanoate, ${ }^{5} 6$-nitrohex-1-ene ${ }^{5} 4$-nitrobutanenitrile, ${ }^{5}$-iodophenyl acetate, ${ }^{6} 3$-methyl-1-(prop2-yn-1-yl)-1H-indole, ${ }^{7,8}$ (((5-bromopent-3-yn-1-yl)oxy)methyl)benzene, ${ }^{9}$ 3-(4-nitrophenyl)prop-2yn-1-ol, ${ }^{10} \quad$ 1-(3-bromoprop-1-yn-1-yl)4-nitrobenzene, ${ }^{11} \quad$ 4-chlorobutanal, ${ }^{12} \quad \mathrm{~N}$-benzylidene-4methylbenzene-sulfonamide, ${ }^{13,14}$ were synthesized according to the published procedures. All other reagents and chemicals were purchased from commercial suppliers at reagent grade or higher purity (typically $>95 \%$ ) and used as received. All liquid chemicals used in the glovebox were de-gassed with $\mathrm{N}_{2}$ for 15 mins. All anhydrous glassware was either oven-dried for a minimum of $2 \mathrm{~h}$ at $150^{\circ} \mathrm{C}$, and then cooled to room temperature under vacuum or flame-dried under vacuum prior to use. All glassware used in the glovebox was oven-dried for a minimum of $1 \mathrm{~d}$, and then cooled to rt under vacuum in the glovebox antechamber. Reaction optimization was performed on a $250 \mu \mathrm{mol}$ scale in 1-dram vials with Teflon lined caps, then sealed with vinyl tape, and heated in temperature-controlled silicone oil bath (as appropriate) with stirring. All yields determined by ${ }^{1} \mathrm{H}$ NMR analysis were obtained using 1,3,5-trimethoxybenzene as the internal standard. All other reactions (or anaerobic reactions, as appropriate) were set up using standard Schlenk technique. "Double manifold" refers to a standard Schlenk-line gas manifold equipped with $\mathrm{N}_{2}$ and vacuum (ca. $0.1 \mathrm{~mm} \mathrm{Hg}$ ). As appropriate, reactions were heated with stirring in temperature-controlled silicone oil baths.

\section{Instrumentation and Chromatography}

$400 \mathrm{MHz}{ }^{1} \mathrm{H}, 101 \mathrm{MHz}{ }^{13} \mathrm{C}$, and $376 \mathrm{MHz}{ }^{19} \mathrm{~F}$ spectra were obtained on a $400 \mathrm{MHz}$ FT-NMR spectrometer equipped with a Bruker CryoPlatform. $600 \mathrm{MHz}{ }^{1} \mathrm{H}, 151 \mathrm{MHz}{ }^{13} \mathrm{C}, 565 \mathrm{MHz}{ }^{19} \mathrm{~F}$, and $119 \mathrm{MHz}{ }^{29} \mathrm{Si}$ spectra were obtained on a $600 \mathrm{MHz}$ FT-NMR spectrometer equipped with a Bruker SMART probe. ${ }^{13} \mathrm{C}$ NMR spectra were recorded using Attached Proton Test (ATP) phase pulse sequence; carbons with odd number of protons are phased down and those with an even number of protons are phased up. All samples were analyzed in the indicated deutero-solvent and were recorded at ambient temperatures. ${ }^{1} \mathrm{H}$ NMR spectra were calibrated using the residual protiosignal in the deutero-solvents as standard. ${ }^{13} \mathrm{C}$ NMR spectra were calibrated using the deuterosolvent as a standard. Chemical shifts are reported in parts per million (ppm). IR spectra were recorded on a Nicolet Magma-IR 560 FT-IR spectrometer as thin films on a $\mathrm{KBr}$ plate. High resolution MS data was obtained on a Waters GCT Premier spectrometer using electron ionization (EI), or liquid injection field desorption ionization (LIFDI), or on a Thermo Scientific, Q Exactive Model Orbitrap instrument using electrospray ionization (ESI). Optical rotations were recorded on a JASCO P-2000 polarimeter. Unless otherwise noted, column chromatography was 
performed with 40-63 $\mu \mathrm{m}$ silica gel with the eluent reported in parenthesis. Analytical thin-layer chromatography (TLC) was performed on precoated glass plates and visualized by ultraviolet light (UV) or by staining with potassium permanganate $\left(\mathrm{KMnO}_{4}\right)$.

\section{Additional Optimization Details}

Experimental Procedure for Optimization of Copper-Catalyzed Propargylation Reaction. In a $\mathrm{N}_{2}$-filled glovebox, $\mathrm{CuBr}(0.10-0.22$ equiv), ligand $(0.23-0.30$ equiv), base ( $1.05-1.20$ equiv), and solvent $(0.17 \mathrm{M})$ were added to a 1-dram vial. The vial was capped with a Teflon-line screw cap and stirred at it for 10 mins. Then, nitroalkane (1.0 equiv) was added and the resulting viscous suspension was stirred vigorously at rt for 30 mins, before propargyl bromide (1.15 - 1.25 equiv) was added. The vial was sealed with PVC electrical tape, removed from the glovebox, and stirred at the specified temperature (Note: a pre-heated silicone oil bath was used for temperatures above $r t$ ) for the indicated time. The reaction was cooled to rt, opened to air, diluted with a solution of 1,3,5-trimethoxybenzene ( 0.25 equiv, internal standard) in EtOAc, filtered through a pad of celite, and concentrated in vacuo to afford a crude oil. The crude product was dissolved in $\mathrm{CDCl}_{3}$ and quantified by ${ }^{1} \mathrm{H}$ NMR analysis. The ee of purified material was determined by chiral HPLC analysis.

Table S1: Evaluation of Ligands

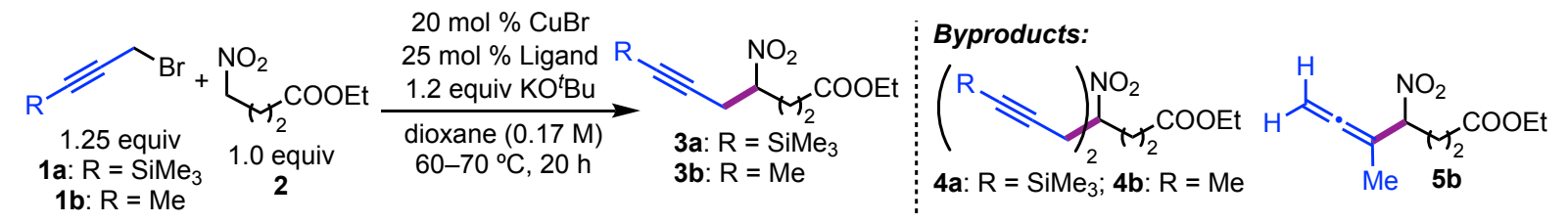<smiles>C/C(=C/C(C)=N/c1c(C)cccc1C)Nc1c(C)cccc1C</smiles>

6

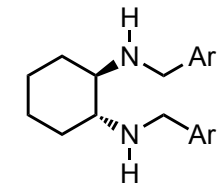

$7, \mathrm{Ar}=\mathrm{C}_{6} \mathrm{H}_{5}$ 8, $\mathrm{Ar}=3,5-\mathrm{CF}_{3}-\mathrm{C}_{6} \mathrm{H}_{3}$ 9, $\mathrm{Ar}=3,5-\mathrm{Me}-\mathrm{C}_{6} \mathrm{H}_{3}$ 9b, $\mathrm{Ar}=4-\mathrm{OMe}-\mathrm{C}_{6} \mathrm{H}_{4}$

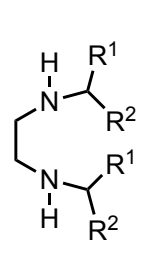

10, $\mathrm{R}^{1}=\mathrm{H}, \mathrm{R}^{2}=\mathrm{Ph}$ $11, R^{1}=M e, R^{2}=P h$ 11b, $R^{1}=M e, R^{2}=C y$ 11c, $R^{1}, R^{2}=P h$ 11d, $R^{1}, R^{2}=\mathrm{CH}_{2} \mathrm{Ph}$ 12, $R^{1}, R^{2}=M e$ 12b, $R^{1}, R^{2}=H$<smiles>c1ccc([C+](c2ccccc2)c2ccccc2)cc1</smiles>

12c, $\mathrm{n}=0$

$12 d, n=2$<smiles>[R]C([R])([R])CNCN(C)C([R])([R])[R]</smiles>

12e, $R^{3}, R^{4}=M e, R^{5}=P h$ 12f, $R^{3}, R^{4}, R^{5}=M e$

\begin{tabular}{|c|c|c|c|c|}
\hline entry & $\mathrm{R}$ & Ligand & Yield of $\mathbf{3} / \mathbf{4} / \mathbf{5}^{\mathrm{e}}$ & $\% \mathrm{ee}^{f}$ \\
\hline $1^{a}$ & $\mathrm{SiMe}_{3}$ & none & $0 \% / 0 \% /-$ & - \\
\hline 2 & $\mathrm{SiMe}_{3}$ & none & $23 \% / 18 \% /-$ & - \\
\hline 3 & $\mathrm{SiMe}_{3}$ & 6 & $34 \% / 6 \% /-$ & - \\
\hline 4 & $\mathrm{SiMe}_{3}$ & 2,2'-bipyridine & $27 \% / 9 \% /-$ & - \\
\hline 5 & $\mathrm{SiMe}_{3}$ & 1,10-phenanthroline & $19 \% / 16 \% /-$ & - \\
\hline 6 & $\mathrm{SiMe}_{3}$ & 2.2':6', 2"-terpyridine & $21 \% / 15 \% /-$ & - \\
\hline 7 & $\mathrm{SiMe}_{3}$ & $7(R, R)$ & $65 \% / 7 \% /-$ & n.d. \\
\hline 8 & $\mathrm{SiMe}_{3}$ & $8(+/-)$ & $60 \% / 7 \% /-$ & - \\
\hline 9 & $\mathrm{SiMe}_{3}$ & $9(\mathrm{R}, \mathrm{R})$ & $65 \% / 8 \% /-$ & $1 \%$ \\
\hline 10 & $\mathrm{SiMe}_{3}$ & $9 b(+/-)$ & $65 \% / 10 \% /-$ & - \\
\hline 11 & $\mathrm{SiMe}_{3}$ & 10 & $73 \% / 3 \% /-$ & - \\
\hline 12 & $\mathrm{SiMe}_{3}$ & $12 c$ & $28 \% / 13 \% /-$ & - \\
\hline 13 & $\mathrm{SiMe}_{3}$ & $12 d$ & $65 \% / 2 \% /-$ & - \\
\hline 14 & $\mathrm{SiMe}_{3}$ & $11(R, R)$ & $74 \% / 3 \% /-$ & $5 \%$ \\
\hline 15 & $\mathrm{SiMe}_{3}$ & $11 \mathrm{c}$ & $47 \% / 14 \% /-$ & - \\
\hline
\end{tabular}




$\begin{array}{ccccc}16^{b} & \mathrm{SiMe}_{3} & \mathbf{1 1}(\mathrm{R}, \mathrm{R}) & 75 \% / 4 \% /- & \text { n.d. } \\ 17^{b, c} & \mathrm{Me} & \mathbf{1 0} & 39 \% / 1 \% / 25 \% & - \\ 18^{b, c} & \mathrm{Me} & \mathbf{1 1}(\mathrm{R}, \mathrm{R}) & 53 \% / 0 \% / 9 \% & 4 \% \\ 19^{b, c} & \mathrm{Me} & \mathbf{1 2 e} & 38 \% / 4 \% / 8 \% & - \\ 20^{b, c} & \mathrm{Me} & \mathbf{1 1} & 35 \% / 0 \% / 18 \% & - \\ 21^{b, c} & \mathrm{Me} & \mathbf{1 1 b}(\mathrm{R}, \mathrm{R}) & 46 \% / 1 \% / 8 \% & \text { n.d. } \\ 22^{b, c} & \mathrm{Me} & \mathbf{1 2} & 54 \% / 3 \% / 4 \% & - \\ 23^{b, c} & \mathrm{Me} & \mathbf{1 2 b} & 20 \% / \mathrm{n} . \mathrm{d} . / 1 \% & - \\ 24^{b, c} & \mathrm{Me} & \mathbf{1 2 f} & 48 \% / 3 \% / 3 \% & - \\ 25^{b, d} & \mathrm{Me} & \mathbf{1 2} & 53 \% / 7 \% / 0 \% & -\end{array}$

${ }^{a}$ No CuBr. ${ }^{b} 4$ h. ${ }^{c} 22 \mathrm{~mol} \% \mathrm{CuBr}, 23 \mathrm{~mol} \%$ Ligand, 1.15 equiv $1,1.05$ equiv $\mathrm{KO}{ }^{t} \mathrm{Bu} .{ }^{d} 10 \mathrm{~mol} \%$ $\mathrm{CuBr}, 30 \mathrm{~mol} \%$ Ligand, 1.15 equiv $1,1.05$ equiv $\mathrm{KO} \mathrm{B}^{t} \mathrm{Bu}$, rt. ${ }^{e}$ Determined by ${ }^{1} \mathrm{H}$ NMR analysis using 1,3,5-trimethoxybenzene as an internal standard. 'D Determined by chiral HPLC analysis.

n.d. $=$ not determined.

Table S2: Evaluation of Bases

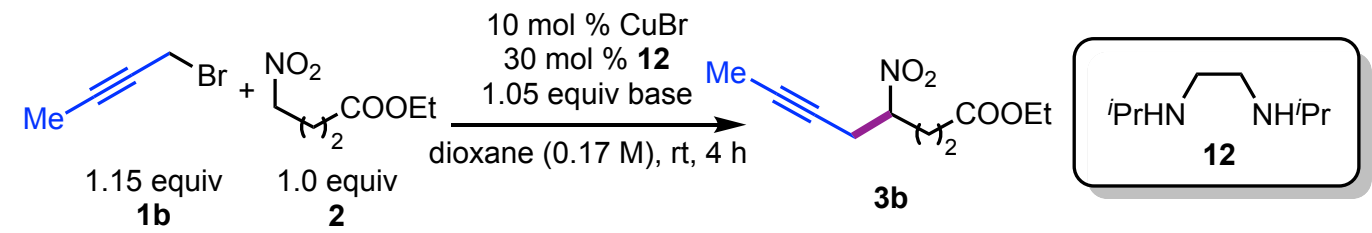

\begin{tabular}{ccc}
\hline entry & Base & Yield of $\mathbf{3 b} / \mathbf{4 b} / \mathbf{5} \mathbf{b}^{\mathbf{a}}$ \\
1 & $\mathrm{KO}^{t} \mathrm{Bu}$ & $53 \% / 7 \% / 0 \%$ \\
2 & $\mathrm{NaO} \mathrm{Bu}$ & $6 \% / 0 \% / 0 \%$ \\
3 & $\mathrm{LiO}^{t} \mathrm{Bu}$ & $6 \% / 0 \% / 0 \%$ \\
4 & $\mathrm{KHMDS}$ & $48 \% / 10 \% / 3 \%$ \\
5 & $\mathrm{KOMe}$ & $33 \% / 14 \% / 1 \%$ \\
6 & $\mathrm{KOTMS}^{t}$ & $20 \% / 4 \% / 0 \%$ \\
7 & $\mathrm{~K}_{2} \mathrm{CO}_{3}$ & $0 \% / 0 \% / 0 \%$ \\
8 & $\mathrm{DBU}$ & $0 \% / 0 \% / 0 \%$
\end{tabular}

${ }^{a}$ Determined by ${ }^{1} \mathrm{H}$ NMR analysis using 1,3,5-trimethoxybenzene as an internal standard.

Table S3: Evaluation of Solvents

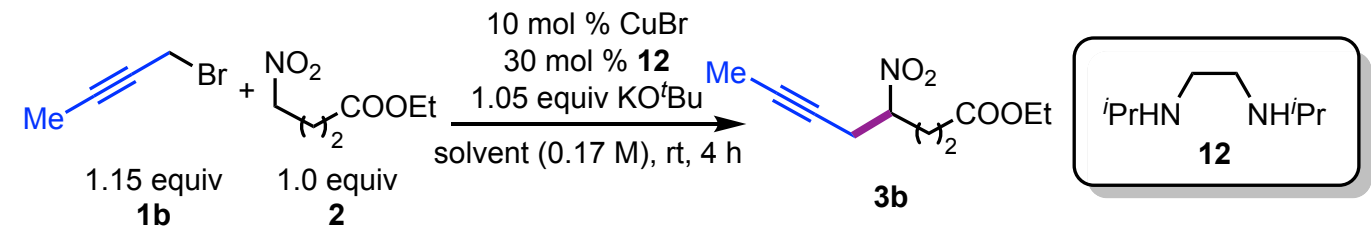

\begin{tabular}{ccc} 
entry & Solvent & Yield of $\mathbf{3 b} / \mathbf{4} \mathbf{b} / \mathbf{5} \mathbf{b}^{\mathbf{a}}$ \\
\hline 1 & dioxane & $53 \% / \mathbf{7} \% / 0 \%$ \\
2 & hexanes & $29 \% / 18 \% / 1 \%$ \\
3 & DCM & $7 \% / 0 \% / 0 \%$ \\
4 & $\mathrm{Et}_{2} \mathrm{O}$ & $34 \% / 10 \% / 2 \%$ \\
5 & $\mathrm{MTBE}$ & $30 \% / 13 \% / 2 \%$ \\
6 & $\mathrm{CPME}$ & $39 \% / 9 \% / 2 \%$ \\
7 & THF & $44 \% / 10 \% / 1 \%$
\end{tabular}

${ }^{a}$ Determined by ${ }^{1} \mathrm{H}$ NMR analysis using 1,3,5-trimethoxybenzene as an internal standard.

\section{Synthesis and Structure Elucidation of the Allene Byproduct $5 b$}



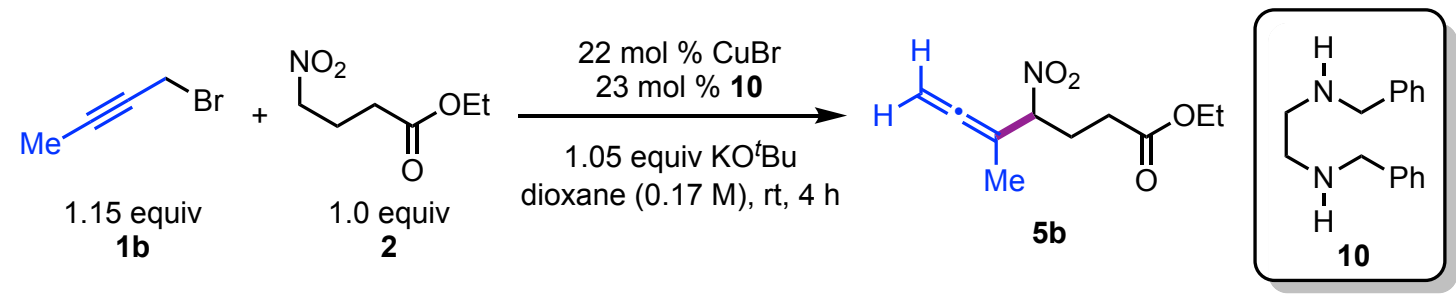

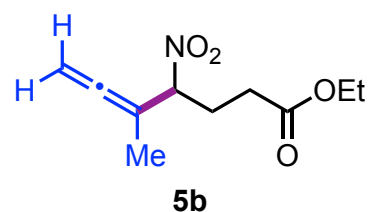

Chemical Formula: $\mathrm{C}_{10} \mathrm{H}_{15} \mathrm{NO}_{4}$ Exact Mass: 213.1001 Molecular Weight: 213.2330 5b: A 1-nk $25 \mathrm{~mL}$ Schlenk flask was fitted with a stir bar and rubber septum, and then the sidearm of the flask was attached to a double manifold using a rubber hose. The flask was evacuated, flame-dried, allowed to cool to rt under vacuum, and then refilled with $\mathrm{N}_{2}$. Under closed $\mathrm{N}_{2}$, the rubber septum was momentarily removed, and $\mathrm{CuBr}$ (31.6 mg, $0.22 \mathrm{mmol}$ ) and $\mathrm{KO}^{t} \mathrm{Bu}(118 \mathrm{mg}, 1.05 \mathrm{mmol})$ were added. The septum was re-fitted, and the atmosphere of the reactor was replaced with $\mathrm{N}_{2}$ via five sequential cycles of evacuation and re-fill. Under positive $\mathrm{N}_{2}$, anhydrous dioxane ( $5 \mathrm{~mL}, 0.2 \mathrm{M}$, with respect to nitroalkane) and $10(55.3 \mathrm{mg}, 0.23 \mathrm{mmol})$ were added sequentially via syringe and allowed to stir vigorously at rt for 10 mins. 2 (161 mg, $1.0 \mathrm{mmol}$ ) was then added via syringe and the viscous suspension was allowed to stir at $r$ for another 30 mins. Lastly, 1b (153 mg, 1.15 equiv) was added via syringe and the reaction mixture was stirred at $\mathrm{rt}$ for $4 \mathrm{~h}$. The $\mathrm{N}_{2}$ line was closed off and the rubber septum was removed. The resulting suspension was diluted with $\mathrm{Et}_{2} \mathrm{O}(5 \mathrm{~mL})$ and quenched by the addition of $\mathrm{NH}_{4} \mathrm{Cl}$ (10 mL, saturated aqueous). The resulting biphasic mixture was rapidly stirred for $5 \mathrm{mins}$, before being poured into a separatory funnel and rinsed with $\mathrm{Et}_{2} \mathrm{O}(3 \times 5 \mathrm{~mL})$. The layers were separated, and the aqueous phase was extracted with $\mathrm{Et}_{2} \mathrm{O}(3 \times 10 \mathrm{~mL})$. The combined organic layers were then washed with brine (15 $\mathrm{mL}$, saturated aqueous), dried over $\mathrm{MgSO}_{4}$, filtered through a fritted funnel, and concentrated in vacuo to afford a crude oil. The crude product was purified by flash silica gel chromatography (80:20 hexanes: $\left.\mathrm{Et}_{2} \mathrm{O}\right)$ to afford $\mathbf{5 b}(68 \mathrm{mg}, 32 \%)$ as yellow oil.

${ }^{1} \mathrm{H}$ NMR (400 MHz, $\left.\mathrm{CDCl}_{3}\right) \delta 4.92-5.00(\mathrm{~m}, 3 \mathrm{H}), 4.15(\mathrm{q}, J=7.1 \mathrm{~Hz}, 2 \mathrm{H}), 2.31-2.46(\mathrm{~m}, 3 \mathrm{H})$, $2.16-2.31(\mathrm{~m}, 1 \mathrm{H}), 1.78(\mathrm{t}, J=3.0 \mathrm{~Hz}, 3 \mathrm{H}), 1.26(\mathrm{t}, J=7.2 \mathrm{~Hz}, 3 \mathrm{H})$.

${ }^{13} \mathrm{C}$ NMR $\left(101 \mathrm{MHz}, \mathrm{CDCl}_{3}\right) \delta 208.1,172.0,95.2,89.1,78.3,61.0,30.3,26.6,15.7,14.3$.

FTIR $\left(\mathrm{cm}^{-1}\right)$ 2985, 2941, 1958, 1735, 1553, 1376, 1186, 1023, 861.

HRMS (ESI) m/z, calcd for $\left[\mathrm{C}_{10} \mathrm{H}_{16} \mathrm{NO}_{4}\right]^{+}:$214.1079; found: 214.1075 .

Note: Shown below are additional 2D NMR experiments (COSY, HMQC, HMBC) that were conducted to elucidate the structure of $5 b$. For $1 D$ NMR experiments $\left({ }^{1} \mathrm{H}\right.$ and $\left.{ }^{13} \mathrm{C}\right)$, please refer to section 12 (Spectroscopic Data) of this Supporting Information. 


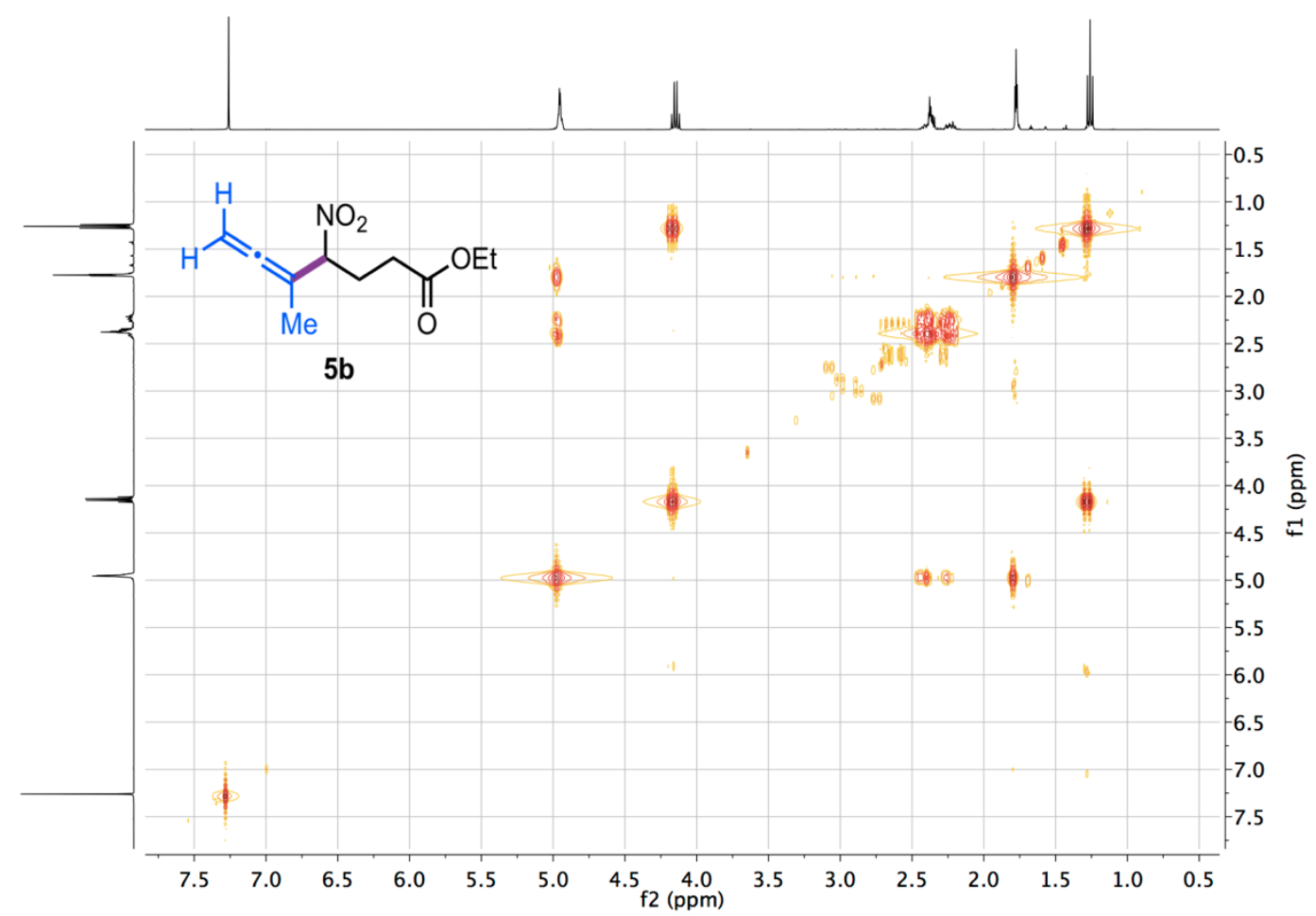

Figure S1. ${ }^{1} \mathrm{H}-{ }^{1} \mathrm{H}$ Correlation Spectroscopy (COSY) of $5 b$

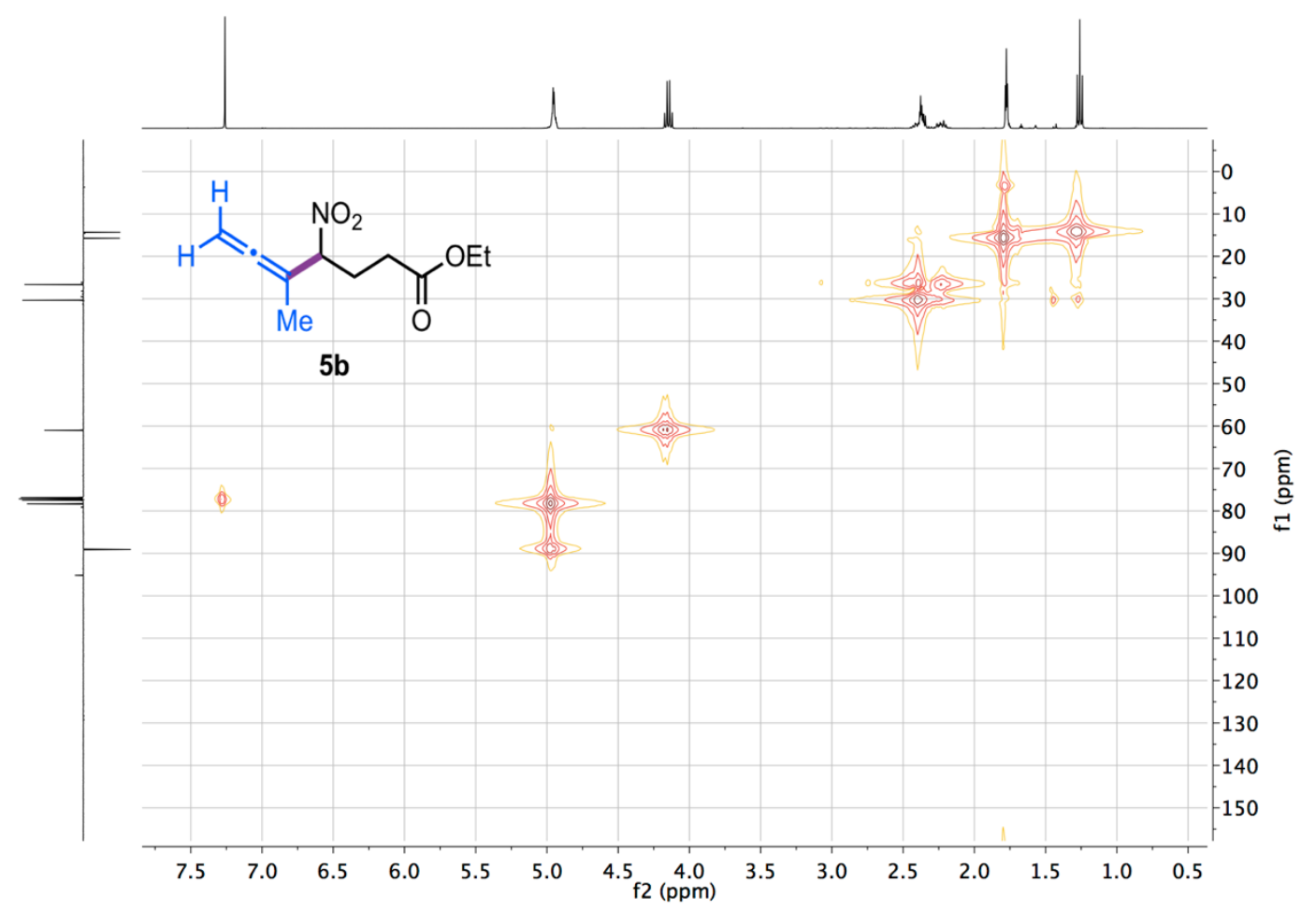

Figure S2. ${ }^{1} \mathrm{H}-{ }^{13} \mathrm{C}$ Heteronuclear Multiple-Quantum Correlation Spectroscopy (HMQC) of $5 b$ 


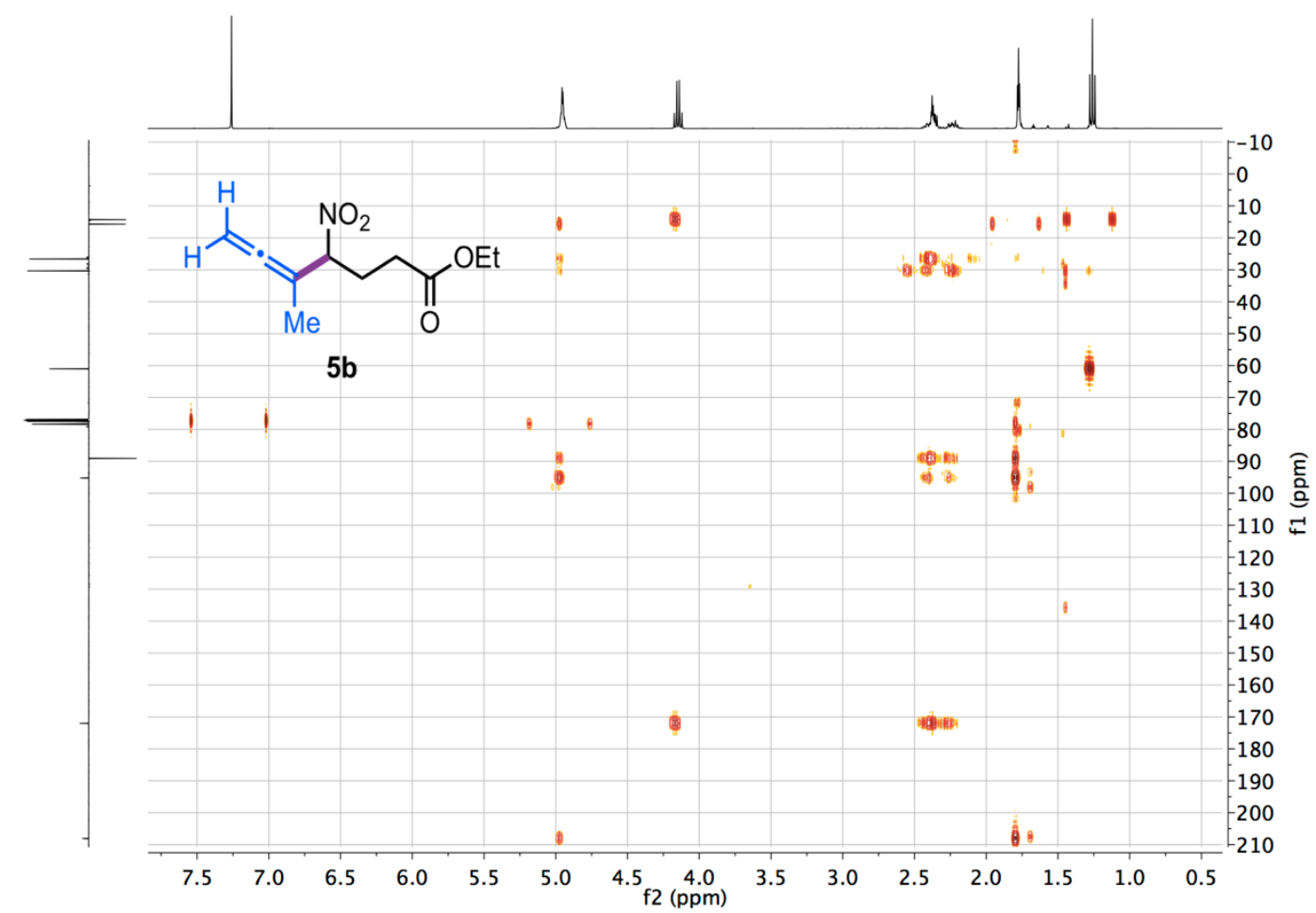

Figure S3. ${ }^{1} \mathrm{H}-{ }^{13} \mathrm{C}$ Heteronuclear Multiple-Bond Correlation Spectroscopy (HMBC) of $5 b$

\section{Preparation of Diamine Ligands}

\section{Note: General Procedure 5A was modified from a known procedure. ${ }^{15}$}

General Procedure 5A: An oven-dried, 1-nk $100 \mathrm{~mL}$ round bottom flask was equipped with a stir bar and a reflux condenser. The condenser was capped with a rubber septum and the atmosphere of the reactor was purged with a balloon of $\mathrm{N}_{2}$ and an outlet needle. Amine (4.0 equiv) was added via syringe and heated to $130^{\circ} \mathrm{C}$ in a silicone oil bath. Then, 1,2-dibromoethane (1.0 equiv) was added dropwise and the reaction was stirred for $0.5-2 \mathrm{~h}$. The reaction mixture was cooled to 80 ${ }^{\circ} \mathrm{C}$ and diluted with EtOAc $(10 \mathrm{~mL})$. A solution of $\mathrm{NaOH}(50 \mathrm{~mL}, 50 \%$ aqueous) was then added and the biphasic mixture was stirred for 5 mins, before being poured into a separatory funnel and rinsed with EtOAc $(3 \times 10 \mathrm{~mL})$. The layers were separated, and the aqueous phase was extracted with EtOAc ( $3 \times 50 \mathrm{~mL})$. The combined organic layers were then washed with brine $(50 \mathrm{~mL}$, saturated aqueous), dried over $\mathrm{MgSO}_{4}$, filtered through a fritted funnel, and concentrated in vacuo to afford a crude oil. Excess amine starting material was removed by short fractional distillation and the remaining crude oil was further purified using the specified method.

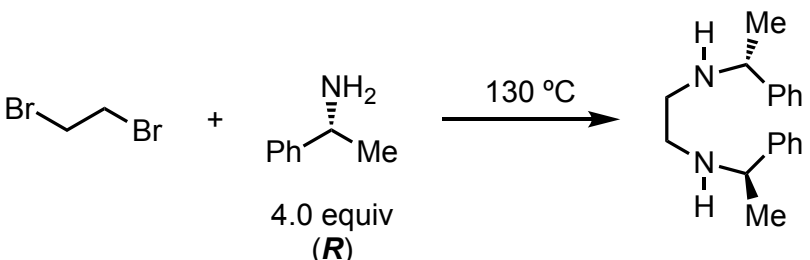

$(\boldsymbol{R})$

$11(R, R)$ 


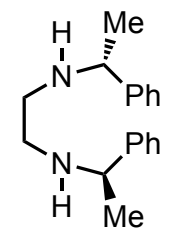

$11(R, R)$

Chemical Formula: $\mathrm{C}_{18} \mathrm{H}_{24} \mathrm{~N}_{2}$ Exact Mass: 268.1939 Molecular Weight: 268.4040
11: According to General Procedure 5A, 1,2-dibromoethane $(1.72 \mathrm{~mL}$, $20 \mathrm{mmol})$ in $(R)-1$-phenylethan-1-amine $(10.2 \mathrm{~mL}, 80 \mathrm{mmol})$ for $30 \mathrm{mins}$, afforded, after further purification by Kugelrohr distillation, 11 (4.05 g, $75 \%$ ) as clear, yellow oil.

${ }^{1} \mathrm{H}$ NMR $\left(600 \mathrm{MHz}, \mathrm{CDCl}_{3}\right) \delta 7.26-7.34(\mathrm{~m}, 8 \mathrm{H}), 7.23(\mathrm{t}, J=7.2 \mathrm{~Hz}$, $2 \mathrm{H}$ ), $3.66(\mathrm{q}, J=6.6 \mathrm{~Hz}, 2 \mathrm{H}), 2.49-2.57(\mathrm{~m}, 4 \mathrm{H}), 1.71(\mathrm{bs}, 2 \mathrm{H}), 1.34$ $(\mathrm{d}, J=6.6 \mathrm{~Hz}, 6 \mathrm{H})$.

${ }^{13} \mathrm{C}$ NMR $\left(151 \mathrm{MHz}^{\mathrm{CDCl}} 3\right) \delta 145.9,128.5,127.0,126.7,58.3,47.4,24.5$.

FTIR $\left(\mathrm{cm}^{-1}\right)$ 3308, 2961, 2825, 1451, 1122, 1028, 761, 700.

HRMS (ESI) m/z, calcd for $\left[\mathrm{C}_{18} \mathrm{H}_{25} \mathrm{~N}_{2}\right]^{+}$: 269.2018; found: 269.2017.

$[\alpha]_{\mathrm{D}}^{21}=+64.5^{\circ}\left(\mathrm{c}=0.01, \mathrm{CHCl}_{3}\right)$.

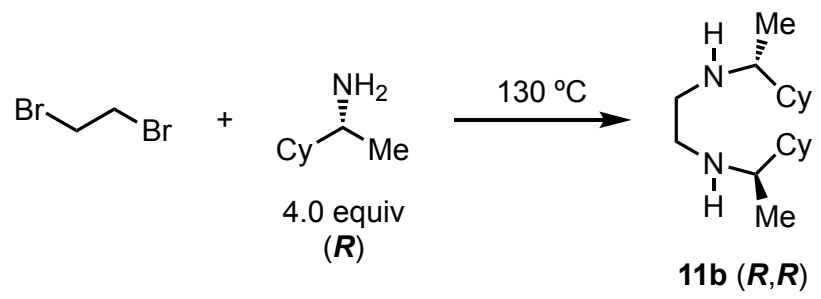

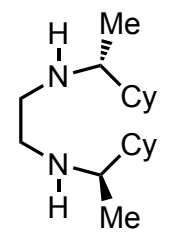

$11 \mathrm{~b}(R, R)$

Chemical Formula: $\mathrm{C}_{18} \mathrm{H}_{36} \mathrm{~N}_{2}$ Exact Mass: 280.2878 Molecular Weight: 280.5000 11b: According to General Procedure 5A, 1,2-dibromoethane (0.43 $\mathrm{mL}, 5 \mathrm{mmol})$ in $(R)$-1-cyclohexylethan-1-amine $(2.94 \mathrm{~mL}, 20 \mathrm{mmol})$ for $2 \mathrm{~h}$, afforded, after further purification by Kugelrohr distillation, 11b $(0.999 \mathrm{~g}, 71 \%)$ as clear, light yellow oil.

${ }^{1} \mathrm{H} \mathrm{NMR}\left(600 \mathrm{MHz}, \mathrm{CDCl}_{3}\right) \delta 2.74-2.79(\mathrm{~m}, 2 \mathrm{H}), 2.55-2.59(\mathrm{~m}, 2 \mathrm{H})$, $2.40(\mathrm{qd}, J=6.4,5.1 \mathrm{~Hz}, 2 \mathrm{H}), 1.62-1.78(\mathrm{~m}, 11 \mathrm{H}), 1.08-1.35(\mathrm{~m}$, $11 \mathrm{H}), 0.94-1.04(\mathrm{~m}, 10 \mathrm{H})$.

${ }^{13} \mathrm{C}$ NMR $\left(151 \mathrm{MHz}, \mathrm{CDCl}_{3}\right) \delta 58.1,47.8,43.3,30.1,28.4,27.0,26.9,26.7,17.3$.

FTIR $\left(\mathrm{cm}^{-1}\right)$ 3316, 2923, 2851, 1448, 1371, 1156, 890, 716.

HRMS (ESI) m/z, calcd for $\left[\mathrm{C}_{18} \mathrm{H}_{37} \mathrm{~N}_{2}\right]^{+}:$281.2957; found: 281.2957.

$[\alpha]_{\mathrm{D}}^{22}=-20.1^{\circ}\left(\mathrm{c}=0.01, \mathrm{CHCl}_{3}\right)$.<smiles>c1ccc(-c2ccccc2)cc1</smiles><smiles>CC(C)(CCCCCC(=O)O)C(=O)O</smiles><smiles>c1ccc([C](c2ccccc2)c2ccccc2)cc1</smiles>

11c 


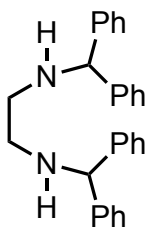

11c

Chemical Formula: $\mathrm{C}_{28} \mathrm{H}_{28} \mathrm{~N}_{2}$

Exact Mass: 392.2252

Molecular Weight: 392.5460

11c: An oven-dried, 1-nk $250 \mathrm{~mL}$ round bottom flask was fitted with a stir bar and $\mathrm{LiAlH}_{4}(0.500 \mathrm{~g}, 13.2 \mathrm{mmol})$ was added. The flask was equipped with a rubber septum and connected to a double manifold via syringe. The atmosphere of the reactor was replaced with $\mathrm{N}_{2}$ via three sequential cycles of evacuation and refill. Under positive $\mathrm{N}_{2}$, anhydrous THF (26 mL, 0.17 M) was added via syringe and the reactor was cooled in an iced water bath. Then, $\mathrm{N}^{1}, \mathrm{~N}^{2}$-dibenzhydrylethane-1,2-diimide $(1.71 \mathrm{~g}, 4.4 \mathrm{mmol})$ was added dropwise as a solution in THF $(2 \mathrm{~mL})$ via syringe. The reaction was allowed to slowly warm to it and stirred for $2 \mathrm{~h}$. The reaction was recooled in an iced water bath, diluted with EtOAc $(50 \mathrm{~mL})$, and $\mathrm{DI} \mathrm{H}_{2} \mathrm{O}(100 \mathrm{~mL})$ was carefully added (Note: vigorous bubbling). The resulting biphasic mixture was stirred at it under air for 10 mins, before being poured into a separatory funnel and rinsed with EtOAc $(3 \times 10 \mathrm{~mL})$. The layers were separated, and the aqueous phase was extracted with EtOAc ( $3 \times 50 \mathrm{~mL}$ ). The combined organic layers were then washed with brine $\left(50 \mathrm{~mL}\right.$, saturated aqueous), dried over $\mathrm{MgSO}_{4}$, filtered through a fritted funnel, and concentrated in vacuo to afford a crude solid. The crude product was purified by recrystallization $(\mathrm{EtOH})$ to afford $11 \mathrm{c}(0.970 \mathrm{~g}, 56 \%)$ as yellow crystals.

${ }^{1} \mathrm{H}$ NMR $\left(600 \mathrm{MHz}, \mathrm{CDCl}_{3}\right) \delta 7.39(\mathrm{~d}, J=7.2 \mathrm{~Hz}, 8 \mathrm{H}), 7.29(\mathrm{t}, J=7.4 \mathrm{~Hz}, 8 \mathrm{H}), 7.22(\mathrm{t}, J=7.3 \mathrm{~Hz}$, $4 \mathrm{H}), 4.79(\mathrm{~s}, 2 \mathrm{H}), 2.72(\mathrm{~s}, 4 \mathrm{H}), 1.86(\mathrm{~s}, 2 \mathrm{H})$.

${ }^{13} \mathrm{C}$ NMR $\left(151 \mathrm{MHz}, \mathrm{CDCl}_{3}\right) \delta 144.4,128.6,127.4,127.1,67.4,47.9$.

FTIR $\left(\mathrm{cm}^{-1}\right)$ 3310, 3060, 3024, 2824, 1492, 1452, 1028, 745, 701.

HRMS (ESI) m/z, calcd for $\left[\mathrm{C}_{28} \mathrm{H}_{29} \mathrm{~N}_{2}\right]^{+}$: 393.2331; found: 393.2327 .

MP: $105-107^{\circ} \mathrm{C}(\mathrm{EtOH})$.

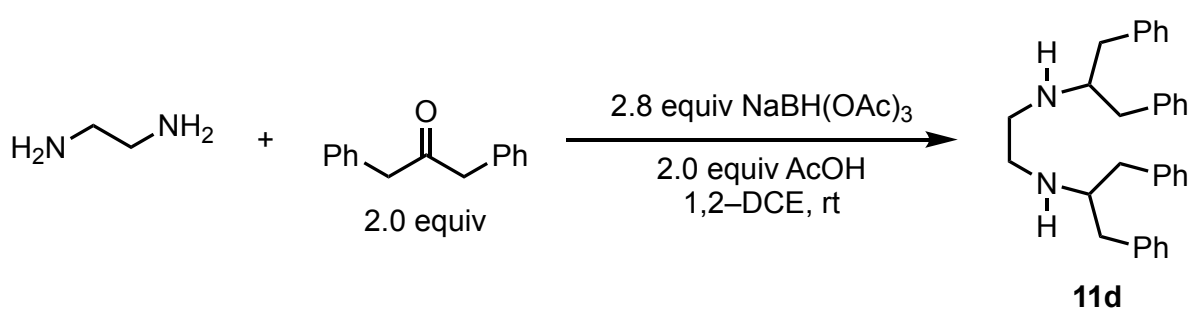

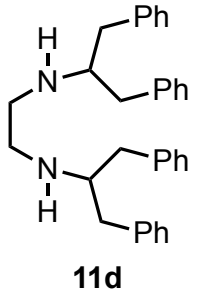

Chemical Formula: $\mathrm{C}_{32} \mathrm{H}_{36} \mathrm{~N}_{2}$

Exact Mass: 448.2878

Molecular Weight: 448.6540 11d was prepared according to a published procedure. ${ }^{16}$

11d: An oven-dried, 1-nk $250 \mathrm{~mL}$ round bottom flask was fitted with a stir bar and a rubber septum. A balloon of $\mathrm{N}_{2}$ was attached to the flask and 1,2-ethylenediamine $(0.67 \mathrm{~mL}, 10 \mathrm{mmol})$ was added via syringe. Then, anhydrous 1,2-DCE (34 mL, $0.29 \mathrm{M}$ ) and 1,3-diphenyl-2propanone $(4.0 \mathrm{~mL}, 20 \mathrm{mmol})$ were added sequentially via syringe. The rubber septum was momentarily removed to add sodium triacetoxyborohydride $(5.9 \mathrm{~g}, 28 \mathrm{mmol})$ portion-wise over 10 mins and acetic acid $(1.1 \mathrm{~mL}, 20 \mathrm{mmol})$ via syringe. The reaction was stirred rapidly at $\mathrm{rt}$ for $4 \mathrm{~d}$. The rubber septum was removed and a solution of $\mathrm{NaOH}(100 \mathrm{~mL}, 1 \mathrm{M}$ aqueous) was added. The biphasic mixture was stirred for 5 mins, before being poured into a separatory funnel and rinsed with DCM 
( $3 \mathrm{X} 10 \mathrm{~mL}$ ). The layers were separated, and the aqueous phase was extracted with DCM ( $3 \mathrm{X}$ $50 \mathrm{~mL}$ ). The combined organic layers were then washed with brine (100 mL, saturated aqueous), dried over $\mathrm{MgSO}_{4}$, filtered through a fritted funnel, and concentrated in vacuo to afford a crude oil. The crude product was purified by flash silica gel chromatography (gradient, 50:50 to 40:60 hexanes/EtOAc) and Kugelrohr distillation to afford $11 \mathrm{~d}(2.25 \mathrm{~g}, 50 \%)$ as white solid.

${ }^{1} \mathrm{H}$ NMR $\left(600 \mathrm{MHz}, \mathrm{CDCl}_{3}\right) \delta 7.27(\mathrm{t}, J=7.4 \mathrm{~Hz}, 8 \mathrm{H}), 7.20(\mathrm{t}, J=7.3 \mathrm{~Hz}, 4 \mathrm{H}), 7.13(\mathrm{~d}, J=7.2 \mathrm{~Hz}$, $8 \mathrm{H}), 2.93(\mathrm{p}, J=6.6 \mathrm{~Hz}, 2 \mathrm{H}), 2.55-2.65(\mathrm{~m}, 12 \mathrm{H}), 1.23$ (bs, $2 \mathrm{H})$.

${ }^{13} \mathrm{C}$ NMR $\left(151 \mathrm{MHz}, \mathrm{CDCl}_{3}\right) \delta 139.7,129.5,128.5,126.2,61.1,47.4,40.9$.

FTIR $\left(\mathrm{cm}^{-1}\right)$ 3307, 3083, 3025, 2922, 1495, 1453, 750, 699.

HRMS (ESI) m/z, calcd for $\left[\mathrm{C}_{32} \mathrm{H}_{37} \mathrm{~N}_{2}\right]^{+}:$449.2957; found: 449.2978 .

MP: $65-67^{\circ} \mathrm{C}($ EtOAc)

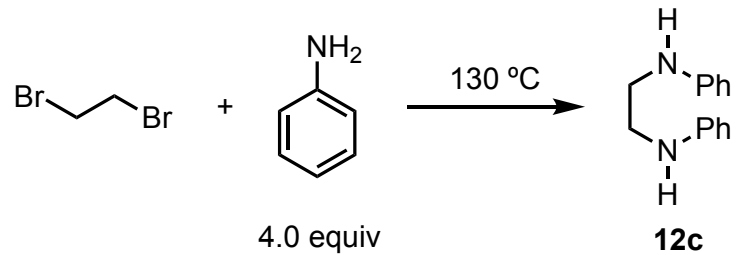

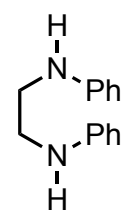

12c

Chemical Formula: $\mathrm{C}_{14} \mathrm{H}_{16} \mathrm{~N}_{2}$ Exact Mass: 212.1313 Molecular Weight: 212.2960 12c: According to General Procedure 5A, 1,2-dibromoethane (0.86 $\mathrm{mL}, 10 \mathrm{mmol}$ ) in aniline (3.65 $\mathrm{mL}, 40 \mathrm{mmol})$ for 30 mins, afforded, after further purification by trituration (hexanes) and recrystallization $(\mathrm{EtOH})$, 12c $(0.391 \mathrm{~g}, 18 \%)$ as pale solid.

${ }^{1} \mathrm{H} \mathrm{NMR}\left(600 \mathrm{MHz}, \mathrm{CDCl}_{3}\right) \delta 7.20(\mathrm{tq}, J=7.3,1.2 \mathrm{~Hz}, 4 \mathrm{H}), 6.75$ (tq, $J$ $=7.3,1.1 \mathrm{~Hz}, 2 \mathrm{H}), 6.66(\mathrm{dp}, J=7.6,1.1 \mathrm{~Hz}, 4 \mathrm{H}), 3.86(\mathrm{bs}, 2 \mathrm{H}), 3.41(\mathrm{~s}$, $4 \mathrm{H})$.

${ }^{13} \mathrm{C}$ NMR $\left(151 \mathrm{MHz}, \mathrm{CDCl}_{3}\right) \delta 148.2,129.5,118.0,113.2,43.5$.

FTIR $\left(\mathrm{cm}^{-1}\right)$ 3418, 3050, 2946, 2868, 1601, 1514, 1265, 746, 693.

HRMS (ESI) m/z, calcd for $\left[\mathrm{C}_{14} \mathrm{H}_{17} \mathrm{~N}_{2}\right]^{+}:$213.1392; found: 213.1390 .

MP: $62-64^{\circ} \mathrm{C}(\mathrm{EtOH})$.

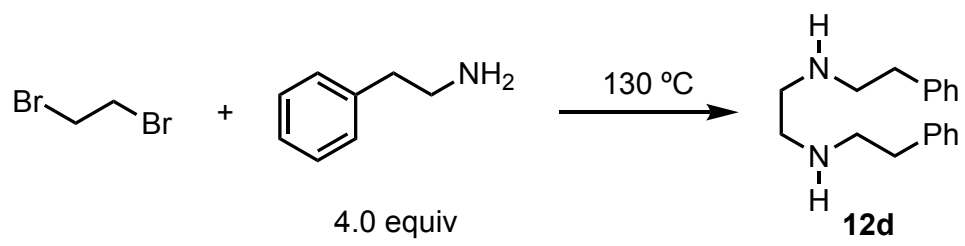




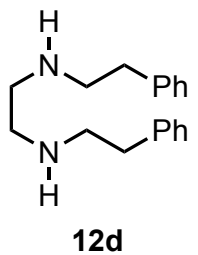

Chemical Formula: $\mathrm{C}_{18} \mathrm{H}_{24} \mathrm{~N}_{2}$ Exact Mass: 268.1939 Molecular Weight: 268.4040 12d: According to General Procedure 5A, 1,2-dibromoethane (0.86 $\mathrm{mL}, 10 \mathrm{mmol}$ ) in 2-phenylethan-1-amine $(5.04 \mathrm{~mL}, 40 \mathrm{mmol})$ for 30 mins, afforded, after further purification by Kugelrohr distillation, 12d $(1.17 \mathrm{~g}, 44 \%)$ as white solid.

${ }^{1} \mathrm{H} \mathrm{NMR}\left(600 \mathrm{MHz}, \mathrm{CDCl}_{3}\right) \delta 7.27-7.31(\mathrm{~m}, 4 \mathrm{H}), 7.20(\mathrm{td}, J=7.3,6.8$, $1.4 \mathrm{~Hz}, 6 \mathrm{H}), 2.86(\mathrm{t}, J=7.0 \mathrm{~Hz}, 4 \mathrm{H}), 2.78(\mathrm{t}, J=7.2 \mathrm{~Hz}, 4 \mathrm{H}), 2.73(\mathrm{~s}$, $4 \mathrm{H}), 1.49$ (bs, 2H).

${ }^{13} \mathrm{C}$ NMR $\left(151 \mathrm{MHz}, \mathrm{CDCl}_{3}\right) \delta 140.2,128.9,128.6,126.3,51.3,49.3,36.6$.

FTIR $\left(\mathrm{cm}^{-1}\right)$ 3304, 3025, 2931, 2814, 1603, 1496, 1453, 1124, 748, 699.

HRMS (ESI) m/z, calcd for [ $\left.\mathrm{C}_{18} \mathrm{H}_{25} \mathrm{~N}_{2}\right]^{+}:$269.2018; found: 269.2018.

MP: $85-87^{\circ} \mathrm{C}(\mathrm{EtOAc})$.

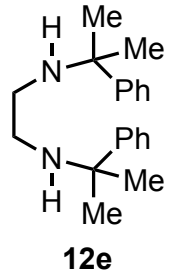

Chemical Formula: $\mathrm{C}_{20} \mathrm{H}_{28} \mathrm{~N}_{2}$ Exact Mass: 296.2252 Molecular Weight: 296.4580

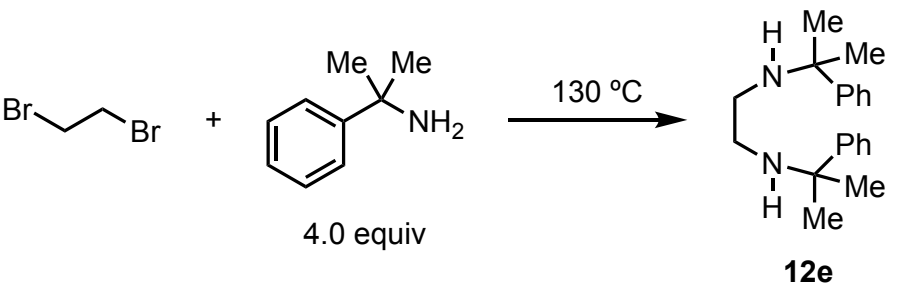

12e: According to General Procedure 5A, 1,2-dibromoethane (0.22 $\mathrm{mL}, 2.5 \mathrm{mmol})$ in 2-phenylpropan-2-amine $(1.44 \mathrm{~mL}, 10 \mathrm{mmol})$ for 30 mins, afforded, after further purification by flash silica gel chromatography (95:5 DCM:MeOH), $12 \mathrm{e}(0.408 \mathrm{~g}, 55 \%)$ as clear, yellow oil that solidified as white solid overtime.

${ }^{1} \mathrm{H}$ NMR $\left(600 \mathrm{MHz}, \mathrm{CDCl}_{3}\right) \delta 7.40-7.44(\mathrm{~m}, 4 \mathrm{H}), 7.31(\mathrm{t}, J=7.8 \mathrm{~Hz}$, $4 \mathrm{H}), 7.19-7.23(\mathrm{~m}, 2 \mathrm{H}), 2.39(\mathrm{~s}, 4 \mathrm{H}), 1.45(\mathrm{~s}, 12 \mathrm{H})$.

${ }^{13} \mathrm{C}$ NMR $\left(101 \mathrm{MHz}, \mathrm{CDCl}_{3}\right) \delta 148.0,128.2,126.3,125.9,55.8,43.6,29.6$.

FTIR $\left(\mathrm{cm}^{-1}\right)$ 3318, 3085, 2972, 2843, 1494, 1443, 1379, 1182, 764, 699.

HRMS (ESI) m/z, calcd for $\left[\mathrm{C}_{20} \mathrm{H}_{29} \mathrm{~N}_{2}\right]^{+}: 297.2331$; found: 297.2332 .

MP: $34-35^{\circ} \mathrm{C}(\mathrm{DCM})$.

\section{Preparation of Propargyl Bromides}

General Procedure 6A: An oven-dried, 1-nk $1000 \mathrm{~mL}$ Schlenk flask was fitted with a stir bar and $\mathrm{Pd}\left(\mathrm{PPh}_{3}\right)_{2} \mathrm{Cl}_{2}(0.01-0.05$ equiv) and $\mathrm{Cul}(0.02-0.10$ equiv) were added. The flask was equipped with a rubber septum and the sidearm of the flask was attached to a double manifold using a rubber hose. The atmosphere of the reactor was replaced with $\mathrm{N}_{2}$ via three sequential cycles of evacuation and refill. Under positive $\mathrm{N}_{2}$, anhydrous amine $(0.10-0.60 \mathrm{M}$, with respect to haloarene) and haloarene (1.0 equiv) were added sequentially via syringe. This mixture was 
stirred at rt for 5 mins, before propargyl alcohol (1.0 - 1.1 equiv) was added via syringe and stirred rapidly at $\mathrm{rt}$ for the indicated time. The $\mathrm{N}_{2}$ line was closed off and the rubber septum was removed. The resulting suspension was diluted with EtOAc $(100 \mathrm{~mL})$ and quenched by the addition of $\mathrm{NH}_{4} \mathrm{Cl}$ (100 mL, saturated aqueous). The resulting biphasic mixture was rapidly stirred for 5 mins, before being poured into a separatory funnel and rinsed with EtOAc $(3 \times 20 \mathrm{~mL})$. The layers were separated, and the aqueous phase was extracted with EtOAc $(3 \times 50 \mathrm{~mL})$. The combined organic layers were then washed with brine $\left(100 \mathrm{~mL}\right.$, saturated aqueous), dried over $\mathrm{MgSO}_{4}$, filtered through a fritted funnel, and concentrated in vacuo to afford a crude oil. The crude product was purified by flash silica gel chromatography using the specified condition.

General Procedure 6B: A flame-dried, 1-nk $500 \mathrm{~mL}$ round bottom flask was fitted with a stir bar and a rubber septum. The flask was equipped with a $\mathrm{N}_{2}$-filled balloon and purged with an outlet needle for 5 mins. Then, alkyne (1.0 equiv) and anhydrous THF $(0.20-0.40 \mathrm{M})$ were added via syringe. The reactor was cooled in a dry ice/acetone bath and $n$-BuLi (1.05 - 1.3 equiv) was added dropwise via syringe. The reaction was stirred in the dry ice/acetone bath for $1 \mathrm{~h}$, before aldehyde (1.1 equiv) was added dropwise via syringe (or the rubber septum was momentarily removed to add paraformaldehyde (1.2 equiv) in one portion). The reaction was then warmed to $\mathrm{rt}$ and stirred rapidly for the indicated time. The reaction mixture was diluted with EtOAc $(50 \mathrm{~mL})$ and quenched by the addition of $\mathrm{NH}_{4} \mathrm{Cl}$ (100 $\mathrm{mL}$, saturated aqueous). The biphasic mixture was stirred for 5 mins, before being poured into a separatory funnel and rinsed with EtOAc ( $3 \times 10$ $\mathrm{mL})$. The layers were separated, and the aqueous phase was extracted with EtOAc ( $3 \times 40 \mathrm{~mL})$. The combined organic layers were then washed with brine $(100 \mathrm{~mL}$, saturated aqueous), dried over $\mathrm{MgSO}_{4}$, filtered through a fritted funnel, and concentrated in vacuo to afford a crude oil. The crude product was purified by distillation or flash silica gel chromatography using the specified condition.

General Procedure 6C: A flame-dried, 1-nk $100 \mathrm{~mL}$ round bottom flask was fitted with a stir bar and a rubber septum. The flask was then equipped with a $\mathrm{N}_{2}$-filled balloon and purged with an outlet needle for 5 mins. Alcohol (1.0 equiv) and solvent $(0.36-0.50 \mathrm{M})$ were added via syringe and the reactor was cooled in an iced water bath. While stirring rapidly, $\mathrm{PBr}_{3}(0.61-1.5$ equiv) was added dropwise via syringe and the reaction was continued to stir rapidly for the indicated time while slowly warming to rt overtime. The reaction was re-cooled in an iced water bath and carefully quenched with $\mathrm{NaHCO}_{3}(20 \mathrm{~mL}$, saturated aqueous, Note: vigorous bubbling). The biphasic mixture was stirred for 5 mins, before being poured into a separatory funnel and rinsed with DCM $(3 \times 10 \mathrm{~mL})$. The layers were separated, and the aqueous phase was extracted with $\mathrm{DCM}(3 \times 20 \mathrm{~mL})$. The combined organic layers were then washed with brine $(20 \mathrm{~mL}$, saturated aqueous), dried over $\mathrm{MgSO}_{4}$, filtered through a fritted funnel, and concentrated in vacuo to afford a crude oil. The crude product was purified by flash silica gel chromatography using the specified condition.

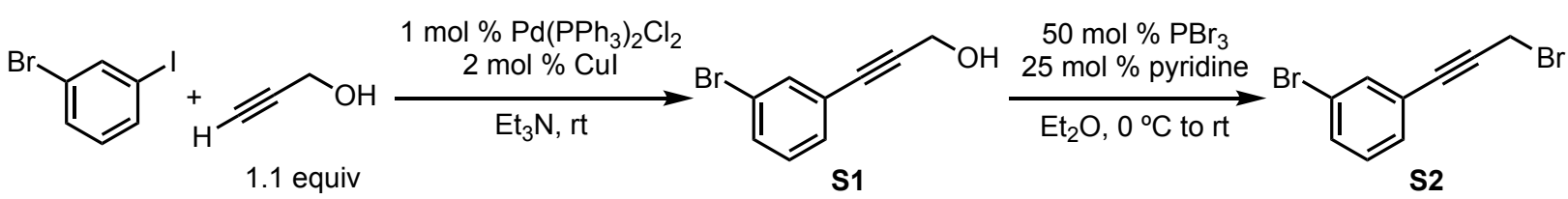




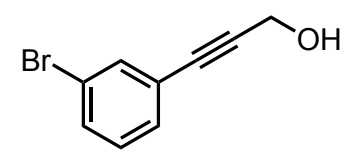

s1

Chemical Formula: $\mathrm{C}_{9} \mathrm{H}_{7} \mathrm{BrO}$

Exact Mass: 209.9680

Molecular Weight: 211.0580

S1: According to General Procedure 6A, $\mathrm{Pd}\left(\mathrm{PPh}_{3}\right)_{2} \mathrm{Cl}_{2}(140 \mathrm{mg}, 0.2$ $\mathrm{mmol})$, Cul (76 mg, $0.4 \mathrm{mmol}), 1$-bromo-3-iodobenzene $(2.55 \mathrm{~mL}, 20$ $\mathrm{mmol})$, and propargyl alcohol $(1.28 \mathrm{~mL}, 22 \mathrm{mmol})$ in anhydrous $\mathrm{Et}_{3} \mathrm{~N}$ $(200 \mathrm{~mL}, 0.1 \mathrm{M})$ for $3 \mathrm{~h}$, afforded, after flash silica gel chromatography (80:20 hexanes:EtOAc), S1 (3.99 g, 95\%) as orange oil.

S1 is a known compound and its spectra are in accord with published data. ${ }^{17}$

${ }^{1} \mathrm{H}$ NMR $\left(400 \mathrm{MHz}, \mathrm{CDCl}_{3}\right) \delta 7.58(\mathrm{~s}, 1 \mathrm{H}), 7.46(\mathrm{~d}, J=8.2 \mathrm{~Hz}, 1 \mathrm{H}), 7.36(\mathrm{~d}, J=7.7 \mathrm{~Hz}, 1 \mathrm{H}), 7.18$ (t, $J=7.8 \mathrm{~Hz}, 1 \mathrm{H}), 4.50(\mathrm{~d}, J=5.2 \mathrm{~Hz}, 2 \mathrm{H}), 1.76(\mathrm{t}, J=5.8 \mathrm{~Hz}, 1 \mathrm{H})$.

${ }^{13} \mathrm{C}$ NMR $\left(101 \mathrm{MHz}, \mathrm{CDCl}_{3}\right) \delta 134.5,131.8,130.4,129.9,124.6,122.2,88.6,84.3,51.7$.

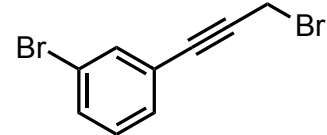

S2

Chemical Formula: $\mathrm{C}_{9} \mathrm{H}_{6} \mathrm{Br}_{2}$

Exact Mass: 271.8836

Molecular Weight: 273.9550
S2 was prepared according to a published procedure. ${ }^{18}$

${ }^{1} \mathrm{H}$ NMR $\left(400 \mathrm{MHz}, \mathrm{CDCl}_{3}\right) \delta 7.59(\mathrm{t}, J=1.7 \mathrm{~Hz}, 1 \mathrm{H}), 7.47$ (ddd, $J=8.1$, 2.0, 1.0 Hz, 1H), $7.37(\mathrm{dt}, J=7.8,1.3 \mathrm{~Hz}, 1 \mathrm{H}), 7.19(\mathrm{t}, J=7.9 \mathrm{~Hz}, 1 \mathrm{H})$, $4.14(\mathrm{~s}, 2 \mathrm{H})$.

${ }^{13} \mathrm{C}$ NMR $\left(101 \mathrm{MHz}, \mathrm{CDCl}_{3}\right) \delta 134.7,132.2,130.6,129.9,124.2,122.3$, 85.6, 85.1, 14.9 .

FTIR $\left(\mathrm{cm}^{-1}\right)$ 3062, 2999, 2952, 2361, 2337, 2223, 1557, 1473, 1201, 1001, 781.

HRMS (LIFDI) m/z, calcd for $\left[\mathrm{C}_{9} \mathrm{H}_{6} \mathrm{Br}_{2}\right]^{+}:$271.8836; found 271.8841.

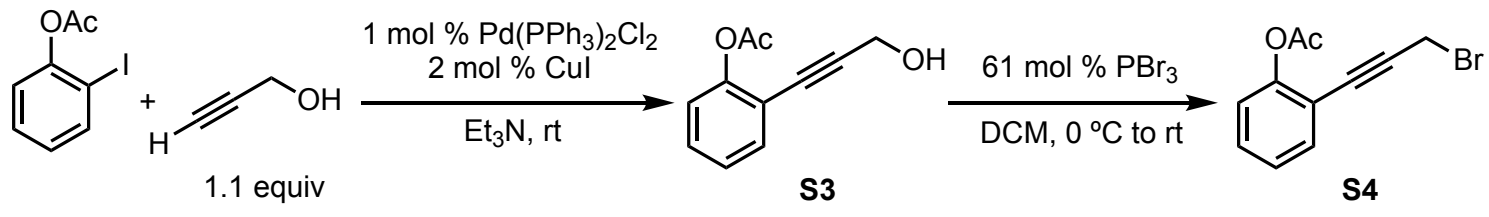

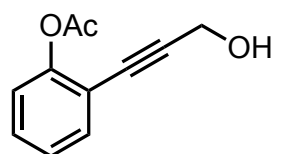

S3

Chemical Formula: $\mathrm{C}_{11} \mathrm{H}_{10} \mathrm{O}_{3}$ Exact Mass: 190.0630 Molecular Weight: 190.1980
S3: According to General Procedure 6A, $\mathrm{Pd}\left(\mathrm{PPh}_{3}\right)_{2} \mathrm{Cl}_{2}(70.2 \mathrm{mg}, 0.1$ $\mathrm{mmol})$, Cul (38.1 mg, $0.2 \mathrm{mmol}), 2$-iodophenyl acetate $(2.62 \mathrm{~g}, 10$ $\mathrm{mmol})$, and propargyl alcohol $(0.64 \mathrm{~mL}, 11 \mathrm{mmol})$ in anhydrous $\mathrm{Et}_{3} \mathrm{~N}$ $(100 \mathrm{~mL}, 0.1 \mathrm{M})$ for $20 \mathrm{~h}$, afforded, after flash silica gel chromatography (50:50 hexanes: $\left.\mathrm{Et}_{2} \mathrm{O}\right)$, S3 (1.26 g, 66\%) as orange oil.

${ }^{1} \mathrm{H}$ NMR $\left(400 \mathrm{MHz}, \mathrm{CDCl}_{3}\right) \delta 7.48(\mathrm{dd}, J=7.7,1.7 \mathrm{~Hz}, 1 \mathrm{H}), 7.36(\mathrm{td}, J$ = 7.8, $1.7 \mathrm{~Hz}, 1 \mathrm{H}), 7.20$ (td, J = 7.6, 1.2 Hz, 1H), 7.09 (dd, J = 8.1, 1.2 Hz, 1H), $4.48(\mathrm{~s}, 2 \mathrm{H}), 2.35$ (s, 3H), 1.86 (bs, 1H).

${ }^{13} \mathrm{C}$ NMR $\left(101 \mathrm{MHz}, \mathrm{CDCl}_{3}\right) \delta 169.3,151.7,133.3,129.9,126.1,122.4,116.8,92.3,80.7,51.7$, 21.1.

FTIR $\left(\mathrm{cm}^{-1}\right)$ 3413, 2918, 1761, 1487, 1369, 1211, 1186, 1024, 757.

HRMS (ESI) m/z, calcd for $\left[\mathrm{C}_{11} \mathrm{H}_{11} \mathrm{O}_{3}\right]^{+}:$191.0708; found 191.0705 . 


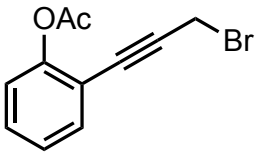

S4

Chemical Formula: $\mathrm{C}_{11} \mathrm{H}_{9} \mathrm{BrO}_{2}$

Exact Mass: 251.9786

Molecular Weight: 253.0950

S4: According to General Procedure 6C, S3 $(0.51 \mathrm{~g}, 2.7 \mathrm{mmol})$ and $\mathrm{PBr}_{3}(0.15 \mathrm{~mL}, 1.6 \mathrm{mmol})$ in anhydrous DCM $(7.5 \mathrm{~mL}, 0.36 \mathrm{M})$ for 14 $\mathrm{h}$, afforded, after flash silica gel chromatography $(80: 20$ hexanes:Et $\left.\mathrm{t}_{2} \mathrm{O}\right)$, $\mathbf{S} 4(0.45 \mathrm{~g}, 66 \%)$ as clear, yellow oil.

${ }^{1} \mathrm{H}$ NMR $\left(600 \mathrm{MHz}, \mathrm{CDCl}_{3}\right) \delta 7.47(\mathrm{dd}, J=7.7,1.6 \mathrm{~Hz}, 1 \mathrm{H}), 7.37(\mathrm{td}, J$ $=7.8,1.6 \mathrm{~Hz}, 1 \mathrm{H}), 7.21(\mathrm{td}, J=7.6,1.2 \mathrm{~Hz}, 1 \mathrm{H}), 7.10(\mathrm{dd}, J=8.2,1.2$ $\mathrm{Hz}, 1 \mathrm{H}), 4.15$ (s, 2H), 2.37 (s, 3H).

${ }^{13} \mathrm{C}$ NMR $\left(151 \mathrm{MHz}, \mathrm{CDCl}_{3}\right) \delta 169.0,152.1,133.2,130.2,126.0,122.5,116.6,89.1,81.9,21.0$, 14.8 .

FTIR $\left(\mathrm{cm}^{-1}\right)$ 3006, 1763, 1487, 1369, 1211, 1185, 757.

HRMS (ESI) m/z, calcd for $\left[\mathrm{C}_{11} \mathrm{H}_{10} \mathrm{BrO}_{2}\right]^{+}:$252.9864; found 252.9862 .

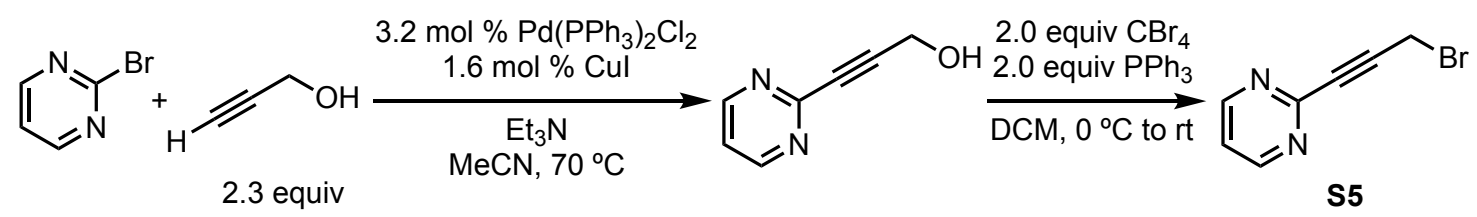

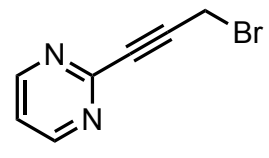

S5

Chemical Formula: $\mathrm{C}_{7} \mathrm{H}_{5} \mathrm{BrN}_{2}$ Exact Mass: 195.9636 Molecular Weight: 197.0350

S5: A flame-dried, 3-nk $250 \mathrm{~mL}$ round bottom flask was fitted with a stir bar and 2-bromopyrimidine $(3.2 \mathrm{~g}, 20 \mathrm{mmol}), \mathrm{Pd}\left(\mathrm{PPh}_{3}\right)_{2} \mathrm{Cl}_{2}(0.45 \mathrm{~g}$, $0.64 \mathrm{mmol})$, and $\mathrm{Cul}(0.061 \mathrm{~g}, 0.32 \mathrm{mmol})$ were added. The flask was equipped with a condenser and the reactor was fitted with a rubber septum. The flask was then attached to a double manifold using a rubber hose and syringe, and the atmosphere of the reactor was replaced with $\mathrm{N}_{2}$ via five sequential cycles of evacuation and refill. Under positive $\mathrm{N}_{2}$, anhydrous $\mathrm{MeCN}(61 \mathrm{~mL}, 0.33 \mathrm{M})$ and anhydrous $\mathrm{Et}_{3} \mathrm{~N}(10 \mathrm{~mL}, 2.0 \mathrm{M})$ were added via syringe. While rapidly stirring, propargyl alcohol $(2.7 \mathrm{~mL}, 46 \mathrm{mmol})$ was added dropwise via syringe. The reaction was then heated to $70^{\circ} \mathrm{C}$ in a silicone oil bath and stirred for $3 \mathrm{~h}$. The reaction was quenched by the addition of $\mathrm{DI}_{2} \mathrm{O}(50 \mathrm{~mL})$ and the biphasic mixture was stirred for 5 mins, before being poured into a separatory funnel and rinsed with EtOAc $(3 \times 10 \mathrm{~mL})$. The layers were separated, and the aqueous phase was extracted with EtOAc $(3 \times 40 \mathrm{~mL})$. The combined organic layers were then washed with brine $(100 \mathrm{~mL}$, saturated aqueous), dried over $\mathrm{MgSO}_{4}$, filtered through a fritted funnel, and concentrated in vacuo to afford a crude oil. The crude product was purified by flash silica gel chromatography (90:10 hexanes:EtOAc) to afford 3(pyrimidin-2-yl)prop-2-yn-1-ol (1.0 g, 37\%) as yellow solid (minor impurities were inseparable by chromatography). ${ }^{1} \mathrm{H}$ NMR data for identification purposes: ${ }^{1} \mathrm{H}$ NMR $\left(400 \mathrm{MHz}, \mathrm{CDCl}_{3}\right) \delta 8.72(\mathrm{~d}$, $J=5.0 \mathrm{~Hz}, 2 \mathrm{H}), 7.27(\mathrm{t}, J=5.0 \mathrm{~Hz}, 1 \mathrm{H}), 4.55(\mathrm{~d}, J=6.5 \mathrm{~Hz}, 2 \mathrm{H}), 3.05(\mathrm{bs}, 1 \mathrm{H}) .{ }^{13} \mathrm{C}$ NMR $(101$ $\left.\mathrm{MHz}, \mathrm{CDCl}_{3}\right) \delta 157.5,152.7,120.3,87.1,84.0,51.3$.

An oven-dried, 1-nk $100 \mathrm{~mL}$ round bottom flask was fitted with a stir bar and 3-(pyrimidin2-yl)prop-2-yn-1-ol $(0.67 \mathrm{~g}, 5.0 \mathrm{mmol})$ was added. The flask was equipped with a rubber septum and a $\mathrm{N}_{2}$-filled balloon, and purged using an outlet needle for 5 mins. Then, anhydrous DCM (17 $\mathrm{mL}, 0.3 \mathrm{M}$ ) was added via syringe and the reactor was cooled in an iced water bath. While stirring, 
the rubber septum was momentarily removed, and $\mathrm{PPh}_{3}(2.6 \mathrm{~g}, 10 \mathrm{mmol})$ and $\mathrm{CBr}_{4}(3.3 \mathrm{~g}, 10$ $\mathrm{mmol})$ were added sequentially in one portion. The reaction was slowly warmed to rt and stirred rapidly for $3 \mathrm{~h}$. The reaction was diluted with non-anhydrous hexanes $(70 \mathrm{~mL})$ and the resulting suspension was filtered through a fritted funnel. The filter cake was washed with hexanes $(3 \times 20$ $\mathrm{mL}$ ) and the filtrate was concentrated in vacuo to afford a crude oil. The crude product was purified by flash silica gel chromatography (60:40 hexanes:EtOAc) to afford S5 $(0.54 \mathrm{~g}, 55 \%)$ as yellow crystals.

${ }^{1} \mathrm{H}$ NMR $\left(400 \mathrm{MHz}, \mathrm{CDCl}_{3}\right) \delta 8.73(\mathrm{~d}, J=4.9 \mathrm{~Hz}, 2 \mathrm{H}), 7.27(\mathrm{t}, J=4.9 \mathrm{~Hz}, 2 \mathrm{H}), 4.13(\mathrm{~s}, 2 \mathrm{H})$.

${ }^{13} \mathrm{C}$ NMR $\left(101 \mathrm{MHz}, \mathrm{CDCl}_{3}\right) \delta 157.5,152.4,120.5,84.5,82.9,13.3$.

FTIR $\left(\mathrm{cm}^{-1}\right)$ 2990, 2945, 2235, 1554, 1409, 1222, 813.

HRMS (ESI) m/z, calcd for [ $\left.\mathrm{C}_{7} \mathrm{H}_{6} \mathrm{BrN}_{2}\right]^{+}:$196.9714; found 196.9719.

MP: $100-102^{\circ} \mathrm{C}(\mathrm{EtOAc})$.

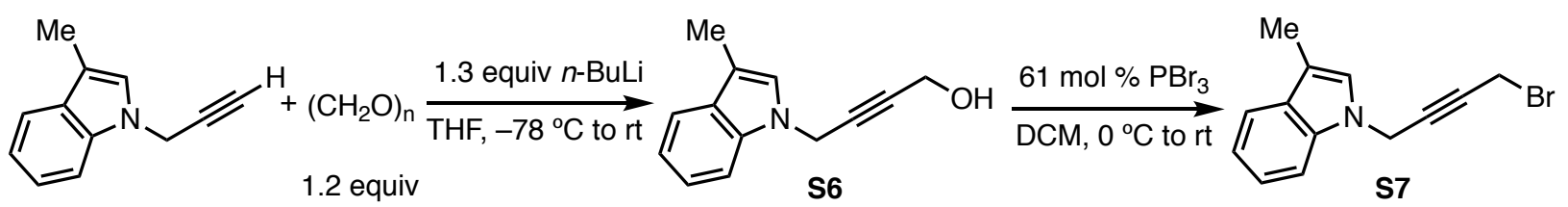

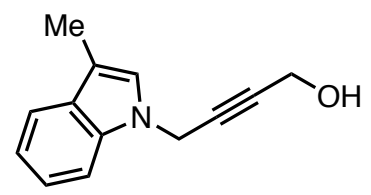

S6

Chemical Formula: $\mathrm{C}_{13} \mathrm{H}_{13} \mathrm{NO}$ Exact Mass: 199.0997 Molecular Weight: 199.2530

S6: According to General Procedure 6B, 3-methyl-1-(prop-2-yn-1-yl)$1 H$-indole $(7.55 \mathrm{~g}, 44.6 \mathrm{mmol}), n$-BuLi $(36 \mathrm{~mL}, 58 \mathrm{mmol}, 1.6 \mathrm{M}$ in hexane), and paraformaldehyde $(1.61 \mathrm{~g}, 54 \mathrm{mmol})$ in anhydrous THF $(149 \mathrm{~mL}, 0.3 \mathrm{M})$ stirred overnight, afforded, after flash silica gel chromatography $\left(60: 40\right.$ hexanes: $\left.\mathrm{Et}_{2} \mathrm{O}\right), \mathbf{S 6}(7.29 \mathrm{~g}, 82 \%)$ as orange oil.

${ }^{1} \mathrm{H}$ NMR $\left(400 \mathrm{MHz}, \mathrm{CDCl}_{3}\right) \delta 7.58(\mathrm{~d}, J=7.9 \mathrm{~Hz}, 1 \mathrm{H}), 7.35(\mathrm{~d}, J=8.2$ $\mathrm{Hz}, 1 \mathrm{H}), 7.24(\mathrm{t}, J=7.5 \mathrm{~Hz}, 1 \mathrm{H}), 7.14(\mathrm{t}, J=7.6 \mathrm{~Hz}, 1 \mathrm{H}), 6.96(\mathrm{~s}, 1 \mathrm{H}), 4.87(\mathrm{~s}, 2 \mathrm{H}), 4.26(\mathrm{~d}, J=$ $6.3 \mathrm{~Hz}, 2 \mathrm{H}), 2.33(\mathrm{~s}, 3 \mathrm{H}), 1.50-1.57(\mathrm{~m}, 1 \mathrm{H})$.

${ }^{13} \mathrm{C}$ NMR $\left(101 \mathrm{MHz}, \mathrm{CDCl}_{3}\right) \delta 136.2,129.2,125.0,121.9,119.3,119.3,111.4,109.3,82.9,80.4$, $51.3,35.8,9.8$.

FTIR $\left(\mathrm{cm}^{-1}\right)$ 3335, 2916, 2860, 1466, 1329, 1014, 740.

HRMS (ESI) m/z, calcd for $\left[\mathrm{C}_{13} \mathrm{H}_{14} \mathrm{NO}\right]^{+}:$200.1075; found 200.1072 . 


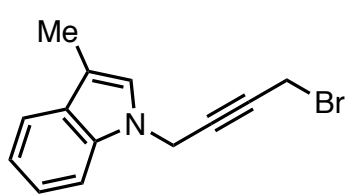

S7

Chemical Formula: $\mathrm{C}_{13} \mathrm{H}_{12} \mathrm{BrN}$

Exact Mass: 261.0153

Molecular Weight: 262.1500
S7: According to General Procedure 6C, S6 $(6.5 \mathrm{~g}, 33 \mathrm{mmol})$ and $\mathrm{PBr}_{3}(1.9 \mathrm{~mL}, 20 \mathrm{mmol})$ in anhydrous DCM $(91 \mathrm{~mL}, 0.36 \mathrm{M})$ for $3 \mathrm{~h}$, afforded, after flash silica gel chromatography (90:10 hexanes: $\left.\mathrm{Et}_{2} \mathrm{O}\right)$, S7 $(2.49 \mathrm{~g}, 29 \%)$ as orange oil.

${ }^{1} \mathrm{H} \mathrm{NMR}\left(400 \mathrm{MHz}, \mathrm{CDCl}_{3}\right) \delta 7.59(\mathrm{~d}, J=7.9 \mathrm{~Hz}, 1 \mathrm{H}), 7.35(\mathrm{~d}, J=8.2$ $\mathrm{Hz}, 1 \mathrm{H}), 7.26(\mathrm{t}, J=7.5 \mathrm{~Hz}, 2 \mathrm{H}), 7.16(\mathrm{t}, J=7.9 \mathrm{~Hz}, 1 \mathrm{H}), 6.95(\mathrm{~s}, 1 \mathrm{H})$, $4.87-4.90(\mathrm{~m}, 2 \mathrm{H}), 3.88-3.91(\mathrm{~m}, 2 \mathrm{H}), 2.34(\mathrm{~s}, 3 \mathrm{H})$.

${ }^{13} \mathrm{C}$ NMR $\left(101 \mathrm{MHz}, \mathrm{CDCl}_{3}\right) \delta 136.2,129.2,125.0,122.0,119.32,119.30,111.5,109.3,81.4$, $79.9,35.9,14.2,9.8$.

FTIR $\left(\mathrm{cm}^{-1}\right)$ 3052, 2915, 1465, 1330, 1210, 1035, 740, 613.

HRMS (ESI) m/z, calcd for $\left[\mathrm{C}_{13} \mathrm{H}_{13} \mathrm{BrN}\right]^{+}: 262.0231$; found 262.0224 .

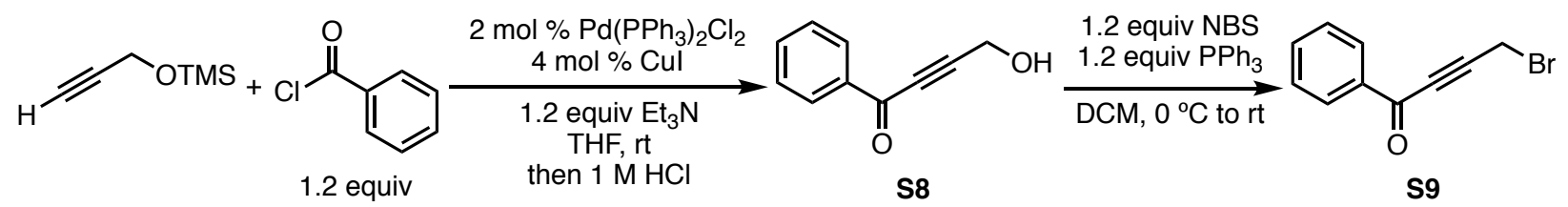

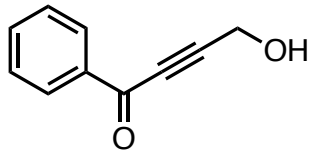

S8

Chemical Formula: $\mathrm{C}_{10} \mathrm{H}_{8} \mathrm{O}_{2}$

Exact Mass: 160.0524

Molecular Weight: 160.1720

S8: A flame-dried, 1-nk $250 \mathrm{~mL}$ round bottom flask was fitted with a stir bar and $\mathrm{Pd}\left(\mathrm{PPh}_{3}\right)_{2} \mathrm{Cl}_{2}(0.28 \mathrm{~g}, 0.4 \mathrm{mmol})$ and $\mathrm{Cul}(0.15 \mathrm{~g}, 0.8 \mathrm{mmol})$ were added. The flask was equipped with a rubber septum and attached to a double manifold using a rubber hose and a syringe. The atmosphere of the reactor was then replaced with $\mathrm{N}_{2}$ via five sequential cycles of evacuation and refill. Under positive $\mathrm{N}_{2}$, anhydrous THF (61 $\mathrm{mL}, 0.33 \mathrm{M})$ and anhydrous $\mathrm{Et}_{3} \mathrm{~N}(3.4 \mathrm{~mL}, 24 \mathrm{mmol})$ were added sequentially via syringe. Then, benzoyl chloride $(2.8 \mathrm{~mL}, 24 \mathrm{mmol})$ was added via syringe and stirred at rt for 10 mins, before trimethyl(prop-2-yn-1-yloxy)silane $(3.1 \mathrm{~mL}, 20 \mathrm{mmol})$ was added dropwise via syringe. The reaction was stirred rapidly at it for $17 \mathrm{~h}$, before the reaction was exposed to air and quenched by the addition of $\mathrm{NH}_{4} \mathrm{Cl}$ (100 $\mathrm{mL}$, saturated aqueous). The biphasic mixture was stirred for 5 mins, before being poured into a separatory funnel and rinsed with $\mathrm{Et}_{2} \mathrm{O}$ $(3 \times 10 \mathrm{~mL})$. The layers were separated, and the aqueous phase was extracted with $\mathrm{Et}_{2} \mathrm{O}(3 \times 50$ $\mathrm{mL}$ ). The combined organic layers were then washed with brine (100 mL, saturated aqueous), dried over $\mathrm{MgSO}_{4}$, filtered through a fritted funnel, and concentrated in vacuo to afford a crude oil. The crude product was purified by flash silica gel chromatography (90:10 hexanes:EtOAc) to afford a red-orange oil. The oil was diluted with non-anhydrous $\mathrm{Et}_{2} \mathrm{O}(150 \mathrm{~mL})$ and $\mathrm{HCl}(100 \mathrm{~mL}$, $1 \mathrm{M}$ aqueous) was added. The biphasic mixture was stirred rapidly for $30 \mathrm{~min}$, before being poured into a separatory funnel and rinsed with $\mathrm{Et}_{2} \mathrm{O}(3 \times 10 \mathrm{~mL})$. The layers were separated, and the aqueous phase was extracted with $\mathrm{Et}_{2} \mathrm{O}(3 \times 50 \mathrm{~mL})$. The combined organic layers were washed with brine, dried over $\mathrm{MgSO}_{4}$, filtered through a fritted funnel, and concentrated in vacuo to afford a crude oil. The crude product was purified by flash silica gel chromatography (50:50 hexanes: $\left.\mathrm{Et}_{2} \mathrm{O}\right)$ to afford $\mathbf{S 8}(2.4 \mathrm{~g}, 75 \%)$ as dark, orange oil.

The spectra for $\mathbf{S 8}$ are in accord with published data. ${ }^{19}$ 
${ }^{1} \mathrm{H}$ NMR $\left(400 \mathrm{MHz}, \mathrm{CDCl}_{3}\right) \delta 8.10-8.18(\mathrm{~m}, 2 \mathrm{H}), 7.58-7.66(\mathrm{~m}, 1 \mathrm{H}), 7.49(\mathrm{dd}, J=8.4,7.1 \mathrm{~Hz}$, $2 \mathrm{H}), 4.58$ (s, 2H), 2.31 (bs, 1H).

${ }^{13} \mathrm{C}$ NMR $\left(101 \mathrm{MHz}, \mathrm{CDCl}_{3}\right) \delta 177.9,136.3,134.6,129.8,128.8,92.3,83.5,51.2$.

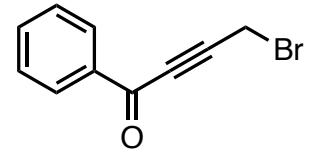

S9

Chemical Formula: $\mathrm{C}_{10} \mathrm{H}_{7} \mathrm{BrO}$

Exact Mass: 221.9680

Molecular Weight: 223.0690

S9: A 1-nk $50 \mathrm{~mL}$ round bottom flask was fitted with a stir bar and a rubber septum. The flask was equipped with a $\mathrm{N}_{2}$-filled balloon and purged using an outlet needle for $5 \mathrm{~min}$. Then, $\mathbf{S 8}(1.87 \mathrm{~g}, 11.7 \mathrm{mmol})$ and anhydrous DCM (33 mL, $0.36 \mathrm{M})$ were added via syringe and the reactor was cooled in an iced water bath. The rubber septum was momentarily removed and NBS $(2.49 \mathrm{~g}, 14 \mathrm{mmol})$ and $\mathrm{PPh}_{3}(3.67 \mathrm{~g}$, $14 \mathrm{mmol}$ ) were added sequentially in one portion. The cooling bath was removed, and the reaction was stirred at rt for $30 \mathrm{~min}$. The reaction was concentrated in vacuo and the crude product was purified by flash silica gel chromatography (95:5 hexanes: $\left.\mathrm{Et}_{2} \mathrm{O}\right)$ to afford S9 (1.74 g, 67\%) as light, orange solid.

${ }^{1} \mathrm{H}$ NMR $\left(600 \mathrm{MHz}, \mathrm{CDCl}_{3}\right) \delta 8.09-8.14(\mathrm{~m}, 2 \mathrm{H}), 7.60-7.66(\mathrm{~m}, 1 \mathrm{H}), 7.47-7.53(\mathrm{~m}, 2 \mathrm{H}), 4.13$ $(\mathrm{s}, 2 \mathrm{H})$.

${ }^{13} \mathrm{C}$ NMR $\left(151 \mathrm{MHz}, \mathrm{CDCl}_{3}\right) \delta 177.2,136.6,134.6,129.8,128.8,88.1,83.4,12.4$.

FTIR $\left(\mathrm{cm}^{-1}\right)$ 3009, 2960, 2248, 2209, 1650, 1597, 1449, 1314, 1275, 1214, 920, 697.

HRMS (ESI) m/z, calcd for [ $\left.\mathrm{C}_{10} \mathrm{H}_{8} \mathrm{BrO}\right]^{+}: 222.9759$; found 222.9756 .

$\mathrm{MP}: 47-50^{\circ} \mathrm{C}\left(\mathrm{Et}_{2} \mathrm{O}\right)$.

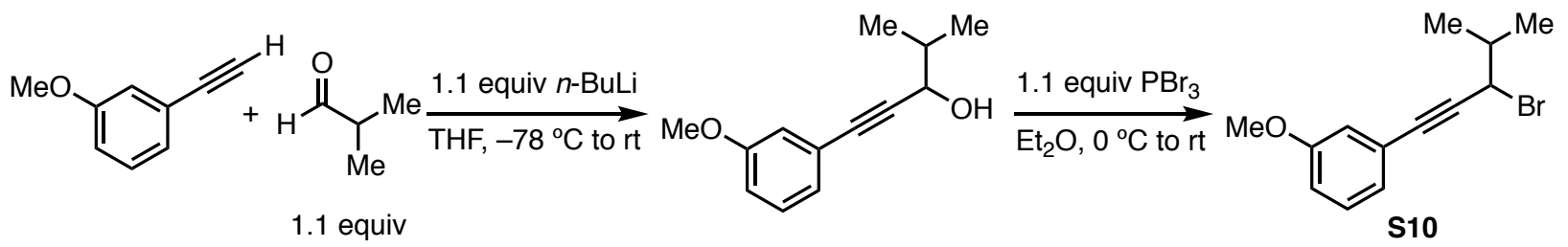

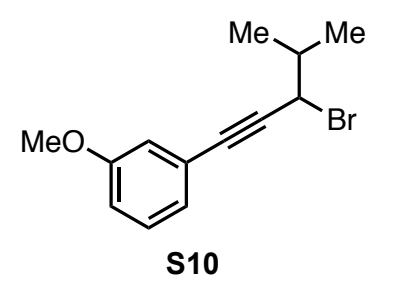

Chemical Formula: $\mathrm{C}_{13} \mathrm{H}_{15} \mathrm{BrO}$ Exact Mass: 266.0306 Molecular Weight: 267.1660

S10: According to General Procedure 6B, 1-ethynyl-3methoxybenzene $(2.5 \mathrm{~mL}, 20 \mathrm{mmol}), n$-BuLi $(8.8 \mathrm{~mL}, 22 \mathrm{mmol}, 2.5 \mathrm{M}$ in hexane), and isobutyraldehyde $(2.0 \mathrm{~mL}, 22 \mathrm{mmol})$ in anhydrous THF (53 mL, $0.38 \mathrm{M})$ for $12 \mathrm{~h}$, afforded the crude product $(4.0 \mathrm{~g}, 98 \%$ crude yield) as orange oil, which was used in the next step without further purification. ${ }^{1} \mathrm{H}$ and ${ }^{13} \mathrm{C}$ NMR data for identification purposes: ${ }^{1} \mathrm{H} \mathrm{NMR}\left(400 \mathrm{MHz}, \mathrm{CDCl}_{3}\right) \delta 7.22(\mathrm{t}, J=8.0 \mathrm{~Hz}, 1 \mathrm{H}), 7.03(\mathrm{dt}, J=7.6$, $1.2 \mathrm{~Hz}, 1 \mathrm{H}), 6.96(\mathrm{dd}, J=2.5,1.4 \mathrm{~Hz}, 1 \mathrm{H}), 6.87$ (ddd, $J=8.3,2.7,0.9$ $\mathrm{Hz}, 1 \mathrm{H}), 4.39(\mathrm{~d}, J=5.6 \mathrm{~Hz}, 1 \mathrm{H}), 3.80(\mathrm{~s}, 3 \mathrm{H}), 1.93-2.03(\mathrm{~m}, 1 \mathrm{H}), 1.88(\mathrm{bs}, 1 \mathrm{H}), 1.07(\mathrm{dd}, J=$ 8.5, 6.7 Hz, 6H). ${ }^{13} \mathrm{C}$ NMR $\left(101 \mathrm{MHz}, \mathrm{CDCl}_{3}\right) \delta 159.4,129.5,124.4,123.8,116.6,115.1,88.8$, 85.6, 68.5, 55.4, 34.8, 18.3, 17.7. 
According to General Procedure 5C, 1-(3-methoxyphenyl)-4-methylpent-1-yn-3-ol (1.31 $\mathrm{g}, 6.4 \mathrm{mmol})$ and $\mathrm{PBr}_{3}(0.70 \mathrm{~mL}, 7.0 \mathrm{mmol})$ in anhydrous $\mathrm{Et}_{2} \mathrm{O}(13 \mathrm{~mL}, 0.5 \mathrm{M})$ for $4 \mathrm{~h}$, afforded, after flash silica gel flash chromatography (97:3 hexanes:EtOAc), $\mathbf{S 1 0}(0.63 \mathrm{~g}, 37 \%)$ as yellow oil.

${ }^{1} \mathrm{H}$ NMR $\left(600 \mathrm{MHz}, \mathrm{CDCl}_{3}\right) \delta 7.22(\mathrm{t}, J=7.9 \mathrm{~Hz}, 1 \mathrm{H}), 7.04(\mathrm{dt}, J=7.6,1.1 \mathrm{~Hz}, 1 \mathrm{H}), 6.96(\mathrm{dd}, J=$ 2.6, $1.4 \mathrm{~Hz}, 1 \mathrm{H}$ ), 6.89 (ddd, $J=8.3,2.7,1.0 \mathrm{~Hz}, 1 \mathrm{H}$ ), 4.73 (d, J = 4.6 Hz, 1H), 3.80 (s, 3H), 2.15 (heptd, $J=6.6,4.6 \mathrm{~Hz}, 1 \mathrm{H}), 1.18(\mathrm{~d}, J=6.6 \mathrm{~Hz}, 3 \mathrm{H}), 1.16(\mathrm{~d}, J=6.7 \mathrm{~Hz}, 3 \mathrm{H})$.

${ }^{13} \mathrm{C}$ NMR $\left(151 \mathrm{MHz}, \mathrm{CDCl}_{3}\right) \delta 159.5,129.5,124.5,123.5,116.7,115.5,87.7,86.8,55.5,46.4$, $36.2,20.0,19.5$.

FTIR $\left(\mathrm{cm}^{-1}\right)$ 2965, 2871, 2225, 1575, 1465, 1291, 1165, 1045, 778, 685.

HRMS (ESI) m/z, calcd for $\left[\mathrm{C}_{13} \mathrm{H}_{16} \mathrm{BrO}^{+}:\right.$267.0385; found 267.0379.
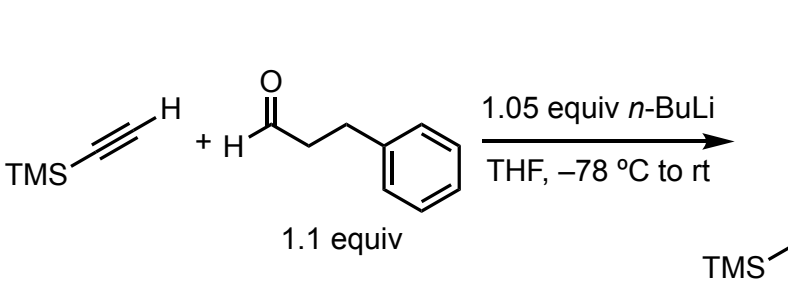

S11

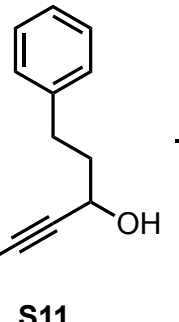

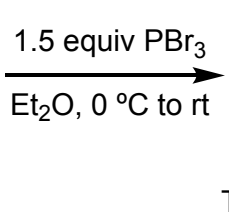

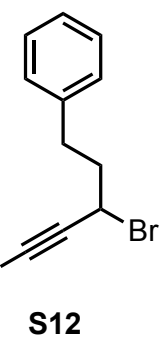

S11: According to General Procedure 6B, ethynyltrimethylsilane (6.9 $\mathrm{mL}, 50 \mathrm{mmol}$ ), $n$-BuLi (21 mL, $53 \mathrm{mmol}, 2.5 \mathrm{M}$ in hexane), and 3phenylpropanal $(7.2 \mathrm{~mL}, 55 \mathrm{mmol})$ in anhydrous THF $(132 \mathrm{~mL}, 0.38$ M) for $16 \mathrm{~h}$, afforded, after flash silica gel chromatography (80:20 hexanes: $\left.\mathrm{Et}_{2} \mathrm{O}\right), \mathbf{S} 11$ (9.4 g, 81\%) as clear, yellow oil.

${ }^{1} \mathrm{H} \mathrm{NMR}\left(600 \mathrm{MHz}, \mathrm{CDCl}_{3}\right) \delta 7.27-7.31(\mathrm{~m}, 2 \mathrm{H}), 7.18-7.23(\mathrm{~m}, 3 \mathrm{H})$, $4.36(\mathrm{q}, J=6.3 \mathrm{~Hz}, 1 \mathrm{H}), 2.77-2.84(\mathrm{~m}, 2 \mathrm{H}), 1.97-2.09(\mathrm{~m}, 2 \mathrm{H}), 1.81$ (bs, $1 \mathrm{H}), 0.19(\mathrm{~s}, 9 \mathrm{H})$.

Chemical Formula: $\mathrm{C}_{14} \mathrm{H}_{20} \mathrm{OSi}$

Exact Mass: 232.1283

Molecular Weight: 232.3980

${ }^{13} \mathrm{C}$ NMR $\left(151 \mathrm{MHz}, \mathrm{CDCl}_{3}\right) \delta 141.5,128.7,128.6,126.1,106.6,90.1,62.4,39.4,31.6,0.0$.

${ }^{29} \mathrm{Si}$ NMR $\left(119 \mathrm{MHz}, \mathrm{CDCl}_{3}\right) \delta-17.7$.

FTIR $\left(\mathrm{cm}^{-1}\right)$ 3336, 2957, 2172, 1496, 1250, 1047, 843, 699.

HRMS (ESI) m/z, calcd for [ $\left.\mathrm{C}_{14} \mathrm{H}_{21} \mathrm{OSi}\right]^{+}:$233.1362; found: 233.1359 . 


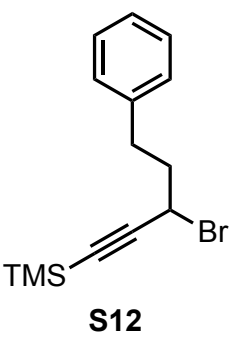

Chemical Formula: $\mathrm{C}_{14} \mathrm{H}_{19} \mathrm{BrSi}$

Exact Mass: 294.0439

Molecular Weight: 295.2950

S12: According to General Procedure 6C, S11 (2.8 g, $12.2 \mathrm{mmol})$ and $\mathrm{PBr}_{3}(1.7 \mathrm{~mL}, 18.3 \mathrm{mmol})$ in anhydrous $\mathrm{Et}_{2} \mathrm{O}(25 \mathrm{~mL}, 0.5 \mathrm{M})$ for $15 \mathrm{~h}$, afforded, after flash silica gel chromatography (hexanes), then Kugelrohr distillation, $\mathbf{S 1 2}(1.25 \mathrm{~g}, 35 \%)$ as clear, colorless oil.

${ }^{1} \mathrm{H} \mathrm{NMR}\left(600 \mathrm{MHz}, \mathrm{CDCl}_{3}\right) \delta 7.28-7.33(\mathrm{~m}, 2 \mathrm{H}), 7.19-7.24(\mathrm{~m}, 3 \mathrm{H})$, $4.45(\mathrm{t}, J=6.8 \mathrm{~Hz}, 1 \mathrm{H}), 2.81-2.90(\mathrm{~m}, 2 \mathrm{H}), 2.26-2.36(\mathrm{~m}, 2 \mathrm{H}), 0.20$ $(\mathrm{s}, 9 \mathrm{H})$.

${ }^{13} \mathrm{C}$ NMR $\left(101 \mathrm{MHz}, \mathrm{CD}_{2} \mathrm{Cl}_{2}\right) \delta 140.8,129.1,129.0,126.8,104.1,92.9$,

$41.8,37.2,33.9,-0.1$.

${ }^{29} \mathrm{Si}$ NMR $\left(119 \mathrm{MHz}, \mathrm{CDCl}_{3}\right) \delta-17.1$.

FTIR $\left(\mathrm{cm}^{-1}\right)$ 3064, 3027, 2959, 1496, 1454, 1250, 844, 699.

HRMS (LIFDI) m/z, calcd for [ $\left.\mathrm{C}_{14} \mathrm{H}_{19} \mathrm{BrSi}\right]^{+}:$294.0439; found: 294.0428.

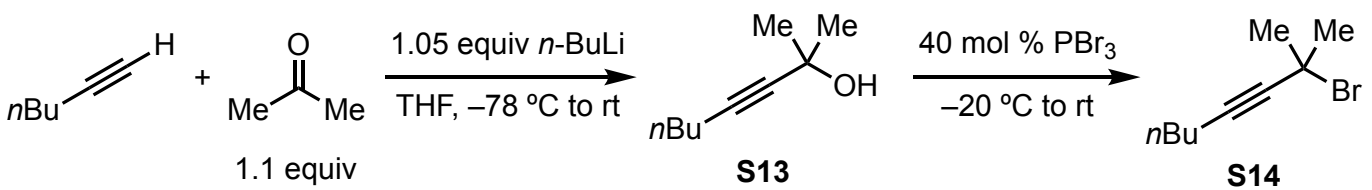

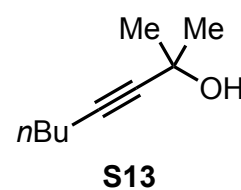

Chemical Formula: $\mathrm{C}_{9} \mathrm{H}_{16} \mathrm{O}$

Exact Mass: 140.1201

Molecular Weight: 140.2260
S13: According to General Procedure 6B, hex-1-yne (3.5 mL, $30 \mathrm{mmol})$, $n$-BuLi (12.6 mL, $32 \mathrm{mmol}, 2.5 \mathrm{M}$ in hexane), and acetone $(2.4 \mathrm{~mL}, 33$ mmol) in anhydrous THF ( $75 \mathrm{~mL}, 0.4 \mathrm{M})$ for $17 \mathrm{~h}$, afforded, after flash silica gel chromatography (80:20 hexanes: $\left.\mathrm{Et}_{2} \mathrm{O}\right), \mathbf{S 1 3}(2.9 \mathrm{~g}, 69 \%)$ as clear, yellow oil.

${ }^{1} \mathrm{H}$ NMR $\left(400 \mathrm{MHz}, \mathrm{CDCl}_{3}\right) \delta 2.17(\mathrm{t}, J=7.0 \mathrm{~Hz}, 2 \mathrm{H}), 1.95(\mathrm{dd}, J=5.9$, $3.5 \mathrm{~Hz}, 1 \mathrm{H}), 1.31-1.54(\mathrm{~m}, 10 \mathrm{H}), 0.90(\mathrm{t}, \mathrm{J}=7.2 \mathrm{~Hz}, 3 \mathrm{H})$.

${ }^{13} \mathrm{C} \mathrm{NMR}\left(101 \mathrm{MHz}, \mathrm{CDCl}_{3}\right) \delta 85.2,82.7,65.4,31.9,30.9,22.0,18.4,13.8$.

FTIR $\left(\mathrm{cm}^{-1}\right)$ 3348, 2959, 2933, 2873, 2361, 2337, 1027, 945.

HRMS (ESI) m/z, calcd for $\left[\mathrm{C}_{9} \mathrm{H}_{17} \mathrm{O}\right]^{+}:$141.1279; found: 141.1272 .

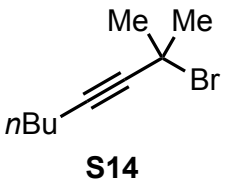

Chemical Formula: $\mathrm{C}_{9} \mathrm{H}_{15} \mathrm{Br}$ Exact Mass: 202.0357 Molecular Weight: 203.1230
S14: A flame-dried, 1-nk $50 \mathrm{~mL}$ round bottom flask was fitted with a stir bar and a rubber septum. The flask was equipped with a $\mathrm{N}_{2}$-filled balloon and purged using an outlet needle for 5 mins. Then, $\mathbf{S} 13(2.9 \mathrm{~g}, 21 \mathrm{mmol})$ was added and cooled in an ice/ $\mathrm{NaCl}$ bath. Then, $\mathrm{PBr}_{3}(0.8 \mathrm{~mL}, 8.4$ $\mathrm{mmol}$ ) was added dropwise via syringe. The reactor was warmed to $\mathrm{rt}$ and stirred rapidly for $1 \mathrm{~h}$. The crude reaction mixture was directly purified by short fractional distillation (initially at $\mathrm{rt}$ at $\sim 500$ mtorr to remove impurities, then heated to $50^{\circ} \mathrm{C}$ in a silicone oil bath at $\left.\sim 500 \mathrm{mtorr}\right)$ to afford $\mathbf{S 1 4}(2.1 \mathrm{~g}$, $49 \%$ ) as clear, light yellow oil. 
Note: S14 fumes and decomposes rapidly in air and should be stored cold inside a $\mathrm{N}_{2}$-filled glovebox.

${ }^{1} \mathrm{H} \mathrm{NMR}\left(600 \mathrm{MHz}, \mathrm{CDCl}_{3}\right) \delta 2.22(\mathrm{t}, J=7.1 \mathrm{~Hz}, 2 \mathrm{H}), 2.00(\mathrm{~s}, 6 \mathrm{H}), 1.46-1.52(\mathrm{~m}, 2 \mathrm{H}), 1.37-$ $1.44(\mathrm{~m}, 2 \mathrm{H}), 0.91(\mathrm{t}, J=7.3 \mathrm{~Hz}, 3 \mathrm{H})$.

${ }^{13} \mathrm{C}$ NMR $\left(101 \mathrm{MHz}, \mathrm{CDCl}_{3}\right) \delta 86.2,84.8,50.6,37.0,30.6,22.1,18.7,13.8$.

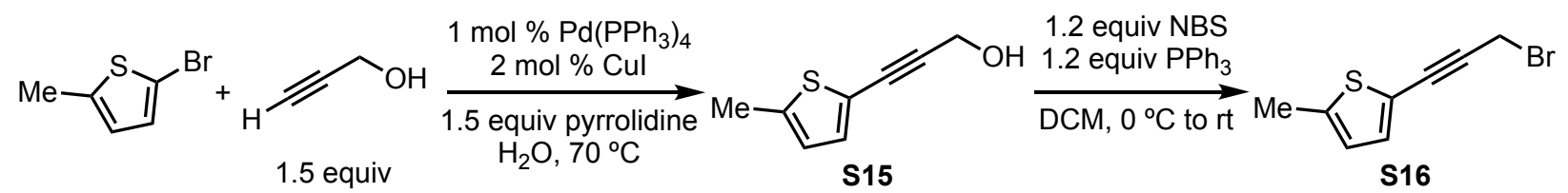

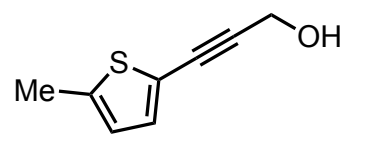

S15

Chemical Formula: $\mathrm{C}_{8} \mathrm{H}_{8} \mathrm{OS}$

Exact Mass: 152.0296

Molecular Weight: 152.2110

S15: In a $\mathrm{N}_{2}$-filled glovebox, an oven-dried, 1-nk $500 \mathrm{~mL}$ round bottom flask was fitted with a stir bar and $\mathrm{Pd}\left(\mathrm{PPh}_{3}\right)_{4}(350 \mathrm{mg}, 0.3 \mathrm{mmol})$ and Cul $(115 \mathrm{mg}, 0.6 \mathrm{mmol})$ were added. The flask was equipped with a reflux condenser and a rubber septum, and the flask was removed from the glovebox. The flask was then equipped with a $\mathrm{N}_{2}$-filled balloon and DI $\mathrm{H}_{2} \mathrm{O}(150 \mathrm{~mL}, 0.2 \mathrm{M})$ was added via syringe. Pyrrolidine $(3.8 \mathrm{~mL}, 45$ $\mathrm{mmol})$ and propargyl alcohol $(2.7 \mathrm{~mL}, 45 \mathrm{mmol})$ were then added sequentially via syringe and stirred for 5 mins, before 2-bromo-5-methylthiophene $(5.3 \mathrm{~g}, 30 \mathrm{mmol})$ was added dropwise via syringe. The reaction was then heated to $70^{\circ} \mathrm{C}$ in a silicone oil bath and stirred rapidly overnight. The resulting suspension was cooled to rt, diluted with EtOAc $(100 \mathrm{~mL})$, and the biphasic mixture was rapidly stirred for 5 mins, before being poured into a separatory funnel and rinsed with EtOAc $(3 \mathrm{X} 10 \mathrm{~mL})$. The layers were separated, and the aqueous phase was extracted with EtOAc (3X $50 \mathrm{~mL})$. The combined organic layers were then washed with brine $(100 \mathrm{~mL}$, saturated aqueous), dried over $\mathrm{MgSO}_{4}$, filtered through a fritted funnel, and concentrated in vacuo to afford a crude oil. The crude product was purified by flash silica gel chromatography (80:20 hexanes:EtOAc) to afford S15 (3.4 g, 74\%) as dark, orange oil.

${ }^{1} \mathrm{H}$ NMR $\left(400 \mathrm{MHz}, \mathrm{CDCl}_{3}\right) \delta 7.01(\mathrm{~d}, J=3.6 \mathrm{~Hz}, 1 \mathrm{H}), 6.61(\mathrm{dt}, J=3.5,1.1 \mathrm{~Hz}, 1 \mathrm{H}), 4.49(\mathrm{~s}, 2 \mathrm{H})$, $2.45(\mathrm{~s}, 3 \mathrm{H}), 1.82(\mathrm{bs}, 1 \mathrm{H})$.

${ }^{13} \mathrm{C}$ NMR $\left(101 \mathrm{MHz}, \mathrm{CDCl}_{3}\right) \delta$ 142.5, 132.8, 125.4, 120.0, 90.4, 79.6, 51.9, 15.5.

FTIR $\left(\mathrm{cm}^{-1}\right)$ 3325, 2919, 1439, 1194, 1117, 799.

HRMS (ESI) m/z, calcd for $\left[\mathrm{C}_{8} \mathrm{H}_{9} \mathrm{OS}\right]^{+} 153.0374$; found 153.0370 .

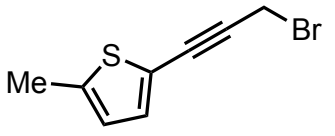

S16

Chemical Formula: $\mathrm{C}_{8} \mathrm{H}_{7} \mathrm{BrS}$

Exact Mass: 213.9452

Molecular Weight: 215.1080
S16: A flame-dried, 1-nk $50 \mathrm{~mL}$ round bottom flask was fitted with a stir bar and a rubber septum. The flask was equipped with a $\mathrm{N}_{2}$-filled balloon and purged using an outlet needle for 5 mins. Then, S15 (1.52 $\mathrm{g}, 10 \mathrm{mmol})$ and anhydrous DCM $(28 \mathrm{~mL}, 0.36 \mathrm{M})$ were added sequentially via syringe and the reactor was cooled in an iced water bath. While stirring, the rubber septum was momentarily removed and NBS $(2.14 \mathrm{~g}, 12 \mathrm{mmol})$ and $\mathrm{PPh}_{3}(3.15 \mathrm{~g}, 12 \mathrm{mmol})$ were added sequentially in one portion. The cooling bath was removed, and the reaction was stirred at rt for $1 \mathrm{~h}$. The reaction was 
concentrated in vacuo and the crude product was purified by flash silica gel chromatography (98:2 hexanes: $\left.\mathrm{Et}_{2} \mathrm{O}\right)$, then Kugelrohr distillation to afford $\mathrm{S} 16(0.98 \mathrm{~g}, 46 \%)$ as clear, yellow oil.

Note: At times during column chromatography, the column turned black and the desired product decomposed.

${ }^{1} \mathrm{H}$ NMR $\left(400 \mathrm{MHz}, \mathrm{CDCl}_{3}\right) \delta 7.05(\mathrm{~d}, \mathrm{~J}=3.6 \mathrm{~Hz}, 1 \mathrm{H}), 6.63(\mathrm{~d}, \mathrm{~J}=3.5 \mathrm{~Hz}, 1 \mathrm{H}), 4.18(\mathrm{~s}, 2 \mathrm{H}), 2.46$ $(\mathrm{s}, 3 \mathrm{H})$.

${ }^{13} \mathrm{C}$ NMR $\left(101 \mathrm{MHz}, \mathrm{CDCl}_{3}\right) \delta 143.2,133.5,125.5,119.6,87.5,80.8,15.9,15.6$.

FTIR $\left(\mathrm{cm}^{-1}\right)$ 3072, 2919, 2216, 1205, 1031, 799.

HRMS (ESI) m/z, calcd for $\left[\mathrm{C}_{8} \mathrm{H}_{8} \mathrm{BrS}\right]^{+}:$214.9525; found: 214.9531.

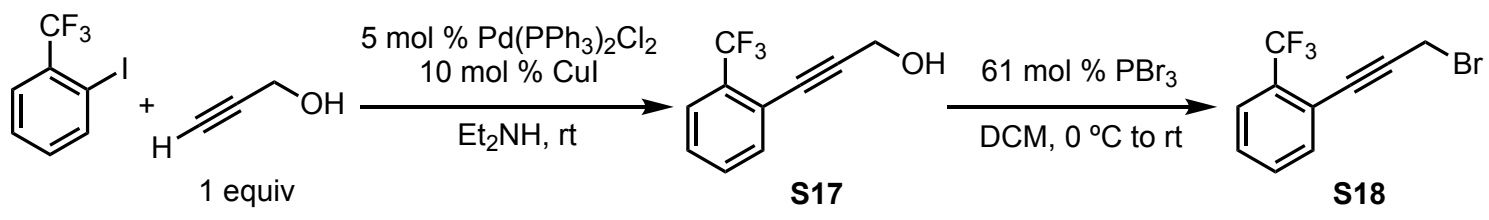

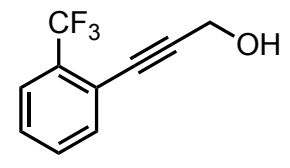

S17

Chemical Formula: $\mathrm{C}_{10} \mathrm{H}_{7} \mathrm{~F}_{3} \mathrm{O}$ Exact Mass: 200.0449 Molecular Weight: 200.1602

S17: According to General Procedure 6A, $\mathrm{Pd}\left(\mathrm{PPh}_{3}\right)_{2} \mathrm{Cl}_{2}(0.702 \mathrm{~g}, 1.0$ $\mathrm{mmol})$, Cul (0.381 g, $2.0 \mathrm{mmol})$, 3-(2-(trifluoromethyl)phenyl)prop-2yn-1-ol (2.8 mL, $20 \mathrm{mmol})$, and propargyl alcohol $(1.2 \mathrm{~mL}, 20 \mathrm{mmol})$ in anhydrous $\mathrm{Et}_{2} \mathrm{NH}(33 \mathrm{~mL}, 0.6 \mathrm{M})$ for $19 \mathrm{~h}$, afforded, after flash silica gel chromatography (DCM), $\mathbf{S} 17(3.44 \mathrm{~g}, 86 \%)$ as orange oil.

${ }^{1} \mathrm{H}$ NMR $\left(600 \mathrm{MHz}, \mathrm{CDCl}_{3}\right) \delta 7.65(\mathrm{~d}, J=7.8 \mathrm{~Hz}, 1 \mathrm{H}), 7.58(\mathrm{~d}, J=7.7$ $\mathrm{Hz}, 1 \mathrm{H}), 7.49$ (t, $J=7.6 \mathrm{~Hz}, 1 \mathrm{H}), 7.41$ (t, $J=7.7 \mathrm{~Hz}, 1 \mathrm{H}), 4.53(\mathrm{~d}, J=6.3 \mathrm{~Hz}, 2 \mathrm{H}), 1.76(\mathrm{bs}, 1 \mathrm{H})$.

${ }^{13} \mathrm{C}$ NMR $\left(151 \mathrm{MHz}, \mathrm{CDCl}_{3}\right) \delta 134.2,131.8(\mathrm{q}, J=30.1 \mathrm{~Hz}), 131.5,128.4,126.0(\mathrm{q}, J=5.1 \mathrm{~Hz})$, 123.6 (q, $J=273.4 \mathrm{~Hz}), 121.0,93.0,81.8,51.8$.

${ }^{19} \mathrm{~F}$ NMR $\left(565 \mathrm{MHz}, \mathrm{CDCl}_{3}\right) \delta-62.3$.

FTIR $\left(\mathrm{cm}^{-1}\right)$ 3327, 2868, 1491, 1319, 1133, 1034, 765.

HRMS (El) m/z, calcd for $\left[\mathrm{C}_{10} \mathrm{H}_{7} \mathrm{~F}_{3} \mathrm{O}\right]^{+}:$200.0449; found: 200.0456 .

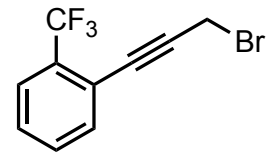

S18

Chemical Formula: $\mathrm{C}_{10} \mathrm{H}_{6} \mathrm{BrF}_{3}$

Exact Mass: 261.9605

Molecular Weight: 263.0572
S18: According to General Procedure 6C, S17 (3.38 g, $12.8 \mathrm{mmol})$ and $\mathrm{PBr}_{3}(0.73 \mathrm{~mL}, 7.8 \mathrm{mmol})$ in anhydrous $\mathrm{DCM}(36 \mathrm{~mL}, 0.36 \mathrm{M})$ for $3 \mathrm{~h}$, afforded, after flash silica gel chromatography (hexanes), S18 $(2.37 \mathrm{~g}, 70 \%)$ as colorless oil.

${ }^{1} \mathrm{H}$ NMR $\left(600 \mathrm{MHz}, \mathrm{CDCl}_{3}\right) \delta 7.66(\mathrm{~d}, J=7.9 \mathrm{~Hz}, 1 \mathrm{H}), 7.59(\mathrm{~d}, J=7.7$ $\mathrm{Hz}, 1 \mathrm{H}), 7.50$ (t, J = 7.6 Hz, 1H), 7.43 (t, J=7.7 Hz, 1H), $4.17(\mathrm{~s}, 2 \mathrm{H})$.

${ }^{13} \mathrm{C}$ NMR $\left(101 \mathrm{MHz}, \mathrm{CDCl}_{3}\right) \delta 134.4,131.9$ (q, J = 30.8 Hz), 131.5, 128.8, 126.0 (q, J = 5.1 Hz), 123.5 (q, J = 274.4 Hz), 120.5 (q, J = 2.1 Hz), 89.7, 82.5, 14.7. 
${ }^{19} \mathrm{~F} \mathrm{NMR}\left(565 \mathrm{MHz}, \mathrm{CDCl}_{3}\right) \delta-62.3$.

FTIR $\left(\mathrm{cm}^{-1}\right)$ 2361, 2337, 1604, 1492, 1320, 1134, 1062, 765.

HRMS (LIFDI) m/z, calcd for $\left[\mathrm{C}_{10} \mathrm{H}_{6} \mathrm{BrF}_{3}\right]^{+}:$261.9605; found: 261.9603 .

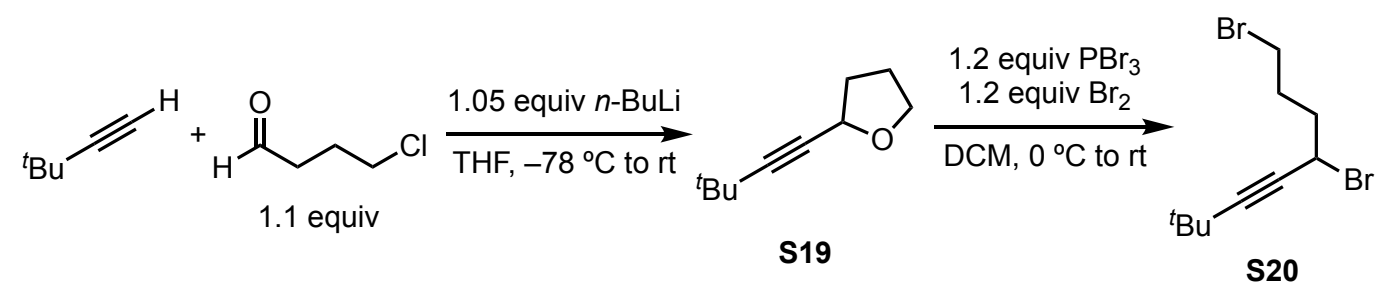

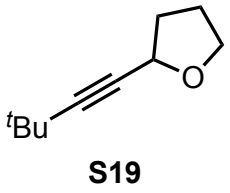

Chemical Formula: $\mathrm{C}_{10} \mathrm{H}_{16} \mathrm{O}$

Exact Mass: 152.1201

Molecular Weight: 152.2370
S19: According to General Procedure 6B, 3,3-dimethylbut-1-yne (1.4 $\mathrm{g}, 17 \mathrm{mmol}), n$-BuLi $(7.2 \mathrm{~mL}, 17.9 \mathrm{mmol}, 2.5 \mathrm{M}$ in hexane), and 4chlorobutanal $(2.0 \mathrm{~g}, 18.8 \mathrm{mmol})$ in anhydrous THF $(85 \mathrm{~mL}, 0.2 \mathrm{M})$ for $20 \mathrm{~h}$, afforded, after Kugelrohr distillation, $\mathbf{S 1 9}(2.0 \mathrm{~g}, 77 \%)$ as clear, colorless oil.

${ }^{1} \mathrm{H}$ NMR $\left(400 \mathrm{MHz}, \mathrm{CDCl}_{3}\right) \delta 4.53(\mathrm{dd}, J=6.9,5.7 \mathrm{~Hz}, 1 \mathrm{H}), 3.89-3.98$

$(\mathrm{m}, 1 \mathrm{H}), 3.72-3.80(\mathrm{~m}, 1 \mathrm{H}), 2.05-2.16(\mathrm{~m}, 1 \mathrm{H}), 1.94-2.05(\mathrm{~m}, 1 \mathrm{H}), 1.79-1.94(\mathrm{~m}, 2 \mathrm{H}), 1.20$ $(\mathrm{s}, 9 \mathrm{H})$.

${ }^{13} \mathrm{C}$ NMR $\left(101 \mathrm{MHz}, \mathrm{CDCl}_{3}\right) \delta 93.5,78.3,68.6,67.7,33.8,31.1,27.5,25.5$.

FTIR $\left(\mathrm{cm}^{-1}\right)$ 2969, 2869, 2237, 1457, 1362, 1265, 1053, 913.

HRMS (LIFDI) m/z, calcd for $\left[\mathrm{C}_{10} \mathrm{H}_{16} \mathrm{O}\right]^{+}:$152.1201; found: 152.1190 .

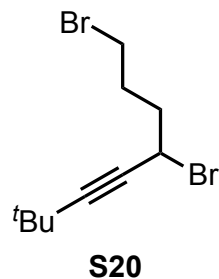

Chemical Formula: $\mathrm{C}_{10} \mathrm{H}_{16} \mathrm{Br}_{2}$

Exact Mass: 293.9619

Molecular Weight: 296.0460

S20: A flame-dried, 1-nk $50 \mathrm{~mL}$ round bottom flask was fitted with a stir bar and a rubber septum. The flask was then equipped with a $\mathrm{N}_{2}$-filled balloon and purged with an outlet needle for 5 mins. Anhydrous DCM $(22 \mathrm{~mL}, 0.36 \mathrm{M})$ and $\mathrm{PBr}_{3}(0.9 \mathrm{~mL}, 9.5 \mathrm{mmol})$ were sequentially added via syringe and the reactor was cooled in an iced water bath. While stirring rapidly, $\mathrm{Br}_{2}(0.5 \mathrm{~mL}, 9.5 \mathrm{mmol})$ was added dropwise via syringe and the mixture was stirred at $0^{\circ} \mathrm{C}$ for 30 mins. Then, $\mathbf{S 1 9}(1.5 \mathrm{~g}, 8.0$ $\mathrm{mmol}$ ) was added dropwise via syringe and the reaction was stirred for $15 \mathrm{~h}$ while slowly warming to rt. The reaction was diluted with DCM $(10 \mathrm{~mL})$, re-cooled in an iced water bath, and carefully quenched with $\mathrm{NaHCO}_{3}(20 \mathrm{~mL}$, saturated aqueous, Note: vigorous bubbling). The biphasic mixture was stirred for 5 mins, before being poured into a separatory funnel and rinsed with DCM $(3 \times 10 \mathrm{~mL})$. The layers were separated, and the aqueous phase was extracted with DCM (3 X $20 \mathrm{~mL})$. The combined organic layers were then washed with brine (20 $\mathrm{mL}$, saturated aqueous), dried over $\mathrm{MgSO}_{4}$, filtered through a fritted funnel, and concentrated in vacuo to afford a crude oil. The crude product was purified by flash silica gel chromatography (hexanes) to afford $\mathbf{S 2 0}(0.90 \mathrm{~g}, 38 \%)$ as clear, colorless oil.

${ }^{1} \mathrm{H}$ NMR $\left(400 \mathrm{MHz}, \mathrm{CDCl}_{3}\right) \delta 4.58-4.62(\mathrm{~m}, 1 \mathrm{H}), 3.42-3.49(\mathrm{~m}, 2 \mathrm{H}), 2.06-2.18(\mathrm{~m}, 4 \mathrm{H}), 1.21$ $(\mathrm{s}, 9 \mathrm{H})$. 
${ }^{13} \mathrm{C}$ NMR $\left(101 \mathrm{MHz}, \mathrm{CD}_{2} \mathrm{Cl}_{2}\right) \delta$ 97.3, 77.9, 39.1, 38.0, 33.3, 30.94, 30.91, 28.1.

FTIR $\left(\mathrm{cm}^{-1}\right)$ 2969, 2930, 2237, 1456, 1363, 1264, 1204, 768, 675.

HRMS (LIFDI) m/z, calcd for $\left[\mathrm{C}_{10} \mathrm{H}_{16} \mathrm{Br}_{2}\right]^{+}:$293.9619; found: 293.9645 .

\section{Preparation of Starting Nitroalkanes}

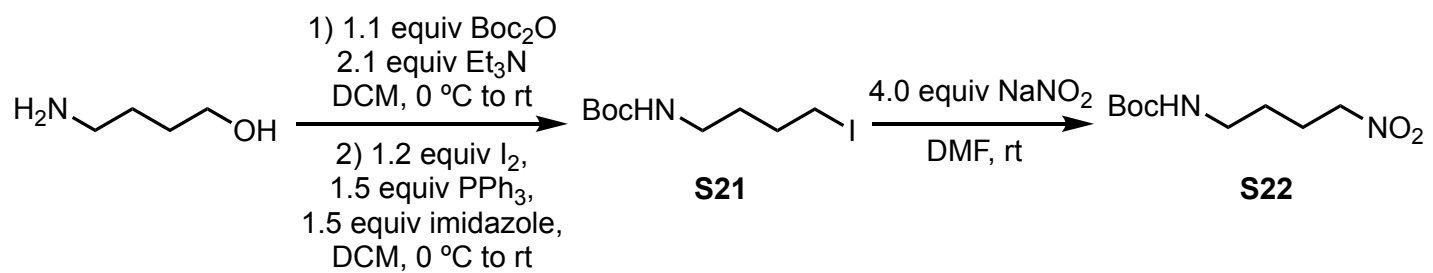

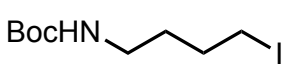

S21

Chemical Formula: $\mathrm{C}_{9} \mathrm{H}_{18} \mathrm{INO}_{2}$

Exact Mass: 299.0382

Molecular Weight: 299.1525

S21 was prepared according to a known procedure. ${ }^{20}$

${ }^{1} \mathrm{H} \mathrm{NMR}\left(400 \mathrm{MHz}, \mathrm{CDCl}_{3}\right) \delta 4.53$ (bs, $\left.1 \mathrm{H}\right), 3.20(\mathrm{t}, J=6.9 \mathrm{~Hz}, 2 \mathrm{H})$, $3.14(\mathrm{q}, J=6.7 \mathrm{~Hz}, 2 \mathrm{H}), 1.80-1.90(\mathrm{~m}, 2 \mathrm{H}), 1.54-1.64(\mathrm{~m}, 2 \mathrm{H}), 1.44$ $(\mathrm{s}, 9 \mathrm{H})$.

${ }^{13} \mathrm{C}$ NMR $\left(101 \mathrm{MHz}, \mathrm{CDCl}_{3}\right) \delta$ 156.1, 79.4, 39.6, 31.2, 30.8, 28.6, 6.4.

FTIR $\left(\mathrm{cm}^{-1}\right)$ 3345, 2976, 2932, 1691, 1523, 1365, 1274, 1251, 1172.

HRMS (ESI) m/z, calcd for $\left[\mathrm{C}_{9} \mathrm{H}_{19} \mathrm{O}_{2} \mathrm{NI}\right]^{+}: 300.0460$; found: 300.0441 .

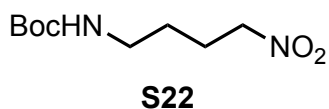

Chemical Formula: $\mathrm{C}_{9} \mathrm{H}_{18} \mathrm{~N}_{2} \mathrm{O}_{4}$

Exact Mass: 218.1267

Molecular Weight: 218.2530
S22: A 1-nk $250 \mathrm{~mL}$ round bottom flask was equipped with a stir bar, a rubber septum, and a $\mathrm{N}_{2}$-filled balloon. The system was purged with $\mathrm{N}_{2}$ and an outlet needle for 5 mins, before $\mathbf{S 2 1}$ (3.09 g, $10.3 \mathrm{mmol}$ ) and anhydrous DMF (21 mL, $0.5 \mathrm{M})$ were added via syringe. While stirring, the rubber septum was momentarily removed and $\mathrm{NaNO}_{2}$

$(2.85 \mathrm{~g}, 41.2 \mathrm{mmol})$ was added in 4 portions over $10 \mathrm{mins}$. The reaction mixture was stirred rapidly at rt until completion by TLC analysis. $\mathrm{DI} \mathrm{H}_{2} \mathrm{O}(50 \mathrm{~mL})$ was then added to the reaction and the resulting biphasic mixture was stirred for $5 \mathrm{~min}$, before being poured into a separatory funnel and rinsed with $\mathrm{Et}_{2} \mathrm{O}(10 \mathrm{~mL})$. The layers were separated, and the aqueous phase was extracted with $\mathrm{Et}_{2} \mathrm{O}(3 \times 30 \mathrm{~mL})$. The combined organic layers were then washed with brine $(50 \mathrm{~mL}$, saturated aqueous), dried over MgSO4, filtered through a fritted funnel, and concentrated in vacuo to afford crude oil. The crude product was purified by flash silica gel chromatography (gradient, 90:10 to 85:15 hexanes: EtOAc) to afford $\mathbf{S 2 2}(0.680 \mathrm{~g}, 30 \%)$ as clear, yellow oil.

${ }^{1} \mathrm{H}$ NMR $\left(600 \mathrm{MHz}, \mathrm{CDCl}_{3}\right) \delta 4.67(\mathrm{bs}, 1 \mathrm{H}), 4.39(\mathrm{t}, J=7.0 \mathrm{~Hz}, 2 \mathrm{H}), 3.14(\mathrm{q}, J=6.8 \mathrm{~Hz}, 2 \mathrm{H}), 2.01$ (p, J=7.1 Hz, 2H), 1.55 (p, J=7.0 Hz, 2H), 1.41 (s, 9H).

${ }^{13} \mathrm{C}$ NMR $(151 \mathrm{MHz}, \mathrm{CDCl} 3) \delta 156.1,79.5,75.2,39.6,28.5,27.1,24.6$.

FTIR $\left(\mathrm{cm}^{-1}\right)$ 3352, 2978, 1698, 1554, 1367, 1172.

HRMS (ESI) m/z, calcd for [ $\left.\mathrm{C}_{9} \mathrm{H}_{19} \mathrm{~N}_{2} \mathrm{O}_{4}\right]^{+}:$: 219.1345; found: 219.1335 . 


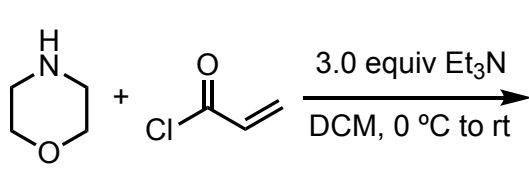

1.5 equiv<smiles>CCC(CCC(=O)N1CCOCC1)[N+](=O)[O-]</smiles>

S23

Chemical Formula: $\mathrm{C}_{10} \mathrm{H}_{18} \mathrm{~N}_{2} \mathrm{O}_{4}$ Exact Mass: 230.1267

Molecular Weight: 230.2640

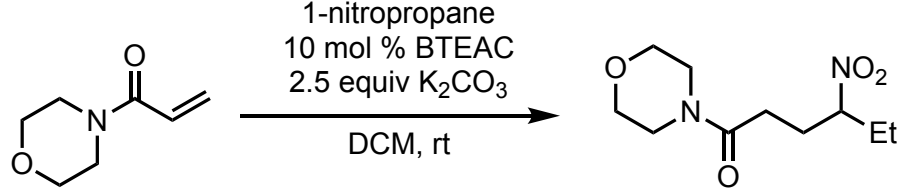

s23

S23: A flame-dried, 1-nk $250 \mathrm{~mL}$ round bottom flask was fitted with a stir bar and a rubber septum and the system was purged with a $\mathrm{N}_{2-}$ filled balloon and an outlet needle for 5 mins. Acryloyl chloride $(2.44$ $\mathrm{mL}, 30 \mathrm{mmol})$ and anhydrous $\mathrm{DCM}(61 \mathrm{~mL}, 0.33 \mathrm{M})$ were added to the reactor via syringe and cooled in an iced water bath. While stirring, morpholine $(1.75 \mathrm{~mL}, 20 \mathrm{mmol})$ and anhydrous $\mathrm{Et}_{3} \mathrm{~N}(8.4 \mathrm{~mL}$, $60 \mathrm{mmol}$ ) were added sequentially via syringe. The cooling bath was removed, and the reaction was stirred rapidly at $\mathrm{rt}$ for $2 \mathrm{~h}$. The reaction was concentrated in vacuo and diluted with non-anhydrous $\mathrm{Et}_{2} \mathrm{O}(100 \mathrm{~mL})$. The resulting suspension was filtered through a fritted funnel and the filter cake was washed with non-anhydrous $\mathrm{Et}_{2} \mathrm{O}(3 \times 20 \mathrm{~mL})$. The filtrate was concentrated in vacuo to afford 1-morpholinoprop-2-en-1-one (2.8 g, 99\% crude yield) as a clear, orange oil. The crude product was used in the next step without further purification. ${ }^{1} \mathrm{H}$ NMR data for identification purposes: ${ }^{1} \mathrm{H}$ NMR $\left(400 \mathrm{MHz} \mathrm{CDCl}_{3}\right) \delta 6.53(\mathrm{dd}, J=16.8,10.5 \mathrm{~Hz}, 1 \mathrm{H}$ ), $6.31(\mathrm{~d}, J=16.9 \mathrm{~Hz}, 1 \mathrm{H}), 5.71(\mathrm{~d}, J=10.5 \mathrm{~Hz}, 1 \mathrm{H}), 3.68(\mathrm{~s}, 6 \mathrm{H}), 3.56$ (bs, 2H).

A 1-nk $250 \mathrm{~mL}$ round bottom flask was fitted with a stir bar and $\mathrm{K}_{2} \mathrm{CO}_{3}(6.12 \mathrm{~g}, 44.3 \mathrm{mmol})$ and benzyltriethylammonium chloride $(0.41 \mathrm{~g}, 1.8 \mathrm{mmol})$ were added. The flask was fitted with a rubber septum and a $\mathrm{N}_{2}$-filled balloon. Non-anhydrous DCM $(98.0 \mathrm{~mL}, 0.18 \mathrm{M})$ and 1-nitropropane $(1.6 \mathrm{~mL}, 17.7 \mathrm{mmol})$ were added sequentially via syringe and stirred rapidly at rt for $15 \mathrm{mins}$. The crude 1-morpholinoprop-2-en-1-one $(3.28 \mathrm{~g}, 23 \mathrm{mmol})$ was then added dropwise via syringe and the reaction was stirred rapidly at $\mathrm{rt}$ for $21 \mathrm{~h}$. The reaction mixture was filtered through a pad of celite, washed with DCM $(3 \times 20 \mathrm{~mL})$, and concentrated in vacuo to afford a crude oil. The crude product was purified by flash silica gel chromatography (50:50 EtOAc:DCM) to afford $\mathbf{S 2 3}$ (0.686 $\mathrm{g}, 17 \%)$ as clear, yellow oil.

${ }^{1} \mathrm{H}$ NMR $\left(400 \mathrm{MHz}, \mathrm{CDCl}_{3}\right) \delta 4.53(\mathrm{tt}, \mathrm{J}=9.2,4.4 \mathrm{~Hz}, 1 \mathrm{H}), 3.64-3.70(\mathrm{~m}, 4 \mathrm{H}), 3.61(\mathrm{t}, J=4.0 \mathrm{~Hz}$, $2 \mathrm{H}), 3.38-3.43(\mathrm{~m}, 2 \mathrm{H}), 2.11-2.40(\mathrm{~m}, 4 \mathrm{H}), 1.94-2.08(\mathrm{~m}, 1 \mathrm{H}), 1.76-1.90(\mathrm{~m}, 1 \mathrm{H}), 0.97(\mathrm{t}, J$ $=7.4 \mathrm{~Hz}, 3 \mathrm{H})$.

${ }^{13} \mathrm{C}$ NMR $\left(101 \mathrm{MHz}, \mathrm{CDCl}_{3}\right) \delta 169.5,89.9,67.0,66.6,45.8,42.2,28.8,28.7,27.6,10.4$.

FTIR $\left(\mathrm{cm}^{-1}\right)$ 2971, 2932, 2858, 1648, 1547, 1438, 1116.

HRMS (ESI) m/z, calcd for $\left[\mathrm{C}_{10} \mathrm{H}_{19} \mathrm{~N}_{2} \mathrm{O}_{4}\right]^{+}:$231.1345; found: 231.1329 .

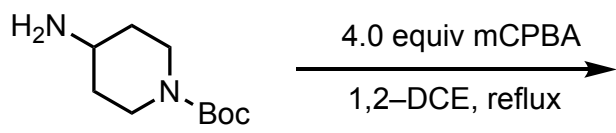<smiles>CC(C)(C)OC(=O)N1CCC(C(=O)O)CC1</smiles> 


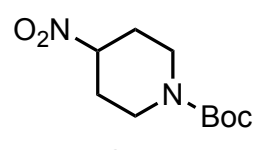

S24

Chemical Formula: $\mathrm{C}_{10} \mathrm{H}_{18} \mathrm{~N}_{2} \mathrm{O}_{4}$

Exact Mass: 230.1267

Molecular Weight: 230.2640

S24: A 1-nk $500 \mathrm{~mL}$ round bottom flask was fitted with a stir bar and mCPBA (13.8 g, $80 \mathrm{mmol}, 75 \%$ pure) was added. The reaction flask was equipped with a condenser and non-anhydrous 1,2-DCE (133 $\mathrm{mL}, 0.15 \mathrm{M}$ ) was added via syringe under air. Then, tert-butyl 4aminopiperidine-1-carboxylate $(4.0 \mathrm{~g}, 20 \mathrm{mmol})$ in non-anhydrous $1,2-\mathrm{DCE}(10 \mathrm{~mL}, 2 \mathrm{M})$ was added dropwise via syringe. The resulting solution was stirred rapidly under reflux for $22 \mathrm{~h}$. The reaction mixture was cooled to rt, filtered through a fritted funnel, and poured into a separatory funnel. The filtrate was washed with $\mathrm{NaOH}$ ( $3 \times 20 \mathrm{~mL}, 1 \mathrm{M}$ aqueous), dried over $\mathrm{MgSO}_{4}$, filtered through a fritted funnel, and concentrated in vacuo to afford a crude dark oil. The crude product was purified by flash silica gel chromatography (60:40 hexanes:EtOAc) to afford $\mathbf{S 2 4}(0.780 \mathrm{~g}, 17 \%)$ as clear, yellow oil.

${ }^{1} \mathrm{H}$ NMR $\left(400 \mathrm{MHz}, \mathrm{CDCl}_{3}\right) \delta 4.48(\mathrm{tt}, J=10.1,4.2 \mathrm{~Hz}, 1 \mathrm{H}), 3.88-4.13(\mathrm{~m}, 2 \mathrm{H}), 2.88-3.05(\mathrm{~m}$, $2 \mathrm{H}), 2.10-2.28(\mathrm{~m}, 2 \mathrm{H}), 1.93-2.09(\mathrm{~m}, 2 \mathrm{H}), 1.43(\mathrm{~s}, 9 \mathrm{H})$.

$\left.{ }^{13} \mathrm{C} \mathrm{NMR} \mathrm{(101} \mathrm{MHz,} \mathrm{CDCl}_{3}\right) \delta$ 154.4, 82.0, 80.3, 29.8, 28.4.

FTIR $\left(\mathrm{cm}^{-1}\right)$ 2977, 2934, 1696, 1550, 1422, 1367, 1238, 1170.

HRMS (LIFDI) m/z, calcd for $\left[\mathrm{C}_{10} \mathrm{H}_{18} \mathrm{~N}_{2} \mathrm{O}_{4}\right]^{+} 230.1267$; found 230.1264 .

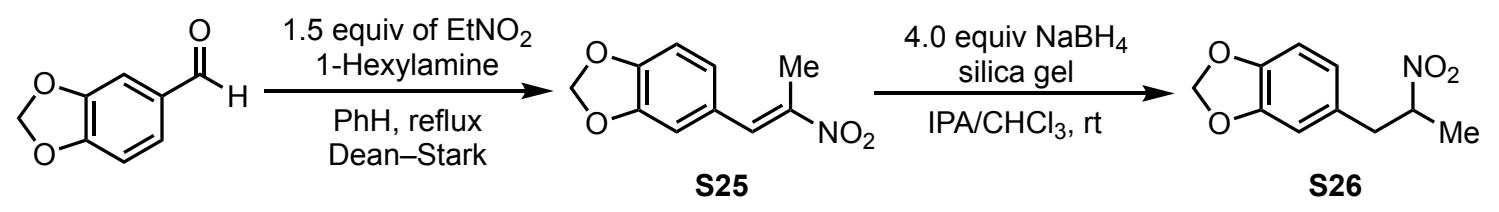

S25 is a known compound and its spectra are in accord with published data. ${ }^{21,22} \mathrm{~A}$ known procedure was modified to prepare $\mathbf{S} 25 .{ }^{23}$

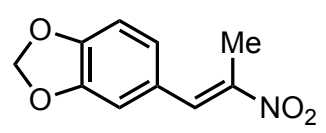

S25

Chemical Formula: $\mathrm{C}_{10} \mathrm{H}_{9} \mathrm{NO}_{4}$

Exact Mass: 207.0532

Molecular Weight: 207.1850

S25: A 1-nk $50 \mathrm{~mL}$ round bottom flask was fitted with a stir bar and piperonal $(7.5 \mathrm{~g}, 50 \mathrm{mmol})$ was added. Under air, non-anhydrous $\mathrm{PhH}$ $(20 \mathrm{~mL}, 2.5 \mathrm{M})$, nitroethane $(5.6 \mathrm{~g}, 75 \mathrm{mmol})$, and 1-hexylamine $(1 \mathrm{~mL}$, $50 \mathrm{M}$ ) were added sequentially via syringe at $\mathrm{rt}$. The flask was equipped with a Dean-Stark apparatus and stirred rapidly under reflux for $24 \mathrm{~h}$. The reaction was cooled to $\mathrm{rt}$, poured into a separatory funnel, rinsed with EtOAc $(3 \times 10 \mathrm{~mL})$, and diluted with additional EtOAc $(100 \mathrm{~mL})$. The organic phase was washed with $\mathrm{HCl}\left(100 \mathrm{~mL}, 1 \mathrm{M}\right.$ aqueous), dried over $\mathrm{MgSO}_{4}$, filtered through a fritted funnel, and concentrated in vacuo to afford crude product. The crude product was crystallized from $\mathrm{MeOH}$ $(50 \mathrm{~mL})$ to afford $\mathbf{S 2 5}(4.05 \mathrm{~g}, 39 \%)$ as yellow solid.

${ }^{1} \mathrm{H}$ NMR $\left(400 \mathrm{MHz}, \mathrm{CDCl}_{3}\right) \delta 8.01(\mathrm{~s}, 1 \mathrm{H}), 6.98(\mathrm{dd}, J=8.1,1.8 \mathrm{~Hz}, 1 \mathrm{H}), 6.94(\mathrm{~d}, J=1.7 \mathrm{~Hz}, 1 \mathrm{H})$, $6.89(\mathrm{~d}, J=8.1 \mathrm{~Hz}, 1 \mathrm{H}), 6.04(\mathrm{~s}, 2 \mathrm{H}), 2.46(\mathrm{~d}, J=1.1 \mathrm{~Hz}, 3 \mathrm{H})$.

${ }^{13} \mathrm{C} \mathrm{NMR}\left(101 \mathrm{MHz}, \mathrm{CDCl}_{3}\right) \delta 149.4,148.4,146.2,133.8,126.3,126.1,109.6,109.0,101.9,14.3$. 


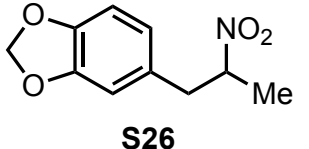

Chemical Formula: $\mathrm{C}_{10} \mathrm{H}_{11} \mathrm{NO}_{4}$ Exact Mass: 209.0688 Molecular Weight: 209.2010

S26: A 1-nk $1000 \mathrm{~mL}$ round bottom flask was fitted with a stir bar, $\mathbf{S 2 5}$ $(5.18 \mathrm{~g}, 25 \mathrm{mmol})$ was added, and the reaction flask was fitted with a rubber septum and a $\mathrm{N}_{2}$-filled balloon. Isopropanol $(75 \mathrm{~mL}, 0.33 \mathrm{M})$ and $\mathrm{CHCl}_{3}(400 \mathrm{~mL}, 0.063 \mathrm{M})$ were then added via syringe and stirred at $\mathrm{rt}$ for $15 \mathrm{~min}$. The rubber septum was momentarily removed to add silica gel $(75 \mathrm{~g}, 40-63 \mu \mathrm{m})$ and $\mathrm{NaBH}_{4}(3.90 \mathrm{~g}, 103 \mathrm{mmol})$ respectively in 4 portions over 30 mins. The reaction mixture was stirred vigorously at rt for 2 days and a solution of $\mathrm{HCl}$ ( $30 \mathrm{~mL}, 1 \mathrm{M}$ aqueous) was added to the reaction. The resulting biphasic mixture was stirred for $5 \mathrm{~min}$, before being poured into a separatory funnel and rinsed with DCM $(3 \times 10$ $\mathrm{mL})$. The layers were separated, and the aqueous phase was extracted with DCM $(3 \times 30 \mathrm{~mL})$. The combined organic layers were then washed with brine (15 mL, saturated aqueous), dried over $\mathrm{MgSO}_{4}$, filtered through a fritted funnel, and concentrated in vacuo to afford a crude oil. The crude product was purified by flash silica gel chromatography (gradient, 90:10 to 80:20 hexanes: EtOAc) to afford $\mathbf{S} 26(4.5 \mathrm{~g}, 86 \%)$ as clear, yellow oil.

${ }^{1} \mathrm{H} \mathrm{NMR}\left(600 \mathrm{MHz}, \mathrm{CDCl}_{3}\right) \delta 6.73(\mathrm{~d}, J=7.9 \mathrm{~Hz}, 1 \mathrm{H}), 6.58-6.65(\mathrm{~m}, 2 \mathrm{H}), 5.93(\mathrm{~s}, 2 \mathrm{H}), 4.72$ (hept, $J=6.8 \mathrm{~Hz}, 1 \mathrm{H}), 3.22(\mathrm{dd}, J=14.1,7.6 \mathrm{~Hz}, 1 \mathrm{H}), 2.92(\mathrm{dd}, J=14.1,6.6 \mathrm{~Hz}, 1 \mathrm{H}), 1.53(\mathrm{~d}, J=6.6$ $\mathrm{Hz}, 3 \mathrm{H})$.

${ }^{13} \mathrm{C}$ NMR $(151 \mathrm{MHz}, \mathrm{CDCl} 3) \delta$ 148.1, 147.0, 129.2, 122.3, 109.3, 108.6, 101.2, 84.7, 41.0, 18.8.

FTIR $\left(\mathrm{cm}^{-1}\right)$ 2898, 1549, 1490, 1444, 1250, 1039, 929.

HRMS (EI) m/z, calcd for $\left[\mathrm{C}_{10} \mathrm{H}_{11} \mathrm{NO}_{4}\right]^{+}: 209.0688$; found: 209.0701.

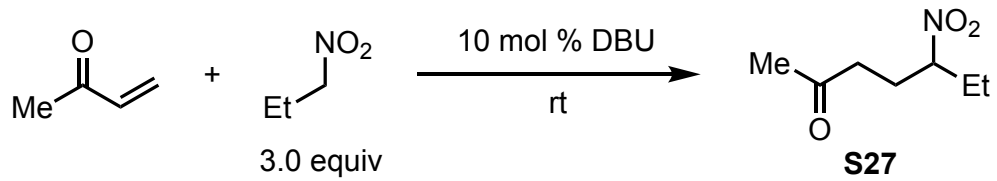

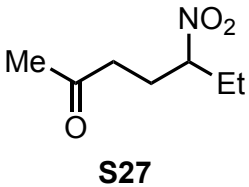

Chemical Formula: $\mathrm{C}_{7} \mathrm{H}_{13} \mathrm{NO}_{3}$ Exact Mass: 159.0895

Molecular Weight: 159.1850

S27: A 1-nk $50 \mathrm{~mL}$ round bottom flask was fitted with a stir bar and 1nitropropane $(26.7 \mathrm{~g}, 300 \mathrm{mmol})$ and $\mathrm{DBU}(1.52 \mathrm{~g}, 10 \mathrm{mmol})$ were added sequentially via syringe under air. The flask was then equipped with an addition funnel and methyl vinyl ketone $(7.0 \mathrm{~g}, 100 \mathrm{mmol})$ was added dropwise at $\mathrm{rt}$. After complete addition, the reaction was continued to stir at $\mathrm{rt}$ for another $20 \mathrm{~h}$. Then, $\mathrm{Et}_{2} \mathrm{O}(40 \mathrm{~mL})$ was added and the combined organic phase was washed with $\mathrm{HCl}(3 \times 30 \mathrm{~mL}, 1$

$\mathrm{M}$ aqueous), dried over $\mathrm{MgSO}_{4}$, filtered through a fritted funnel, and concentrated in vacuo to afford a crude oil. The crude product was purified by fractional distillation $\left(\sim 40 \mathrm{mtorr}, 85^{\circ} \mathrm{C}\right.$ in a silicone oil bath) to afford $\mathbf{S 2 7}(11.4 \mathrm{~g}, 72 \%)$ as clear, colorless oil.

${ }^{1} \mathrm{H}$ NMR $\left(400 \mathrm{MHz}, \mathrm{CDCl}_{3}\right) \delta 4.42(\mathrm{tt}, J=9.2,5.0 \mathrm{~Hz}, 1 \mathrm{H}), 2.41-2.56(\mathrm{~m}, 2 \mathrm{H}), 2.15(\mathrm{~s}, 3 \mathrm{H}), 2.05$ $-2.13(\mathrm{~m}, 2 \mathrm{H}), 1.92-2.05(\mathrm{~m}, 1 \mathrm{H}), 1.79(\mathrm{dqd}, J=14.6,7.4,4.7 \mathrm{~Hz}, 1 \mathrm{H}), 0.96$ (td, $J=7.4,1.0$ $\mathrm{Hz}, 3 \mathrm{H})$.

${ }^{13} \mathrm{C}$ NMR $\left(101 \mathrm{MHz}, \mathrm{CDCl}_{3}\right) \delta$ 206.6, 89.5, 39.2, 30.2, 27.5, 27.2, 10.4. 
FTIR $\left(\mathrm{cm}^{-1}\right)$ 2975, 2940, 1718, 1548, 1367, 1169, 803.

HRMS (ESI) m/z, calcd for $\left[\mathrm{C}_{7} \mathrm{H}_{14} \mathrm{NO}_{3}\right]^{+}:$160.0974; found: 160.0962.

\section{Synthesis of Homopropargylic Nitroalkanes via Cu-catalysis}

\section{General Experimental Procedure for the Synthesis of Homopropargylic Nitroalkanes}

General Procedure 8A: Using liquid propargyl bromide. A 1-nk $25 \mathrm{~mL}$ Schlenk flask was fitted with a stir bar and rubber septum, and then the sidearm of the flask was attached to a double manifold using a rubber hose. The flask was evacuated, flame-dried, allowed to cool to rt under vacuum, and then refilled with $\mathrm{N}_{2}$. Under closed $\mathrm{N}_{2}$, the rubber septum was momentarily removed, and $\mathrm{CuBr}\left(0.1-0.2\right.$ equiv) and $\mathrm{KO}^{t} \mathrm{Bu}$ (1.05 equiv) were added. The septum was refitted, and the atmosphere of the reactor was replaced with $\mathrm{N}_{2}$ via five sequential cycles of evacuation and refill. Under positive $\mathrm{N}_{2}$, anhydrous dioxane $(0.20 \mathrm{M}$, with respect to nitroalkane) and 12 (0.3 equiv) were added sequentially via syringe and allowed to stir at rt for 10 mins. Nitroalkane (1.0 equiv) was then added via syringe and allowed to stir at rt for another 30 mins. Lastly, propargyl bromide (1.15 equiv) was added via syringe and the reaction mixture was stirred at rt for 4-20 $\mathrm{h}$. The $\mathrm{N}_{2}$ line was closed off and the rubber septum was removed. The resulting suspension was diluted with $\mathrm{Et}_{2} \mathrm{O}(5 \mathrm{~mL})$ and quenched by the addition of $\mathrm{NH}_{4} \mathrm{Cl}(10 \mathrm{~mL}$, saturated aqueous). The resulting biphasic mixture was rapidly stirred for 5 mins, before being poured into a separatory funnel and rinsed with $\mathrm{Et}_{2} \mathrm{O}(3 \times 5 \mathrm{~mL})$. The layers were separated, and the aqueous phase was extracted with $\mathrm{Et}_{2} \mathrm{O}(3 \times 10 \mathrm{~mL})$. The combined organic layers were then washed with brine (15 $\mathrm{mL}$, saturated aqueous), dried over $\mathrm{MgSO}_{4}$, filtered through a fritted funnel, and concentrated in vacuo to afford a crude oil. The crude product was purified by flash silica gel chromatography using the specified condition.

General Procedure 8B: Using solid propargyl bromide. A 1-nk $25 \mathrm{~mL}$ Schlenk flask was fitted with a stir bar and rubber septum, and then the sidearm of the flask was attached to a double manifold using a rubber hose. The flask was evacuated, flame-dried, allowed to cool to rt under vacuum, and then refilled with $\mathrm{N}_{2}$. Under closed $\mathrm{N}_{2}$, the rubber septum was momentarily removed, and $\mathrm{CuBr}\left(0.1-0.2\right.$ equiv) and $\mathrm{KO}^{t} \mathrm{Bu}$ (1.05 equiv) were added. The septum was refitted, and the atmosphere of the reactor was replaced with $\mathrm{N}_{2}$ via five sequential cycles of evacuation and refill. Under positive $\mathrm{N}_{2}$, anhydrous dioxane $(0.25 \mathrm{M}$, with respect to nitroalkane) and 12 (0.3 equiv) were added sequentially via syringe and allowed to stir at rt for $10 \mathrm{mins}$. Nitroalkane (1.0 equiv) was then added via syringe and allowed to stir at rt for another 30 mins. During this time, propargyl bromide (1.15 equiv) was added to a 2-dram vial (oven-dried and cooled under vacuum) and capped with a septa screw cap. The atmosphere of the 2-dram vial was evacuated and refilled with $\mathrm{N}_{2}$ five times via syringe using the double manifold. Anhydrous dioxane (1.0 M with respect to nitroalkane) was then added to the 2-dram vial. The propargyl bromide solution was added to the reactor via syringe and the reaction mixture was stirred at rt for 4-20 h. The $\mathrm{N}_{2}$ line was closed off and the rubber septum was removed. The resulting suspension was diluted with $\mathrm{Et}_{2} \mathrm{O}(5 \mathrm{~mL})$ and quenched by the addition of $\mathrm{NH}_{4} \mathrm{Cl}(10 \mathrm{~mL}$, saturated aqueous). The resulting biphasic mixture was rapidly stirred for 5 mins, before being poured into a separatory funnel and rinsed with $\mathrm{Et}_{2} \mathrm{O}(3 \times 5 \mathrm{~mL})$. The layers were separated, and the aqueous phase was extracted with $\mathrm{Et}_{2} \mathrm{O}$ $(3 \times 10 \mathrm{~mL})$. The combined organic layers were then washed with brine $(15 \mathrm{~mL}$, saturated 
aqueous), dried over $\mathrm{MgSO}_{4}$, filtered through a fritted funnel, and concentrated in vacuo to afford a crude oil. The crude product was purified by flash silica gel chromatography using the specified condition.

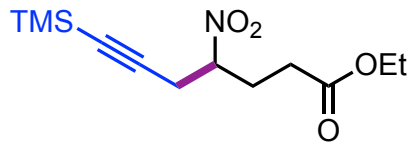

3a

Chemical Formula: $\mathrm{C}_{12} \mathrm{H}_{21} \mathrm{NO}_{4} \mathrm{Si}$ Exact Mass: 271.1240 Molecular Weight: 271.3880 3a: According to General Procedure 8A, ethyl 4-nitrobutanoate (161 mg, $1.0 \mathrm{mmol}$ ), (3-bromoprop-1-yn-1-yl)trimethylsilane (220 $\mathrm{mg}, 1.15 \mathrm{mmol}), \mathrm{CuBr}(14.4 \mathrm{mg}, 0.1 \mathrm{mmol}), \mathrm{KO}{ }^{\mathrm{B}} \mathrm{Bu}(118 \mathrm{mg}, 1.05$ $\mathrm{mmol})$, and 12 (43.3 $\mathrm{mg}, 0.3 \mathrm{mmol})$ in anhydrous dioxane $(5 \mathrm{~mL}, 0.2$ M) for $4 \mathrm{~h}$, afforded, after flash silica gel chromatography (gradient, $90: 10$ to $80: 20$ hexanes:Et $\left.{ }_{2} \mathrm{O}\right), 3 a(181 \mathrm{mg}, 67 \%)$ as dark-yellow oil.

${ }^{1} \mathrm{H}$ NMR $\left(600 \mathrm{MHz}, \mathrm{CDCl}_{3}\right) \delta 4.64-4.70(\mathrm{~m}, 1 \mathrm{H}), 4.15(\mathrm{q}, J=7.1 \mathrm{~Hz}, 2 \mathrm{H}), 2.89$ (dd, J = 17.2, 7.1 $\mathrm{Hz} 1 \mathrm{H}), 2.77(\mathrm{dd}, J=17.2,6.3 \mathrm{~Hz}, 1 \mathrm{H}), 2.35-2.47(\mathrm{~m}, 2 \mathrm{H}), 2.21-2.32(\mathrm{~m}, 2 \mathrm{H}), 1.26(\mathrm{t}, J=7.1$ $\mathrm{Hz}, 3 \mathrm{H}), 0.14(\mathrm{~s}, 9 \mathrm{H})$.

${ }^{13} \mathrm{C}$ NMR $\left(151 \mathrm{MHz}, \mathrm{CDCl}_{3}\right) \delta 171.8,99.0,89.6,85.3,61.0,30.2,27.9,25.0,14.3,-0.1$.

${ }^{29} \mathrm{Si} \mathrm{NMR}\left(119 \mathrm{MHz}, \mathrm{CDCl}_{3}\right) \delta-17.8$.

FTIR $\left(\mathrm{cm}^{-1}\right)$ 2962, 2183, 1736, 1556, 1251, 1191, 845.

HRMS (ESI) m/z, calcd for $\left[\mathrm{C}_{12} \mathrm{H}_{22} \mathrm{NO}_{4} \mathrm{Si}^{+}:\right.$272.1318; found 272.1315.

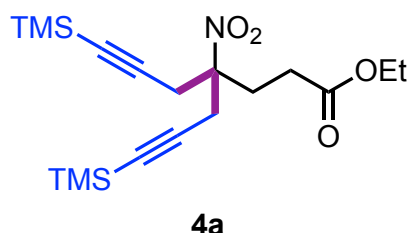

Chemical Formula: $\mathrm{C}_{18} \mathrm{H}_{31} \mathrm{NO}_{4} \mathrm{Si}_{2}$ Exact Mass: 381.1792 Molecular Weight: 381.6190 4a: According to General Procedure 8A, 3a (271 mg, $1.0 \mathrm{mmol})$, (3-bromoprop-1-yn-1-yl)trimethylsilane (220 mg, $1.15 \mathrm{mmol}), \mathrm{CuBr}$ (14.4 mg, $0.1 \mathrm{mmol}), \mathrm{KO}{ }^{t} \mathrm{Bu}(118 \mathrm{mg}, 1.05 \mathrm{mmol}$ ), and 12 (43.3 mg, $0.3 \mathrm{mmol})$ in anhydrous dioxane $(5 \mathrm{~mL}, 0.2 \mathrm{M})$ for $4 \mathrm{~h}$, afforded, after flash silica gel chromatography (90:10 hexanes: $\left.\mathrm{Et}_{2} \mathrm{O}\right), \mathbf{4 a}(100$ $\mathrm{mg}, 26 \%$ ) as yellow solid.

${ }^{1} \mathrm{H}$ NMR $\left(600 \mathrm{MHz}, \mathrm{CDCl}_{3}\right) \delta 4.14(\mathrm{q}, J=7.1 \mathrm{~Hz}, 2 \mathrm{H}), 3.06(\mathrm{~d}, J=$ $17.2 \mathrm{~Hz}, 2 \mathrm{H}), 2.95(\mathrm{~d}, J=17.1 \mathrm{~Hz}, 2 \mathrm{H}), 2.39-2.44(\mathrm{~m}, 2 \mathrm{H}), 2.33-2.39(\mathrm{~m}, 2 \mathrm{H}), 1.26(\mathrm{t}, J=7.1$ $\mathrm{Hz}, 3 \mathrm{H}), 0.15(\mathrm{~s}, 18 \mathrm{H})$.

${ }^{13} \mathrm{C}$ NMR $\left(151 \mathrm{MHz}, \mathrm{CDCl}_{3}\right) \delta 171.7,98.9,90.9,90.1,61.0,31.6,29.0,27.6,14.3,-0.1$.

${ }^{29} \mathrm{Si}$ NMR $\left(119 \mathrm{MHz}, \mathrm{CDCl}_{3}\right) \delta-17.7$.

FTIR $\left(\mathrm{cm}^{-1}\right)$ 2961, 2182, 1740, 1550, 1251, 1185, 1034, 845.

HRMS (ESI) m/z, calcd for $\left[\mathrm{C}_{18} \mathrm{H}_{32} \mathrm{NO}_{4} \mathrm{Si}_{2}\right]^{+}:$382.1870; found 382.1860.

MP: $45-47^{\circ} \mathrm{C}\left(\mathrm{Et}_{2} \mathrm{O}\right)$. 


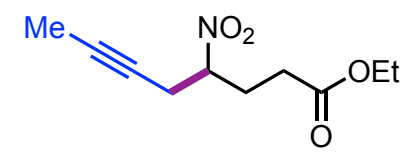

$3 b$

Chemical Formula: $\mathrm{C}_{10} \mathrm{H}_{15} \mathrm{NO}_{4}$ Exact Mass: 213.1001

Molecular Weight: 213.2330 3b: According to General Procedure 8A, ethyl 4-nitrobutanoate (322 mg, $2.0 \mathrm{mmol}$ ), 1-bromo-2-butyne (306 mg, $2.3 \mathrm{mmol}), \mathrm{CuBr}(28.7 \mathrm{mg}$, $0.2 \mathrm{mmol}), \mathrm{KO}{ }^{\mathrm{B}} \mathrm{Bu}(236 \mathrm{mg}, 2.1 \mathrm{mmol})$, and $12(86.4 \mathrm{mg}, 0.6 \mathrm{mmol})$ in anhydrous dioxane $(10 \mathrm{~mL}, 0.2 \mathrm{M})$ for $4 \mathrm{~h}$, afforded, after flash silica gel chromatography (gradient, 100:0 to 85:15 hexanes: $\mathrm{Et}_{2} \mathrm{O}$ ), $\mathbf{3 b}$ (205 $\mathrm{mg}, 48 \%$ ) as clear, yellow oil.

${ }^{1} \mathrm{H}$ NMR $\left(600 \mathrm{MHz}, \mathrm{CDCl}_{3}\right) \delta 4.63$ (dddd, $\left.J=8.9,7.2,6.2,4.7 \mathrm{~Hz}, 1 \mathrm{H}\right), 4.15(\mathrm{q}, J=7.1 \mathrm{~Hz}, 2 \mathrm{H})$, 2.81 (ddq, $J=16.9,7.4,2.5 \mathrm{~Hz}, 1 \mathrm{H}$ ), 2.69 (ddq, $J=16.9,6.2,2.5 \mathrm{~Hz}, 1 \mathrm{H}), 2.34-2.46(\mathrm{~m}, 2 \mathrm{H}$ ), $2.20-2.31(\mathrm{~m}, 2 \mathrm{H}), 1.77(\mathrm{t}, \mathrm{J}=2.5 \mathrm{~Hz}, 3 \mathrm{H}), 1.26(\mathrm{t}, J=7.1 \mathrm{~Hz}, 3 \mathrm{H})$.

${ }^{13} \mathrm{C}$ NMR $\left(151 \mathrm{MHz}, \mathrm{CDCl}_{3}\right) \delta 171.9,85.8,80.2,72.0,61.0,30.3,27.9,24.2,14.3,3.6$.

FTIR $\left(\mathrm{cm}^{-1}\right)$ 2983, 2924, 1735, 1555, 1372, 1192.

HRMS (ESI) m/z, calcd for $\left[\mathrm{C}_{10} \mathrm{H}_{16} \mathrm{NO}_{4}\right]^{+}:$: 214.1079; found 214.1079.

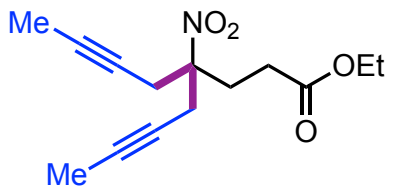

4b

Chemical Formula: $\mathrm{C}_{14} \mathrm{H}_{19} \mathrm{NO}_{4}$ Exact Mass: 265.1314 Molecular Weight: 265.3090 4b: According to General Procedure 8A, 3b (213 mg, $1.0 \mathrm{mmol})$, 1bromo-2-butyne (153 mg, $1.15 \mathrm{mmol}), \mathrm{CuBr}(14.4 \mathrm{mg}, 0.1 \mathrm{mmol}$ ), $\mathrm{KO}^{t} \mathrm{Bu}(118 \mathrm{mg}, 1.05 \mathrm{mmol})$, and $12(43.3 \mathrm{mg}, 0.3 \mathrm{mmol})$ in anhydrous dioxane $(5 \mathrm{~mL}, 0.2 \mathrm{M})$ for $4 \mathrm{~h}$, afforded, after flash silica gel chromatography (80:20 hexanes: $\left.\mathrm{Et}_{2} \mathrm{O}\right), \mathbf{4 b}(81 \mathrm{mg}, 31 \%)$ as yellow oil.

${ }^{1} \mathrm{H}$ NMR $\left(600 \mathrm{MHz}, \mathrm{CDCl}_{3}\right) \delta 4.13(\mathrm{q}, J=7.2 \mathrm{~Hz}, 2 \mathrm{H}), 2.98(\mathrm{dq}, J=$ $16.8,2.5 \mathrm{~Hz}, 2 \mathrm{H}), 2.85$ (dq, $J=16.8,2.5 \mathrm{~Hz}, 2 \mathrm{H}), 2.35-2.40(\mathrm{~m}, 2 \mathrm{H})$, $J=2.5 \mathrm{~Hz}, 6 \mathrm{H}), 1.25(\mathrm{t}, J=7.2 \mathrm{~Hz}, 3 \mathrm{H})$.

${ }^{13} \mathrm{C}$ NMR $\left(151 \mathrm{MHz} \mathrm{CDCl}_{3}\right) \delta 171.9,91.5,80.3,71.8,61.0,31.3,28.9,26.6,14.3,3.7$.

FTIR $\left(\mathrm{cm}^{-1}\right)$ 2982, 2923, 1736, 1546, 1443, 1313, 1186, 1030, 855.

HRMS (ESI) m/z, calcd for $\left[\mathrm{C}_{14} \mathrm{H}_{20} \mathrm{O}_{4} \mathrm{~N}\right]^{+}:$: 266.1392; found 266.1385.

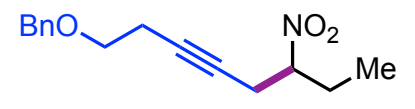

13

Chemical Formula: $\mathrm{C}_{15} \mathrm{H}_{19} \mathrm{NO}_{3}$

Exact Mass: 261.1365

Molecular Weight: 261.3210
13: According to General Procedure 8A, 1-nitropropane $(89.1 \mathrm{mg}$, $1.0 \mathrm{mmol}),(((5-b r o m o p e n t-3-y n-1-y \mathrm{l}) 0 x y)$ methyl)benzene $(291 \mathrm{mg}$, $1.15 \mathrm{mmol}), \mathrm{CuBr}$ (14.4 mg, $0.1 \mathrm{mmol}), \mathrm{KO}$ Bu (118 mg, $1.05 \mathrm{mmol}$ ), and 12 (43.4 mg, $0.3 \mathrm{mmol})$ in anhydrous dioxane $(5 \mathrm{~mL}, 0.2 \mathrm{M})$ for 4 h, afforded, after flash silica gel chromatography $\mathbf{( 9 0 : 1 0}$ hexanes: $\mathrm{Et}_{2} \mathrm{O}$ ), 13 (188 mg, 72\%) as clear, yellow oil.

${ }^{1} \mathrm{H}$ NMR $\left(400 \mathrm{MHz}, \mathrm{CD}_{2} \mathrm{Cl}_{2}\right) \delta 7.32-7.38(\mathrm{~m}, 4 \mathrm{H}), 7.25-7.31(\mathrm{~m}, 1 \mathrm{H}), 4.44-4.53(\mathrm{~m}, 3 \mathrm{H}), 3.53$ (t, $J=6.8 \mathrm{~Hz}, 2 \mathrm{H}$ ), 2.81 (ddt, $J=17.0,7.9,2.4 \mathrm{~Hz}, 1 \mathrm{H}$ ), 2.67 (ddt, $J=17.0,5.8,2.4 \mathrm{~Hz}, 1 \mathrm{H}$ ), 2.44 (tt, $J=6.8,2.4 \mathrm{~Hz}, 2 \mathrm{H}), 2.05-1.84(\mathrm{~m}, 2 \mathrm{H}), 0.95(\mathrm{t}, J=7.4 \mathrm{~Hz}, 3 \mathrm{H})$.

${ }^{13} \mathrm{C}$ NMR $\left(101 \mathrm{MHz}, \mathrm{CD}_{2} \mathrm{Cl}_{2}\right) \delta 139.0,128.8,128.2,128.1,88.9,81.3,74.9,73.3,69.1,26.8,24.0$, 20.5, 10.3.

FTIR $\left(\mathrm{cm}^{-1}\right)$ 2861, 1551, 1373, 1101, 737, 698. 
HRMS (ESI) m/z, calcd for $\left[\mathrm{C}_{15} \mathrm{H}_{20} \mathrm{NO}_{3}\right]^{+}:$262.1443; found 262.1433.

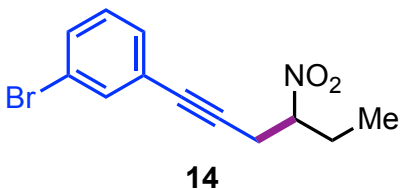

Chemical Formula: $\mathrm{C}_{12} \mathrm{H}_{12} \mathrm{BrNO}_{2}$ Exact Mass: 281.0051

Molecular Weight: 282.1370

14: According to General Procedure 8A, 1-nitropropane (89.1 mg, $1.0 \mathrm{mmol}$ ), 1-bromo-3-(3-bromoprop-1-yn-1-yl)benzene (315 mg, $1.15 \mathrm{mmol}), \mathrm{CuBr}$ (14.4 mg, $0.1 \mathrm{mmol}), \mathrm{KO} \mathrm{B}^{\mathrm{B} u}(118 \mathrm{mg}, 1.05 \mathrm{mmol})$, and $12(43.3 \mathrm{mg}, 0.3 \mathrm{mmol})$ in anhydrous dioxane $(5 \mathrm{~mL}, 0.2 \mathrm{M})$ for $4 \mathrm{~h}$, afforded, after flash silica gel flash chromatography (90:10 hexanes: $\left.\mathrm{Et}_{2} \mathrm{O}\right), 14$ (204 $\mathrm{mg}, 72 \%$ ) as clear, yellow oil.

${ }^{1} \mathrm{H} \mathrm{NMR}\left(400 \mathrm{MHz}, \mathrm{CDCl}_{3}\right) \delta 7.53(\mathrm{t}, J=1.8 \mathrm{~Hz}, 1 \mathrm{H}), 7.44$ (ddd, $\left.J=8.0,2.0,1.1 \mathrm{~Hz}, 1 \mathrm{H}\right), 7.31$ (dt, $J=7.7,1.3 \mathrm{~Hz}, 1 \mathrm{H}$ ), $7.16(\mathrm{t}, J=7.9 \mathrm{~Hz}, 1 \mathrm{H}), 4.60$ (dddd, $J=8.7,7.6,6.0,4.9 \mathrm{~Hz}, 1 \mathrm{H}), 3.08$ (dd, $J=17.2,7.6 \mathrm{~Hz}, 1 \mathrm{H}), 2.93(\mathrm{dd}, J=17.2,6.1 \mathrm{~Hz}, 1 \mathrm{H}), 1.94-2.16(\mathrm{~m}, 2 \mathrm{H}), 1.03(\mathrm{t}, J=7.4 \mathrm{~Hz}, 3 \mathrm{H})$.

${ }^{13} \mathrm{C} \mathrm{NMR}\left(101 \mathrm{MHz}, \mathrm{CDCl}_{3}\right) \delta 134.6,131.7,130.4,129.9,124.7,122.2,87.8,84.4,82.5,26.5$, 24.1, 10.2.

FTIR $\left(\mathrm{cm}^{-1}\right)$ 2975, 2938, 1591, 1553, 1473, 1374, 784, 681.

HRMS (ESI) m/z, calcd for $\left[\mathrm{C}_{12} \mathrm{H}_{13} \mathrm{BrNO}_{2}\right]^{+}:$282.0130; found 282.0133 .

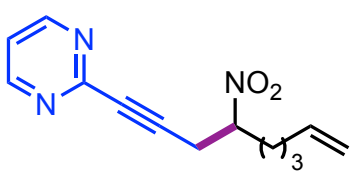

15

Chemical Formula: $\mathrm{C}_{13} \mathrm{H}_{15} \mathrm{~N}_{3} \mathrm{O}_{2}$ Exact Mass: 245.1164 Molecular Weight: 245.2820
15: According to General Procedure 8B, 6-nitrohex-1-ene (129 mg, $1.0 \mathrm{mmol}$ ), 2-(3-bromoprop1-yn-1-yl)pyrimidine (227 mg, $1.15 \mathrm{mmol})$, $\mathrm{CuBr}(14.4 \mathrm{mg}, 0.1 \mathrm{mmol}), \mathrm{KO}{ }^{\mathrm{B} u}$ (118 mg, $\left.1.05 \mathrm{mmol}\right)$, and 12 (43.3 $\mathrm{mg}, 0.3 \mathrm{mmol}$ ) in anhydrous dioxane $(5 \mathrm{~mL}, 0.2 \mathrm{M})$ for $4 \mathrm{~h}$, afforded, after flash silica gel chromatography (10:90 hexanes:EtOAc), 15 (174 $\mathrm{mg}, 71 \%$ ) as orange oil.

${ }^{1} \mathrm{H}$ NMR $\left(600 \mathrm{MHz} \mathrm{CDCl}_{3}\right) \delta 8.70(\mathrm{~d}, \mathrm{~J}=4.9 \mathrm{~Hz}, 2 \mathrm{H}), 7.24(\mathrm{t}, \mathrm{J}=4.9 \mathrm{~Hz}, 1 \mathrm{H}), 5.75$ (ddt, J = 16.9 , 10.2, 6.7 Hz, 1H), 4.95-5.06 (m, 2H), 4.73 (dtd, J = 9.1, 6.8, 4.6 Hz, 1H), 3.16 (dd, J = $17.3,7.0$ $\mathrm{Hz}, 1 \mathrm{H}), 3.00$ (dd, $J=17.3,6.7 \mathrm{~Hz}, 1 \mathrm{H}), 2.05-2.17(\mathrm{~m}, 3 \mathrm{H}), 1.97-2.04(\mathrm{~m}, 1 \mathrm{H}), 1.49(\mathrm{p}, \mathrm{J}=7.6$ $\mathrm{Hz}, 2 \mathrm{H})$.

${ }^{13} \mathrm{C}$ NMR $\left(151 \mathrm{MHz} \mathrm{CDCl}_{3}\right) \delta 157.4,152.6,137.3,120.2,115.9,85.6,82.9,82.4,32.9,32.6,24.8$, 24.2 .

FTIR $\left(\mathrm{cm}^{-1}\right)$ 3076, 2930, 2243, 1640, 1552, 1413.

HRMS (ESI) m/z, calcd for $\left[\mathrm{C}_{13} \mathrm{H}_{16} \mathrm{~N}_{3} \mathrm{O}_{2}\right]^{+}: 246.1243$; found 246.1249.

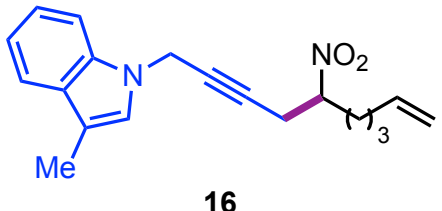

Chemical Formula: $\mathrm{C}_{19} \mathrm{H}_{22} \mathrm{~N}_{2} \mathrm{O}_{2}$ Exact Mass: 310.1681 Molecular Weight: 310.3970

16: According to General Procedure 8A, 6-nitrohex-1-ene (129 mg, $1.0 \mathrm{mmol}$ ), 1-(4-bromobut-2-yn-1-yl)-3-methyl-1H-indole (301 mg, $1.15 \mathrm{mmol}), \mathrm{CuBr}(14.4 \mathrm{mg}, 0.1 \mathrm{mmol}), \mathrm{KO} \mathrm{Bu}^{\mathrm{B} u}(118 \mathrm{mg}, 1.05 \mathrm{mmol})$, and $12(43.3 \mathrm{mg}, 0.3 \mathrm{mmol})$ in anhydrous dioxane $(5 \mathrm{~mL}, 0.2 \mathrm{M})$ for $4 \mathrm{~h}$, afforded, after flash silica gel chromatography (90:10 hexanes: $\left.\mathrm{Et}_{2} \mathrm{O}\right), 16(215 \mathrm{mg}, 69 \%)$ as yellow oil.

${ }^{1} \mathrm{H} \mathrm{NMR}\left(600 \mathrm{MHz}, \mathrm{CDCl}_{3}\right) \delta 7.57(\mathrm{~d}, J=7.9 \mathrm{~Hz}, 1 \mathrm{H}), 7.32(\mathrm{~d}, J=8.2$ $\mathrm{Hz}, 1 \mathrm{H}), 7.24$ (t, $J=7.9 \mathrm{~Hz}, 1 \mathrm{H}), 7.13(\mathrm{t}, J=7.9 \mathrm{~Hz}, 1 \mathrm{H}), 5.71$ (ddt, $J=17.0,10.1,6.7 \mathrm{~Hz}, 1 \mathrm{H}$ ), 
$4.96-5.03(\mathrm{~m}, 2 \mathrm{H}), 4.78(\mathrm{t}, J=2.2 \mathrm{~Hz}, 2 \mathrm{H}$ ), 4.54 (dddd, $J=9.0,7.6,5.9,4.8 \mathrm{~Hz}, 1 \mathrm{H}$ ), 2.85 (ddt, $J=17.1,7.6,2.2 \mathrm{~Hz}, 1 \mathrm{H}), 2.69$ (ddt, $J=17.1,5.9,2.2 \mathrm{~Hz}, 1 \mathrm{H}), 2.33(\mathrm{~s}, 3 \mathrm{H}), 2.01-2.10(\mathrm{~m}, 2 \mathrm{H})$, $1.93-2.01(\mathrm{~m}, 1 \mathrm{H}), 1.77-1.85(\mathrm{~m}, 1 \mathrm{H}), 1.41(\mathrm{p}, J=7.5 \mathrm{~Hz}, 2 \mathrm{H})$.

${ }^{13} \mathrm{C} \mathrm{NMR}\left(151 \mathrm{MHz}, \mathrm{CDCl}_{3}\right) \delta 137.4,136.2,129.3,125.0,121.9,119.3,119.2,115.8,111.4,109.3$, 86.3, 78.6, 78.5, 35.8, 32.9, 32.4, 24.8, 23.9, 9.7 .

FTIR $\left(\mathrm{cm}^{-1}\right)$ 2919, 1641, 1552, 1465, 1331, 741.

HRMS (ESI) m/z, calcd for $\left[\mathrm{C}_{19} \mathrm{H}_{23} \mathrm{~N}_{2} \mathrm{O}_{2}\right]^{+}: 311.1760$; found 311.1760.

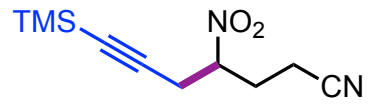

17

Chemical Formula: $\mathrm{C}_{10} \mathrm{H}_{16} \mathrm{~N}_{2} \mathrm{O}_{2} \mathrm{Si}$ Exact Mass: 224.0981

Molecular Weight: 224.3350
17: According to General Procedure 8A, 4-nitrobutanenitrile (114 $\mathrm{mg}, 1.0 \mathrm{mmol})$, (3-bromoprop-1-yn-1-yl)trimethylsilane $(220 \mathrm{mg}$, $1.15 \mathrm{mmol}), \mathrm{CuBr}(28.7 \mathrm{mg}, 0.2 \mathrm{mmol}), \mathrm{KO} \mathrm{Bu}^{t} \mathrm{Bu}(18 \mathrm{mg}, 1.05 \mathrm{mmol})$, and $12(43.3 \mathrm{mg}, 0.3 \mathrm{mmol})$ in anhydrous dioxane $(5 \mathrm{~mL}, 0.2 \mathrm{M})$ for $20 \mathrm{~h}$, afforded, after flash silica gel chromatography (gradient, 100:0 to $90: 10$ hexanes:EtOAc), 17 (89.6 mg, 40\%) as yellow oil.

${ }^{1} \mathrm{H}$ NMR $\left(600 \mathrm{MHz}, \mathrm{CDCl}_{3}\right) \delta 4.68$ (dddd, $\left.J=9.5,7.1,6.0,3.9 \mathrm{~Hz}, 1 \mathrm{H}\right), 2.95(\mathrm{dd}, J=17.2,6.0 \mathrm{~Hz}$, $1 \mathrm{H}), 2.87(\mathrm{dd}, J=17.2,7.2 \mathrm{~Hz}, 1 \mathrm{H}), 2.39-2.60(\mathrm{~m}, 3 \mathrm{H}), 2.27-2.34(\mathrm{~m}, 1 \mathrm{H}), 0.16(\mathrm{~s}, 9 \mathrm{H})$.

${ }^{13} \mathrm{C}$ NMR $\left(151 \mathrm{MHz}, \mathrm{CDCl}_{3}\right) \delta 117.7,97.8,90.8,83.7,28.2,24.9,14.5,-0.1$.

${ }^{29} \mathrm{Si} \mathrm{NMR}\left(119 \mathrm{MHz}, \mathrm{CDCl}_{3}\right) \delta-17.4$.

FTIR $\left(\mathrm{cm}^{-1}\right)$ 2962, 2901, 2251, 2183, 1557, 1251, 845.

HRMS (ESI) m/z, calcd for $\left[\mathrm{C}_{10} \mathrm{H}_{17} \mathrm{~N}_{2} \mathrm{O}_{2} \mathrm{Si}\right]^{+}:$225.1059; found 225.1049.

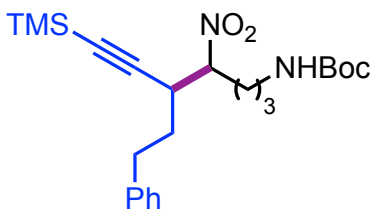

18 (dr 56:42) Exact Mass: 432.2444

Molecular Weight: 432.6360
Chemical Formula: $\mathrm{C}_{23} \mathrm{H}_{36} \mathrm{~N}_{2} \mathrm{O}_{4} \mathrm{Si}$

18: According to General Procedure 8A, tert-butyl (4nitrobutyl)carbamate (218 mg, $1.0 \mathrm{mmol})$, (3-bromo-5-phenylpent1-yn-1-yl)trimethylsilane (340 mg, $1.15 \mathrm{mmol}), \mathrm{CuBr}(28.7 \mathrm{mg}, 0.2$ $\mathrm{mmol}), \mathrm{KO}{ }^{\mathrm{B}} \mathrm{Bu}(118 \mathrm{mg}, 1.05 \mathrm{mmol})$, and 12 (43.3 $\left.\mathrm{mg}, 0.3 \mathrm{mmol}\right)$ in anhydrous dioxane $(5 \mathrm{~mL}, 0.2 \mathrm{M})$ for $20 \mathrm{~h}$. NMR analysis of the crude reaction mixture revealed a 56:42 ratio of diastereomers. After flash silica gel chromatography ( $70: 30$ hexanes: $\left.\mathrm{Et}_{2} \mathrm{O}\right), 18$ was afforded (d1: $129 \mathrm{mg}$, d2: $145 \mathrm{mg}, 63 \%$ combined, dr 47:53) as clear, yellow oil (d1) and clear, yellow oil (d2).

diastereomer 1 (d1):

${ }^{1} \mathrm{H}$ NMR $\left(600 \mathrm{MHz}, \mathrm{CDCl}_{3}\right) \delta 7.28(\mathrm{t}, J=7.5 \mathrm{~Hz}, 2 \mathrm{H}), 7.20(\mathrm{t}, J=7.4 \mathrm{~Hz}, 1 \mathrm{H}), 7.16(\mathrm{~d}, J=7.2 \mathrm{~Hz}$, 2H), 4.51 (bs, 1H), $4.44(\mathrm{td}, J=10.4,2.8 \mathrm{~Hz}, 1 \mathrm{H}), 3.07-3.20(\mathrm{~m}, 2 \mathrm{H}), 2.86-2.99(\mathrm{~m}, 2 \mathrm{H}), 2.70$ $(\mathrm{dt}, J=13.7,8.4 \mathrm{~Hz}, 1 \mathrm{H}), 2.07-2.16(\mathrm{~m}, 1 \mathrm{H}), 1.96-2.06(\mathrm{~m}, 1 \mathrm{H}), 1.73(\mathrm{q}, J=7.9 \mathrm{~Hz}, 2 \mathrm{H}), 1.46$ $-1.58(\mathrm{~m}, 2 \mathrm{H}), 1.46(\mathrm{~s}, 9 \mathrm{H}), 0.21(\mathrm{~s}, 9 \mathrm{H})$.

${ }^{13} \mathrm{C}$ NMR $\left(151 \mathrm{MHz}, \mathrm{CDCl}_{3}\right) \delta 156.0,140.8,128.63,128.56,126.3,102.8,91.3,90.6,79.5,39.8$, $36.9,33.4,32.9,29.6,28.5,26.5,0.1$. 
${ }^{29} \mathrm{Si} \mathrm{NMR}\left(119 \mathrm{MHz}, \mathrm{CDCl}_{3}\right) \delta-17.8$.

FTIR $\left(\mathrm{cm}^{-1}\right) 3356,2961,2931,2174,1705,1553,1251,845$.

HRMS (ESI) m/z, calcd for $\left[\mathrm{C}_{23} \mathrm{H}_{35} \mathrm{~N}_{2} \mathrm{O}_{4} \mathrm{Si}\right]^{-:}$: 431.2366; found 431.2357.

diastereomer 2 (d2):

${ }^{1} \mathrm{H}$ NMR $\left(600 \mathrm{MHz}, \mathrm{CDCl}_{3}\right) \delta 7.29(\mathrm{t}, \mathrm{J}=7.5 \mathrm{~Hz}, 2 \mathrm{H}), 7.17-7.23(\mathrm{~m}, 3 \mathrm{H}), 4.42-4.58(\mathrm{~m}, 2 \mathrm{H})$, $3.05-3.20(\mathrm{~m}, 2 \mathrm{H}), 2.84-2.94(\mathrm{~m}, 2 \mathrm{H}), 2.72(\mathrm{dt}, J=13.9,8.3 \mathrm{~Hz}, 1 \mathrm{H}), 2.00-2.11(\mathrm{~m}, 1 \mathrm{H}), 1.70$ $-1.87(\mathrm{~m}, 3 \mathrm{H}), 1.45-1.54(\mathrm{~m}, 2 \mathrm{H}), 1.42(\mathrm{~s}, 9 \mathrm{H}), 0.19(\mathrm{~s}, 9 \mathrm{H})$.

${ }^{13} \mathrm{C}$ NMR $\left(151 \mathrm{MHz}, \mathrm{CDCl}_{3}\right) \delta 156.1,140.8,128.7,128.6,126.4,102.8,90.7,90.2,79.5,39.7$, $36.5,33.3,32.6,28.5,28.1,26.8,0.1$.

${ }^{29} \mathrm{Si} \mathrm{NMR}\left(119 \mathrm{MHz}, \mathrm{CDCl}_{3}\right) \delta-17.8$.

FTIR $\left(\mathrm{cm}^{-1}\right)$ 3354, 2961, 2931, 2174, 1710, 1554, 1251, 846.

HRMS (ESI) m/z, calcd for $\left[\mathrm{C}_{23} \mathrm{H}_{35} \mathrm{~N}_{2} \mathrm{O}_{4} \mathrm{Si}\right]^{-}:$: 431.2366; found 431.2357.

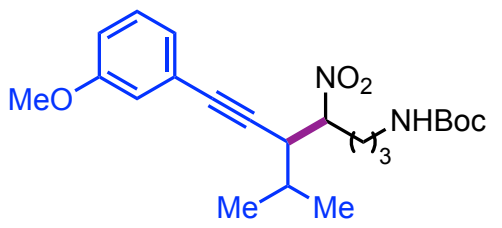

19 (dr 53:47)

Chemical Formula: $\mathrm{C}_{22} \mathrm{H}_{32} \mathrm{~N}_{2} \mathrm{O}_{5}$

Exact Mass: 404.2311

Molecular Weight: 404.5070

19: According to General Procedure 8A, tert-butyl (4nitrobutyl)carbamate (218 mg, $1.0 \mathrm{mmol}), \quad$ 1-(3-bromo-4methylpent-1-yn-1-yl)-3-methoxybenzene (307 mg, $1.15 \mathrm{mmol}$ ), $\mathrm{CuBr}(28.7 \mathrm{mg}, 0.2 \mathrm{mmol}), \mathrm{KO}{ }^{t} \mathrm{Bu}(118 \mathrm{mg}, 1.05 \mathrm{mmol})$, and 12 (43.3 $\mathrm{mg}, 0.3 \mathrm{mmol})$ in anhydrous dioxane $(5 \mathrm{~mL}, 0.2 \mathrm{M})$ for $20 \mathrm{~h}$. NMR analysis of the crude reaction mixture revealed a 53:47 ratio of diastereomers. After flash silica gel chromatography $(80: 20$ hexanes:EtOAc), 19 was afforded (d1: $82.6 \mathrm{mg}$, d2: $56.8 \mathrm{mg}, 34 \%$ combined, dr 59:41) as clear, yellow oil (d1) and white solid (d2).

diastereomer 1 (d1):

${ }^{1} \mathrm{H}$ NMR $\left(400 \mathrm{MHz}_{\mathrm{CDCl}}\right) \delta 7.22(\mathrm{t}, J=7.9 \mathrm{~Hz}, 1 \mathrm{H}), 7.01(\mathrm{dd}, J=7.6,1.3 \mathrm{~Hz}, 1 \mathrm{H}), 6.93(\mathrm{t}, J=$ $2.0 \mathrm{~Hz}, 1 \mathrm{H}), 6.88(\mathrm{dd}, J=8.4,2.6 \mathrm{~Hz}, 1 \mathrm{H}), 4.63(\mathrm{td}, J=10.6,2.9 \mathrm{~Hz}, 1 \mathrm{H}), 4.53(\mathrm{bs}, 1 \mathrm{H}), 3.81(\mathrm{~s}$, $3 \mathrm{H}$ ), 3.09-3.23 (m, 3H), 2.23 (dddd, $J=14.2,10.7,6.1,3.0 \mathrm{~Hz}, 1 \mathrm{H}), 2.07$ (dtd, $J=14.9,10.5,4.9$ $\mathrm{Hz}, 1 \mathrm{H}), 1.66-1.76(\mathrm{~m}, 1 \mathrm{H}), 1.45-1.64(\mathrm{~m}, 2 \mathrm{H}), 1.40(\mathrm{~s}, 9 \mathrm{H}), 1.07$ (dd, $J=10.3,6.6 \mathrm{~Hz}, 6 \mathrm{H})$.

${ }^{13} \mathrm{C}$ NMR $\left(101 \mathrm{MHz}, \mathrm{CDCl}_{3}\right) \delta 159.4,156.0,129.6,124.4,123.8,116.8,114.9,89.1,86.5,84.2$, $79.5,55.5,43.9,39.8,30.3,28.7,28.5,26.7,21.8,16.8$.

FTIR $\left(\mathrm{cm}^{-1}\right)$ 3354, 2966, 2932, 1700, 1552, 1167, 782.

HRMS (ESI) m/z, calcd for $\left[\mathrm{C}_{22} \mathrm{H}_{33} \mathrm{~N}_{2} \mathrm{O}_{5}\right]^{+}:$405.2389; found 405.2382.

diastereomer 2 (d2):

${ }^{1} \mathrm{H}$ NMR $\left(400 \mathrm{MHz}, \mathrm{CDCl}_{3}\right) \delta 7.19(\mathrm{t}, J=7.9 \mathrm{~Hz}, 1 \mathrm{H}), 6.99(\mathrm{~d}, J=7.8 \mathrm{~Hz}, 1 \mathrm{H}), 6.91(\mathrm{t}, J=2.0 \mathrm{~Hz}$, $1 \mathrm{H}), 6.85(\mathrm{dd}, J=8.3,2.7 \mathrm{~Hz}, 1 \mathrm{H}), 4.62-4.72(\mathrm{~m}, 1 \mathrm{H}), 4.54(\mathrm{bs}, 1 \mathrm{H}), 3.79(\mathrm{~s}, 3 \mathrm{H}), 3.17(\mathrm{dt}, J=$ 
10.0, $5.0 \mathrm{~Hz}, 2 \mathrm{H}), 2.98(\mathrm{dd}, J=8.6,5.1 \mathrm{~Hz}, 1 \mathrm{H}), 1.99-2.11(\mathrm{~m}, 1 \mathrm{H}), 1.83-1.97(\mathrm{~m}, 2 \mathrm{H}), 1.47-$ $1.62(\mathrm{~m}, 1 \mathrm{H}), 1.43(\mathrm{~s}, 9 \mathrm{H}), 1.15(\mathrm{~d}, J=6.6 \mathrm{~Hz}, 3 \mathrm{H}), 1.03(\mathrm{~d}, J=6.7 \mathrm{~Hz}, 3 \mathrm{H})$.

${ }^{13} \mathrm{C}$ NMR $\left(101 \mathrm{MHz}, \mathrm{CDCl}_{3}\right) \delta 159.3,156.1,129.4,124.5,123.9,116.7,114.9,89.8,86.0,84.6$, $55.4,43.7,39.7,29.9,28.9,28.5,28.4,26.8,21.9,18.0$.

FTIR $\left(\mathrm{cm}^{-1}\right)$ 3350, 2966, 2931, 1709, 1554, 1167, 783.

HRMS (ESI) m/z, calcd for $\left[\mathrm{C}_{22} \mathrm{H}_{33} \mathrm{~N}_{2} \mathrm{O}_{5}\right]^{+}:$405.2389; found 405.2381.

MP: $77-79^{\circ} \mathrm{C}(\mathrm{EtOAc})$.

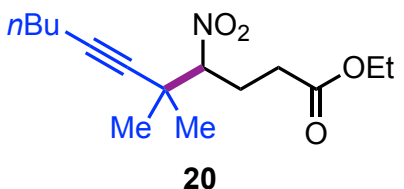

Chemical Formula: $\mathrm{C}_{15} \mathrm{H}_{25} \mathrm{NO}_{4}$ Exact Mass: 283.1784

Molecular Weight: 283.3680
20: According to General Procedure 8A, ethyl 4-nitrobutanoate (161 $\mathrm{mg}, 1.0 \mathrm{mmol})$, 2-bromo-2-methyloct-3-yne (234 mg, $1.15 \mathrm{mmol})$, $\mathrm{CuBr}(28.7 \mathrm{mg}, 0.2 \mathrm{mmol}), \mathrm{KO} \mathrm{Bu}^{t}(118 \mathrm{mg}, 1.05 \mathrm{mmol})$, and 12 (43.3 $\mathrm{mg}, 0.3 \mathrm{mmol})$ in anhydrous dioxane $(5 \mathrm{~mL}, 0.2 \mathrm{M})$ for $20 \mathrm{~h}$, afforded, after flash silica gel chromatography (90:10 hexanes:Et $\left.{ }_{2} \mathrm{O}\right), 20$ (65.1 $\mathrm{mg}, 23 \%$ ) as clear, yellow oil.

${ }^{1} \mathrm{H}$ NMR $\left(400 \mathrm{MHz}, \mathrm{CDCl}_{3}\right) \delta 4.44(\mathrm{dd}, J=10.8,1.8 \mathrm{~Hz}, 1 \mathrm{H}), 4.14$ (q, $\left.J=7.2 \mathrm{~Hz}, 2 \mathrm{H}\right), 2.34-2.48$ $(\mathrm{m}, 2 \mathrm{H}), 2.22-2.34(\mathrm{~m}, 2 \mathrm{H}), 2.15(\mathrm{t}, J=6.9 \mathrm{~Hz}, 2 \mathrm{H}), 1.35-1.51(\mathrm{~m}, 4 \mathrm{H}), 1.31(\mathrm{~s}, 3 \mathrm{H}), 1.28(\mathrm{~s}$, $3 \mathrm{H}), 1.25(\mathrm{t}, J=7.1 \mathrm{~Hz}, 3 \mathrm{H}), 0.90(\mathrm{t}, J=7.2 \mathrm{~Hz}, 3 \mathrm{H})$.

${ }^{13} \mathrm{C}$ NMR $\left(101 \mathrm{MHz}, \mathrm{CDCl}_{3}\right) \delta 172.1,95.2,83.9,81.8,60.9,35.2,31.0,30.8,27.5,25.9,24.9$, 22.0, 18.4, 14.3, 13.8 .

FTIR $\left(\mathrm{cm}^{-1}\right)$ 2959, 2934, 2873, 1737, 1552, 1187.

HRMS (ESI) m/z, calcd for $\left[\mathrm{C}_{15} \mathrm{H}_{26} \mathrm{NO}_{4}\right]^{+}$: 284.1862; found 284.1850.

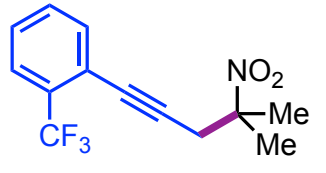

21

Chemical Formula: $\mathrm{C}_{13} \mathrm{H}_{12} \mathrm{~F}_{3} \mathrm{NO}_{2}$

Exact Mass: 271.0820

Molecular Weight: 271.2392

21: According to General Procedure 8A, 2-nitropropane (89.1 mg, $1.0 \mathrm{mmol}$ ), 1-(3-bromoprop-1-yn-1-yl)-2-(trifluoromethyl)benzene (303 mg, $1.15 \mathrm{mmol}), \mathrm{CuBr}(14.4 \mathrm{mg}, 0.1 \mathrm{mmol}), \mathrm{KO} \mathrm{B}^{\mathrm{B} u}(118 \mathrm{mg}$, $1.05 \mathrm{mmol})$, and 12 (43.3 $\mathrm{mg}, 0.3 \mathrm{mmol})$ in anhydrous dioxane (5 $\mathrm{mL}, 0.2 \mathrm{M}$ ) for $4 \mathrm{~h}$, afforded, after flash silica gel chromatography (90:10 hexanes/ $\left.\mathrm{Et}_{2} \mathrm{O}\right), 21$ (228 mg, 84\%) as clear, light yellow oil.

${ }^{1} \mathrm{H}$ NMR $\left(600 \mathrm{MHz}, \mathrm{CDCl}_{3}\right) \delta 7.64(\mathrm{~d}, J=7.8 \mathrm{~Hz}, 1 \mathrm{H}), 7.55(\mathrm{~d}, J=7.7 \mathrm{~Hz}, 1 \mathrm{H}), 7.48(\mathrm{t}, J=7.5 \mathrm{~Hz}$, $1 \mathrm{H}), 7.40$ (t, $J=7.7 \mathrm{~Hz}, 1 \mathrm{H}), 3.12(\mathrm{~s}, 2 \mathrm{H}), 1.75(\mathrm{~s}, 6 \mathrm{H})$.

${ }^{13} \mathrm{C}$ NMR $\left(151 \mathrm{MHz}, \mathrm{CDCl}_{3}\right) \delta 134.3,131.7$ (q, $\left.J=30.3 \mathrm{~Hz}\right), 131.6,128.2,125.9(\mathrm{q}, J=5.1 \mathrm{~Hz})$, $123.6(q, J=273 \mathrm{~Hz}), 121.2(q, J=2.1 \mathrm{~Hz}), 89.5,87.1,80.2,31.9,25.6$.

${ }^{19} \mathrm{~F} \mathrm{NMR}\left(565 \mathrm{MHz}, \mathrm{CDCl}_{3}\right) \delta-62.4$.

FTIR $\left(\mathrm{cm}^{-1}\right)$ 2994, 2943, 2882, 1544, 1318, 1172, 1133, 1112, 767.

HRMS (ESI) m/z, calcd for $\left[\mathrm{C}_{13} \mathrm{H}_{13} \mathrm{~F}_{3} \mathrm{NO}_{2}\right]^{+}:$272.0898; found 272.0898. 


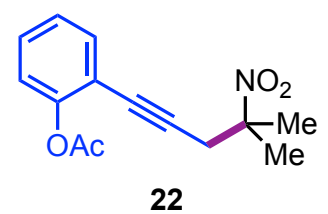

Chemical Formula: $\mathrm{C}_{14} \mathrm{H}_{15} \mathrm{NO}_{4}$ Exact Mass: 261.1001 Molecular Weight: 261.2770

22: According to General Procedure 8A, 2-nitropropane $(89.1 \mathrm{mg}$, $1.0 \mathrm{mmol}$ ), 2-(3-bromoprop-1-yn-1-yl)phenyl acetate (291 mg, 1.15 $\mathrm{mmol}), \mathrm{CuBr}(14.4 \mathrm{mg}, 0.1 \mathrm{mmol}), \mathrm{KO}^{t} \mathrm{Bu}(118 \mathrm{mg}, 1.05 \mathrm{mmol})$, and 12 (43.3 $\mathrm{mg}, 0.3 \mathrm{mmol})$ in anhydrous dioxane $(5 \mathrm{~mL}, 0.2 \mathrm{M})$ for $4 \mathrm{~h}$, afforded, after flash silica gel chromatography (100\% DCM), 22 (198 $\mathrm{mg}, 76 \%$ ) as clear, yellow oil.

${ }^{1} \mathrm{H}$ NMR $\left(600 \mathrm{MHz}, \mathrm{CDCl}_{3}\right) \delta 7.44(\mathrm{dd}, J=7.7,1.7 \mathrm{~Hz}, 1 \mathrm{H}), 7.33(\mathrm{td}, J=8.0,1.6 \mathrm{~Hz}, 1 \mathrm{H}), 7.18$ (td, $J=7.6,1.2 \mathrm{~Hz}, 1 \mathrm{H}), 7.07$ (dd, $J=8.2,1.2 \mathrm{~Hz}, 1 \mathrm{H}), 3.07(\mathrm{~s}, 2 \mathrm{H}), 2.33(\mathrm{~s}, 3 \mathrm{H}), 1.73(\mathrm{~s}, 6 \mathrm{H})$.

${ }^{13} \mathrm{C}$ NMR $\left(151 \mathrm{MHz}, \mathrm{CDCl}_{3}\right) \delta 169.0,151.8,133.5,129.6,126.0,122.5,117.0,88.2,87.0,79.4$, 32.0, 25.7, 20.9 .

FTIR $\left(\mathrm{cm}^{-1}\right)$ 2991, 1763, 1542, 1210, 1186, 759.

HRMS (ESI) m/z, calcd for $\left[\mathrm{C}_{14} \mathrm{H}_{16} \mathrm{NO}_{4}\right]^{+}:$: 262.1079; found 262.1077.

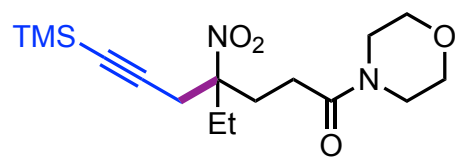

23

Chemical Formula: $\mathrm{C}_{16} \mathrm{H}_{28} \mathrm{~N}_{2} \mathrm{O}_{4} \mathrm{Si}$ Exact Mass: 340.1818

Molecular Weight: 340.4950
23: According to General Procedure 8A, 1-morpholino-4nitrohexan-1-one (230 mg, $1.0 \mathrm{mmol})$, (3-bromoprop-1-yn-1yl)trimethylsilane (220 mg, $1.15 \mathrm{mmol}), \mathrm{CuBr}(14.4 \mathrm{mg}, 0.1 \mathrm{mmol})$, KO $\mathrm{Bu}$ (118 mg, $1.05 \mathrm{mmol})$, and 12 (43.3 $\mathrm{mg}, 0.3 \mathrm{mmol})$ in anhydrous dioxane ( $5 \mathrm{~mL}, 0.2 \mathrm{M}$ ) for $4 \mathrm{~h}$, afforded, after flash silica gel chromatography (20:80 hexanes:Et $\left.{ }_{2} \mathrm{O}\right), 23(251 \mathrm{mg}, 74 \%)$ as yellow oil.

${ }^{1} \mathrm{H}$ NMR $\left(600 \mathrm{MHz}, \mathrm{CDCl}_{3}\right) \delta 3.64(\mathrm{t}, J=4.9 \mathrm{~Hz}, 4 \mathrm{H}), 3.54-3.62(\mathrm{~m}, 2 \mathrm{H}), 3.40(\mathrm{t}, J=4.9 \mathrm{~Hz}, 2 \mathrm{H})$, $2.95(\mathrm{~d}, J=17.3 \mathrm{~Hz}, 1 \mathrm{H}), 2.84(\mathrm{~d}, J=17.3 \mathrm{~Hz}, 1 \mathrm{H}), 2.29-2.43(\mathrm{~m}, 3 \mathrm{H}), 2.09-2.23(\mathrm{~m}, 2 \mathrm{H}), 2.03$ (dq, $J=14.8,7.4 \mathrm{~Hz}, 1 \mathrm{H}), 0.90(\mathrm{t}, J=7.4 \mathrm{~Hz}, 3 \mathrm{H}), 0.12(\mathrm{~s}, 9 \mathrm{H})$.

${ }^{13} \mathrm{C}$ NMR $\left(101 \mathrm{MHz}, \mathrm{CDCl}_{3}\right) \delta 169.6,99.7,92.9,89.2,67.0,66.7,45.9,42.2,32.0,30.1,27.6$, $25.8,8.2,0.0$.

${ }^{29} \mathrm{Si} \mathrm{NMR}\left(119 \mathrm{MHz}, \mathrm{CDCl}_{3}\right) \delta-17.9$.

FTIR $\left(\mathrm{cm}^{-1}\right)$ 2962, 2857, 2180, 1651, 1541, 1442, 1250, 1117, 845.

HRMS (ESI) m/z, calcd for $\left[\mathrm{C}_{16} \mathrm{H}_{29} \mathrm{~N}_{2} \mathrm{O}_{4} \mathrm{Si}\right]^{+}: 341.1897$; found 341.1887.

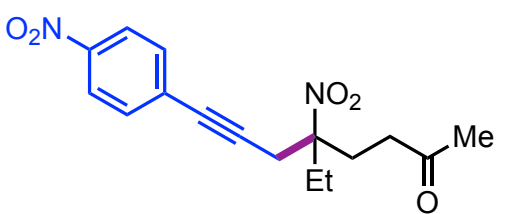

24

Chemical Formula: $\mathrm{C}_{16} \mathrm{H}_{18} \mathrm{~N}_{2} \mathrm{O}_{5}$ Exact Mass: 318.1216 Molecular Weight: 318.3290
24: According to General Procedure 8B, 5-nitroheptan-2-one (159 mg, $1.0 \mathrm{mmol}$ ), 1-(3-bromoprop-1-yn-1-yl)-4-nitrobenzene (276 mg, $1.15 \mathrm{mmol}), \mathrm{CuBr}$ (14.4 mg, $0.1 \mathrm{mmol}$ ), KOtBu (118 mg, $1.05 \mathrm{mmol})$, and 12 (43.3 $\mathrm{mg}, 0.3 \mathrm{mmol})$ in anhydrous dioxane (5 $\mathrm{mL}, 0.2 \mathrm{M}$ ) for $4 \mathrm{~h}$, afforded, after flash silica gel chromatography (gradient, 90:10 to 80:20 hexanes:EtOAc), 24 (249 mg, 78\%) as light orange solid. 
${ }^{1} \mathrm{H}$ NMR $\left(400 \mathrm{MHz}, \mathrm{CDCl}_{3}\right) \delta 8.17(\mathrm{~d}, J=8.8 \mathrm{~Hz}, 2 \mathrm{H}), 7.52(\mathrm{~d}, J=8.7 \mathrm{~Hz}, 2 \mathrm{H}), 3.19(\mathrm{~d}, J=17.5$ $\mathrm{Hz}, 1 \mathrm{H}), 3.08(\mathrm{~d}, J=17.5 \mathrm{~Hz}, 1 \mathrm{H}), 2.31-2.59(\mathrm{~m}, 4 \mathrm{H}), 2.15-2.26(\mathrm{~m}, 4 \mathrm{H}), 2.01-2.15(\mathrm{~m}, 1 \mathrm{H})$, $0.96(\mathrm{t}, J=7.4 \mathrm{~Hz}, 3 \mathrm{H})$.

${ }^{13} \mathrm{C} \mathrm{NMR}\left(151 \mathrm{MHz}, \mathrm{CDCl}_{3}\right) \delta 206.0,147.4,132.7,129.6,123.7,92.7,88.6,82.5,37.8,30.3,30.2$, $30.0,25.9,8.3$.

FTIR $\left(\mathrm{cm}^{-1}\right) 3419,3109,2934,1715,1537,1514,1345,855$.

HRMS (ESI) m/z, calcd for $\left[\mathrm{C}_{16} \mathrm{H}_{19} \mathrm{~N}_{2} \mathrm{O}_{5}\right]^{+}: 319.1294$; found 319.1285 .

MP: $98-100^{\circ} \mathrm{C}(\mathrm{EtOAc})$.

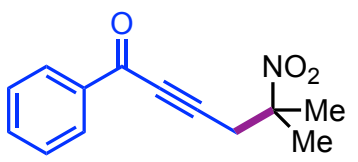

25

Chemical Formula: $\mathrm{C}_{13} \mathrm{H}_{13} \mathrm{NO}_{3}$ Exact Mass: 231.0895 Molecular Weight: 231.2510
25: According to General Procedure 8B, 2-nitropropane (89.1 mg, $1.0 \mathrm{mmol}$ ), 4-bromo-1-phenylbut-2-yn-1-one (257 mg, $1.15 \mathrm{mmol})$, $\mathrm{CuBr}(14.4 \mathrm{mg}, 0.1 \mathrm{mmol}), \mathrm{KO}{ }^{\mathrm{B}} \mathrm{Bu}(118 \mathrm{mg}, 1.05 \mathrm{mmol})$, and 12 (43.3 $\mathrm{mg}, 0.3 \mathrm{mmol})$ in anhydrous dioxane $(5 \mathrm{~mL}, 0.2 \mathrm{M})$ for $4 \mathrm{~h}$, afforded, after flash silica gel chromatography (70:30 hexanes: $\left.\mathrm{Et}_{2} \mathrm{O}\right), 25$ (101 $\mathrm{mg}, 44 \%$ ) as clear, dark-orange oil.

${ }^{1} \mathrm{H}$ NMR $\left(600 \mathrm{MHz}, \mathrm{CDCl}_{3}\right) \delta 8.07-8.10(\mathrm{~m}, 2 \mathrm{H}), 7.60-7.64(\mathrm{~m}, 1 \mathrm{H}), 7.47-7.52(\mathrm{~m}, 2 \mathrm{H}), 3.17$ (s, 2H), $1.78(\mathrm{~s}, 6 \mathrm{H})$.

${ }^{13} \mathrm{C} \mathrm{NMR}\left(151 \mathrm{MHz}, \mathrm{CDCl}_{3}\right) \delta 177.6,136.6,134.5,129.7,128.8,88.4,86.4,82.4,31.5,26.0$.

FTIR $\left(\mathrm{cm}^{-1}\right)$ 2941, 2241, 2203, 1646, 1543, 1266, 701.

HRMS (ESI) m/z, calcd for $\left[\mathrm{C}_{13} \mathrm{H}_{14} \mathrm{NO}_{3}\right]^{+}: 232.0974$; found 232.0972 .

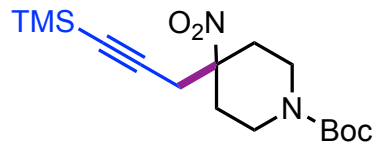

26

Chemical Formula: $\mathrm{C}_{16} \mathrm{H}_{28} \mathrm{~N}_{2} \mathrm{O}_{4} \mathrm{Si}$ Exact Mass: 340.1818 Molecular Weight: 340.4950
26: According to General Procedure 8A, tert-butyl 4nitropiperidine-1-carboxylate (230 mg, $1.0 \mathrm{mmol}$ ), (3-bromoprop-1yn-1-yl)trimethylsilane (220 mg, $1.15 \mathrm{mmol}), \mathrm{CuBr}(14.4 \mathrm{mg}, 0.1$ $\mathrm{mmol}$ ), KOtBu (118 mg, $1.05 \mathrm{mmol})$, and 12 (43.3 $\mathrm{mg}, 0.3 \mathrm{mmol}$ ) in anhydrous dioxane ( $5 \mathrm{~mL}, 0.2 \mathrm{M})$ for $4 \mathrm{~h}$, afforded, after flash silica gel chromatography (80:20 hexanes: $\left.\mathrm{Et}_{2} \mathrm{O}\right), 26(287 \mathrm{mg}, 84 \%)$ as white solid.

${ }^{1} \mathrm{H}$ NMR (600 MHz, CDCl $\left.{ }_{3}\right) \delta 3.89$ (bs, 2H), 2.99 (bs, 2H), $2.79(\mathrm{~s}, 2 \mathrm{H}), 2.46$ (d, J = $\left.13.9 \mathrm{~Hz}, 2 \mathrm{H}\right)$, 1.89 (ddd, $J=15.1,11.1,4.7 \mathrm{~Hz}, 2 \mathrm{H}), 1.45(\mathrm{~s}, 9 \mathrm{H}), 0.14(\mathrm{~s}, 9 \mathrm{H})$.

${ }^{13} \mathrm{C}$ NMR $\left(151 \mathrm{MHz}, \mathrm{CDCl}_{3}\right) \delta 154.6,98.2,90.8,88.5,80.2,32.6,32.1,28.5,-0.1$.

${ }^{29} \mathrm{Si} \mathrm{NMR}\left(119 \mathrm{MHz}, \mathrm{CDCl}_{3}\right) \delta-17.7$.

FTIR $\left(\mathrm{cm}^{-1}\right)$ 2969, 2182, 1670, 1546, 1422, 1367, 1250, 845.

HRMS (ESI) m/z, calcd for $\left[\mathrm{C}_{16} \mathrm{H}_{29} \mathrm{~N}_{2} \mathrm{O}_{4} \mathrm{Si}\right]^{+}:$341.1897; found 341.1886.

MP: $70-72^{\circ} \mathrm{C}\left(\mathrm{Et}_{2} \mathrm{O}\right)$. 


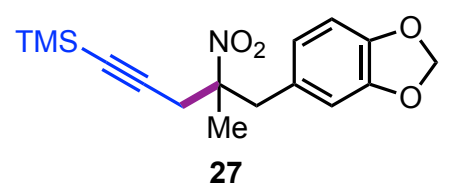

Chemical Formula: $\mathrm{C}_{16} \mathrm{H}_{21} \mathrm{NO}_{4} \mathrm{Si}$

Exact Mass: 319.1240

Molecular Weight: 319.4320

white solid.

27: According to General Procedure 8A, 5-(2nitropropyl)benzo[d][1,3]dioxole (209 mg, $1.0 \mathrm{mmol})$, (3-bromoprop1-yn-1-yl)trimethylsilane (220 mg, $1.15 \mathrm{mmol}), \mathrm{CuBr}(14.4 \mathrm{mg}, 0.1$ $\mathrm{mmol}), \mathrm{KO} \mathrm{Bu}(118 \mathrm{mg}, 1.05 \mathrm{mmol})$, and 12 (43.3 $\mathrm{mg}, 0.3 \mathrm{mmol})$ in anhydrous dioxane $(5 \mathrm{~mL}, 0.2 \mathrm{M})$ for $4 \mathrm{~h}$, afforded, after flash silica gel chromatography (80:20 hexanes: $\left.\mathrm{Et}_{2} \mathrm{O}\right), 27(277 \mathrm{mg}, 87 \%)$ as

${ }^{1} \mathrm{H}$ NMR $\left(400 \mathrm{MHz}, \mathrm{CDCl}_{3}\right) \delta 6.73(\mathrm{~d}, J=7.9 \mathrm{~Hz}, 1 \mathrm{H}), 6.64(\mathrm{~d}, J=1.7 \mathrm{~Hz}, 1 \mathrm{H}), 6.60(\mathrm{dd}, J=7.9$, $1.8 \mathrm{~Hz}, 1 \mathrm{H}), 5.94(\mathrm{~s}, 2 \mathrm{H}), 3.22(\mathrm{~d}, J=14.1 \mathrm{~Hz}, 1 \mathrm{H}), 3.17(\mathrm{~d}, J=14.1 \mathrm{~Hz}, 1 \mathrm{H}), 2.84(\mathrm{~d}, J=17.0$ $\mathrm{Hz}, 1 \mathrm{H}), 2.78(\mathrm{~d}, J=17.0 \mathrm{~Hz}, 1 \mathrm{H}), 1.65(\mathrm{~s}, 3 \mathrm{H}), 0.18(\mathrm{~s}, 9 \mathrm{H})$.

${ }^{13} \mathrm{C}$ NMR $\left(101 \mathrm{MHz}, \mathrm{CDCl}_{3}\right) \delta 147.9,147.3,127.9,123.4,110.3,108.5,101.2,100.6,90.6,89.8$, 43.9, 29.5, 23.4, 0.0.

${ }^{29} \mathrm{Si} \mathrm{NMR}\left(119 \mathrm{MHz}, \mathrm{CDCl}_{3}\right) \delta-17.9$.

FTIR $\left(\mathrm{cm}^{-1}\right)$ 2960, 2899, 2180, 1544, 1504, 1491, 1445, 1251, 1040, 846.

HRMS (ESI) m/z, calcd for $\left[\mathrm{C}_{16} \mathrm{H}_{22} \mathrm{NO}_{4} \mathrm{Si}\right]^{+} 320.1318$; found 320.1318.

$\mathrm{MP}: 68-70^{\circ} \mathrm{C}\left(\mathrm{Et}_{2} \mathrm{O}\right)$

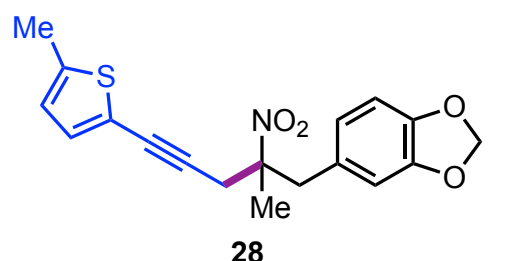

Chemical Formula: $\mathrm{C}_{18} \mathrm{H}_{17} \mathrm{NO}_{4} \mathrm{~S}$ Exact Mass: 343.0878 Molecular Weight: 343.3970
28: According to General Procedure 8A, 5-(2nitropropyl)benzo[d][1,3]dioxole (209 mg, $1.0 \mathrm{mmol}), 2-(3-$ bromoprop-1-yn-1-yl)-5-methylthiophene (247 mg, $1.15 \mathrm{mmol}$ ), $\mathrm{CuBr}(28.7 \mathrm{mg}, 0.2 \mathrm{mmol}), \mathrm{KO}{ }^{\mathrm{B}} \mathrm{Bu}(118 \mathrm{mg}, 1.05 \mathrm{mmol})$, and 12 (43.3 $\mathrm{mg}, 0.3 \mathrm{mmol})$ in anhydrous dioxane $(5 \mathrm{~mL}, 0.2 \mathrm{M})$ for $4 \mathrm{~h}$, afforded, after flash silica gel chromatography (95:05 hexanes:Et $\left.{ }_{2} \mathrm{O}\right), 28$ (202 mg, 59\%) as yellow-orange oil.

${ }^{1} \mathrm{H}$ NMR $\left(600 \mathrm{MHz} \mathrm{CDCl}_{3}\right) \delta 6.99(\mathrm{~d}, J=3.5 \mathrm{~Hz}, 1 \mathrm{H}), 6.74(\mathrm{~d}, J=7.9 \mathrm{~Hz}, 1 \mathrm{H}), 6.67-6.59(\mathrm{~m}$, $3 \mathrm{H}), 5.94(\mathrm{~s}, 2 \mathrm{H}), 3.27(\mathrm{~d}, J=14.2 \mathrm{~Hz}, 1 \mathrm{H}), 3.22(\mathrm{~d}, J=14.2 \mathrm{~Hz}, 1 \mathrm{H}), 3.05(\mathrm{~d}, J=17.0 \mathrm{~Hz}, 1 \mathrm{H})$, $3.00(\mathrm{~d}, J=17.0 \mathrm{~Hz}, 1 \mathrm{H}), 2.46(\mathrm{~s}, 3 \mathrm{H}), 1.70(\mathrm{~s}, 3 \mathrm{H})$.

${ }^{13} \mathrm{C} \mathrm{NMR}\left(151 \mathrm{MHz}, \mathrm{CDCl}_{3}\right) \delta 147.9,147.3,142.0,132.4,127.9,125.3,123.5,120.3,110.3,108.6$, $101.3,90.8,86.8,78.4,44.1,29.5,23.5,15.5$.

FTIR $\left(\mathrm{cm}^{-1}\right)$ 2921, 1542, 1490, 1444, 1249, 1039, 802.

HRMS (ESI) m/z, calcd for $\left[\mathrm{C}_{18} \mathrm{H}_{18} \mathrm{NO}_{4} \mathrm{~S}\right]^{+}: 344.0957$; found 344.0936 . 


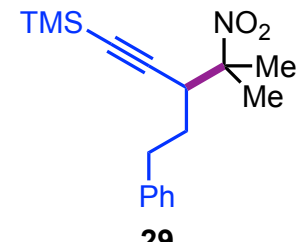

29

Chemical Formula: $\mathrm{C}_{17} \mathrm{H}_{25} \mathrm{NO}_{2} \mathrm{Si}$

Exact Mass: 303.1655

Molecular Weight: 303.4770

29: According to General Procedure 8A, 2-nitropropane $(89.1 \mathrm{mg}$, $1.0 \mathrm{mmol}$ ), (3-bromo-5-phenylpent-1-yn-1-yl)trimethylsilane (340 mg, $1.15 \mathrm{mmol}), \mathrm{CuBr}(14.4 \mathrm{mg}, 0.1 \mathrm{mmol}), \mathrm{KO} \mathrm{Bu}^{\mathrm{B} u}(118 \mathrm{mg}, 1.05 \mathrm{mmol})$, and 12 (43.3 $\mathrm{mg}, 0.3 \mathrm{mmol})$ in anhydrous dioxane $(5 \mathrm{~mL}, 0.2 \mathrm{M})$ for $20 \mathrm{~h}$, afforded, after flash silica gel chromatography (98:2 hexanes:Et ${ }_{2} \mathrm{O}$ ), 29 (193 mg, 64\%) as clear, light yellow oil.

${ }^{1} \mathrm{H}$ NMR $\left(600 \mathrm{MHz}, \mathrm{CDCl}_{3}\right) \delta 7.29(\mathrm{t}, J=7.7 \mathrm{~Hz}, 2 \mathrm{H}), 7.21(\mathrm{t}, J=7.3$ $\mathrm{Hz}, 1 \mathrm{H}$ ), 7.17 (d, $J=7.4 \mathrm{~Hz}, 2 \mathrm{H}$ ), 3.16 (dd, $J=11.7,3.2 \mathrm{~Hz}, 1 \mathrm{H}$ ), 2.95 (ddd, $J=14.0,9.6,4.5 \mathrm{~Hz}$, 1H), 2.65 (ddd, $J=13.7,9.5,7.5 \mathrm{~Hz}, 1 \mathrm{H}), 1.65-1.73(\mathrm{~m}, 4 \mathrm{H}), 1.54-1.61(\mathrm{~m}, 4 \mathrm{H}), 0.20(\mathrm{~s}, 9 \mathrm{H})$.

${ }^{13} \mathrm{C}$ NMR $\left(151 \mathrm{MHz}, \mathrm{CDCl}_{3}\right) \delta 141.0,128.61,128.58,126.3,103.9,90.5,90.2,42.3,34.0,31.8$, $26.2,21.4,0.12$.

${ }^{29} \mathrm{Si} \mathrm{NMR}\left(119 \mathrm{MHz}, \mathrm{CDCl}_{3}\right) \delta-17.9$.

FTIR $\left(\mathrm{cm}^{-1}\right)$ 2958, 2175, 1543, 1250, 844, 700.

HRMS (ESI) m/z, calcd for $\left[\mathrm{C}_{17} \mathrm{H}_{26} \mathrm{NO}_{2} \mathrm{Si}\right]^{+}:$304.1733; found 304.1722.

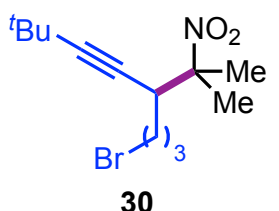

Chemical Formula: $\mathrm{C}_{13} \mathrm{H}_{22} \mathrm{BrNO}_{2}$

Exact Mass: 303.0834 Molecular Weight: 304.2280
30: According to General Procedure 8A, 2-nitropropane $(89.1 \mathrm{mg}$, $1.0 \mathrm{mmol}$ ), 5-bromo-8-chloro-2,2-dimethyloct-3-yne (340 mg, 1.15 $\mathrm{mmol}), \mathrm{CuBr}(14.4 \mathrm{mg}, 0.1 \mathrm{mmol}), \mathrm{KO}^{t} \mathrm{Bu}(118 \mathrm{mg}, 1.05 \mathrm{mmol})$, and 12 (43.3 $\mathrm{mg}, 0.3 \mathrm{mmol})$ in anhydrous dioxane $(5 \mathrm{~mL}, 0.2 \mathrm{M})$ for 20 $\mathrm{h}$, afforded, after flash silica gel flash chromatography (gradient, 99:1 to $97: 3$ hexanes: $\left.\mathrm{Et}_{2} \mathrm{O}\right), \mathbf{3 0}(196 \mathrm{mg}, 64 \%)$ as clear, light yellow oil.

${ }^{1} \mathrm{H}$ NMR $\left(600 \mathrm{MHz}, \mathrm{CDCl}_{3}\right) \delta 3.37-3.49(\mathrm{~m}, 2 \mathrm{H}), 3.10(\mathrm{dd}, J=10.7,4.3 \mathrm{~Hz}, 1 \mathrm{H}), 2.09-2.18(\mathrm{~m}$, $1 \mathrm{H}), 1.87-1.96(\mathrm{~m}, 1 \mathrm{H}), 1.66(\mathrm{~s}, 3 \mathrm{H}), 1.59(\mathrm{~s}, 3 \mathrm{H}), 1.40-1.50(\mathrm{~m}, 2 \mathrm{H}), 1.19(\mathrm{~s}, 9 \mathrm{H})$.

${ }^{13} \mathrm{C}$ NMR $\left(101 \mathrm{MHz}, \mathrm{CD}_{2} \mathrm{Cl}_{2}\right) \delta 94.6,91.4,76.1,41.5,33.8,31.6,31.2,29.1,27.9,25.5,22.0$.

FTIR $\left(\mathrm{cm}^{-1}\right)$ 2968, 2868, 1542, 1458, 1347, 1265, 860.

HRMS (ESI) m/z, calcd for $\left[\mathrm{C}_{13} \mathrm{H}_{23} \mathrm{NO}_{2} \mathrm{Br}\right]^{+}:$304.0912; found 304.0907.

\section{Downstream Functionalization of Homopropargylic Nitroalkanes to Pyrroles}

\section{General Experimental Procedure for the Synthesis of nitro-Mannich Adducts}

Note: General Procedure 9A was modified from a known procedure. ${ }^{24}$

General Procedure 9A: In a $\mathrm{N}_{2}$-filled glovebox, a 1-dram vial was fitted with a stir bar, and Nbenzylidene-4-methylbenzenesulfonamide (1.0 equiv), 4A MS (40 mg), and anhydrous DMSO $(0.3 \mathrm{M})$ were added sequentially. The vial was capped with a Teflon-lined screw cap and the resulting suspension was stirred at it for $5 \mathrm{~min}$. The vial was momentarily uncapped and homopropargylic nitroalkane (2.0 equiv) was added. The vial was recapped, sealed with PVC 
electrical tape, taken out of the glovebox, and stirred rapidly at $\mathrm{rt}$ for $20 \mathrm{~h}$. The suspension was diluted with EtOAc $(1 \mathrm{~mL})$, poured into a separatory funnel, and rinsed with EtOAc ( $3 \times 5 \mathrm{~mL})$. $\mathrm{NaHCO}_{3}(20 \mathrm{~mL}$, saturated aqueous) was then added to the separatory funnel and the layers were separated. The aqueous phase was extracted with EtOAc ( $3 \times 10 \mathrm{~mL})$. The combined organic layers were then washed with brine $\left(20 \mathrm{~mL}\right.$, saturated aqueous), dried over $\mathrm{MgSO}_{4}$, filtered through a fritted funnel, and concentrated in vacuo to afford a crude oil. The crude product was purified by flash C18-reversed phase silica gel chromatography (SNAP Ultra C18 $60 \mathrm{~g}$ column) on a Biotage ${ }^{\circledR}$ Isolera ${ }^{\mathrm{TM}}$ One purification system $(2 \mathrm{X})$ using the specified condition.

\section{General Experimental Procedure for the Synthesis of Pyrroles}

General Procedure 9B: In a $\mathrm{N}_{2}$-filled glovebox, a 1-dram vial was fitted with a stir bar, and the nitro-Mannich adduct (1.0 equiv) and anhydrous toluene $(0.25 \mathrm{M})$ were added. $\mathrm{PPh}_{3} \mathrm{AuCl}(0.1$ equiv) and $\mathrm{AgPF}_{6}$ ( 0.1 equiv) were then added sequentially to the reaction mixture. The vial was capped with a Teflon-lined screw cap, sealed with PVC electrical tape, taken out of the glovebox, and stirred rapidly at $110^{\circ} \mathrm{C}$ in a silicone oil bath for $36 \mathrm{~h}$. The resulting suspension was removed from the oil bath, cooled to rt, diluted with EtOAc $(1 \mathrm{~mL})$, poured into a separatory funnel, and rinsed with EtOAc $(3 \times 5 \mathrm{~mL}) . \mathrm{NaHCO}_{3}(20 \mathrm{~mL}$, saturated aqueous) was then added to the separatory funnel and the layers were separated. The aqueous phase was extracted with EtOAc $(3 \times 10 \mathrm{~mL})$. The combined organic layers were then washed with brine $(20 \mathrm{~mL}$, saturated aqueous), dried over $\mathrm{MgSO}_{4}$, filtered through a fritted funnel, and concentrated in vacuo to afford a crude oil. The crude product was purified by flash silica gel chromatography using the specified condition.

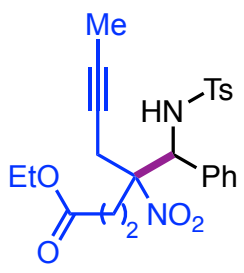

$32 \mathrm{a}(\mathrm{dr} 64: 36)$

Chemical Formula: $\mathrm{C}_{24} \mathrm{H}_{28} \mathrm{~N}_{2} \mathrm{O}_{6} \mathrm{~S}$

Exact Mass: 472.1668

Molecular Weight: 472.5560 32a: According to General Procedure 9A, N-benzylidene-4methylbenzenesulfonamide (104 mg, $0.4 \mathrm{mmol}$ ), 3b (171 mg, 0.8 $\mathrm{mmol})$, and $4 \AA \mathrm{MS}(40.0 \mathrm{mg})$ in anhydrous DMSO $(1.33 \mathrm{~mL}, 0.3 \mathrm{M})$ for $20 \mathrm{~h}$. NMR analysis of the crude reaction mixture revealed a 64:36 ratio of diastereomers. After C18-reversed phase flash silica gel chromatography (2 X, gradient, $30: 70$ to $70: 30 \mathrm{MeCN} / \mathrm{H}_{2} \mathrm{O}$ ), 32a was afforded as mixture of diastereomers (134 mg, 71\%, dr 61:39) as white solid.

${ }^{1} \mathrm{H}$ NMR $\left(600 \mathrm{MHz}, \mathrm{CDCl}_{3}\right) \delta 7.36-7.40(\mathrm{~m}, 2 \mathrm{H}), 7.12-7.17(\mathrm{~m}, 1 \mathrm{H}), 7.05-7.11(\mathrm{~m}, 2 \mathrm{H}), 6.93$ $-6.99(\mathrm{~m}, 2 \mathrm{H}), 6.89-6.93(\mathrm{~m}, 1.23 \mathrm{H}), 6.86-6.89(\mathrm{~m}, 0.78 \mathrm{H}), 6.03-6.13(\mathrm{~m}, 0.60 \mathrm{H}), 5.92-$ $6.01(\mathrm{~m}, 0.38 \mathrm{H}), 5.00(\mathrm{~d}, J=10.7,0.60 \mathrm{H}), 4.94(\mathrm{~d}, J=10.7,0.38 \mathrm{H}), 4.10-4.17(\mathrm{~m}, 2 \mathrm{H}), 2.86-$ $3.05(\mathrm{~m}, 1.39 \mathrm{H}), 2.73(\mathrm{dq}, J=17.4,2.6 \mathrm{~Hz}, 0.61 \mathrm{H}), 2.40-2.50(\mathrm{~m}, 2.63 \mathrm{H}), 2.29-2.40(\mathrm{~m}, 0.90 \mathrm{H})$, $2.25-2.29(\mathrm{~m}, 3 \mathrm{H}), 2.11-2.18(\mathrm{~m}, 0.62 \mathrm{H}), 1.88-1.93(\mathrm{~m}, 1.79 \mathrm{H}), 1.84-1.88(\mathrm{~m}, 1.14 \mathrm{H}), 1.23$ $-1.29(\mathrm{~m}, 3 \mathrm{H})$.

${ }^{13} \mathrm{C}$ NMR $\left(151 \mathrm{MHz}, \mathrm{CDCl}_{3}\right) \delta 171.8,171.44,171.42,143.3,143.2,137.3,137.1,134.1,134.0$, 129.33, 129.27, 128.8, 128.72, 128.67, 127.6, 127.4, 127.00, 126.98, 94.6, 94.4, 82.0, 81.9, 81.7, $71.9,62.3,61.14,61.12,61.07,61.0,30.3,29.2,29.14,29.05,29.0,23.81,23.79,23.0,21.5$, $14.3,3.79,3.79,3.75$.

FTIR $\left(\mathrm{cm}^{-1}\right)$ 3282, 2981, 2922, 1734, 1545, 1335, 1165, 1091, 704, 565. 
HRMS (ESI) m/z, calcd for $\left[\mathrm{C}_{24} \mathrm{H}_{29} \mathrm{~N}_{2} \mathrm{O}_{6} \mathrm{~S}\right]^{+}$: 473.1746; found 473.1740.

MP: $123-125^{\circ} \mathrm{C}$ (EtOAc).

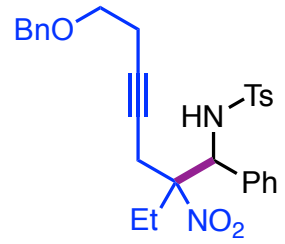

32b (dr 22:78)

Chemical Formula: $\mathrm{C}_{29} \mathrm{H}_{32} \mathrm{~N}_{2} \mathrm{O}_{5} \mathrm{~S}$

Exact Mass: 520.2032

Molecular Weight: 520.6440 32b: According to General Procedure 9A, N-benzylidene-4methylbenzenesulfonamide (104 mg, $0.4 \mathrm{mmol}$ ), 13 (209 mg, 0.8 $\mathrm{mmol})$, and $4 \AA \mathrm{MS}(40.0 \mathrm{mg})$ in anhydrous DMSO $(1.33 \mathrm{~mL}, 0.3 \mathrm{M})$ for $20 \mathrm{~h}$. NMR analysis of the crude reaction mixture revealed a 22:78 ratio of diastereomers. After C18-reversed phase flash silica gel chromatography ( $2 \mathrm{X}$, gradient, $30: 70$ to $80: 20 \mathrm{MeCN} / \mathrm{H}_{2} \mathrm{O}$ ), 32b was afforded as mixture of diastereomers (182 $\mathrm{mg}, 87 \%$, dr $32: 68$ ) as white solid.

${ }^{1} \mathrm{H}$ NMR $\left(600 \mathrm{MHz}, \mathrm{CDCl}_{3}\right) \delta 7.32-7.41(\mathrm{~m}, 6 \mathrm{H}), 7.28-7.32(\mathrm{~m}, 1 \mathrm{H}), 7.10-7.15(\mathrm{~m}, 1 \mathrm{H}), 7.01$ $-7.07(\mathrm{~m}, 2 \mathrm{H}), 6.87-6.96(\mathrm{~m}, 4 \mathrm{H}), 6.19-6.27(\mathrm{~m}, 0.32 \mathrm{H}), 6.04-6.15(\mathrm{~m}, 0.68 \mathrm{H}), 5.09(\mathrm{~d}, J=$ $10.9 \mathrm{~Hz}, 0.33 \mathrm{H}), 5.05(\mathrm{~d}, J=10.7,0.68 \mathrm{H}), 4.60-4.65(\mathrm{~m}, 2 \mathrm{H}), 3.62-3.78(\mathrm{~m}, 2 \mathrm{H}), 3.00(\mathrm{dt}, \mathrm{J}=$ 17.1, $2.4 \mathrm{~Hz}, 0.32 \mathrm{H}), 2.76-2.84(\mathrm{dt}, \mathrm{J}=17.2,2.4 \mathrm{~Hz}, 0.67 \mathrm{H}), 2.26-2.75(\mathrm{~m}, 4.74 \mathrm{H}), 2.25(\mathrm{~s}$, $2 \mathrm{H}), 2.24(\mathrm{~s}, 1 \mathrm{H}), 2.12-2.21(\mathrm{~m}, 0.79 \mathrm{H}), 0.85-0.94(\mathrm{~m}, 3 \mathrm{H})$.

${ }^{13} \mathrm{C}$ NMR $\left(151 \mathrm{MHz}, \mathrm{CDCl}_{3}\right) \delta 143.1,143.0,138.3,138.2,137.5,137.3,134.6,129.2,128.7$, $128.60,128.59,128.55,128.53,128.4,127.85,127.84,127.83,127.81,127.5,127.4,127.0$, $126.9,96.2,96.0,82.9,82.7,75.0,74.7,73.2,72.9,68.7,68.0,63.13,60.95,28.4,27.7,22.3$, $21.5,20.4,20.3,8.2,8.0$.

FTIR $\left(\mathrm{cm}^{-1}\right)$ 3288, 2919, 2863, 2361, 2336, 1542, 1333, 1164, 1092, 702, 563.

HRMS (ESI) m/z, calcd for $\left[\mathrm{C}_{29} \mathrm{H}_{33} \mathrm{~N}_{2} \mathrm{O}_{5} \mathrm{~S}\right]^{+}:$521.2110; found 521.2109.

MP: $118-120^{\circ} \mathrm{C}($ EtOAc).

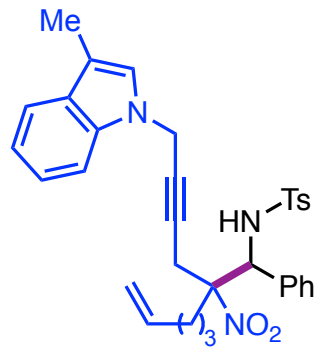

$32 c(d r 66: 34)$

Chemical Formula: $\mathrm{C}_{33} \mathrm{H}_{35} \mathrm{~N}_{3} \mathrm{O}_{4} \mathrm{~S}$

Exact Mass: 569.2348

Molecular Weight: 569.7200 32c: According to General Procedure 9A, N-benzylidene-4methylbenzenesulfonamide (104 mg, $0.4 \mathrm{mmol}), 16$ (248 mg, 0.8 $\mathrm{mmol})$, and $4 \AA \mathrm{MS}(40.0 \mathrm{mg})$ in anhydrous DMSO (1.33 mL, $0.3 \mathrm{M})$ for $20 \mathrm{~h}$. NMR analysis of the crude reaction mixture revealed a 66:34 ratio of diastereomers. After C18-reversed phase flash silica gel chromatography (2 X, gradient, $30: 70$ to $80: 20 \mathrm{MeCN} / \mathrm{H}_{2} \mathrm{O}$ ), 32c was afforded as mixture of diastereomers (109 mg, 48\%, dr 61:39) as yellow solid.

${ }^{1} \mathrm{H}$ NMR $\left(600 \mathrm{MHz}, \mathrm{CDCl}_{3}\right) \delta 7.60-7.66(\mathrm{~m}, 1 \mathrm{H}), 7.40-7.45(\mathrm{~m}$, $1 \mathrm{H}), 7.27-7.32(\mathrm{~m}, 1 \mathrm{H}), 7.21-7.25(\mathrm{~m}, 2 \mathrm{H}), 7.16-7.20(\mathrm{~m}, 1 \mathrm{H})$, $7.05-7.09(\mathrm{~m}, 1 \mathrm{H}), 7.04(\mathrm{~s}, 0.60 \mathrm{H}), 7.01(\mathrm{~s}, 0.30 \mathrm{H}), 6.91-6.97(\mathrm{~m}, 2 \mathrm{H}), 6.88(\mathrm{~d}, \mathrm{~J}=8.0 \mathrm{~Hz}$, $0.83 \mathrm{H}), 6.85(\mathrm{~d}, J=8.0 \mathrm{~Hz}, 1.27 \mathrm{H}), 6.69(\mathrm{~d}, J=7.4 \mathrm{~Hz}, 1.26 \mathrm{H}), 6.58(\mathrm{~d}, J=7.4 \mathrm{~Hz}, 0.83 \mathrm{H}), 5.96$ $(\mathrm{d}, J=10.7 \mathrm{~Hz}, 0.64 \mathrm{H}), 5.55-5.72(\mathrm{~m}, 1.46 \mathrm{H}), 4.81-5.02(\mathrm{~m}, 5 \mathrm{H}), 3.11(\mathrm{dt}, J=17.3,2.3 \mathrm{~Hz}$, $0.43 \mathrm{H}$ ), $2.94(\mathrm{dt}, J=17.6,2.4 \mathrm{~Hz}, 0.43 \mathrm{H}), 2.83(\mathrm{dt}, J=17.5,2.1 \mathrm{~Hz}, 0.66 \mathrm{H}), 2.54$ (dddd, $J=14.6$, 12.6, 4.0, $1.6 \mathrm{~Hz}, 0.64 \mathrm{H}), 2.34-2.43(\mathrm{~m}, 4 \mathrm{H}), 2.20-2.25(\mathrm{~m}, 3 \mathrm{H}), 1.91-2.09(\mathrm{~m}, 2 \mathrm{H}), 1.75-$ $1.89(\mathrm{~m}, 2 \mathrm{H}), 0.80-1.48(\mathrm{~m}, 5 \mathrm{H})$. 
${ }^{13} \mathrm{C}$ NMR $\left(151 \mathrm{MHz}, \mathrm{CDCl}_{3}\right) \delta 143.2,143.1,137.4,137.3,136.9,136.4,136.3,134.1,133.9,129.6$, $129.5,129.3,129.2,128.8,128.6,128.54,128.45,127.4,127.3,127.0,126.9,125.3,125.1,122.3$, $122.2,119.44,119.41,115.7,115.6,111.84,111.79,109.4,95.24,95.15,80.14,80.12,78.6$, $78.5,62.11,61.10,35.99,35.96,34.4,33.3,33.2,33.1,23.6,23.1,22.9,21.47,21.45,9.8$.

FTIR $\left(\mathrm{cm}^{-1}\right)$ 3282, 3059, 2919, 2861, 1544, 1465, 1333, 1164, 1091, 917, 741, 566.

HRMS (ESI) m/z, calcd for $\left[\mathrm{C}_{33} \mathrm{H}_{36} \mathrm{~N}_{3} \mathrm{O}_{4} \mathrm{~S}\right]^{+}:$570.2427; found 570.2433.

MP: $108-110^{\circ} \mathrm{C}($ EtOAc).

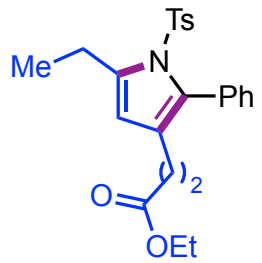

$33 a$

Chemical Formula: $\mathrm{C}_{24} \mathrm{H}_{27} \mathrm{NO}_{4} \mathrm{~S}$

Exact Mass: 425.1661

Molecular Weight: 425.5430 33a: According to General Procedure 9B, 32a (47.3 mg, $0.1 \mathrm{mmol})$, $\mathrm{PPh}_{3} \mathrm{AuCl}$ (4.9 mg, $0.01 \mathrm{mmol}$ ), and $\mathrm{AgPF}_{6}(2.5 \mathrm{mg}, 0.01 \mathrm{mmol})$ in anhydrous toluene $(0.4 \mathrm{~mL}, 0.25 \mathrm{M})$ for $36 \mathrm{~h}$, afforded, after flash silica gel chromatography (70:30 hexanes:EtOAc), 33a (18.7 mg, $44 \%$ ) as yellow oil.

${ }^{1} \mathrm{H}$ NMR $\left(400 \mathrm{MHz}, \mathrm{CDCl}_{3}\right) \delta 7.28-7.36(\mathrm{~m}, 3 \mathrm{H}), 7.23-7.28(\mathrm{~m}$, $2 \mathrm{H}), 7.11-7.18(\mathrm{~m}, 4 \mathrm{H}), 5.97(\mathrm{t}, J=1.6 \mathrm{~Hz}, 1 \mathrm{H}), 4.04(\mathrm{q}, J=7.1 \mathrm{~Hz}$, $2 \mathrm{H}), 2.94$ (qd, $J=7.3,1.2 \mathrm{~Hz}, 2 \mathrm{H}), 2.46(\mathrm{t}, J=8.2 \mathrm{~Hz}, 2 \mathrm{H}), 2.37(\mathrm{~s}$, $3 \mathrm{H}), 2.33(\mathrm{t}, J=8.0 \mathrm{~Hz}, 2 \mathrm{H}), 1.28(\mathrm{t}, J=7.4 \mathrm{~Hz}, 3 \mathrm{H}), 1.18(\mathrm{t}, J=7.1 \mathrm{~Hz}, 3 \mathrm{H})$.

${ }^{13} \mathrm{C}$ NMR $\left(101 \mathrm{MHz}, \mathrm{CDCl}_{3}\right) \delta 173.0,144.3,139.9,137.0,132.8,132.0,131.8,129.5,128.0,127.5$, $126.6,125.7,112.0,60.5,34.9,22.7,21.7,21.5,14.3,13.5$.

FTIR $\left(\mathrm{cm}^{-1}\right)$ 2974, 2931, 1733, 1370, 1177, 702, 662, 586, 546.

HRMS (ESI) m/z, calcd for $\left[\mathrm{C}_{24} \mathrm{H}_{28} \mathrm{NO}_{4} \mathrm{~S}\right]^{+}:$: 426.1739; found 426.1736.

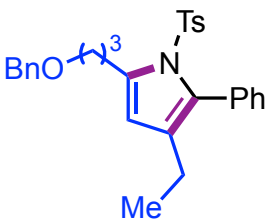

$33 b$

Chemical Formula: $\mathrm{C}_{29} \mathrm{H}_{31} \mathrm{NO}_{3} \mathrm{~S}$

Molecular Weight: 473.6310
Exact Mass: 473.2025

33b: According to General Procedure 9B, 32b (52.1 $\mathrm{mg}, 0.1 \mathrm{mmol})$, $\mathrm{PPh}_{3} \mathrm{AuCl}$ (4.9 mg, $0.01 \mathrm{mmol}$ ), and $\mathrm{AgPF}_{6}(2.5 \mathrm{mg}, 0.01 \mathrm{mmol}$ ) in anhydrous toluene $(0.4 \mathrm{~mL}, 0.25 \mathrm{M})$ for $36 \mathrm{~h}$, afforded, after flash silica gel chromatography (70:30 hexanes:EtOAc), 33b $(24.5 \mathrm{mg}$, $52 \%$ ) as orange oil.

${ }^{1} \mathrm{H}$ NMR $\left(400 \mathrm{MHz}, \mathrm{CDCl}_{3}\right) \delta 7.23-7.41(\mathrm{~m}, 10 \mathrm{H}), 7.09-7.17(\mathrm{~m}$, $4 \mathrm{H}), 5.99(\mathrm{~s}, 1 \mathrm{H}), 4.55(\mathrm{~s}, 2 \mathrm{H}), 3.59(\mathrm{t}, J=6.3 \mathrm{~Hz}, 2 \mathrm{H}), 3.04(\mathrm{t}, J=$ $7.4 \mathrm{~Hz}, 2 \mathrm{H}), 2.36(\mathrm{~s}, 3 \mathrm{H}), 2.02-2.17(\mathrm{~m}, 4 \mathrm{H}), 0.95(\mathrm{t}, J=7.6 \mathrm{~Hz}, 3 \mathrm{H})$.

${ }^{13} \mathrm{C}$ NMR $\left(101 \mathrm{MHz}, \mathrm{CDCl}_{3}\right) \delta 144.1,138.8,137.7,136.8,132.4,132.2,131.8,129.5,129.4$, $128.5,127.8,127.8,127.7,127.3,126.6,113.7,73.0,69.8,29.7,26.3,21.7,19.2,15.0$.

FTIR $\left(\mathrm{cm}^{-1}\right)$ 3030, 2963, 2927, 2856, 2362, 1596, 1454, 1367, 1175, 1095, 699, 592.

HRMS (ESI) m/z, calcd for $\left[\mathrm{C}_{29} \mathrm{H}_{32} \mathrm{NO}_{3} \mathrm{~S}\right]^{+}:$474.2103; found 474.2090. 


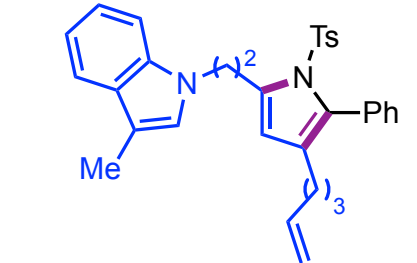

$33 c$

Chemical Formula: $\mathrm{C}_{33} \mathrm{H}_{34} \mathrm{~N}_{2} \mathrm{O}_{2} \mathrm{~S}$

Exact Mass: 522.2341

Molecular Weight: 522.7070

33c: According to General Procedure 9B, 32c (57.0 mg, $0.1 \mathrm{mmol})$, $\mathrm{PPh}_{3} \mathrm{AuCl}\left(9.9 \mathrm{mg}, 0.01 \mathrm{mmol}\right.$ ), and $\mathrm{AgPF}_{6}(2.5 \mathrm{mg}, 0.01 \mathrm{mmol})$ in anhydrous toluene $(0.4 \mathrm{~mL}, 0.25 \mathrm{M})$ for $36 \mathrm{~h}$, afforded, after flash silica gel chromatography (70:30 hexanes:EtOAc), 33c $(30.1 \mathrm{mg}$, $58 \%$ ) as dark yellow oil.

${ }^{1} \mathrm{H}$ NMR $\left(400 \mathrm{MHz}, \mathrm{CDCl}_{3}\right) \delta 7.56(\mathrm{~d}, J=7.8 \mathrm{~Hz}, 1 \mathrm{H}), 7.44(\mathrm{~d}, J=$ $8.2 \mathrm{~Hz}, 1 \mathrm{H}), 7.32-7.40(\mathrm{~m}, 3 \mathrm{H}), 7.20-7.28(\mathrm{~m}, 3 \mathrm{H}), 7.06-7.18$ $(\mathrm{m}, 5 \mathrm{H}), 6.89(\mathrm{~s}, 1 \mathrm{H}), 5.83(\mathrm{~s}, 1 \mathrm{H}), 5.63(\mathrm{ddt}, J=16.9,10.4,6.6 \mathrm{~Hz}$, $1 \mathrm{H}), 4.80-4.91(\mathrm{~m}, 2 \mathrm{H}), 4.51(\mathrm{t}, J=7.0 \mathrm{~Hz}, 2 \mathrm{H}), 3.37(\mathrm{t}, J=7.2 \mathrm{~Hz}, 2 \mathrm{H}), 2.37(\mathrm{~s}, 3 \mathrm{H}), 2.32(\mathrm{~s}$, $3 \mathrm{H}), 2.06(\mathrm{t}, J=7.6 \mathrm{~Hz}, 2 \mathrm{H}), 1.78(\mathrm{q}, J=7.1 \mathrm{~Hz}, 2 \mathrm{H}), 1.30(\mathrm{p}, J=7.4 \mathrm{~Hz}, 2 \mathrm{H})$.

${ }^{13} \mathrm{C} \mathrm{NMR}\left(101 \mathrm{MHz}, \mathrm{CDCl}_{3}\right) \delta 144.5,138.6,136.4,136.3,134.0,133.6,132.0,131.8,129.5,128.8$, 128.1 , 128.0, 127.4, 126.6, 125.6, 121.5, 119.0, 118.6, 116.6, 114.6, 110.4, 109.4, 47.0, 33.1, $31.4,29.3,25.1,21.7,9.8$.

FTIR $\left(\mathrm{cm}^{-1}\right)$ 3055, 2926, 2859, 1468, 1366, 1175, 739, 592.

HRMS (ESI) m/z, calcd for $\left[\mathrm{C}_{33} \mathrm{H}_{35} \mathrm{~N}_{2} \mathrm{O}_{2} \mathrm{~S}\right]^{+}$523.2419; found 523.2406.

\section{Downstream Functionalization of Homopropargylic Nitroalkanes to 2- Pyrrolines}

\section{General Experimental Procedure for the Synthesis of Benzamides}

General Procedure 10A: A 1-nk $25 \mathrm{~mL}$ round bottom flask was fitted with a stir bar and homopropargylic nitroalkane (1.0 equiv) was added. Then, glacial acetic acid $(0.30-0.14 \mathrm{M})$ was added via syringe and the resulting solution was cooled in an iced water bath. While stirring rapidly, zinc dust (10.0 - 20.0 equiv) was added in three portions (Note: bubbling observed, add with caution) under air. The iced water bath was removed, and the resulting suspension was stirred rapidly under air at rt for 1-2 $\mathrm{h}$. The suspension was diluted with EtOAc $(5 \mathrm{~mL})$, filtered through a pad of celite, and rinsed with EtOAc $(3 \times 10 \mathrm{~mL})$. The filtrate was poured into a separatory funnel and washed with $\mathrm{NaHCO}_{3}$ or $\mathrm{Na}_{2} \mathrm{CO}_{3}(3 \times 20 \mathrm{~mL}$, saturated aqueous) (Note: This is done to remove the excess glacial acetic acid). The organic layer was dried over $\mathrm{MgSO}_{4}$, filtered through a fritted funnel, and concentrated in vacuo to afford a crude oil. The crude product was used in the next step without further purification.

A 1-nk $25 \mathrm{~mL}$ round bottom flask was fitted with a stir bar and attached to a double manifold using a rubber hose. The flask was evacuated, flame-dried, allowed to cool to rt under vacuum, and then refilled with $\mathrm{N}_{2}$. The flask was then fitted with a rubber septum and a balloon filled with $\mathrm{N}_{2}$ was attached. The crude homopropargylic amine (1.0 equiv) and anhydrous DCM ( $\left.0.5 \mathrm{M}\right)$ were sequentially added via syringe. The solution was cooled in an iced water bath and anhydrous $\mathrm{Et}_{3} \mathrm{~N}$ (3.0 equiv) and benzoyl chloride (1.1 equiv) were sequentially added via syringe. The iced water bath was removed, and the resulting suspension was stirred at rt for 1-24 $\mathrm{h}$. The suspension was diluted with $\mathrm{Et}_{2} \mathrm{O}(5 \mathrm{~mL})$ and quenched by the addition of $\mathrm{NH}_{4} \mathrm{Cl}(10 \mathrm{~mL}$, saturated aqueous). The resulting biphasic mixture was rapidly stirred for $5 \mathrm{mins}$, before being poured into 
a separatory funnel and rinsed with $\mathrm{Et}_{2} \mathrm{O}(3 \times 5 \mathrm{~mL})$. The layers were separated, and the aqueous phase was washed with $\mathrm{Et}_{2} \mathrm{O}(3 \times 10 \mathrm{~mL})$. The combined organic layers were then washed with brine $\left(15 \mathrm{~mL}\right.$, saturated aqueous), dried over $\mathrm{MgSO}_{4}$, filtered through a fritted funnel, and concentrated in vacuo to afford a crude oil. The crude product was purified by flash silica gel chromatography using the specified condition.

\section{General Experimental Procedure for the Synthesis of 2-Pyrrolines}

General Procedure 10B: In a $\mathrm{N}_{2}$-filled glovebox, a 1-dram vial was fitted with a stir bar, and benzamide (1.0 equiv) and anhydrous $\mathrm{PhMe}(0.25 \mathrm{M})$ were added. Then, $\mathrm{PPh}_{3} \mathrm{AuCl}(0.1$ equiv) and $\mathrm{AgOTf}$ ( 0.1 equiv) were added sequentially to the reaction mixture. The vial was capped with a Teflon-lined screw cap, sealed with PVC tape, taken out of the glovebox, and stirred vigorously at $110^{\circ} \mathrm{C}$ in a silicone oil bath for $2 \mathrm{~h}$. The resulting suspension was cooled to rt, poured into a separatory funnel, and rinsed with $\mathrm{Et}_{2} \mathrm{O}(3 \times 5 \mathrm{~mL})$. A solution of $\mathrm{NaHCO}_{3}(20 \mathrm{~mL}$, saturated aqueous) was then added to the separatory funnel and the layers were separated. The aqueous phase was extracted with $\mathrm{Et}_{2} \mathrm{O}(3 \times 10 \mathrm{~mL})$. The combined organic layers were washed with brine (20 mL, saturated aqueous), dried over $\mathrm{MgSO}_{4}$, filtered through a fritted funnel, and concentrated in vacuo to afford a crude oil. The crude product was purified by flash silica gel chromatography and preparative thin-layer chromatography using the specified condition.

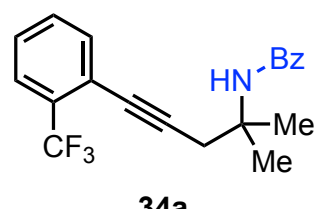

34a

Chemical Formula: $\mathrm{C}_{20} \mathrm{H}_{18} \mathrm{~F}_{3} \mathrm{NO}$

Exact Mass: 345.1340

Molecular Weight: 345.3652

34a: According to General Procedure 10A, 21 (2.28 g, $8.4 \mathrm{mmol})$ and $\mathrm{Zn}$ dust $(5.46 \mathrm{~g}, 84 \mathrm{mmol})$ in $\mathrm{AcOH}(28 \mathrm{~mL}, 0.3 \mathrm{M})$ for $2 \mathrm{~h}$, afforded 2-methyl-5-(2-(trifluoromethyl)phenyl)pent-4-yn-2-amine $(1.81 \mathrm{~g}, 89 \%$ crude yield) as a viscous, orange oil, which was used in the next step without further purification. (Note: $\mathrm{NaHCO}_{3}$ was used for work-up). ${ }^{1} \mathrm{H}$ NMR data for identification purposes: ${ }^{1} \mathrm{H}$ NMR $(600$ $\left.\mathrm{MHz} \mathrm{CDCl}_{3}\right) \delta 7.63(\mathrm{~d}, J=7.8 \mathrm{~Hz}, 1 \mathrm{H}), 7.58(\mathrm{~d}, J=7.7 \mathrm{~Hz}, 1 \mathrm{H}), 7.46$ (t, $J=7.6 \mathrm{~Hz}, 1 \mathrm{H}), 7.37$ (d, $J=7.7 \mathrm{~Hz}, 1 \mathrm{H}), 3.15(\mathrm{bs}, 2 \mathrm{H}), 2.61(\mathrm{~s}, 2 \mathrm{H}), 1.32(\mathrm{~s}, 6 \mathrm{H})$.

2-methyl-5-(2-(trifluoromethyl)phenyl)pent-4-yn-2-amine (1.12 g, $4.6 \mathrm{mmol}), \mathrm{BzCl}(0.6 \mathrm{~mL}$, $5.1 \mathrm{mmol})$, and anhydrous $\mathrm{Et}_{3} \mathrm{~N}(1.92 \mathrm{~mL}, 13.8 \mathrm{mmol})$ in anhydrous $\mathrm{DCM}(9.2 \mathrm{~mL}, 0.5 \mathrm{M})$ for $1 \mathrm{~h}$, afforded, after flash silica gel chromatography (70:30 hexanes: $\left.\mathrm{Et}_{2} \mathrm{O}\right), 34 \mathrm{a}(1.27 \mathrm{~g}, 80 \%, 71 \%$ over two steps) as a pale, yellow solid.

${ }^{1} \mathrm{H}$ NMR $\left(600 \mathrm{MHz}, \mathrm{CDCl}_{3}\right) \delta 7.71-7.77(\mathrm{~m}, 2 \mathrm{H}), 7.60(\mathrm{~d}, J=7.8 \mathrm{~Hz}, 1 \mathrm{H}), 7.32-7.53(\mathrm{~m}, 6 \mathrm{H})$, $6.14(\mathrm{~s}, 1 \mathrm{H}), 3.07(\mathrm{~s}, 2 \mathrm{H}), 1.60(\mathrm{~s}, 6 \mathrm{H})$.

${ }^{13} \mathrm{C} \mathrm{NMR}\left(151 \mathrm{MHz}, \mathrm{CDCl}_{3}\right) \delta 167.4,135.7,134.3,131.5,131.37$ (q, J = 30.4 Hz), 131.33, 131.27, 128.6, 127.6, 126.9, 125.8 (q, $J=5.1 \mathrm{~Hz}), 123.8$ (q, $J=273.4 \mathrm{~Hz}), 122.1$ (q, $J=2.1 \mathrm{~Hz}), 93.1$, $79.0,53.8,31.5,27.0$.

${ }^{19} \mathrm{~F}$ NMR $\left(565 \mathrm{MHz}, \mathrm{CDCl}_{3}\right) \delta-62.3$.

FTIR $\left(\mathrm{cm}^{-1}\right)$ 3318, 3064, 2974, 2361, 2229, 1644, 1535, 1490, 1319, 1133, 765.

HRMS (ESI) m/z, calcd for $\left[\mathrm{C}_{20} \mathrm{H}_{19} \mathrm{~F}_{3} \mathrm{NO}\right]^{+}$346.1419; found 346.1405. 
$M P: 66-68^{\circ} \mathrm{C}\left(\mathrm{Et}_{2} \mathrm{O}\right)$.

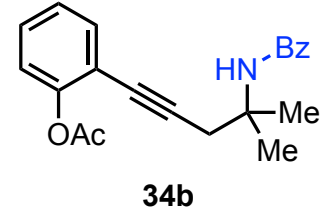

Chemical Formula: $\mathrm{C}_{21} \mathrm{H}_{21} \mathrm{NO}_{3}$ Exact Mass: 335.1521 Molecular Weight: 335.4030

34b: According to General Procedure 10A, $22(0.66 \mathrm{~g}, 2.5 \mathrm{mmol})$ and $\mathrm{Zn}$ dust $(1.64 \mathrm{~g}, 25 \mathrm{mmol})$ in $\mathrm{AcOH}(8.4 \mathrm{~mL}, 0.3 \mathrm{M})$ for $2 \mathrm{~h}$, afforded 2-(4-amino-4-methylpent-1-yn-1-yl)phenyl acetate $(0.52 \mathrm{~g}$, $90 \%$ crude yield) as a viscous, yellow oil, which was used in the next step without further purification. (Note: $\mathrm{Na}_{2} \mathrm{CO}_{3}$ was used for work-up). ${ }^{1} \mathrm{H} \mathrm{NMR}$ data for identification purposes: ${ }^{1} \mathrm{H}$ NMR $\left(600 \mathrm{MHz}, \mathrm{CDCl}_{3}\right)$ $\delta 7.47$ (dd, $J=7.7,1.6 \mathrm{~Hz}, 1 \mathrm{H}), 7.31$ (td, $J=7.9,1.6 \mathrm{~Hz}, 1 \mathrm{H}), 7.18(\mathrm{td}$, $J=7.6,1.2 \mathrm{~Hz}, 1 \mathrm{H}), 7.07$ (dd, $J=8.1,1.2 \mathrm{~Hz}, 1 \mathrm{H}), 2.49$ (s, 2H), 2.33 (s, 3H), 1.82 (bs, 2H), 1.25 $(\mathrm{s}, 6 \mathrm{H})$.

2-(4-amino-4-methylpent-1-yn-1-yl)phenyl acetate $(0.71 \mathrm{~g}, 3.1 \mathrm{mmol}), \mathrm{BzCl}(0.4 \mathrm{~mL}, 3.1$ $\mathrm{mmol})$, and anhydrous $\mathrm{Et}_{3} \mathrm{~N}(1.3 \mathrm{~mL}, 9.2 \mathrm{mmol})$ in anhydrous DCM $(6.2 \mathrm{~mL}, 0.5 \mathrm{M})$ for $24 \mathrm{~h}$, afforded, after flash silica gel chromatography (50:50 hexanes:Et $\left.{ }_{2} \mathrm{O}\right), 34 \mathrm{~b}(0.61 \mathrm{~g}, 59 \%, 53 \%$ over two steps) as white solid.

${ }^{1} \mathrm{H}$ NMR $\left(600 \mathrm{MHz}, \mathrm{CDCl}_{3}\right) \delta 7.74(\mathrm{~d}, J=7.3 \mathrm{~Hz}, 2 \mathrm{H}), 7.47(\mathrm{td}, J=7.3,1.3 \mathrm{~Hz}, 1 \mathrm{H}), 7.38-7.44$ $(\mathrm{m}, 3 \mathrm{H}), 7.30(\mathrm{td}, J=7.8,1.6 \mathrm{~Hz}, 1 \mathrm{H}), 7.16(\mathrm{td}, J=7.6,1.2 \mathrm{~Hz}, 1 \mathrm{H}), 7.05(\mathrm{~d}, J=8.2,1 \mathrm{H}), 6.13(\mathrm{~s}$, $1 \mathrm{H}), 3.02(\mathrm{~s}, 2 \mathrm{H}), 2.18(\mathrm{~s}, 3 \mathrm{H}), 1.59(\mathrm{~s}, 6 \mathrm{H})$.

${ }^{13} \mathrm{C} \mathrm{NMR}\left(151 \mathrm{MHz}, \mathrm{CDCl}_{3}\right) \delta 169.0,167.4,151.7,135.7,133.5,131.4,129.2,128.7,127.0,126.0$, $122.3,117.7,91.7,78.2,53.7,31.7,26.9,20.9$.

FTIR $\left(\mathrm{cm}^{-1}\right)$ 3318, 3059, 2973, 2362, 1762, 1653, 1531, 1488, 1186, 715.

HRMS (ESI) m/z, calcd for $\left[\mathrm{C}_{21} \mathrm{H}_{22} \mathrm{NO}_{3}\right]^{+} 336.1600$; found 336.1589 .

MP: $106-108{ }^{\circ} \mathrm{C}\left(\mathrm{Et}_{2} \mathrm{O}\right)$.

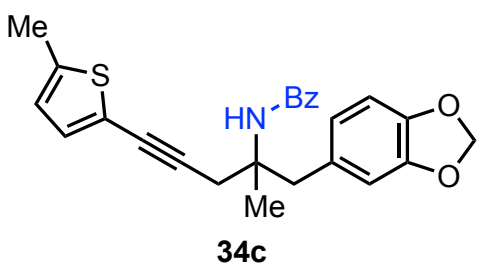

Chemical Formula: $\mathrm{C}_{25} \mathrm{H}_{23} \mathrm{NO}_{3} \mathrm{~S}$ Exact Mass: 417.1399 Molecular Weight: 417.5230

34c: According to General Procedure 10A, $28(0.97 \mathrm{~g}, 2.8 \mathrm{mmol})$ and $\mathrm{Zn}$ dust $(1.84 \mathrm{~g}, 28 \mathrm{mmol})$ in $\mathrm{AcOH}(9.4 \mathrm{~mL}, 0.3 \mathrm{M})$ for $2 \mathrm{~h}$, afforded 1-(benzo[d][1,3]dioxol-5-yl)-2-methyl-5-(5-methylthiophe$\mathrm{n}-2-\mathrm{yl})$ pent-4-yn-2-amine ( $0.80 \mathrm{~g}, 91 \%$ crude yield) as a viscous, light brown oil, which was used in the next step without further purification. (Note: $\mathrm{Na}_{2} \mathrm{CO}_{3}$ was used for work-up). ${ }^{1} \mathrm{H}$ NMR data for identification purposes: ${ }^{1} \mathrm{H}$ NMR $\left(600 \mathrm{MHz}, \mathrm{CDCl}_{3}\right) \delta 6.97$ (d, J $=3.5 \mathrm{~Hz}, 1 \mathrm{H}), 6.75-6.78(\mathrm{~m}, 2 \mathrm{H}), 6.71(\mathrm{dd}, J=7.9,1.7 \mathrm{~Hz}, 1 \mathrm{H})$, $6.60(\mathrm{dq}, J=3.5,1.3 \mathrm{~Hz}, 1 \mathrm{H}), 5.94(\mathrm{~s}, 2 \mathrm{H}), 2.75(\mathrm{~d}, J=13.4 \mathrm{~Hz}, 1 \mathrm{H}), 2.70(\mathrm{~d}, J=13.3 \mathrm{~Hz}, 1 \mathrm{H})$, 2.39-2.47 (m, 5H), $1.42(\mathrm{bs}, 2 \mathrm{H}), 1.19(\mathrm{~s}, 3 \mathrm{H})$.

1-(benzo[d][1,3]dioxol-5-yl)-2-methyl-5-(5-methylthiophen-2-yl)pent-4-yn-2-amine (0.80 g, $2.57 \mathrm{mmol}), \mathrm{BzCl}(0.33 \mathrm{~mL}, 2.8 \mathrm{mmol})$, and anhydrous $\mathrm{Et}_{3} \mathrm{~N}(1.1 \mathrm{~mL}, 7.7 \mathrm{mmol})$ in anhydrous $\mathrm{DCM}(5.2 \mathrm{~mL}, 0.5 \mathrm{M})$ for $3 \mathrm{~h}$, afforded, after flash silica gel chromatography (80:20 hexanes:Et $\left.{ }_{2} \mathrm{O}\right)$, 34c $(0.76 \mathrm{~g}, 71 \%, 65 \%$ over two steps) as white solid. 
${ }^{1} \mathrm{H}$ NMR $\left(400 \mathrm{MHz}_{\mathrm{CDCl}}\right) \delta 7.67-7.72(\mathrm{~m}, 2 \mathrm{H}), 7.46-7.51(\mathrm{~m}, 1 \mathrm{H}), 7.39-7.44(\mathrm{~m}, 2 \mathrm{H}), 6.92$ $(\mathrm{d}, J=3.5 \mathrm{~Hz}, 1 \mathrm{H}), 6.67-6.77(\mathrm{~m}, 3 \mathrm{H}), 6.58(\mathrm{dq}, J=3.5,1.1 \mathrm{~Hz}, 1 \mathrm{H}), 5.95(\mathrm{~s}, 1 \mathrm{H}), 5.92(\mathrm{~s}, 2 \mathrm{H})$, $3.35(\mathrm{~d}, J=13.6 \mathrm{~Hz}, 1 \mathrm{H}), 3.14(\mathrm{~d}, J=16.8 \mathrm{~Hz}, 1 \mathrm{H}), 3.06(\mathrm{~d}, J=13.5 \mathrm{~Hz}, 1 \mathrm{H}), 2.83(\mathrm{~d}, J=16.9$ $\mathrm{Hz}, 1 \mathrm{H}), 2.44(\mathrm{~s}, 3 \mathrm{H}), 1.52(\mathrm{~s}, 3 \mathrm{H})$.

${ }^{13} \mathrm{C} \mathrm{NMR}\left(101 \mathrm{MHz}, \mathrm{CDCl}_{3}\right) \delta 167.8,147.6,146.5,141.3,135.9,131.8,131.5,130.8,128.8,126.9$, $125.2,123.7,121.1,111.0,108.2,101.0,89.5,77.3,56.8,42.9,30.3,24.8,15.5$.

FTIR $\left(\mathrm{cm}^{-1}\right)$ 3309, 3064, 2920, 2360, 1643, 1537, 1488, 1442, 1247, 1039, 800.

HRMS (ESI) m/z, calcd for $\left[\mathrm{C}_{25} \mathrm{H}_{24} \mathrm{NO}_{3} \mathrm{~S}\right]^{+}$418.1477; found 418.1471.

MP: $137-140^{\circ} \mathrm{C}\left(\mathrm{Et}_{2} \mathrm{O}\right)$

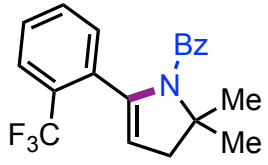

$35 a$

Chemical Formula: $\mathrm{C}_{20} \mathrm{H}_{18} \mathrm{~F}_{3} \mathrm{NO}$

Exact Mass: 345.1340

Molecular Weight: 345.3652 35a: According to General Procedure 10B, 34a (69.1 mg, $0.2 \mathrm{mmol})$, $\mathrm{PPh}_{3} \mathrm{AuCl}(9.89 \mathrm{mg}, 0.02 \mathrm{mmol})$, and AgOTf (5.14 mg, $\left.0.02 \mathrm{mmol}\right)$ in anhydrous PhMe $(0.8 \mathrm{~mL}, 0.25 \mathrm{M})$ for $2 \mathrm{~h}$, afforded, after flash silica gel chromatography and preparative thin-layer chromatography (90:10 hexanes: $\left.\mathrm{Et}_{2} \mathrm{O}\right), 35 \mathrm{a}(56.4 \mathrm{mg}, 82 \%)$ as light orange solid.

${ }^{1} \mathrm{H}$ NMR $\left(400 \mathrm{MHz} \mathrm{CDCl}_{3}\right) \delta 7.28-7.33(\mathrm{~m}, 1 \mathrm{H}), 6.93-7.22(\mathrm{~m}, 8 \mathrm{H}), 5.23(\mathrm{t}, \mathrm{J}=3.0 \mathrm{~Hz}, 1 \mathrm{H})$, $2.66(\mathrm{~s}, 2 \mathrm{H}), 1.73(\mathrm{~s}, 6 \mathrm{H})$.

${ }^{13} \mathrm{C} \mathrm{NMR}\left(101 \mathrm{MHz}, \mathrm{CDCl}_{3}\right) \delta 169.2,139.5,138.4,132.6,131.5,130.9,129.8,128.2,127.8,127.6$ $(q, J=30.2 \mathrm{~Hz}), 127.6,126.1$ (q, $J=5.4 \mathrm{~Hz}), 123.9$ (q, $J=274.7 \mathrm{~Hz}), 114.1$ (q, $J=2.0 \mathrm{~Hz}), 68.1$, 46.0, 26.0.

${ }^{19} \mathrm{~F} \mathrm{NMR}\left(376 \mathrm{MHz}, \mathrm{CDCl}_{3}\right) \delta-58.5$.

FTIR $\left(\mathrm{cm}^{-1}\right)$ 2966, 2936, 1630, 1373, 1314, 1172, 1129, 768.

HRMS (ESI) m/z, calcd for $\left[\mathrm{C}_{20} \mathrm{H}_{19} \mathrm{~F}_{3} \mathrm{NO}\right]^{+}$: 346.1419; found 346.1407.

$\mathrm{MP}: 83-85^{\circ} \mathrm{C}\left(\mathrm{Et}_{2} \mathrm{O}\right)$.

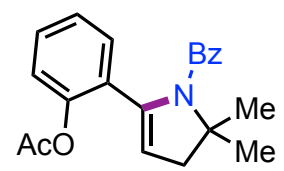

$35 b$

Chemical Formula: $\mathrm{C}_{21} \mathrm{H}_{21} \mathrm{NO}_{3}$

Exact Mass: 335.1521

Molecular Weight: 335.4030 35b: According to General Procedure 10B, 34b (67.1 mg, $0.2 \mathrm{mmol})$, $\mathrm{PPh}_{3} \mathrm{AuCl}$ (9.89 mg, $0.02 \mathrm{mmol}$ ), and AgOTf (5.14 mg, $0.02 \mathrm{mmol}$ ) in anhydrous PhMe $(0.8 \mathrm{~mL}, 0.25 \mathrm{M})$ for $2 \mathrm{~h}$, afforded, after flash silica gel chromatography and preparative thin-layer chromatography (70:30 hexanes: $\left.\mathrm{Et}_{2} \mathrm{O}\right), 35 \mathrm{~b}(42.2 \mathrm{mg}, 63 \%)$ as yellow oil (Note: The product should be stored in the refrigerator under $\mathrm{N}_{2}$ atmosphere due to ease of decomposition).

${ }^{1} \mathrm{H}$ NMR $\left(600 \mathrm{MHz}, \mathrm{CDCl}_{3}\right) \delta 7.31(\mathrm{~d}, J=7.5 \mathrm{~Hz}, 2 \mathrm{H}), 7.12(\mathrm{dd}, J=7.6,1.8 \mathrm{~Hz}, 1 \mathrm{H}), 7.04(\mathrm{tt}, J=$ 7.3, 1.4 Hz, 1H), 6.93-7.00 (m, 3H), $6.90(\mathrm{td}, J=7.5,1.3 \mathrm{~Hz}, 1 \mathrm{H}), 6.61(\mathrm{dd}, J=8.0,1.3 \mathrm{~Hz}, 1 \mathrm{H})$, $5.21(\mathrm{t}, J=3.0 \mathrm{~Hz}, 1 \mathrm{H}), 2.61(\mathrm{bs}, 2 \mathrm{H}), 2.30(\mathrm{~s}, 3 \mathrm{H}), 1.72(\mathrm{~s}, 6 \mathrm{H})$. 
${ }^{13} \mathrm{C}$ NMR $\left(151 \mathrm{MHz}, \mathrm{CDCl}_{3}\right) \delta 169.0,168.9,146.6,140.7,137.4,130.20,130.18,129.00,128.99$, $127.4,127.2,125.6,122.0,112.7,68.4,45.2,26.1,21.3$.

FTIR $\left(\mathrm{cm}^{-1}\right)$ 2965, 2933, 1767, 1626, 1373, 1212, 1192, 701.

HRMS (ESI) m/z, calcd for $\left[\mathrm{C}_{21} \mathrm{H}_{22} \mathrm{NO}_{3}\right]^{+}$: 336.1600; found 336.1588.

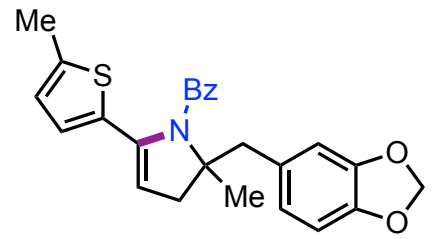

$35 c$

Chemical Formula: $\mathrm{C}_{25} \mathrm{H}_{23} \mathrm{NO}_{3} \mathrm{~S}$

Exact Mass: 417.1399

Molecular Weight: 417.5230

35c: According to General Procedure 10B, 34c (41.8 mg, $0.1 \mathrm{mmol})$, $\mathrm{PPh}_{3} \mathrm{AuCl}(4.95 \mathrm{mg}, 0.01 \mathrm{mmol})$, and AgOTf $(2.57 \mathrm{mg}, 0.01 \mathrm{mmol})$ in anhydrous PhMe $(0.4 \mathrm{~mL}, 0.25 \mathrm{M})$ for $2 \mathrm{~h}$, afforded, after flash silica gel chromatography and preparative thin-layer chromatography (50:50 hexanes: $\left.\mathrm{Et}_{2} \mathrm{O}\right), 35 \mathrm{c}(25.1 \mathrm{mg}, 60 \%)$ as viscous, green oil (Note: The product should be stored in the refrigerator under $\mathrm{N}_{2}$ atmosphere due to ease of decomposition).

Note: The work-up for 35c was performed differently. Upon reaction completion and cooling to $\mathrm{rt}$, the resulting suspension was diluted with $\mathrm{Et}_{2} \mathrm{O}(5 \mathrm{~mL})$, filtered through a pad of celite, rinsed with $E t_{2} \mathrm{O}(3 \times 5 \mathrm{~mL})$, and concentrated in vacuo (without heating).

${ }^{1} \mathrm{H}$ NMR $\left(400 \mathrm{MHz} \mathrm{CDCl}_{3}\right) \delta 7.35-7.40(\mathrm{~m}, 2 \mathrm{H}), 7.18(\mathrm{tt}, \mathrm{J}=6.4,1.3 \mathrm{~Hz}, 1 \mathrm{H}), 7.09(\mathrm{tt}, J=7.1,1$ $\mathrm{Hz}, 2 \mathrm{H}), 6.80(\mathrm{~d}, J=1.6 \mathrm{~Hz}, 1 \mathrm{H}), 6.67-6.75(\mathrm{~m}, 2 \mathrm{H}), 6.22(\mathrm{~d}, J=3.5 \mathrm{~Hz}, 1 \mathrm{H}), 6.12-6.16(\mathrm{~m}$, $1 \mathrm{H}), 5.90(\mathrm{~d}, J=1.4 \mathrm{~Hz}, 1 \mathrm{H}), 5.86(\mathrm{~d}, J=1.4 \mathrm{~Hz}, 1 \mathrm{H}), 5.06(\mathrm{t}, J=3.1 \mathrm{~Hz}, 1 \mathrm{H}), 3.49(\mathrm{~d}, J=13.4$ $\mathrm{Hz}, 1 \mathrm{H}), 3.06(\mathrm{~d}, J=13.4 \mathrm{~Hz}, 1 \mathrm{H}), 2.85(\mathrm{dd}, J=16.7,3.6 \mathrm{~Hz}, 1 \mathrm{H}), 2.48(\mathrm{dd}, J=16.7,2.8 \mathrm{~Hz}, 1 \mathrm{H})$, $2.21(\mathrm{~d}, J=1.1 \mathrm{~Hz}, 3 \mathrm{H}), 1.75(\mathrm{~s}, 3 \mathrm{H})$.

${ }^{13} \mathrm{C}$ NMR $\left(101 \mathrm{MHz}, \mathrm{CDCl}_{3}\right) \delta 169.2,147.4,146.2,139.2,138.2,138.1,133.2,131.4,130.4,128.6$, $127.5,126.4,124.6,123.6,111.4,111.0,108.1,100.9,71.8,43.7,41.2,25.6,15.1$.

FTIR $\left(\mathrm{cm}^{-1}\right)$ 2921, 1623, 1489, 1371, 1245, 1039, 701.

HRMS (ESI) m/z, calcd for $\left[\mathrm{C}_{25} \mathrm{H}_{24} \mathrm{NO}_{3} \mathrm{~S}\right]^{+}: 418.1477$; found 418.1466.

\section{References}

1. Pangborn, A. B.; Giardello, M. A.; Grubbs, R. H.; Rosen, R. K.; Timmers, F. J., Safe and Convenient Procedure for Solvent Purification. Organometallics 1996, 15 (5), 1518-1520.

2. Gildner, P. G.; Gietter, A. A.; Cui, D.; Watson, D. A., Benzylation of Nitroalkanes Using Copper-Catalyzed Thermal Redox Catalysis: Toward the Facile C-Alkylation of Nitroalkanes. J. Am. Chem. Soc. 2012, 134 (24), 9942-5.

3. Devannah, V.; Sharma, R.; Watson, D. A., Nickel-Catalyzed Asymmetric C-Alkylation of Nitroalkanes: Synthesis of Enantioenriched $\beta$-Nitroamides. J. Am. Chem. Soc. 2019, 141 (21), 8436-8440.

4. Liu, L.; Ishida, N.; Ashida, S.; Murakami, M., Synthesis of Chiral N-Heterocyclic Carbene Ligands with Rigid Backbones and Application to the Palladium-Catalyzed Enantioselective Intramolecular $\alpha$-Arylation of Amides. Org. Lett. 2011, 13 (7), 1666-9.

5. Rezazadeh, S.; Devannah, V.; Watson, D. A., Nickel-Catalyzed C-Alkylation of Nitroalkanes with Unactivated Alkyl lodides. J. Am. Chem. Soc. 2017, 139 (24), 8110-8113.

6. Liu, Y.; Ma, S., Benzofurans or Isochromenes via the Ring-Opening Cyclization of Cyclopropene Derivatives with Organolithiums. Org. Lett. 2012, 14 (3), 720-3. 
7. Gharpure, S. J.; Shelke, Y. G., Lewis Acid Mediated Cascade Friedel-Craft/Alkyne Indol2-yl Cation Cyclization/Vinyl Cation Trapping for the Synthesis of N-Fused Indole Derivatives. Org. Lett. 2017, 19 (19), 5406-5409.

8. Toullec, P.; Grandclaudon, C.; Michelet, V., lodonium-Induced Cyclization of NAllenylindoles and N-Allenylpyrroles: An Access to lododihydropyrido[1,2-a]indoles and Dihydroindolizines. Synlett 2017, 29 (03), 310-313.

9. Zhai, H.; Borzenko, A.; Lau, Y. Y.; Ahn, S. H.; Schafer, L. L., Catalytic Asymmetric Synthesis of Substituted Morpholines and Piperazines. Angew. Chem. Int. Ed. Engl. 2012, 51 (49), 12219-23.

10. Guan, Y.; Lopez-Alberca, M. P.; Lu, Z.; Zhang, Y.; Desai, A. A.; Patwardhan, A. P.; Dai, Y.; Vetticatt, M. J.; Wulff, W. D., Catalytic Asymmetric Synthesis of Alkynyl Aziridines: Both Enantiomers of cis-Aziridines from One Enantiomer of the Catalyst. Chem. Eur. J. 2014, 20 (43), 13894-900.

11. Okitsu, T.; Sato, K.; Potewar, T. M.; Wada, A., lodocyclization of Hydroxylamine Derivatives Based on the Control of Oxidative Aromatization Leading to 2,5-Dihydroisoxazoles and Isoxazoles. J. Org. Chem. 2011, 76 (9), 3438-49.

12. Heckenbichler, K.; Schweiger, A.; Brandner, L. A.; Binter, A.; Toplak, M.; Macheroux, P.; Gruber, K.; Breinbauer, R., Asymmetric Reductive Carbocyclization Using Engineered Ene Reductases. Angew. Chem. Int. Ed. 2018, 57 (24), 7240-7244.

13. Patel, R.; Srivastava, V. P.; Yadav, L. D. S., The First Example of Saccharin-Lithium Bromide Catalysis: Direct Synthesis of N-Tosylimines from Alcohols. Adv. Synth. Catal. 2010, 352 (10), 1610-1614.

14. Stark, D. G.; O'Riordan, T. J.; Smith, A. D., Synthesis of Di-, Tri-, and Tetrasubstituted Pyridines from (Phenylthio)carboxylic Acids and 2-[Aryl(tosylimino)methyl]acrylates. Org. Lett. 2014, 16 (24), 6496-9.

15. Kobayashi, Y.; Hayashi, N.; Kishi, Y., Toward the Creation of NMR Databases in Chiral Solvents: Bidentate Chiral NMR Solvents for Assignment of the Absolute Configuration of Acyclic Secondary Alcohols. Org. Lett. 2002, 4 (3), 411-4.

16. Abdel-Magid, A. F.; Carson, K. G.; Harris, B. D.; Maryanoff, C. A.; Shah, R. D., Reductive Amination of Aldehydes and Ketones with Sodium Triacetoxyborohydride. Studies on Direct and Indirect Reductive Amination Procedures(1). J. Org. Chem. 1996, 61 (11), 3849-3862.

17. Asano, N.; Sasaki, K.; Chataigner, I.; Shigeno, M.; Kondo, Y., Sodium Phenoxide Mediated Hydroxymethylation of Alkynylsilanes with $\mathrm{N}$

-[(Trimethylsiloxy)methyl]phthalimide. Eur. J. Org. Chem. 2017, 2017 (46), 6926-6930.

18. Thompson, A. M.; Sutherland, H. S.; Palmer, B. D.; Kmentova, I.; Blaser, A.; Franzblau, S. G.; Wan, B.; Wang, Y.; Ma, Z.; Denny, W. A., Synthesis and Structure-Activity Relationships of Varied Ether Linker Analogues of the Antitubercular Drug (6S)-2-Nitro-6-\{[4(trifluoromethoxy)benzyl]oxy\}-6,7-dihydro-5H-imidazo[2,1-b][1, 3]oxazine (PA-824). J. Med. Chem. 2011, 54 (19), 6563-85.

19. Yang, F.; Jin, T.; Bao, M.; Yamamoto, Y., Facile synthesis of 3,4-dihalofurans via electrophilic iodocyclization. Chem. Commun. 2011, 47 (15), 4541-3.

20. Boddy, A. J.; Affron, D. P.; Cordier, C. J.; Rivers, E. L.; Spivey, A. C.; Bull, J. A., Rapid Assembly of Saturated Nitrogen Heterocycles in One-Pot: Diazo-Heterocycle "Stitching" by N-H Insertion and Cyclization. Angew. Chem. Int. Ed. Engl. 2019, 58 (5), 1458-1462.

21. Chang, M.-Y.; Lin, C.-H.; Tai, H.-Y., Palladium-catalyzed synthesis of substituted nitroolefins. Tetrahedron Lett. 2013, 54 (24), 3194-3198.

22. Rokhum, L.; Bez, G., One-pot solid phase synthesis of (E)-nitroalkenes. Tetrahedron Lett. 2013, 54 (40), 5500-5504.

23. Heinzelman, R. V., o-METHOXYPHENYLACETONE. Org. Synth. 1955, 35 (35), 74.

24. Isobe, T.; Kato, A.; Oriyama, T., Aza-Henry Reaction Using DMSO as a Solvent. Chem.

Lett. 2015, 44 (4), 483-485. 
I $\angle$ ' I$6 t^{\circ} \mathrm{Z}$ $0 S^{\prime} 2$ IS' 2 . $25^{\circ} 2$ 25
25
25 $25^{\circ} 2$ $\varepsilon S^{\prime} z$ $\nabla S^{\circ} 2$ SS' 2 SS'2$9 S^{\circ} 2$ $\succ 9^{\circ} \varepsilon$. $\varsigma 9^{\circ} \varepsilon$ $99^{\circ} \varepsilon$ $89^{\circ} \varepsilon$

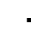

2

¿2 $\nabla \tau^{\circ}$ $\left.\angle Z^{\prime} \angle\right]$ $8 Z^{\circ} L$ $62^{\circ} L$ $0 \varepsilon^{\circ} L$ [ $\varepsilon^{*}\llcorner$ $\varepsilon \varepsilon^{\circ} L$
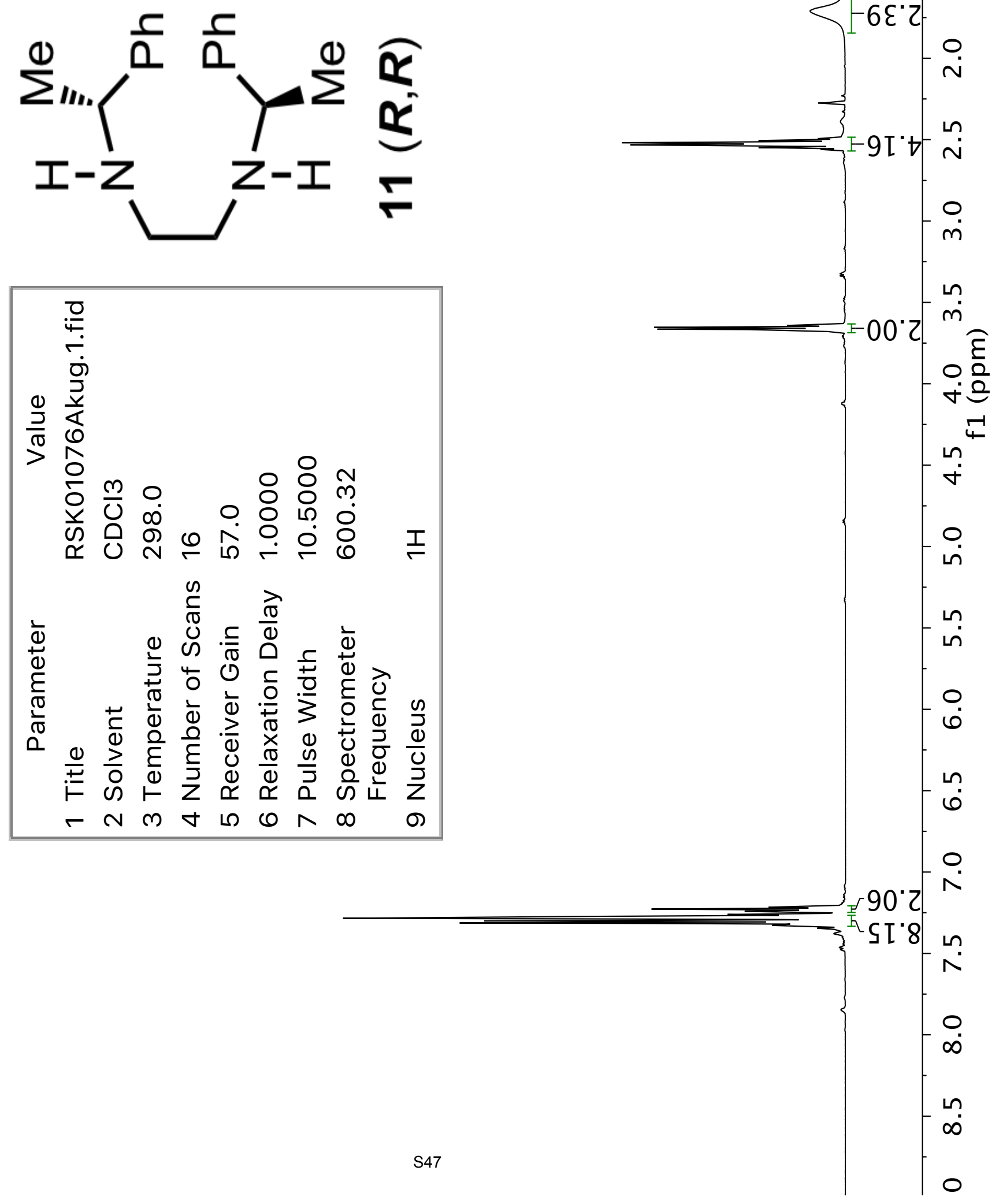
$\varepsilon \varepsilon^{\circ} L$ 
ss't乙-

$\varepsilon t^{\circ} \angle \downarrow-$

† $8 S-$

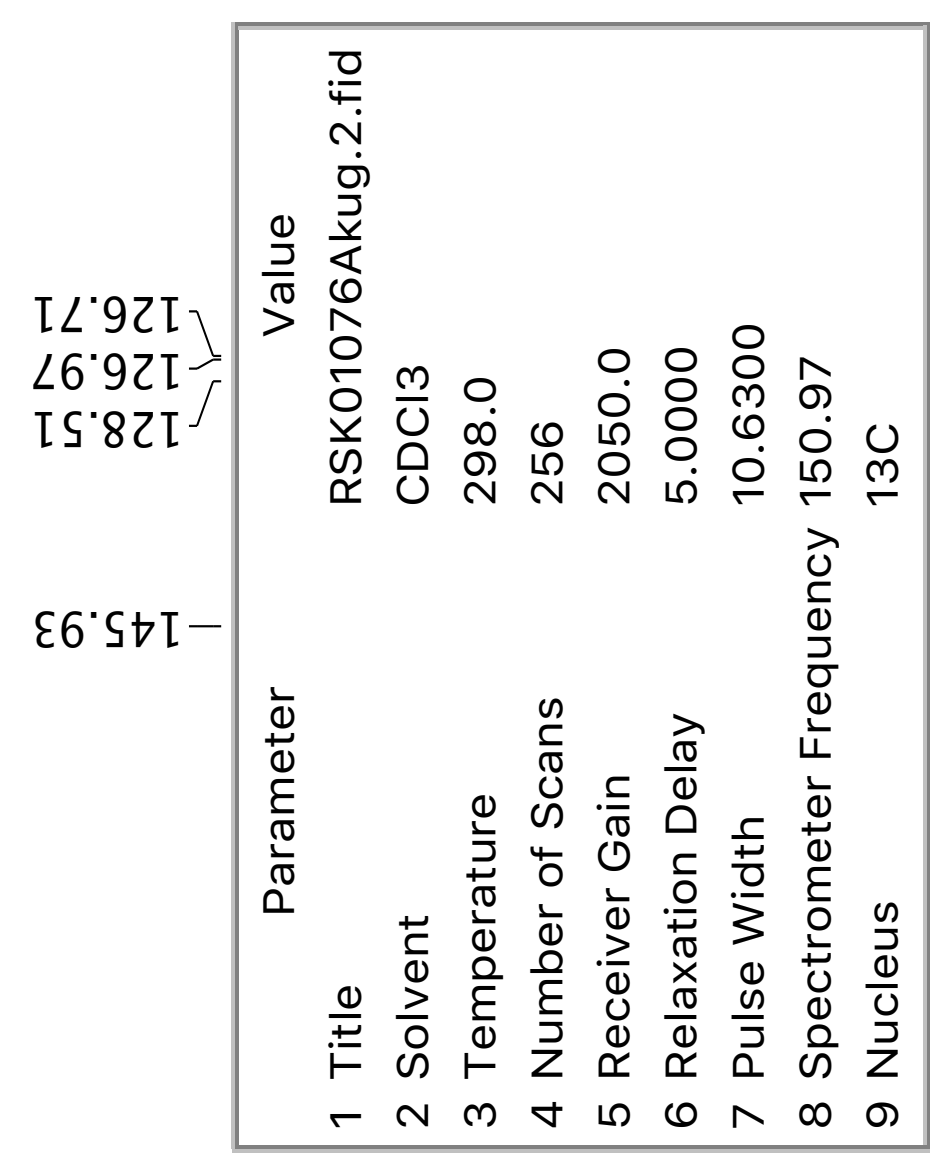

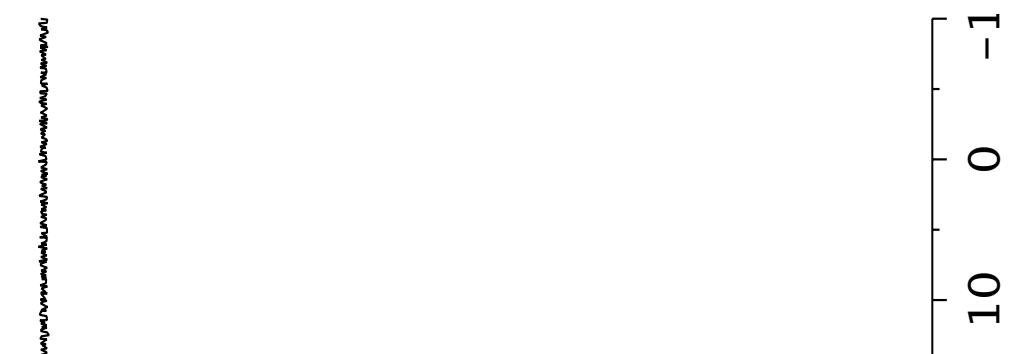

욱

은

음

-

은

- 웅

$-2$

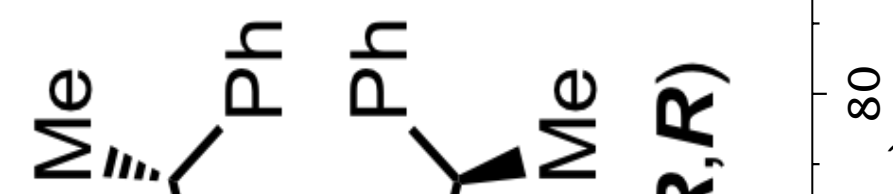

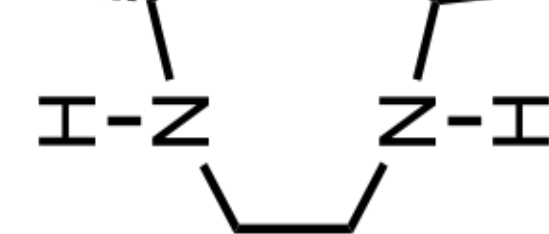

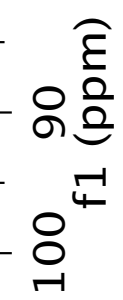

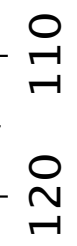

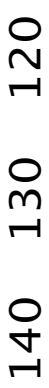

음

0
-1

숙

0
-1
-1 


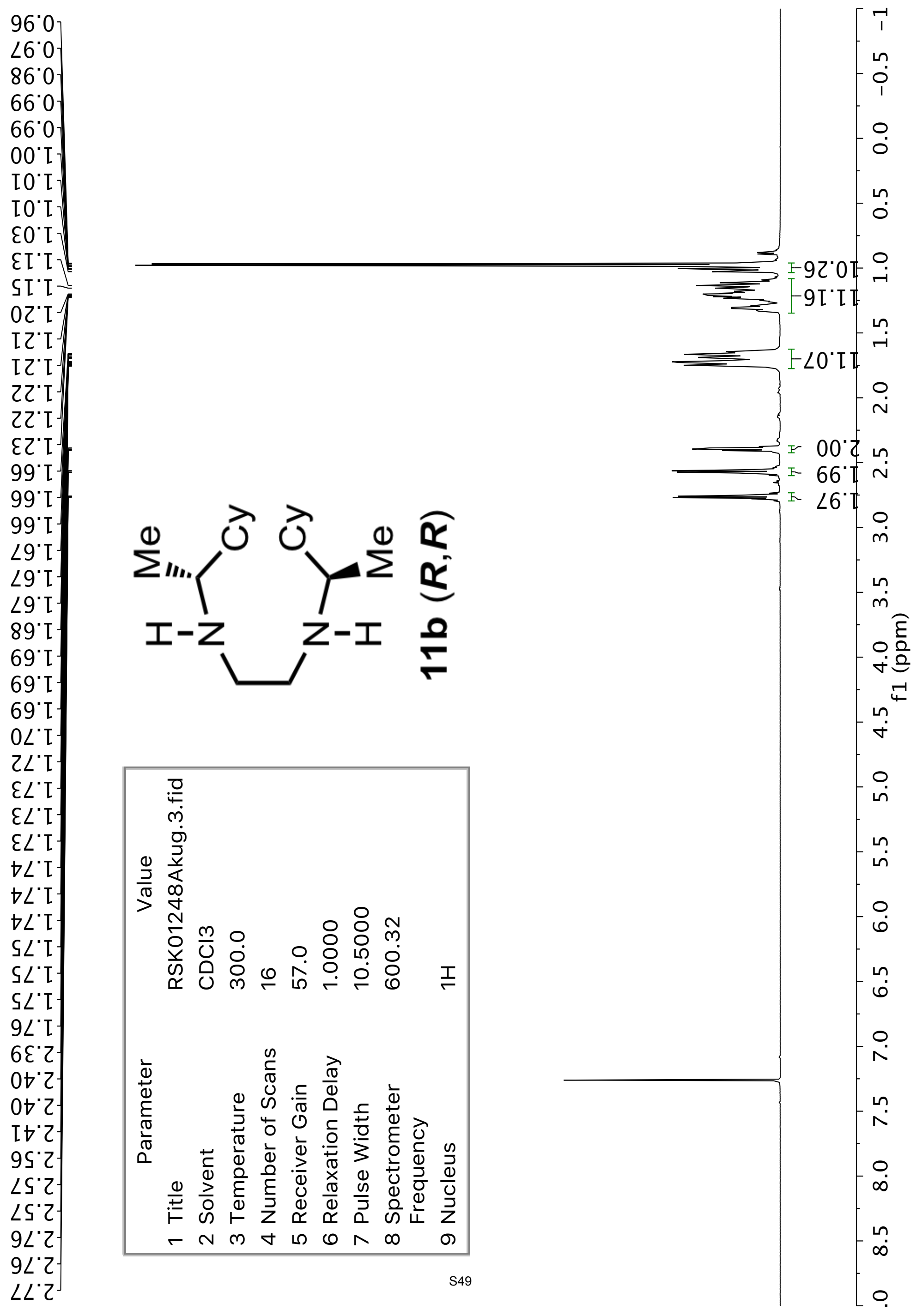


$9 Z^{\circ} \angle I-$

乙L'9乙

58.927

$00^{\circ} \angle Z^{\prime}$

$0 t^{\circ} 8 z^{3}$

$90^{\circ} 0 \varepsilon^{\circ}$

$9 \tau^{\circ} \varepsilon \downarrow-$

$\angle L^{\prime} \angle b-$

$90.85-$

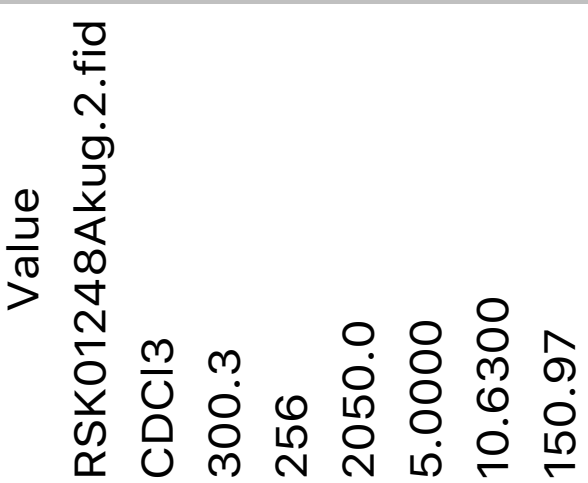

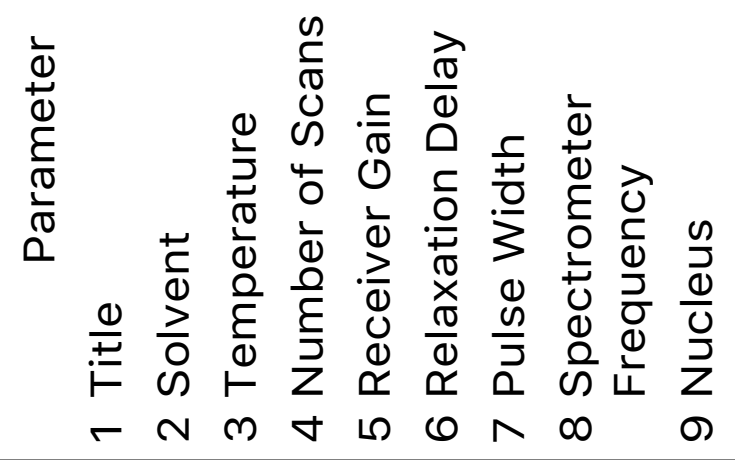

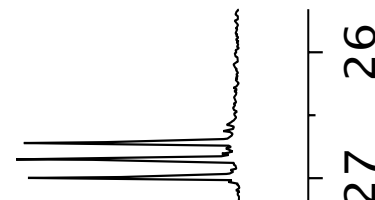

$07^{\circ} 82-$

$90^{\circ} 0 \varepsilon-$

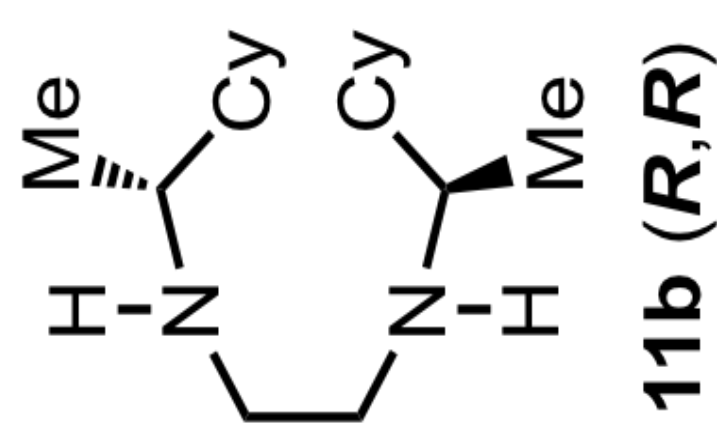

을을 $\circ^{-1}$ 


\section{S $8^{\circ} \mathrm{I}-$}

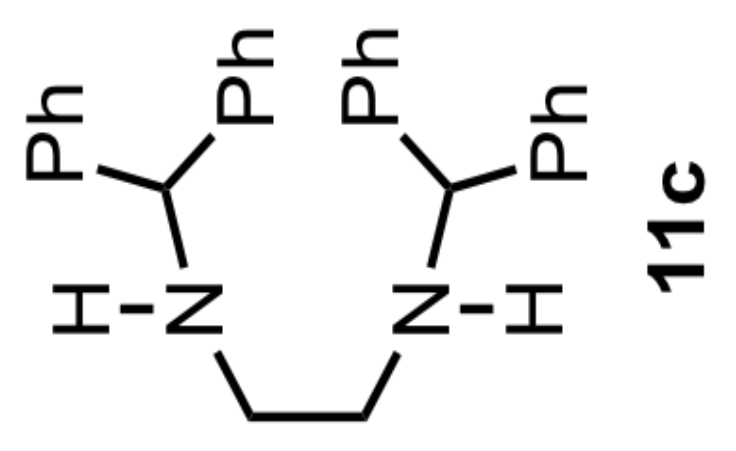

$2 L 2-$

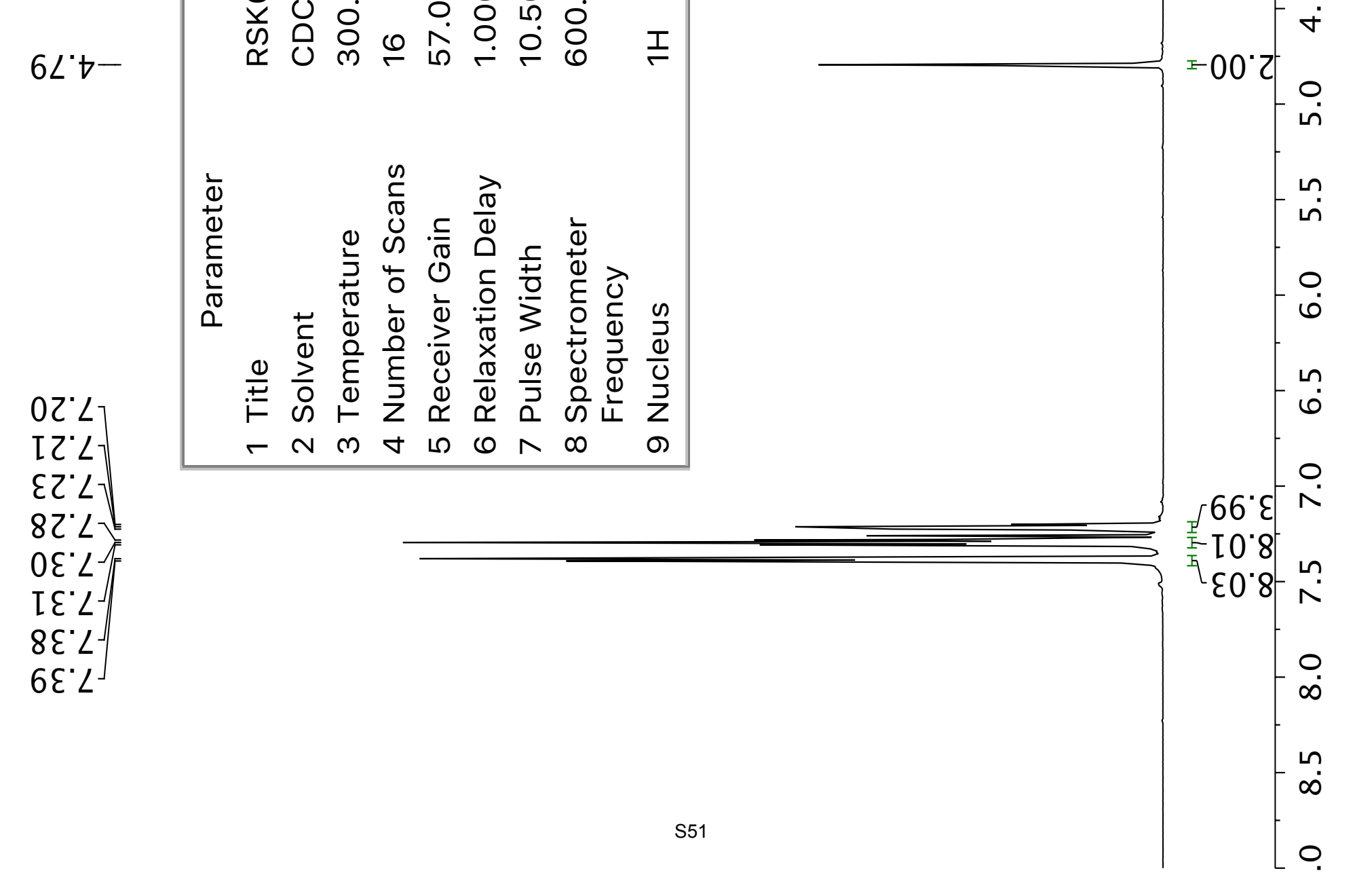


I6 $\angle b-$

$\forall t<9-$

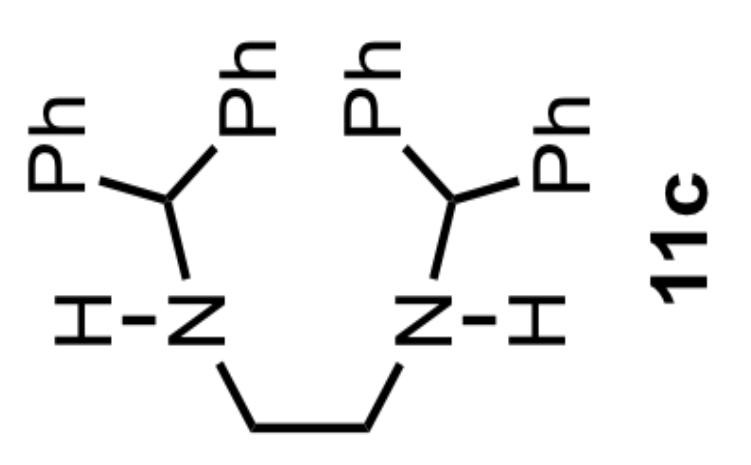

$-0$

욱

$-\stackrel{\circ}{N}$

m

우

우

$-8$

웅

$\infty$

을

$8^{-1}$

옥

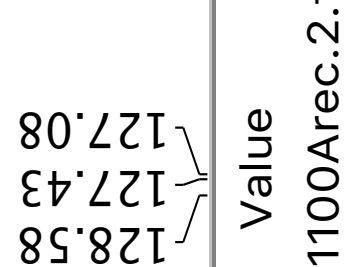

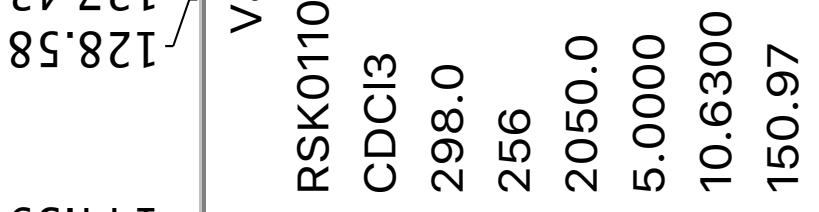

$6 \varepsilon^{\circ} \triangleright \triangleright I-$

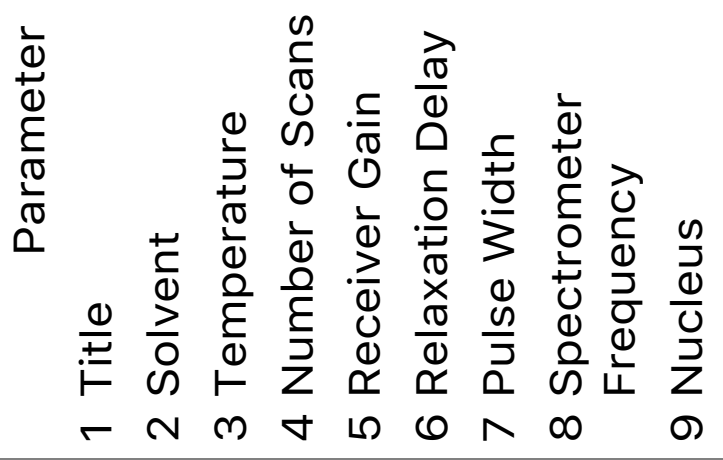

$\stackrel{ }{\rightarrow}$

음

욱

옥

8

옥

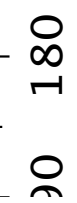




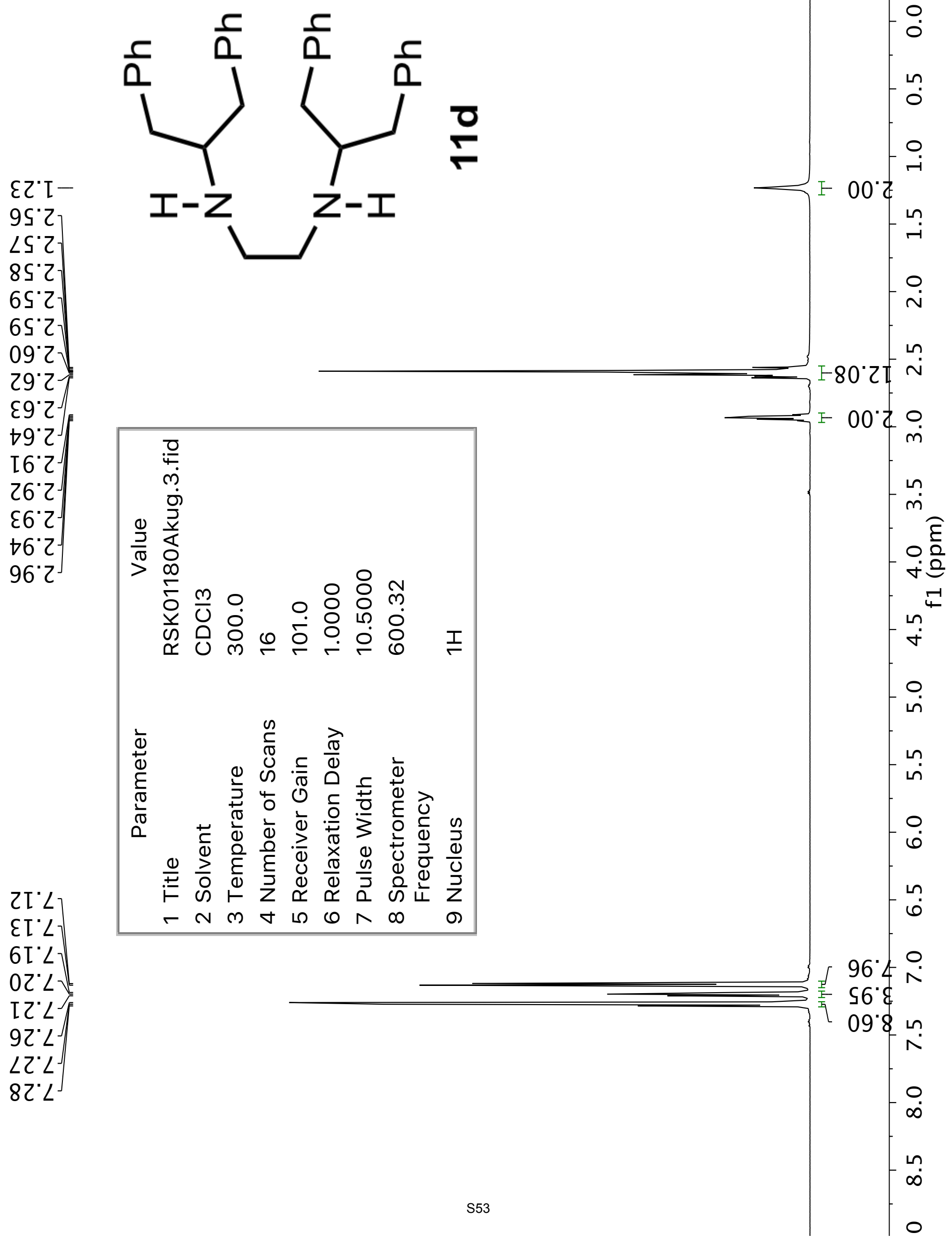




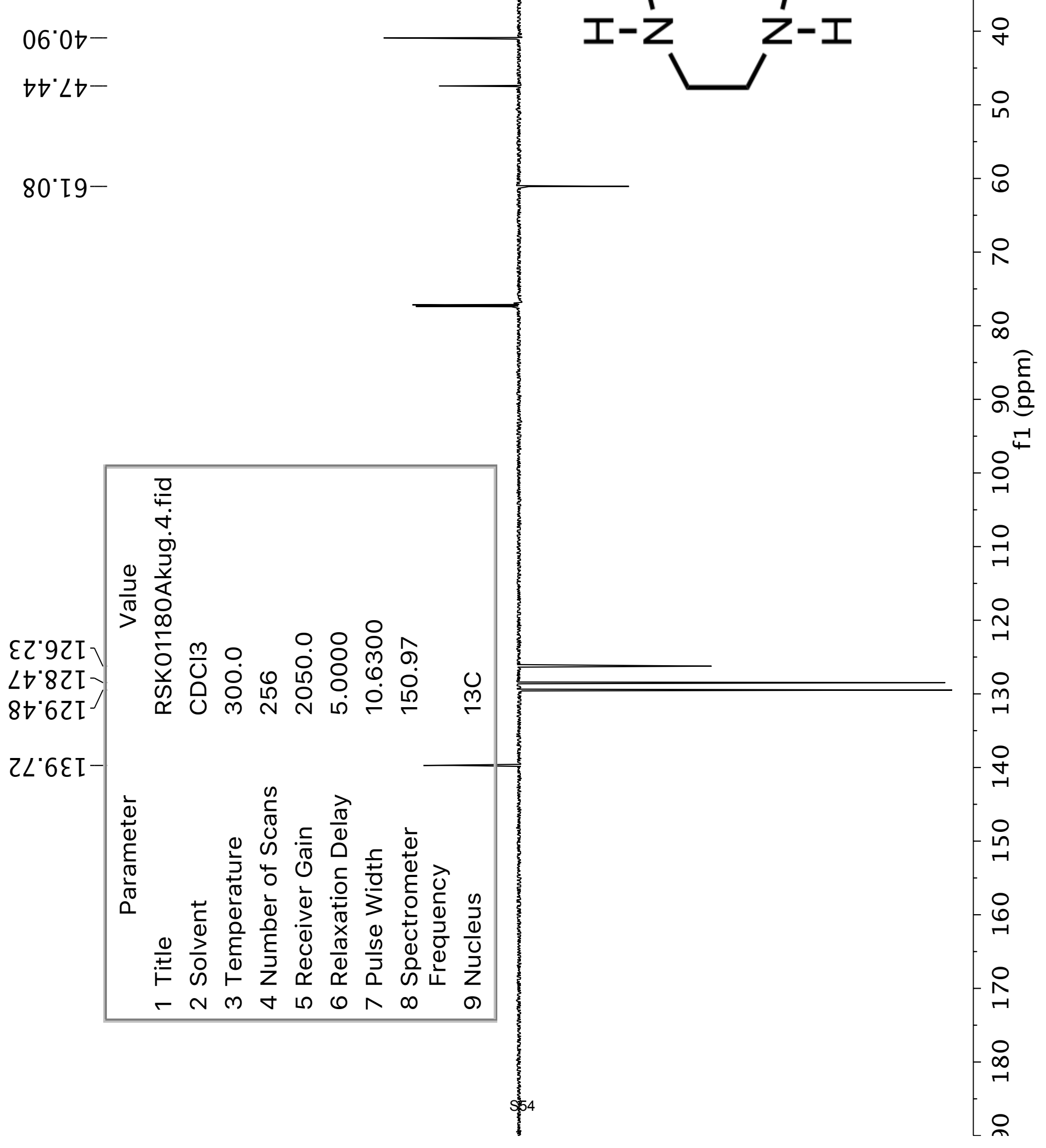


$\left[t^{*} \varepsilon\right.$

$98^{\circ} \varepsilon$

ऽ. 9

$99^{\circ} 9$

$99^{\circ} 9$

$99^{\circ} 9$

$99^{\circ} 9$

$\angle 9^{\circ} 9$

$\angle 9^{\circ} 9$

$\angle 9^{\circ} 9$

$\angle 9^{\circ} 9$

$\angle 9^{\circ} 9$

$\angle 9^{\circ} 9$

$\varepsilon \angle \cdot 9$

$\varepsilon \angle \cdot 9$ -

$\nabla \angle \cdot 9$

$\nabla \angle \circ 9$

$\forall \angle{ }^{\prime} 9$

$S \angle{ }^{\circ} 9$

$S \angle{ }^{\prime} 9$

$S \angle{ }^{\circ} 9$

$9 L^{\circ} 9$

$9<\cdot 9$

$9<\cdot 9$

कर 2

$6 \mathrm{I}^{\circ} \mathrm{L}-$

$6 I^{\circ} \mathrm{L}$

$0 Z^{\circ} \mathrm{L}$

$0 Z^{\circ} \mathrm{L}$

$0 Z^{\circ} \angle$

I $Z^{\circ} \mathrm{L}$

IZ'L

$22^{\circ} L^{\circ}$
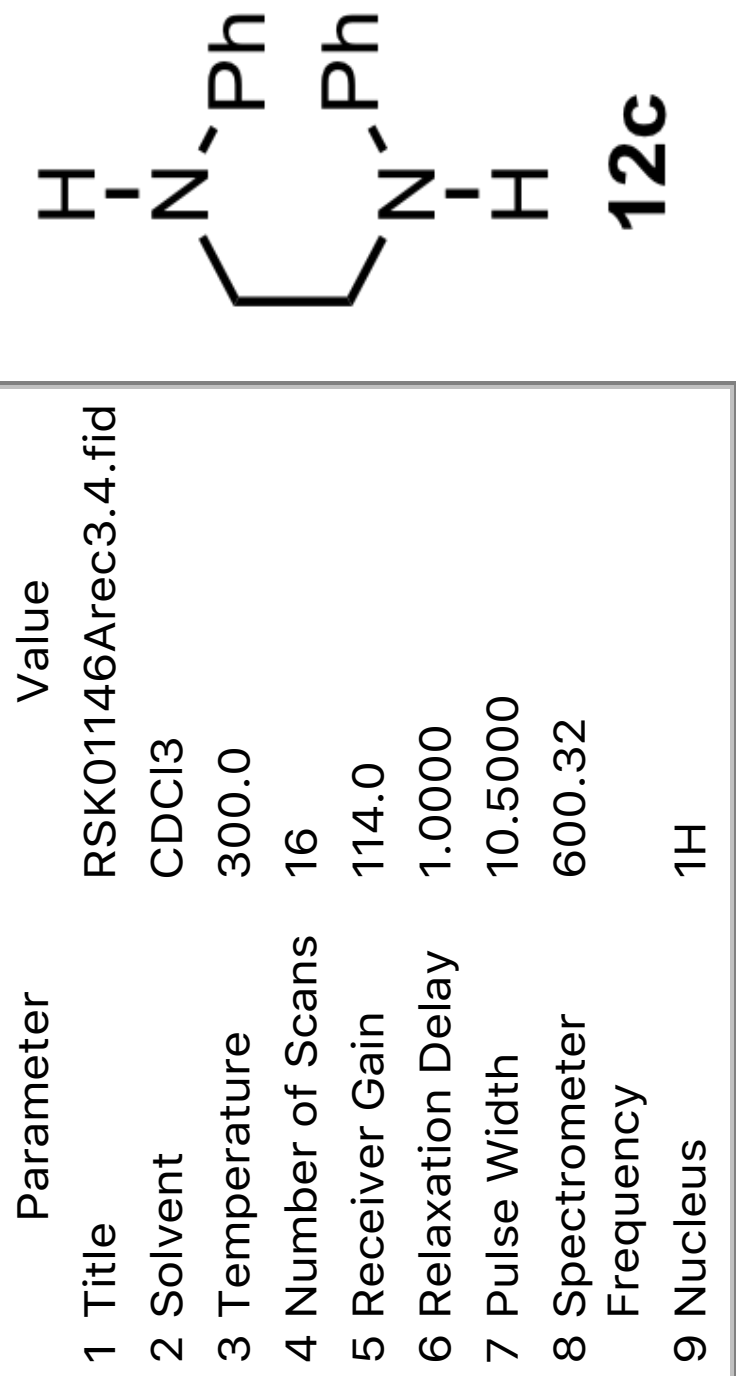

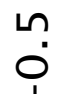

$:$

no

ㄱ.

ก

ํ.

ก

0

$m$

$I S I^{\circ} D$

m

$-16 . t$

워월

$\ln _{4}$

ष

ㅇ.

เก

ก

0
0

ㄴ? 


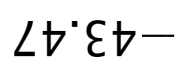

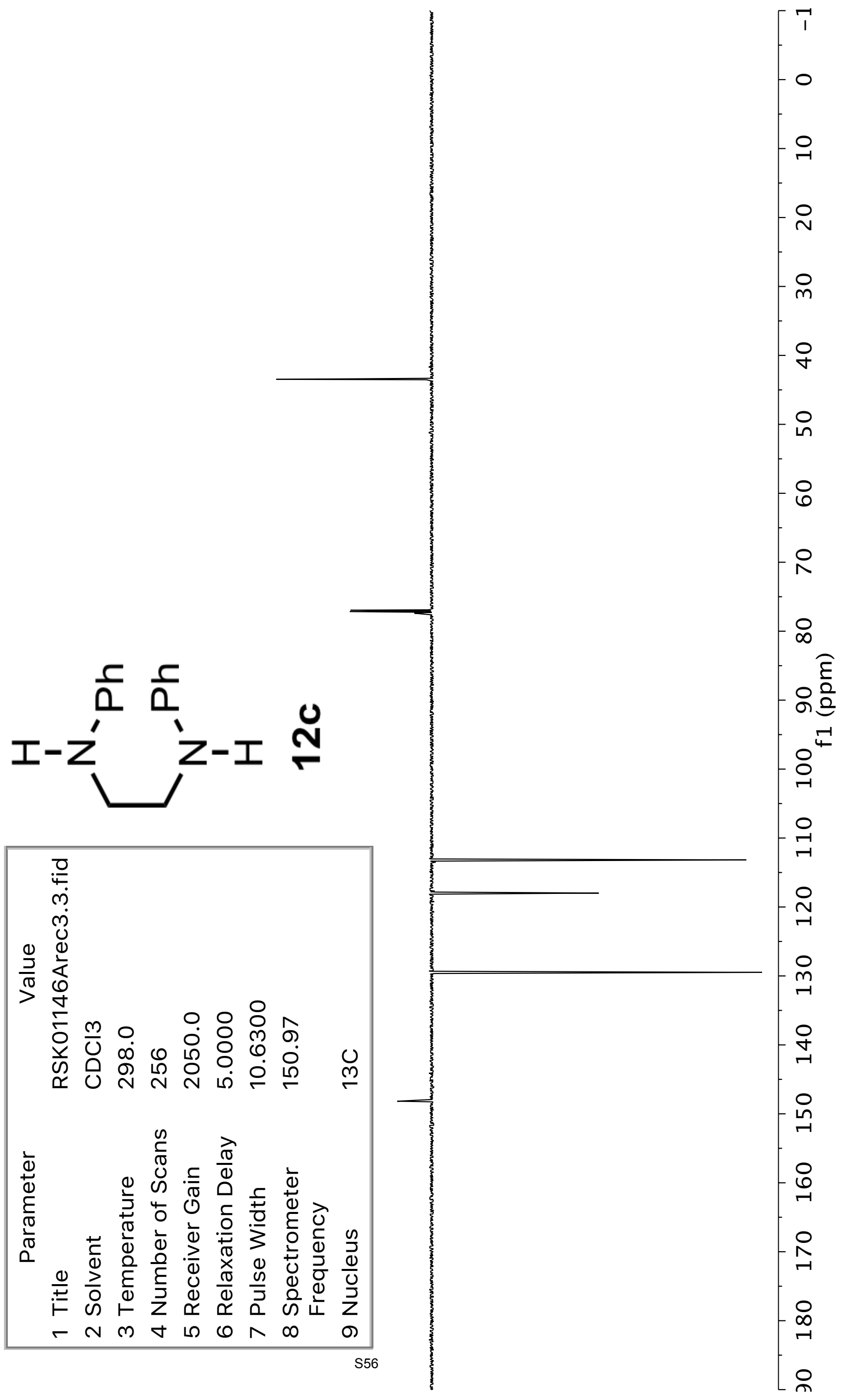


6t' I-

$\varepsilon L^{\prime} Z$

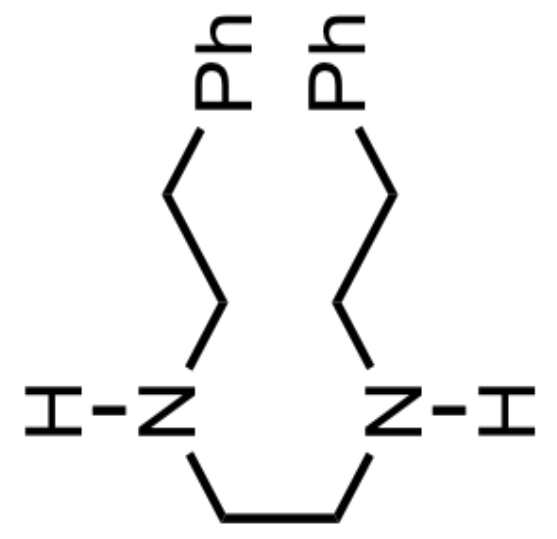

$\angle L^{\prime} Z$

$8 L^{\prime} Z$

$6 \angle ' Z$

$58^{\circ} \mathrm{Z}$

$\left.58^{\circ} \mathrm{Z}\right]$

$98^{\circ} \mathrm{Z}$

$98^{\circ} \mathrm{Z}$

$98^{\circ} \mathrm{Z}$

$98^{\circ} \mathrm{Z}$

$\angle 8^{\circ} \mathrm{Z}$

$88^{\circ} \tau^{\prime}$

$\left.\begin{array}{l}6 I^{\circ} \angle \\ 6 I^{\circ} \angle \\ 0 Z^{\circ} \angle \\ Z^{\circ} \angle \\ 22^{\circ} \angle \\ 22^{\circ} \angle \\ 22^{\circ} \angle \\ 82^{\circ} \angle\end{array}\right]$

$82^{\circ} \mathrm{L}$

$82^{\circ} \mathrm{L}$

$82^{\circ} L$

$62^{\circ} \mathrm{L}$

$62^{\circ} \angle$

$0 \varepsilon^{\circ} L$

$0 \varepsilon^{\circ} L$

[ $\varepsilon^{\circ} L$

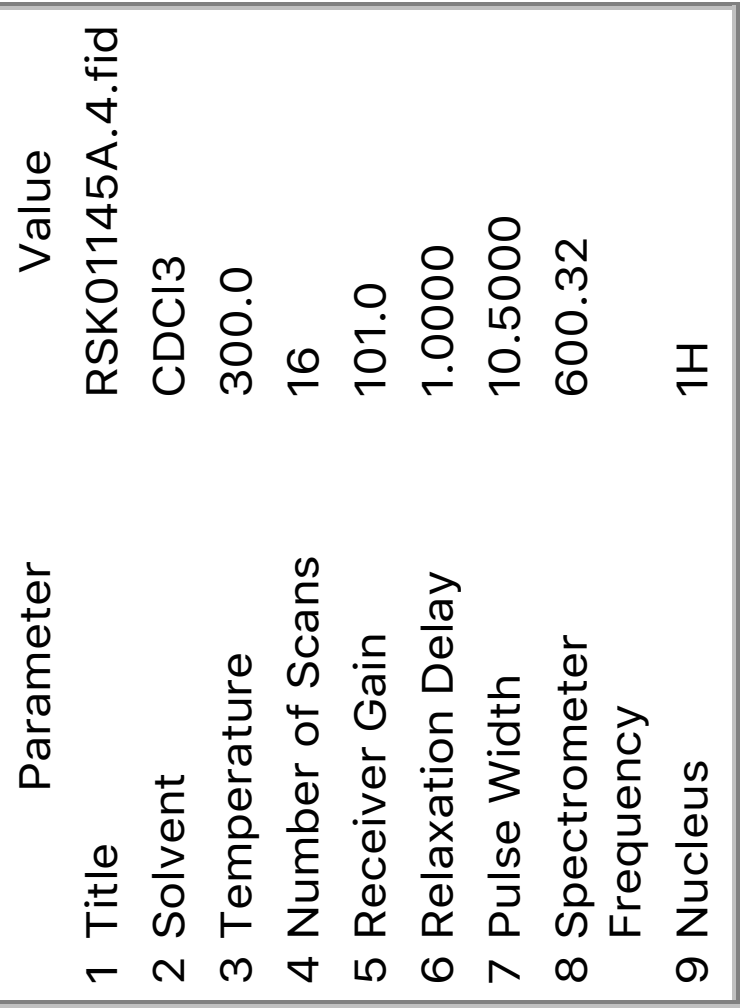


$\angle S^{\circ} 9 \varepsilon-$

$62 \cdot 6 b$

$\angle Z^{\circ}$ IS $^{-}$

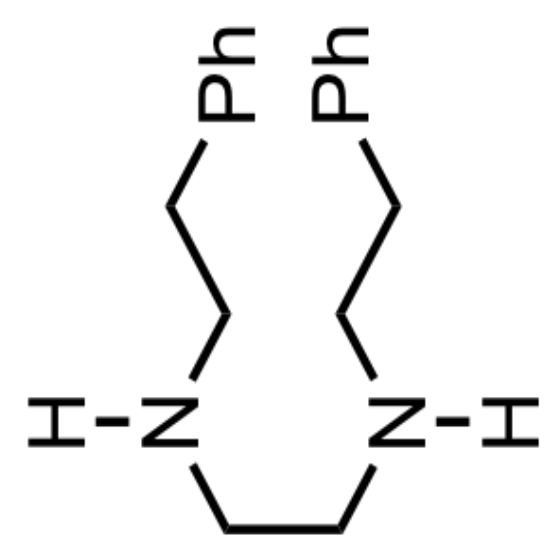

문

운

$\angle Z^{\prime} 9 Z \mathrm{I} \backslash$ 65.8ZI 58.82 I

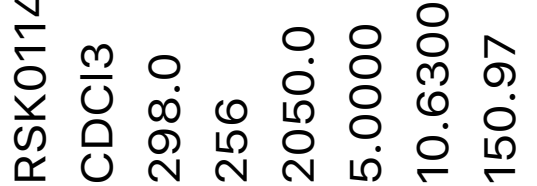

$\stackrel{0}{n}$

IZ'0tI-

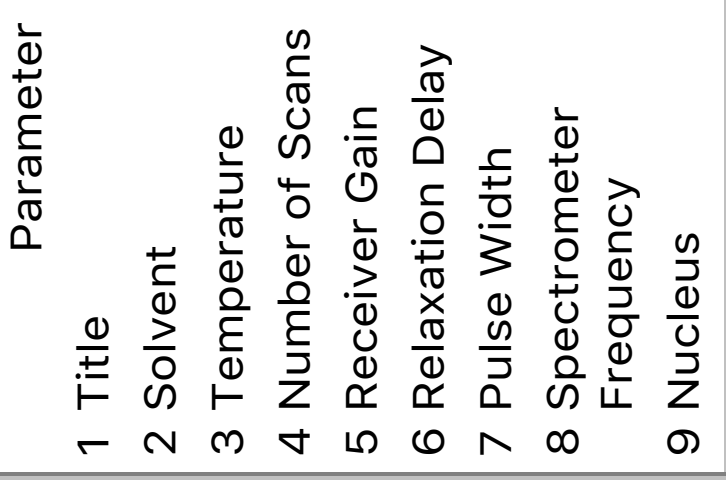


†ฤ I-

$8 \varepsilon^{\prime} 2-$

6I'L

$6 \mathrm{I}^{\circ} \mathrm{L}$

$6 \mathrm{I}^{\circ} \mathrm{L}$

$0 Z^{\circ} L$

$0 Z^{\circ} \angle$

I $Z^{\circ} L$

I ${ }^{\circ} L$

$22^{\circ} L$

$22^{\circ} L$

$62^{\circ} \mathrm{L}$

$0 \varepsilon^{\circ} L$

$0 \varepsilon^{\circ} L$

$O \varepsilon^{\circ} L$

I $\varepsilon^{\circ} L$

โ $\varepsilon^{\circ}\llcorner]$

乙E' $\angle$

$\varepsilon \varepsilon^{\circ}\llcorner]$

$\varepsilon \varepsilon \cdot \angle \downarrow$

$I \nabla^{\circ} \angle J$

$I \nabla^{\circ} L$

$2 \nabla^{\circ} L^{\circ}$

$2 t^{\circ} \angle$

$2 \nabla^{\circ} \angle$

$2 \nabla^{\circ} L$

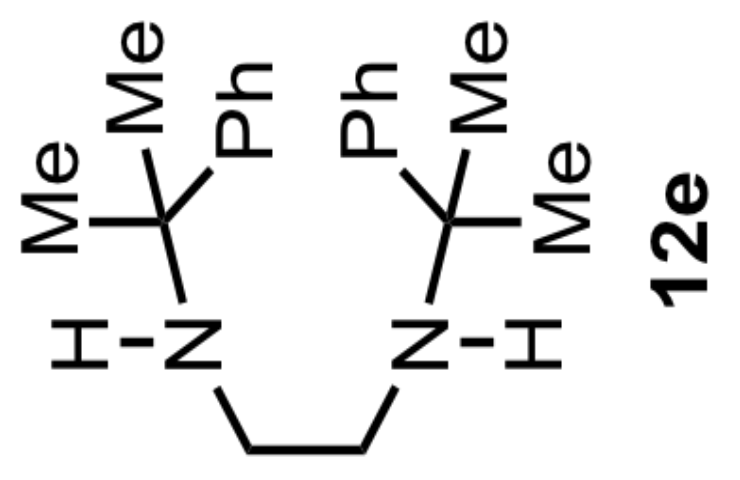

$\varepsilon \nabla^{\circ} L$

$\varepsilon \nabla^{\prime} L$

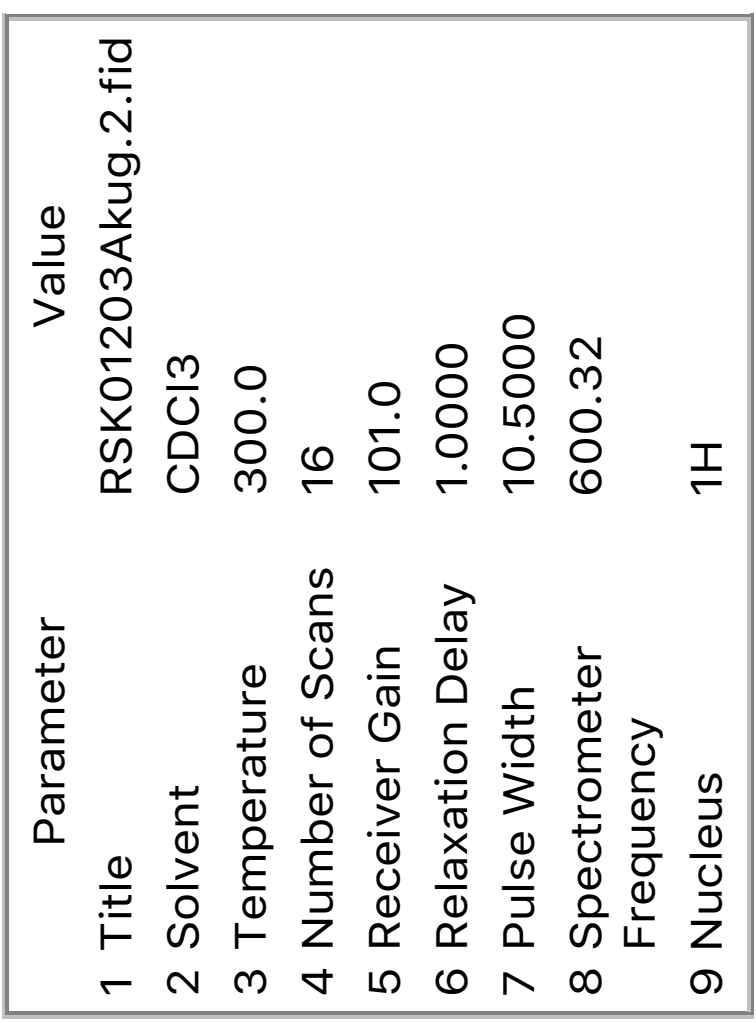


[9.62-

09'عャ-

LLSS-

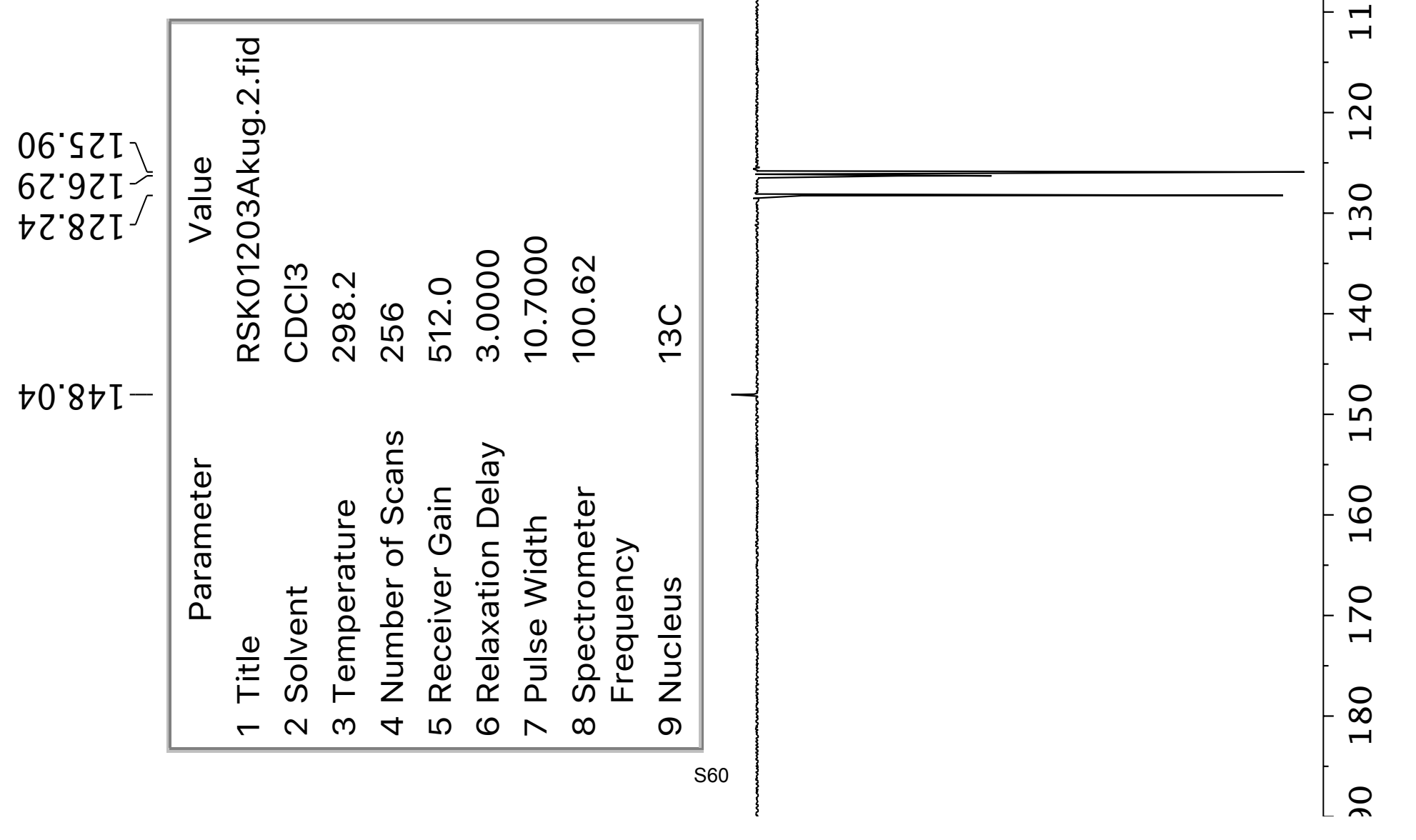




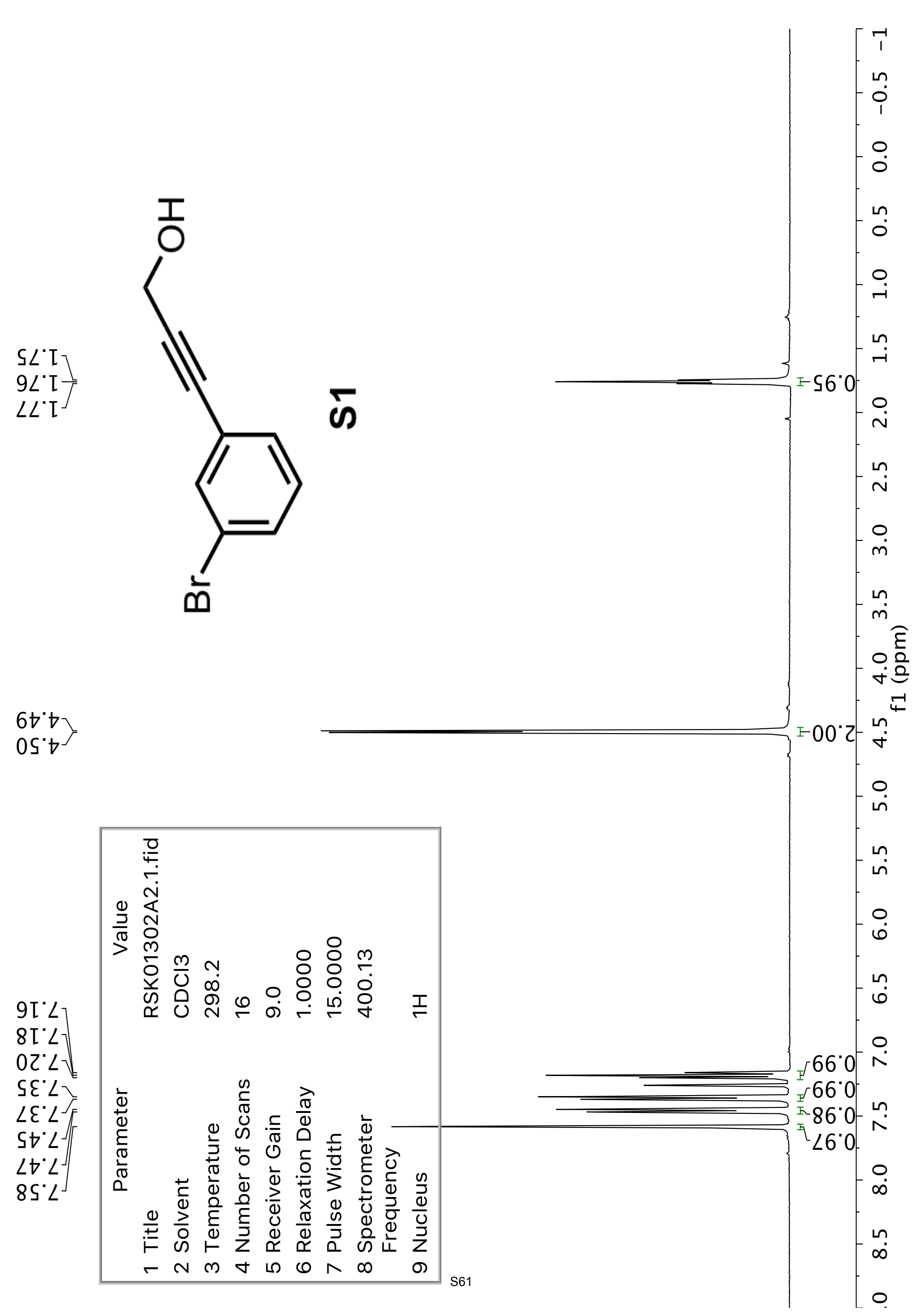


OL'IS-

โع'เ8-

[9.88-

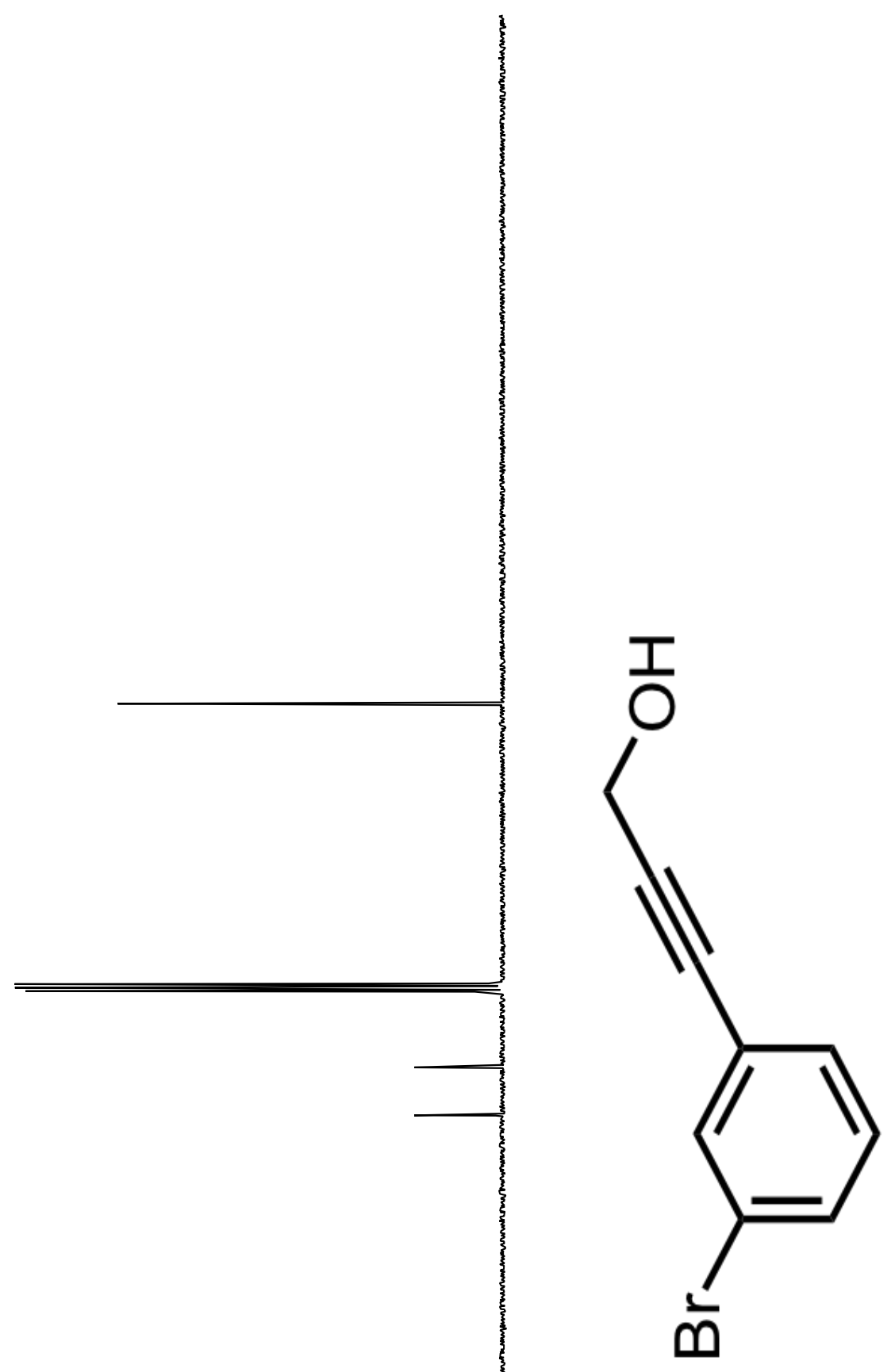

$\left.\begin{array}{l}\diamond 2^{\circ} 2 Z[ \\ {\left[9^{\circ} \nabla 2[\right.}\end{array}\right]$ [6.6Z[]

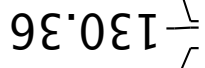
Z8. IE I $\nabla S^{\circ} \nabla \varepsilon I$

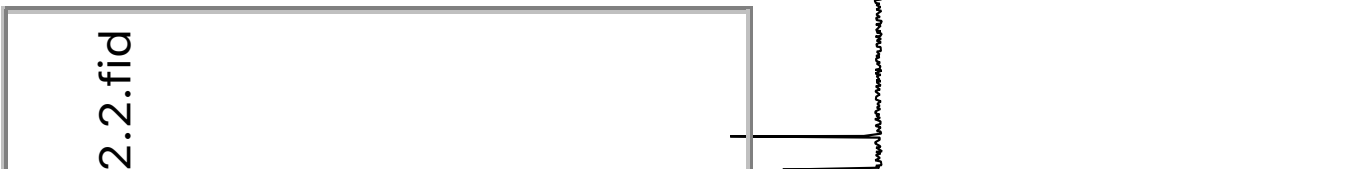

$\stackrel{\circ}{ }$

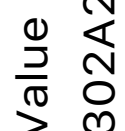

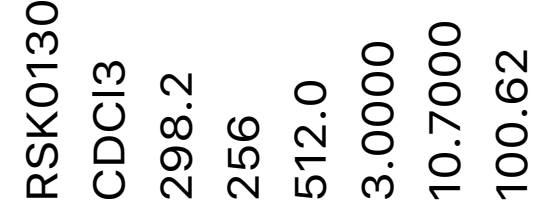

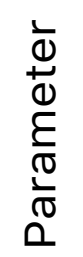

号

凹

$\stackrel{m}{\circ}$

m

움

$\underset{\sim}{\stackrel{ }{r}}$

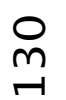

음

움

$\stackrel{0}{r}$

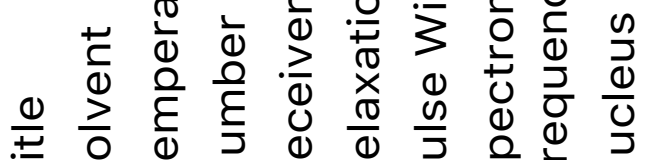

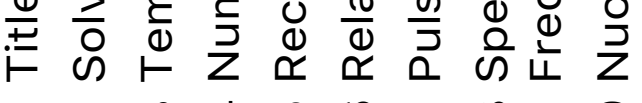

$-N M+L O N \infty \sigma$. 


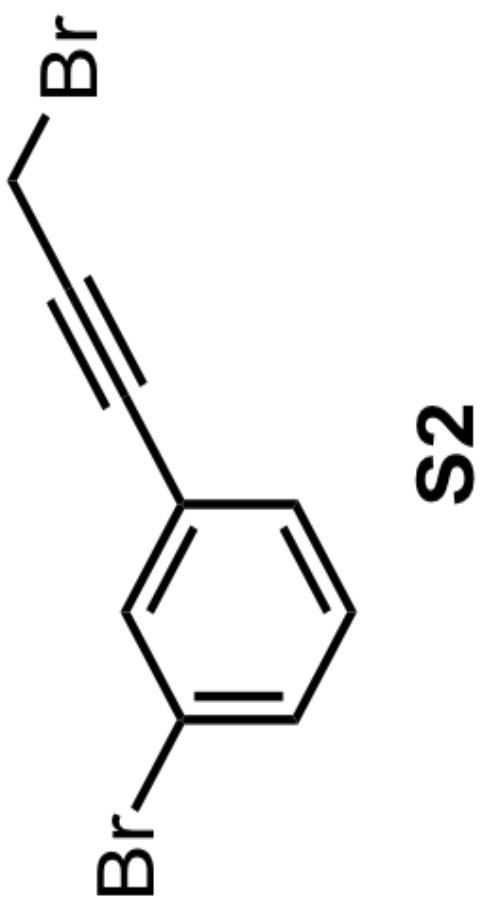

$\nabla I^{\circ} \nabla-$

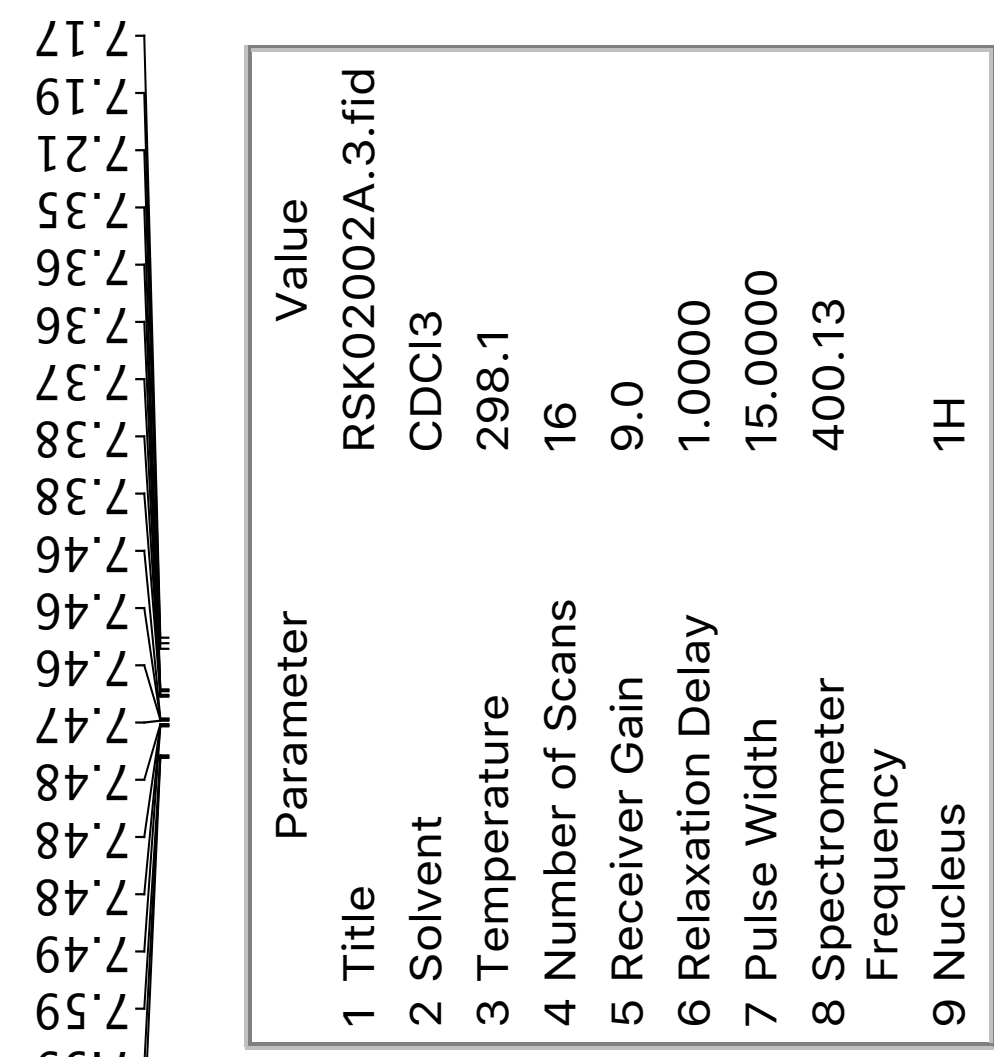

$6 \mathrm{~S}^{\circ} \mathrm{L}$ $09^{\circ} \mathrm{L}$ 
$06^{\circ} \nabla I-$

2I' 58 ר

ह9. ${ }^{\circ} 8^{J}$
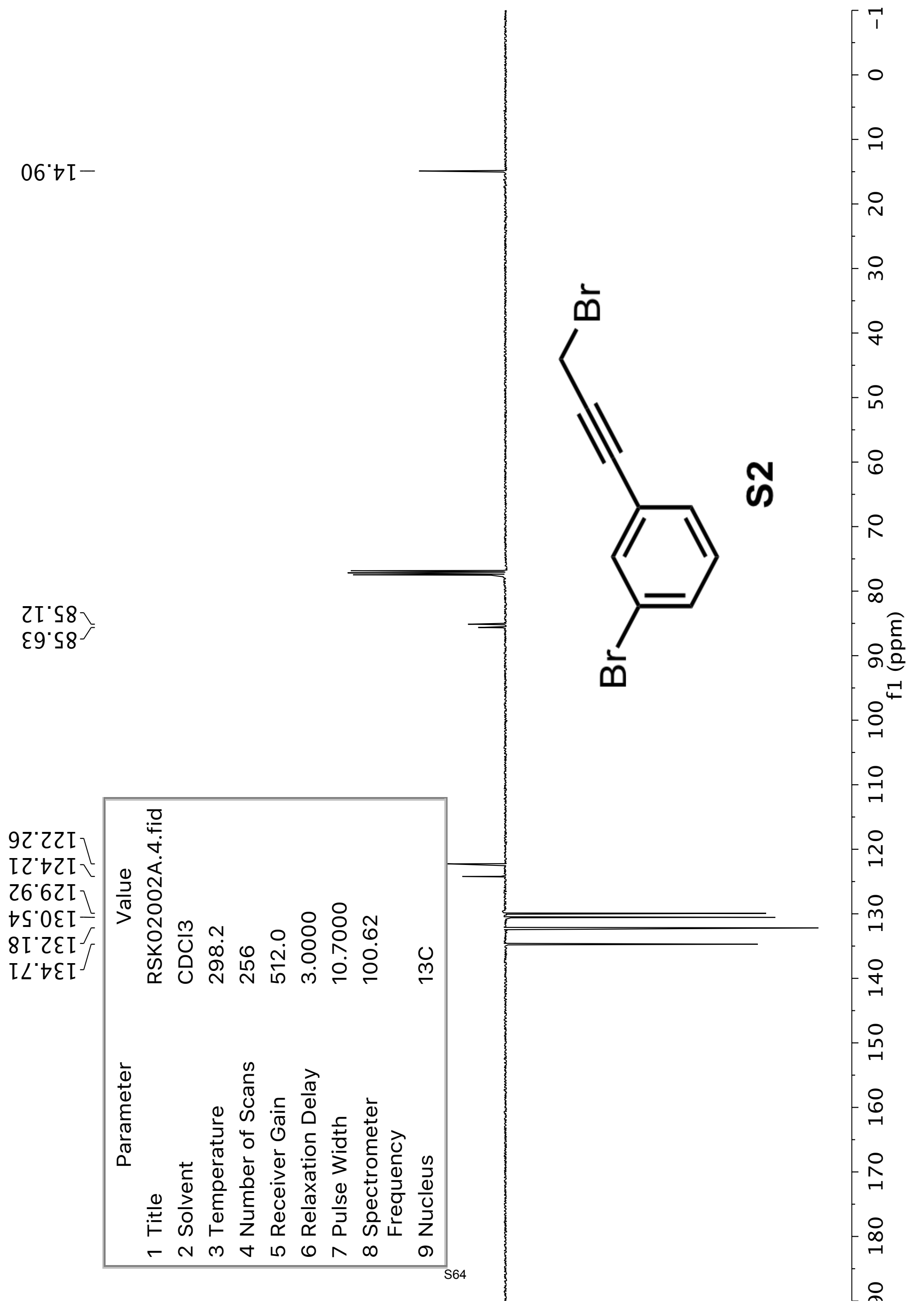


\section{$98^{\circ} \mathrm{I}-$ \\ $s \varepsilon^{\prime} z$
$9 \varepsilon^{\prime} z^{\prime}$}

I

$6 b^{\circ} \bullet-$

$80^{\circ} \mathrm{L}$
$80^{\circ} \mathrm{L}$

$0 \mathrm{I}^{\circ} \mathrm{L}$

$0 \mathrm{I}^{\circ} \mathrm{L}$

$8 \mathrm{I}^{\circ} \mathrm{L}$

$6 \mathrm{I}^{\prime} \mathrm{L}$

$0 Z^{\circ} \angle$

I $Z^{\circ} \angle$

$22^{\circ} \angle$

$\varepsilon Z^{\circ} \angle$

$\left.\downarrow \varepsilon^{\prime} \angle\right]=$

$\nabla \varepsilon \cdot L$

$9 \varepsilon^{\circ} L=$

$9 \varepsilon<-$

$8 \varepsilon^{\circ} L$

$8 \varepsilon^{\circ} L$

$\angle D^{\circ} \angle$

$8 t^{\circ} \mathrm{L}$

$6 t^{\circ} \mathrm{L}$

$6 t^{\circ} L$
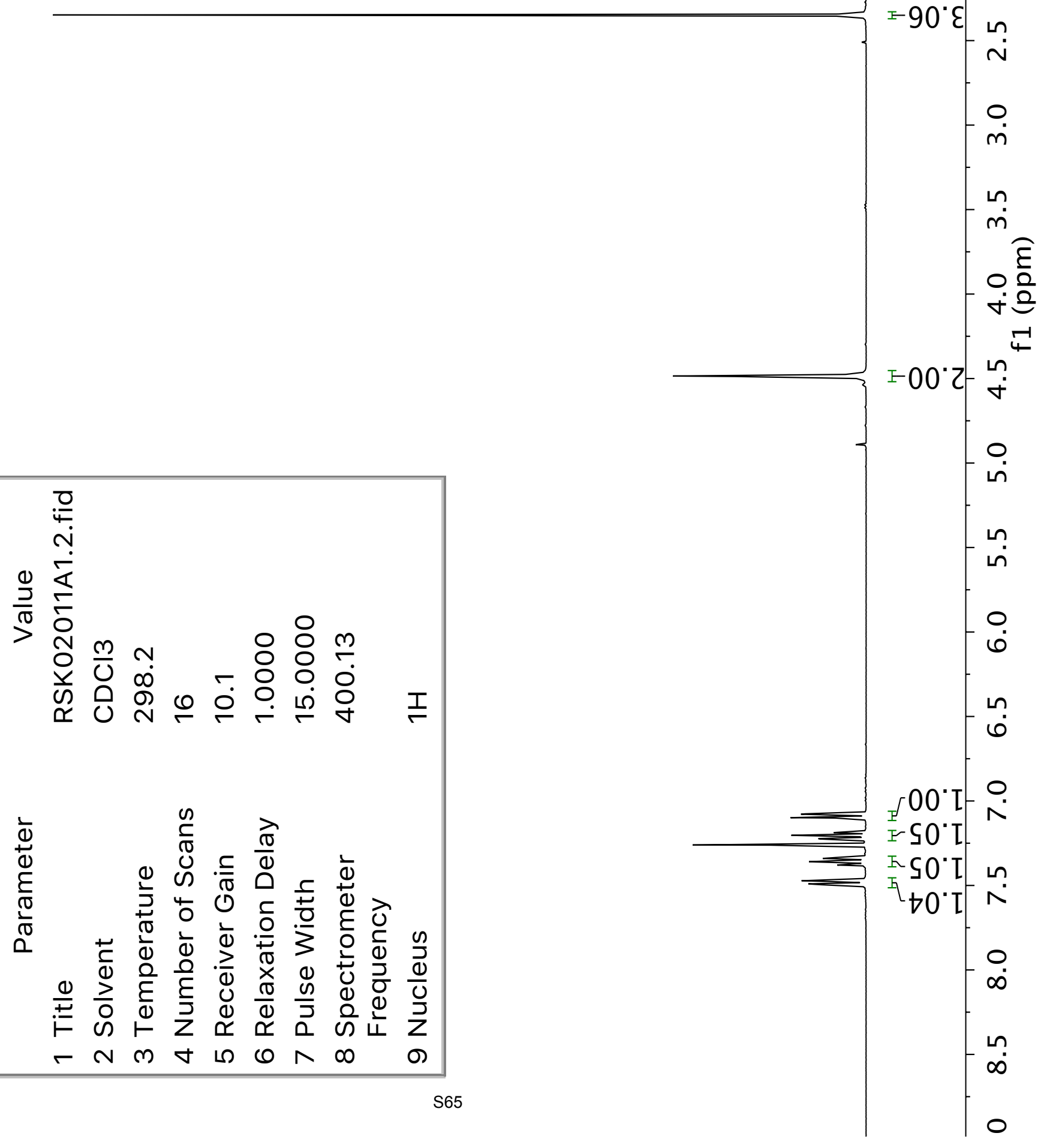
SO'IZ-

ZLIS-

$\forall L \cdot 08-$

乙E' $26-$

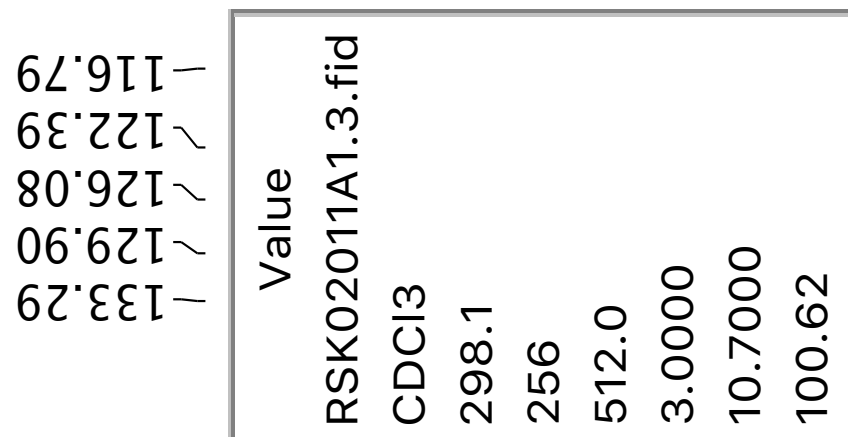

†L'ISI-

$\frac{1}{d}$
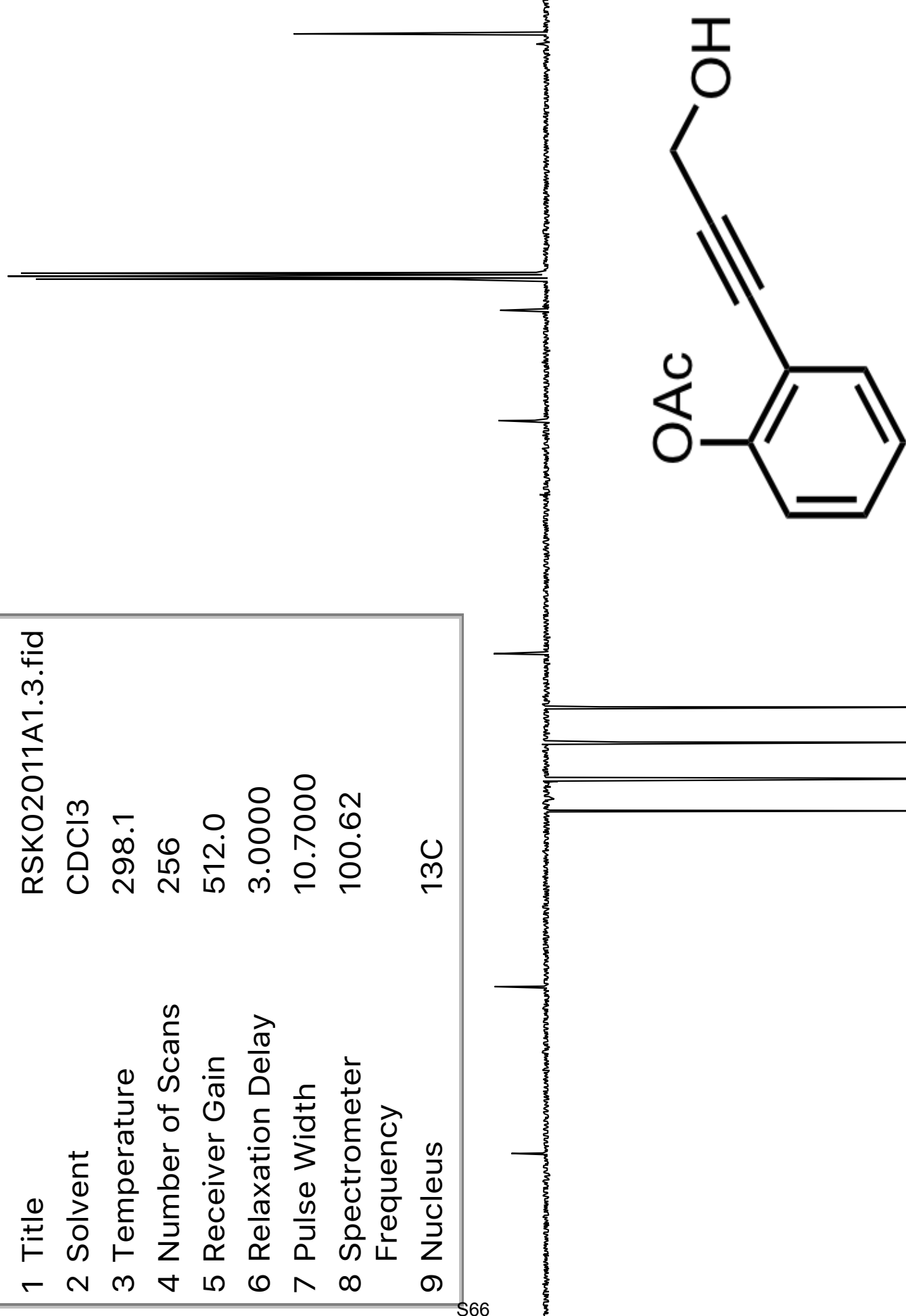

은

8

$\stackrel{\imath}{N}$

$\ddot{\omega}$

$\infty$

으을

$ᄋ^{-1}$

음

$\stackrel{ }{r}$

$\stackrel{\circ}{\mathrm{m}}$

욱

음

$\stackrel{8}{8}$

웃

$-1$

$\stackrel{\infty}{\infty}$ 


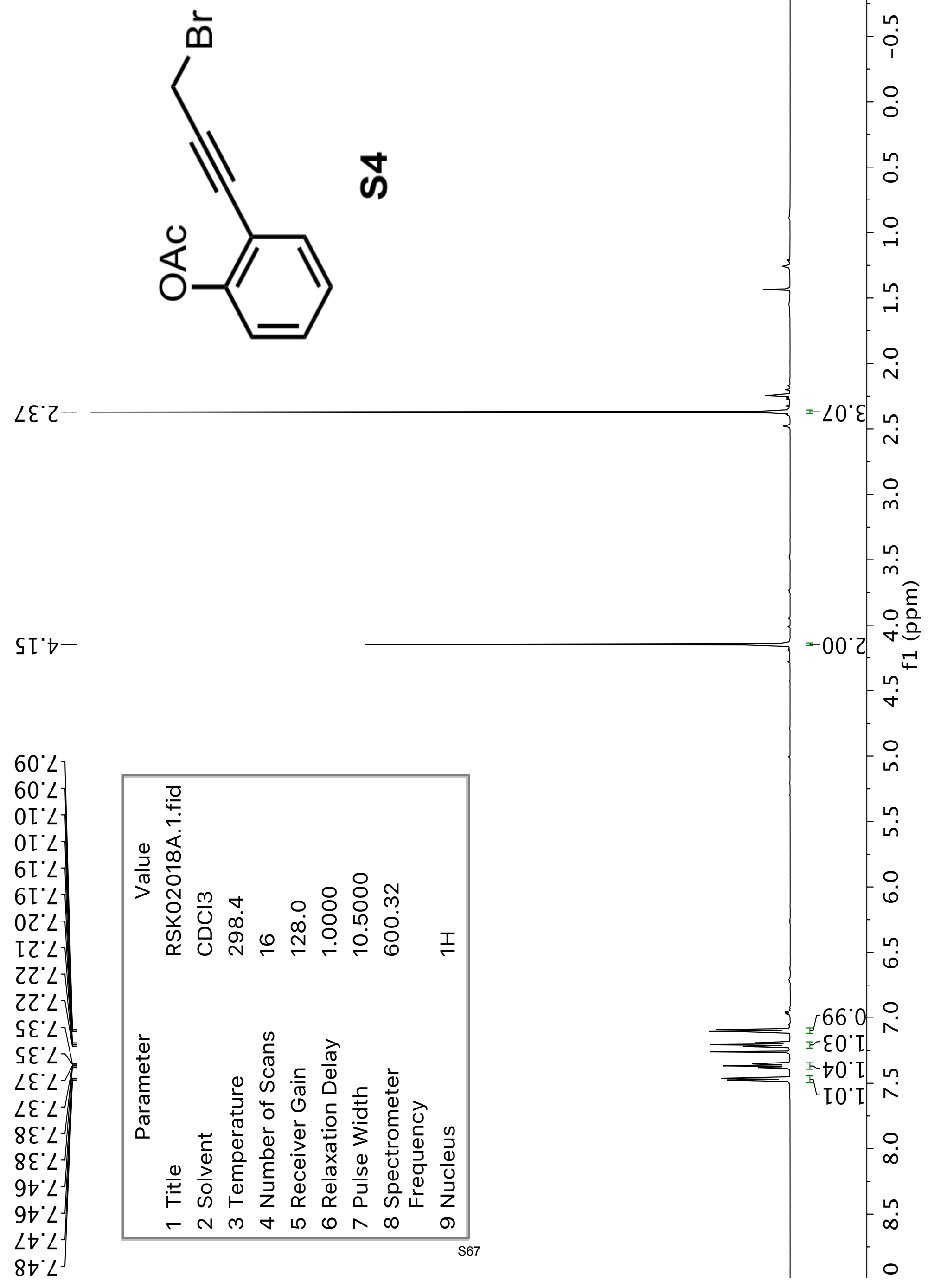


$28^{\circ} \circ \mathrm{I}-$

EO'IZ-

06 '18-

$600^{\circ} 68-$
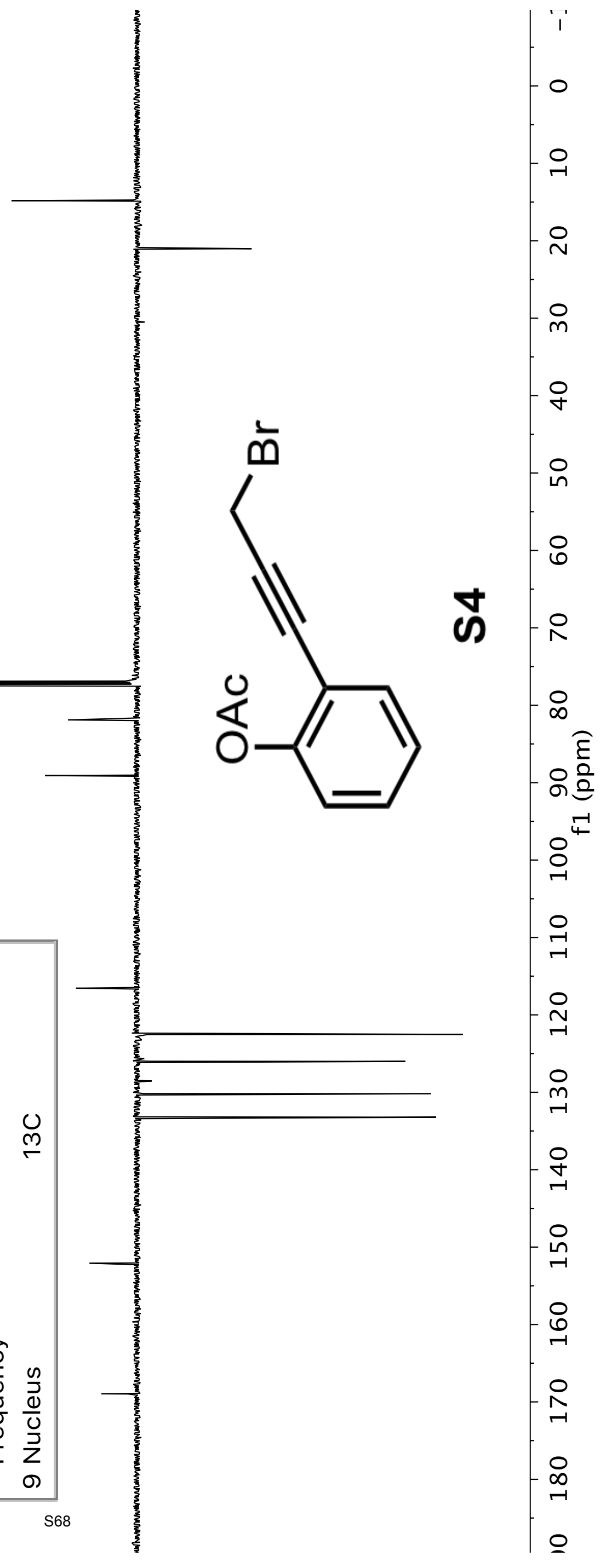


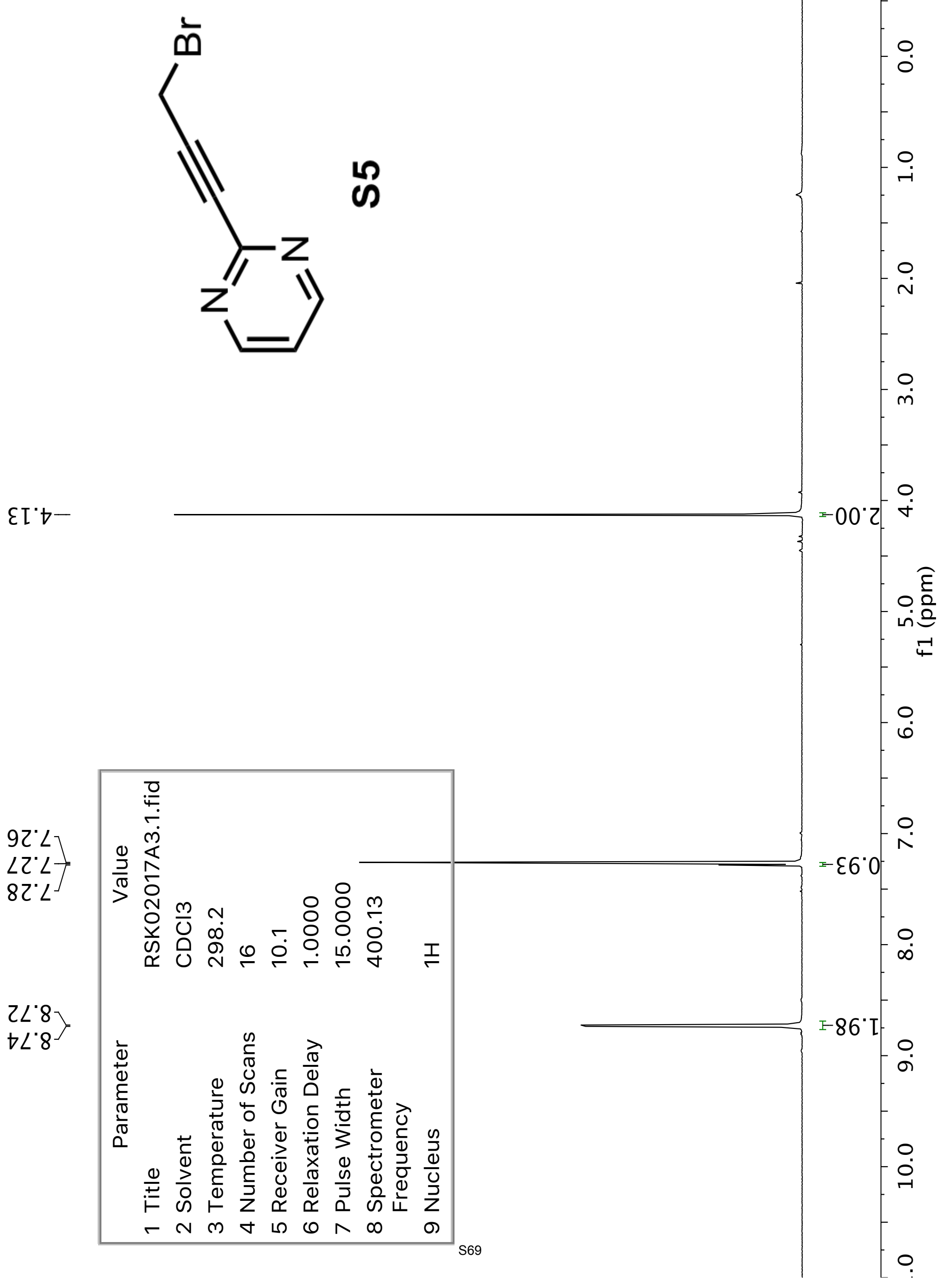




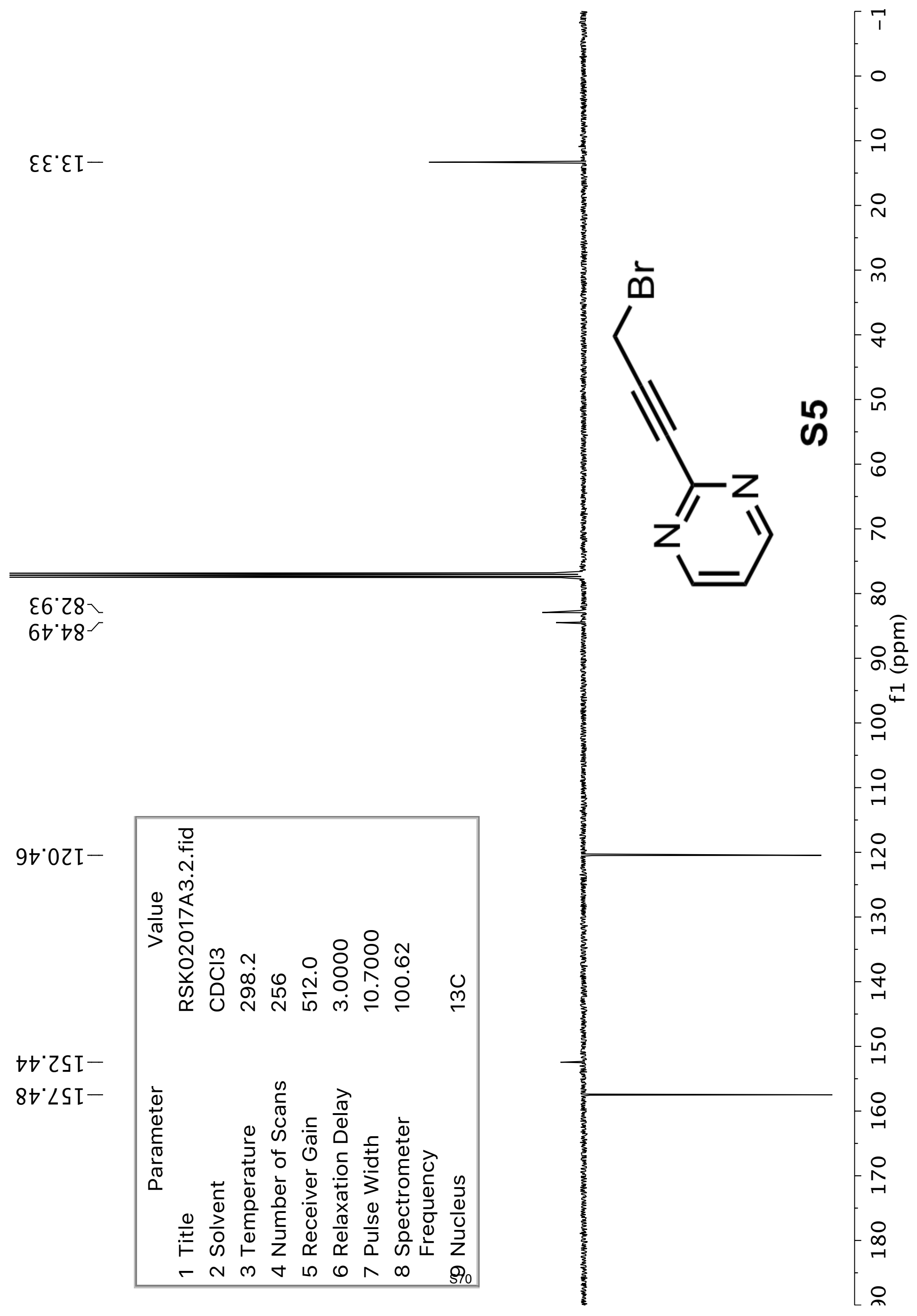




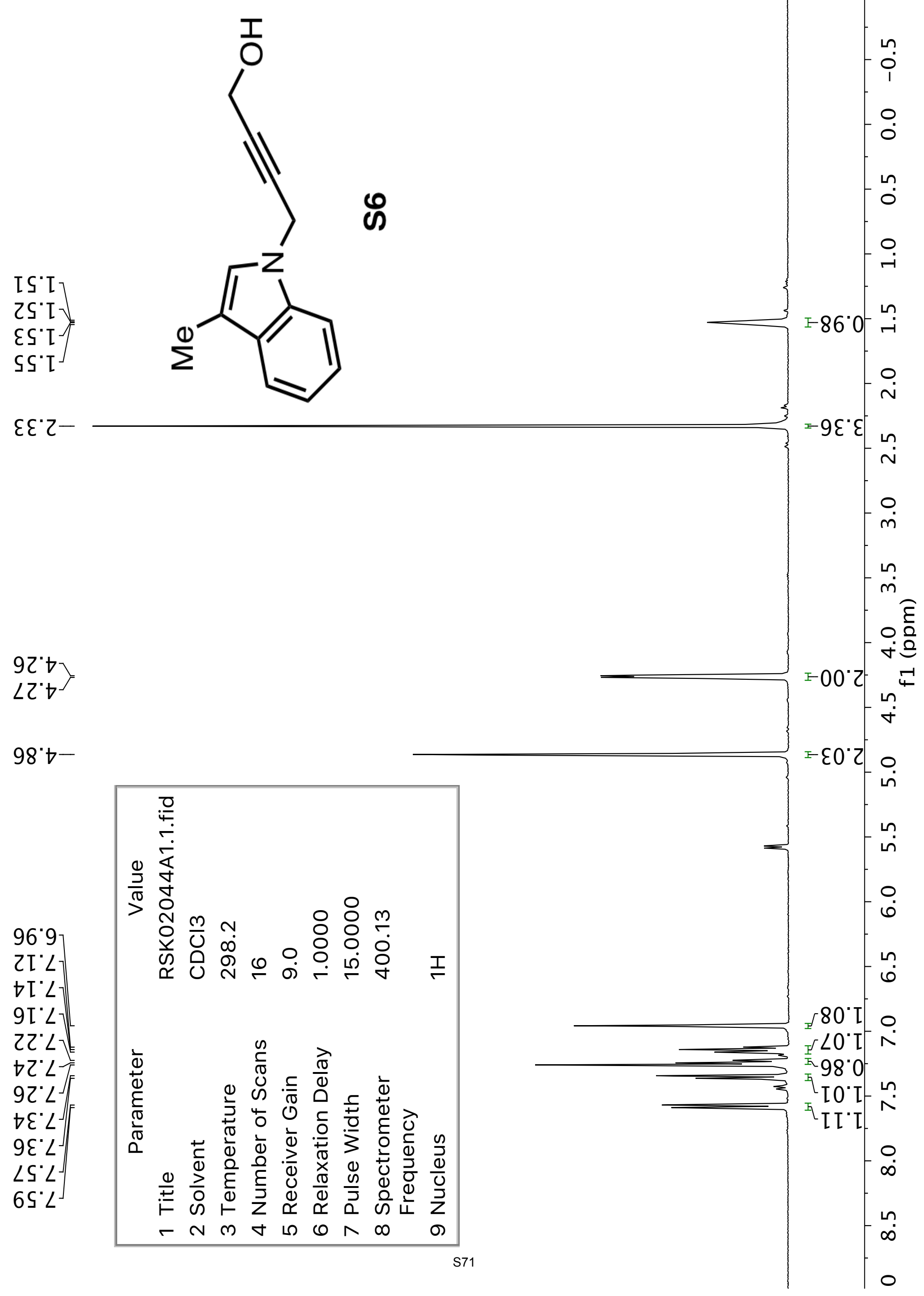


$S L^{\circ} 6-$

乙8. ${ }^{\circ}-$

9Z'IS-

$t t^{\circ} \overline{\overline{0}}$

$\checkmark 6^{\circ} 28^{-}$

$82^{\circ} 60 \mathrm{I}-$

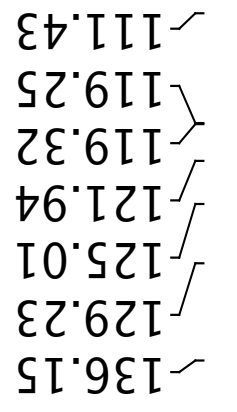

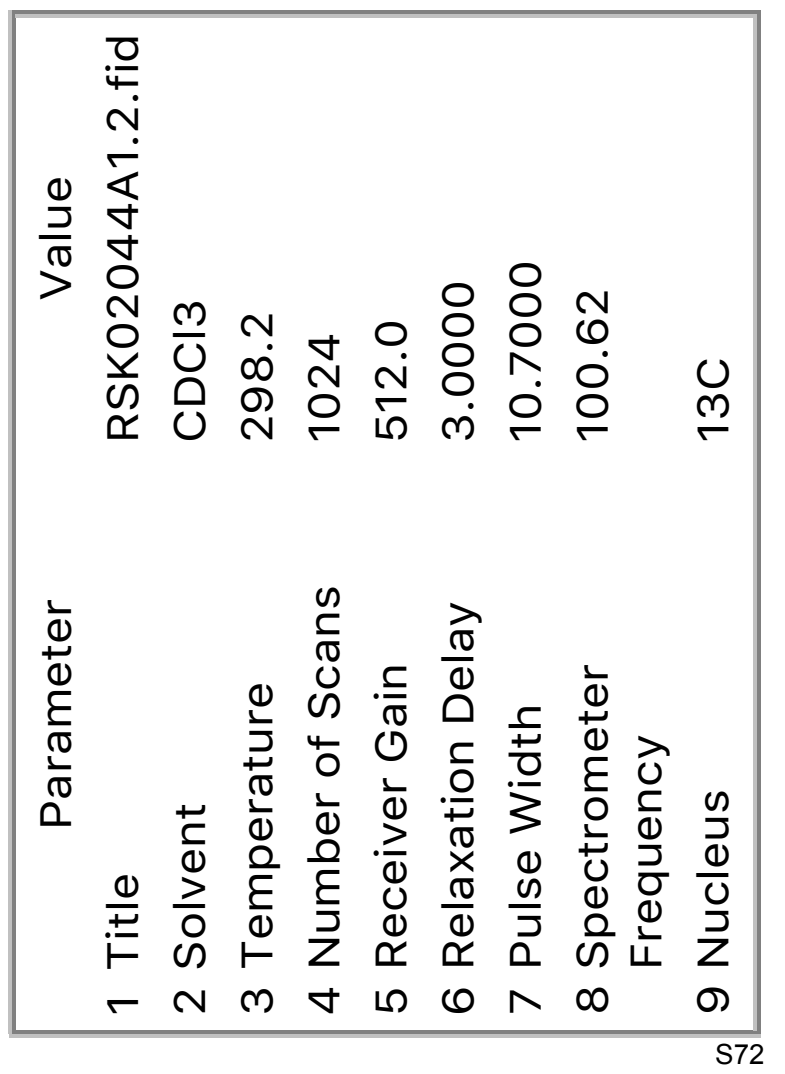

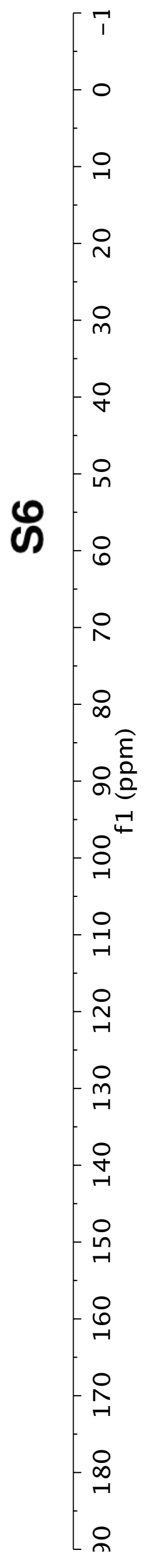




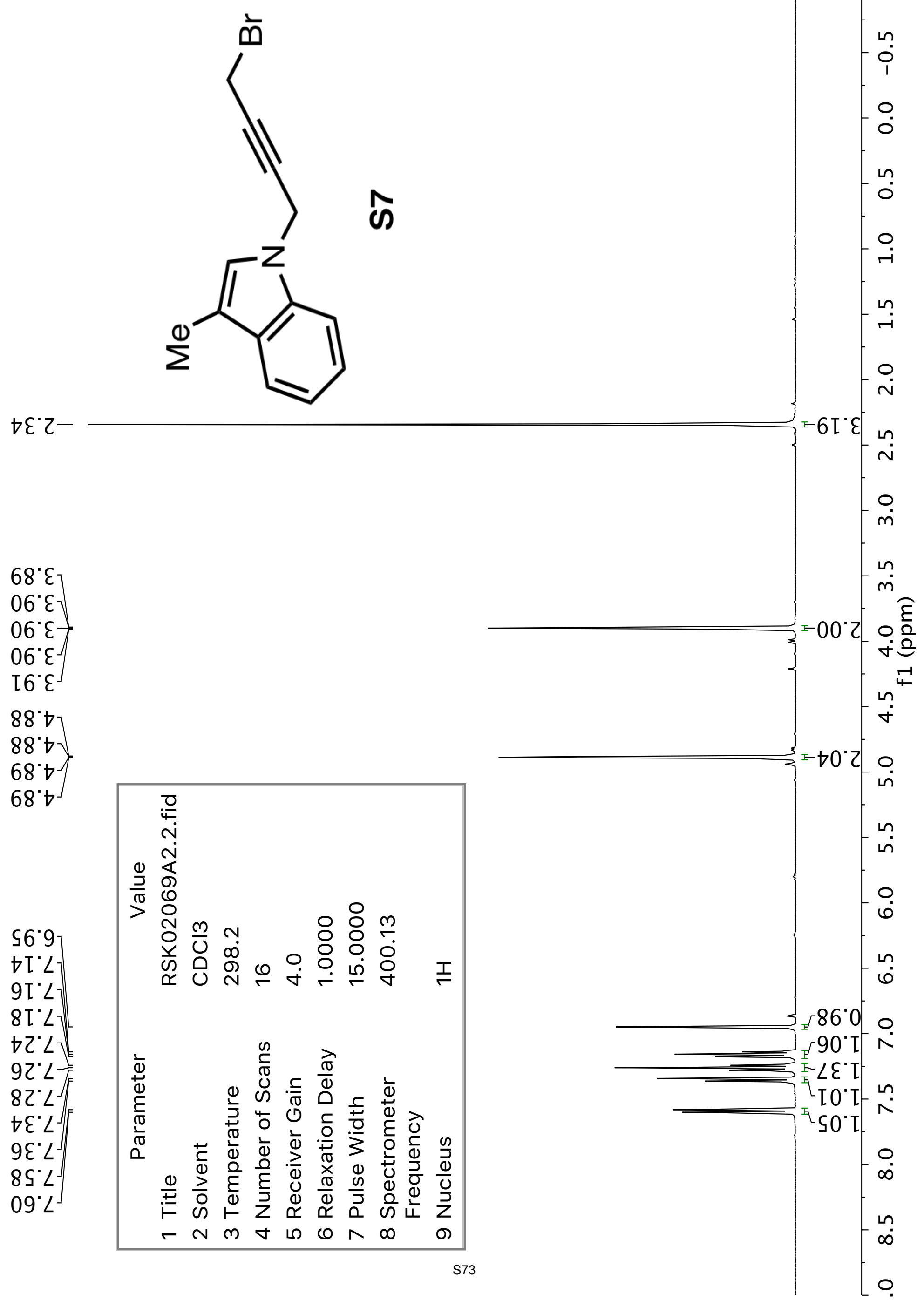


$S \angle{ }^{\circ} 6-$

ع乙'† -

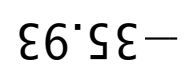

I6 $6 \angle$ 乙

$9 \varepsilon^{\circ}\left[8^{\prime}\right.$
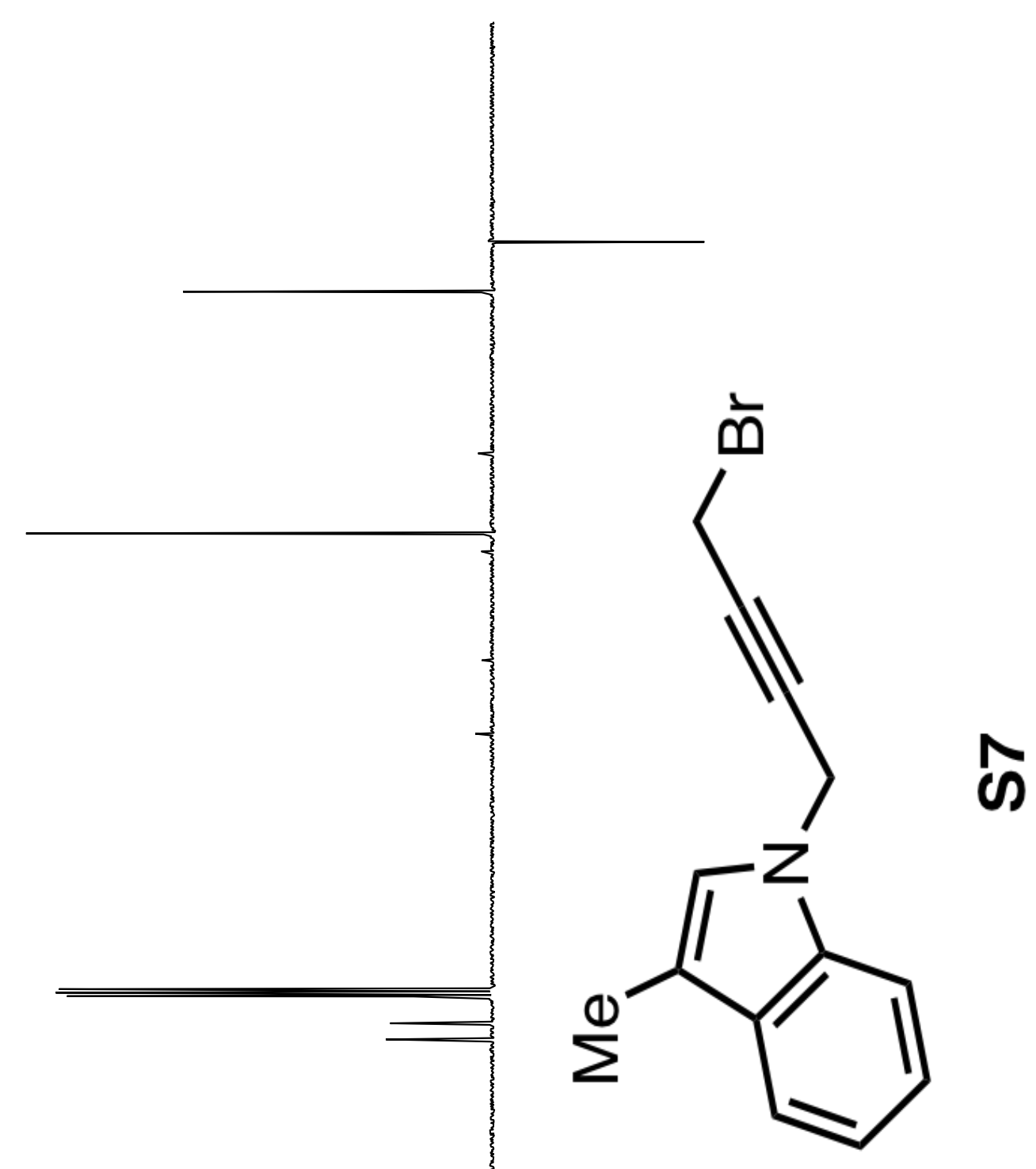

$92^{\circ} 60 \mathrm{I}^{\prime}$ 2S'III $0 \varepsilon^{\circ} 6$ I I 66. IZI $96^{\circ}+2 \tau^{\top}$

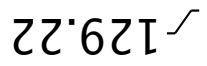
SI'9\&I

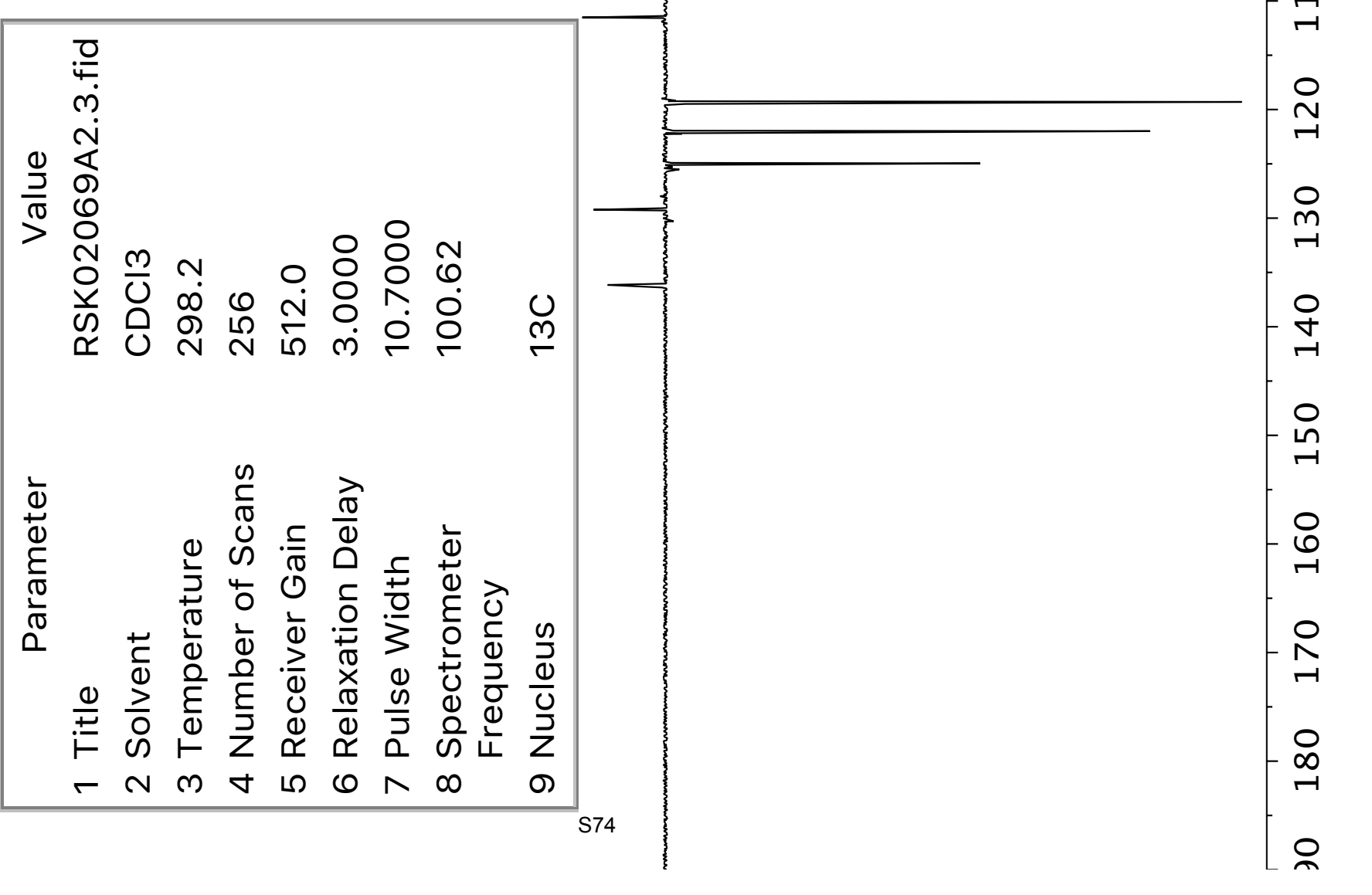




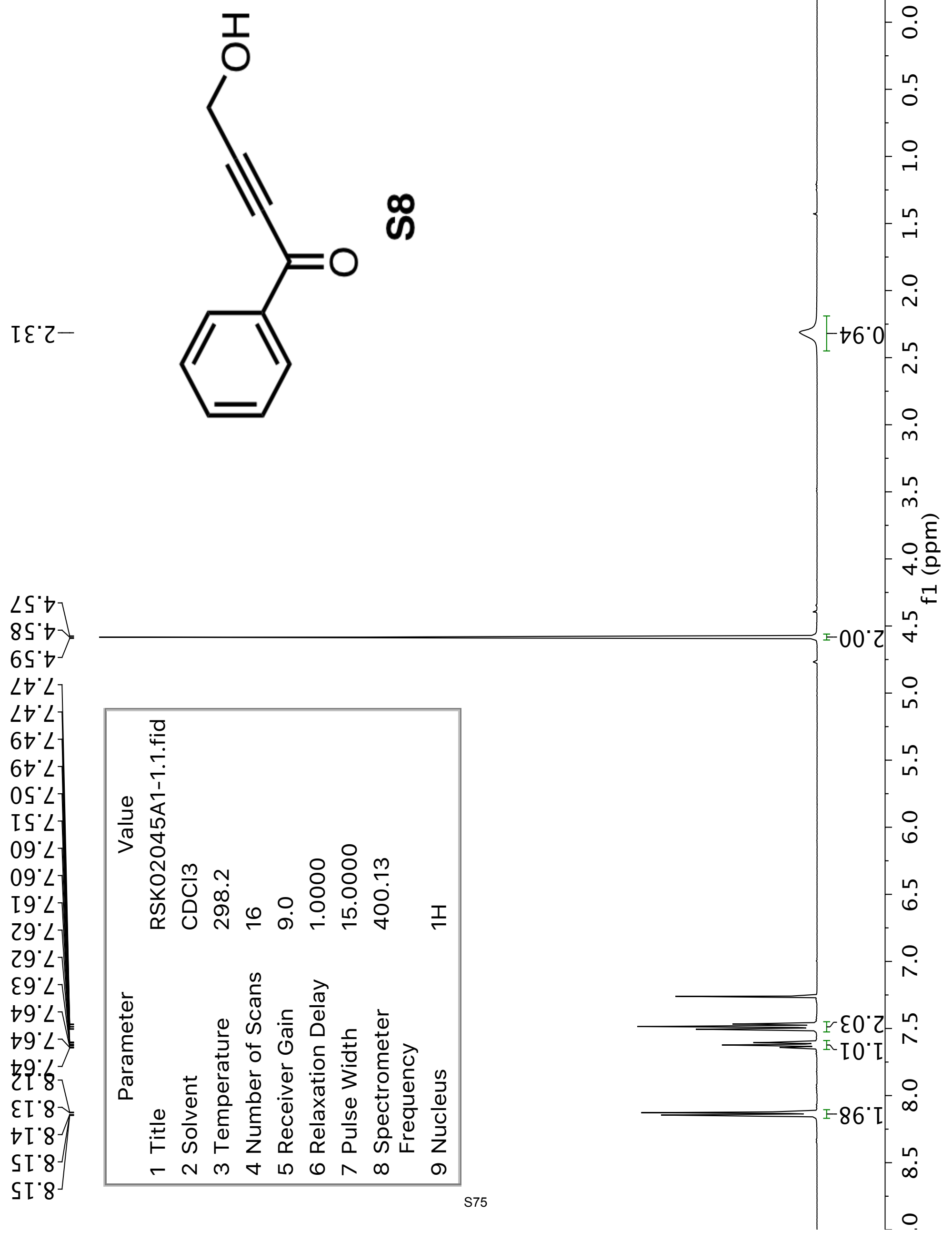


8 I'IS-

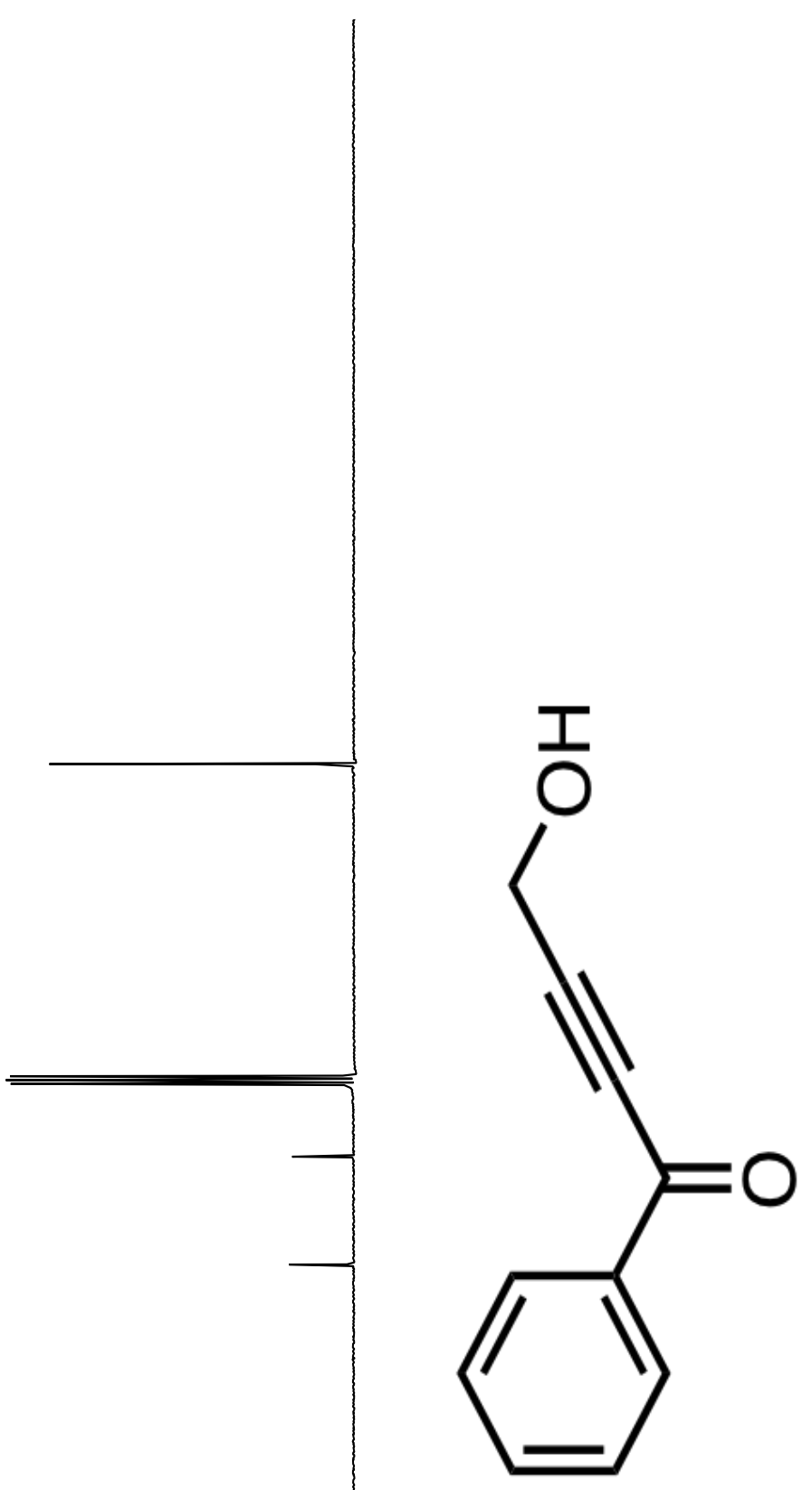

9ฑ $\varepsilon 8-$

2E: $26-$

6L82I $65^{\circ} \nabla \varepsilon \mathrm{I}-$

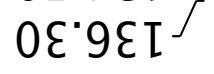

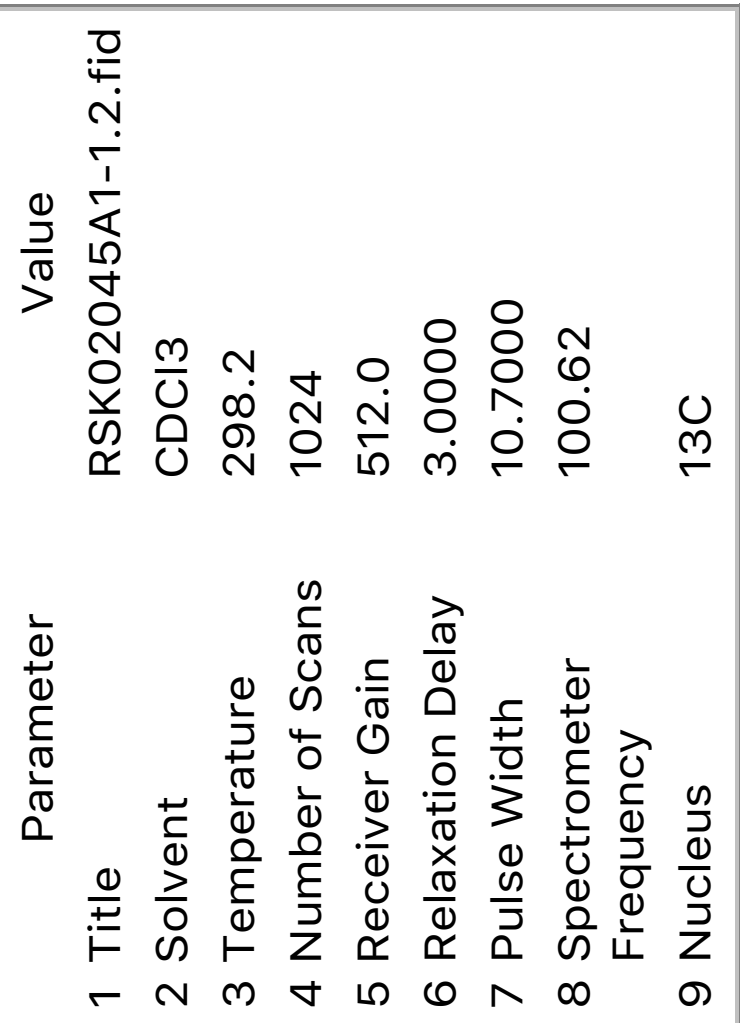




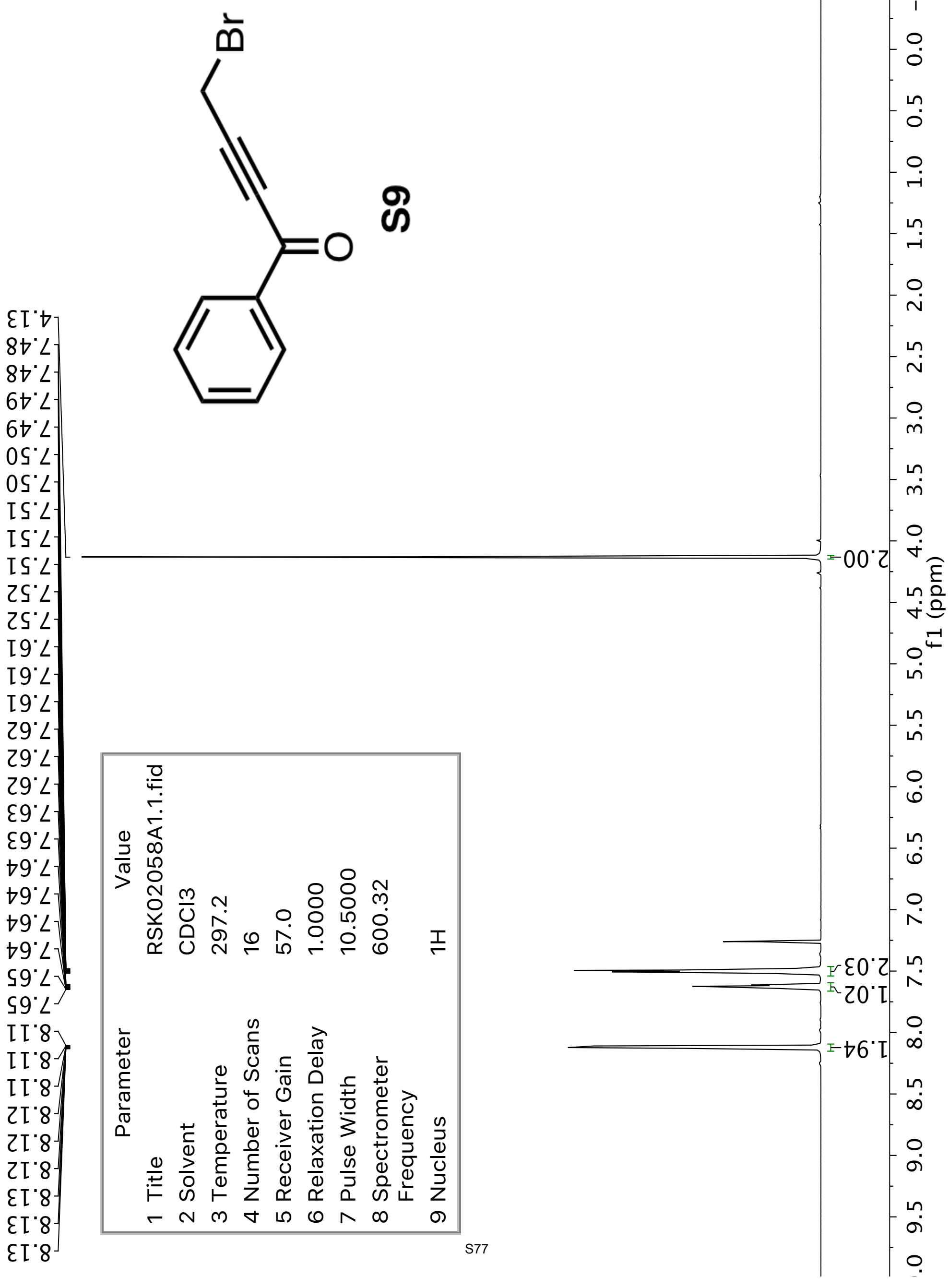



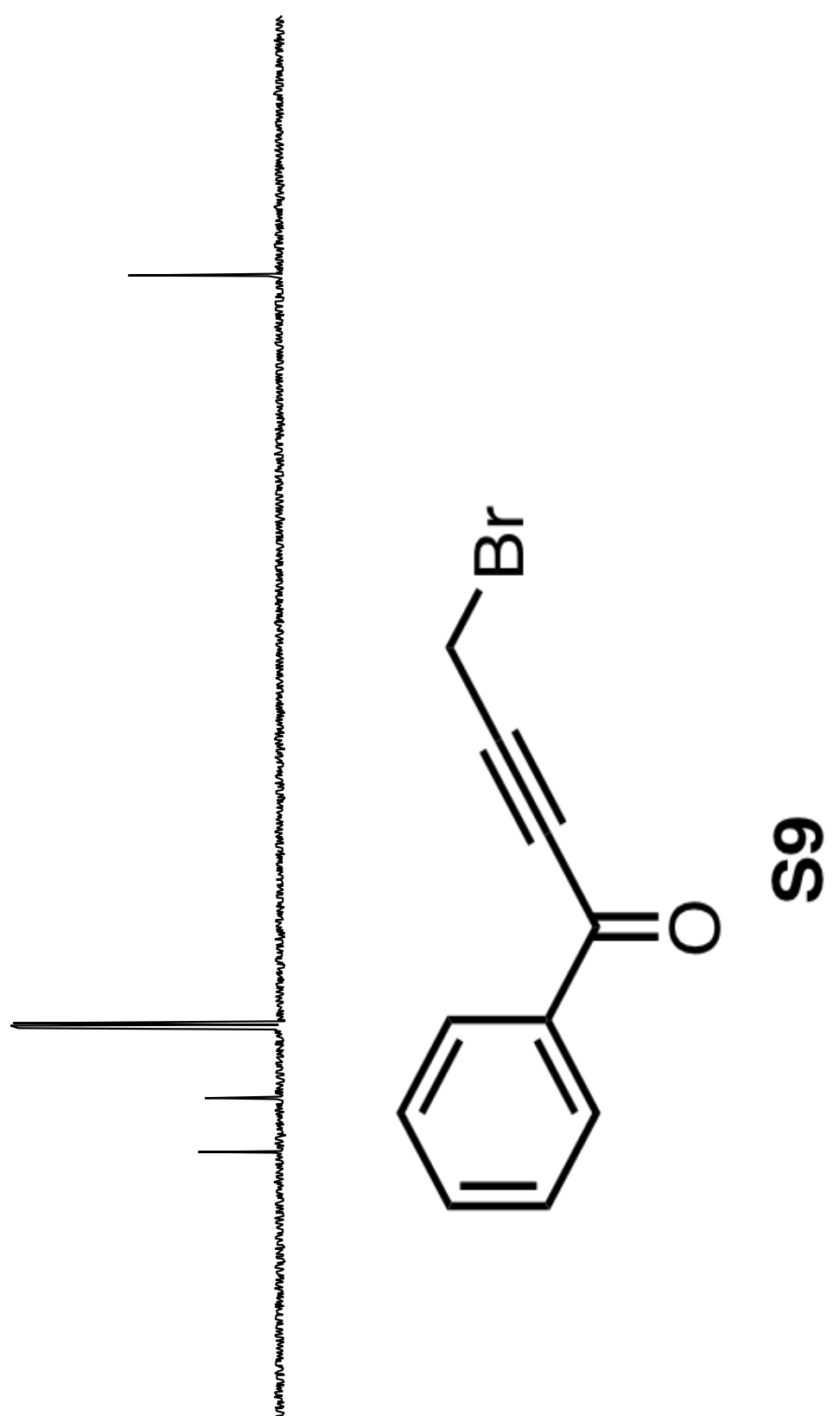

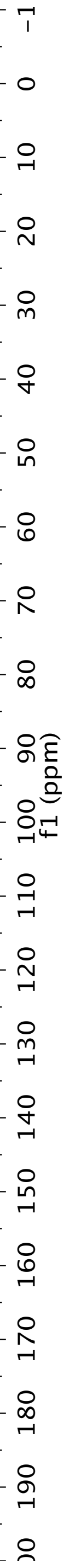


9I' $\mathrm{LI}^{\prime}[]$ $8 \mathrm{I}^{\circ} \mathrm{L}-\mathrm{J}$ 6['] $\varepsilon\left[{ }^{\prime} Z\right.$ $\nabla\left[{ }^{\prime} z\right]$ $t[2]$ SI' 2 SI' 2 9I' 2 9I' 2 $\angle I ' Z$ $\angle I ' Z-$ $8 \mathrm{I}^{\circ} \mathrm{z}$ $08^{\circ} \varepsilon-$ $\varepsilon L^{\prime} \dagger$ $\varepsilon \angle ' t$ $88^{\circ} 9$ $88^{\circ} 9$ $68^{\circ} 9$ $68^{\circ} 9$ $68^{\prime} 9$ $06^{\circ} 9$ $06^{\circ} 9$ 06.9 $\angle 6^{\circ} 9$ $\angle 6^{\circ} 9$ $\angle 6^{\circ} 9$ $\angle 6^{\circ} 9$ $70^{\circ} \mathrm{L}$ $70^{\circ} L$ $70^{\circ} L$ $50^{\circ} \angle$ $50^{\circ} L$ $\mathrm{SO}^{\circ} \mathrm{L}$ I $Z^{\circ} L$ $\varepsilon Z^{\circ} L$ $\nabla Z^{\prime} L$
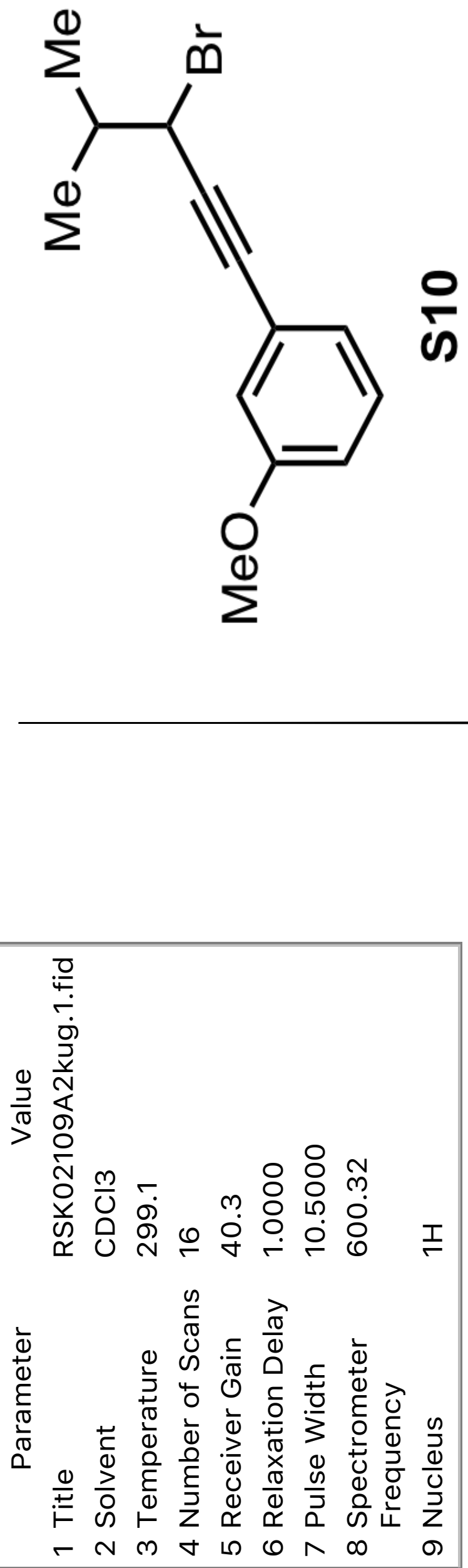


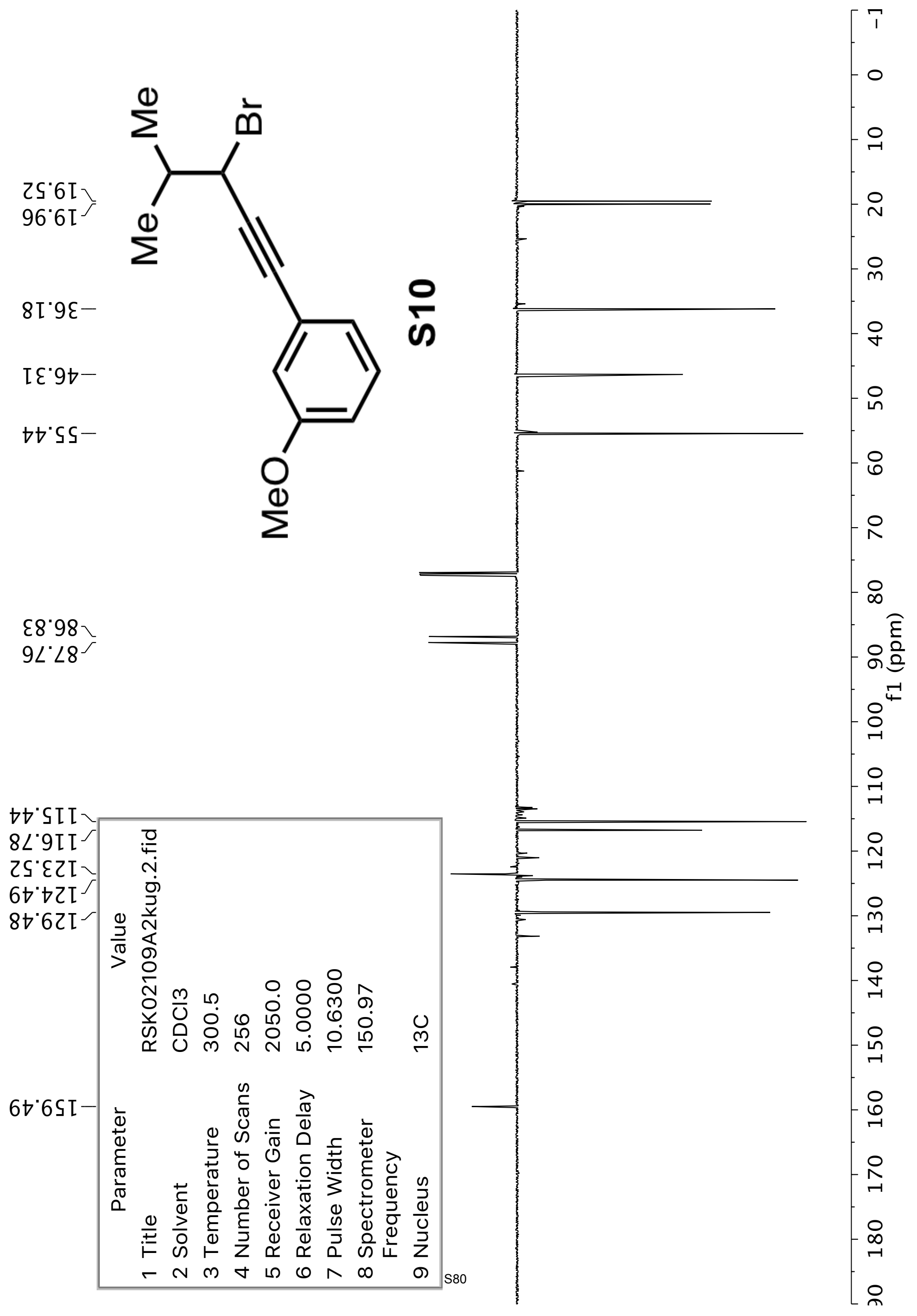




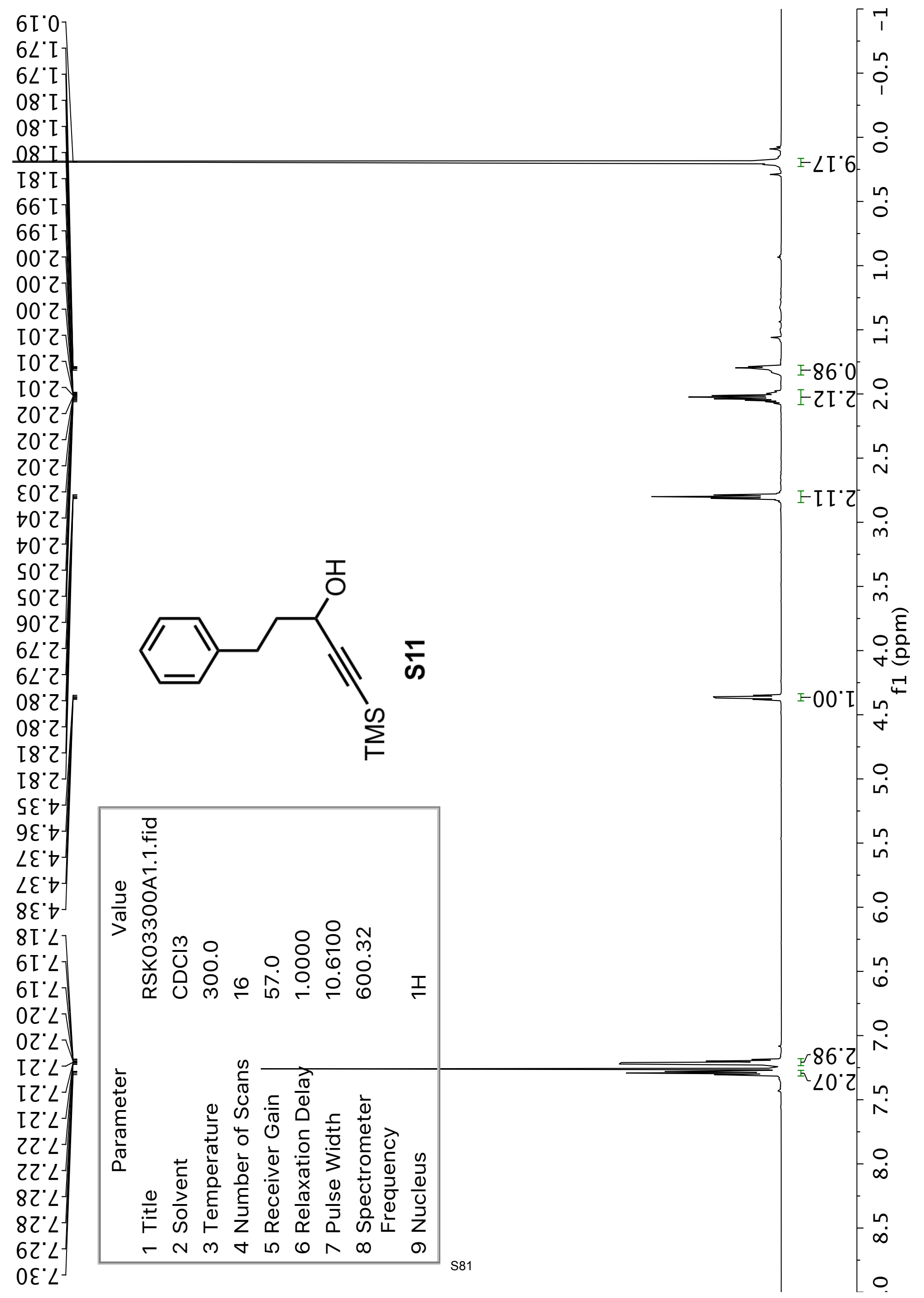


†0 0

$9 S^{\circ} I \varepsilon-$

$\angle \varepsilon^{\prime} 6 \varepsilon-$

५ร'29-

$\angle 0^{\circ} 06-$

29.90 I-

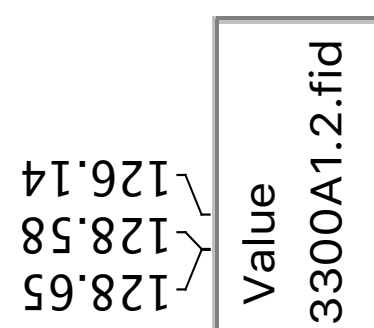

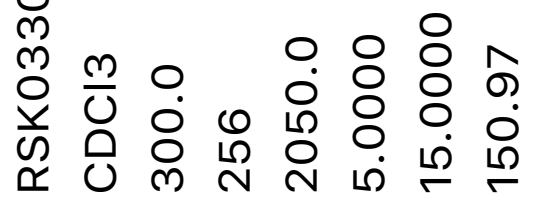

SカItI-

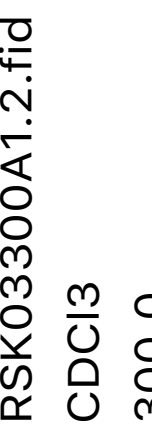

章

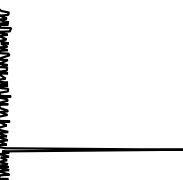

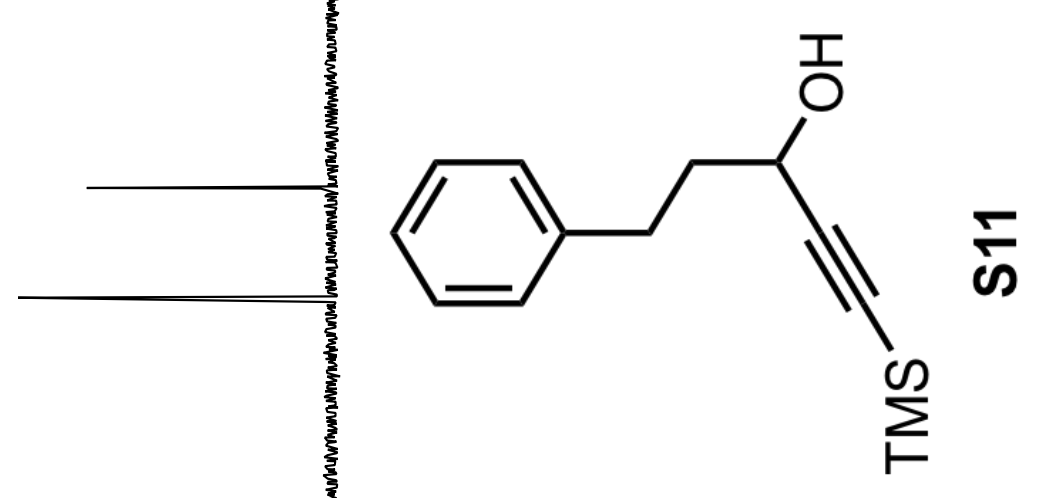

$-\stackrel{ }{N}$

임

$-\stackrel{+}{+}$

은

$-0$

웅

$\infty$

๑응

$\stackrel{\circ}{+1}^{-1}$

음

$85^{\circ} 8 \mathrm{LI}-$

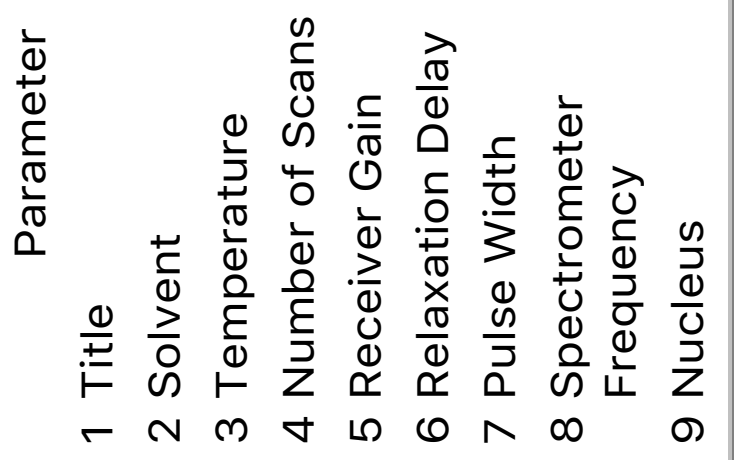
59.8ZI-

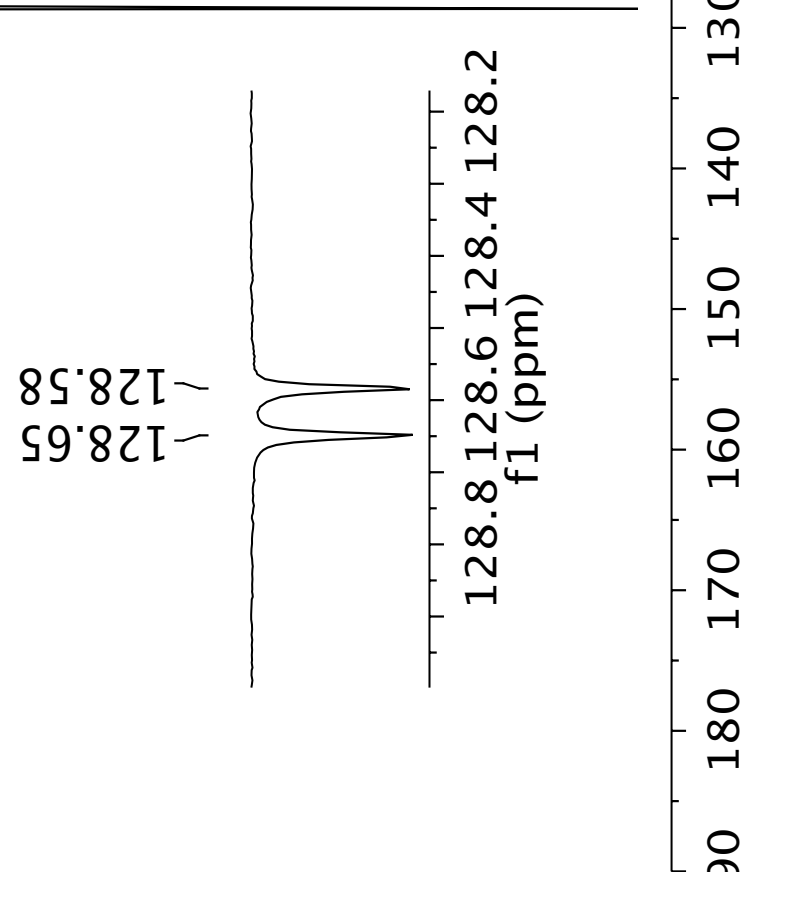




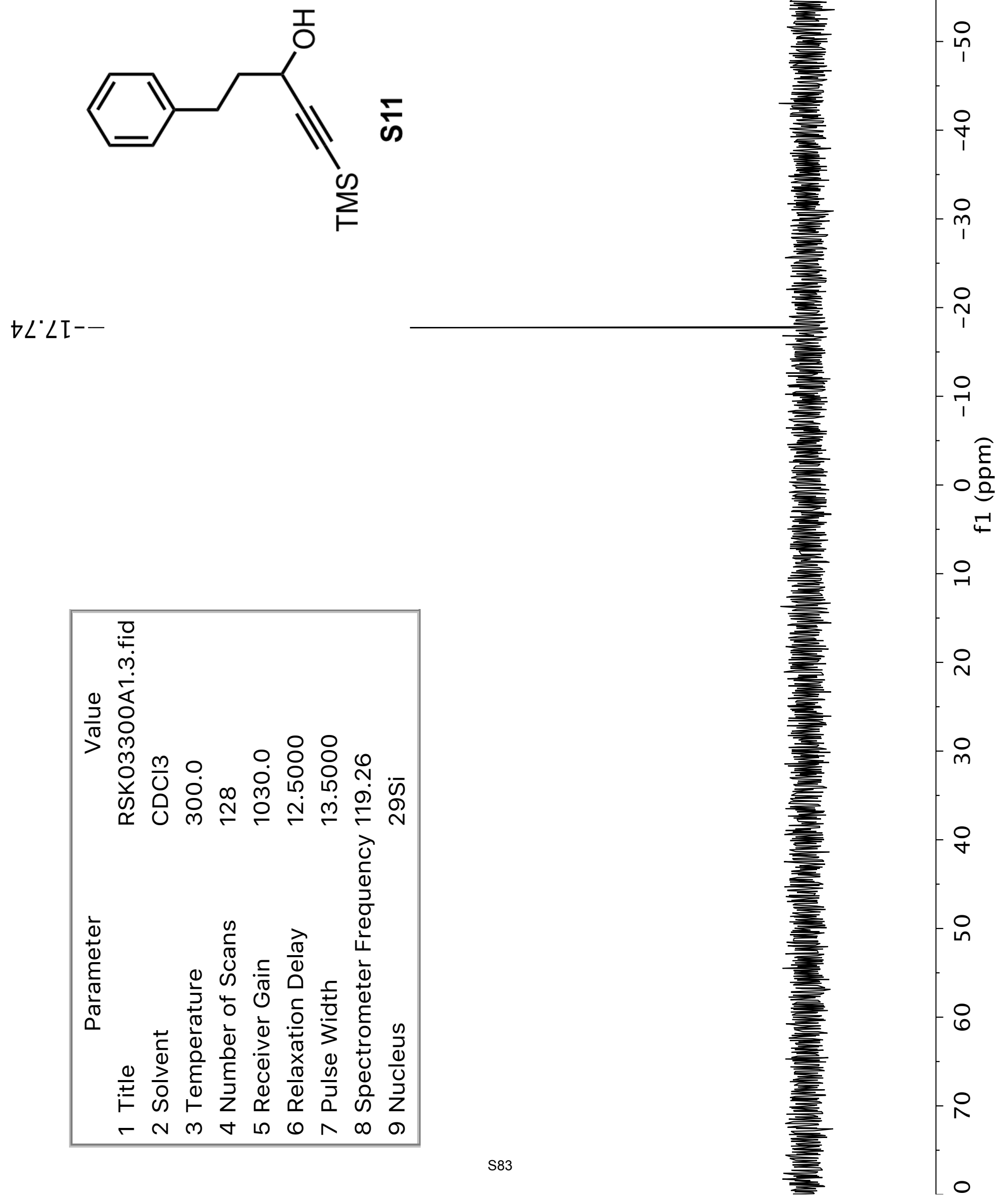




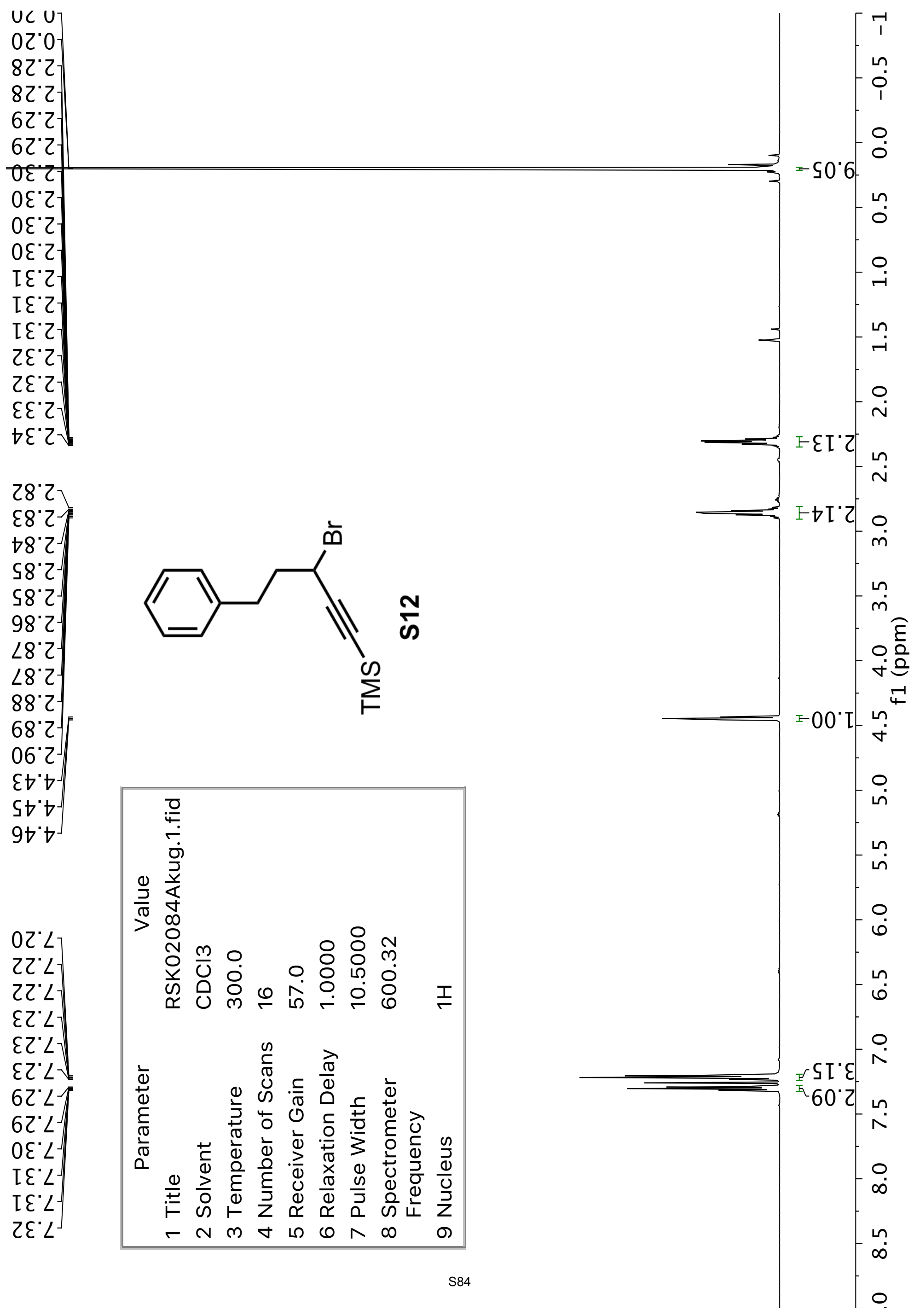


$60^{\circ} 0^{--}$

$\angle 8^{\circ} \varepsilon \varepsilon-$

$0 Z^{\circ} \angle \varepsilon^{-}$

$S \angle I t-$

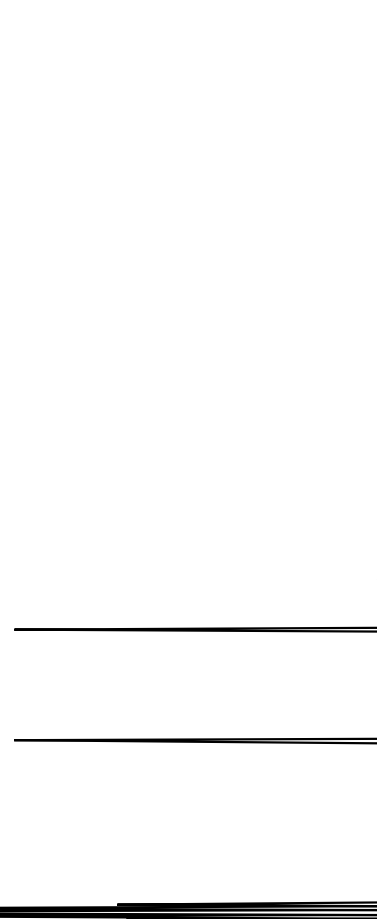

68'26-

$90^{\circ} \sqcup 0 \mathrm{I}-$

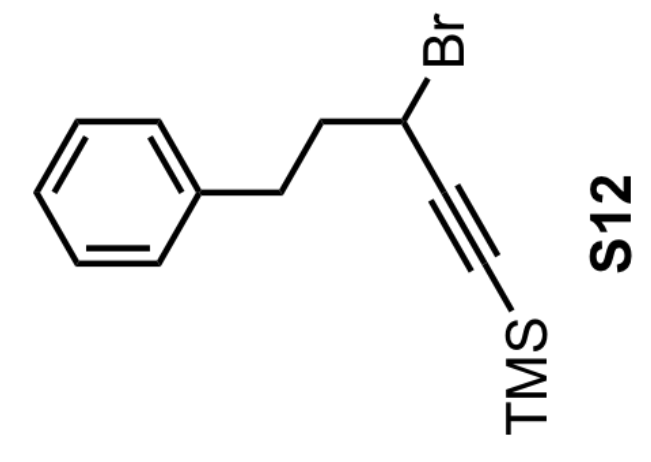

-

$\infty$

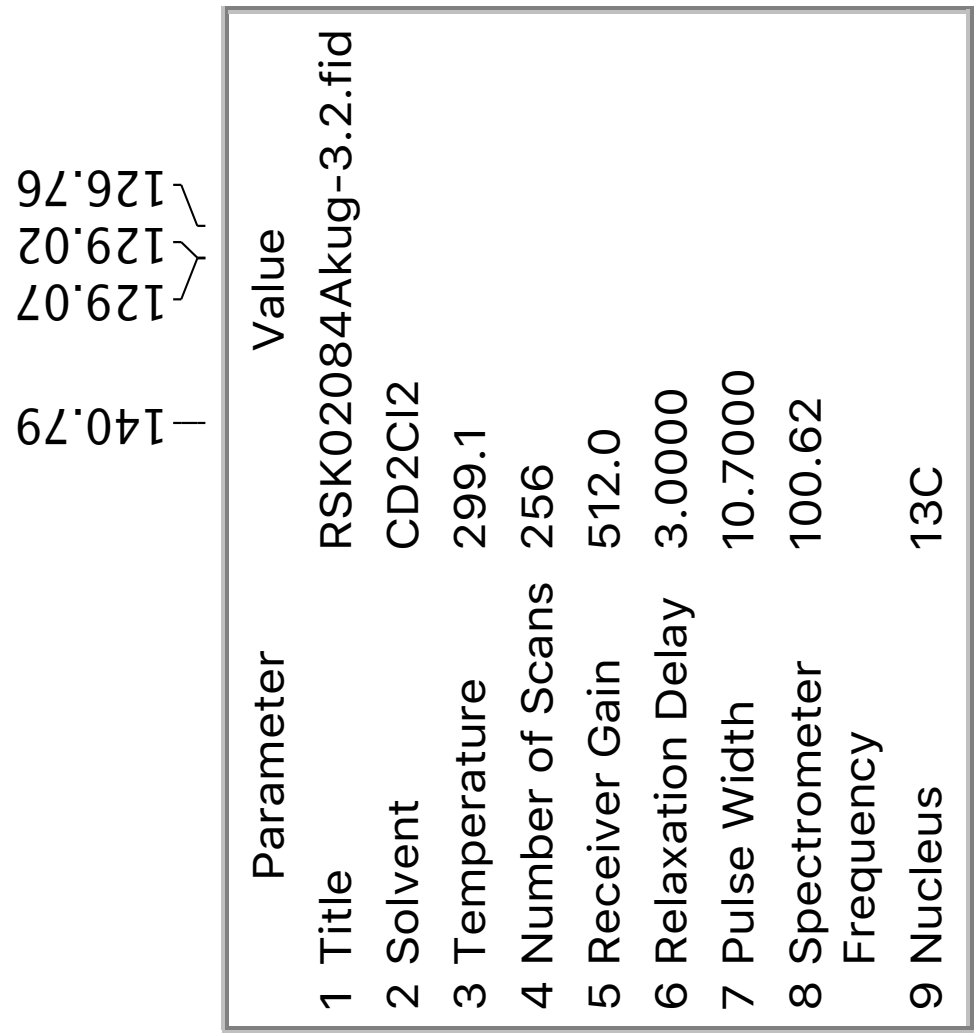

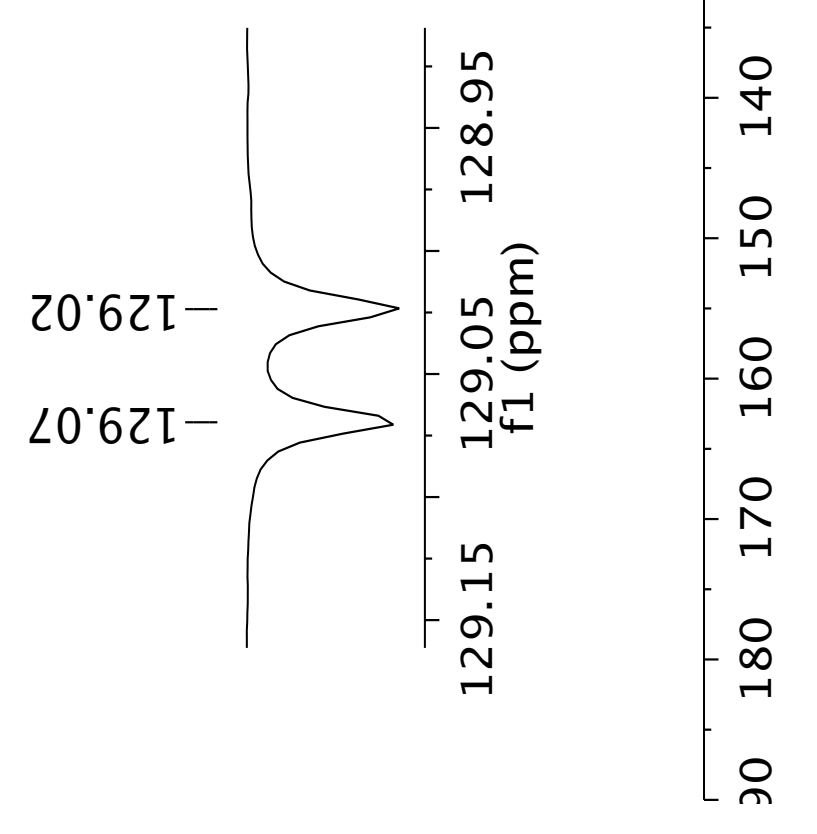



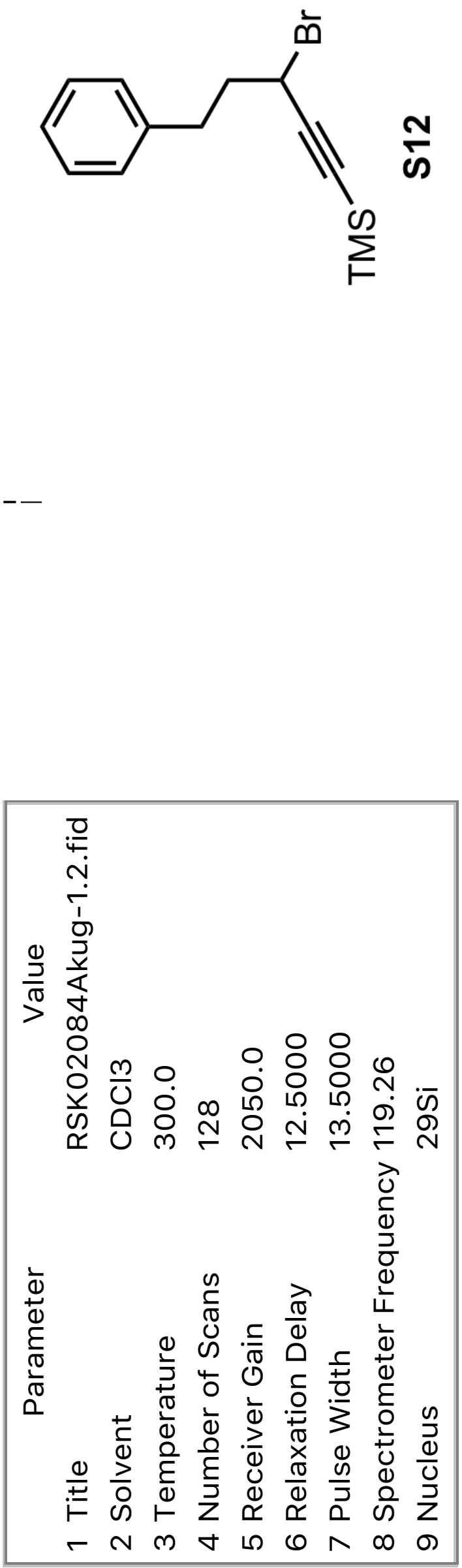


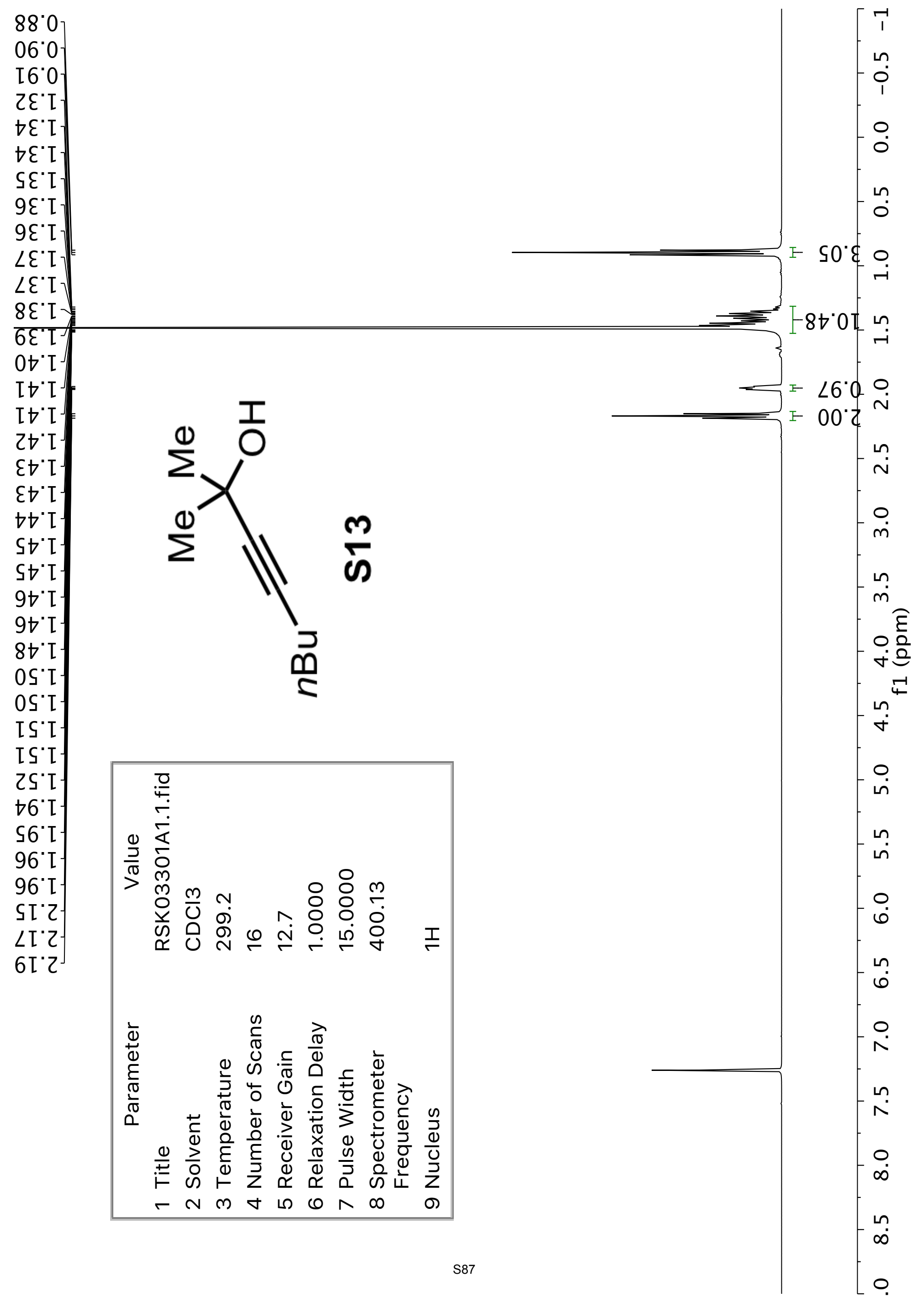


$S L^{\prime} \varepsilon I-$

$8 \varepsilon^{\circ} 8 \mathrm{I}$ -

†० $22-$

$68^{\circ} 0 \varepsilon>$

$88^{\circ} \mathrm{IE}^{\mathcal{J}}$

てザง9-

$0 L^{\prime} 28-$

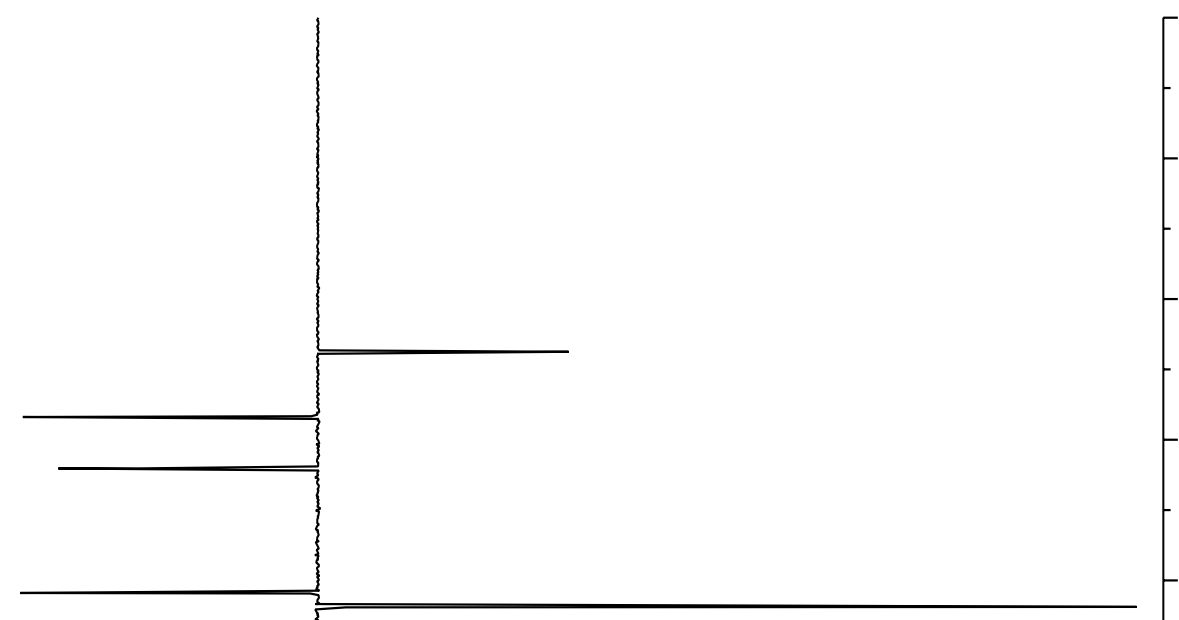

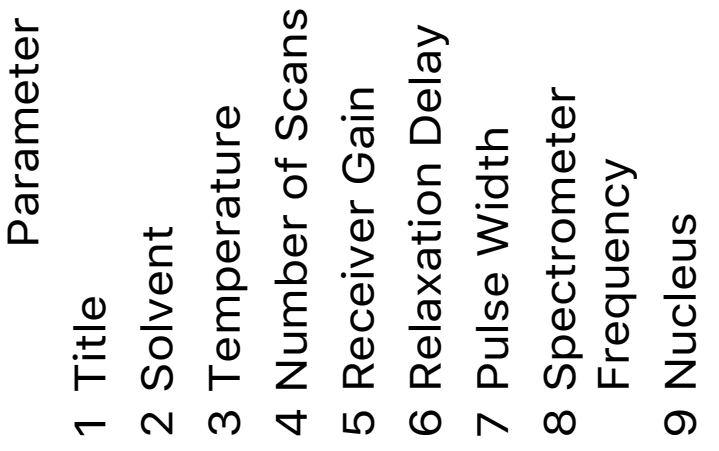

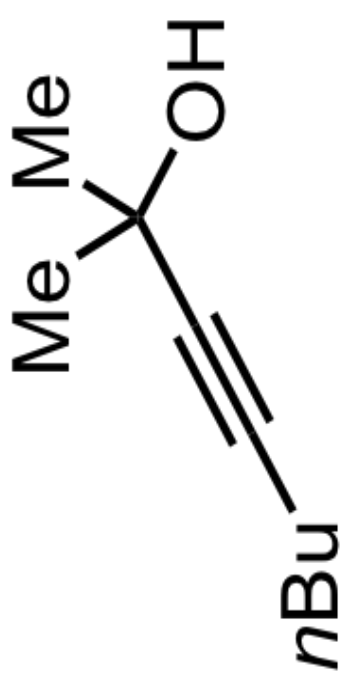

운

ำ

웅

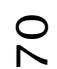

$\infty$

으을

$8^{-1}$

억
억

$\stackrel{ }{m}$

옥

옥

8

$\stackrel{-1}{\circ}$

$\stackrel{\infty}{-\infty}$ 


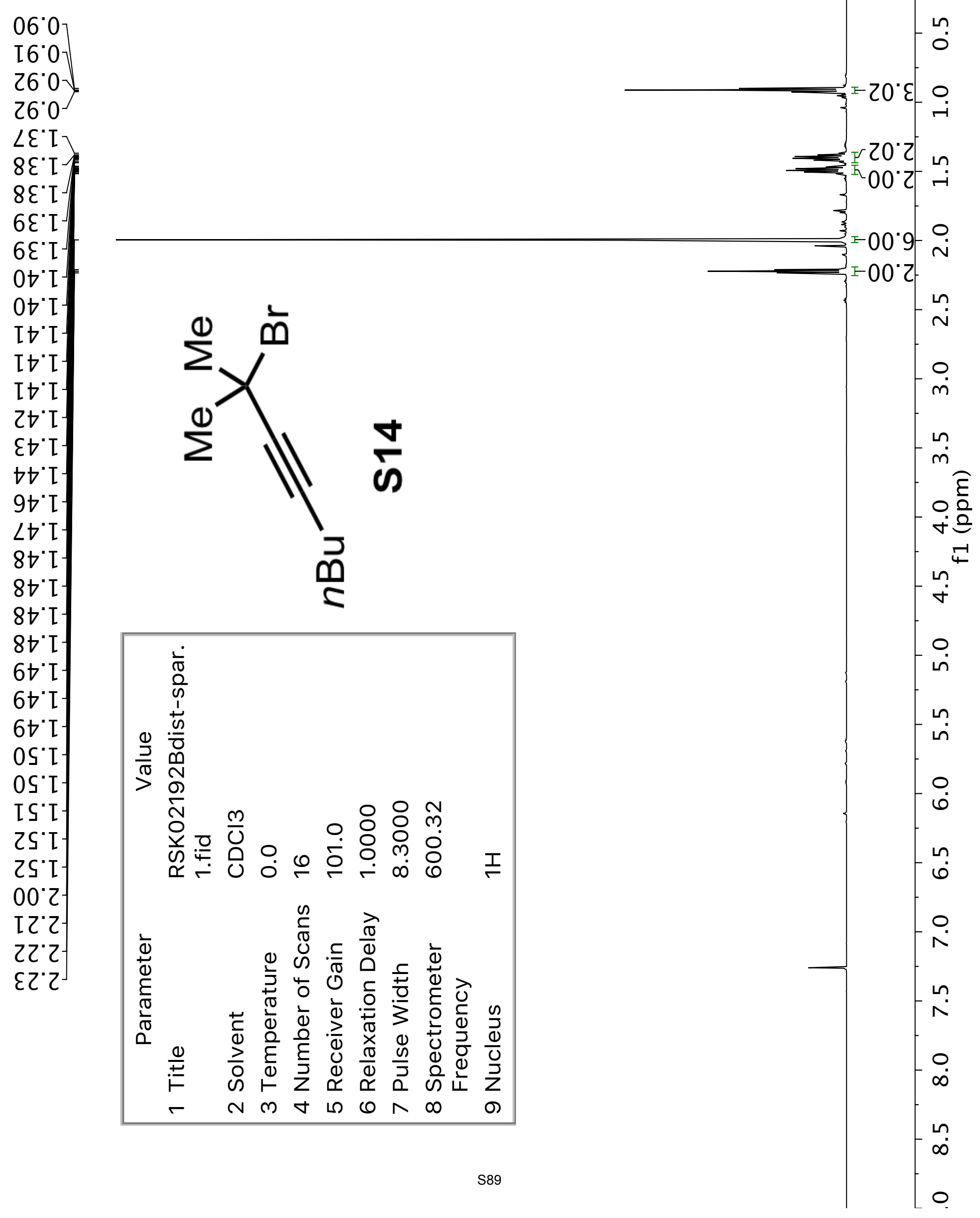


LL'EL-

69.8I -

$90.22-$

ع $9^{\circ} 0 \varepsilon-$

L6.9ع-

$9 S^{\circ} 0 \mathrm{~s}-$

$8 \angle{ }^{\circ}+8$

$02^{\circ} 98^{\prime}$
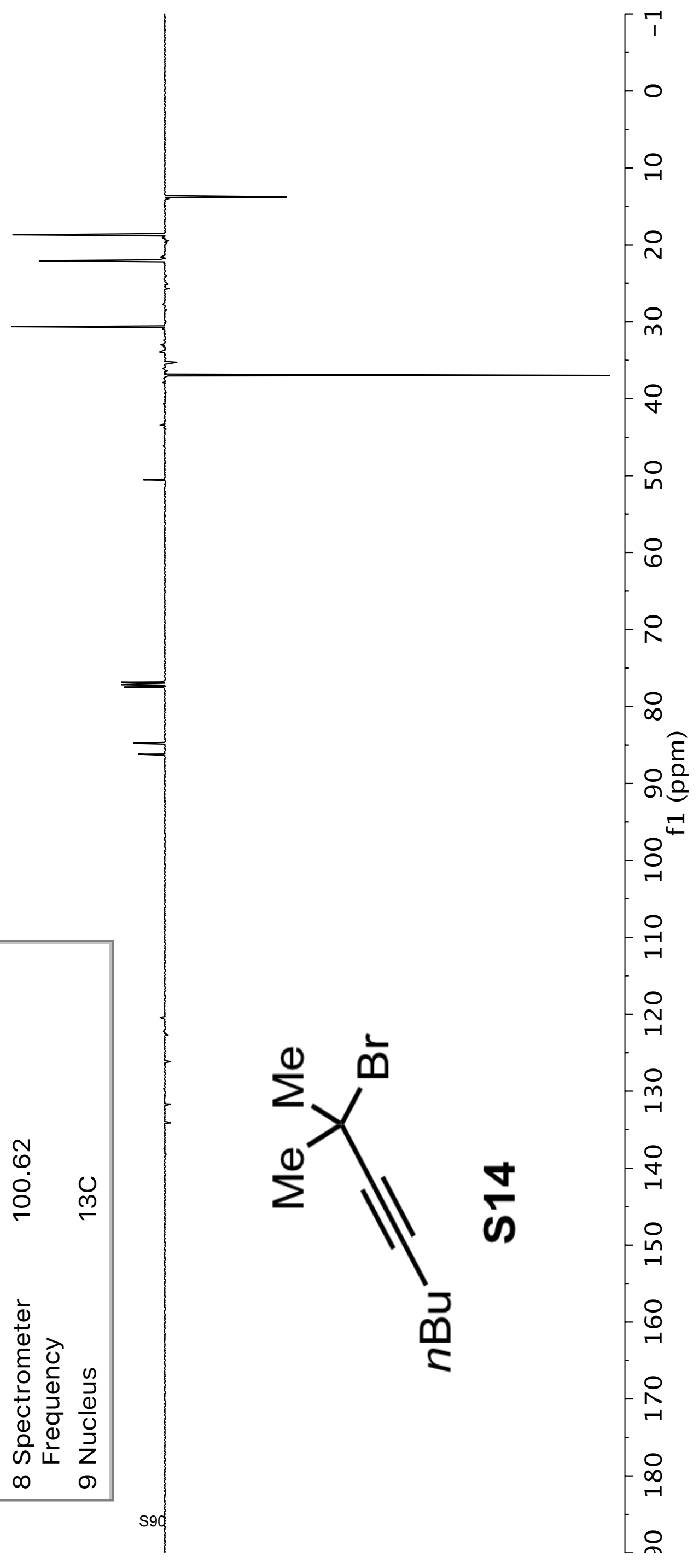

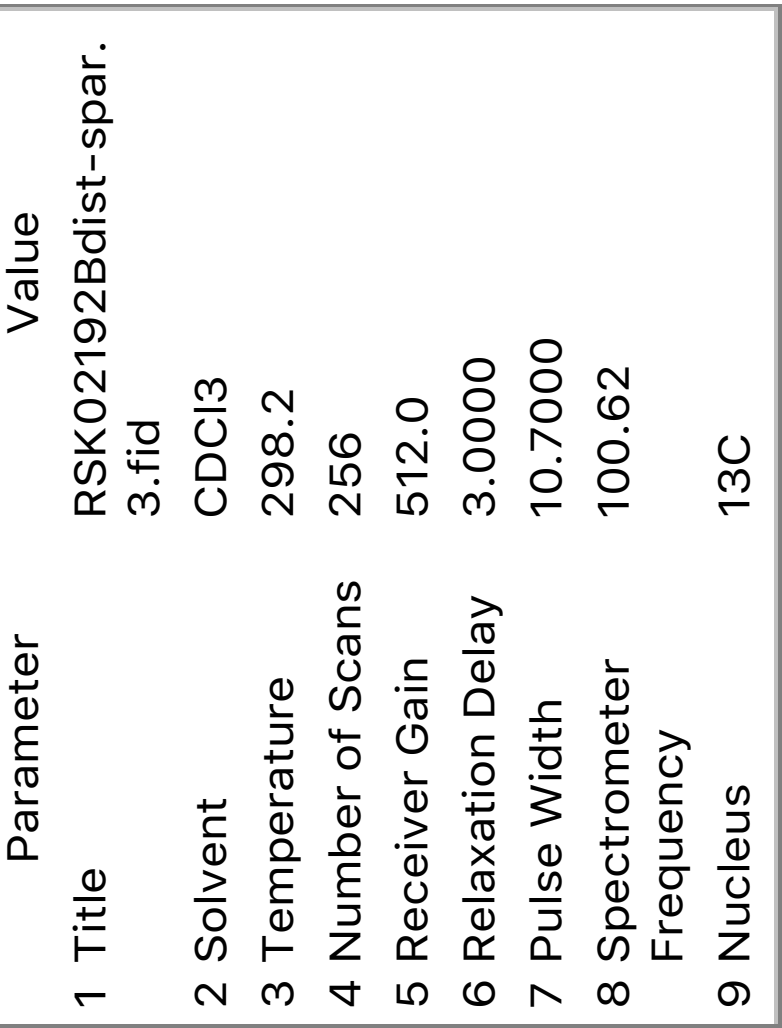

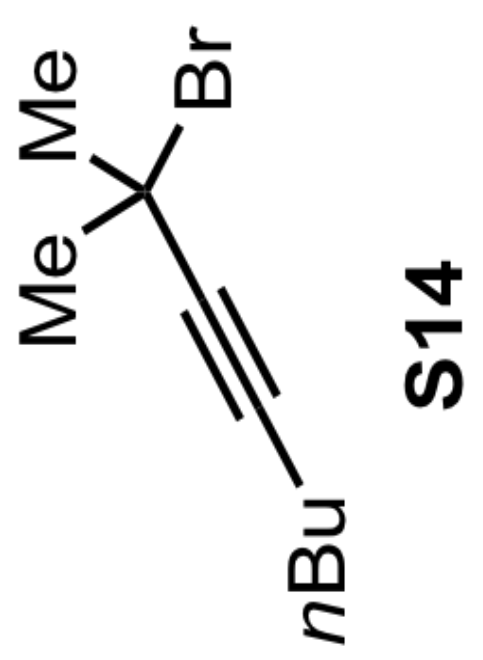




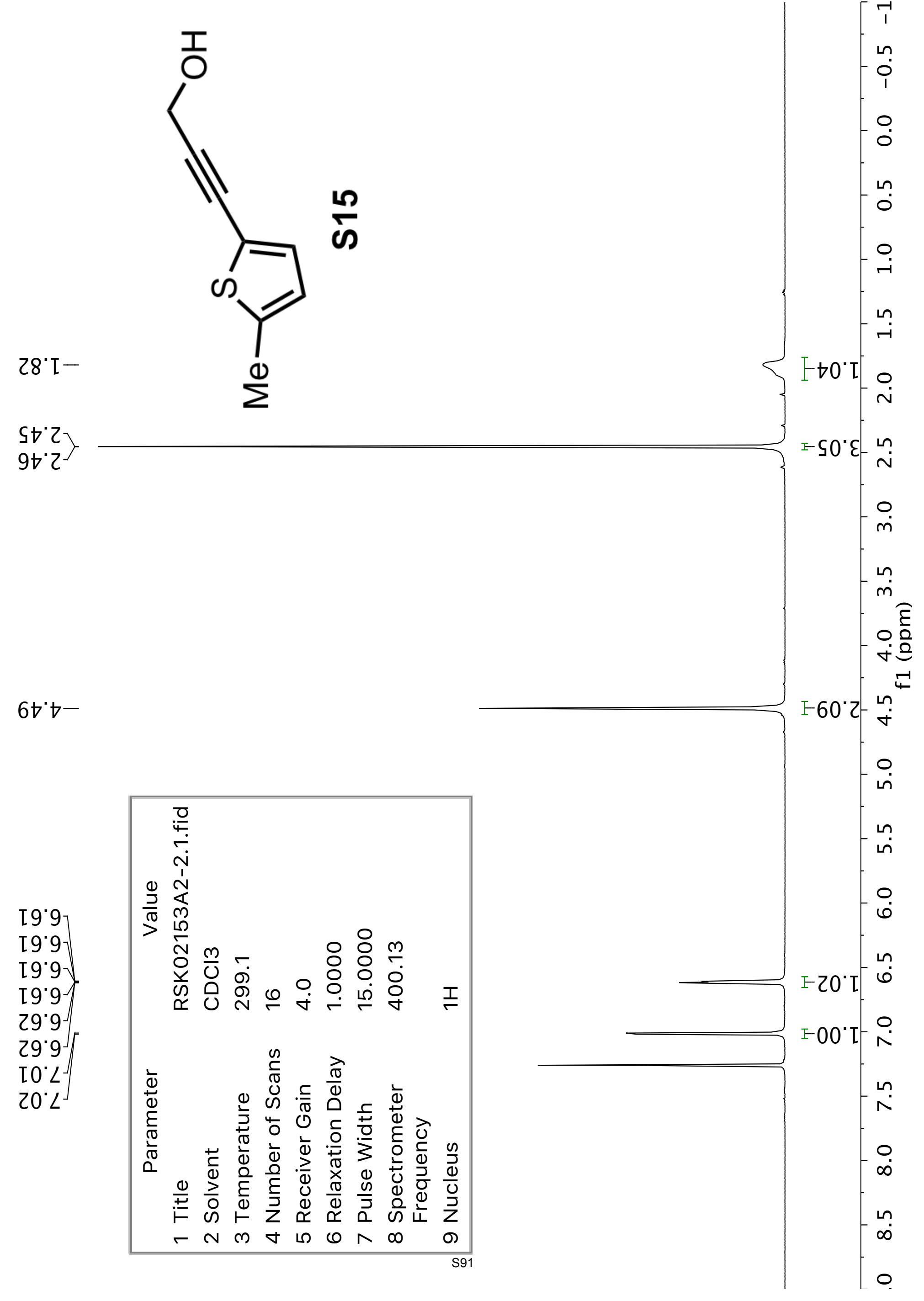


IS'SI-

06. IS-

[9.6L-

ع†'06-

$86^{\circ} 6$ I I $^{\varsigma}$ $\angle \varepsilon^{\circ} \varsigma \mathrm{SI}^{-}$ Z8. ZE I

$9 \nabla^{\prime} Z \forall I-$

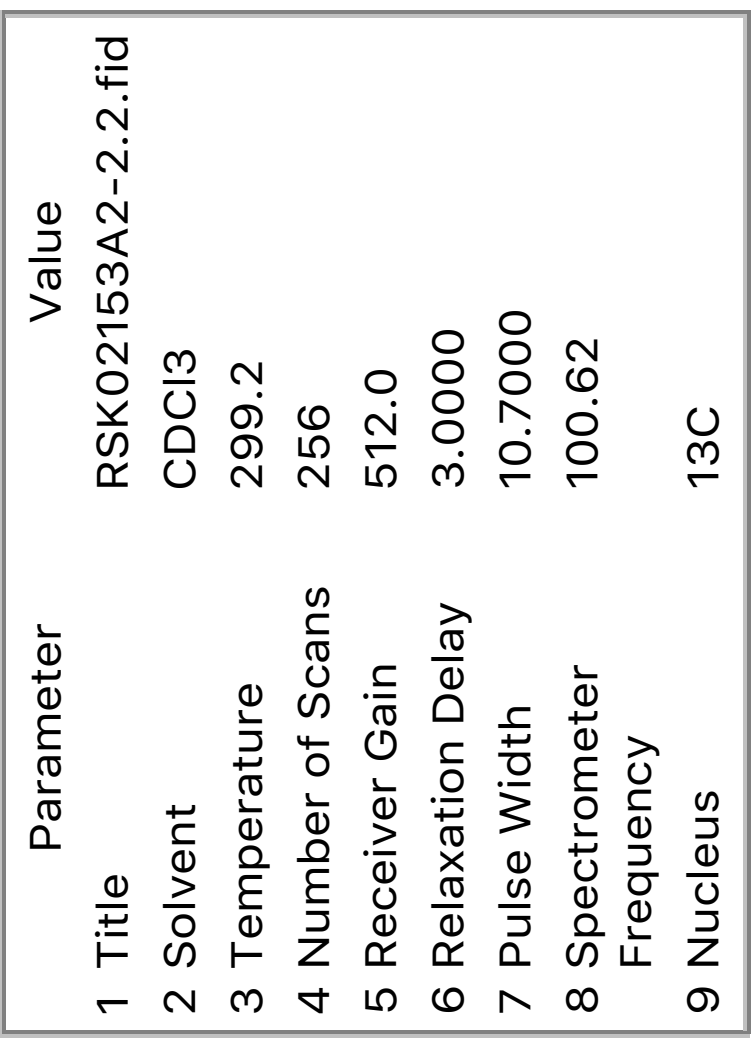

工

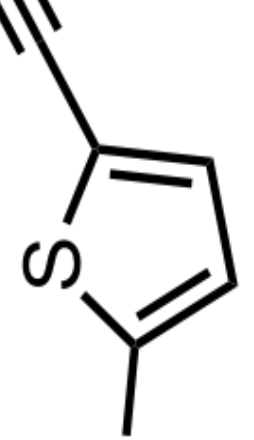

$\stackrel{0}{\Sigma}$ 


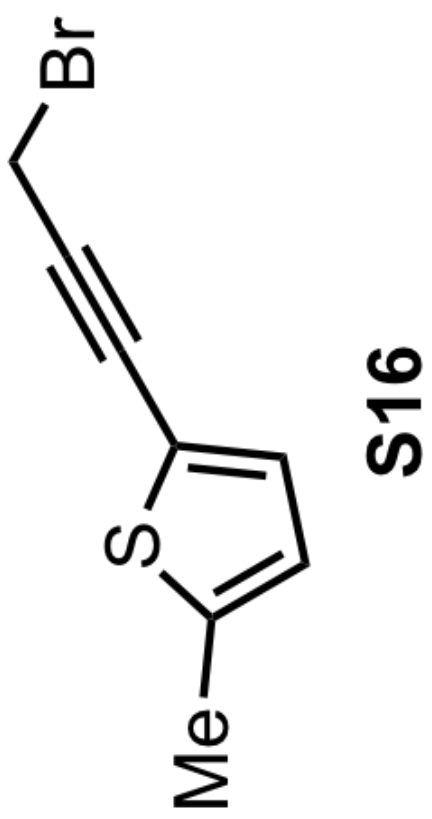

$9 \nabla^{*} 2-$

$8 I^{\circ} b-$

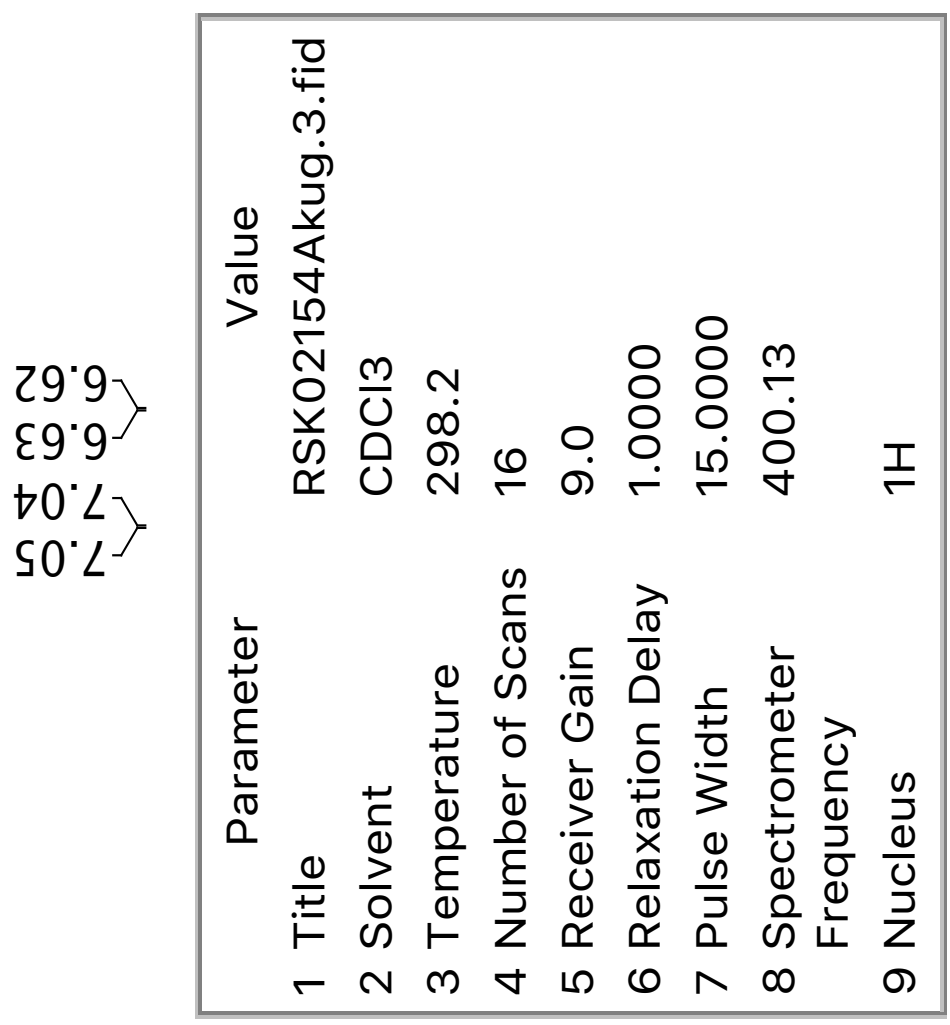


$8 S^{\circ} S^{\prime}$
$\angle 8^{\circ} \mathrm{SI}^{\prime}$

[8.08-

IS $\angle 8-$

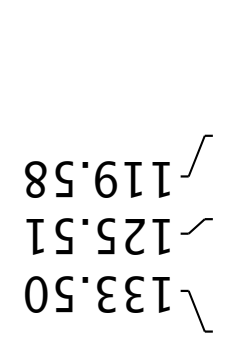



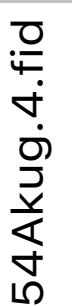

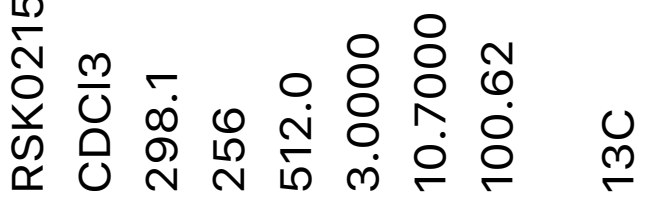

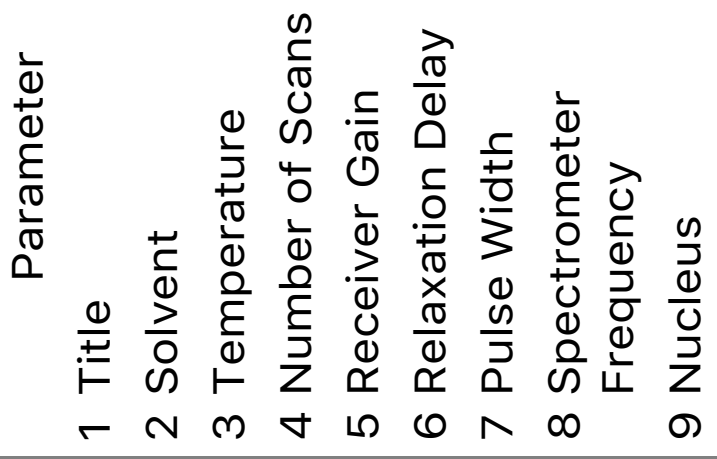

ต̀

웅

우

웅

1

$=$

(1)

$8 I^{*} \varepsilon † T-$

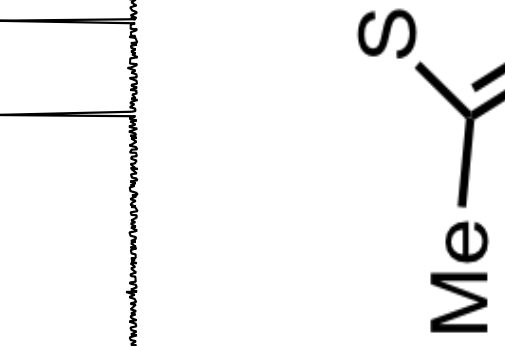

$\infty$

응ํㄹ

$\stackrel{\circ}{+1}^{-1}$

윽

$\stackrel{ }{\sim}$

$\stackrel{ }{m}$

암

음

$\stackrel{0}{6}$

옥

$\stackrel{\infty}{-1}$ 


\section{$9 L^{\prime} I-$}

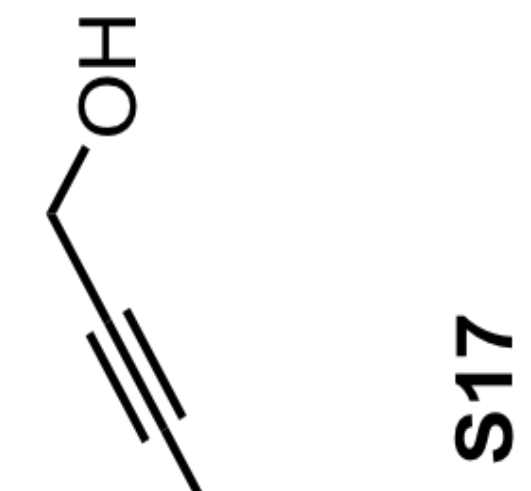

$\varepsilon S^{\circ} \nabla$ $\left.\nabla s^{\circ} b^{\prime}\right\}$

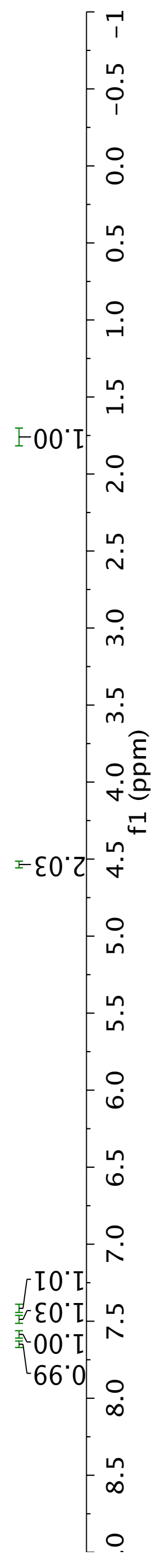




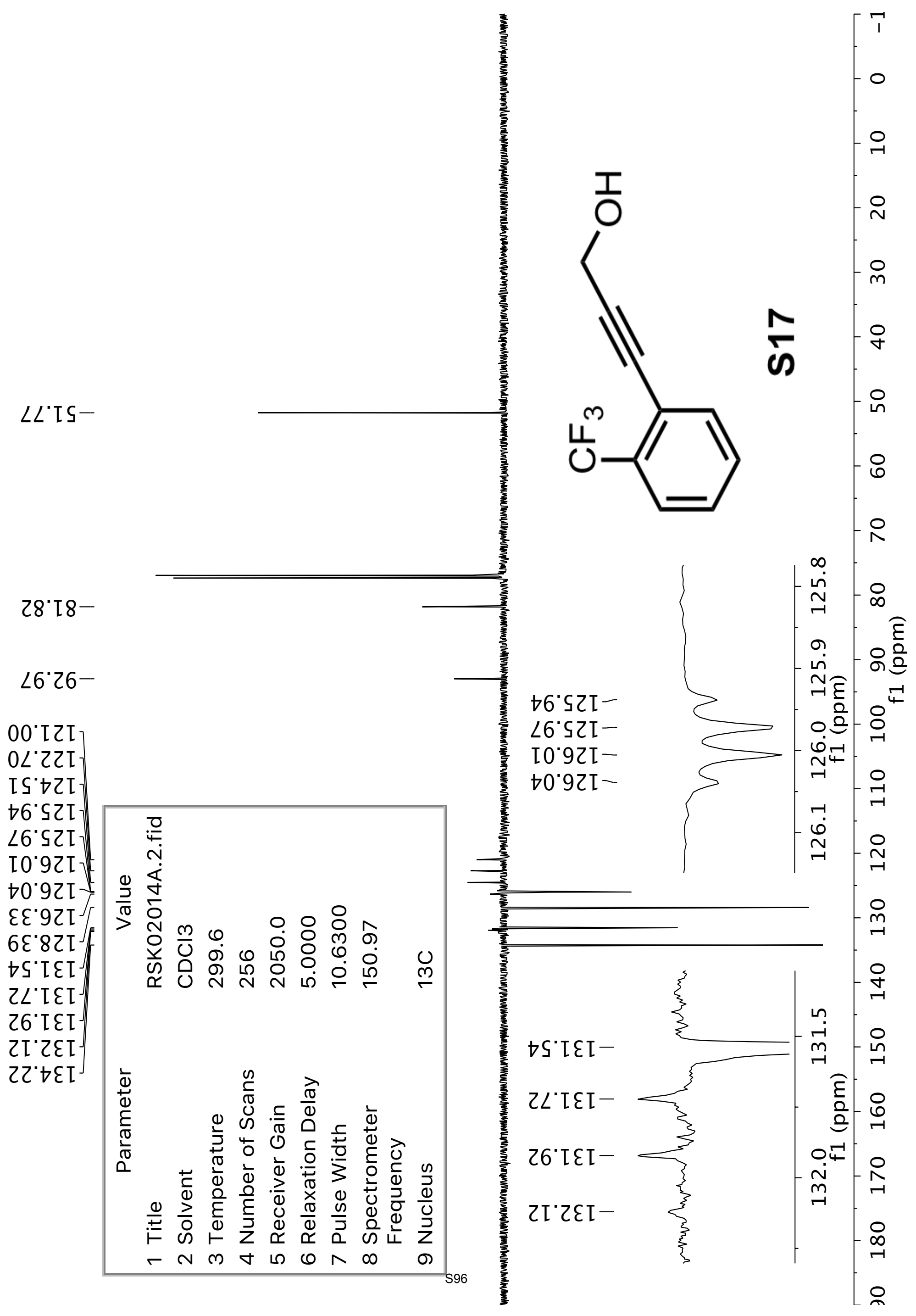




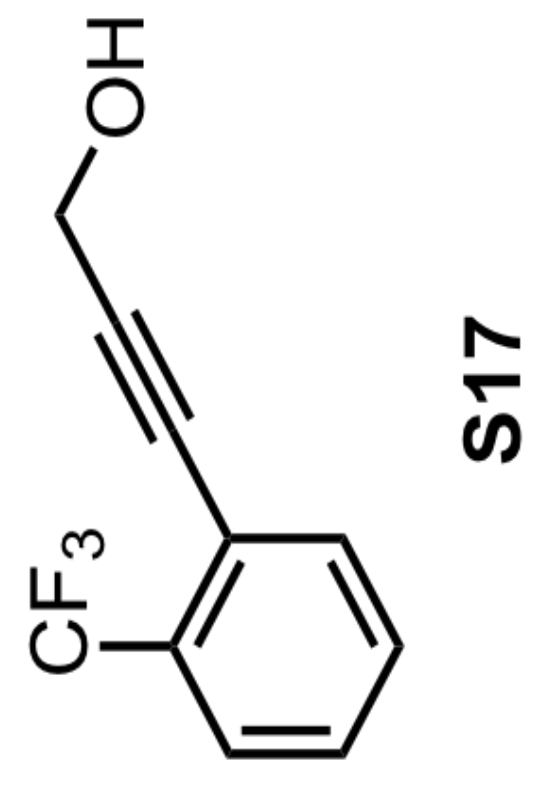



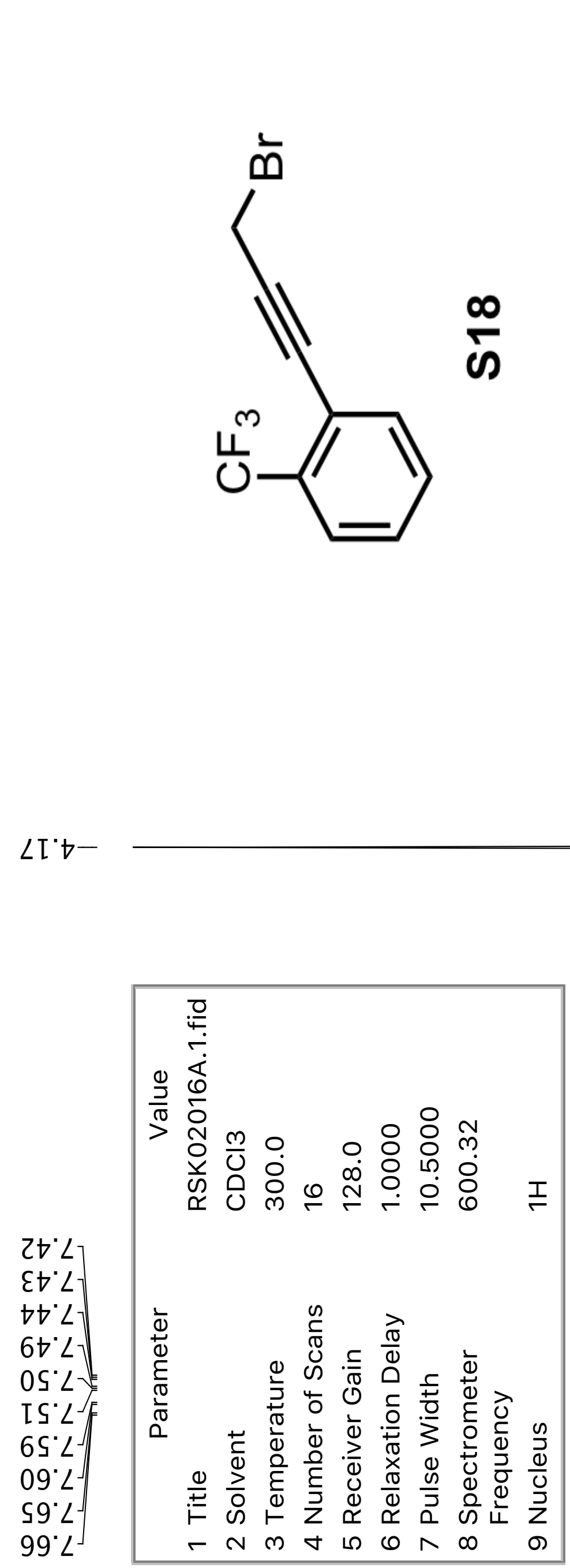


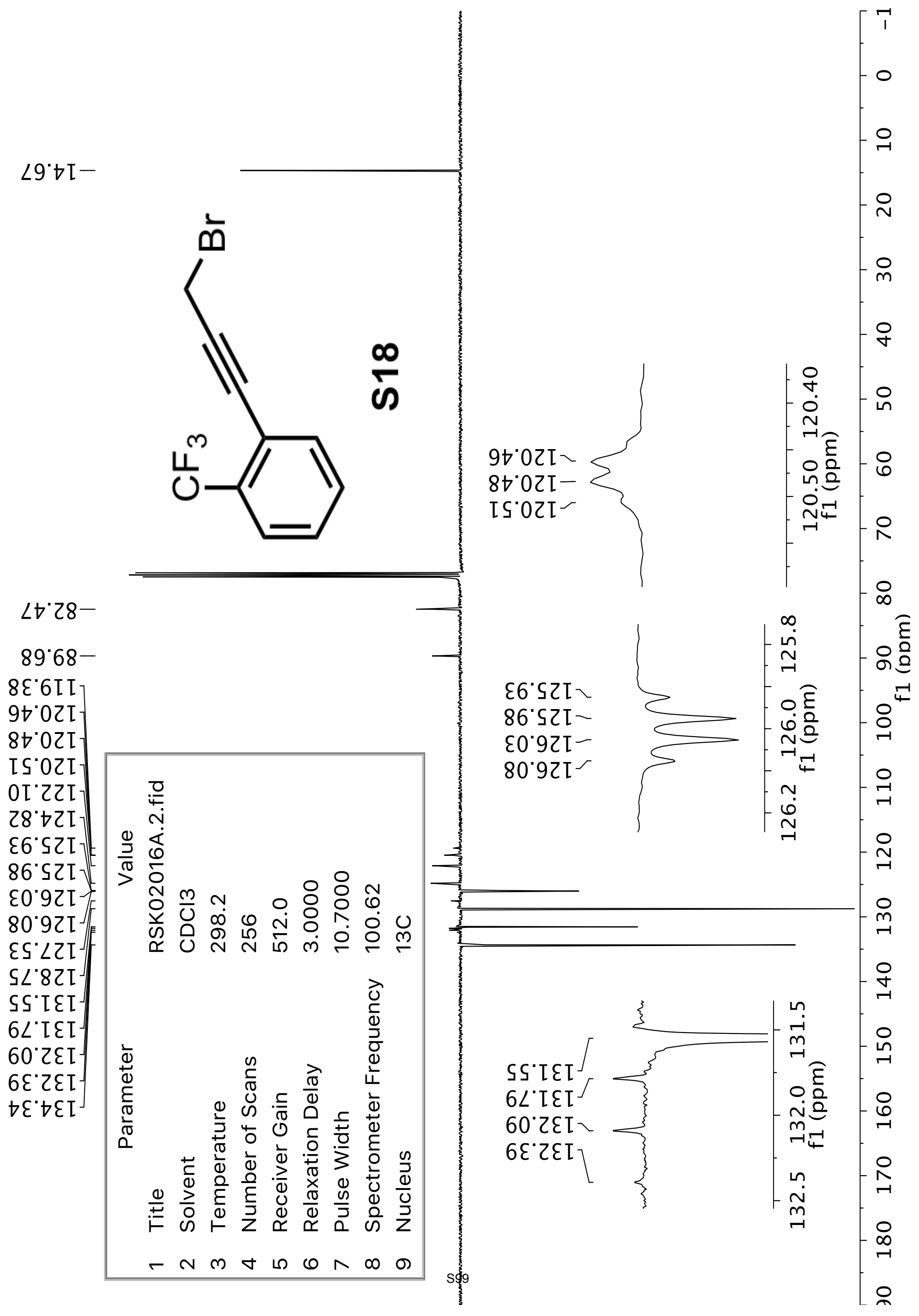




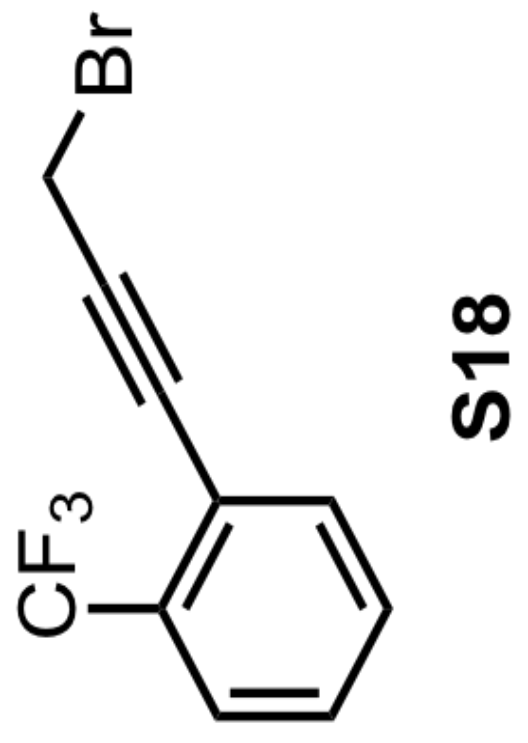




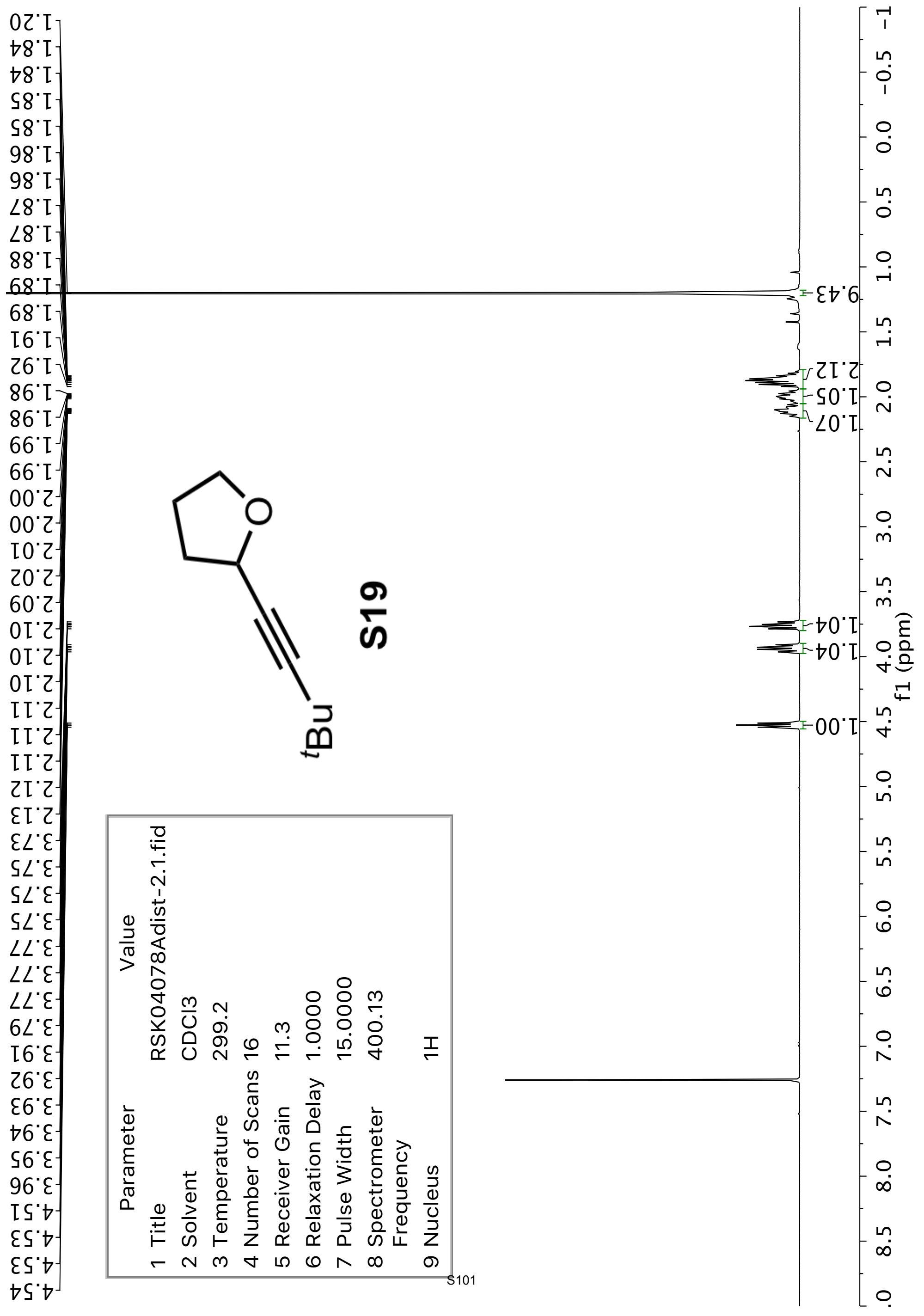


$9 t^{\circ} \varsigma 2$ 乙

$S \nabla^{\circ} \angle Z-$

$\varepsilon I^{\prime}[\varepsilon-$

$S L^{\circ} \varepsilon \varepsilon^{\digamma}$

$0 \angle \angle 9$

$9 S^{\circ} 89^{-}$

$8 Z^{\circ} 8 L-$

0S. \&6-

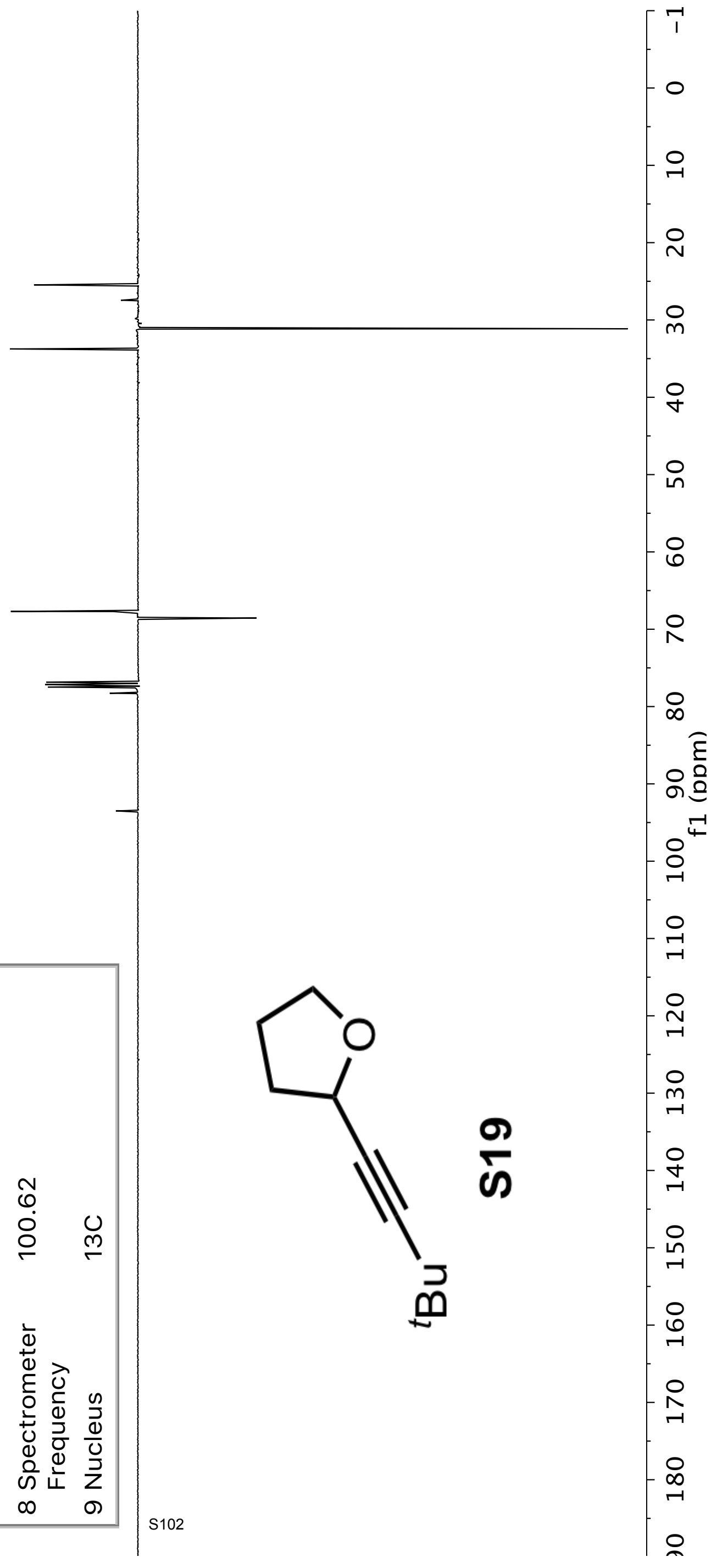




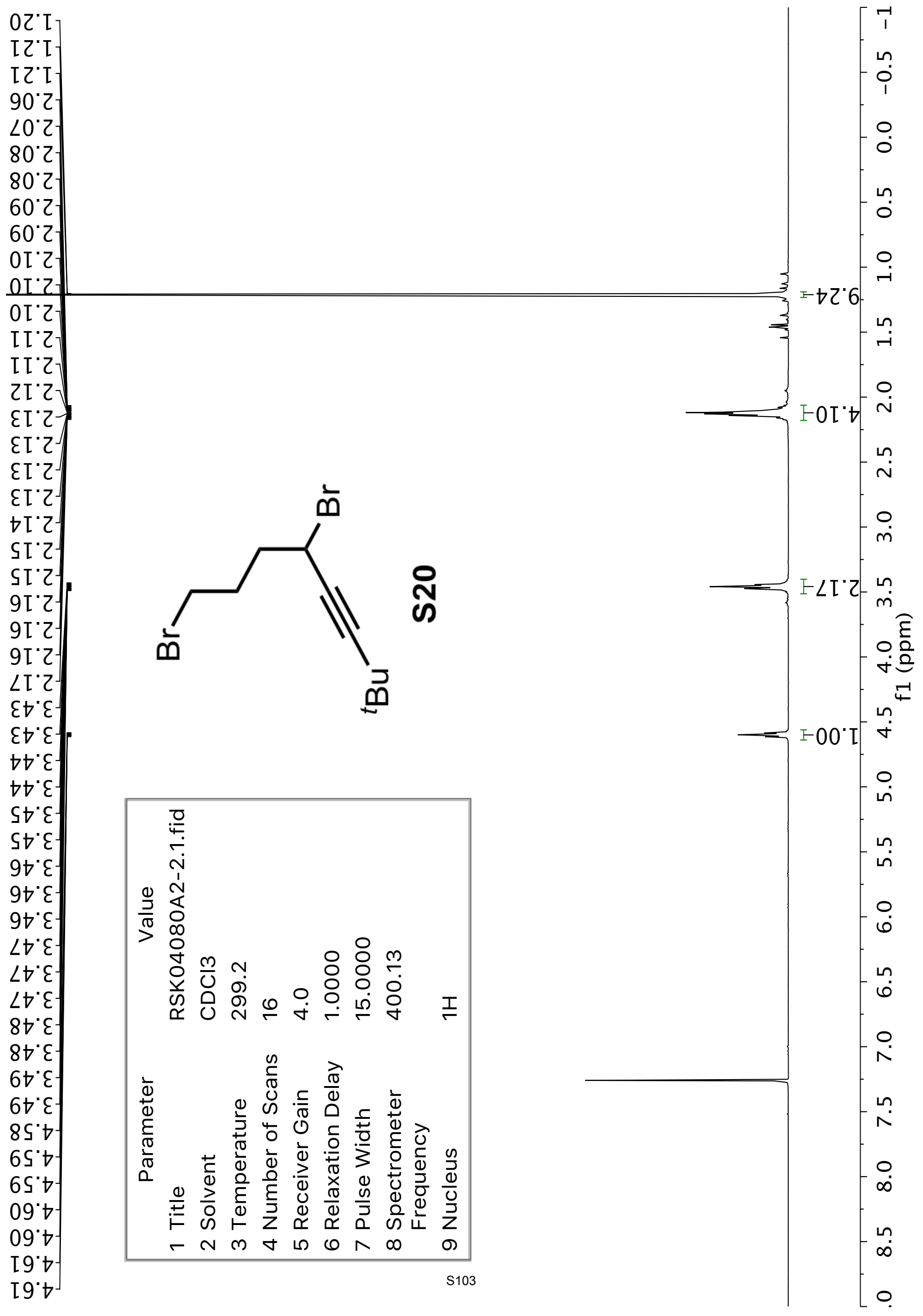



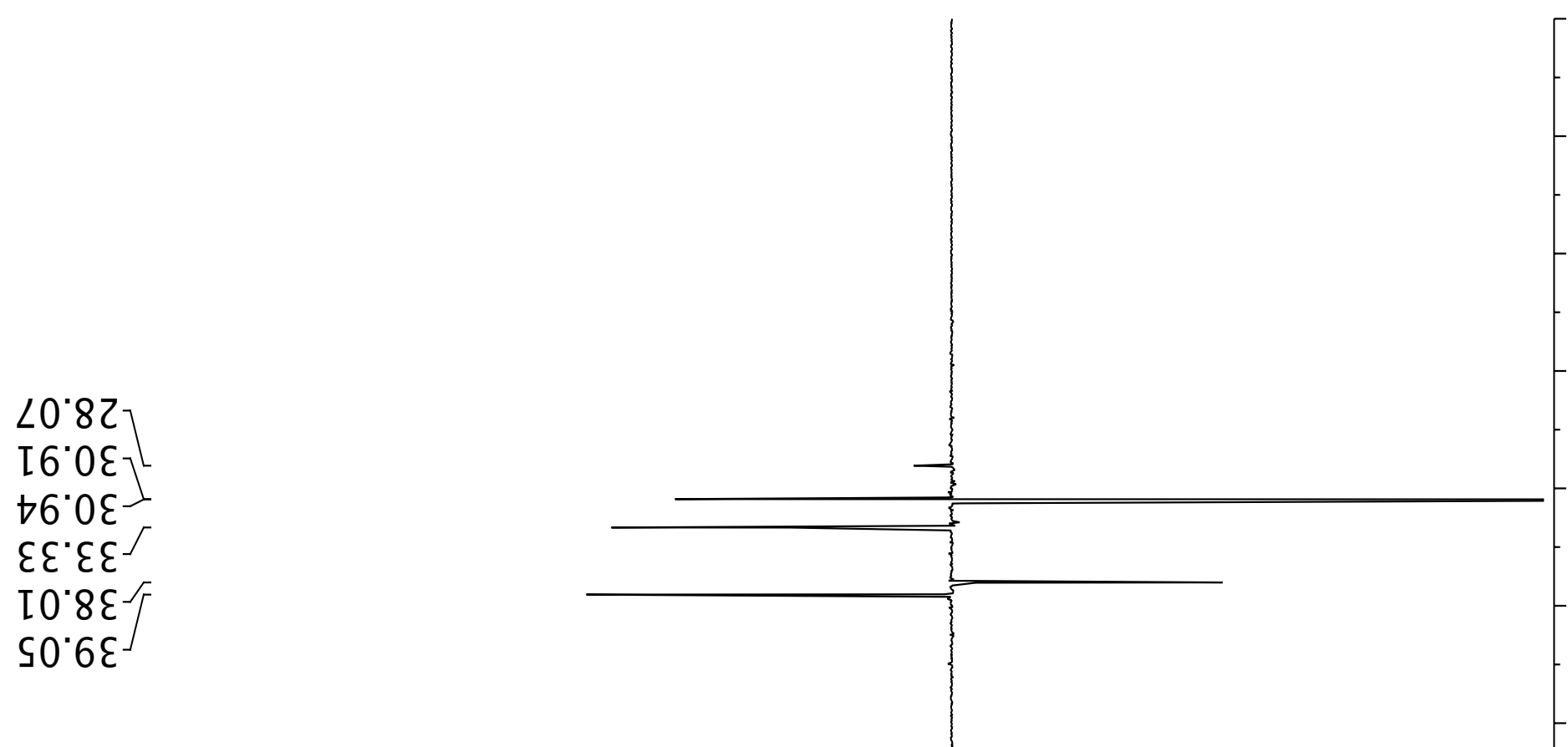

$26^{\circ} \angle L-$

IE' $\angle 6-$

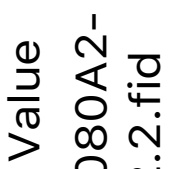

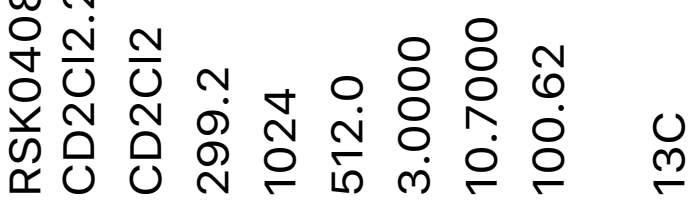

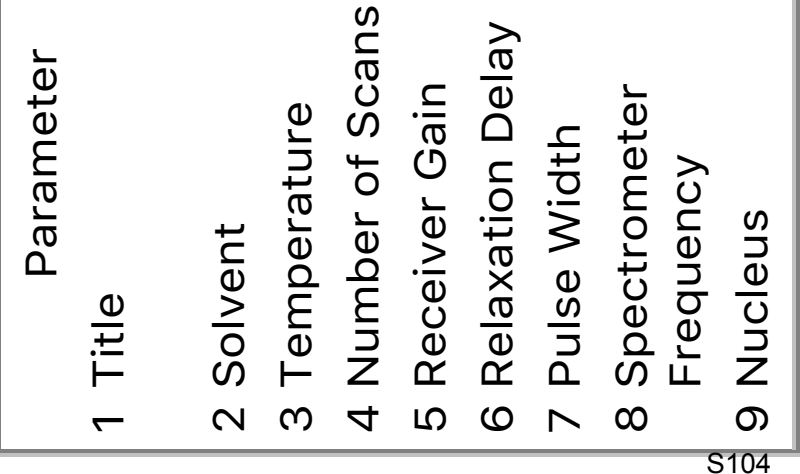

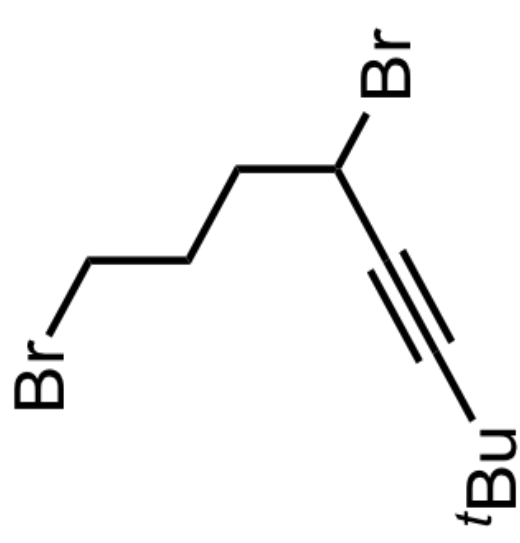




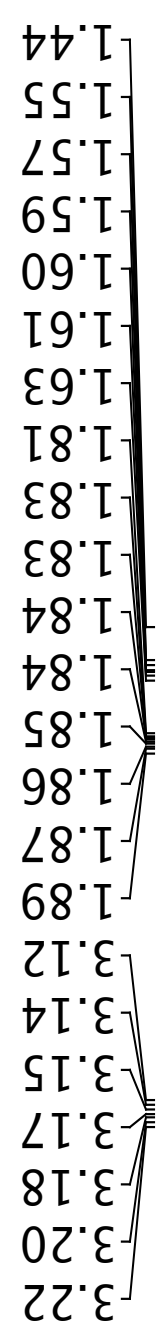




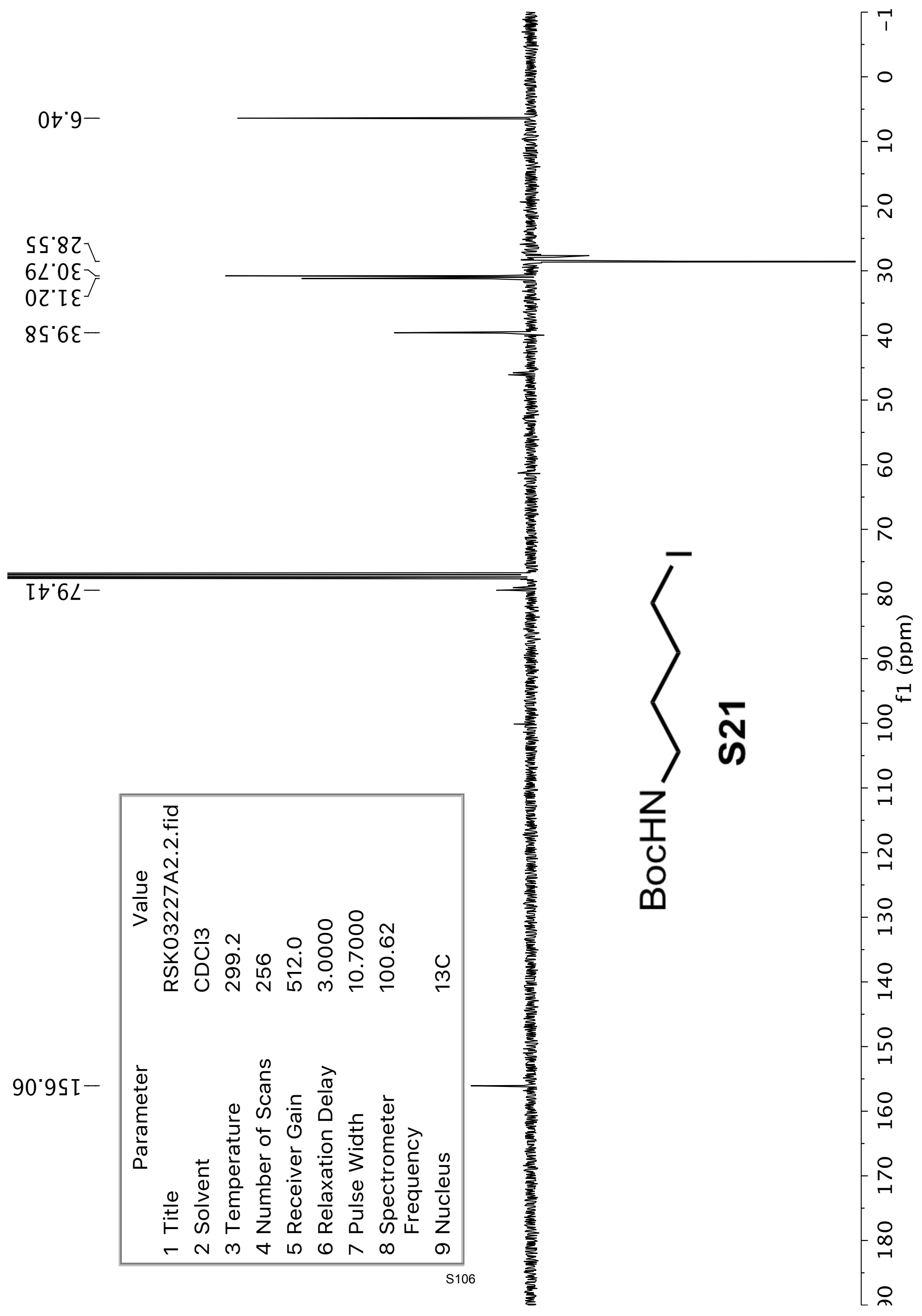




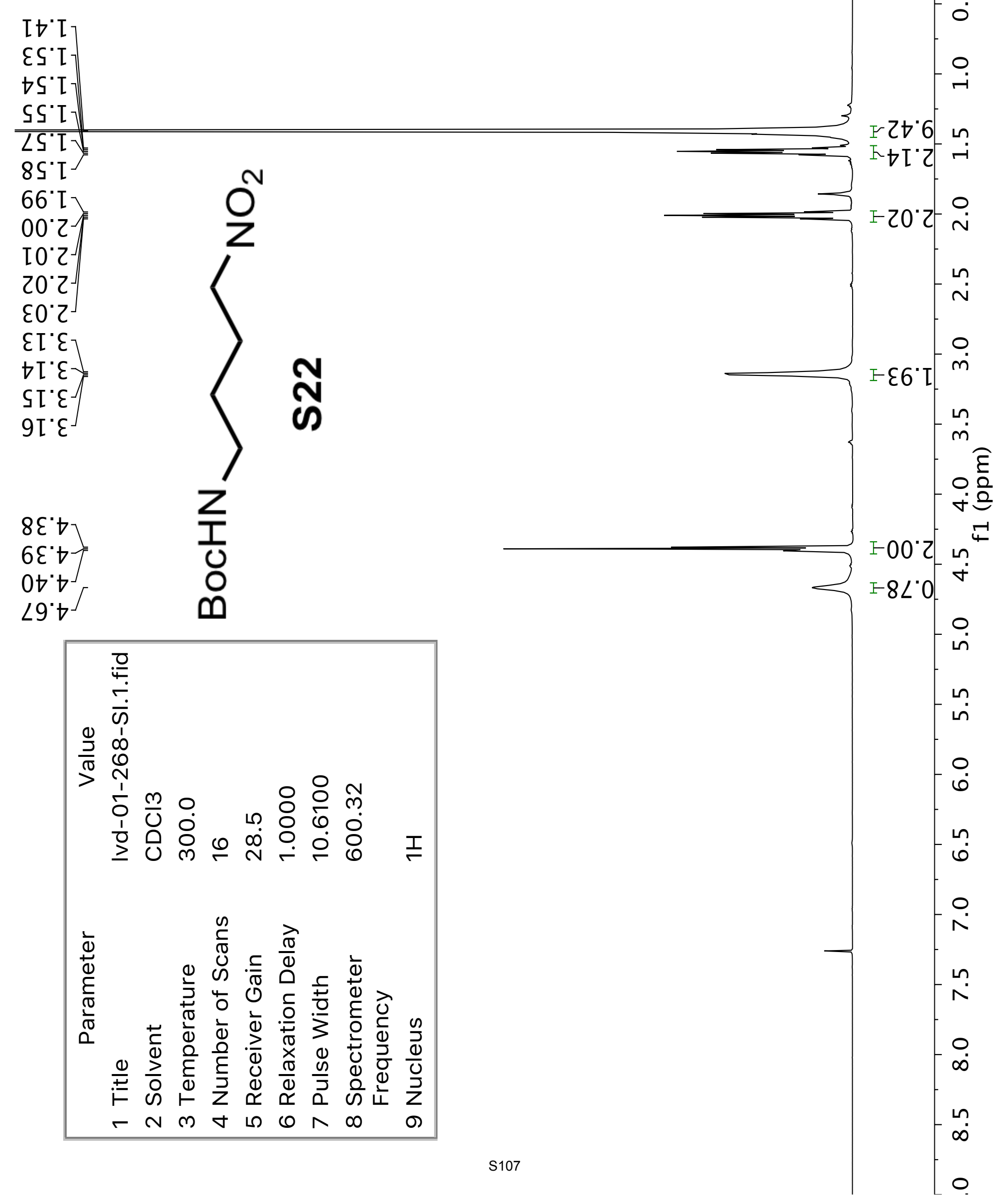


$\left[9^{\circ} \circ 2\right.$

$90^{\circ} \angle 2-$

St $82^{\top}$

$85^{\circ} 6 \varepsilon-$

$\nabla Z^{\circ} S L-$

$9 t^{\circ} 6<-$

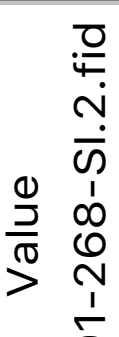

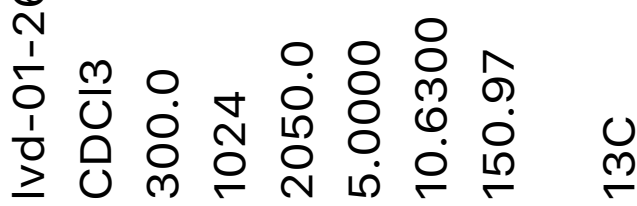

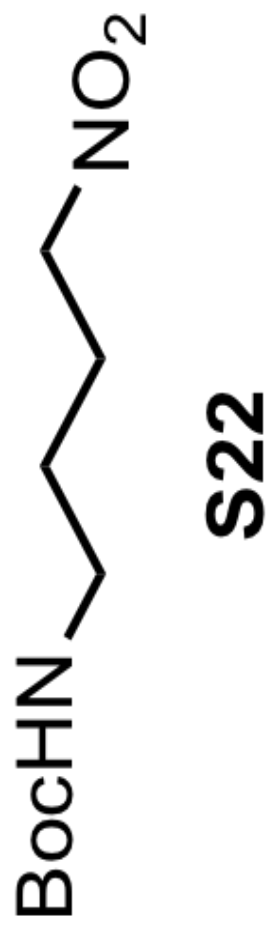




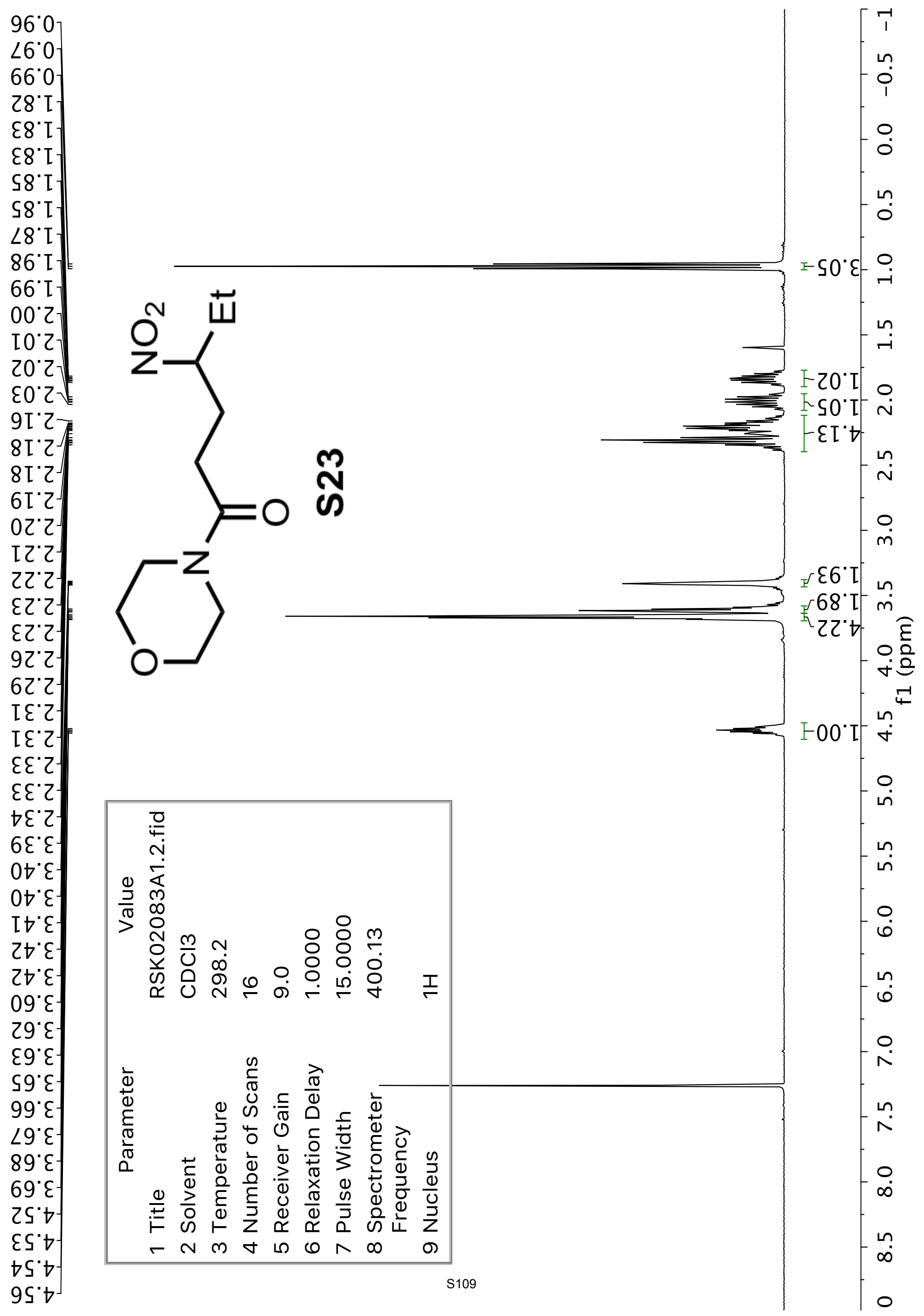




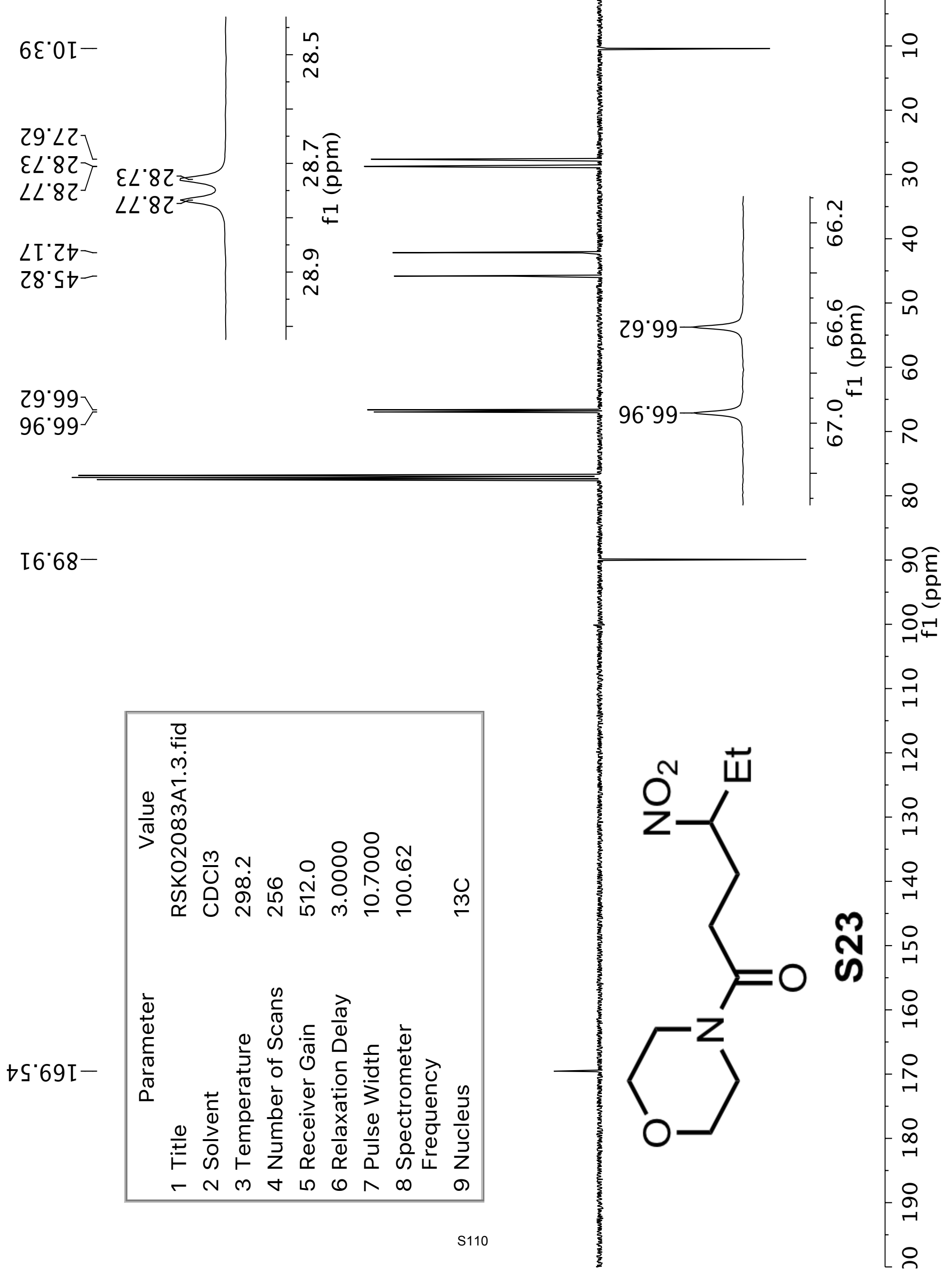


$\left.6 I^{\prime} 2\right]=$

$022^{\prime}$

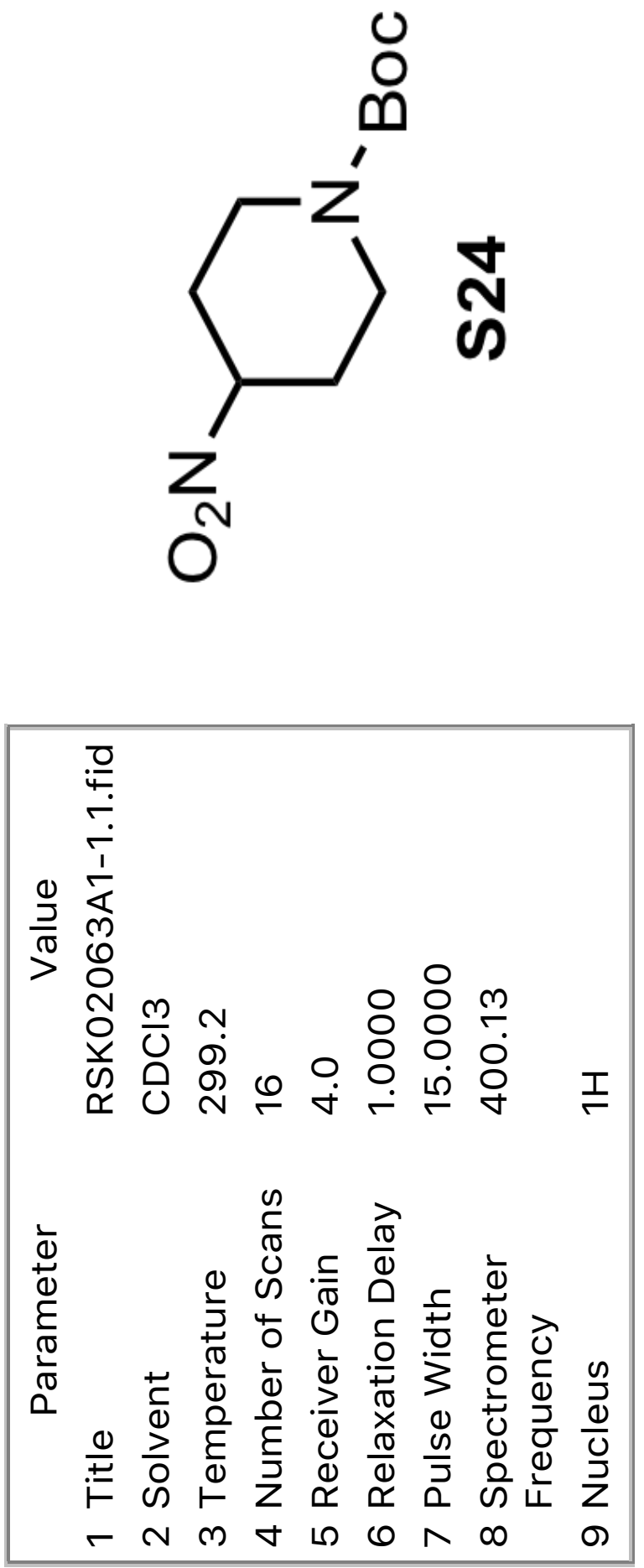

$\varepsilon 6^{\prime} z_{7}$ $\left.\varepsilon 6^{\prime} 2\right]$ $96^{\circ} \mathrm{z}^{-}$ $66^{\circ} \mathrm{Z}$ $00^{\circ} \varepsilon^{\prime}$ $66^{\circ} \varepsilon$ $\varepsilon 0^{\circ} \nabla^{J}$ $\nabla \nabla^{\circ}$ Sガ・$9 t^{\circ} t$ $9 \nabla^{\circ} t$ $\angle \nabla^{\circ} \nabla$ $6 t^{\circ} \nabla$ $6 \nabla^{\circ} \nabla$ $0 S^{\circ} \Rightarrow$ IS. $t$ 
$97^{\circ} 82$ $\angle 8^{\circ} 62^{-}$

$8 \varepsilon^{\circ} 08$ 乙

$70^{\circ} 28^{-}$
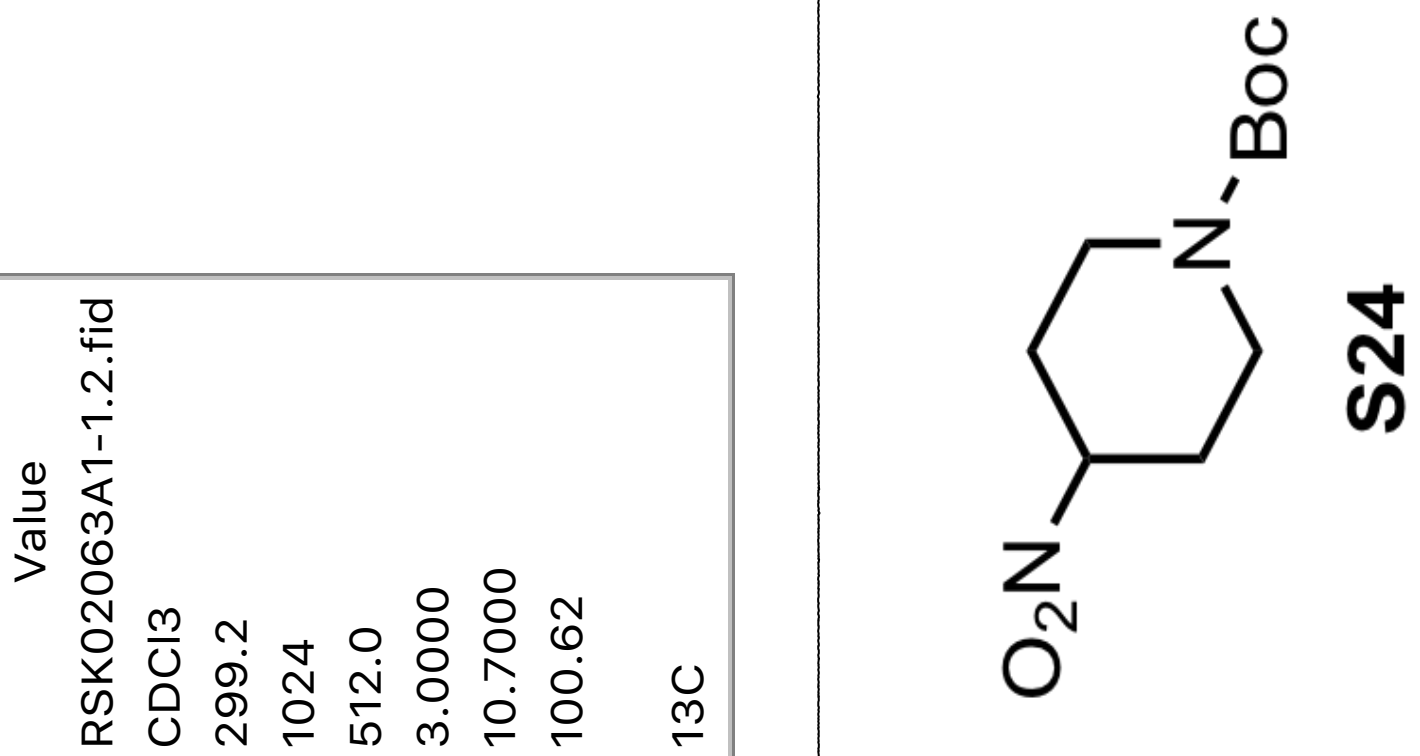


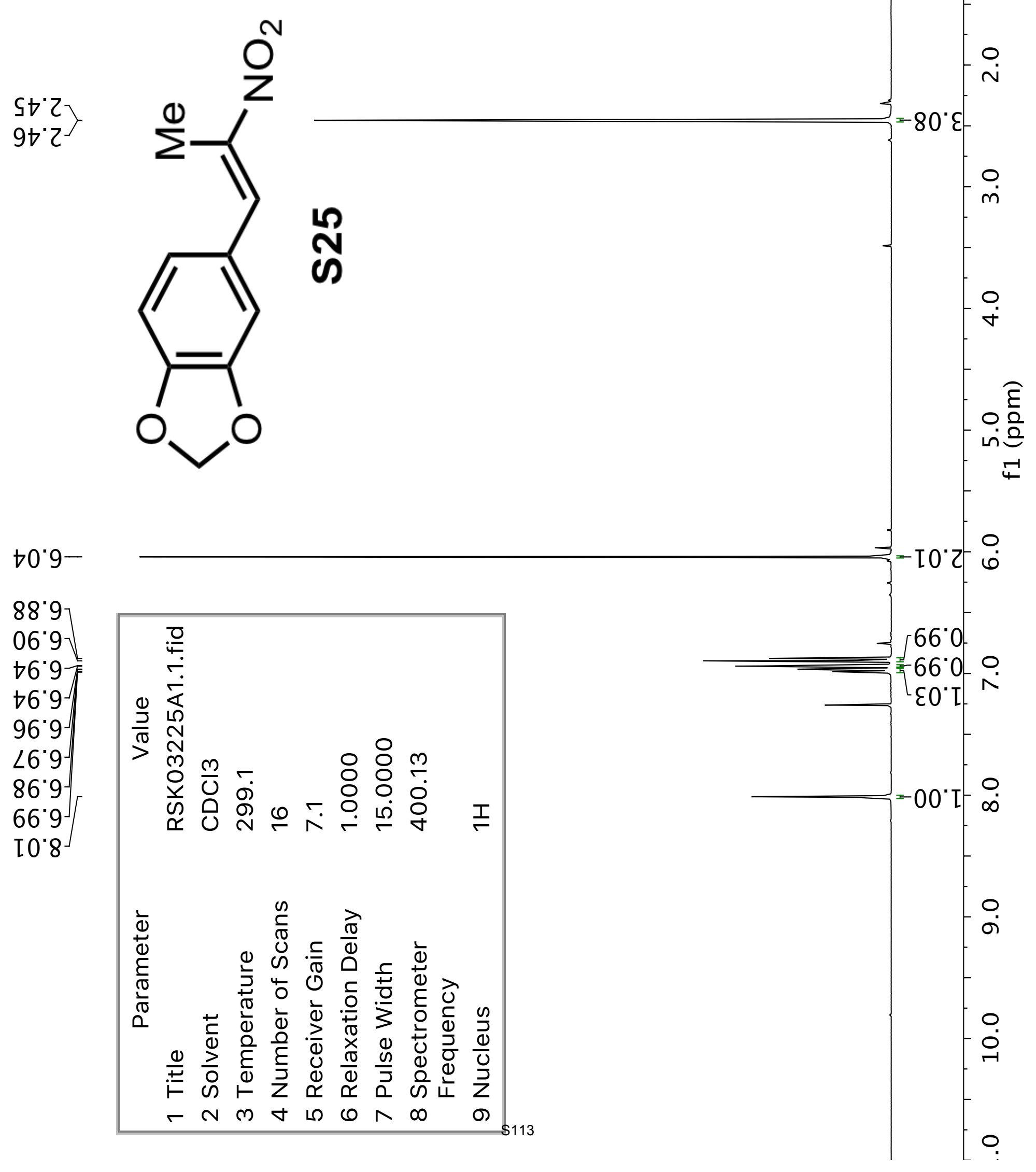


$6 乙^{\circ} \sqcup I-$

$06^{\circ}$ IOI$\angle 6^{\circ} 80 \mathrm{I}$ $89^{\circ} 60 \mathrm{I}$ -

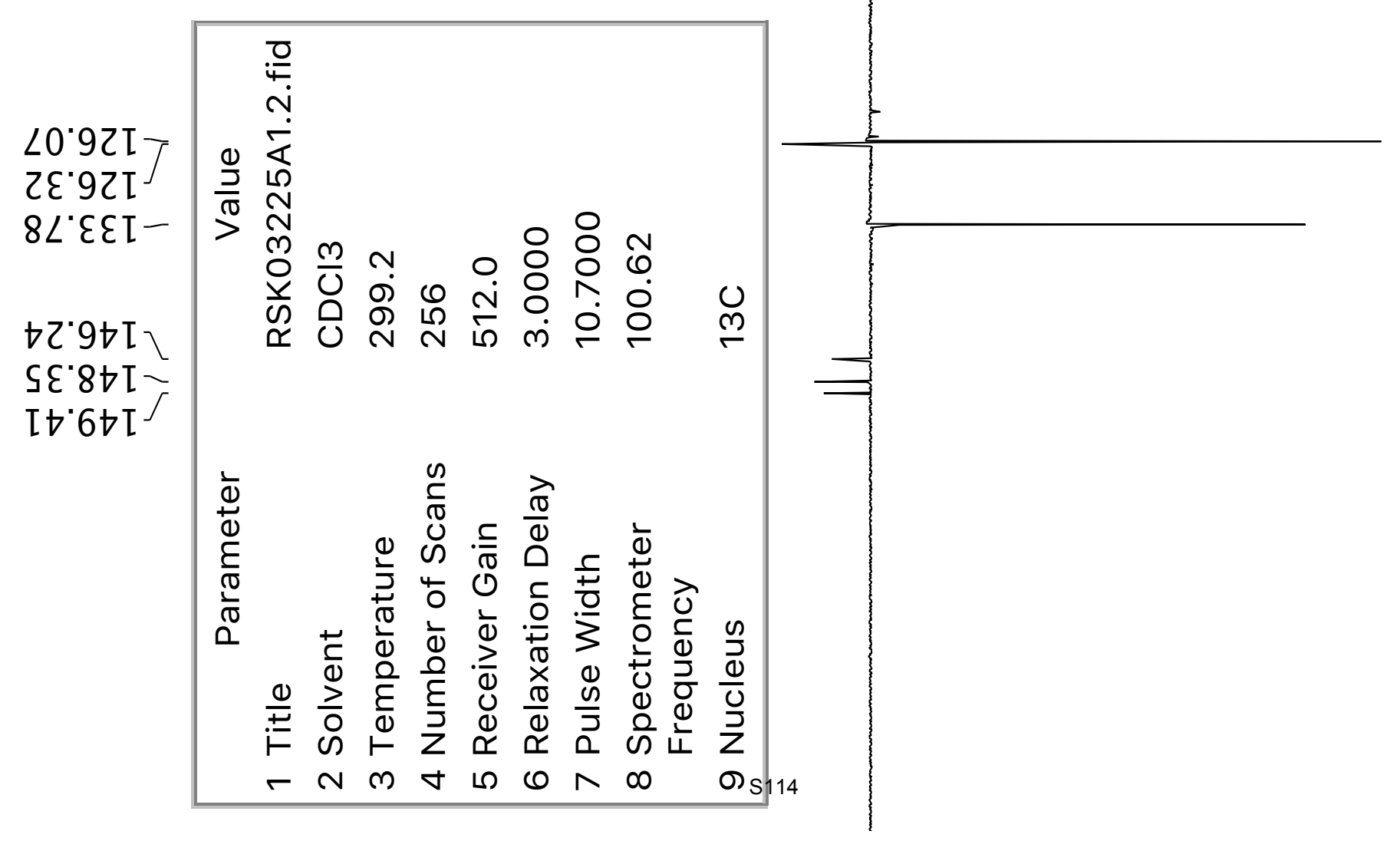

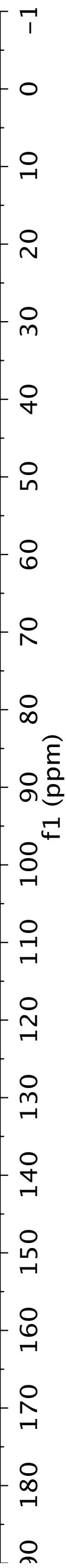




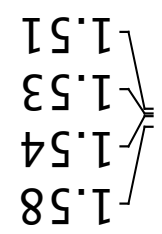
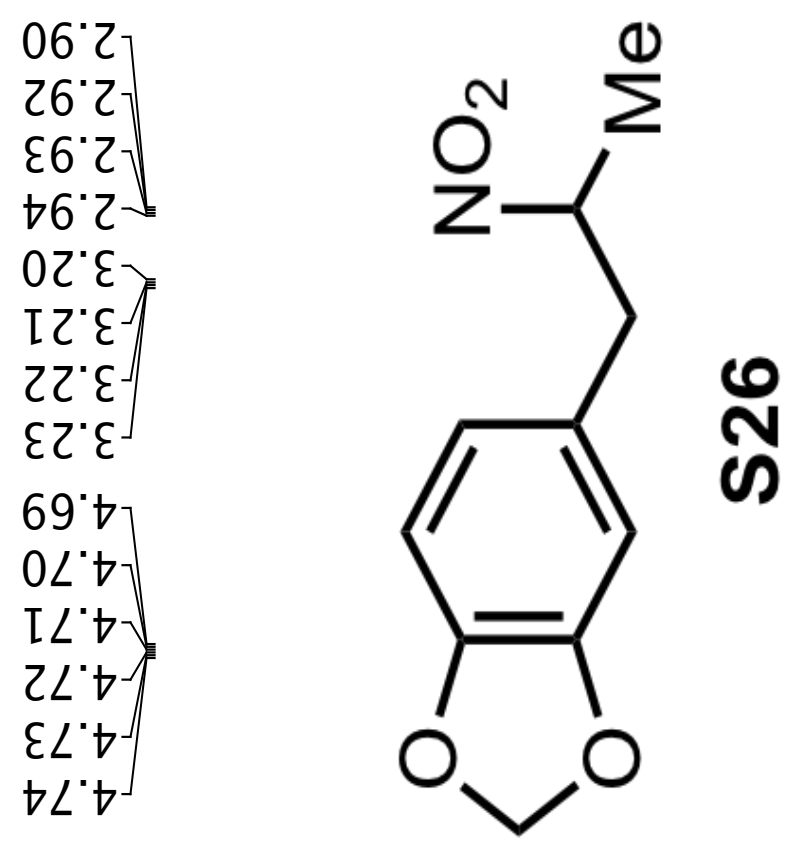

[6. 5

$\varepsilon 6^{\circ} \mathrm{S}^{\mathcal{}}$

$09^{\circ} 9$

[9'9]

$\varepsilon 9^{\circ} 9^{\prime}$

$\varepsilon\llcorner\cdot 9$ -

$\forall \angle{ }^{\circ} 9$

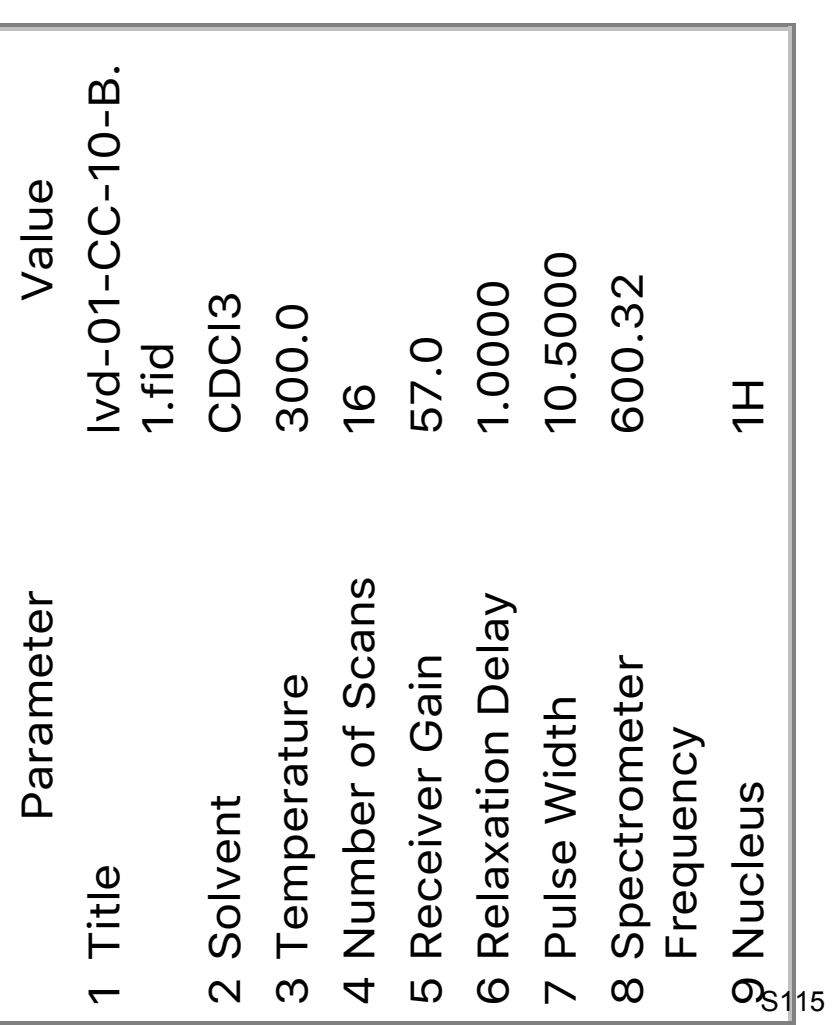

= ZI'Z

FOI't $\circ$

F $60^{\circ}$.

$\stackrel{n}{m}$

$\stackrel{\circ}{+}$

$\stackrel{\operatorname{Ln}}{+} \widehat{\underline{a}}$

넨

in

เ

:

ก

$r \angle 0^{\circ} 20$

${ }^{2} 00{ }^{\circ} \mathrm{I}$

0
$i$
$n$
$n$
0
$\infty$
$\infty$
$n$
$\infty$
0
0
0
$n$
0
0
0
0
-1


ع 8. 8 I -

20 เtด

$\varepsilon L ' \triangleright 8-$
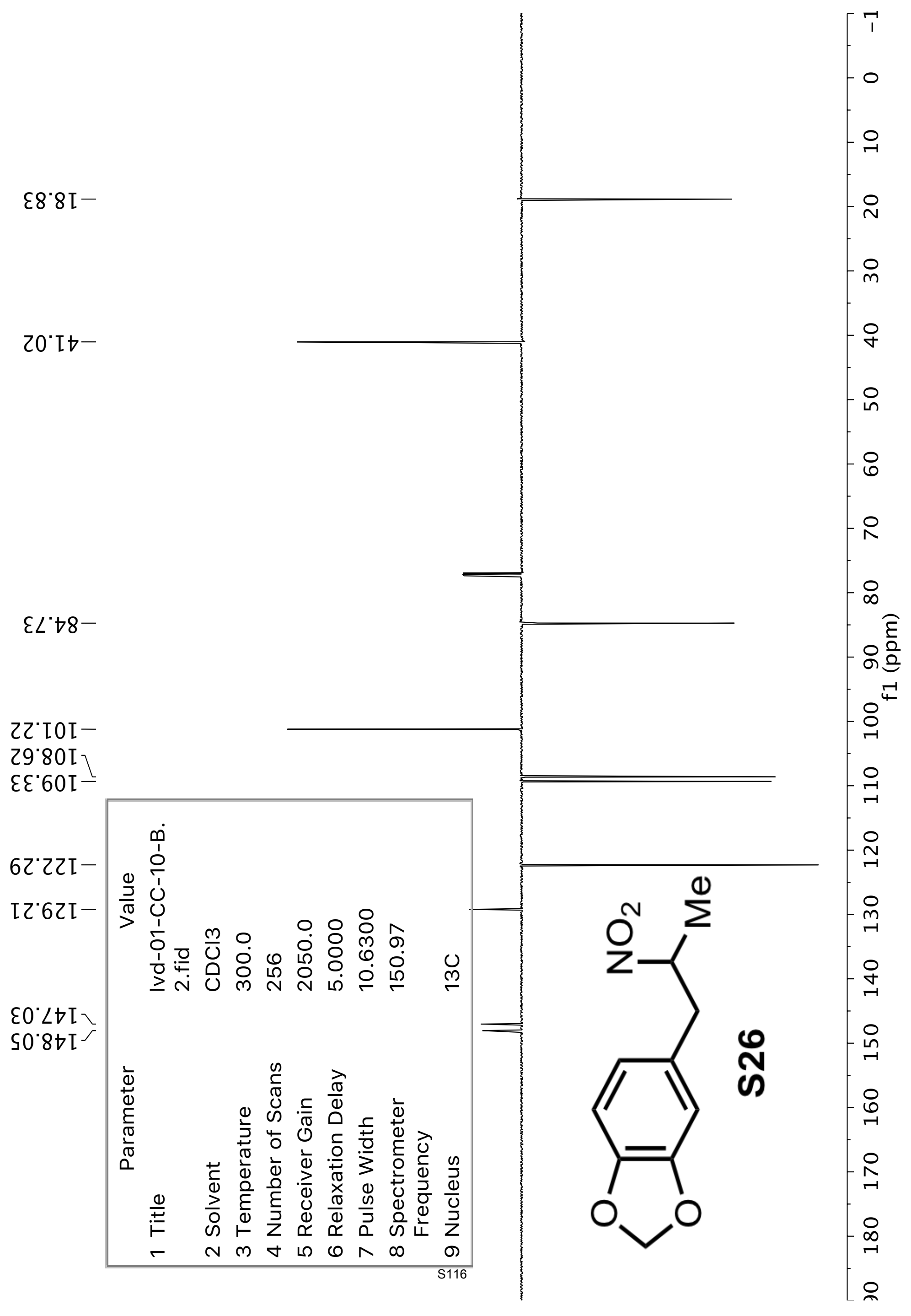

22 ' IOI$29^{\circ} 80 \mathrm{I}$ ع $\varepsilon^{\circ} 60$ I $\varepsilon 0^{\circ} \angle t I \backslash$ $\mathrm{S} 0^{\circ} 8 \mathrm{t} \mathrm{I}^{-}$ 


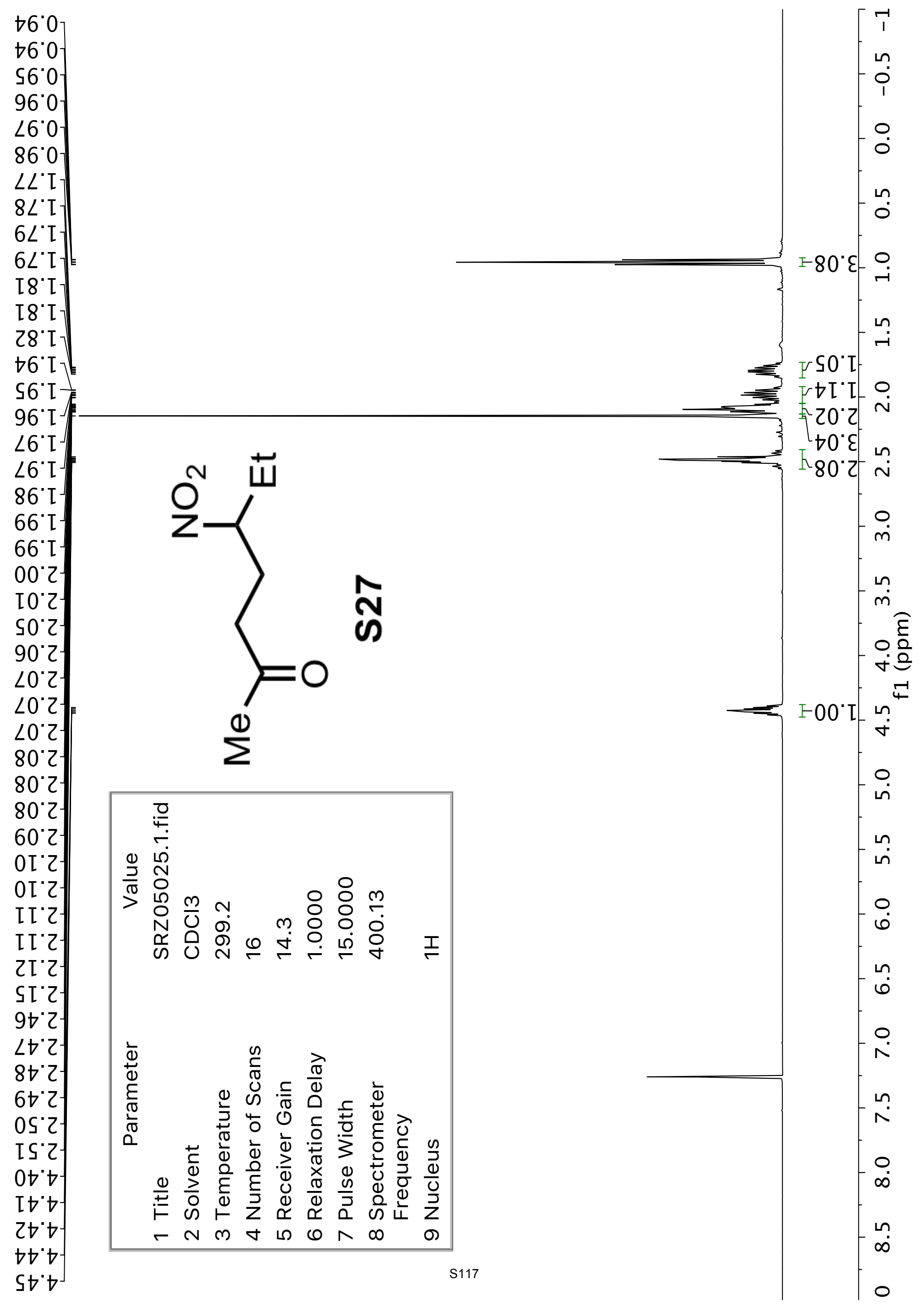


SE'0I-

$0 Z^{\circ} \angle Z$
$S D^{\circ} \angle Z$
$\varepsilon Z^{\circ} 0 \varepsilon$

$\varepsilon Z^{\circ} 0 \varepsilon$

$9 \tau^{\circ} 6 \varepsilon^{-}$

05.68-
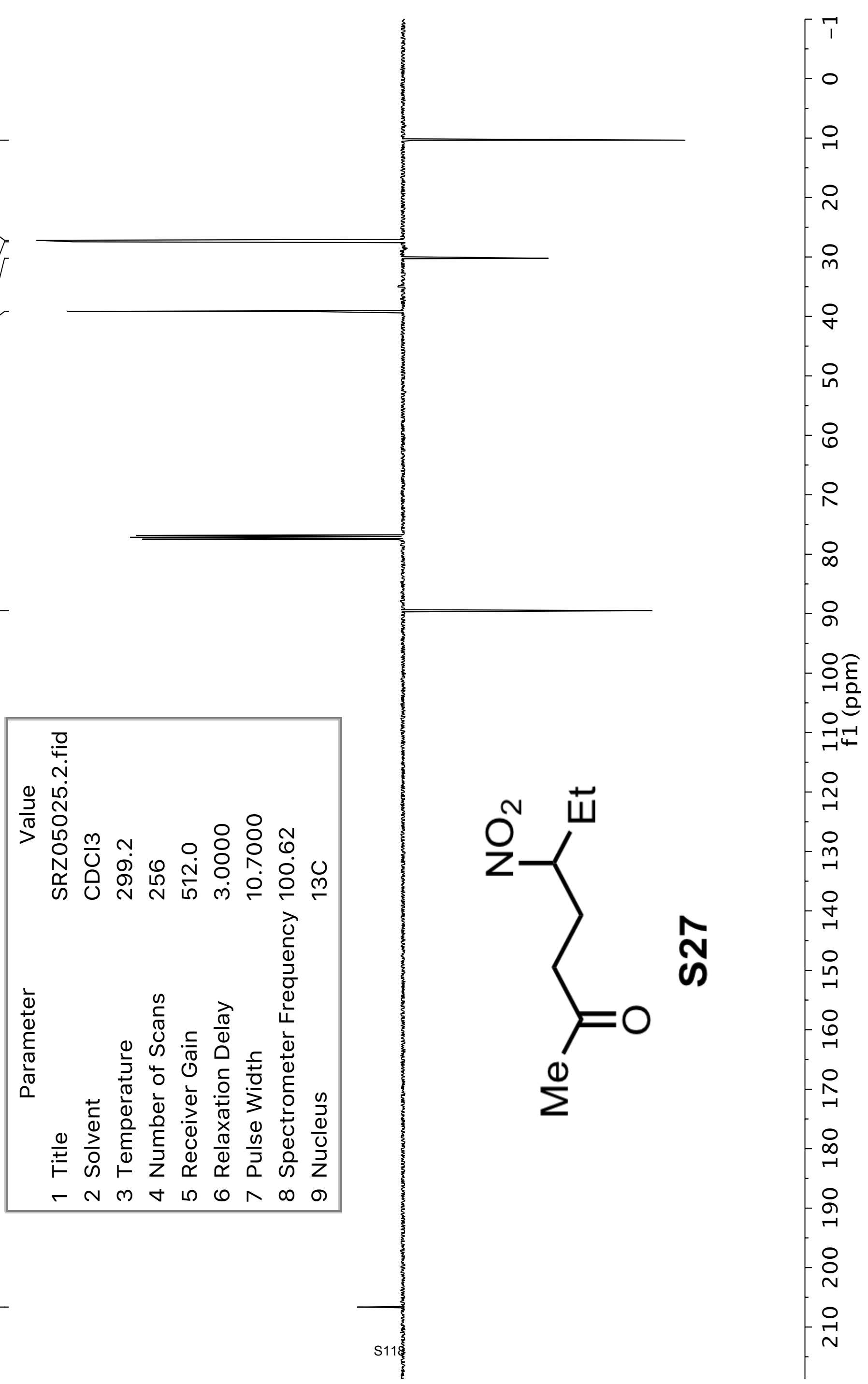


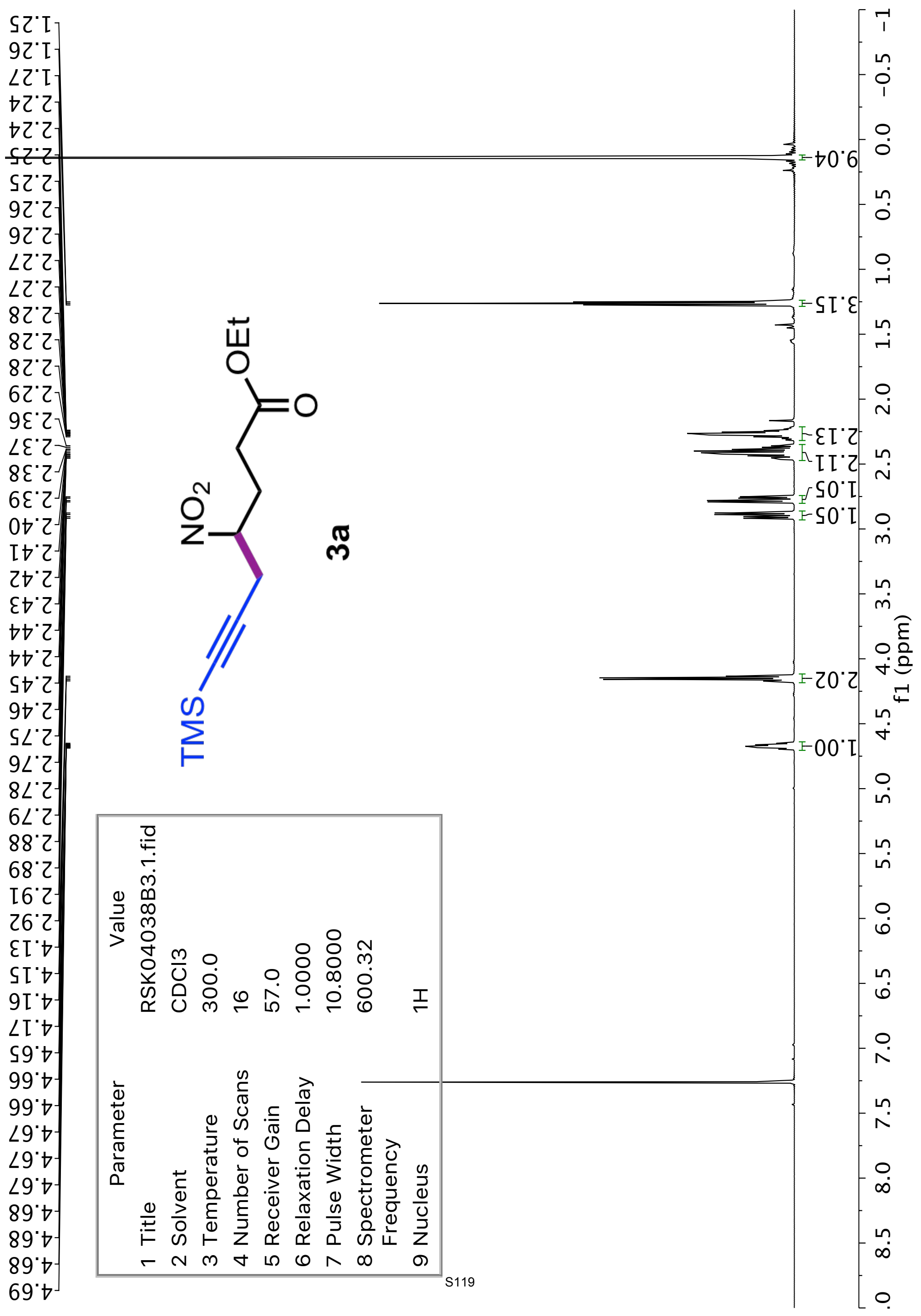


$90^{\circ} 0^{--}$

I $\varepsilon^{\circ} \triangleright I-$

SO'SZ

$06^{\circ} \angle 2-$

IZ $0 \varepsilon^{\prime}$

†0 'T9-

0ะ. ऽ -

†9.68-

$86^{\circ} 86^{-}$

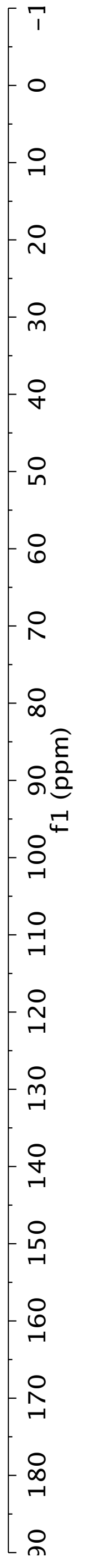




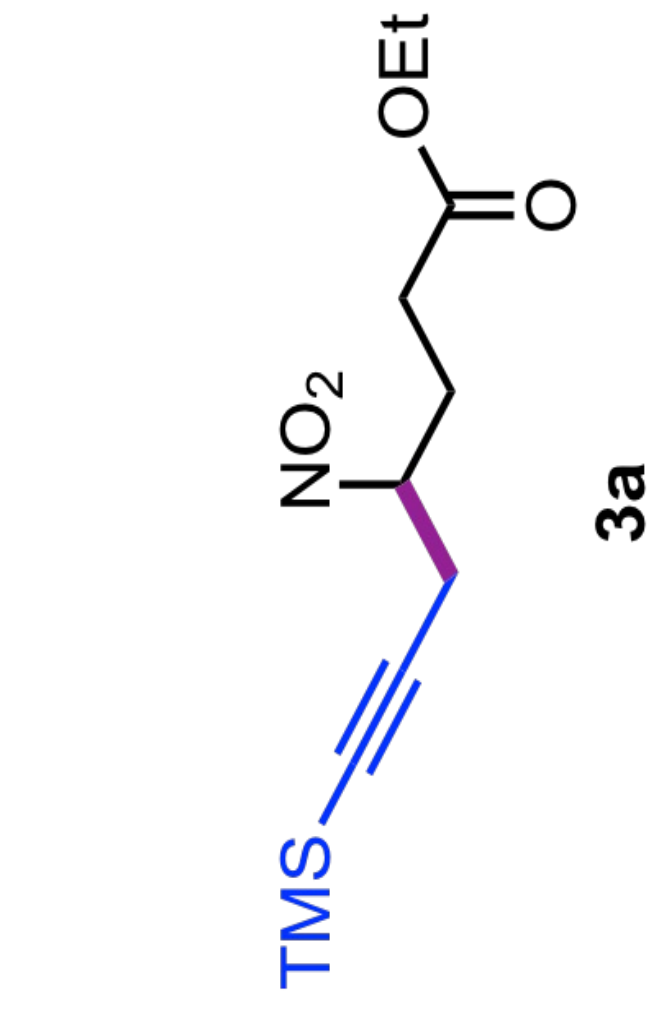

$\angle L ' \angle I--$

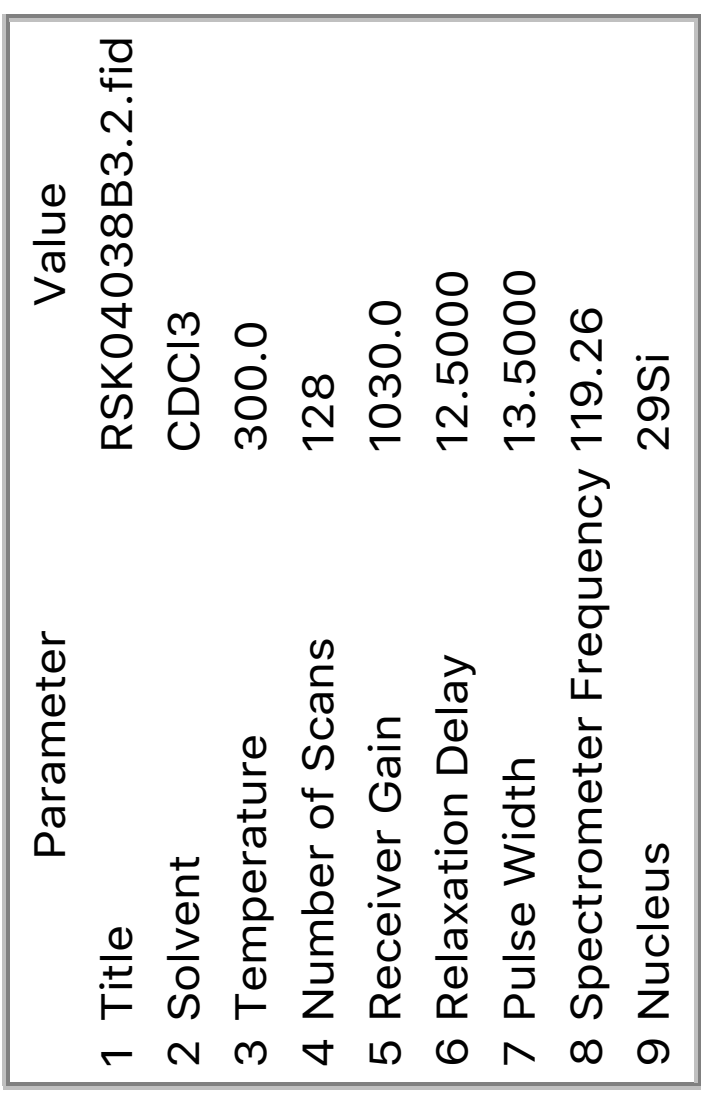




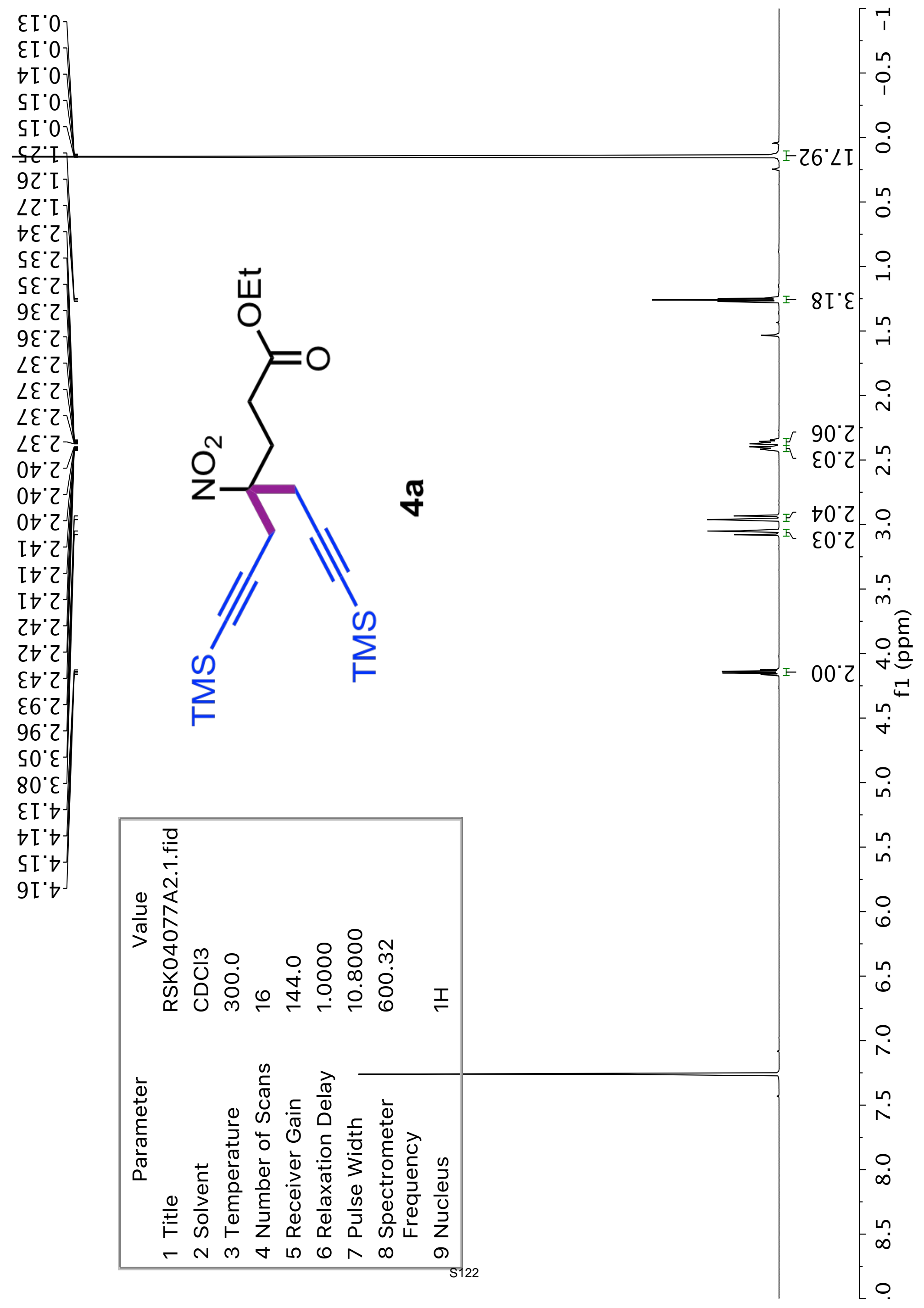


S0.0--

IE'

$29^{\circ} \angle 2 \backslash$

$96.82-$

$\angle S^{\circ}\left[\varepsilon^{\top}\right.$

E0. I9-

$\angle 00^{\circ} 06$

$88^{\circ} 06^{\circ}$

$88^{\circ} 86-$
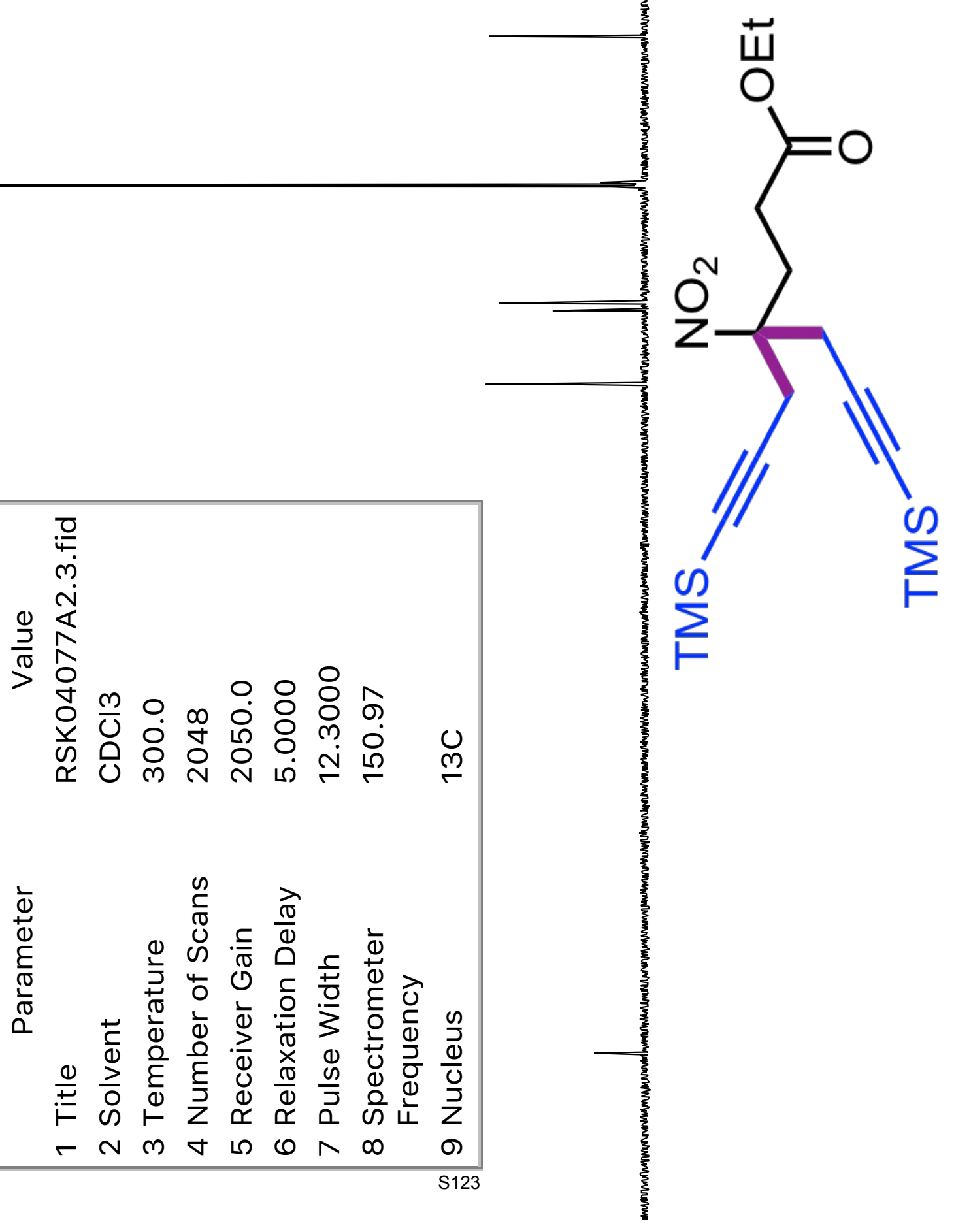

웅

웃

$\infty$

음

$\stackrel{ }{\sim}$

$\stackrel{0}{m}$

$\stackrel{ }{+}$

움

$\stackrel{8}{\circ}$

$\stackrel{2}{2}$

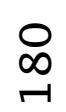

요 


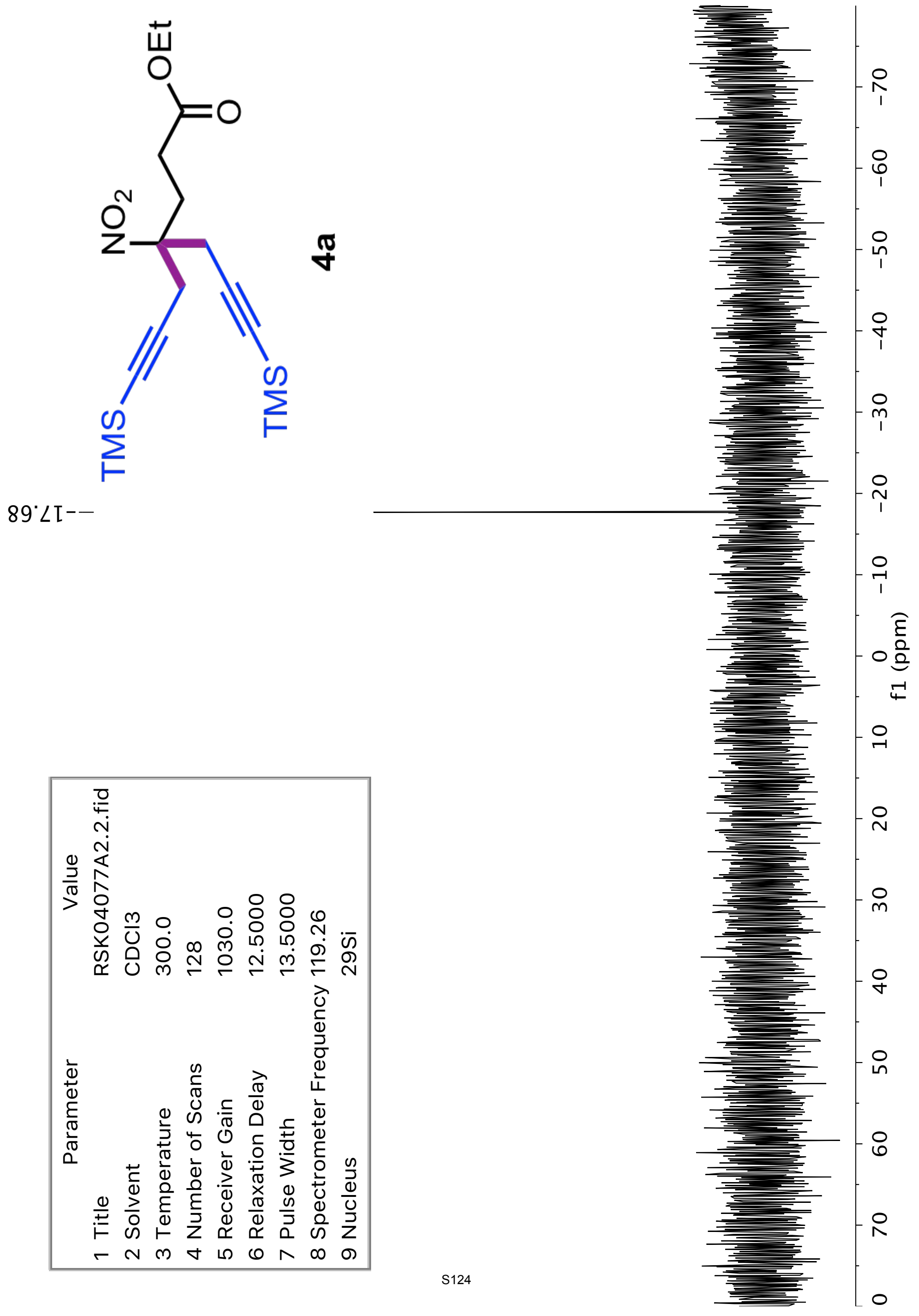




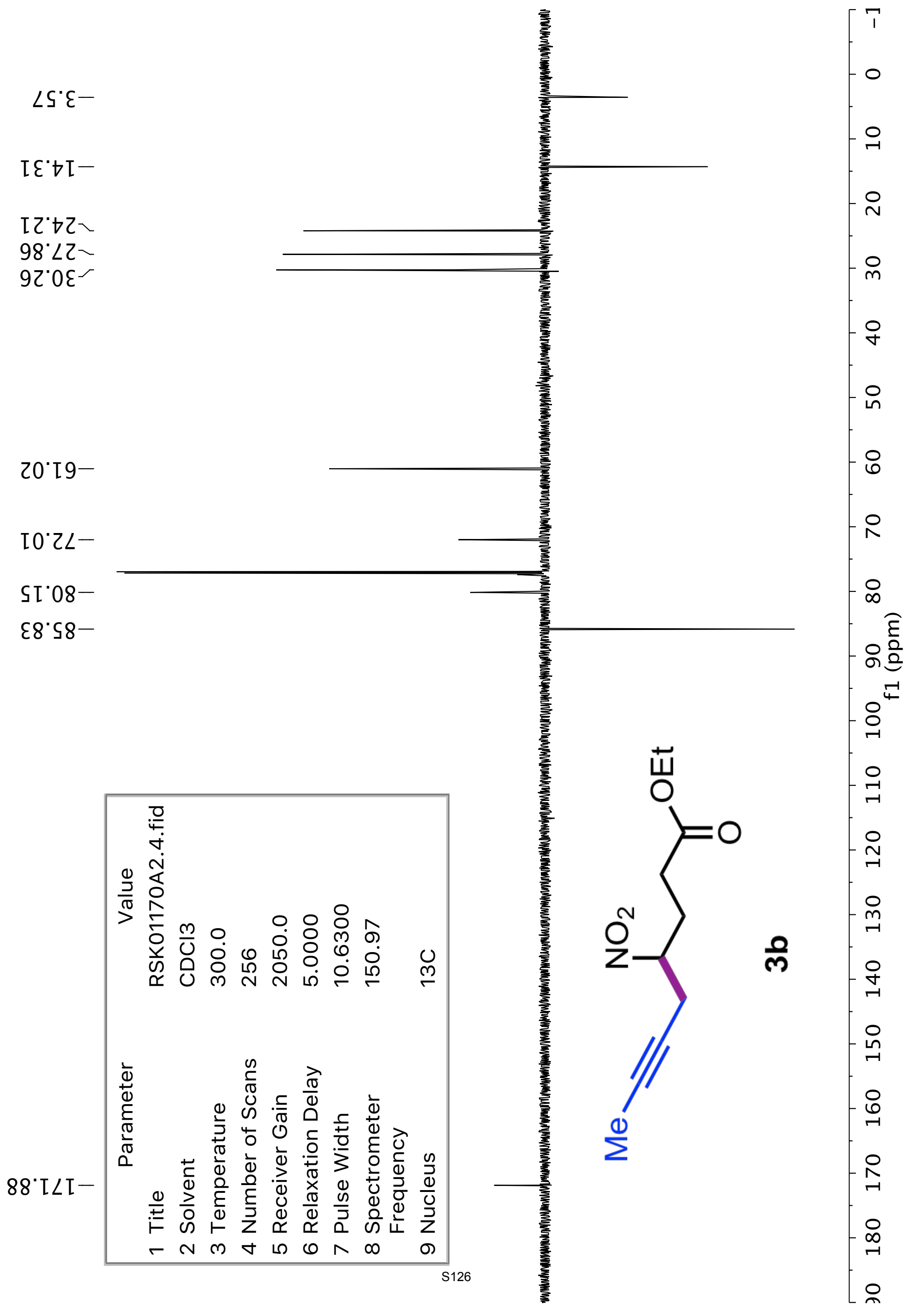


$\nabla C \mathrm{~L}$
$\mathrm{~S} \mathrm{C}^{\circ} \mathrm{I}-$

$\angle Z^{\circ} \mathrm{I}$.

$\angle L^{\prime} \mathrm{I}$

$\angle L ' T$ -

$\angle L ' I$ -

乙E' $ح$

乙ह'

$\varepsilon \varepsilon^{\prime} Z$

$\downarrow \varepsilon^{\prime} 乙$

$\nabla \varepsilon^{\prime} ح$

$9 \varepsilon^{\circ} 乙$

$\angle \varepsilon^{\prime} Z$

$\angle \varepsilon^{\prime} Z$

$\left.\angle \varepsilon^{\prime} Z\right]$

$8 \varepsilon^{\prime} Z$

$\left.8 \varepsilon^{\circ} 乙\right]$

$\varepsilon 8^{\circ} Z$

$78^{\circ} 2$

$78^{\circ} \mathrm{Z}^{\prime}$

$58^{\circ} \mathrm{C}$

$98^{\circ} \mathrm{Z}$

$\angle 8^{\circ} \mathrm{Z}$

$\angle 8^{\circ} 2$

$\angle 8^{\circ} 2$

$96^{\circ} z$

$96^{\circ} \mathrm{Z}$

$\angle 6^{\circ} 2$

$\angle 6^{\circ} 2$

$66^{\circ} 2$

$66^{\circ} 2$

$66^{\circ} 2$

$00^{\circ} \varepsilon$

ZI'

$\varepsilon[" \nabla$

$\nabla\left[{ }^{\circ} b\right.$

SI'
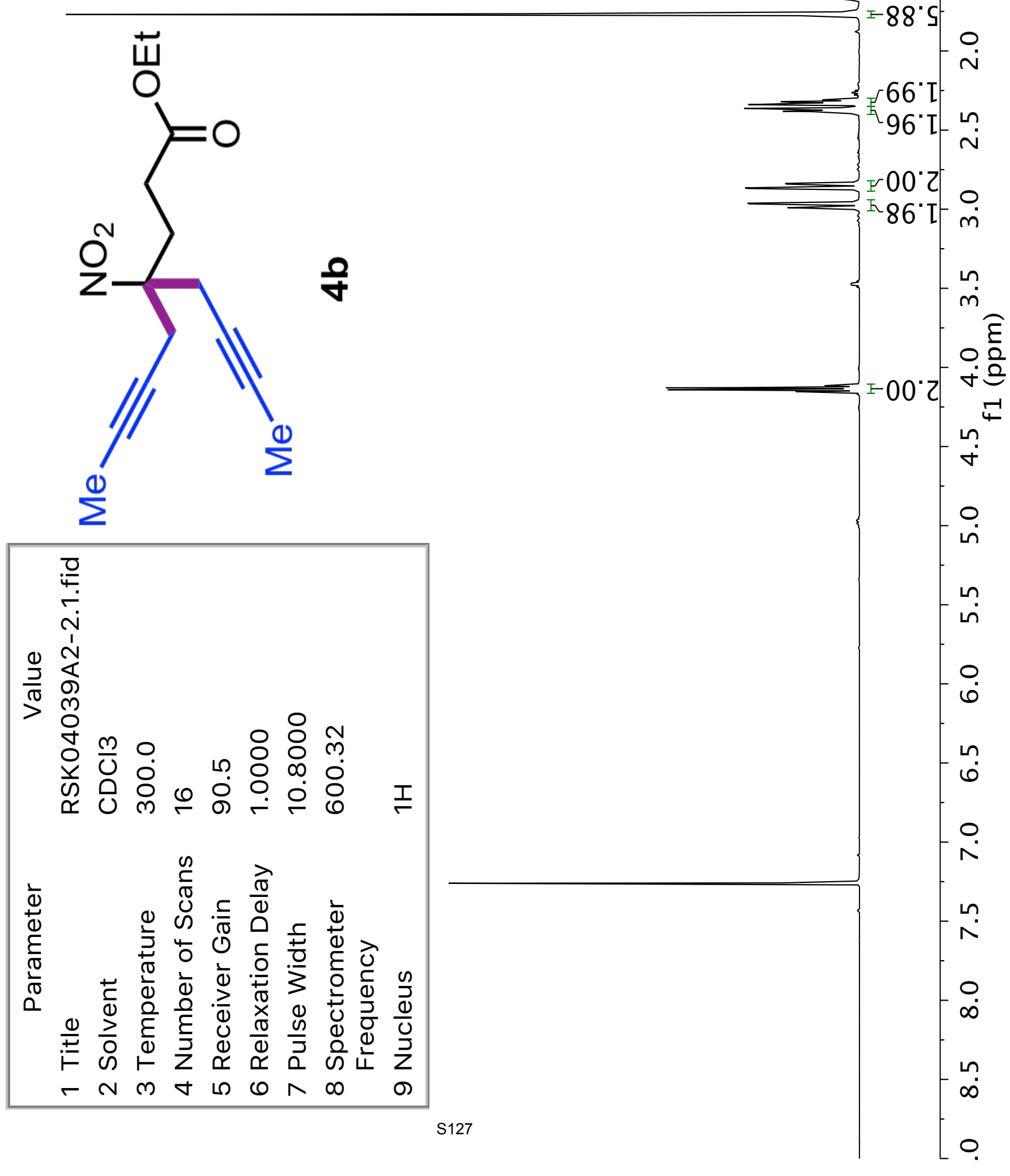

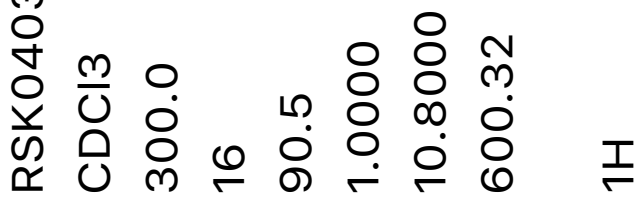

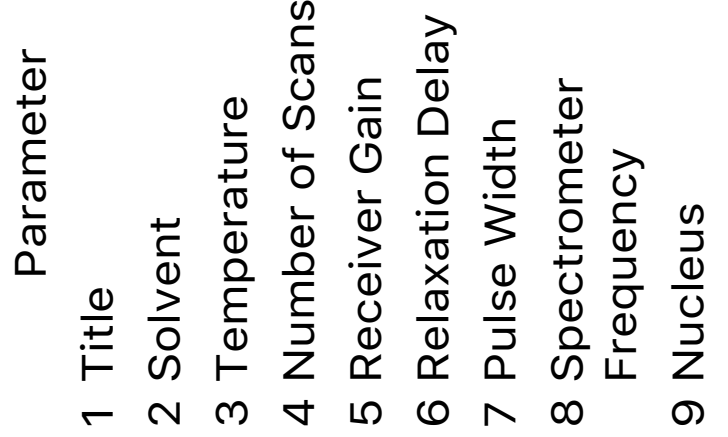




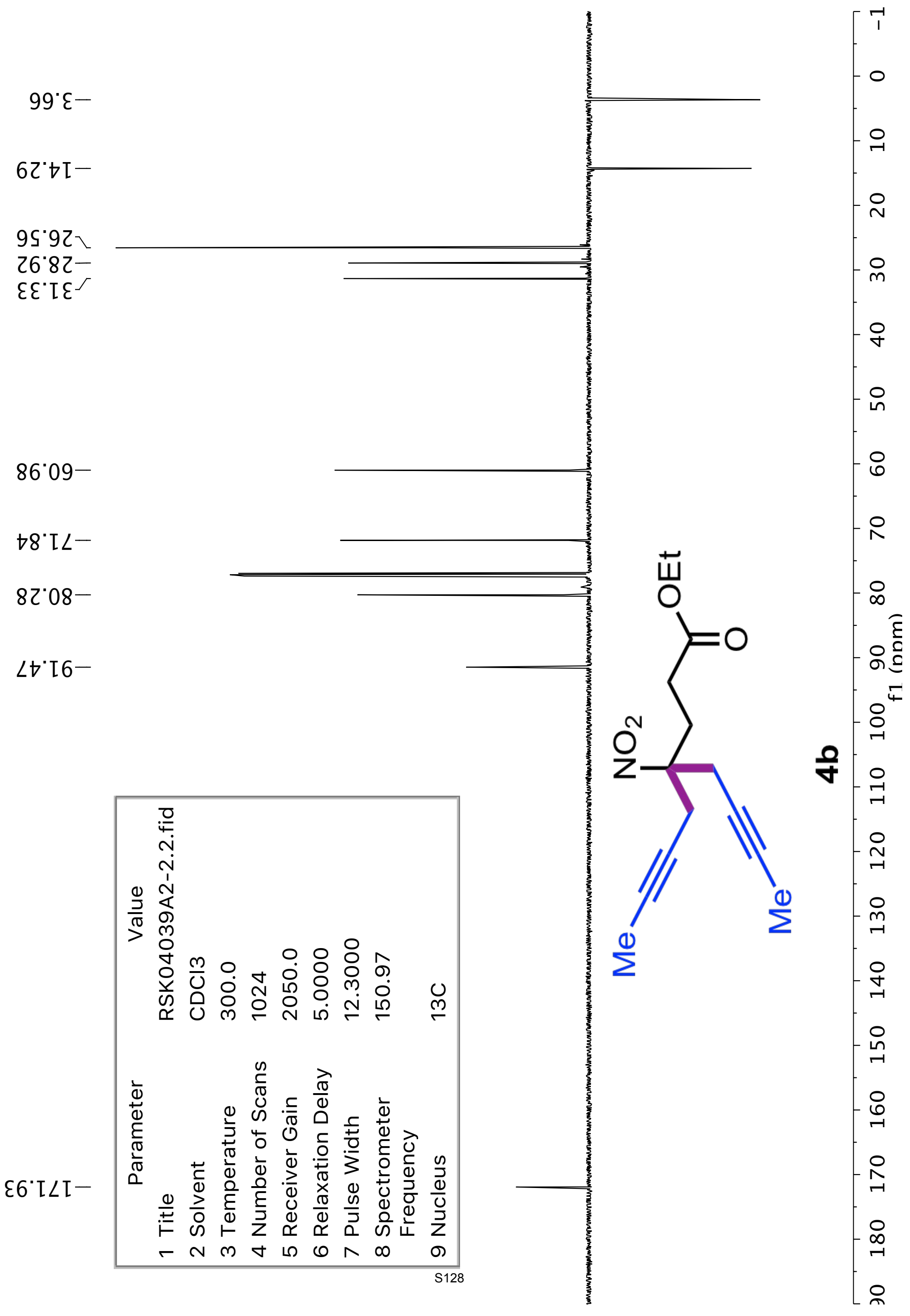




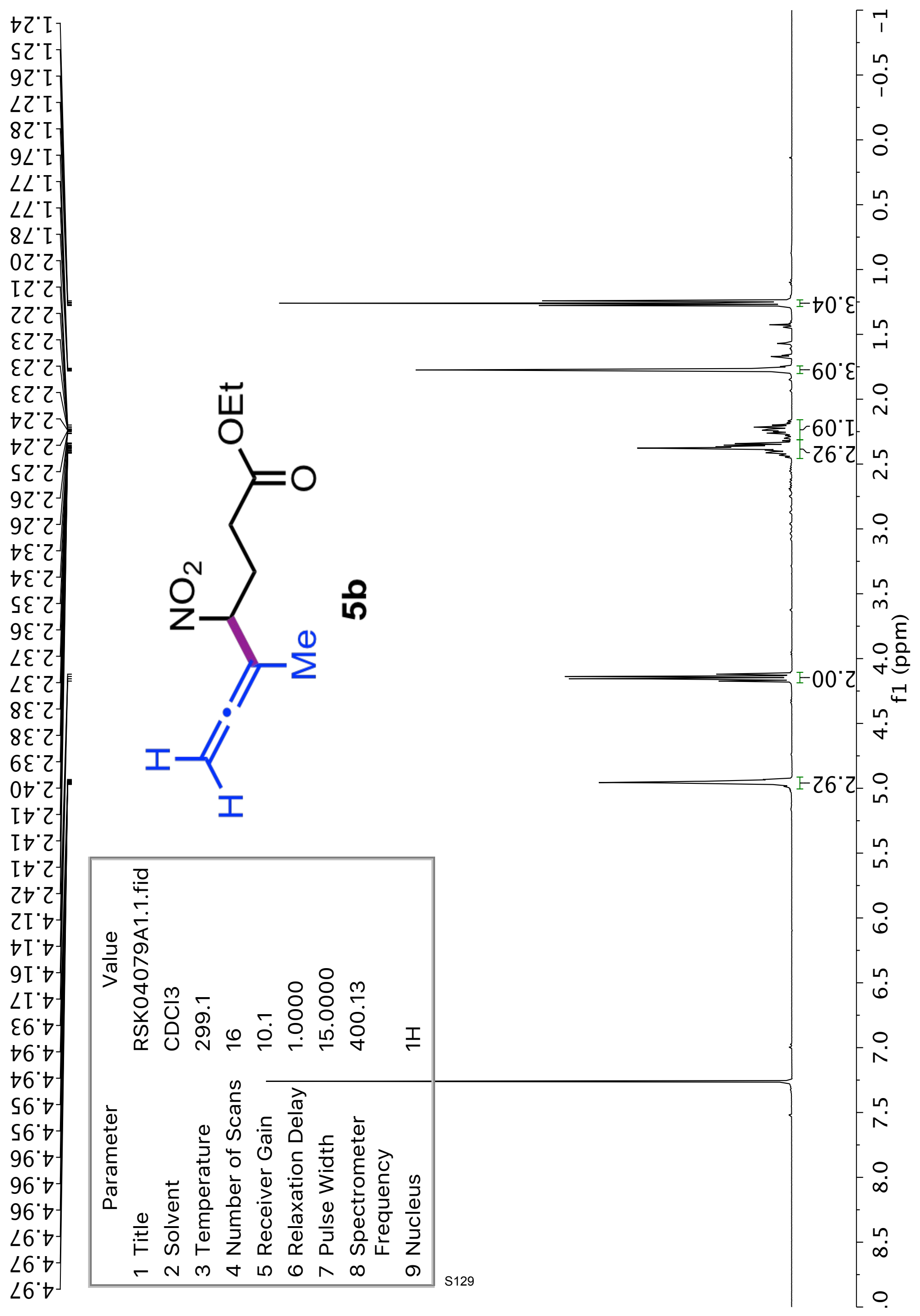


$\left[\varepsilon^{\circ} \downarrow \mathrm{I}\right.$

ZL'SI

$\varepsilon 9.92-$

† $\varepsilon^{\circ} 0 \varepsilon-$

00'ㅇ-

$\downarrow \varepsilon^{\circ} 8 L-$

$\angle 0{ }^{\circ} 68-$

0Z`ऽ6-

$20^{\circ} Z \angle I-$

$\angle 0{ }^{\circ} 802-$

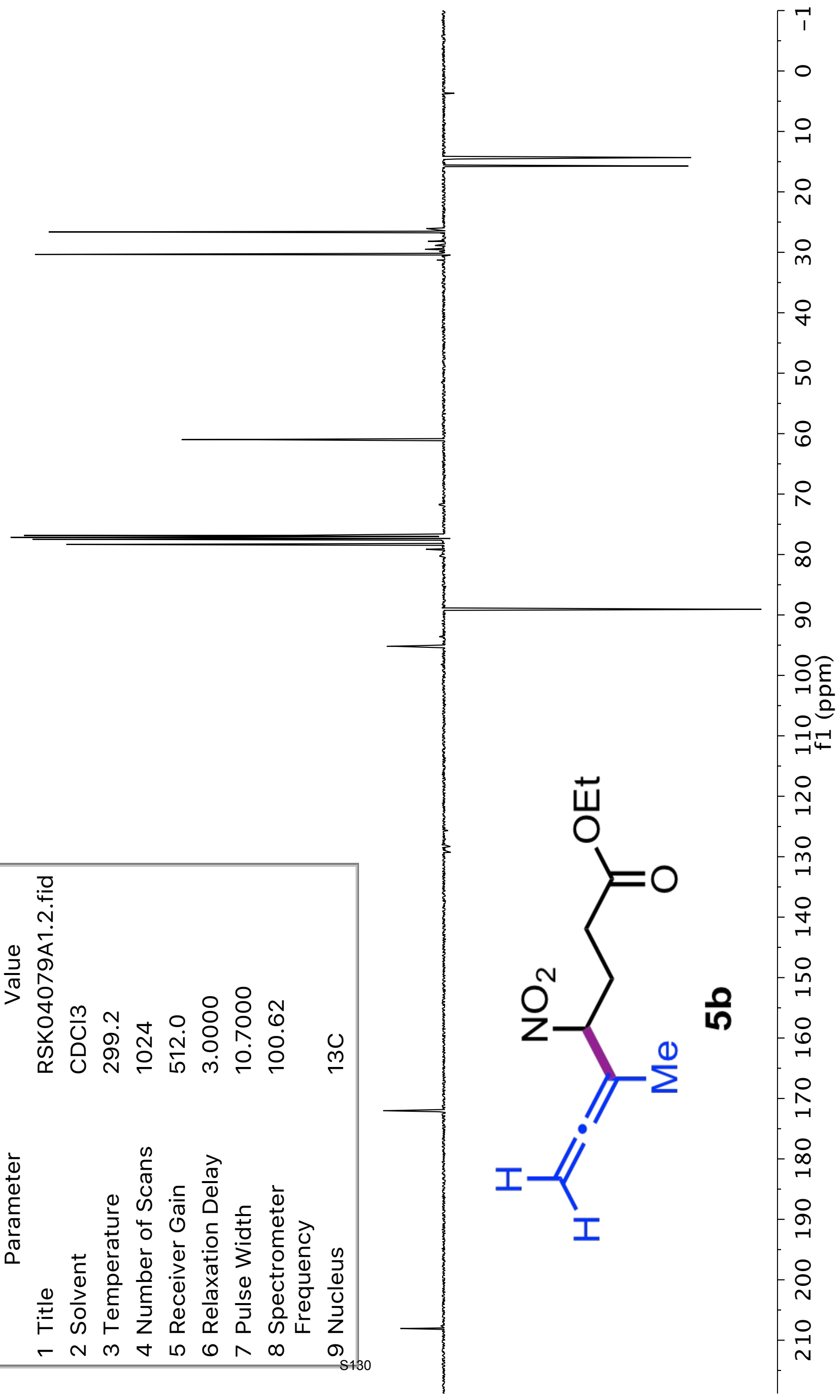




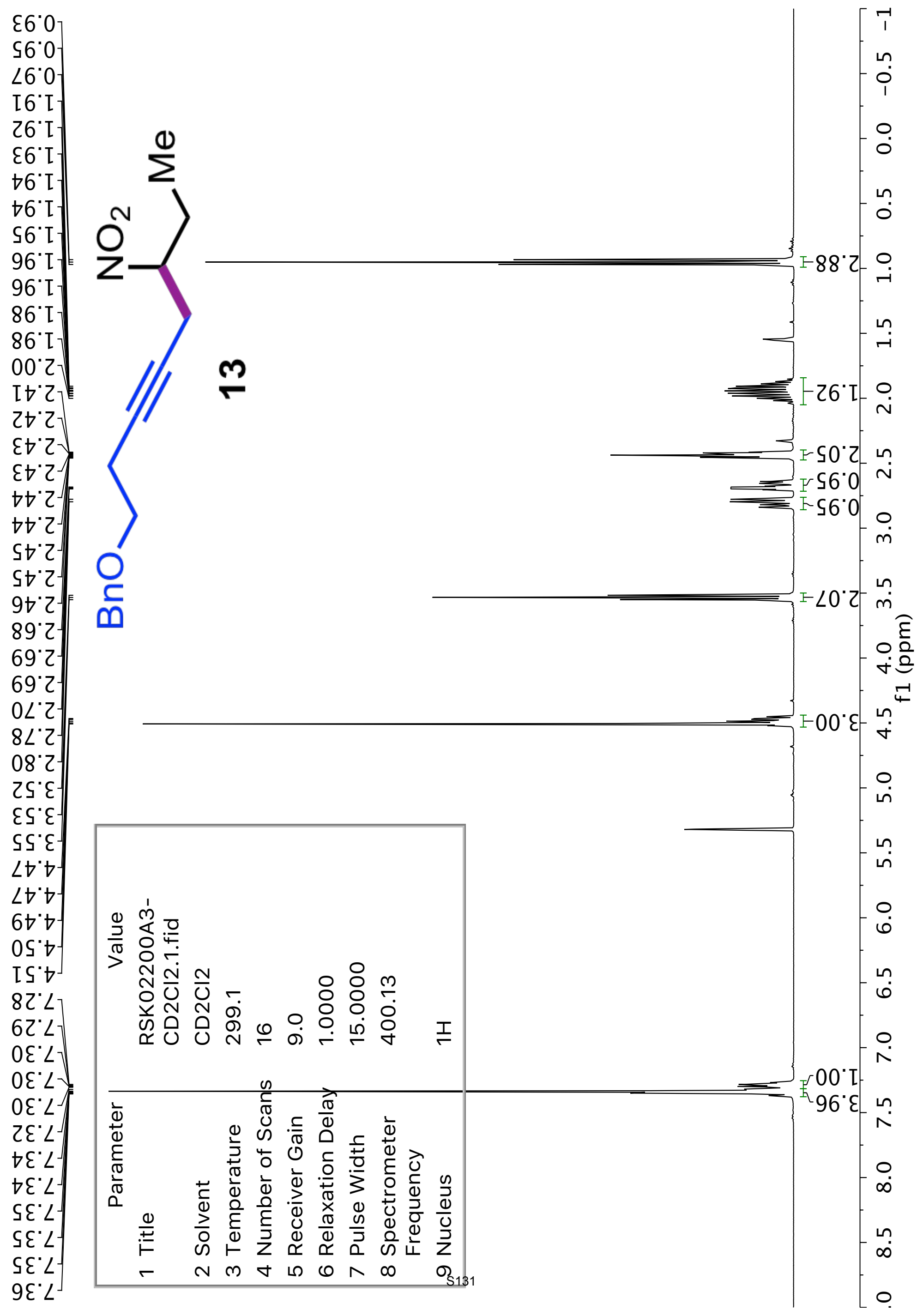


${ } \varepsilon^{\circ} 0 I-$

$\forall S^{\circ} 02-$

$00 \circ 2-$

I8.92-

$80^{\circ} 69^{-}$

$\left.\varepsilon \varepsilon^{\circ} \varepsilon L^{\prime}\right\}$
L6 $6^{\circ} \downarrow L^{\prime}$

$2 \varepsilon^{\circ} \mathrm{T} 8^{-}$

26.88
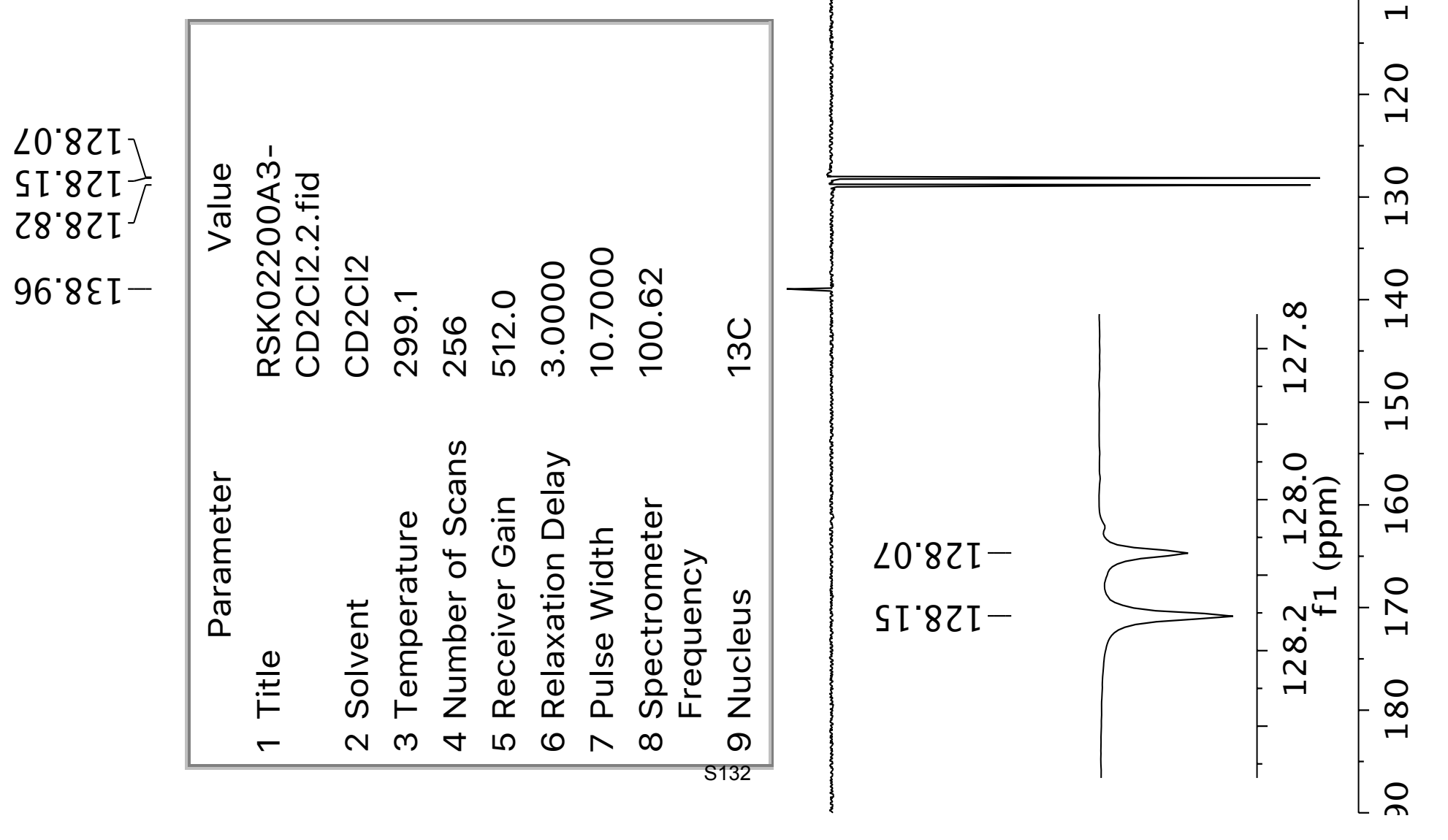


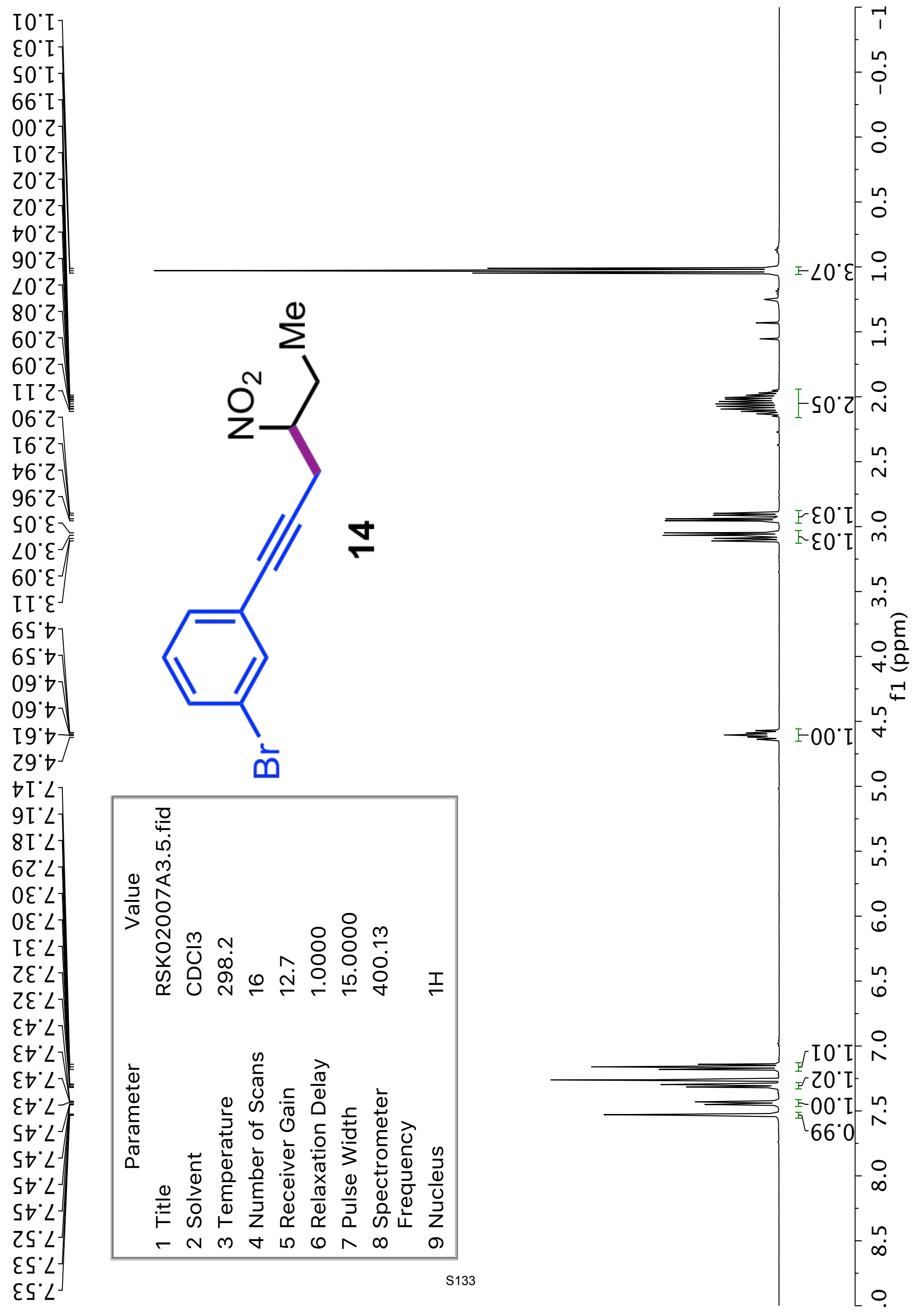


$8 \mathrm{I}^{\circ} 0 \mathrm{I}-$

$\forall I^{\circ} \nabla Z \sim$

$25^{\circ} 92^{-}$

$25^{\circ} 28$

$8 \varepsilon^{\circ} \circ 8^{-}$

$6 L^{\circ} \angle 8^{\prime}$

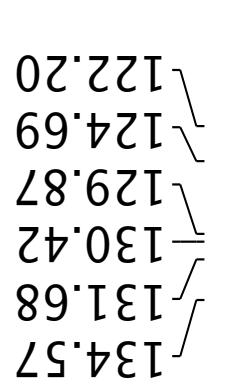

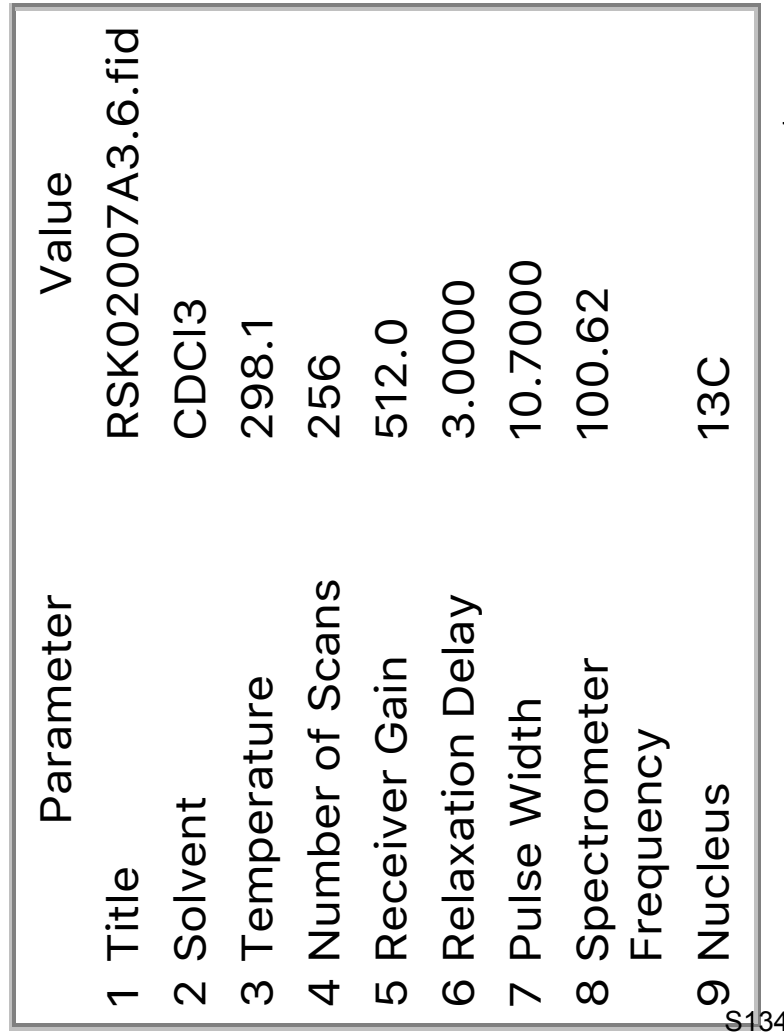

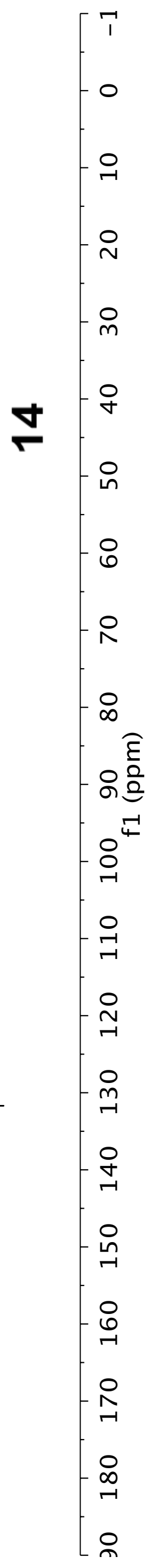




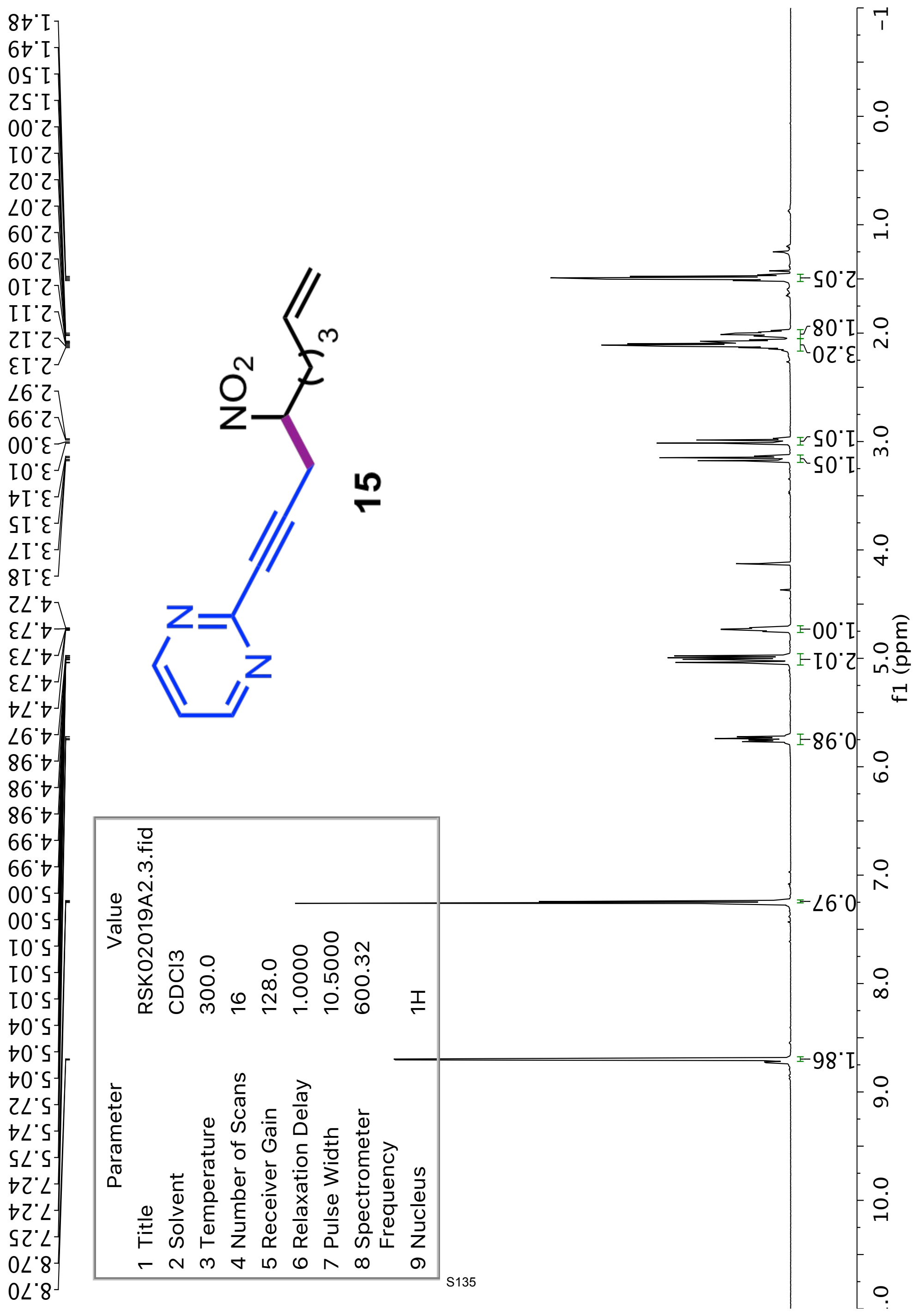


$81^{\circ} \nabla 2$

$\angle L^{\circ} \nabla z^{\prime}$

SS $2 \varepsilon_{2}$

$06^{\circ} 2 \varepsilon^{\jmath}$
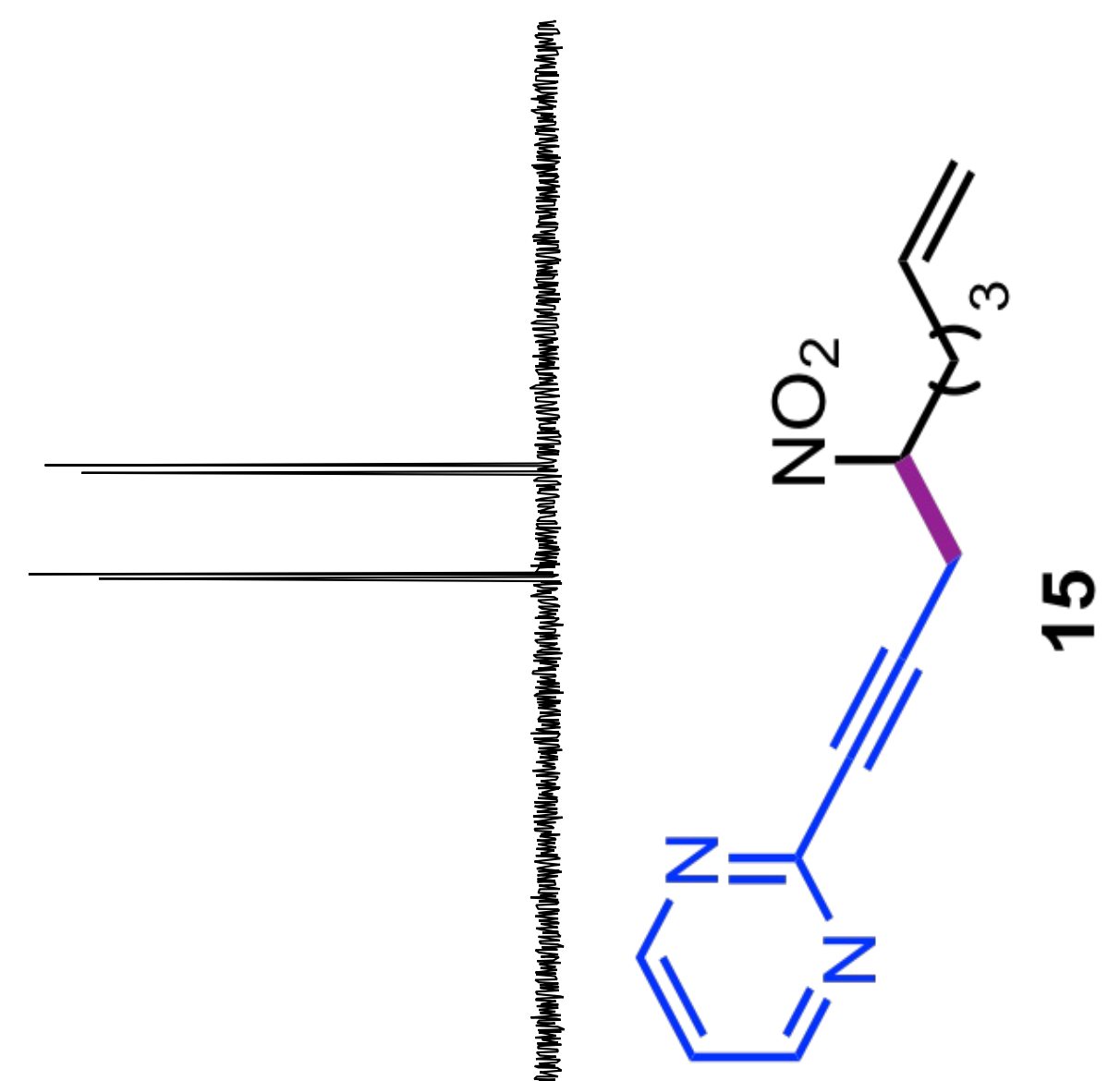

$27 \cdot 28$

$88^{\circ} 28^{\prime}$

$6 \mathrm{~S}^{\circ} \mathrm{S} 8^{\prime}$

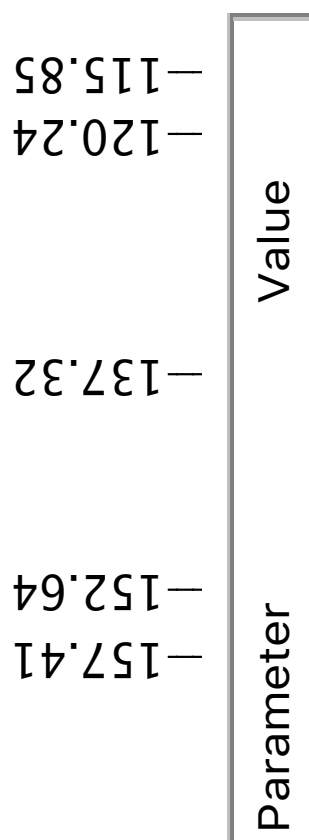

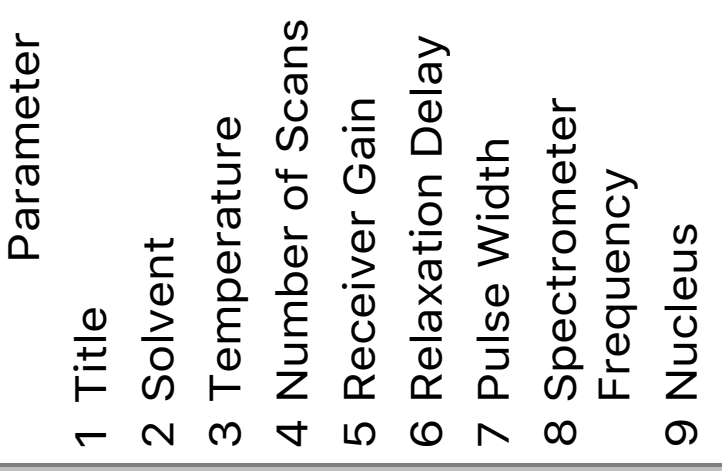

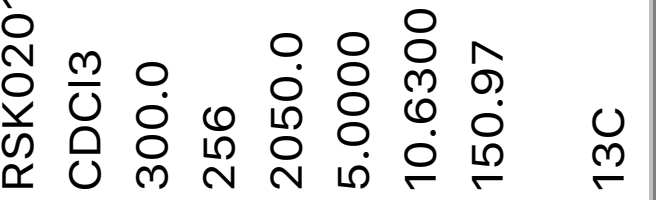




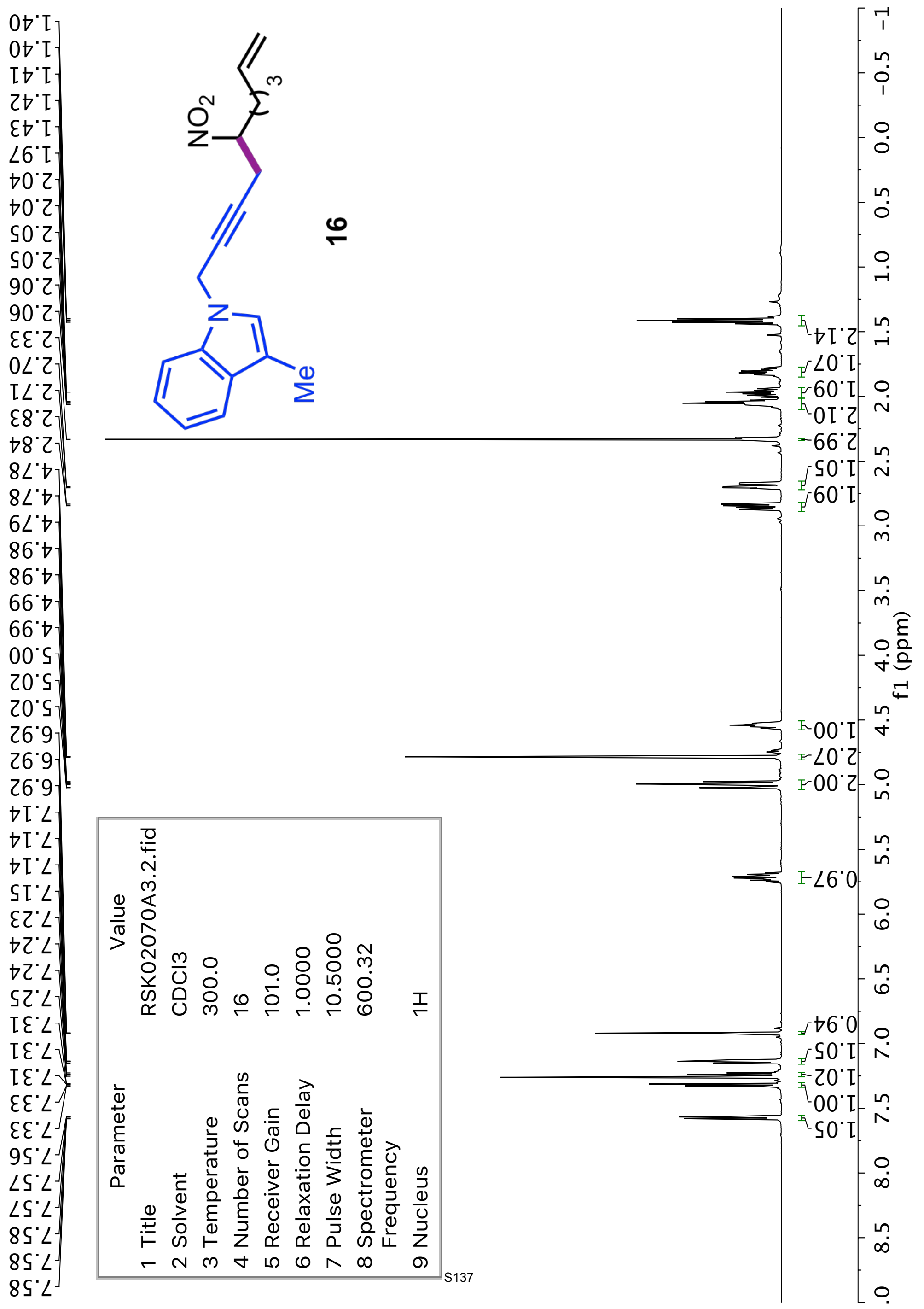




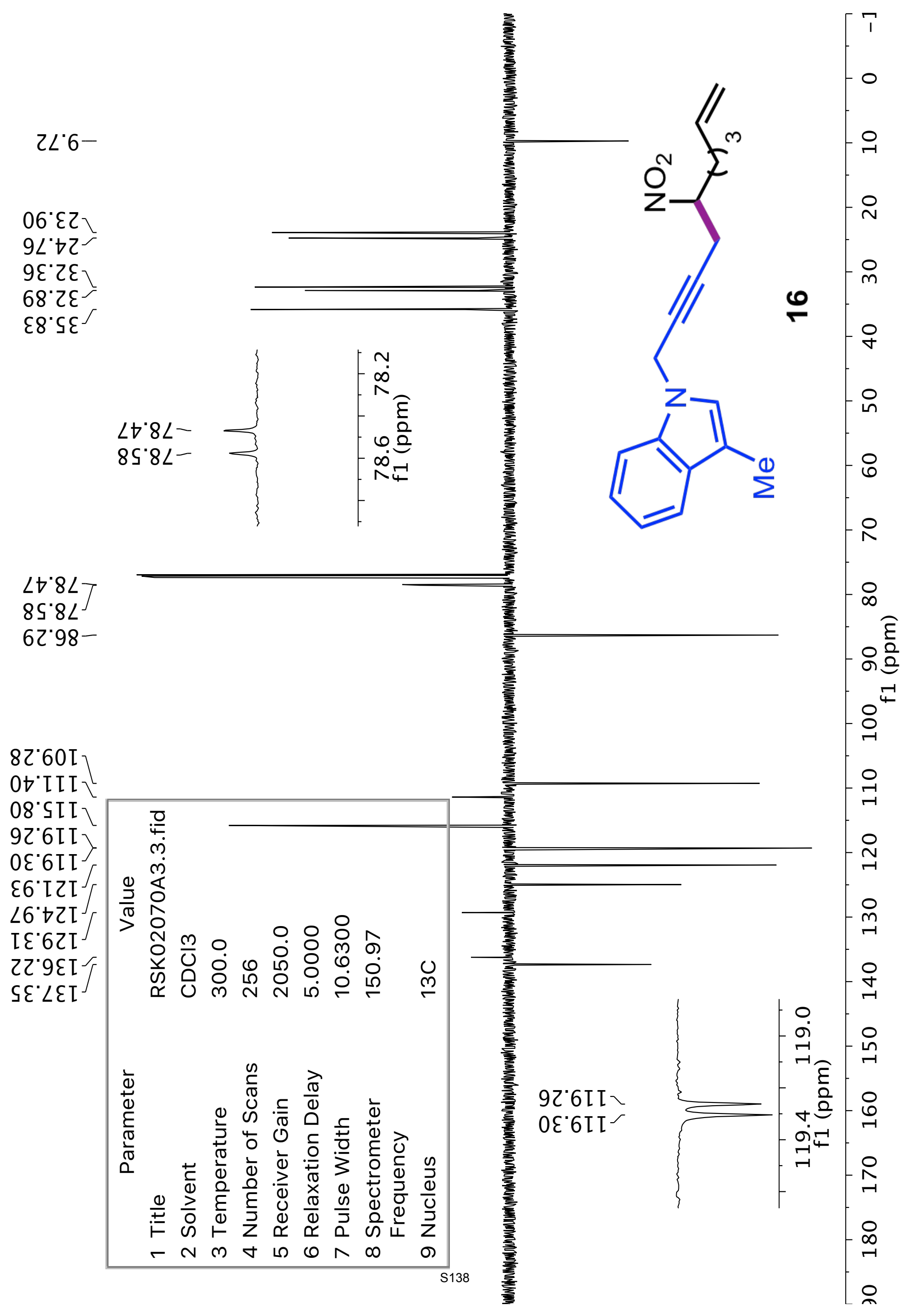




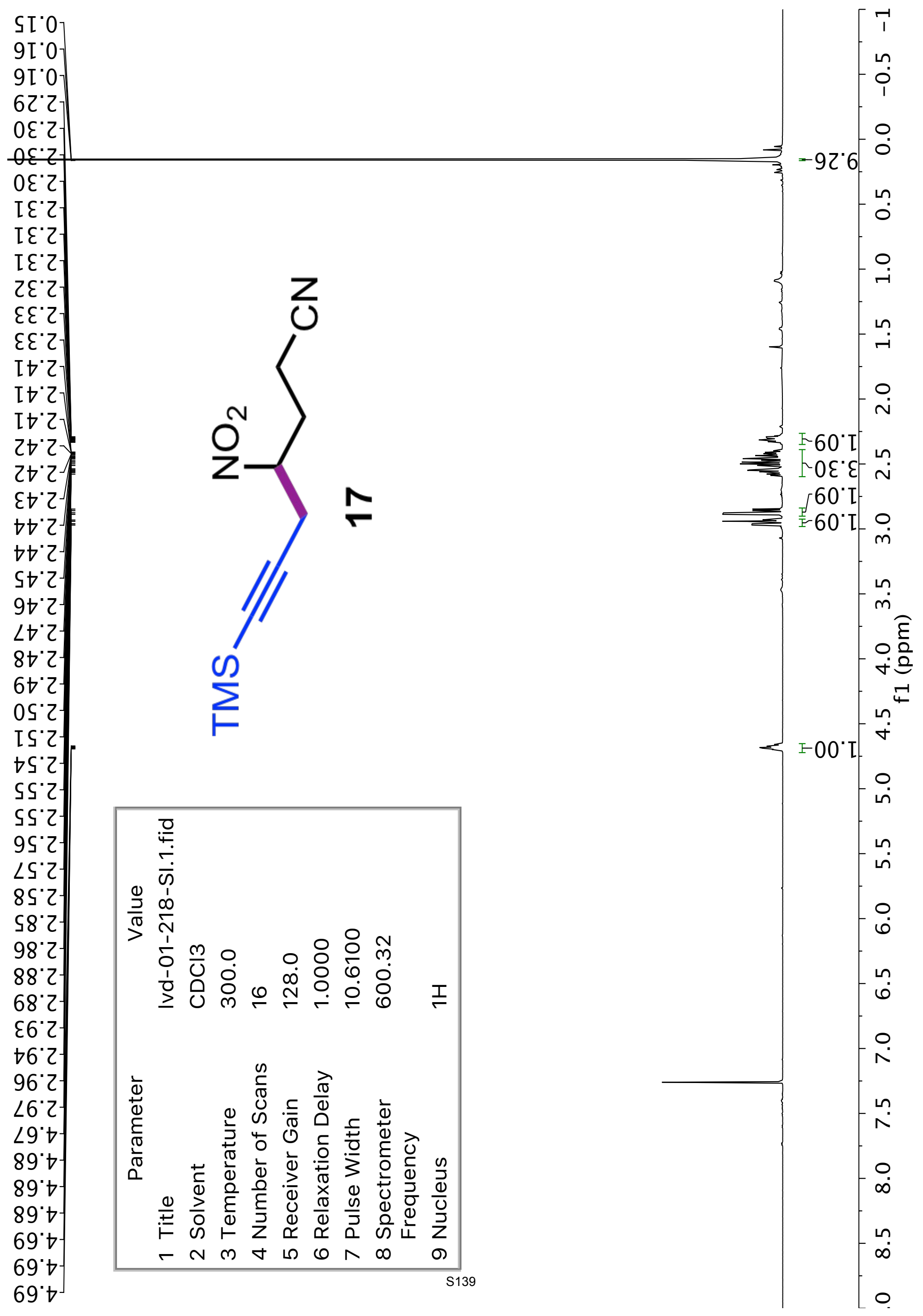


OL'0--

Sカ๋เ -

$\angle 8^{\circ} \circ 2$

8 I 82

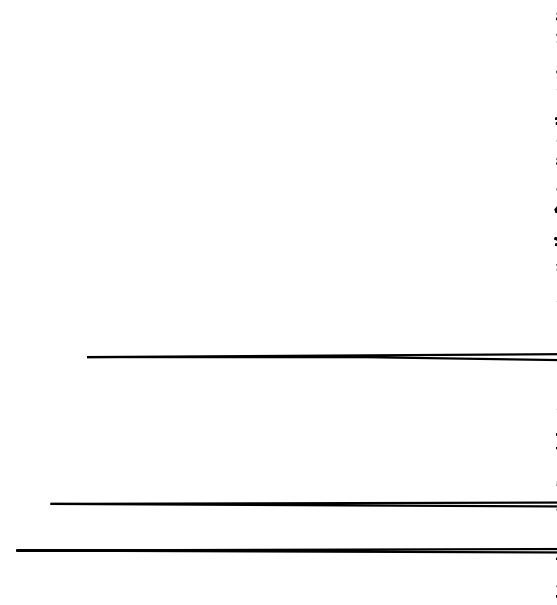

$S L \varepsilon 8^{\digamma}$

6L'06-

$28^{\circ} \angle 6$

$99^{\circ} \angle I I-$
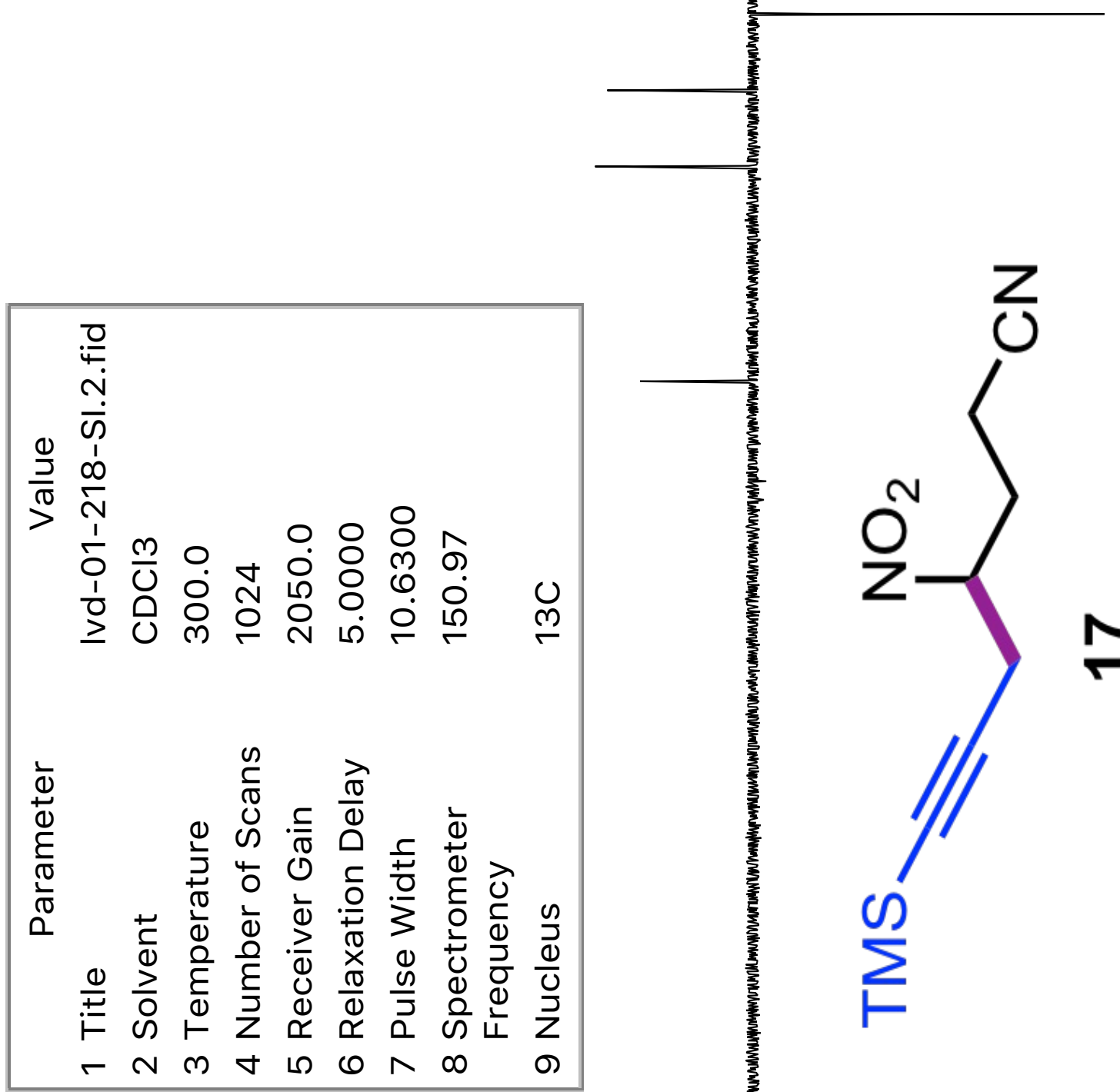

유를

욱

r

음

$\stackrel{\circ}{\mathrm{m}}$

움

윰

$\stackrel{0}{6}$

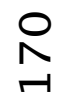

$\stackrel{\infty}{-1}$ 

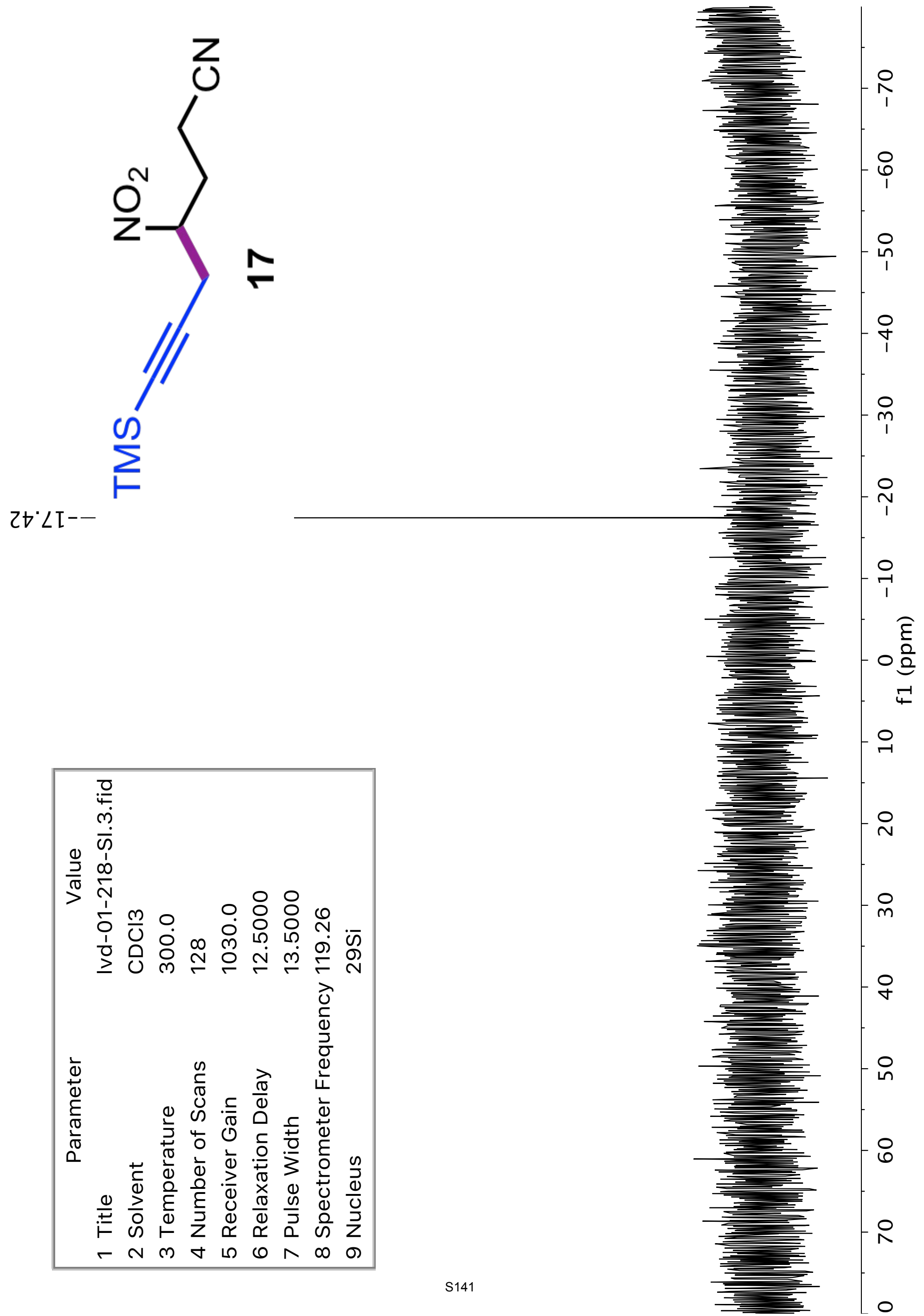


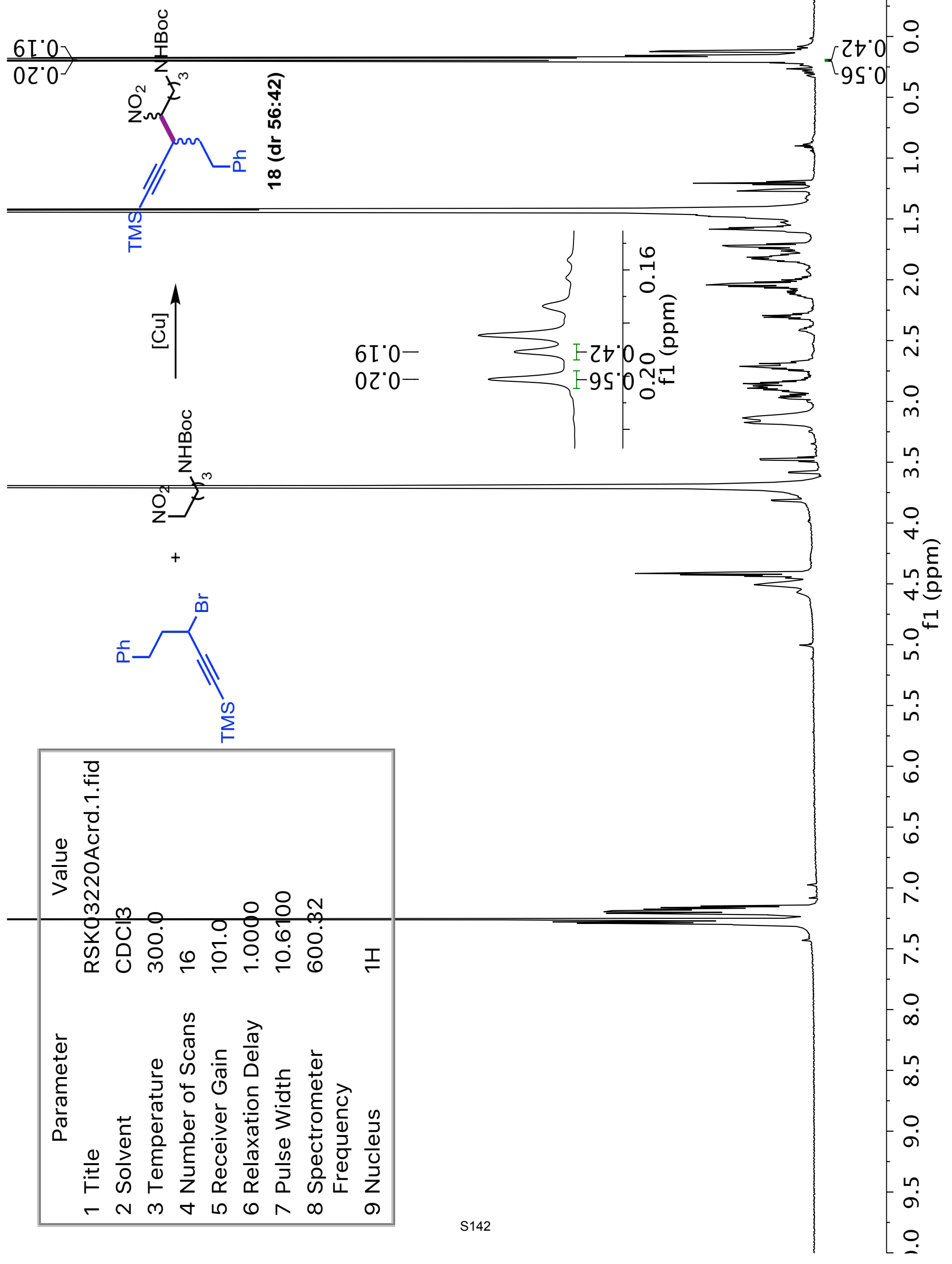




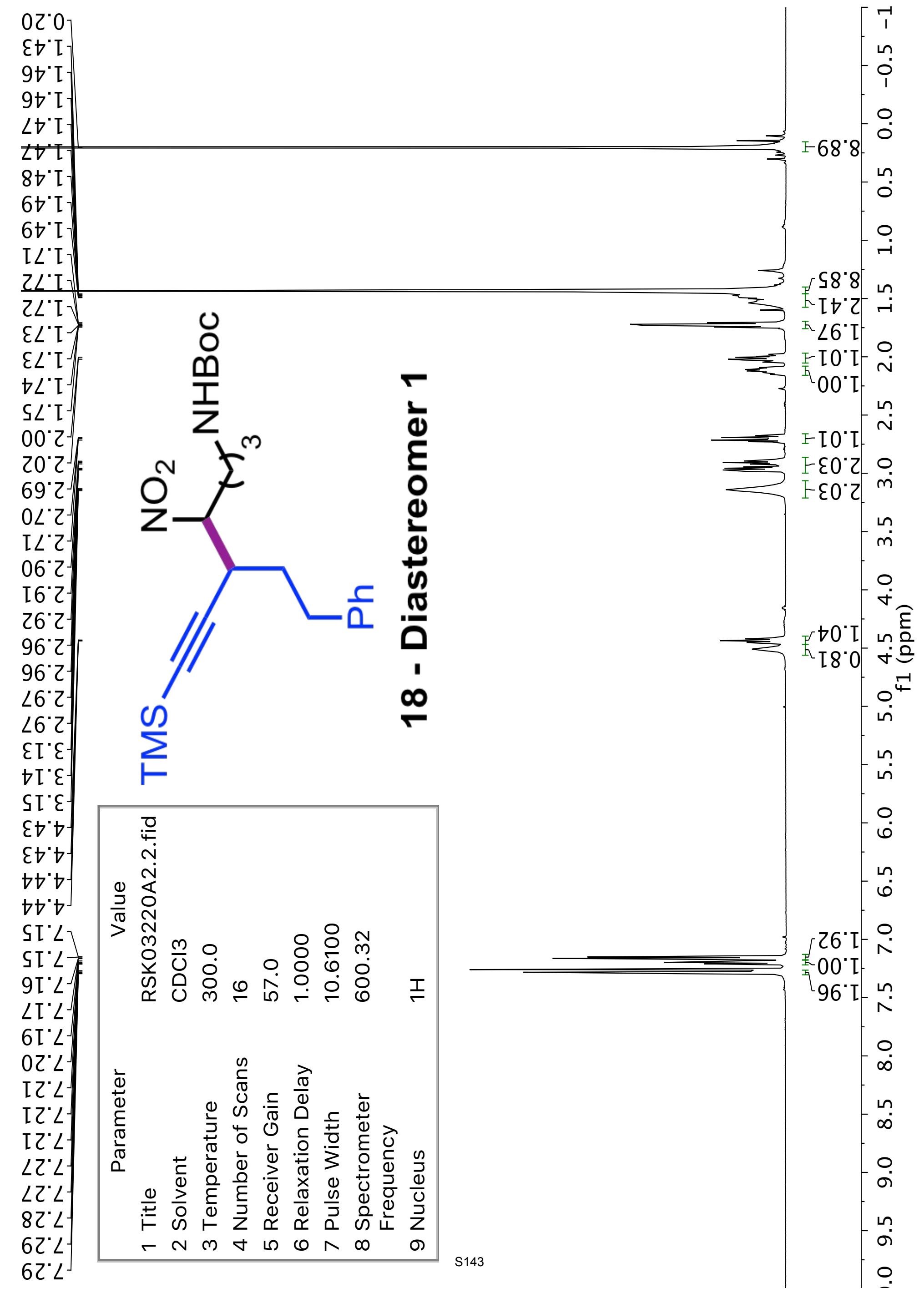




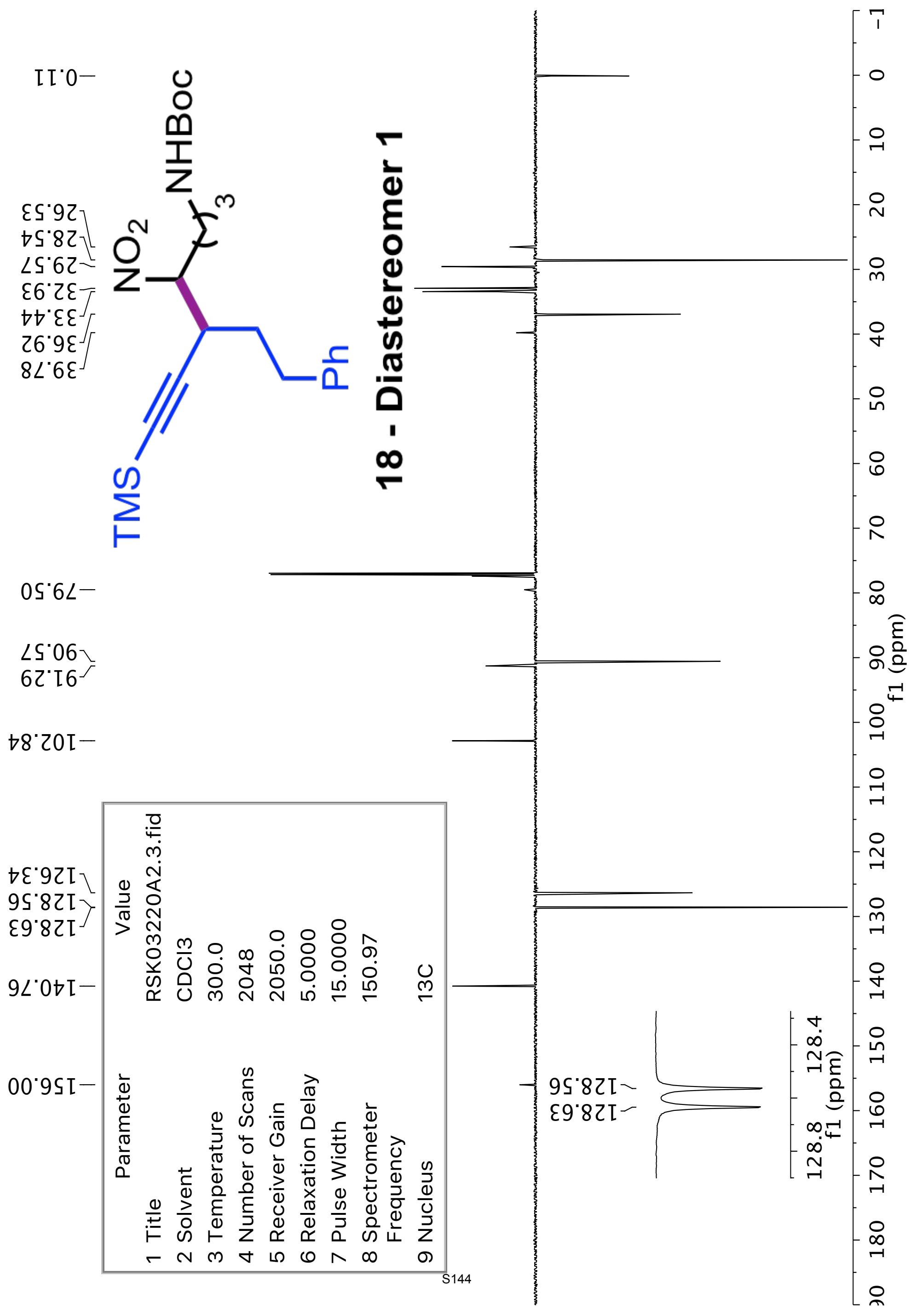



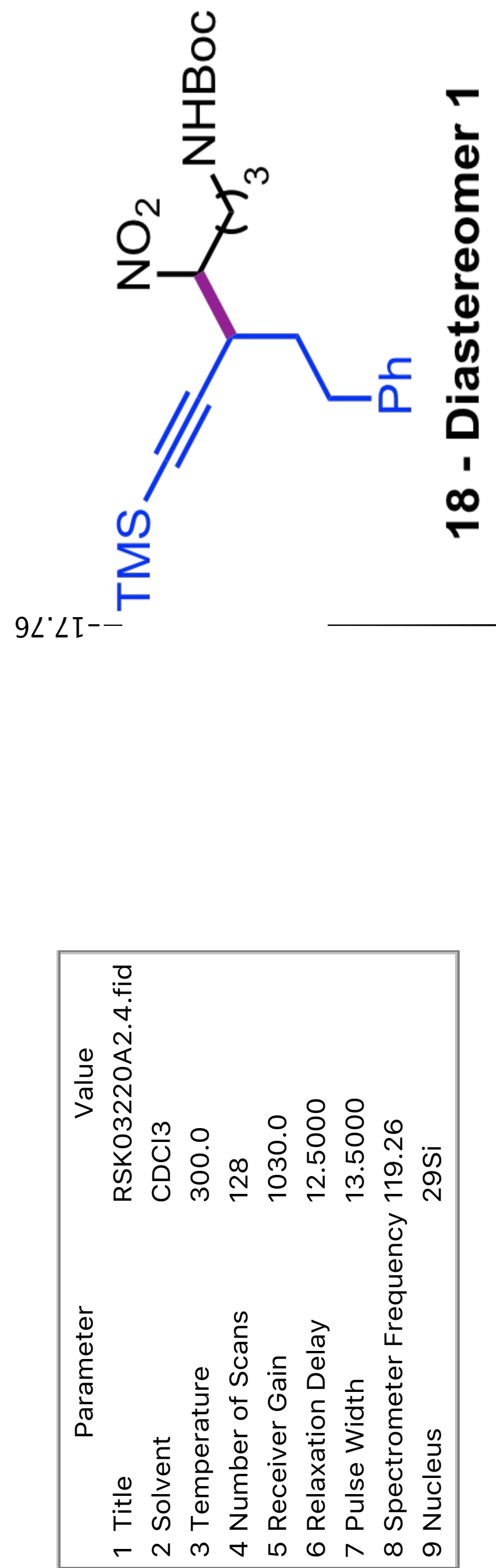


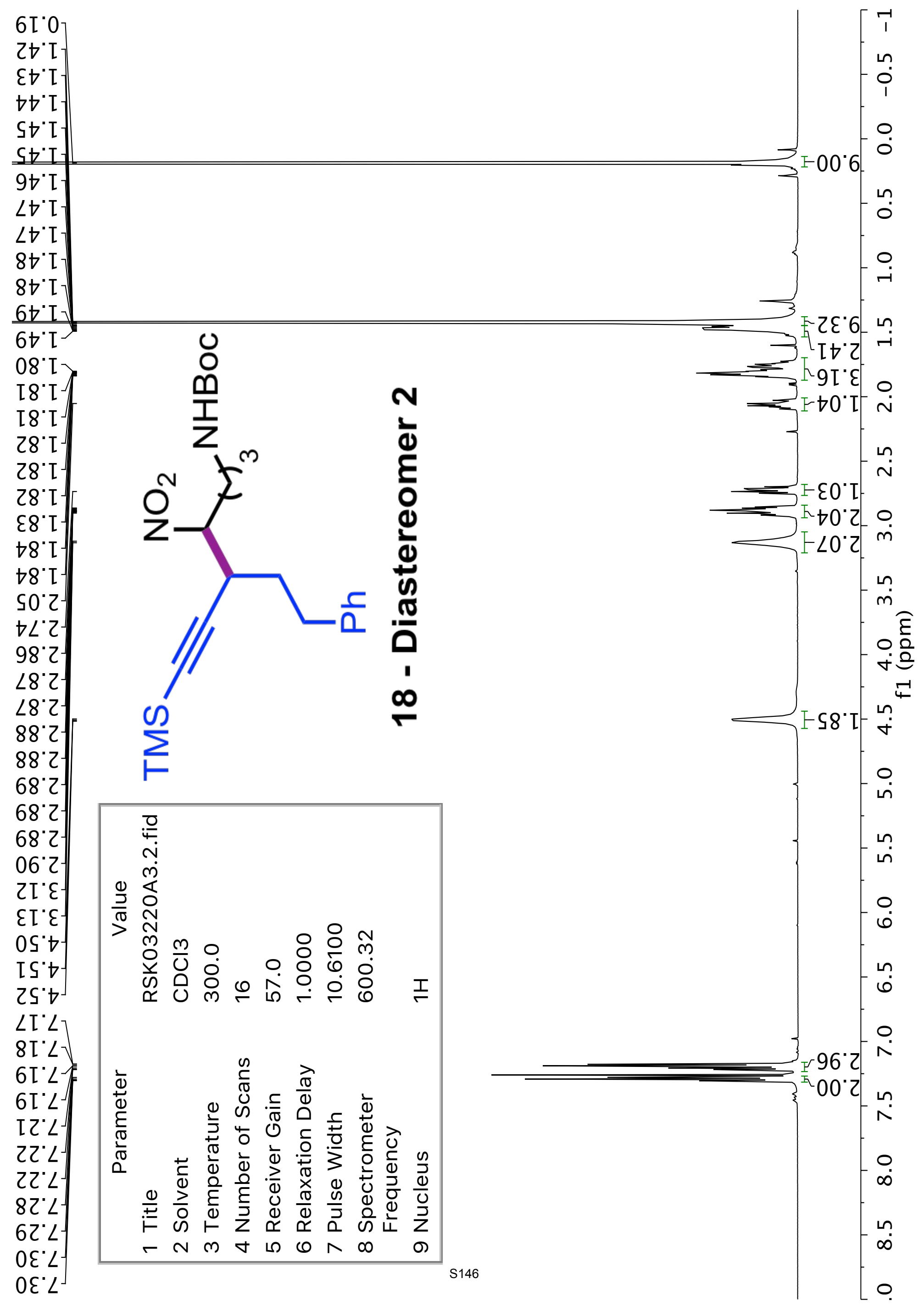




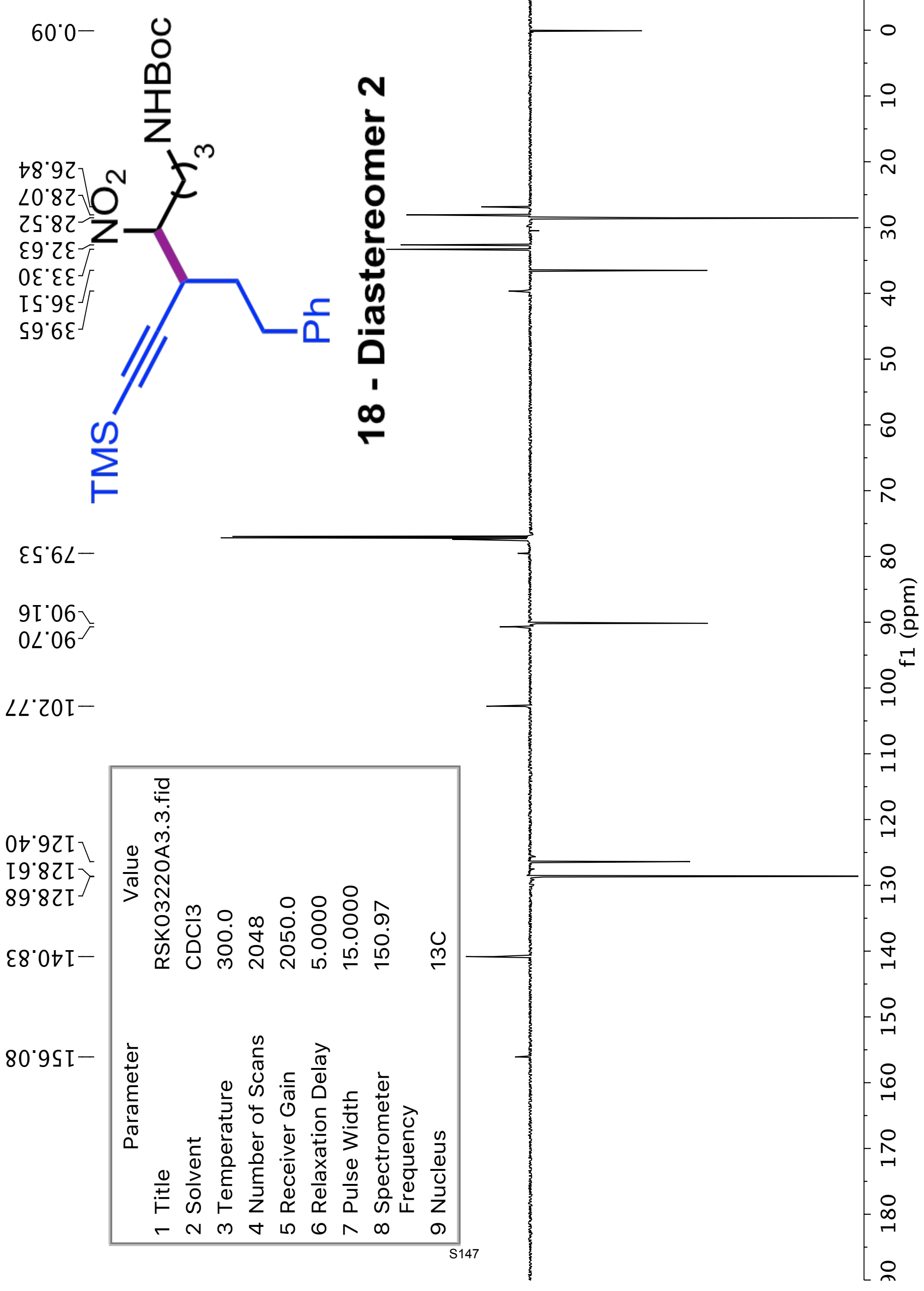



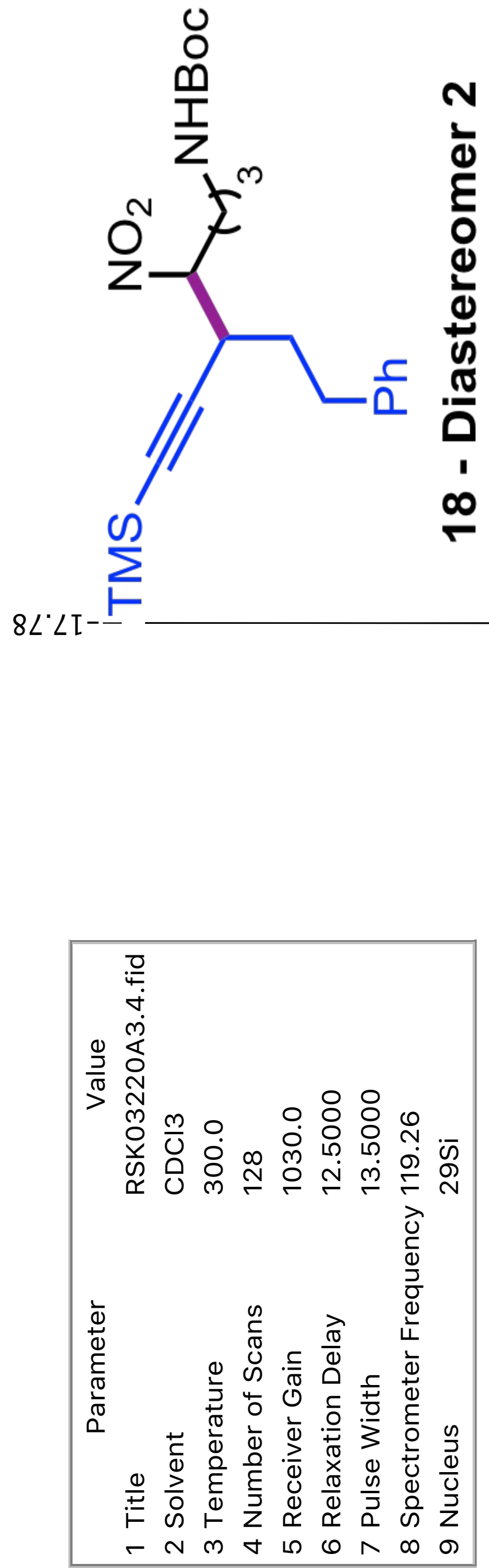


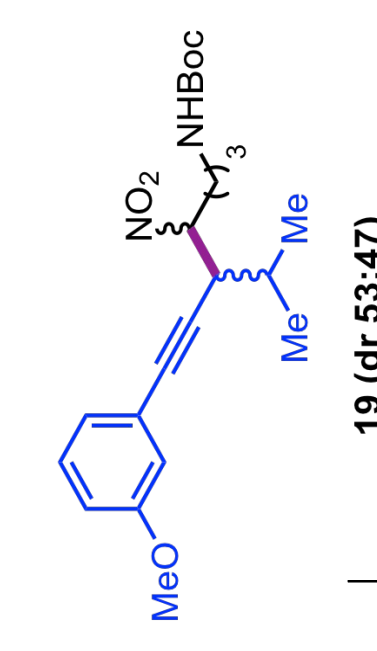

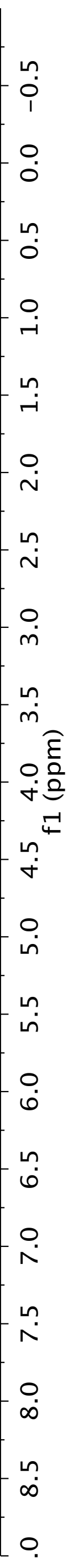




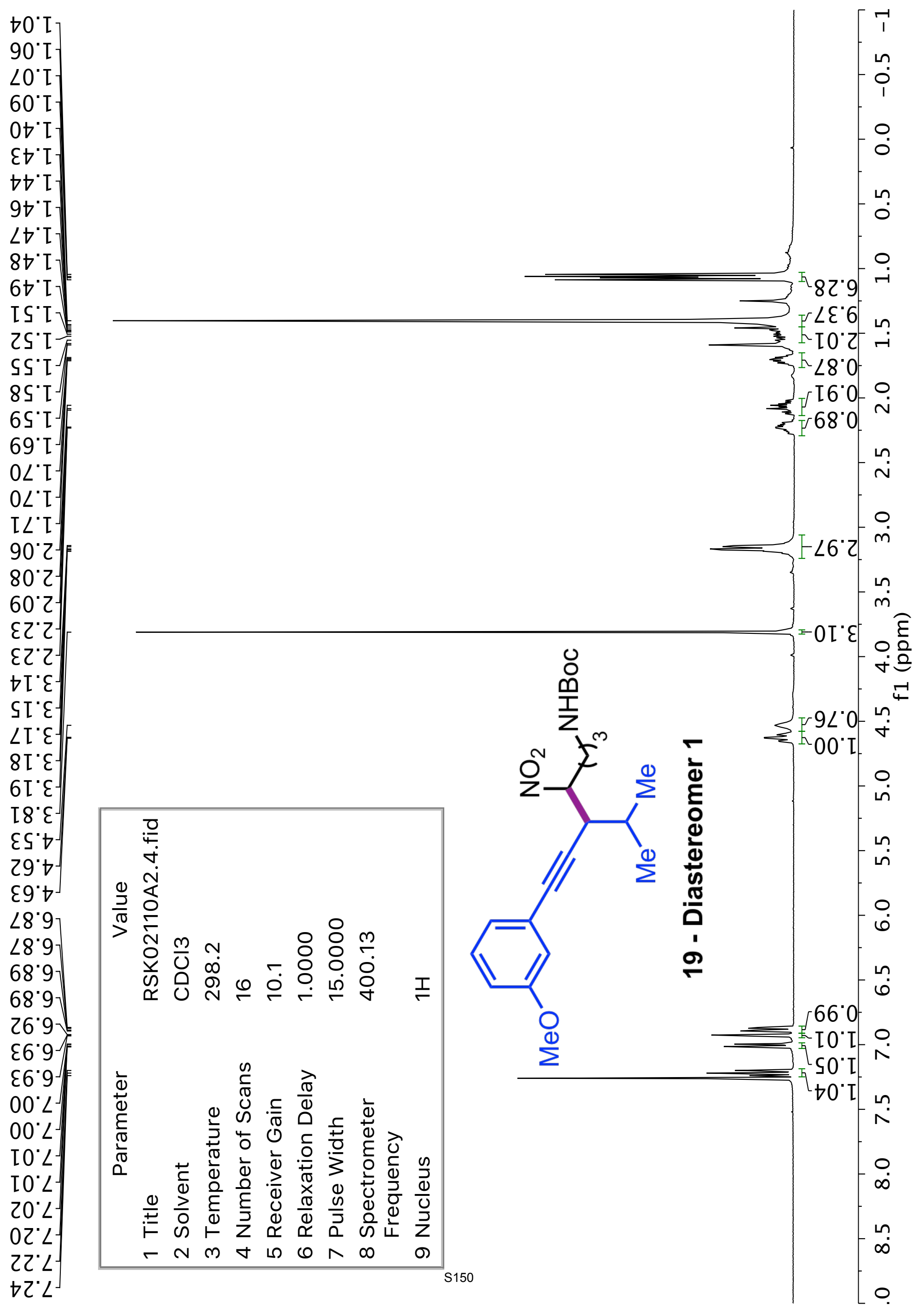




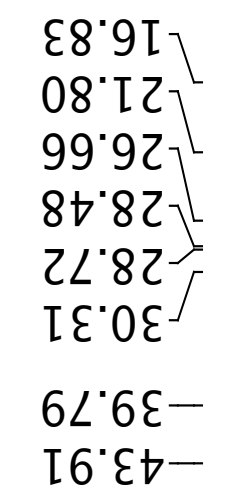

St'sS-

$05^{\circ} 6 \angle$
$02^{\circ}+8$
$05^{\circ} 98-$
$0 I^{\circ} 68^{-}$

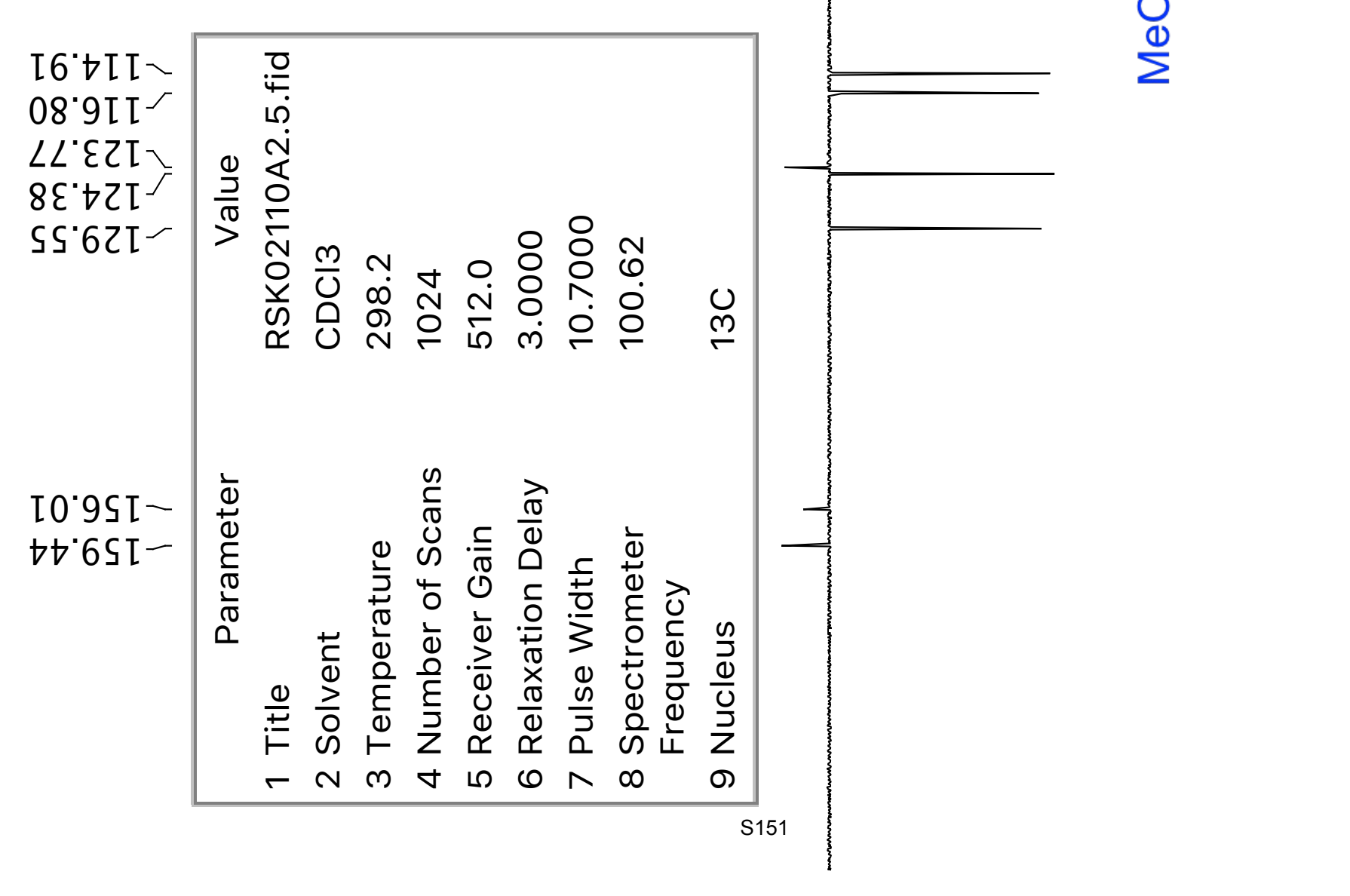




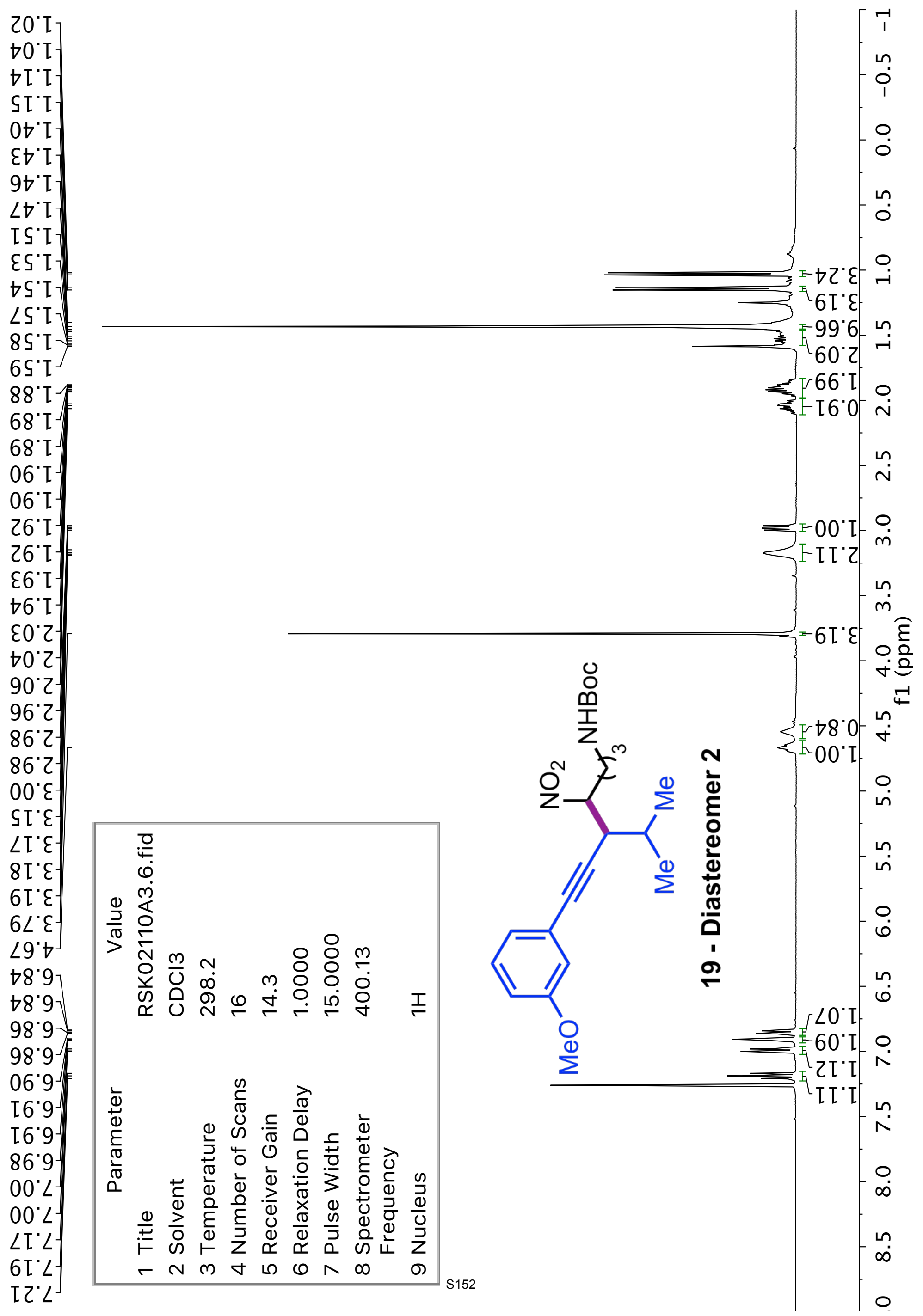




\section{$\varepsilon 0^{\circ} 8 \mathrm{~L}$
$88^{\circ} \mathrm{IZ}$
$5 L^{\circ}-\mathrm{Z}_{7}$ \\ $S \angle{ }^{\circ} 92$ \\ $\forall t 82]$ \\ $05^{\circ} 82-5$ \\ $\angle 82^{\circ}$ \\ $99^{\circ} 6 \varepsilon-$

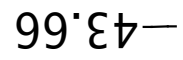

દ†'ડs-

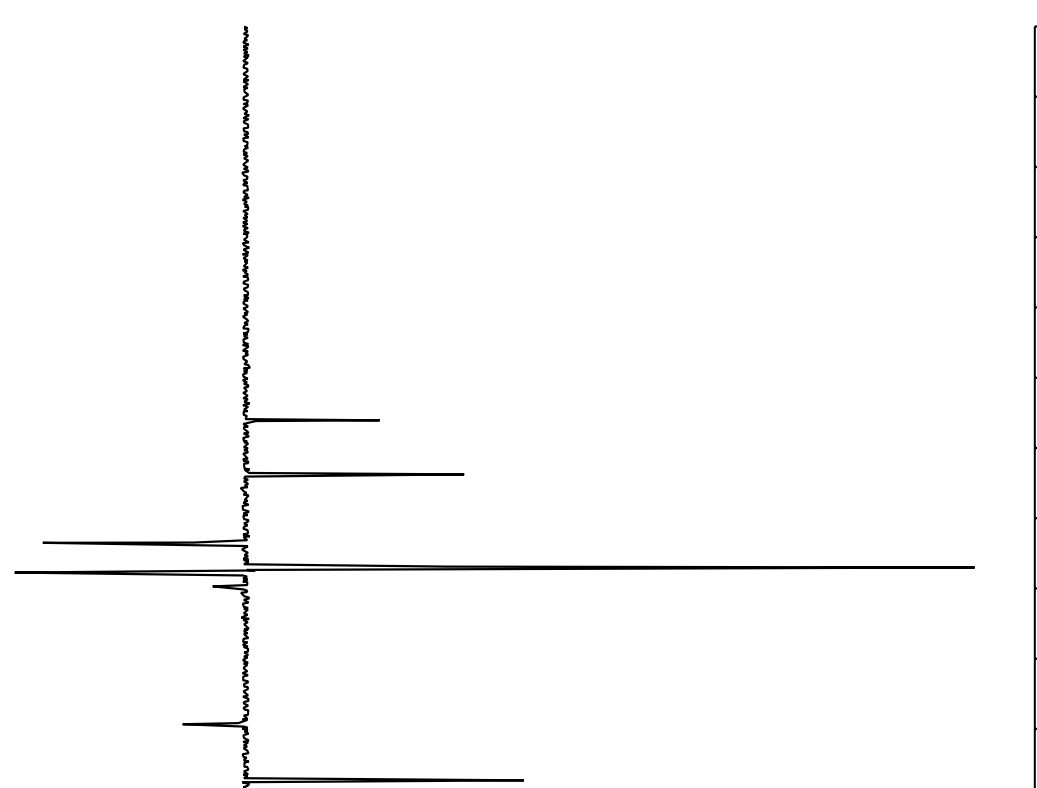

$09^{\circ} 6 \overline{\bar{L}}$ $\angle S^{\circ} \square 8$

[0.98$8 L^{\circ} 68^{\prime}$

$\nabla 6^{\circ} \downarrow \mathrm{II}$ S9.9 I I $\downarrow 6^{\circ} \varepsilon Z \mathrm{I}$ $8 \nabla^{\circ} \bullet Z L^{J}$ $0 t^{\circ} 6 Z^{-}$
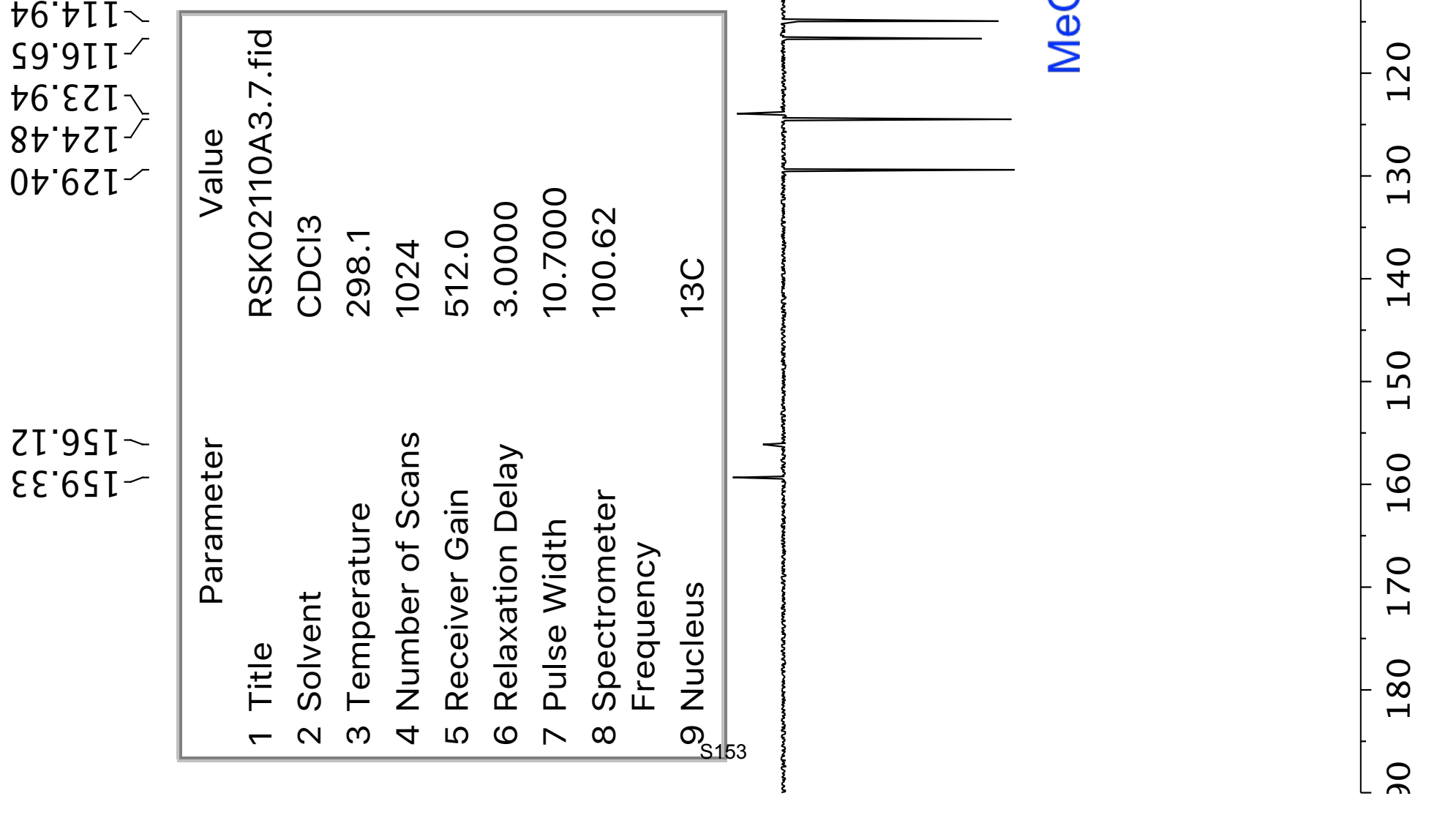


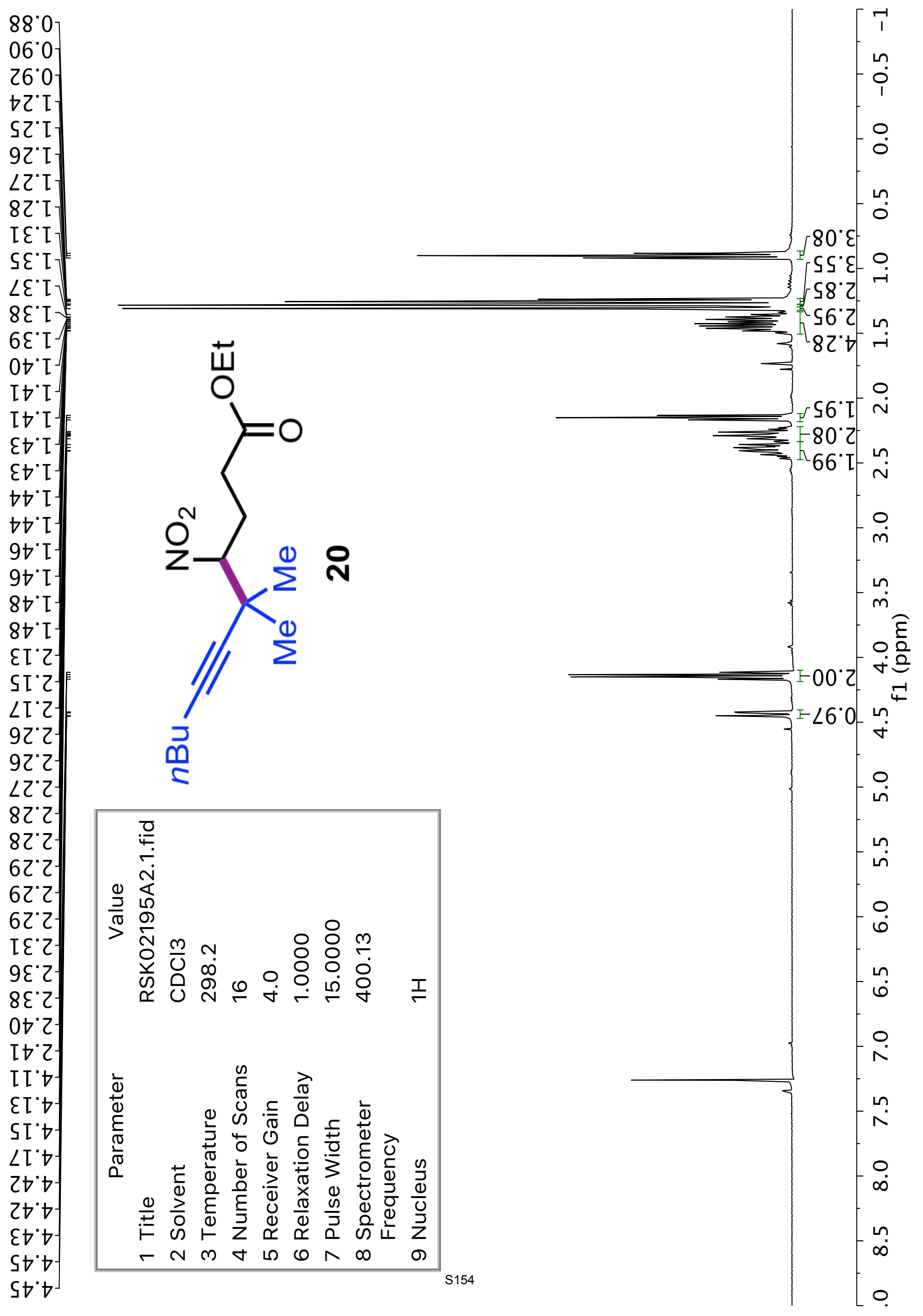


$\varsigma L^{\prime} \varepsilon[$

$\left[\varepsilon^{\circ} \nabla[]\right.$

$27^{\circ} 8 \mathrm{~L}$

00.22

$06^{\circ} \circ 2$

$58.52-$

$87^{\circ} \angle Z^{5}$

$S \angle L^{\circ} O \varepsilon^{-}$

$\angle 6^{\circ} 0 \varepsilon^{\circ}$

9I'ऽ $\varsigma$

†6.09-

08. 18 -

५ $8^{\circ} \varepsilon 8^{-}$

9I'ง6-
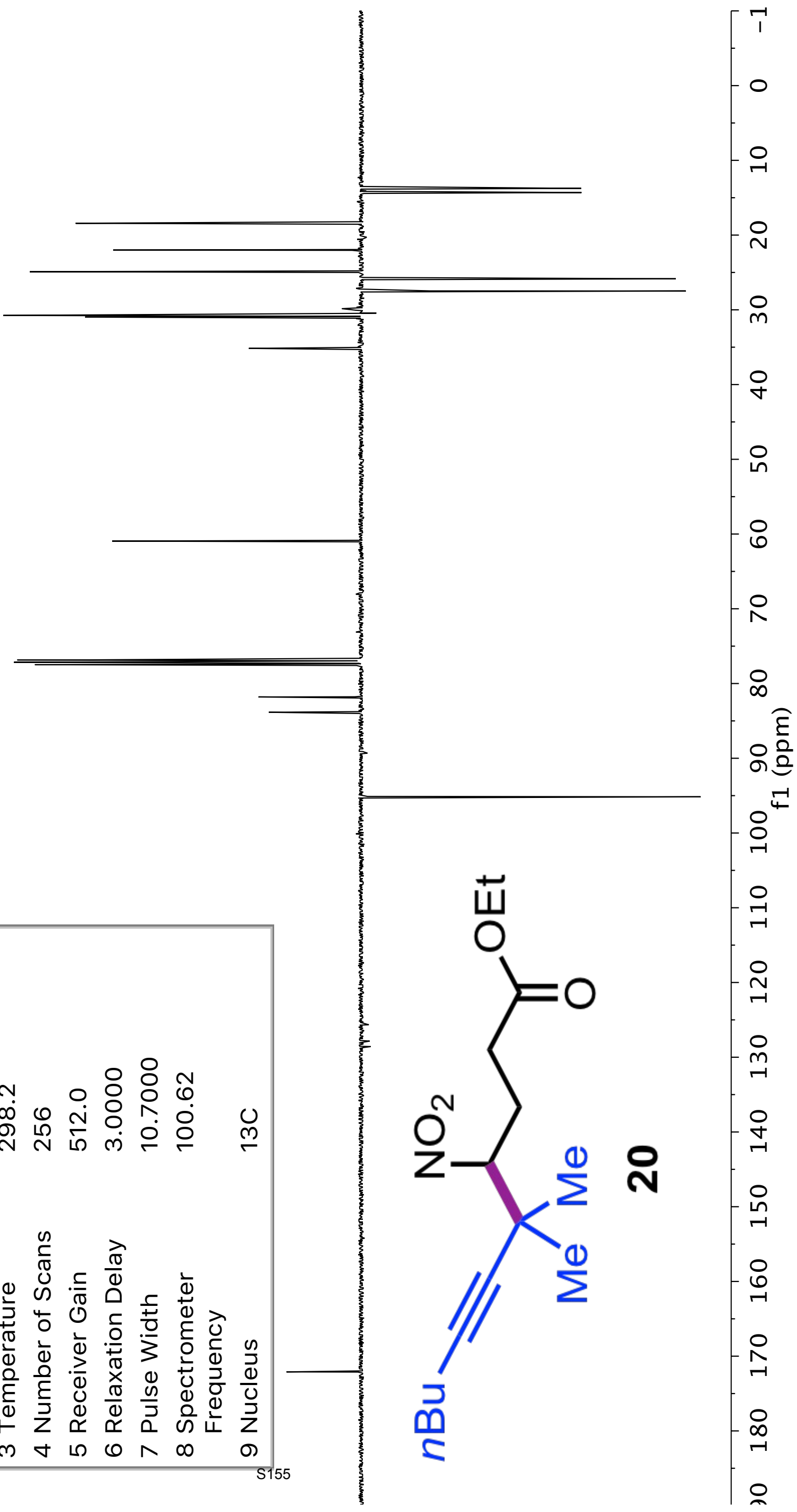

$\frac{7}{2}$

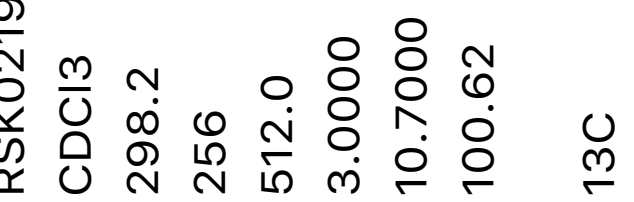

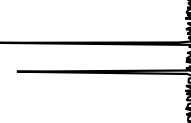

$0 I^{\prime} 2 \angle I-$

$\frac{\bar{d}}{\stackrel{ \pm}{0}}$
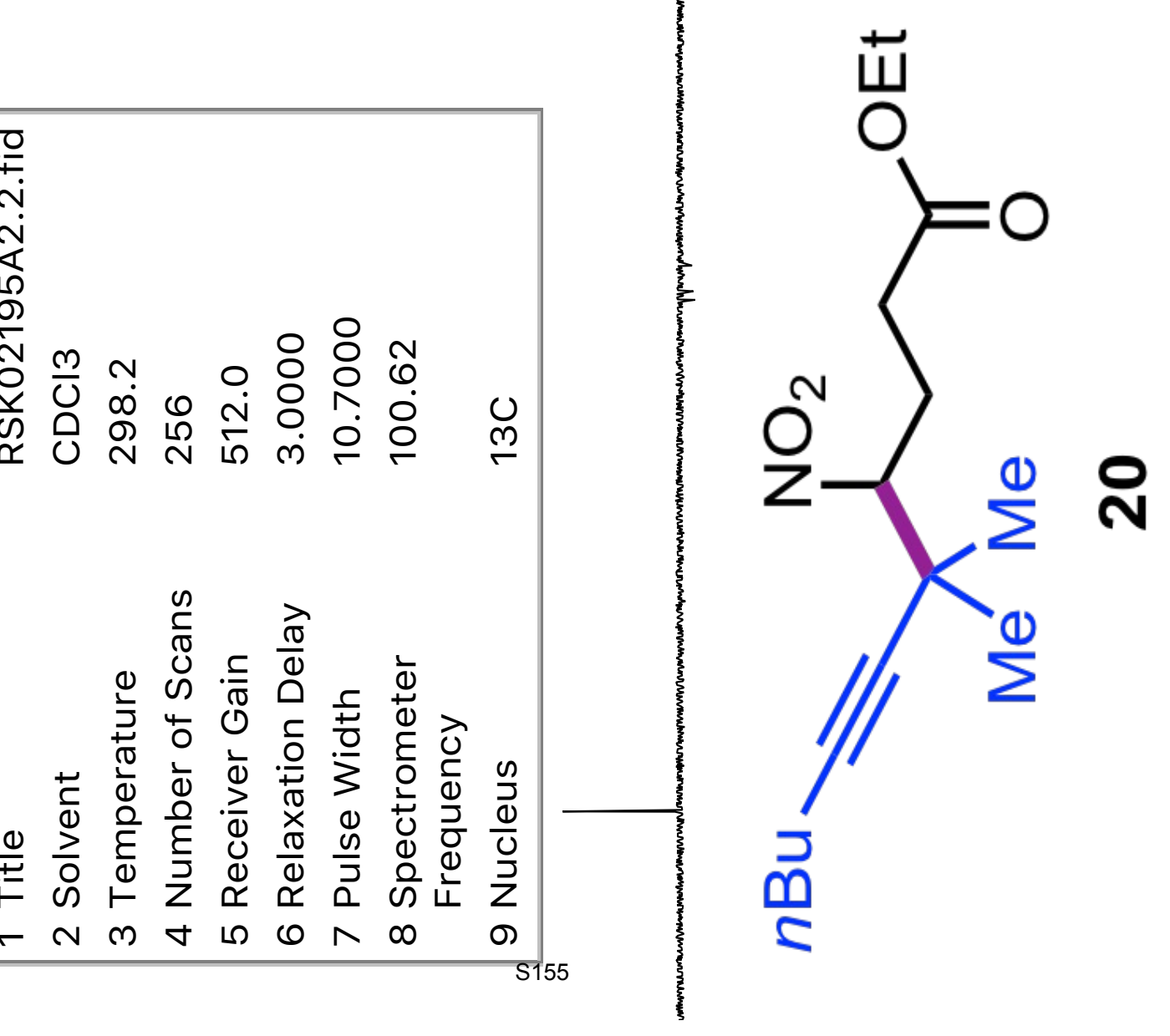


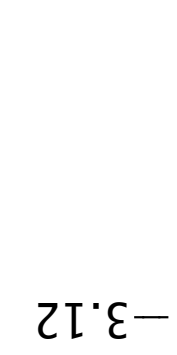

$6 \varepsilon^{\circ} \angle$

$0 t^{\circ} \angle$

$\left[t^{\circ} \angle\right.$

$9 t^{\circ}<$

$8 t^{\circ} \angle$

$6 t^{\circ} \mathrm{L}=$

$\nabla S^{\circ} \circ$

$S S^{\circ} L$

$\varepsilon 9.4$

$79^{\circ} \mathrm{L}$

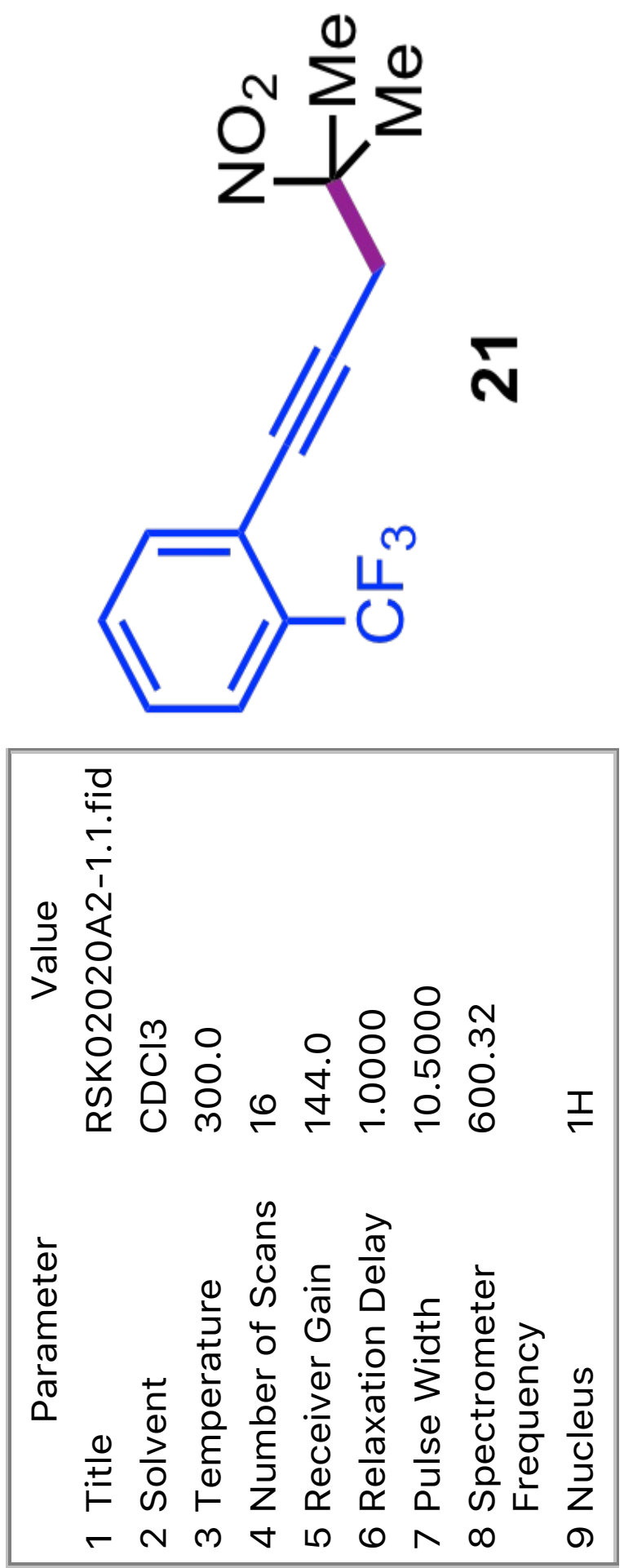

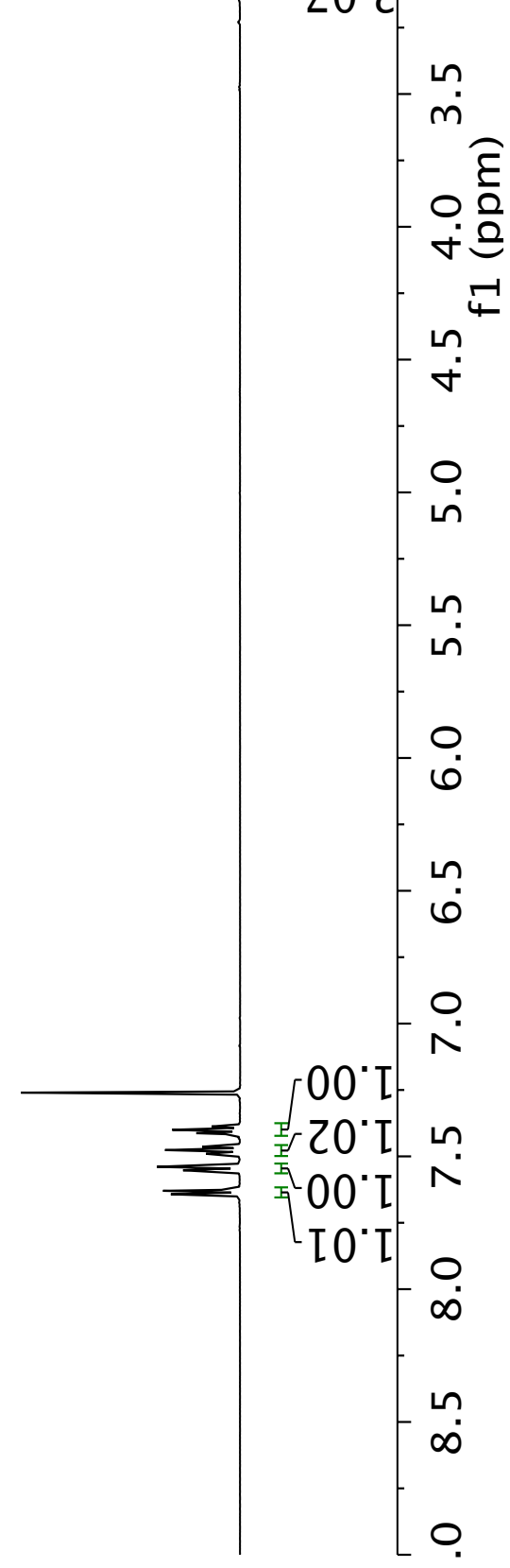


09ऽて-

$06^{\circ}$ ' $\varepsilon-$

દ2.08-

$80^{\circ} \angle 8 \backslash$

05.68-

\&6.0ZI

$\angle I^{\circ}$ IZI

8I'IZI

OZ'LZL]

IZ'IZI

$\forall \angle ' Z Z[$

SS" $\nabla 2[$ ]

$\left.\angle 8^{\circ} \varsigma 2 L\right]{ }^{E}$

$06^{\circ} \mathrm{SZL}$

\&6. SZI

$\angle 6^{\circ} \mathrm{S} \mathrm{II}$

98.9Z [

IZ'8ZL

ZI'TEI-

$9 \varepsilon^{\circ}$ 'L I-

SS'IEI-

$\angle L ' I \varepsilon I$ -

$\angle 6^{\circ}$ IEI-

$\nabla \varepsilon^{\circ} \nabla \varepsilon[$

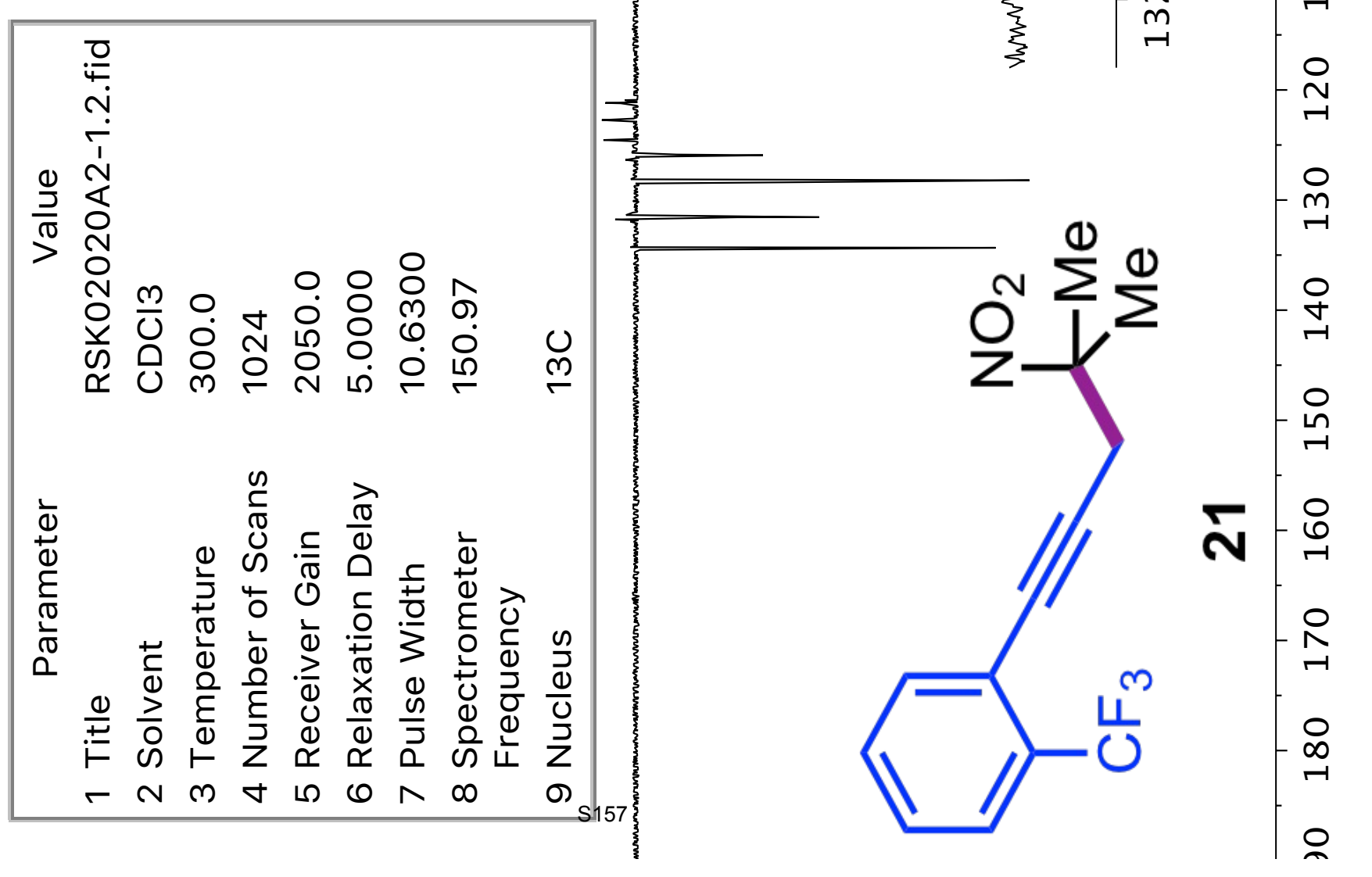




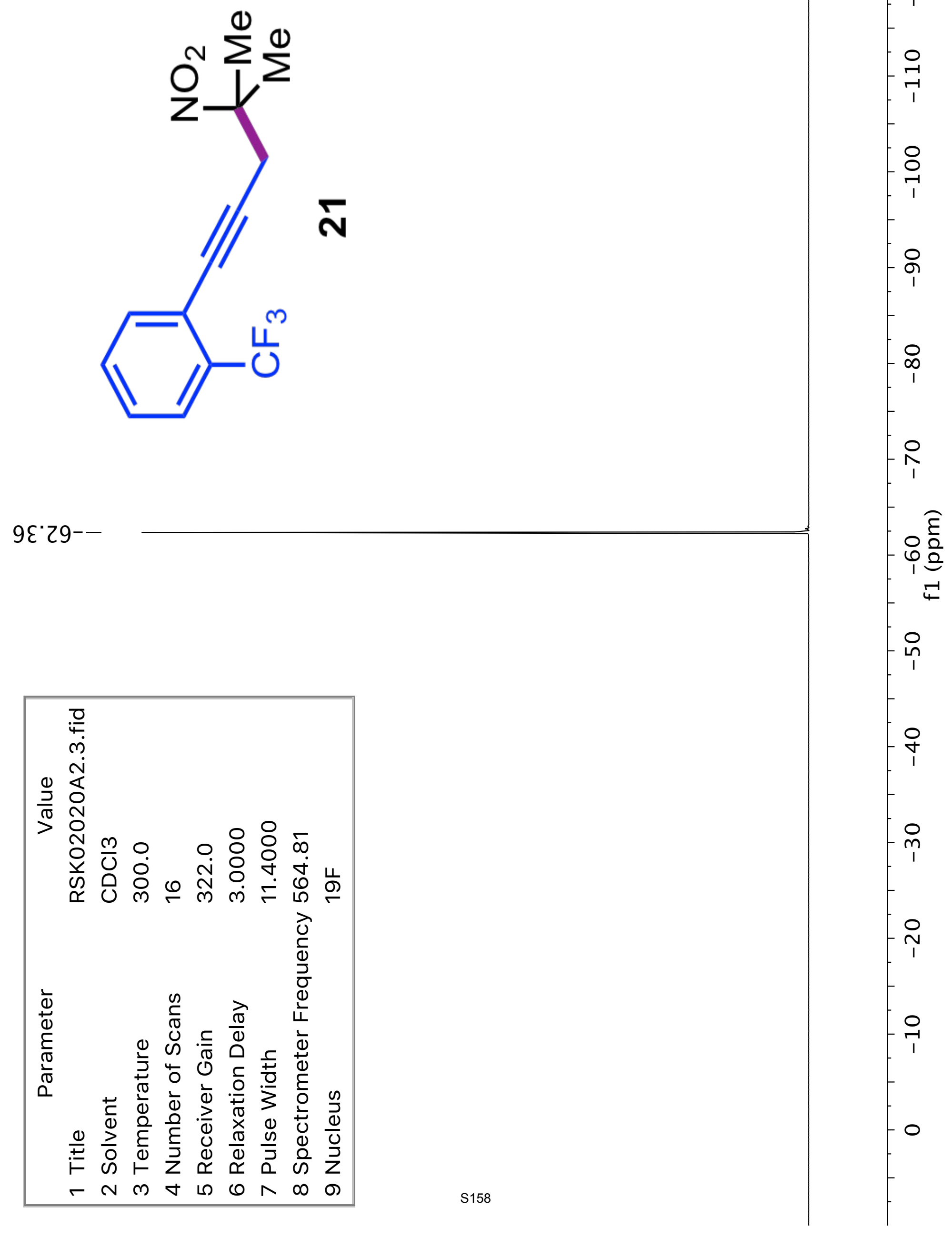




\section{$\varepsilon L^{\prime} I-$}

$\varepsilon \varepsilon^{\prime} 乙-$

$\angle 0^{\circ} \varepsilon-$

$90^{\circ} \mathrm{L}$ $90^{\circ} \mathrm{L}$ $\angle 0^{\circ} \mathrm{L}$ $80^{\circ} \mathrm{L}$ $80^{\circ} \mathrm{L}$ $\angle \mathrm{I}^{\circ} \mathrm{L}$ $\angle T^{\circ} \angle$ $8 \mathrm{I}^{\circ} \mathrm{L}$ $8 I^{\circ} \mathrm{L}$ $6 \mathrm{I}^{\circ} \mathrm{L}$ $6 \mathrm{I}^{\circ} \mathrm{L}$ 乙E' $\angle$ $2 \varepsilon^{\circ} \angle$ $\varepsilon \varepsilon^{\circ}\llcorner]$ $\varepsilon \varepsilon<$ $\varepsilon \varepsilon<-$ $\varepsilon \varepsilon^{\circ} L^{\prime}$ $\downarrow \varepsilon^{\prime} L$ $\forall \varepsilon^{\circ} L$ $\nabla \nabla^{\circ} L$ $\nabla t^{\circ} \angle$ $S t{ }^{\circ} L$ $S D^{\circ} L$

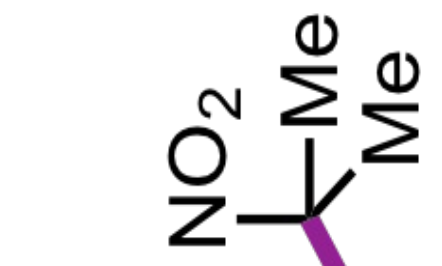

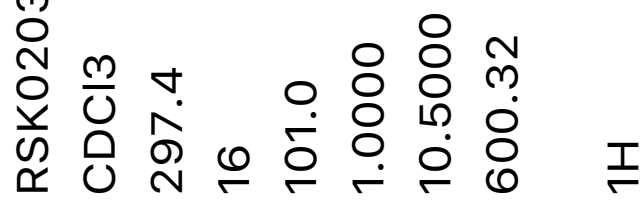

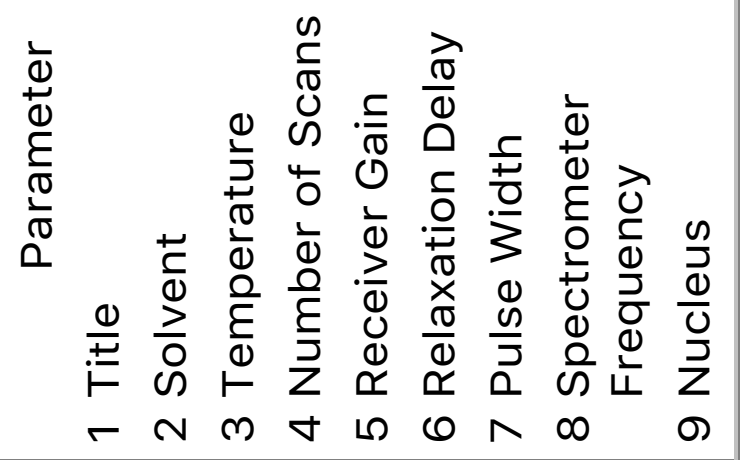

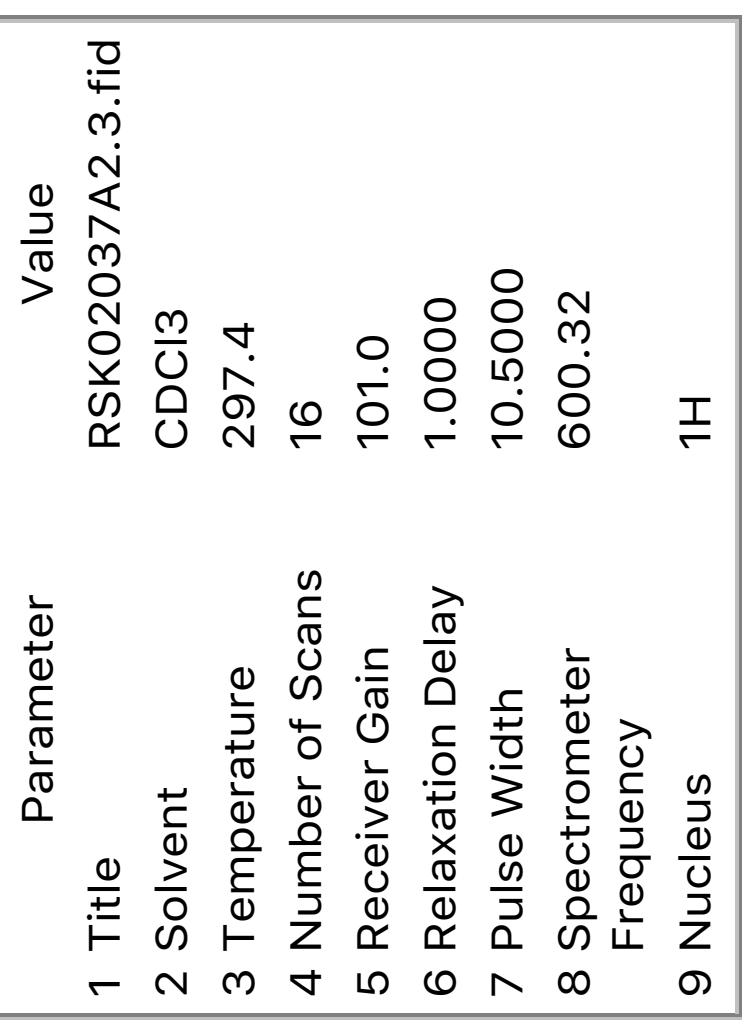


$26^{\circ} 02^{-}$

$\varepsilon L^{\circ} \mathrm{S} Z^{\prime}$

$\varepsilon 0^{\circ} Z \varepsilon \succ$

Et $6 L-$

$\angle 6^{\circ} 98$

I 2.88

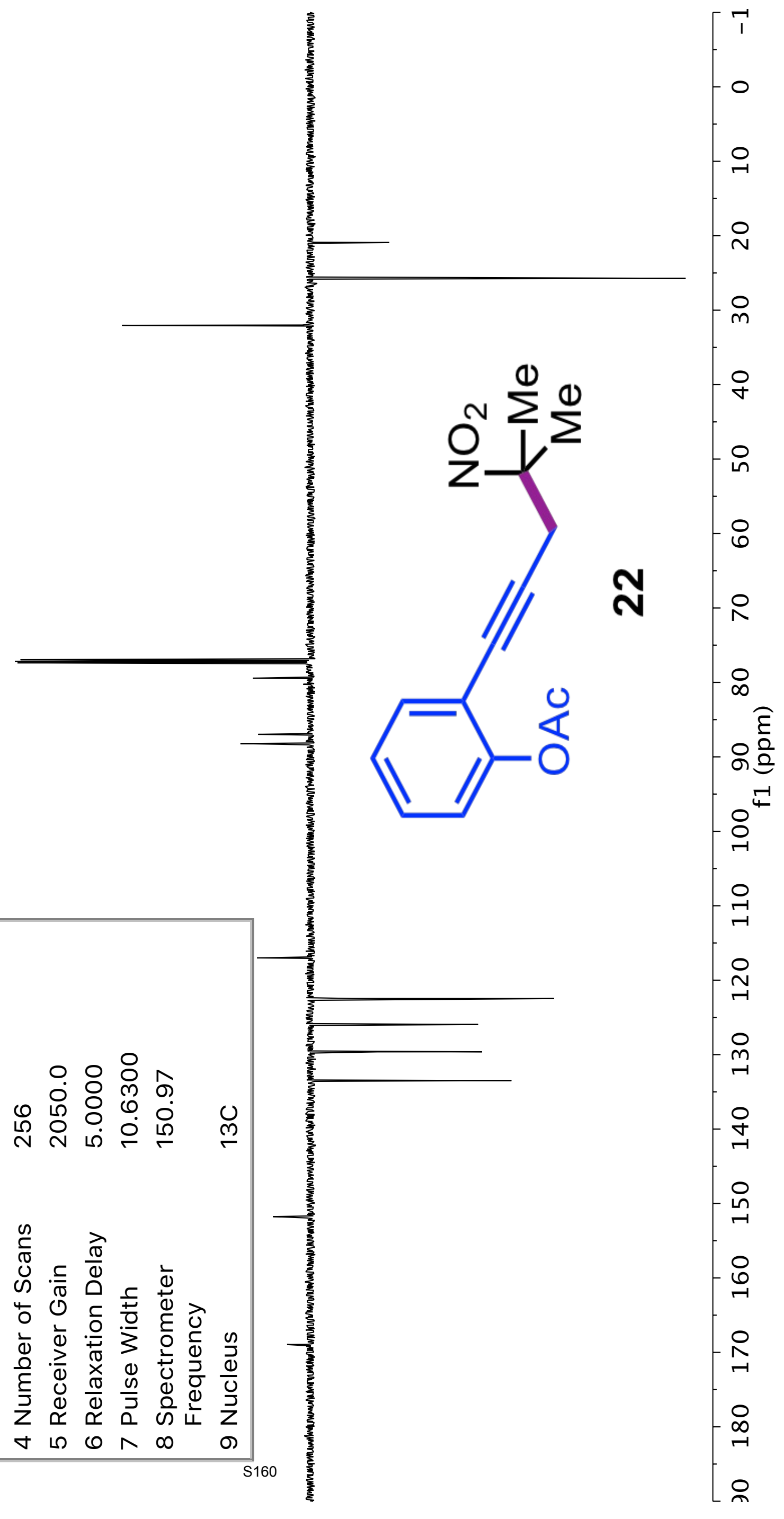




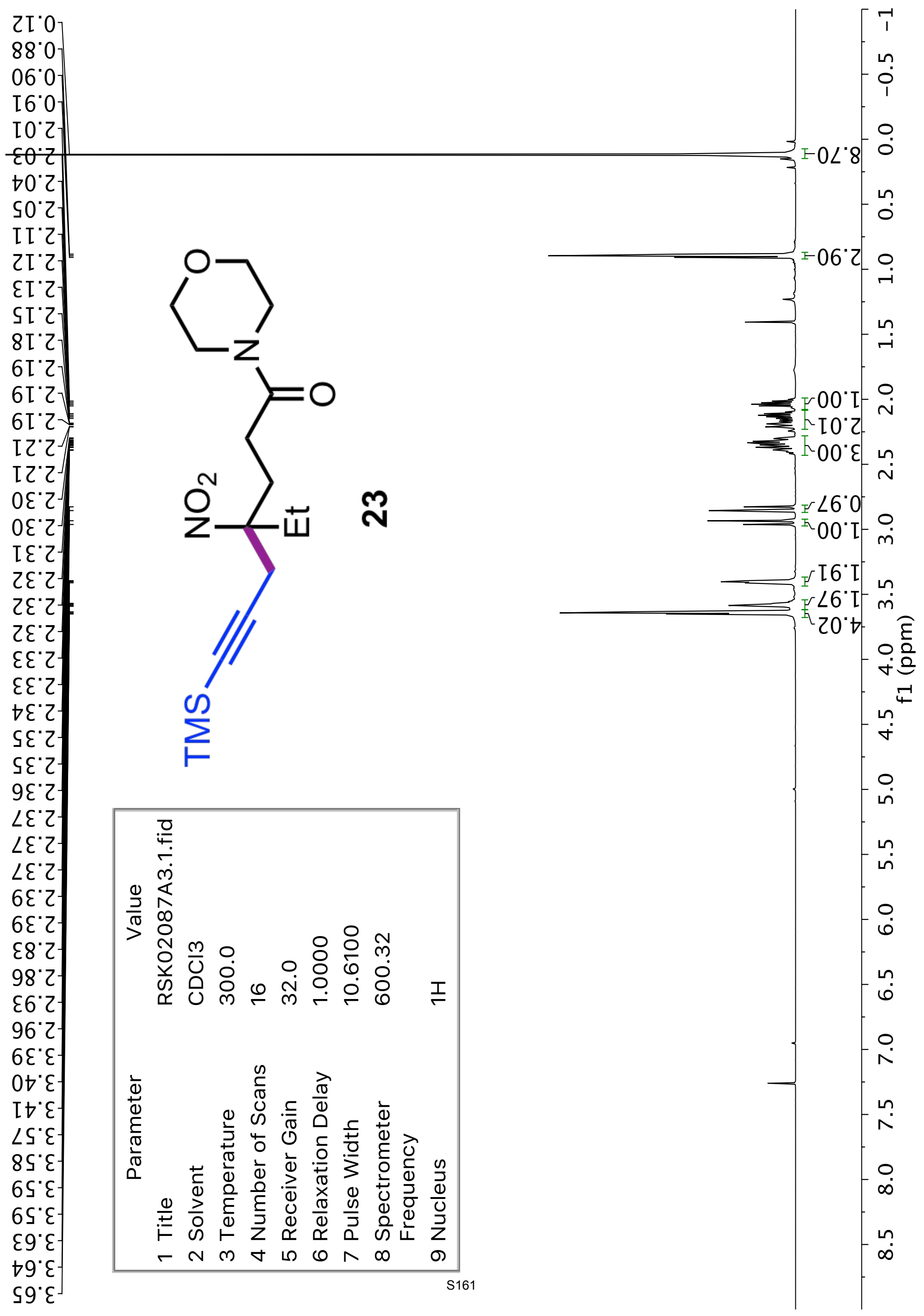




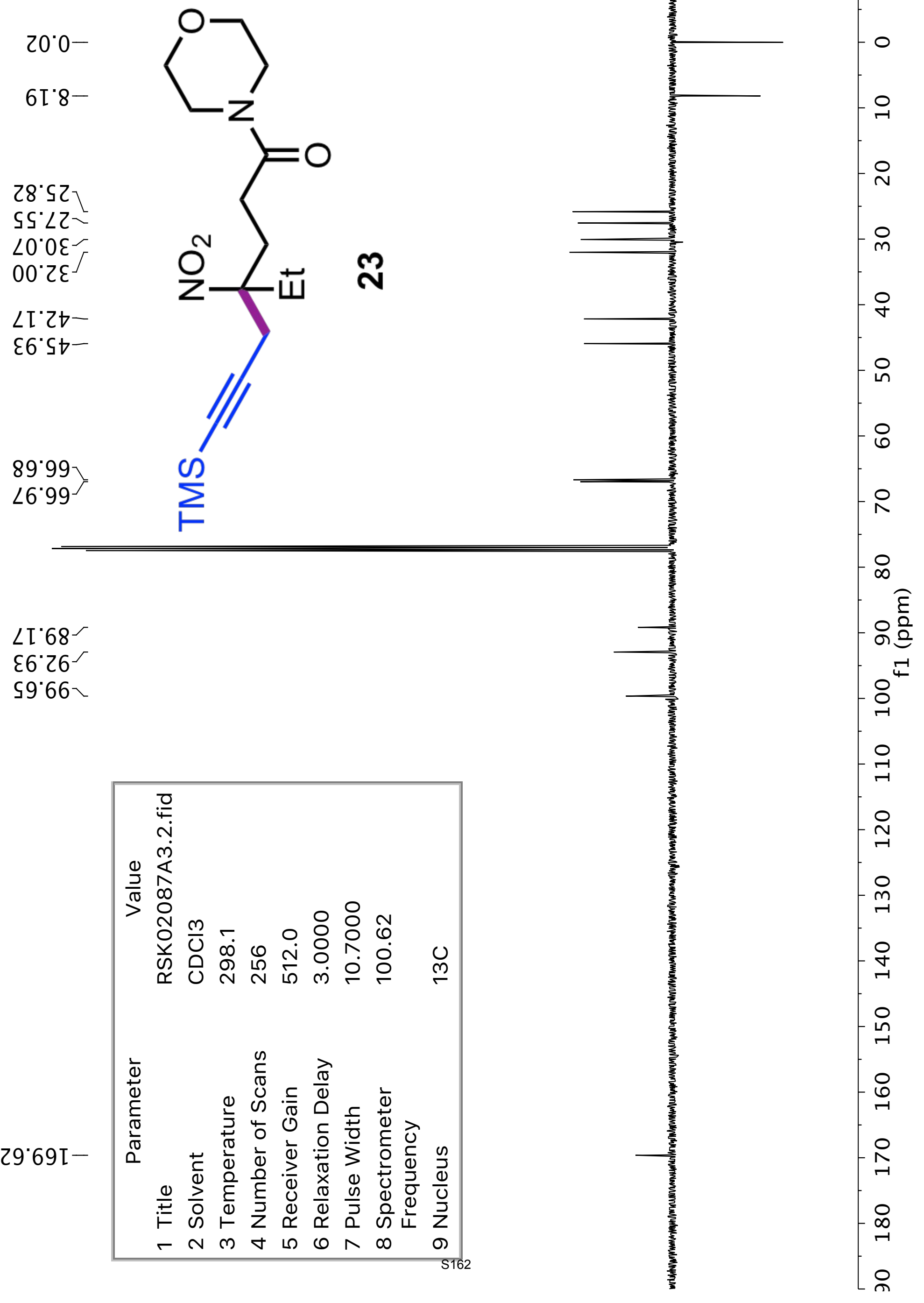


$\nabla 6^{\circ} \angle I^{-}-$
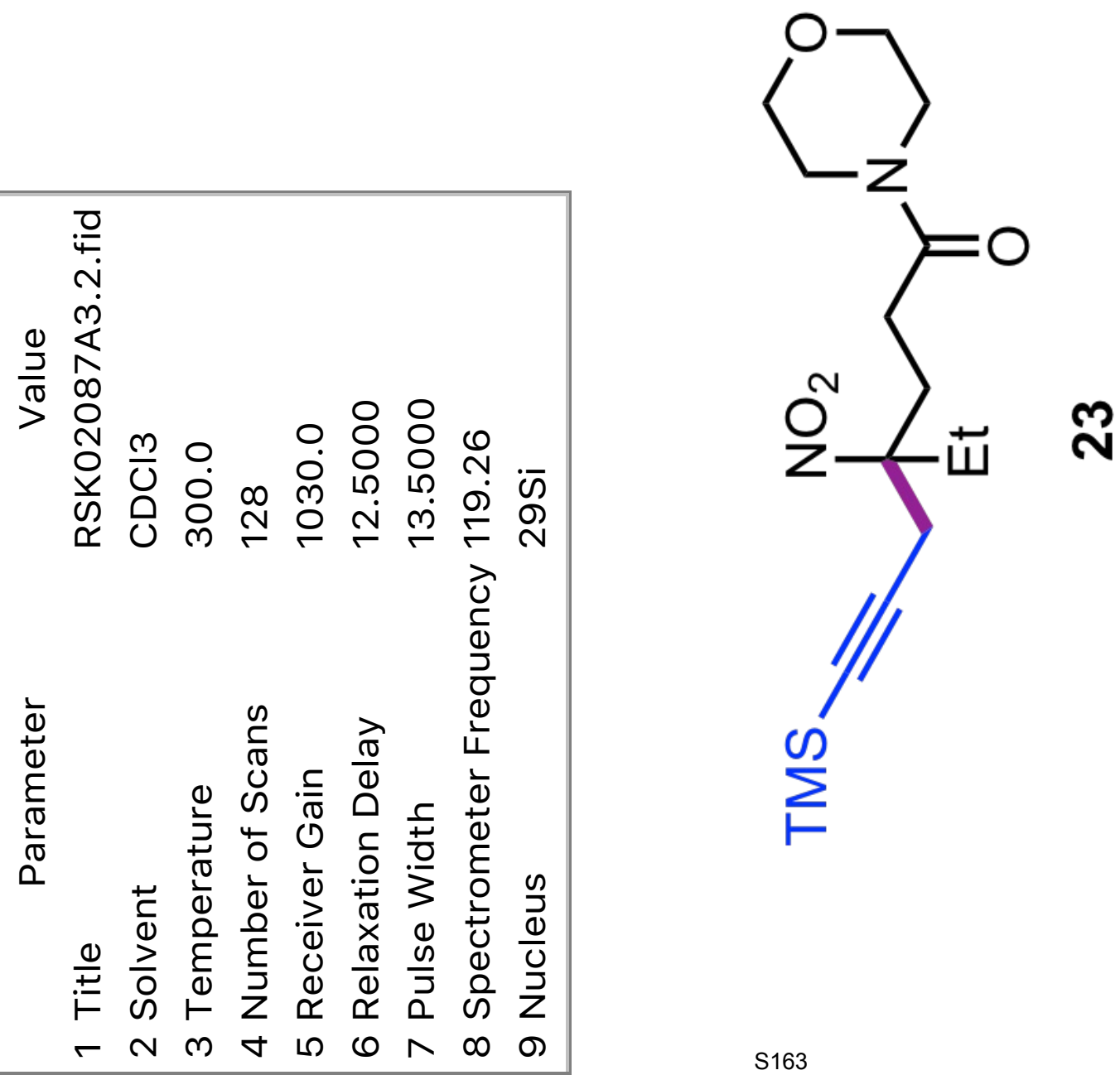


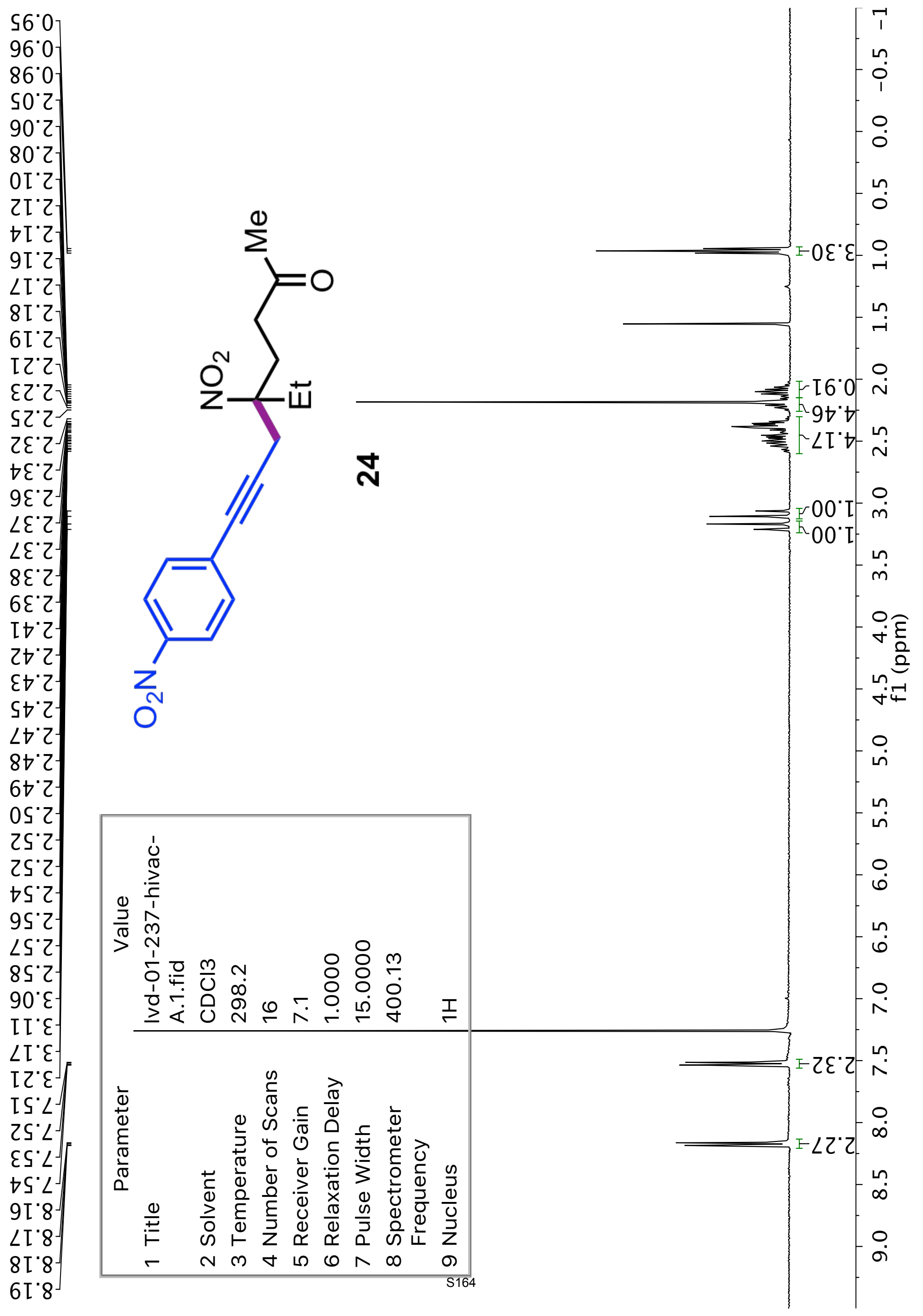




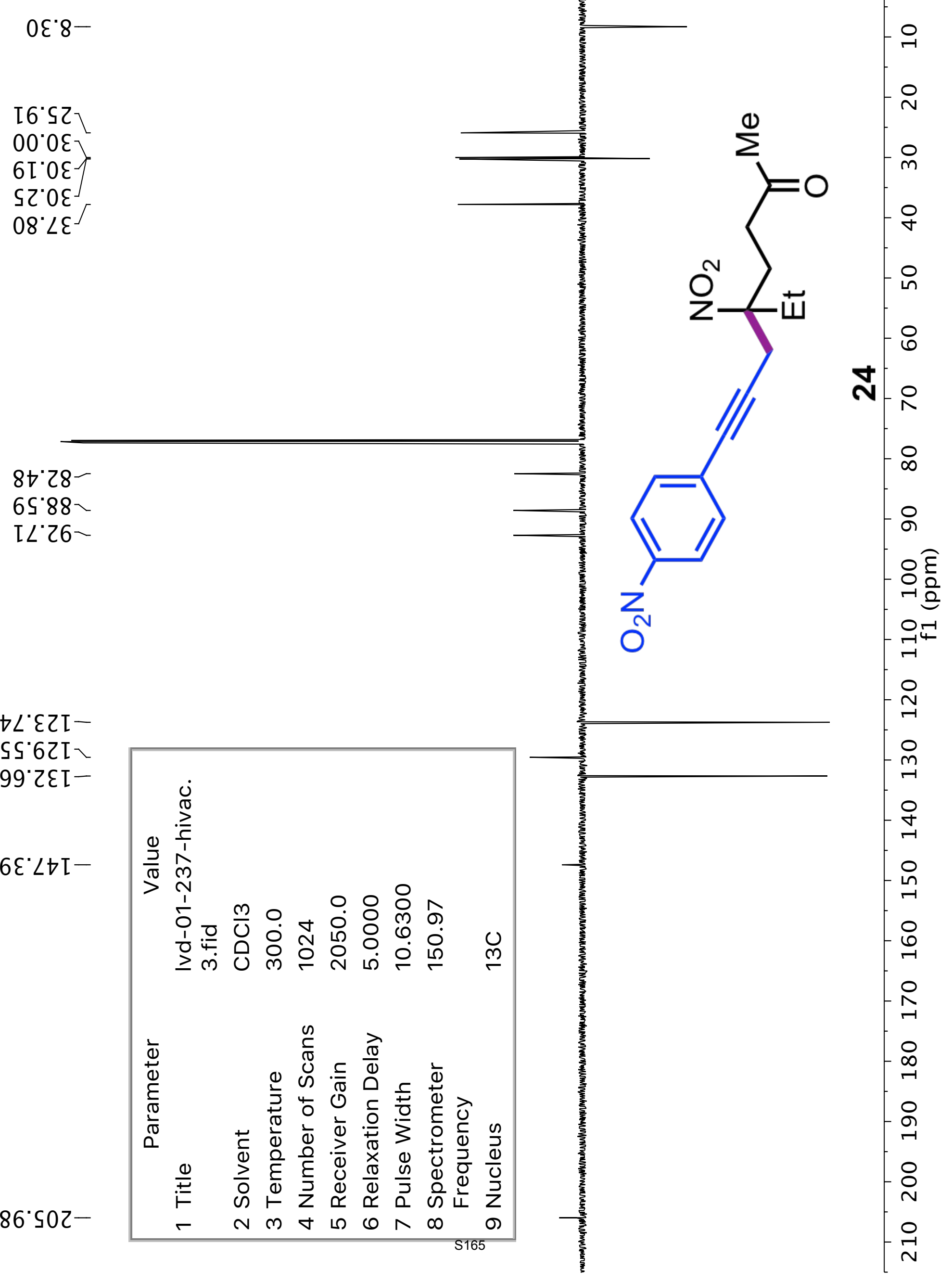


$8 L^{\circ} \mathrm{I}-$

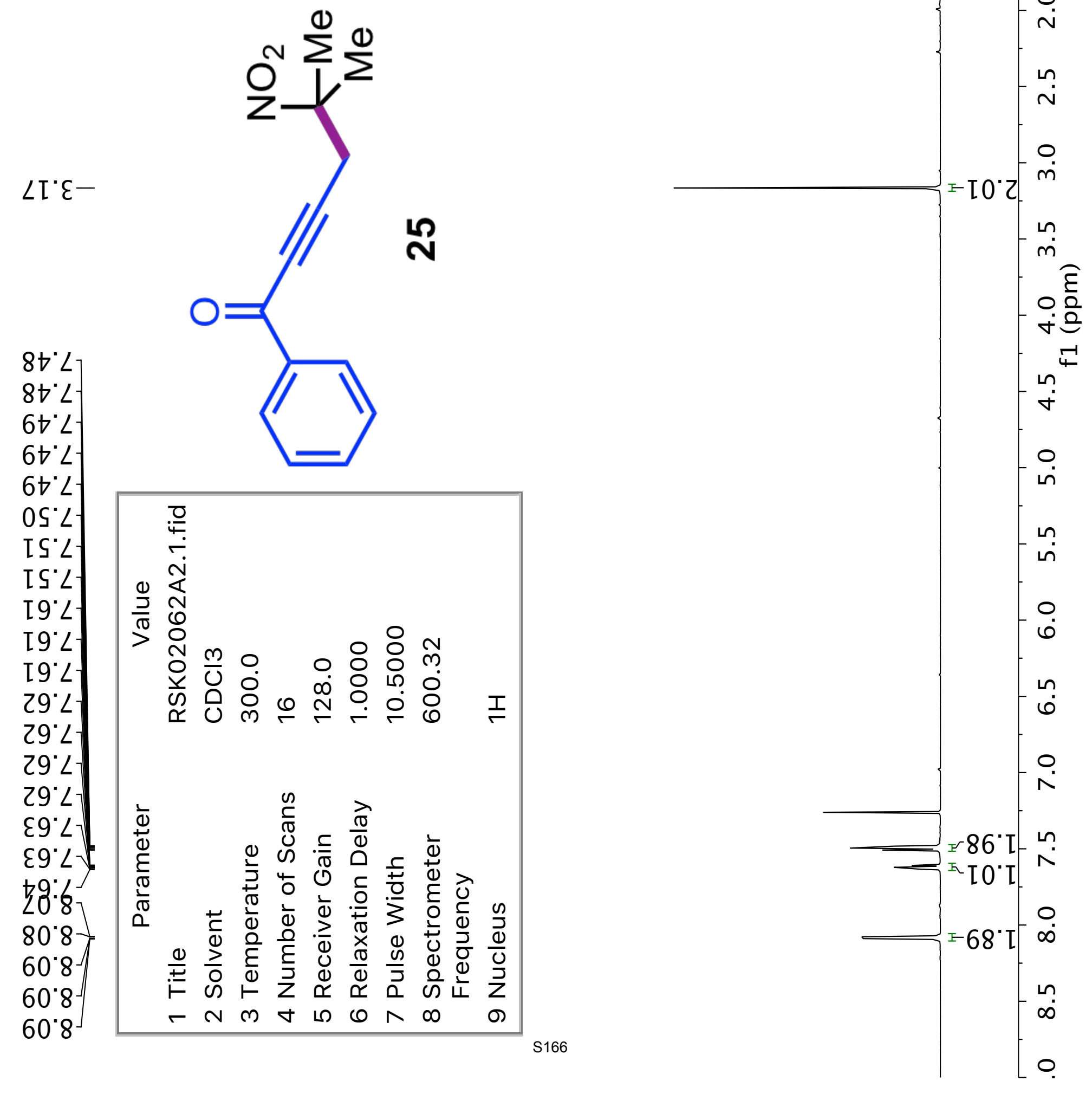


$\angle 6^{\circ} S Z_{-}$

St'IE-

2t'28

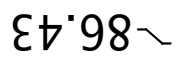

tฑ $88^{-}$

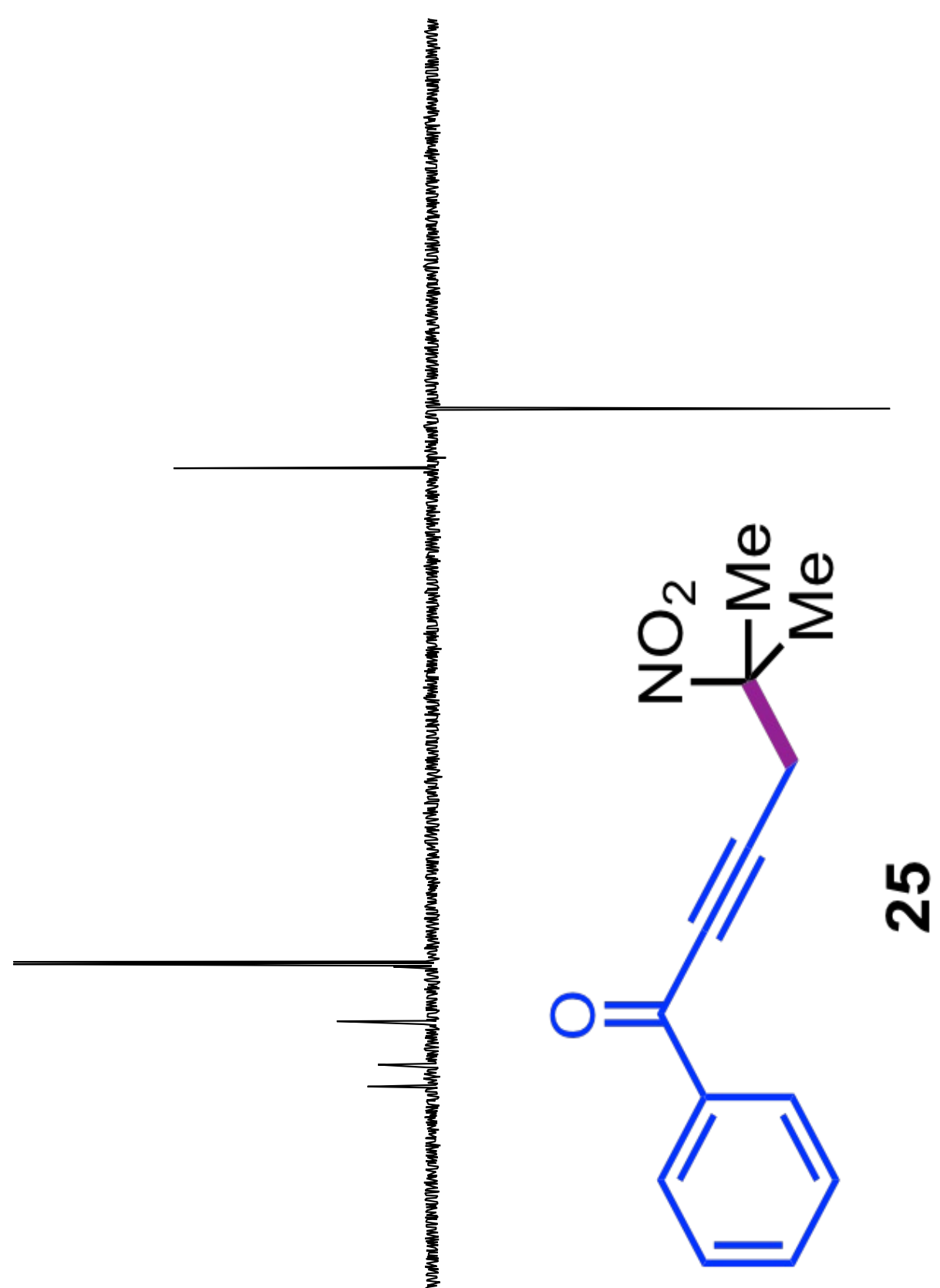

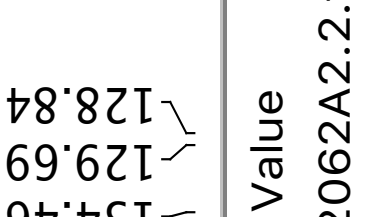

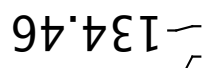
29.9ع [

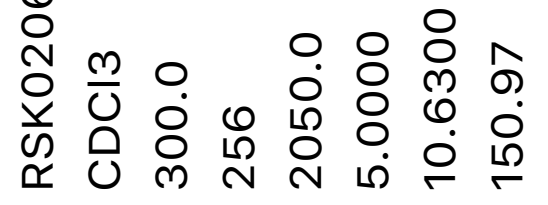

$\frac{1}{0}$
$\stackrel{0}{0}$
$\frac{1}{\sigma}$
$\frac{0}{\sigma}$
$\frac{0}{0}$

\section{as}

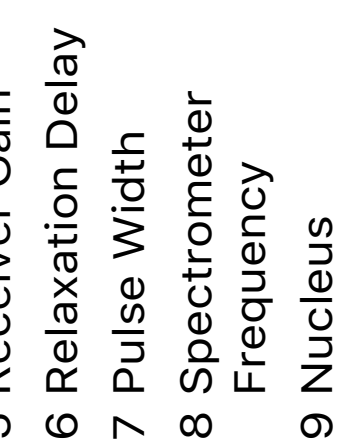

$\stackrel{v}{r}$

움

옴

8

옥

$\infty$

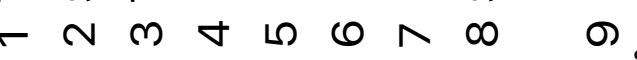




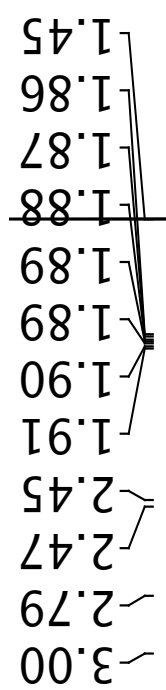

$68^{\circ} \varepsilon-$

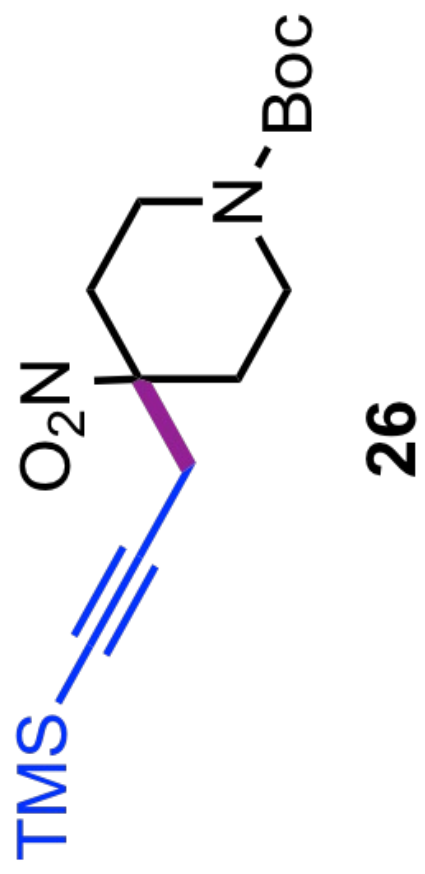

0

in

$m$

เก

0

เก

$\stackrel{0}{1}$

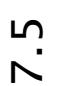

$\stackrel{\infty}{\infty}$

$\stackrel{\infty}{\infty}$

0 
$\angle 0^{\circ} 0^{-}-$

$87^{\circ} 82$

$\angle 0^{\circ} 2 \varepsilon>$

$6 \mathrm{~S}^{\circ} 2 \varepsilon^{\top}$

† $08-$

IS. 88

$08^{\circ} 06^{\digamma}$

$\angle I^{\circ} 86$ -
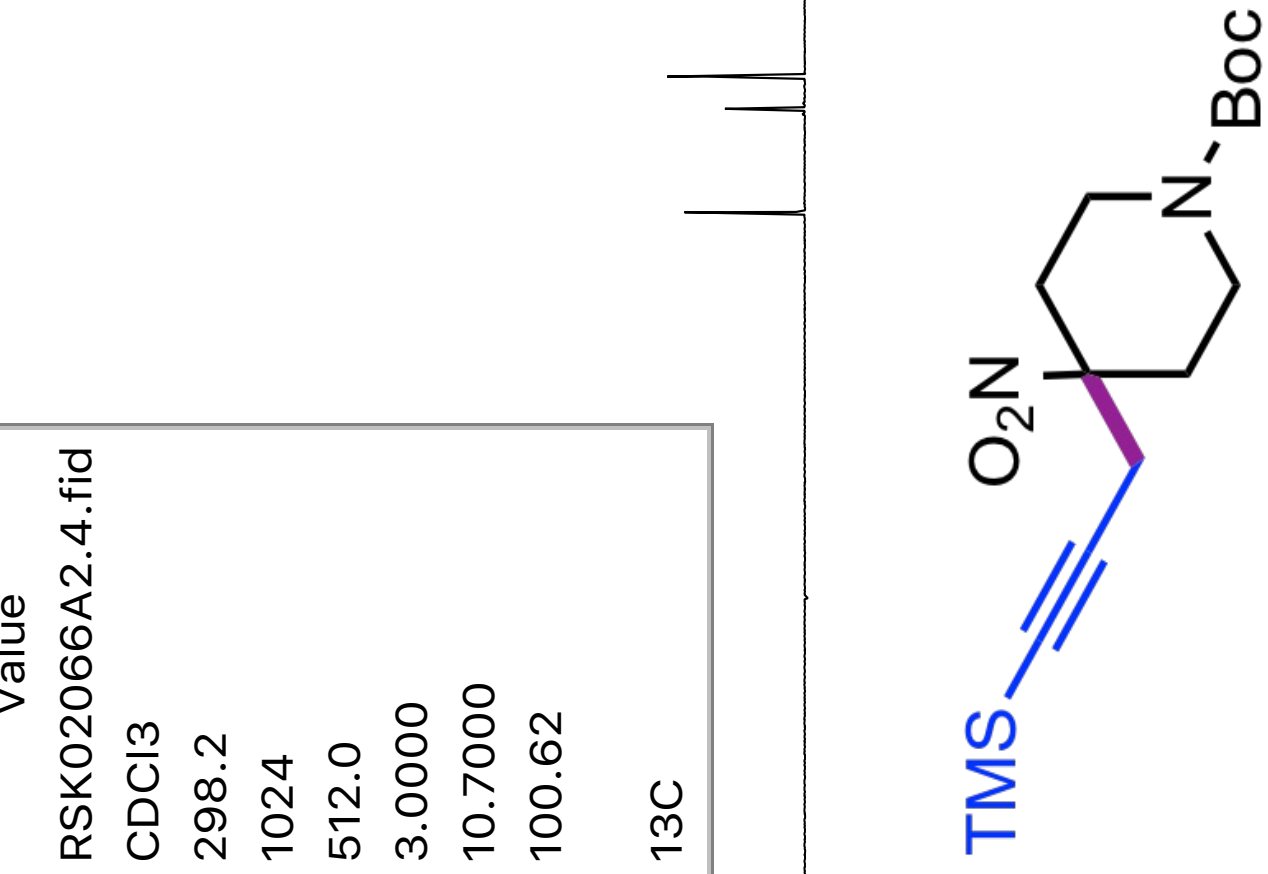

$\infty$

ㅇํํ을

$8^{-1}$

욱

$\stackrel{ }{\sim}$

$\stackrel{ }{m}$

$\stackrel{ }{+}$

음

$\angle S^{\circ} \nabla S I-$

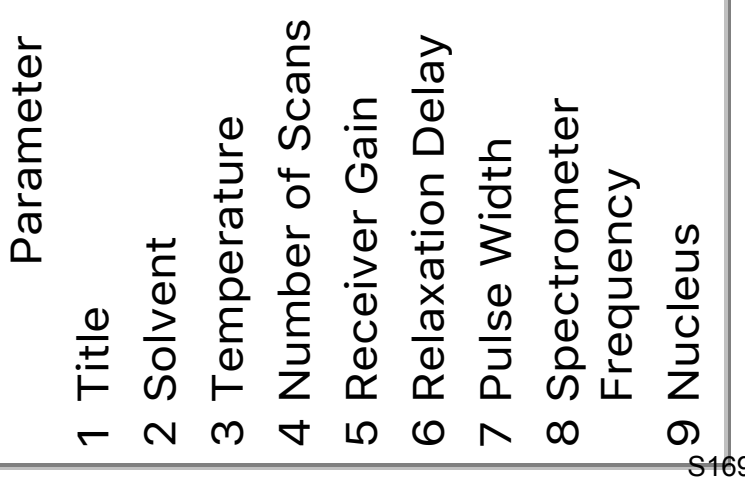

8

옥

$\stackrel{\infty}{\infty}$ 


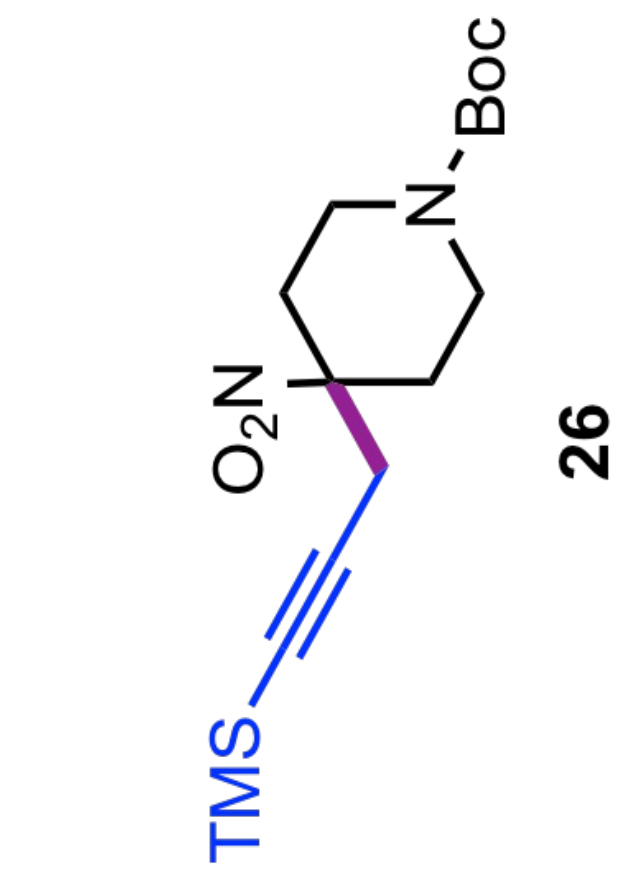

$2 L^{\circ} \angle I^{-}-$ 


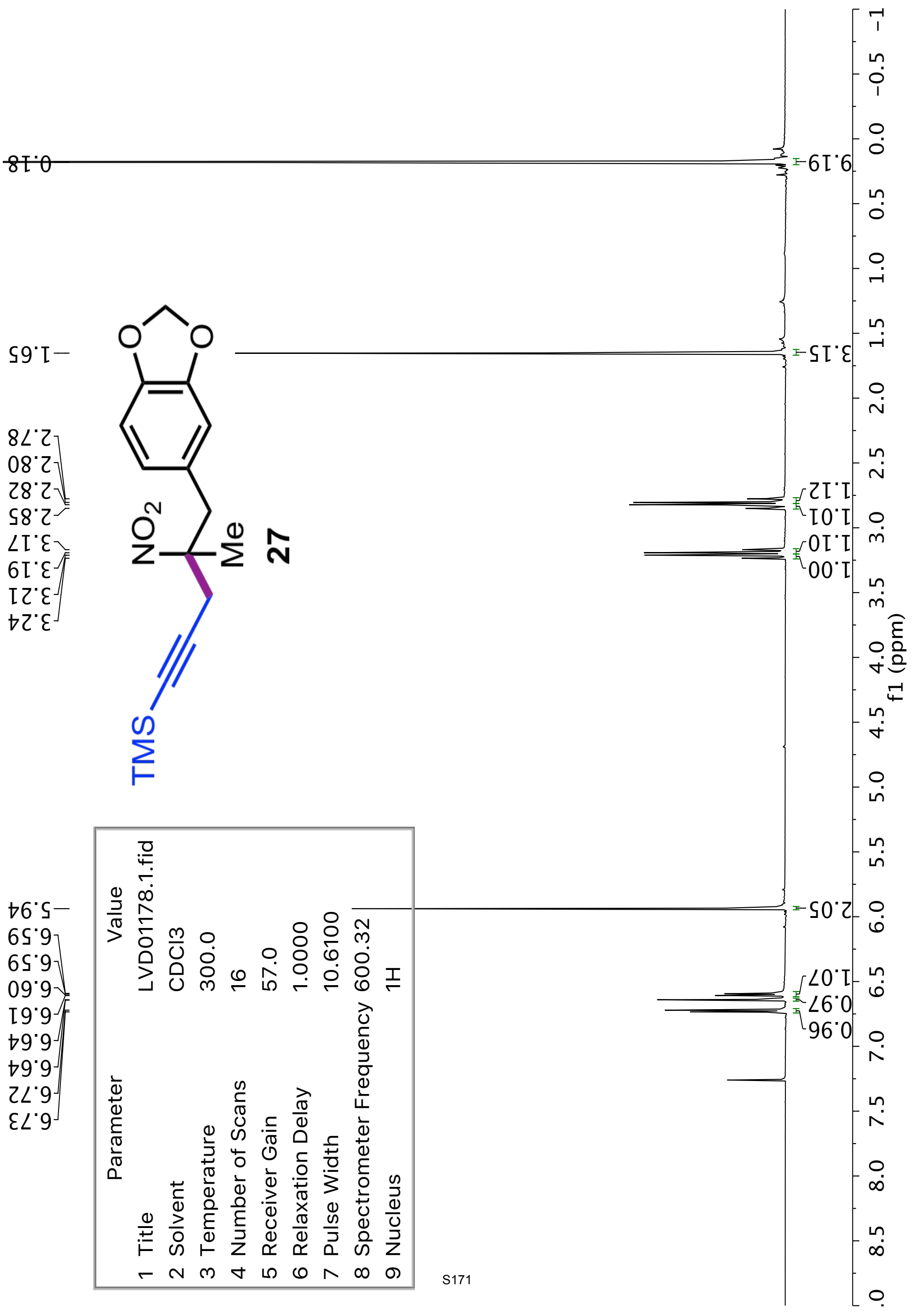


$200^{\circ}-$

0ち દ乙-

25.62-

98.દฤ-

$88^{\circ} 68$
$65^{\circ} 06^{\mathcal{Y}}$

I9.00I
2Z' 20 I $^{\circ}$

$05^{\circ} 80 \mathrm{I}$ -

$0 \varepsilon^{\circ} 0$ I I $^{-}$

$82^{\circ} \angle t I$
$\left[6^{\circ} \angle t I^{\prime}\right.$

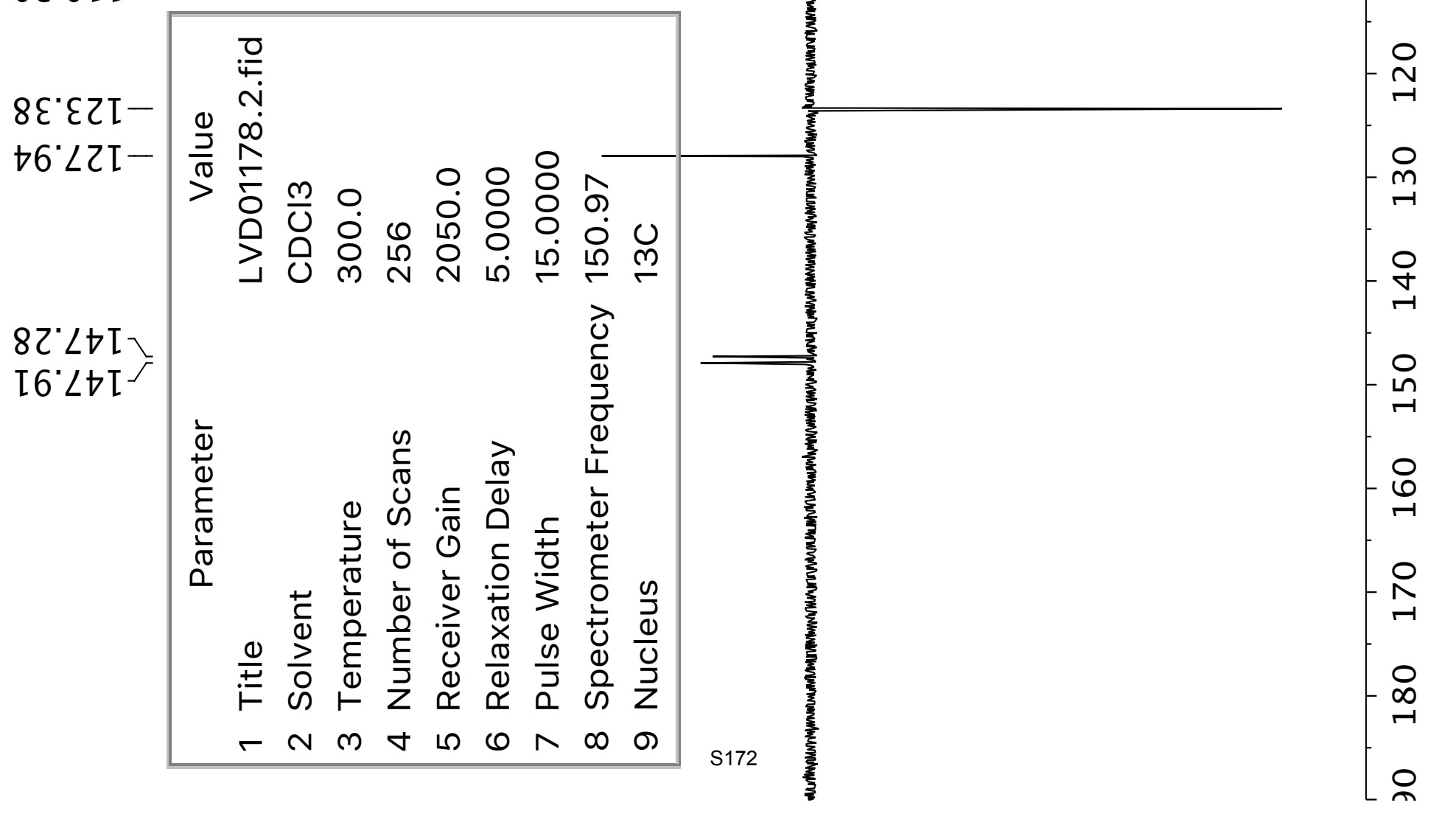




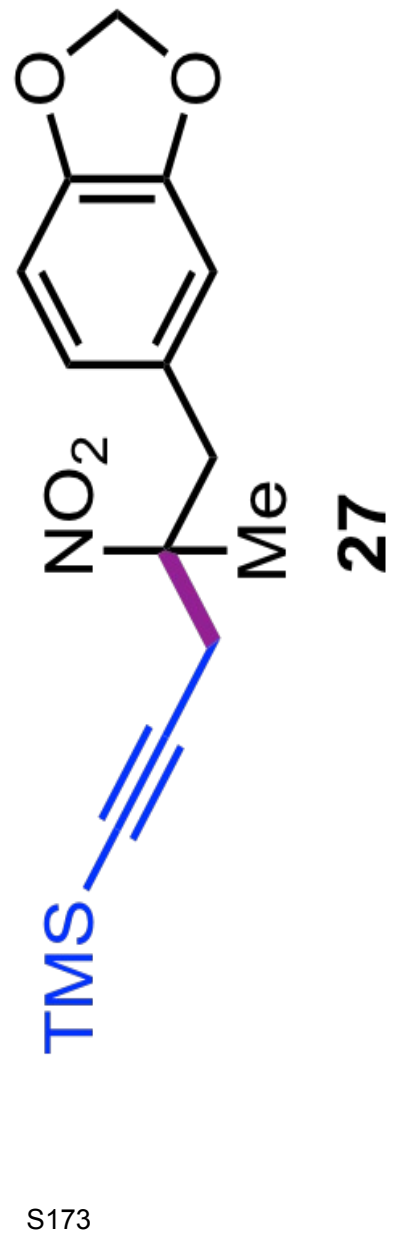


$0 L^{\prime} \mathrm{I}-$

$9 b^{\circ} 2-$

$86^{\circ} \mathrm{Z}$

$\left.00^{\circ} \varepsilon\right]$

I0' $\varepsilon-$

$\varepsilon 0^{\prime} \varepsilon$

$\succ 0^{\circ} \varepsilon$

$\angle 0^{\circ} \varepsilon$

โ $Z^{\circ} \varepsilon$

乙ح'

$\varepsilon Z^{\prime} \varepsilon$

$\varsigma \nearrow^{\prime} \varepsilon$

$92^{\circ} \varepsilon$

$8 \tau^{\circ} \varepsilon$
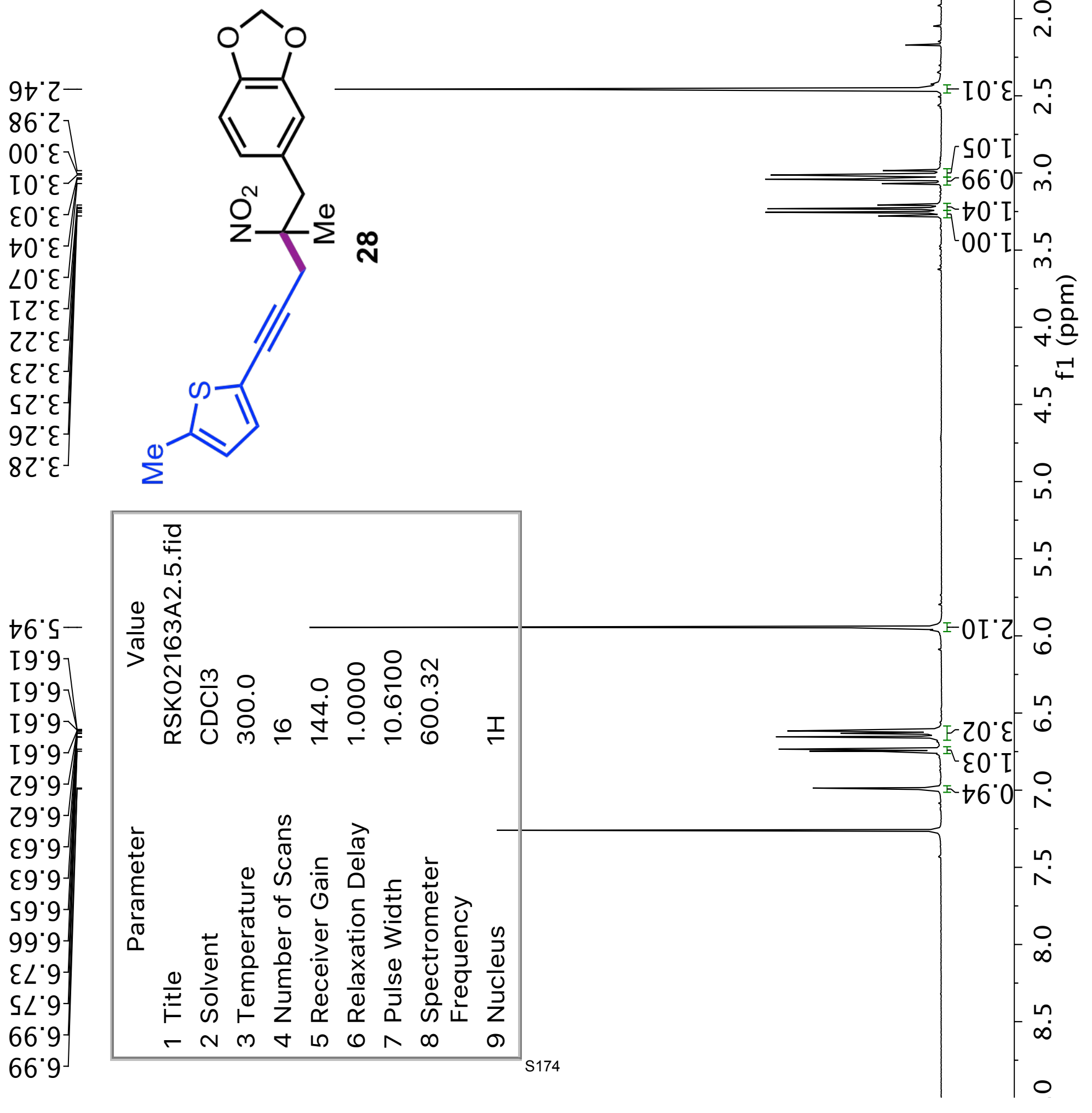

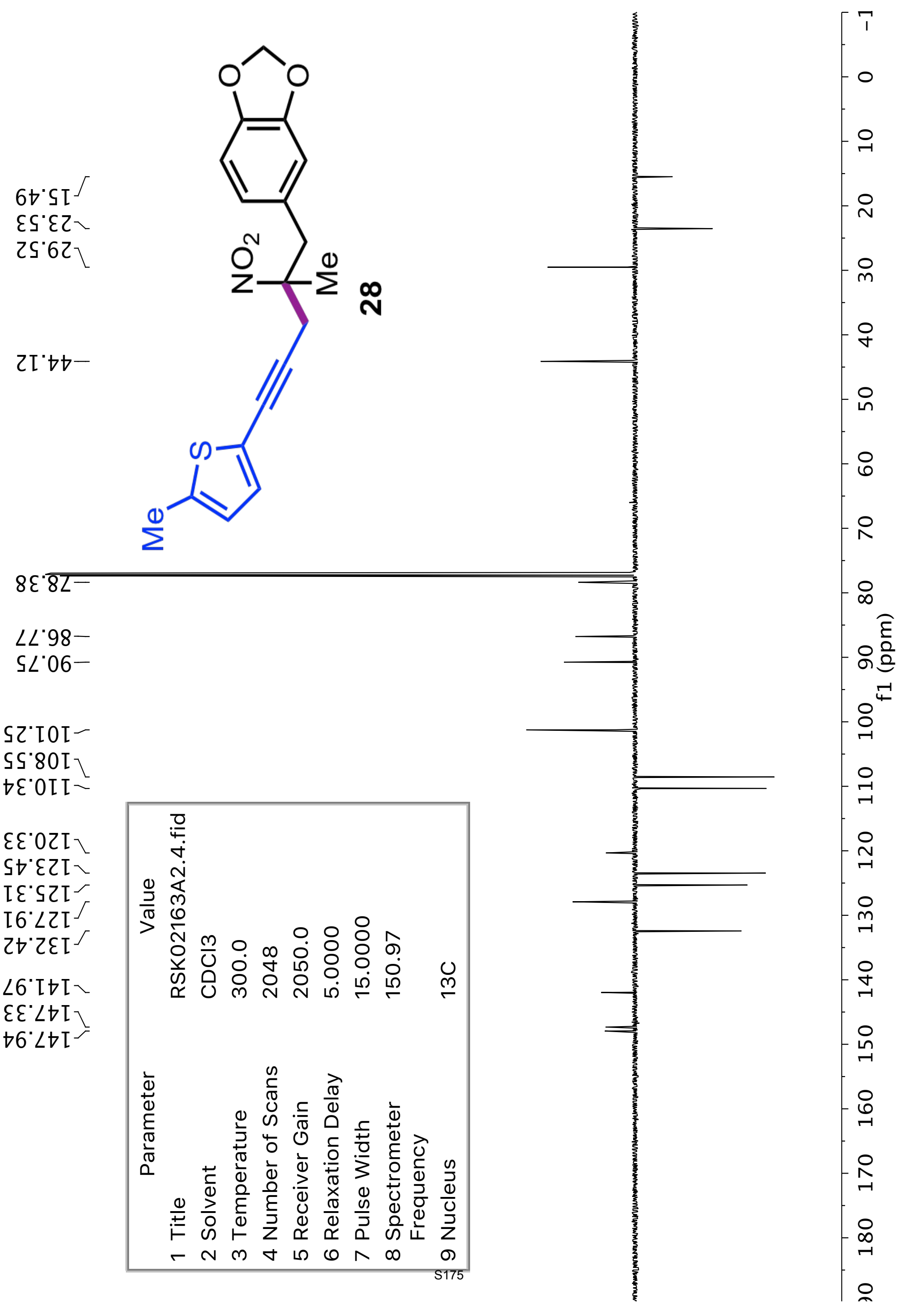


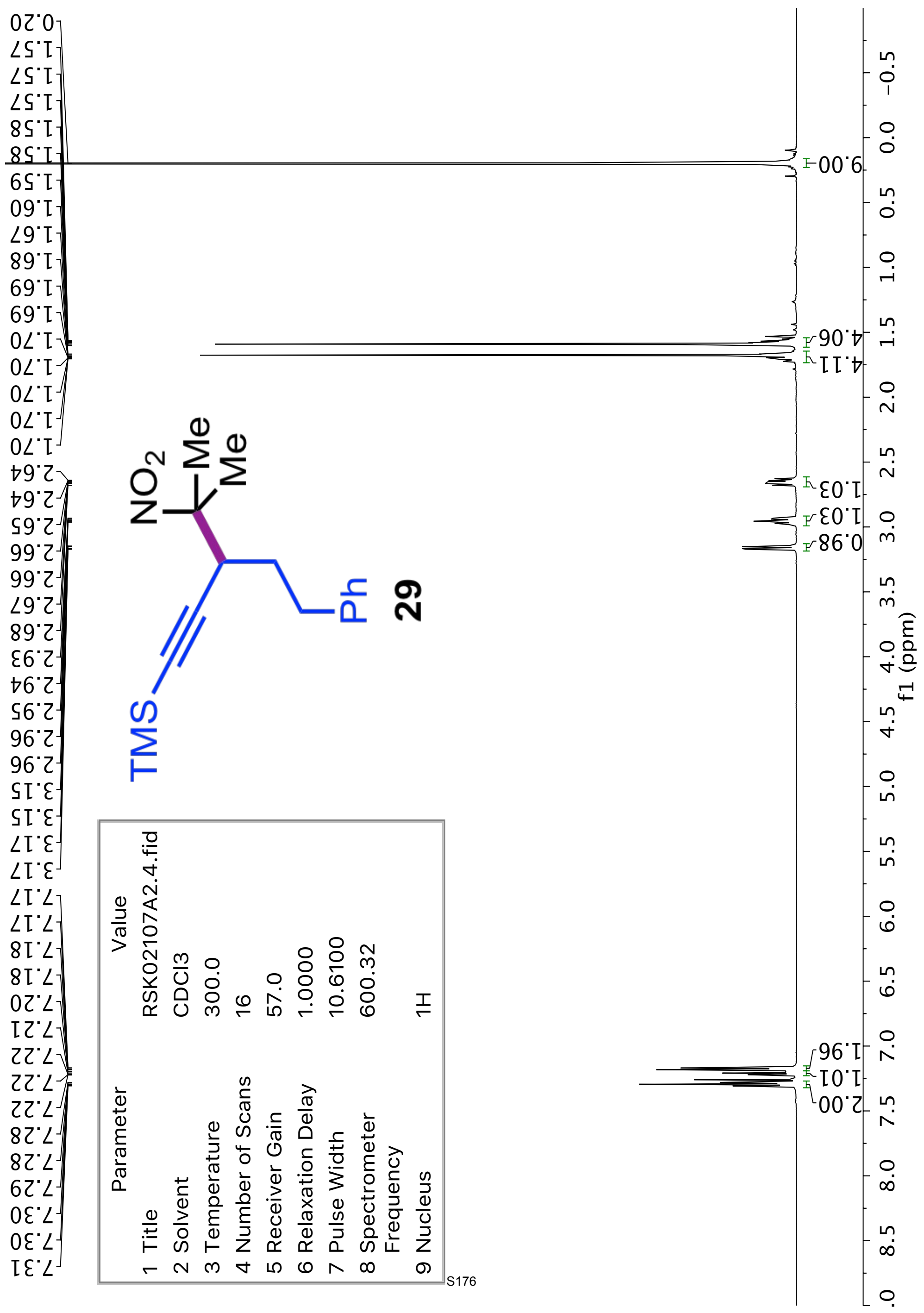


SE'IZ-

SI'9Z-

8L'โE

$66^{\circ} \varepsilon \varepsilon-$

しでャー

$\varepsilon \tau^{\prime} 06 \succ$
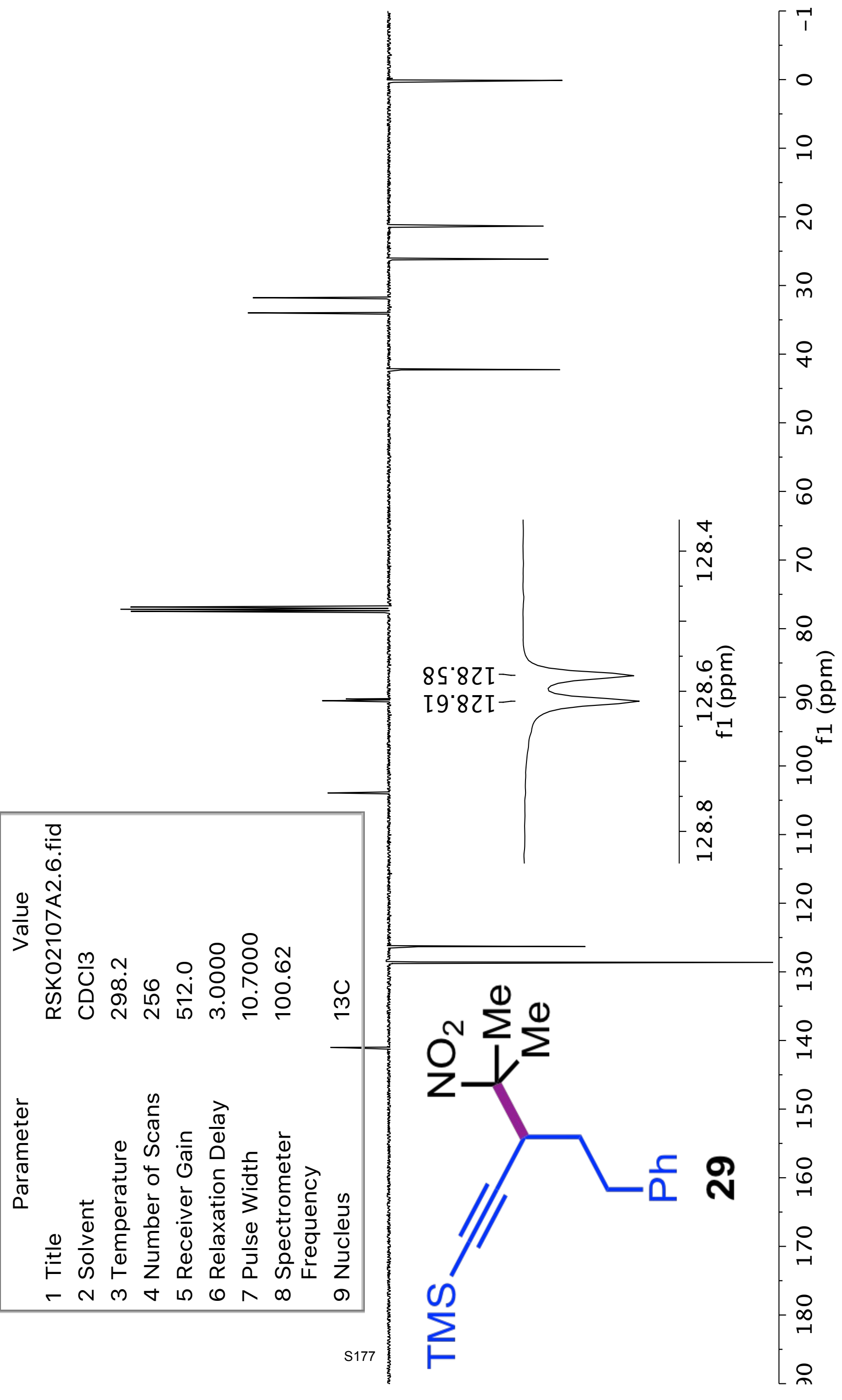


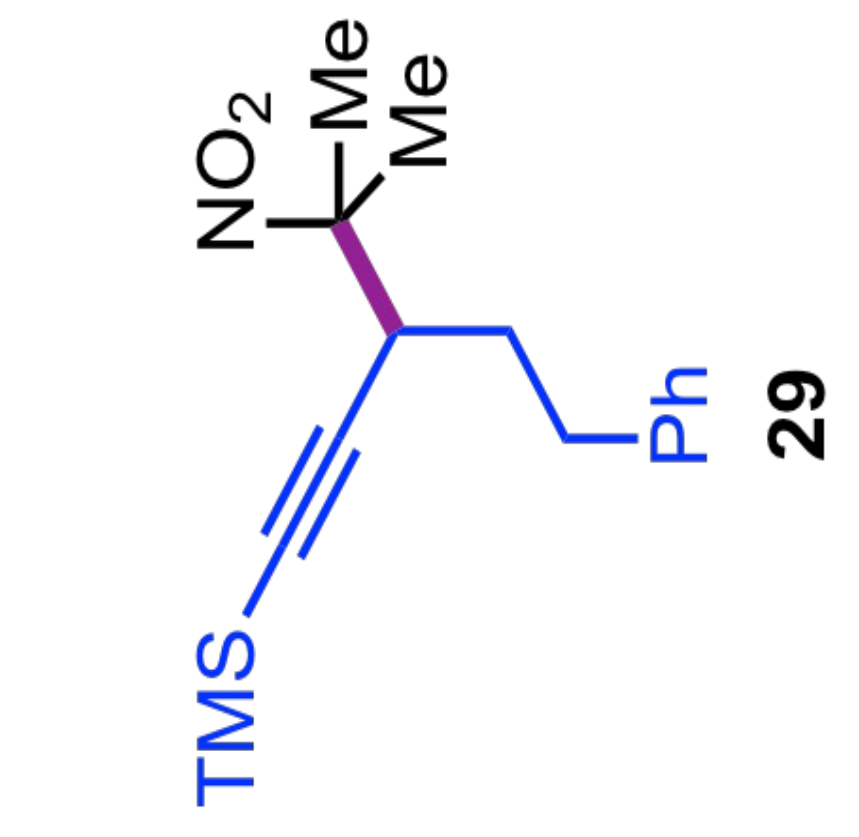

$\nabla 6^{\circ} \angle I^{-}-$

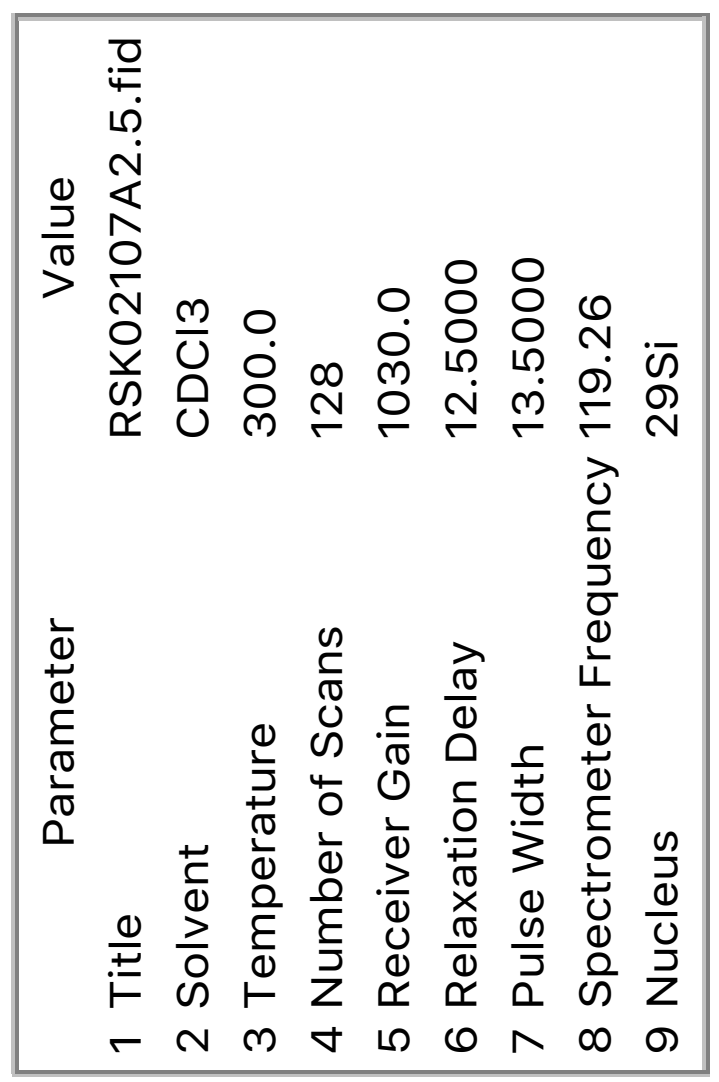




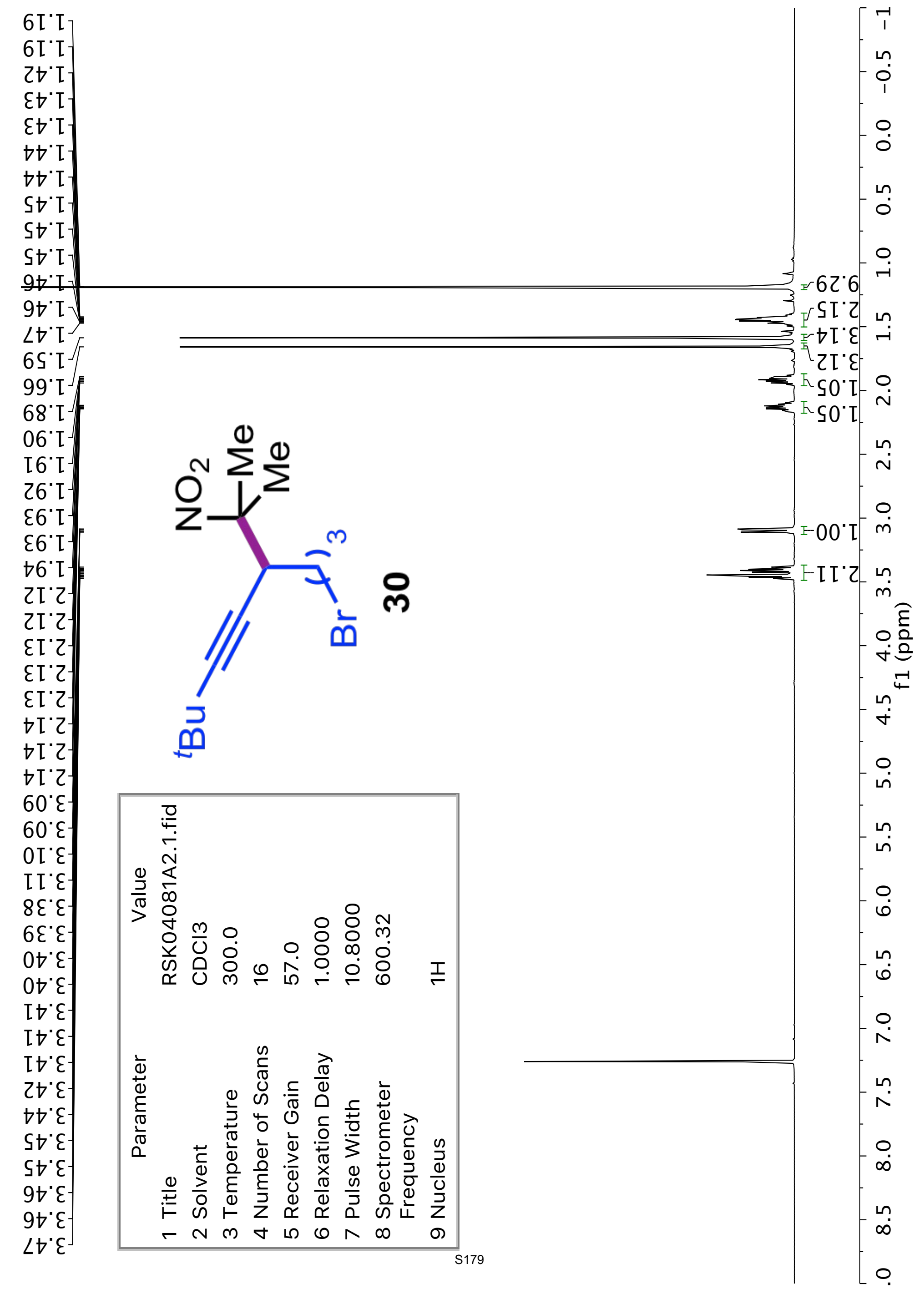


[0.22

OS $S Z$

$68^{\circ} \angle Z \backslash$

2L'62-

$\nabla \tau^{\circ} \tau \varepsilon^{-}$

$09^{\circ}[\varepsilon]$

$\neg 8^{\circ} \varepsilon \varepsilon$

$6 t^{\circ}\left[t^{\circ}\right.$

$\downarrow I^{\circ} 9 L-$

It. $16-$

$85^{\circ}+6-$

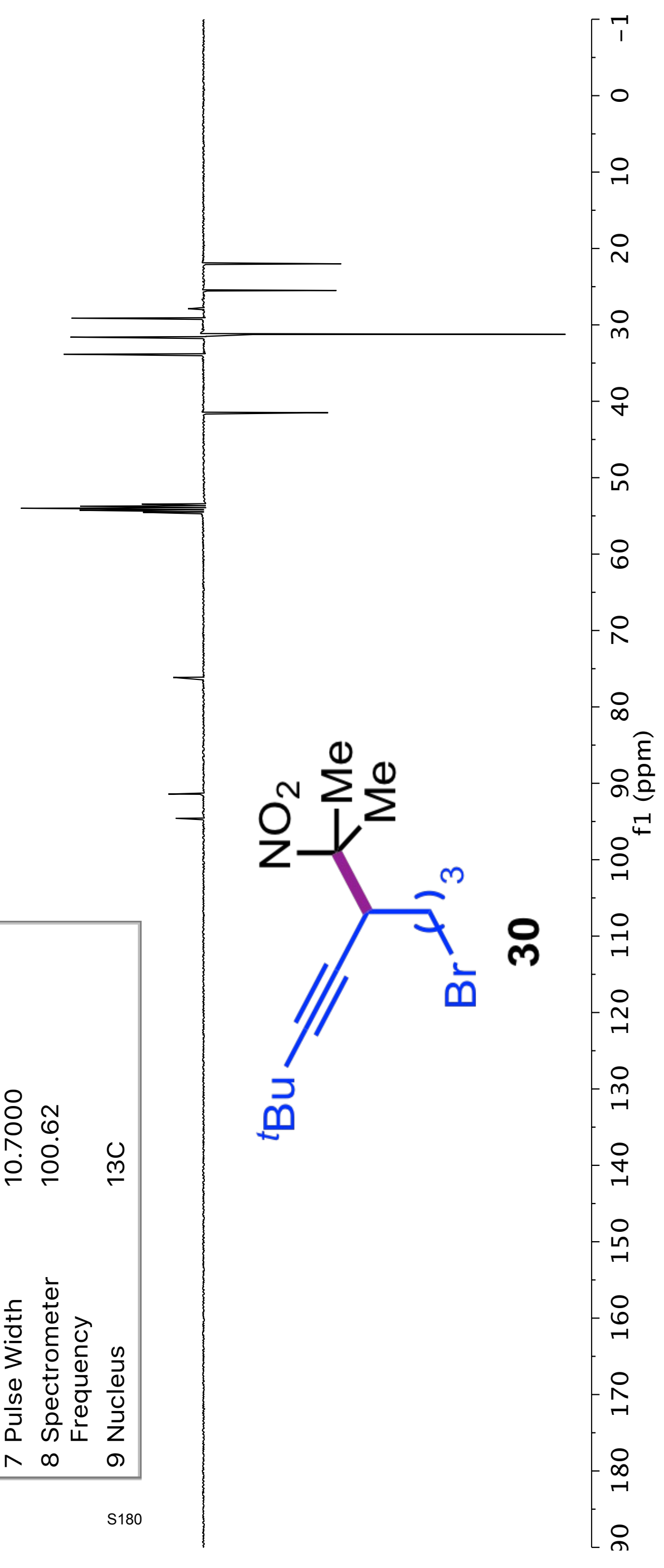




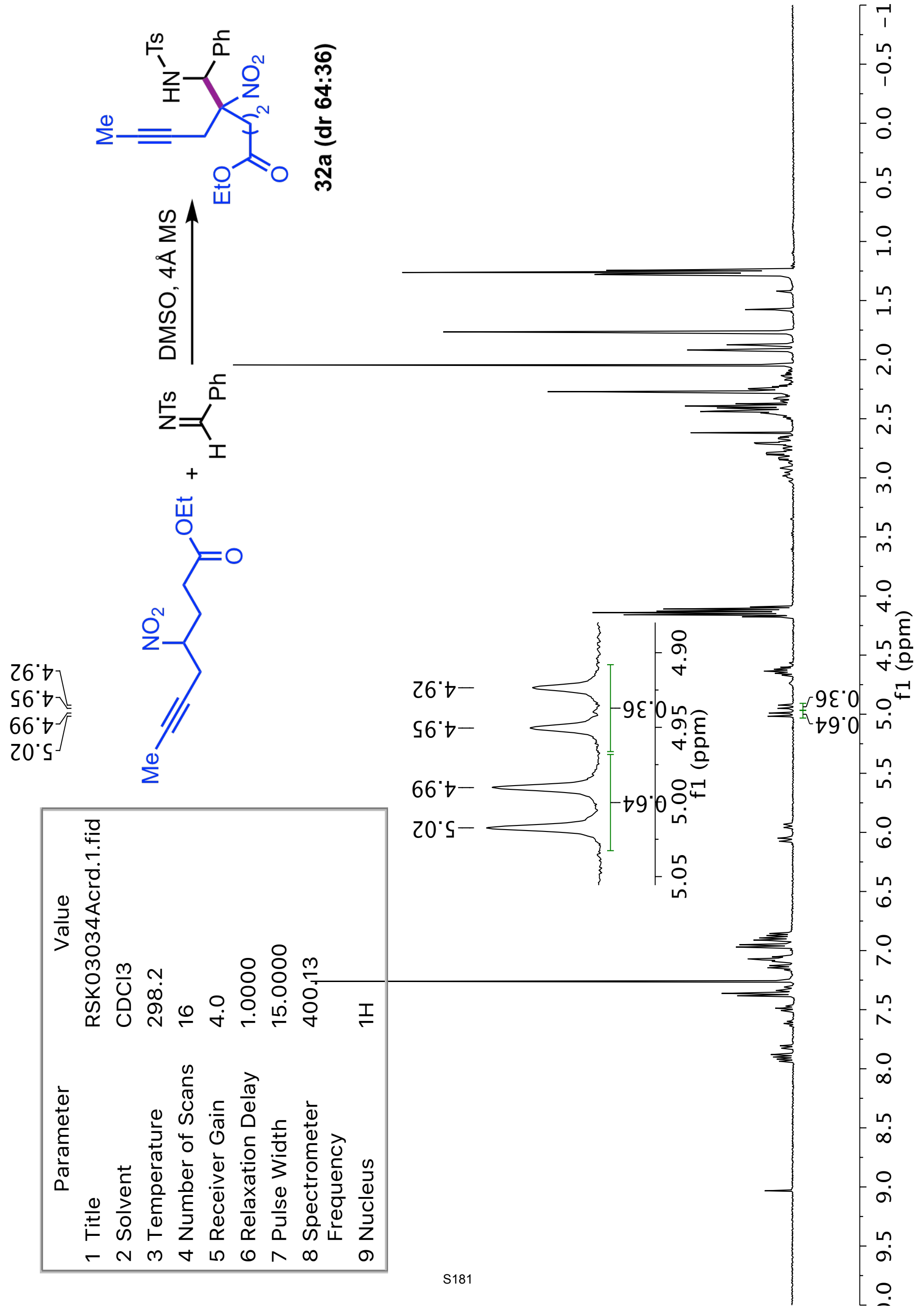




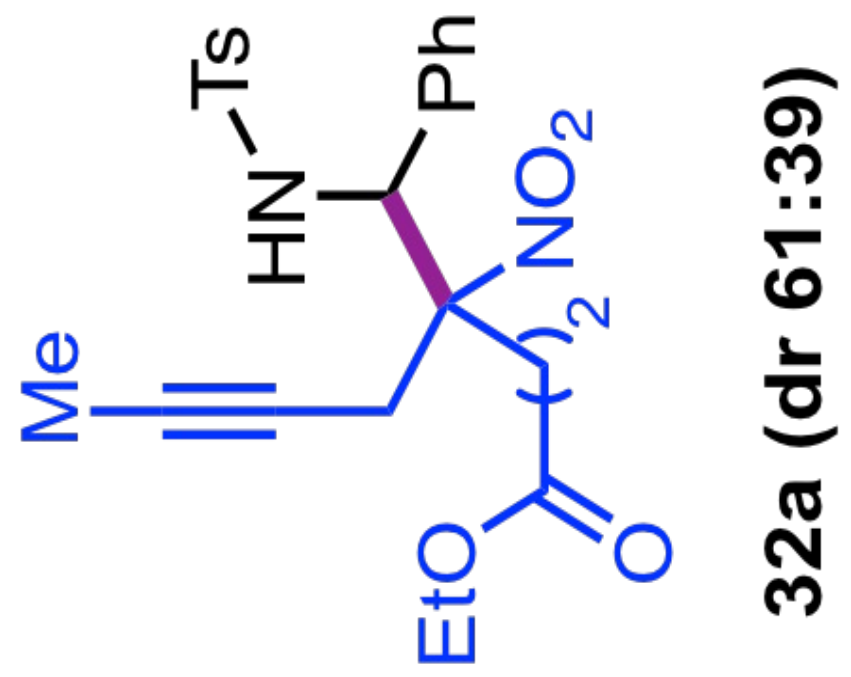

$\varepsilon 6^{\circ} t$
$s 6^{\circ} t-1$
$00^{\circ} s-1$

I0

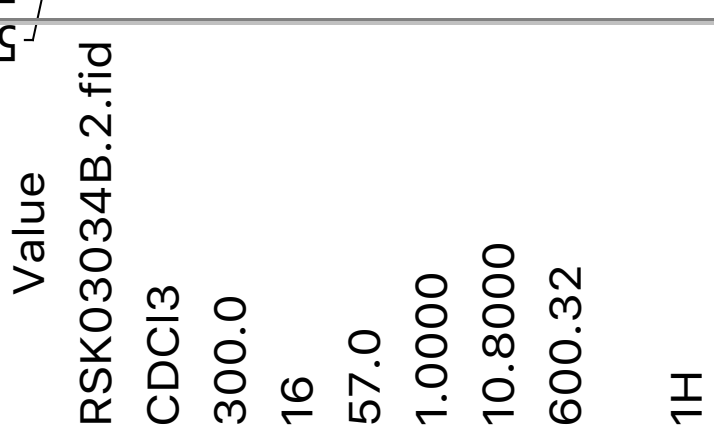

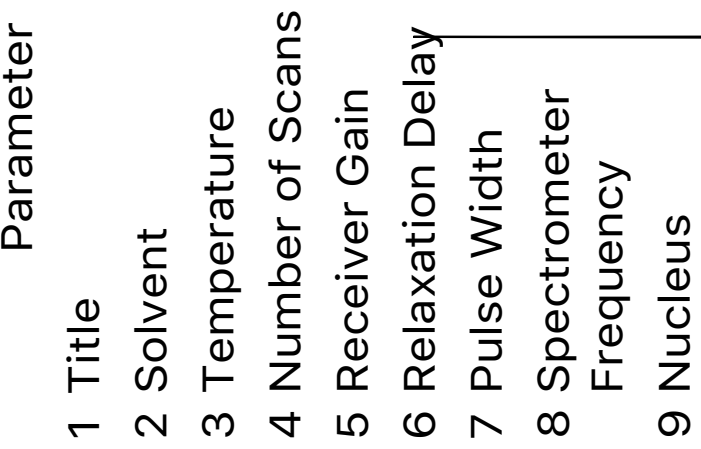




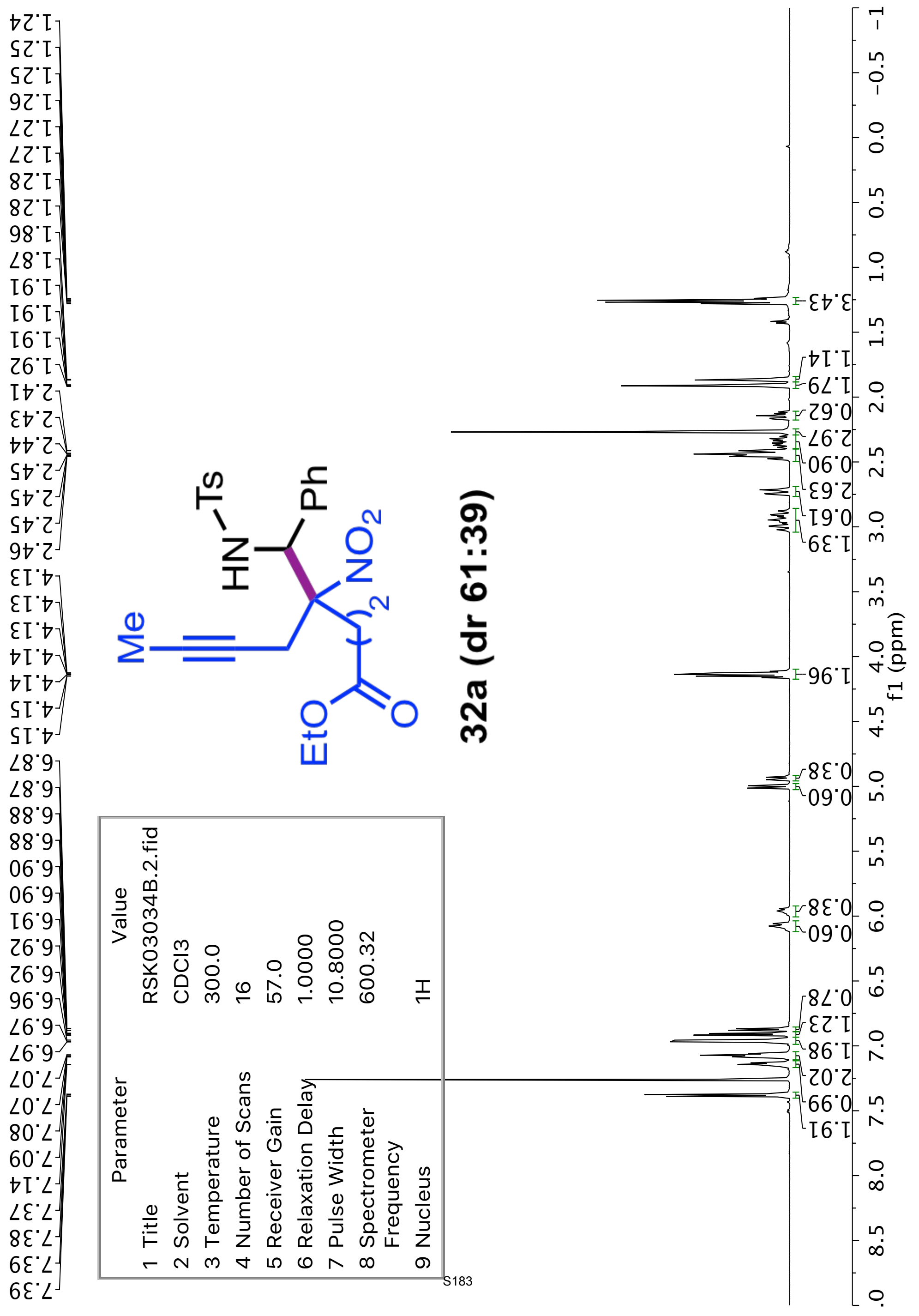




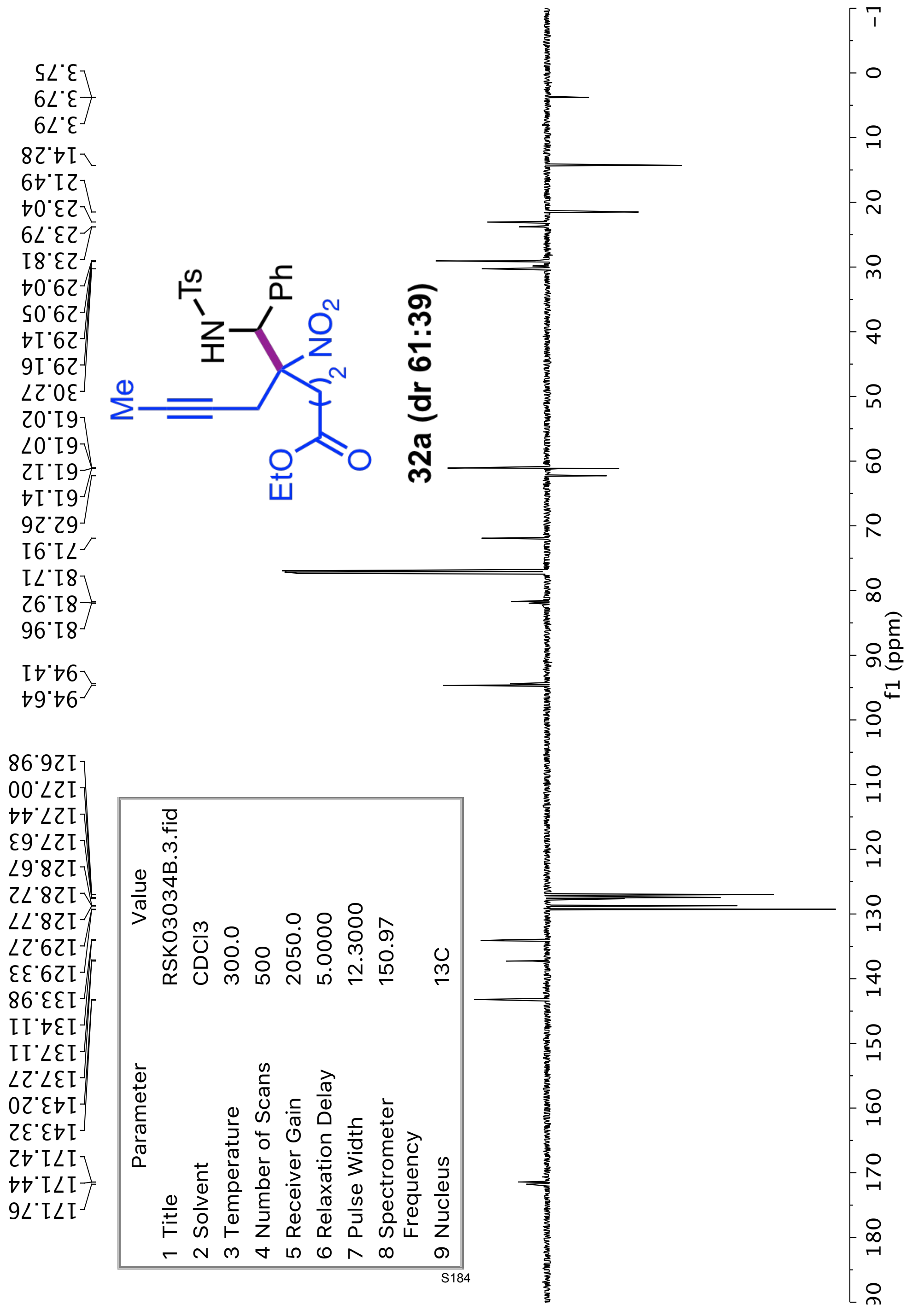




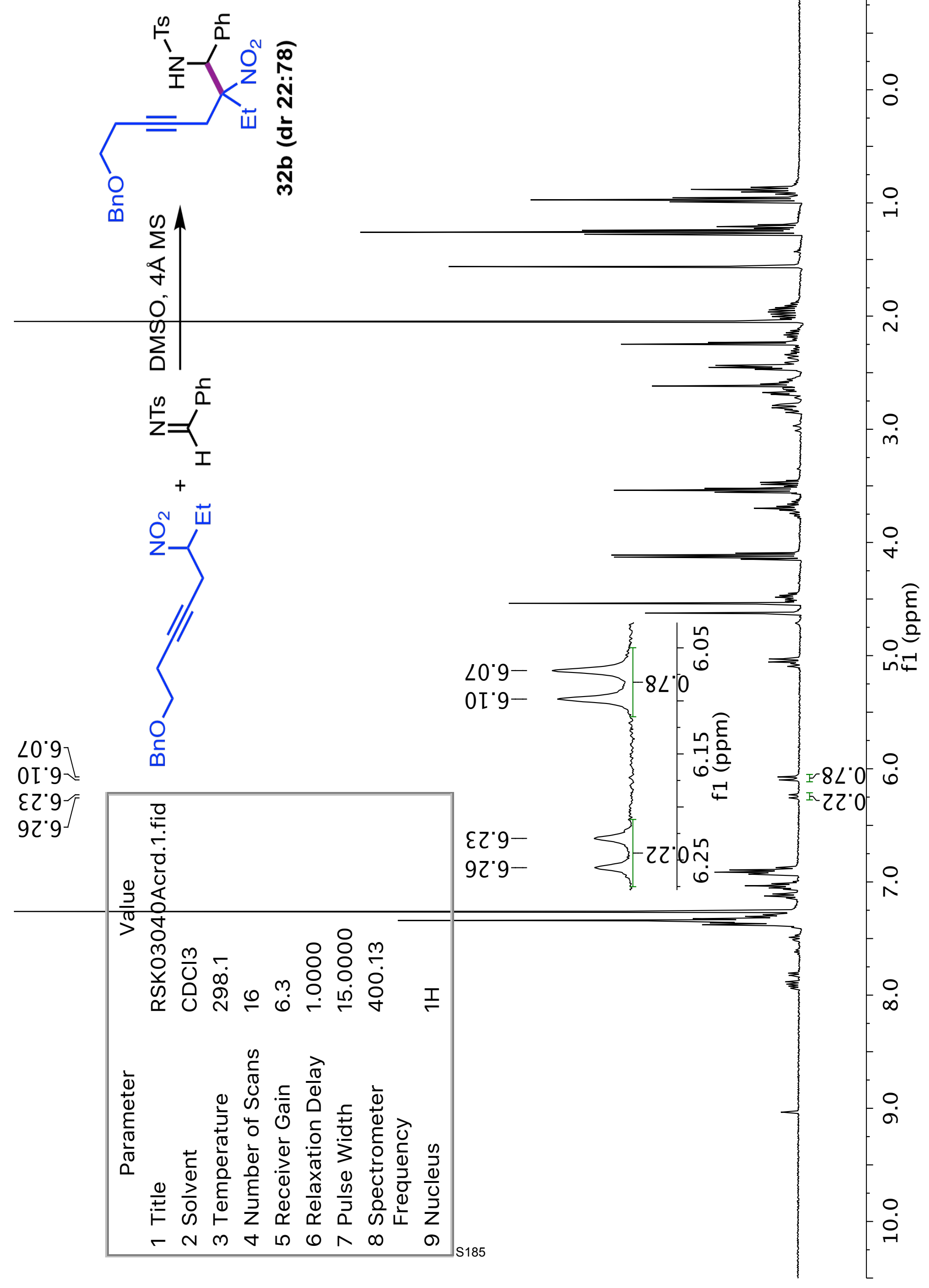



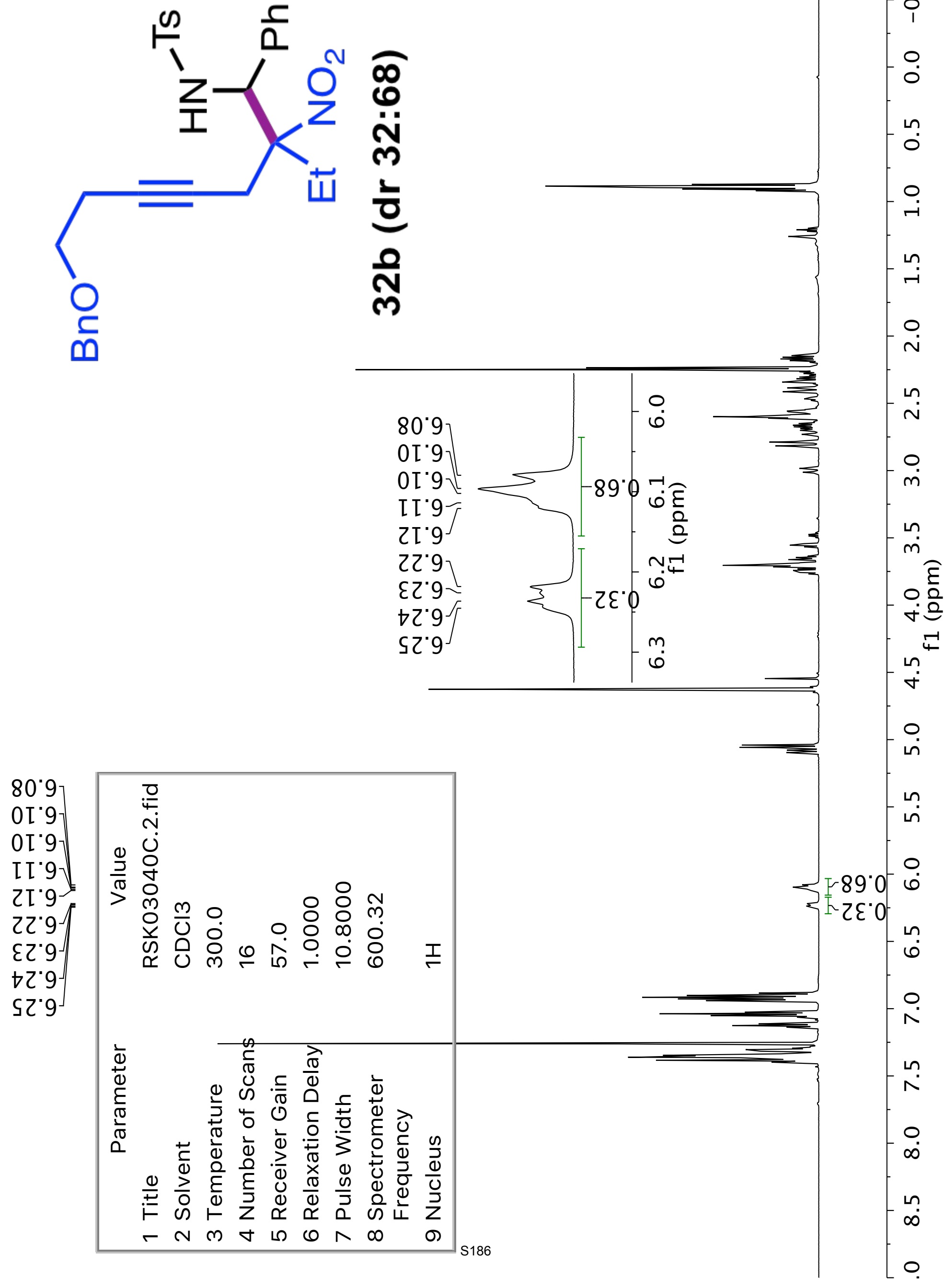


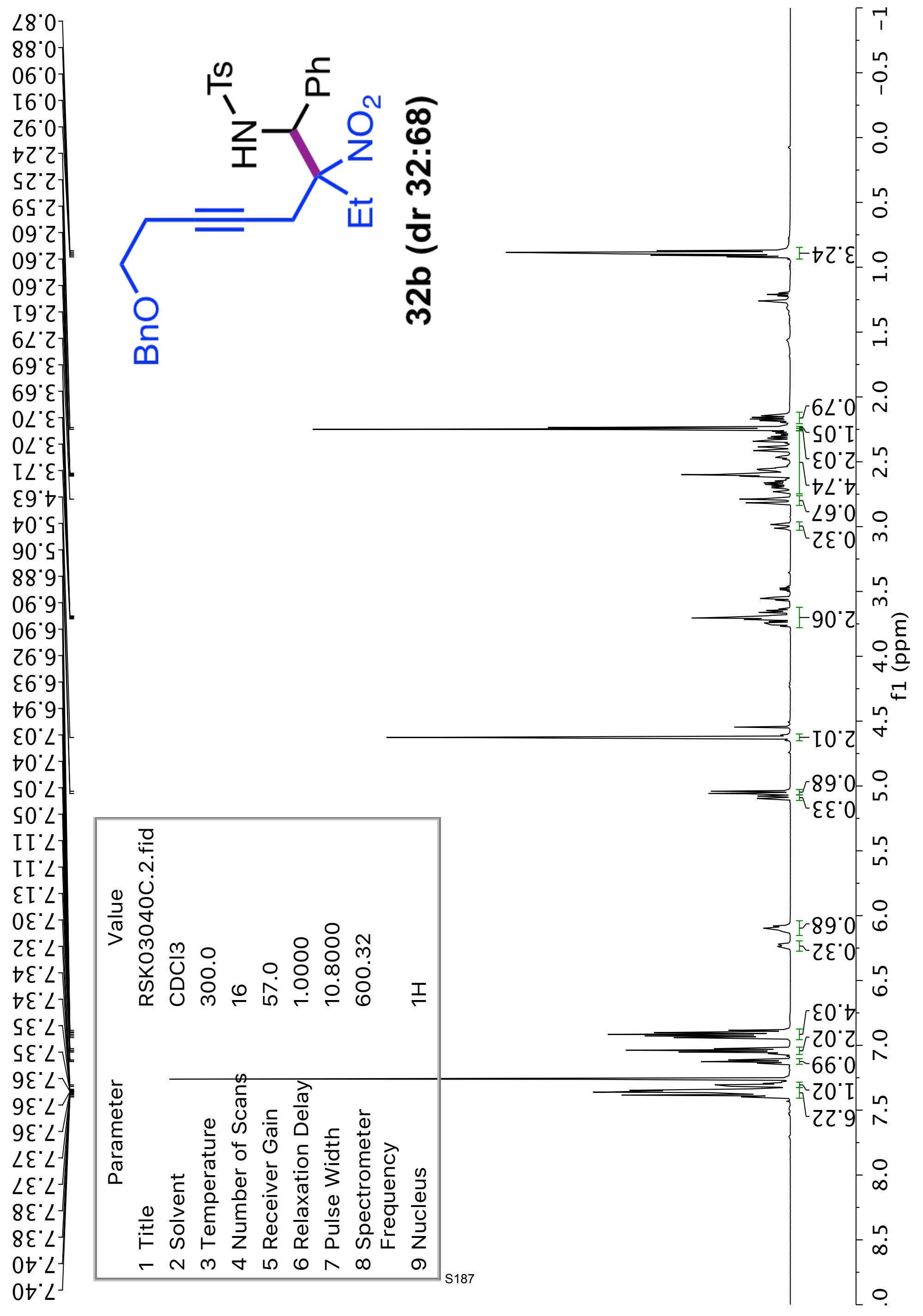


$\left.\begin{array}{l}96^{\circ} \angle \\ \angle I^{\circ} 8 \\ I \varepsilon^{\circ} 0 Z \\ \left.0 t^{\circ} 0 Z\right] \\ 9 t^{\circ} I Z J \\ 0 \varepsilon^{\circ} Z Z^{\prime} \\ Z L^{\circ} \angle Z^{\prime} \\ \varepsilon \varepsilon^{\circ} 8 Z^{\prime}\end{array}\right]$

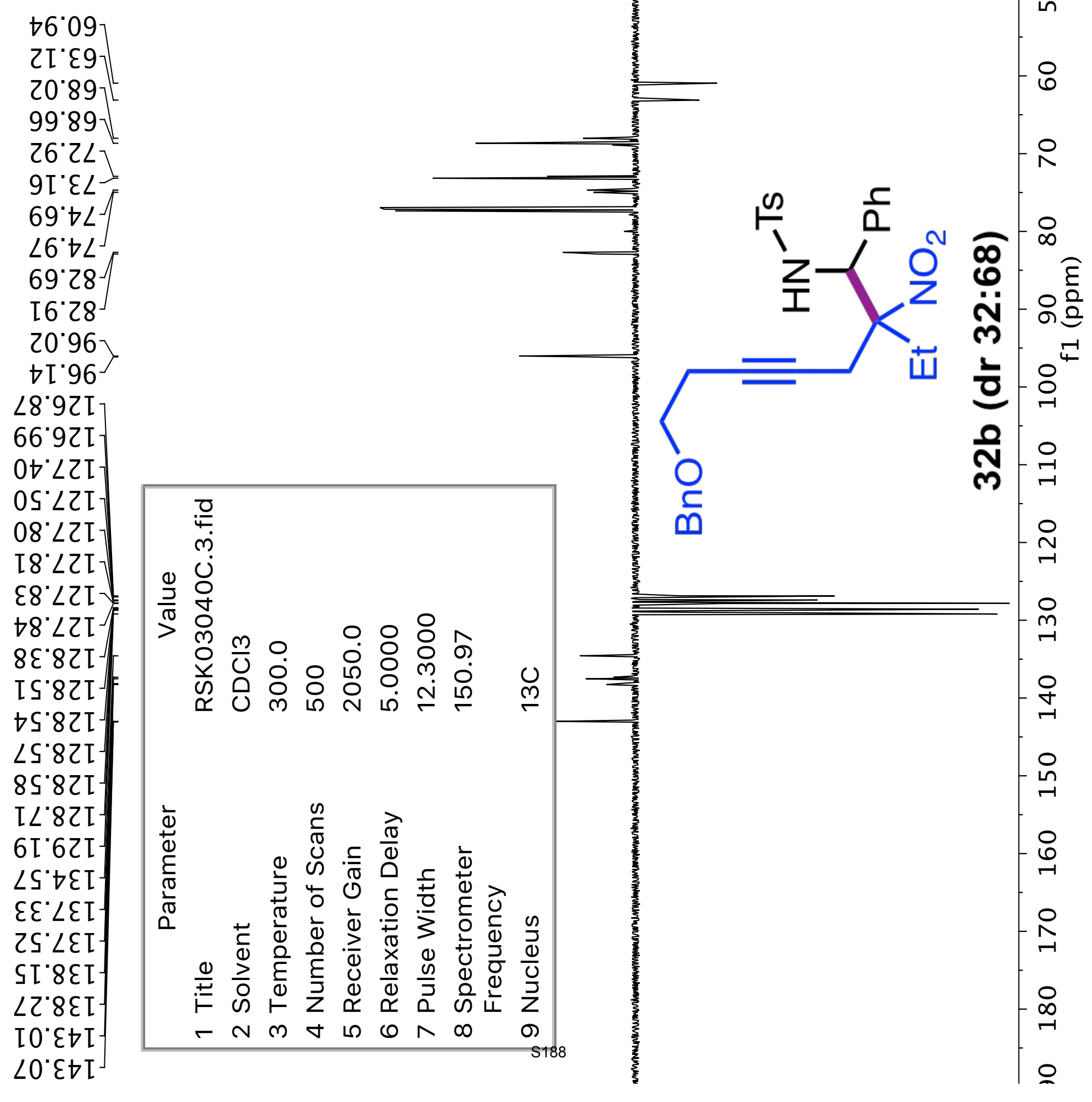




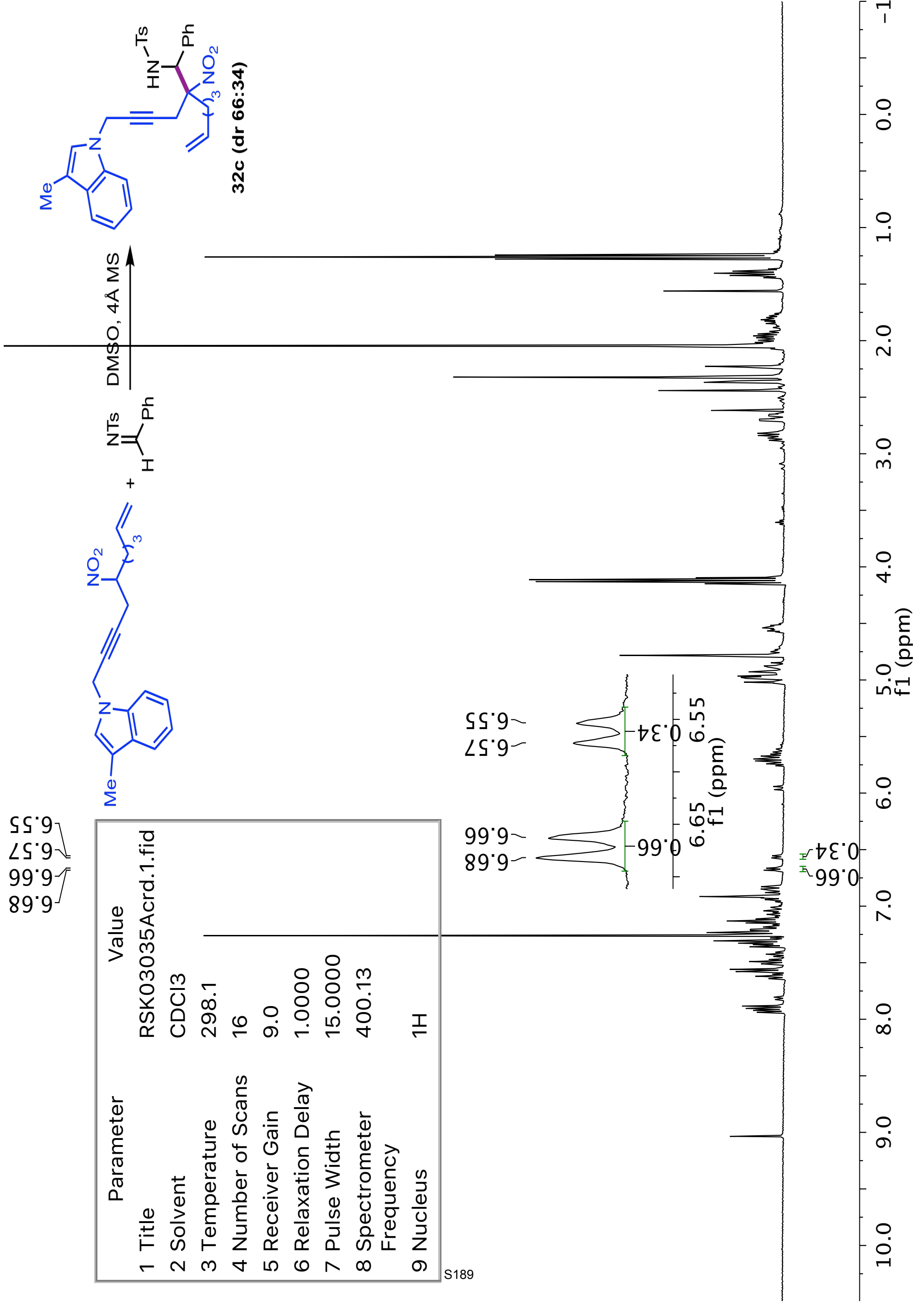



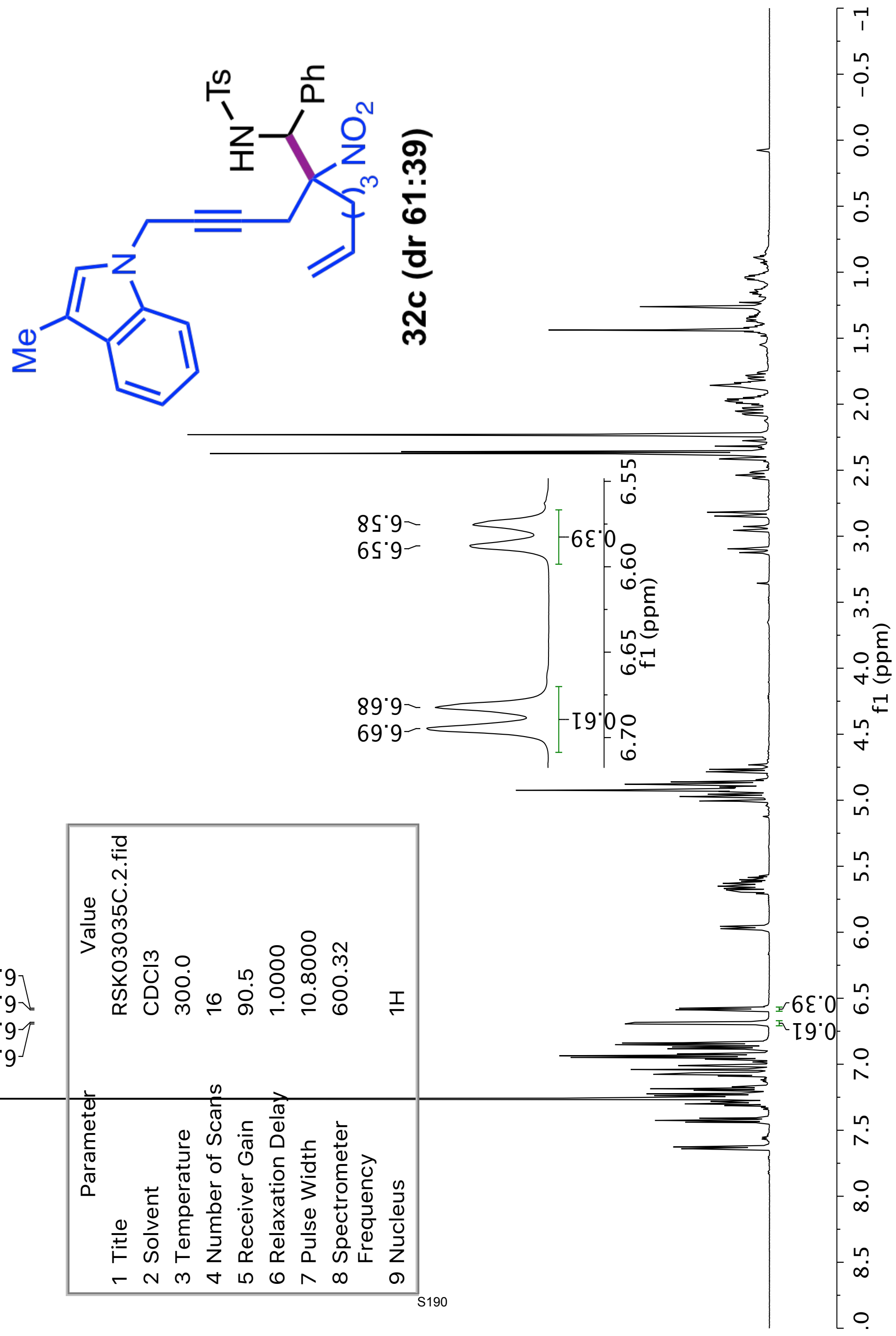


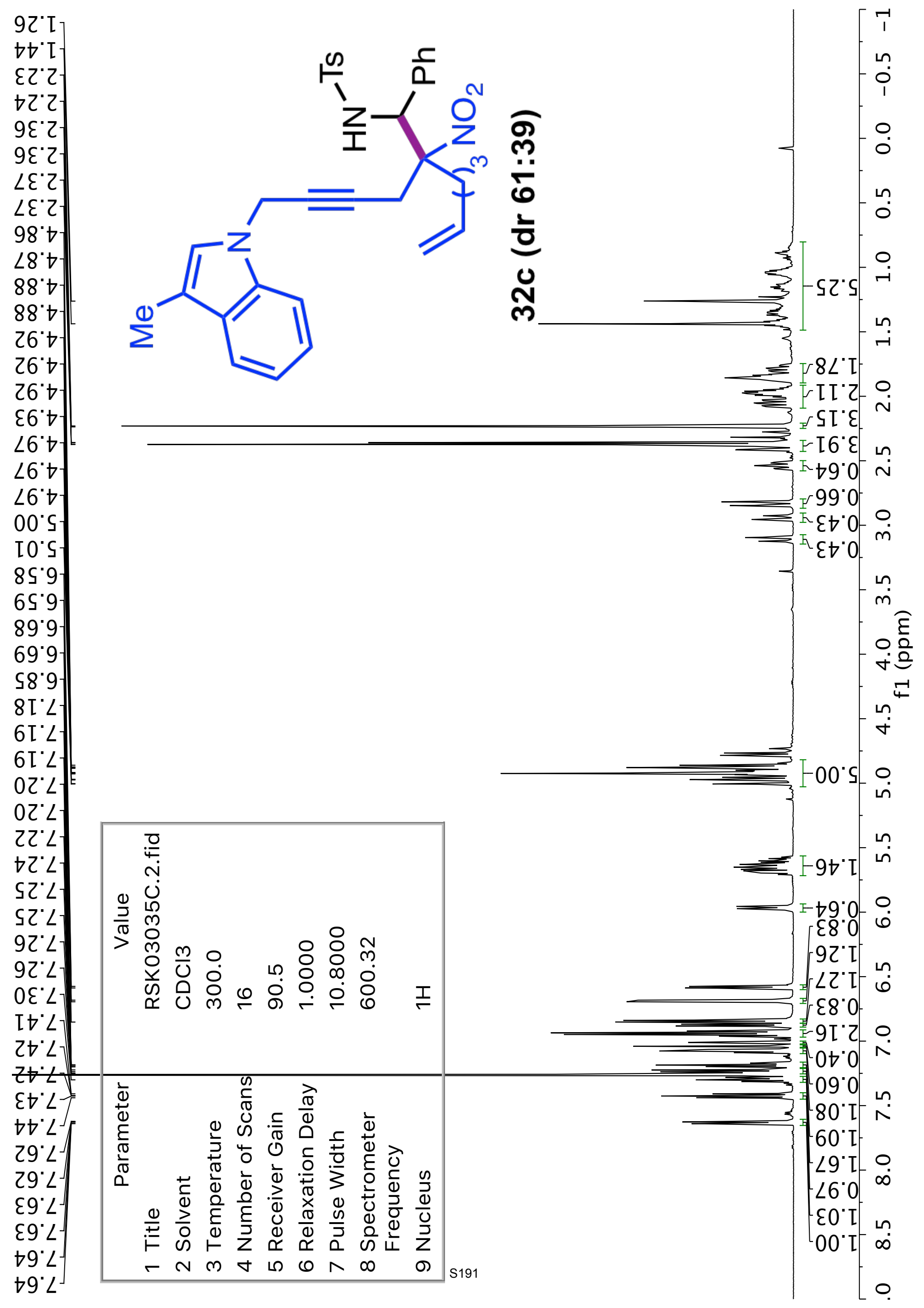




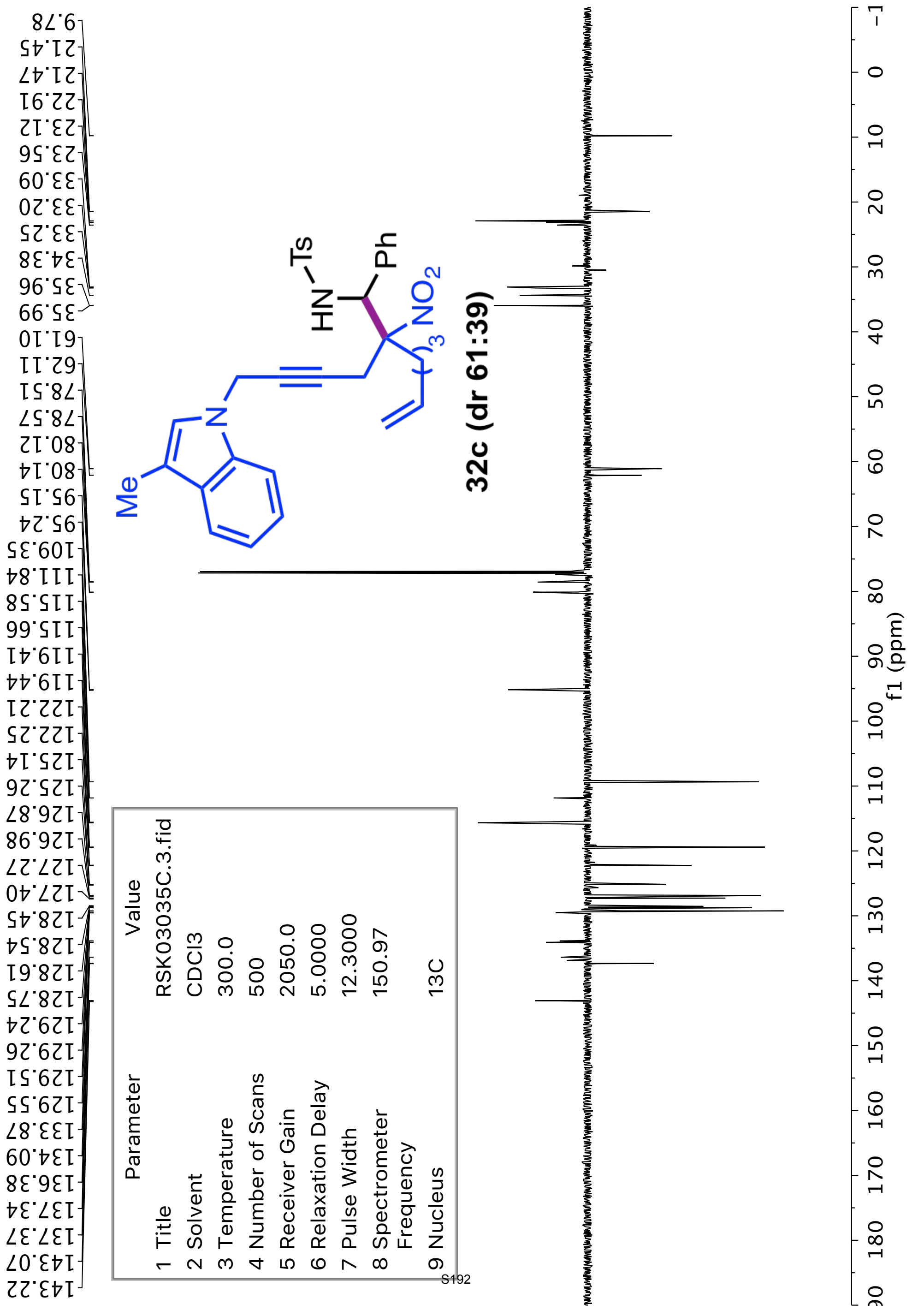




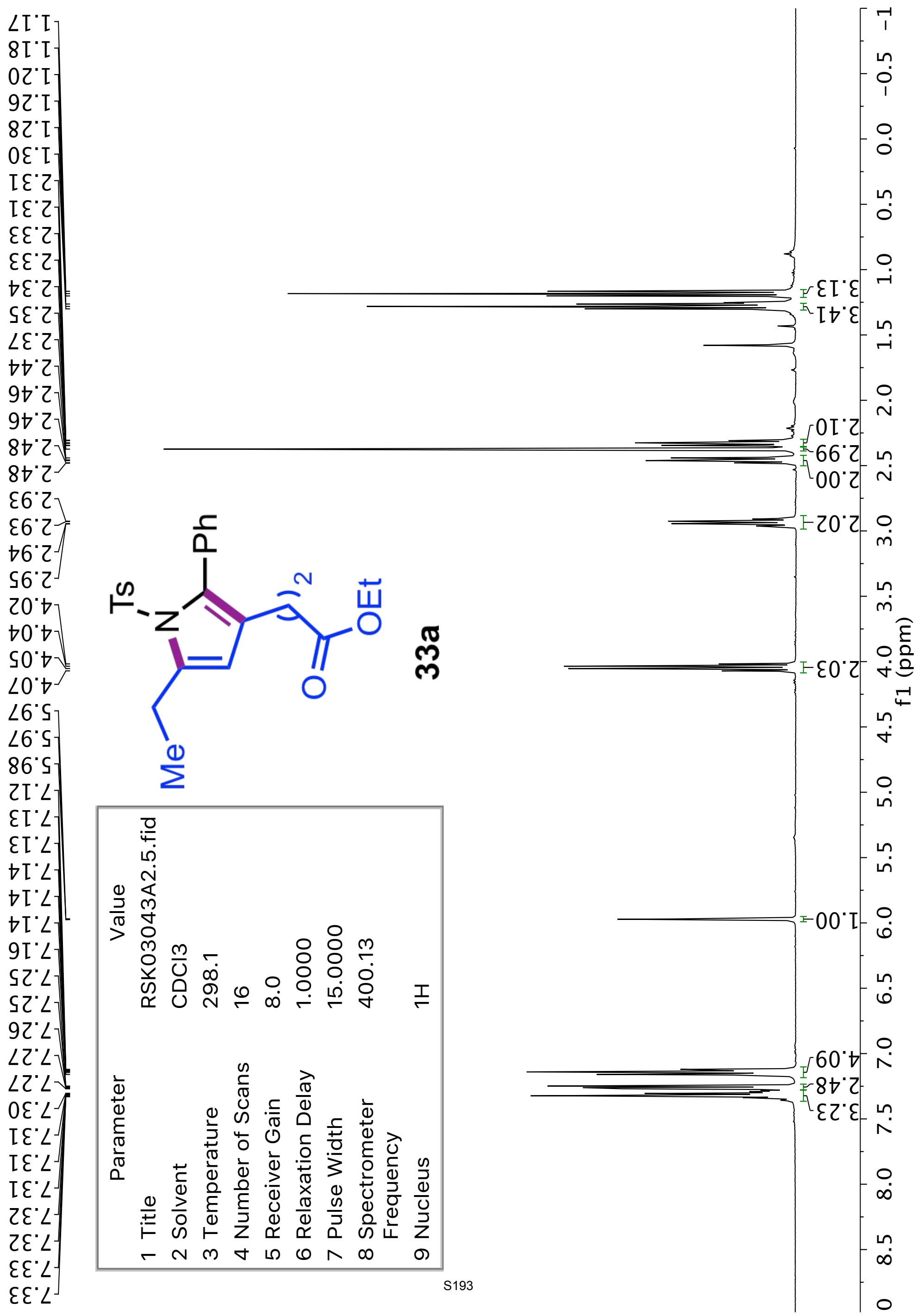


$6 t^{\circ} \varepsilon \mathrm{I}$
$\mathrm{L} \varepsilon^{\circ} \downarrow[$

$\angle t^{\circ}[Z]$

EL'IZ广

$\angle 9^{\circ} 22^{\circ}$

$\varepsilon 6^{\circ} \forall \varepsilon-$

$97^{\circ} 09-$

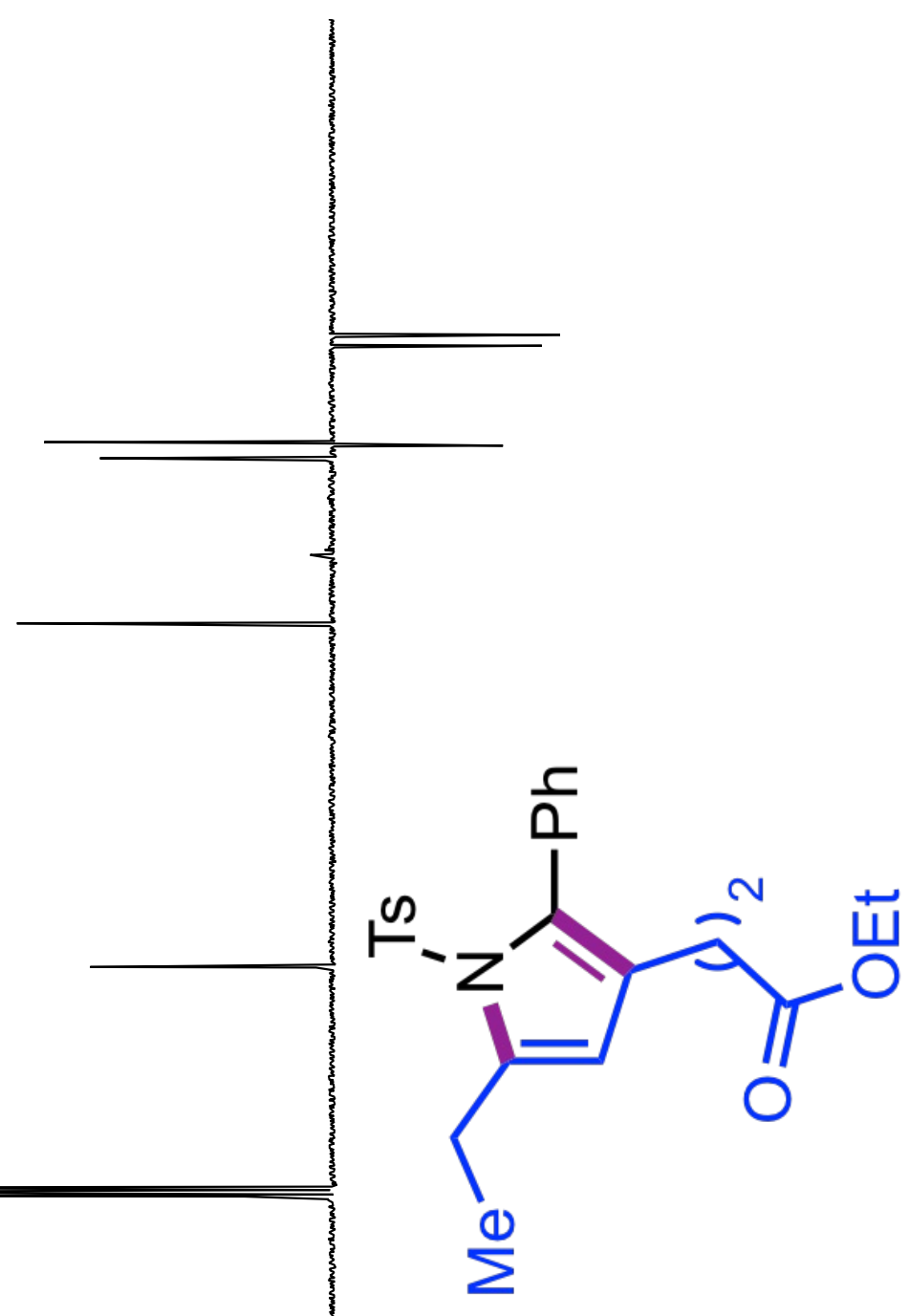

$200^{\circ}$ II-

ऽ9'ৎZL 09. $92 \mathrm{~L}$

$\left.S \sigma^{\circ} \angle Z I\right]$ $80.82 \mathrm{I}$ ZS'6ZIF $6 L^{\circ} \mathrm{LEI} \mathrm{I}^{-}$ $66^{\circ} \mathrm{IEI}$ โ8. ZEโ] $\angle 6^{\circ} 9 \varepsilon \mathrm{I}^{\mathrm{I}}$ $88^{\circ} 6 \varepsilon \mathrm{L}$. $9 Z^{\circ} \triangleright \triangleright t \mathrm{I}$ $00^{\circ} \varepsilon \angle I-$

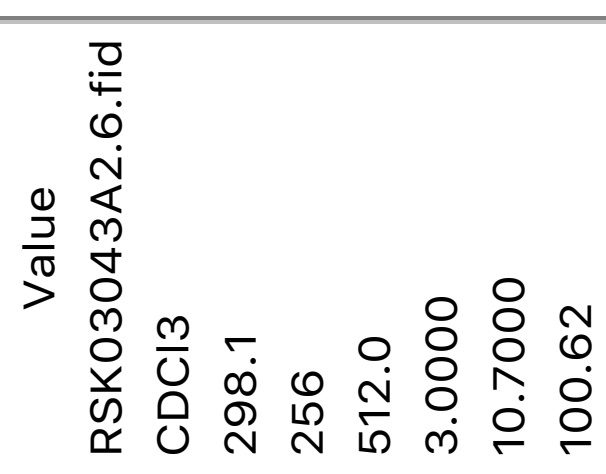

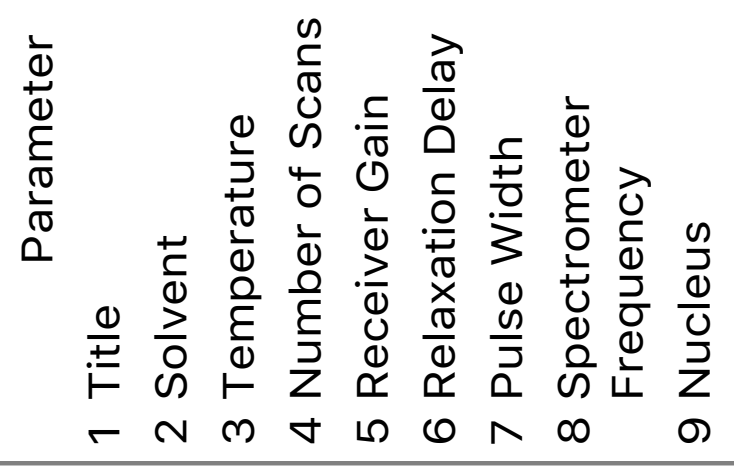

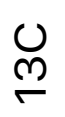




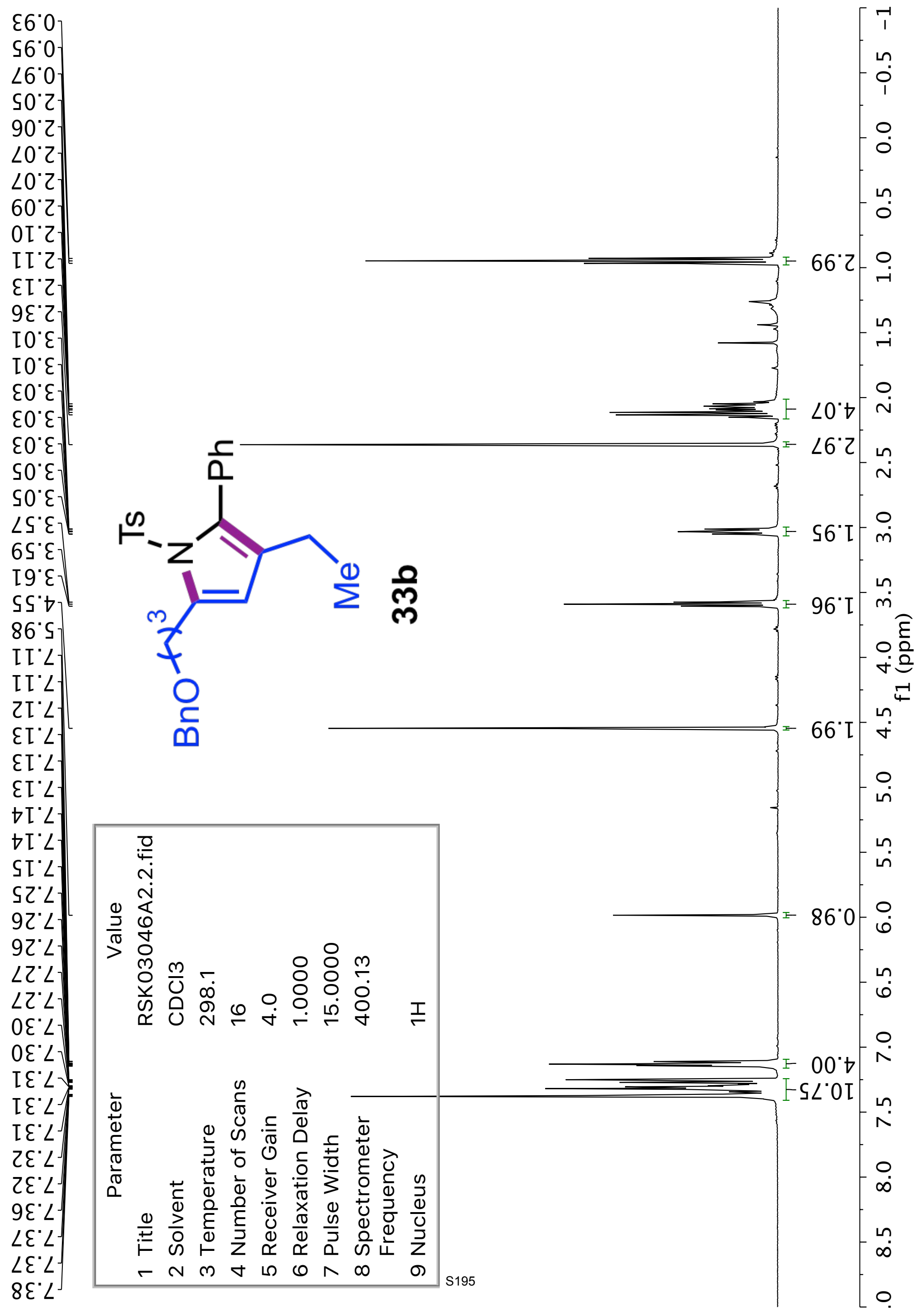


$\angle 6^{\circ} \circ \mathrm{I}-$

I $2^{\prime} 6 \mathrm{I}-$

ZL'IZ-

$0 \varepsilon^{\circ} 92-$

$0 L^{\circ} 6 Z^{\prime}$

$28^{\circ} 69-$

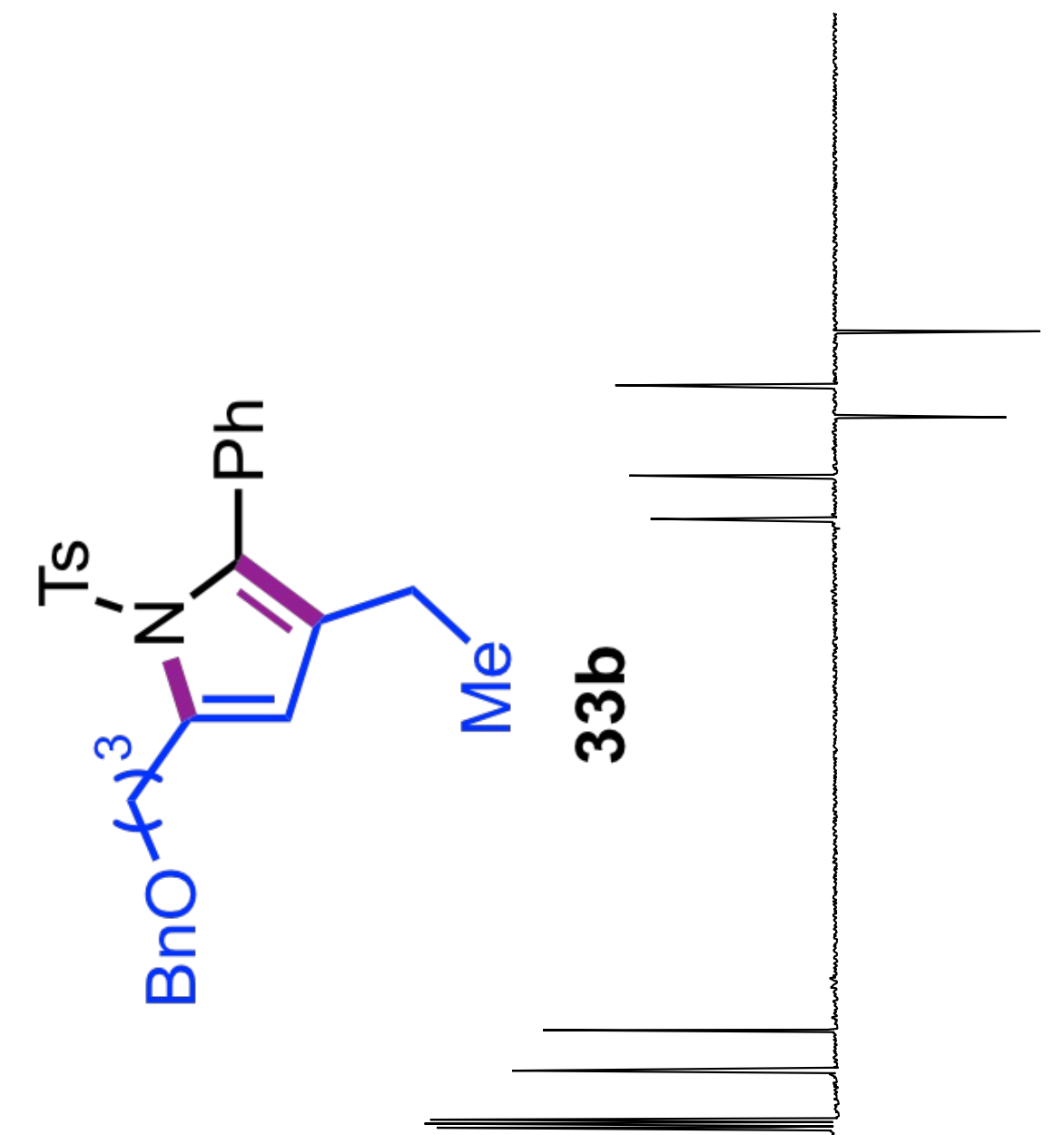

$0 L^{\circ} \varepsilon I I-$ $\angle S^{\circ} 9 Z \mathrm{I}_{\text {T }}$ $\left.8 Z^{\circ} \angle Z I\right]$ $S 9^{\circ} \angle Z \mathrm{~L}$ $9 \angle \angle Z I-$ $28^{\circ} \angle 2 \mathrm{I}$ $05^{\circ} 82 \mathrm{I}$ $\varepsilon t^{\circ} 62 \mathrm{~L}$ OS.6ZI $S L$ IEI IZ'ZعI It'ZEI$\varepsilon 8.9 \varepsilon \mathrm{I}$ $89^{\circ} \angle \varepsilon \mathrm{I}$ $\mathrm{S} \angle{ }^{\prime} 8 \varepsilon \mathrm{I}-$ $\forall\left[\begin{array}{r}* \\ {[}\end{array}\right.$

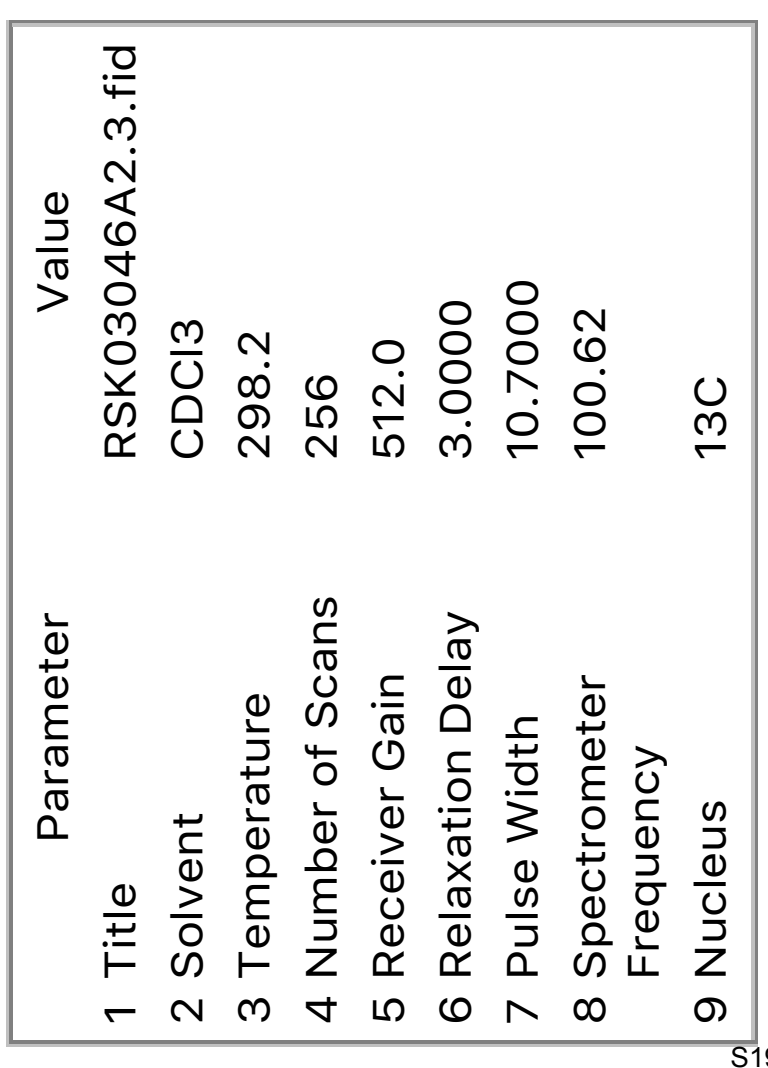

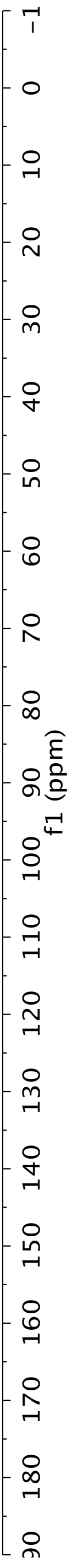




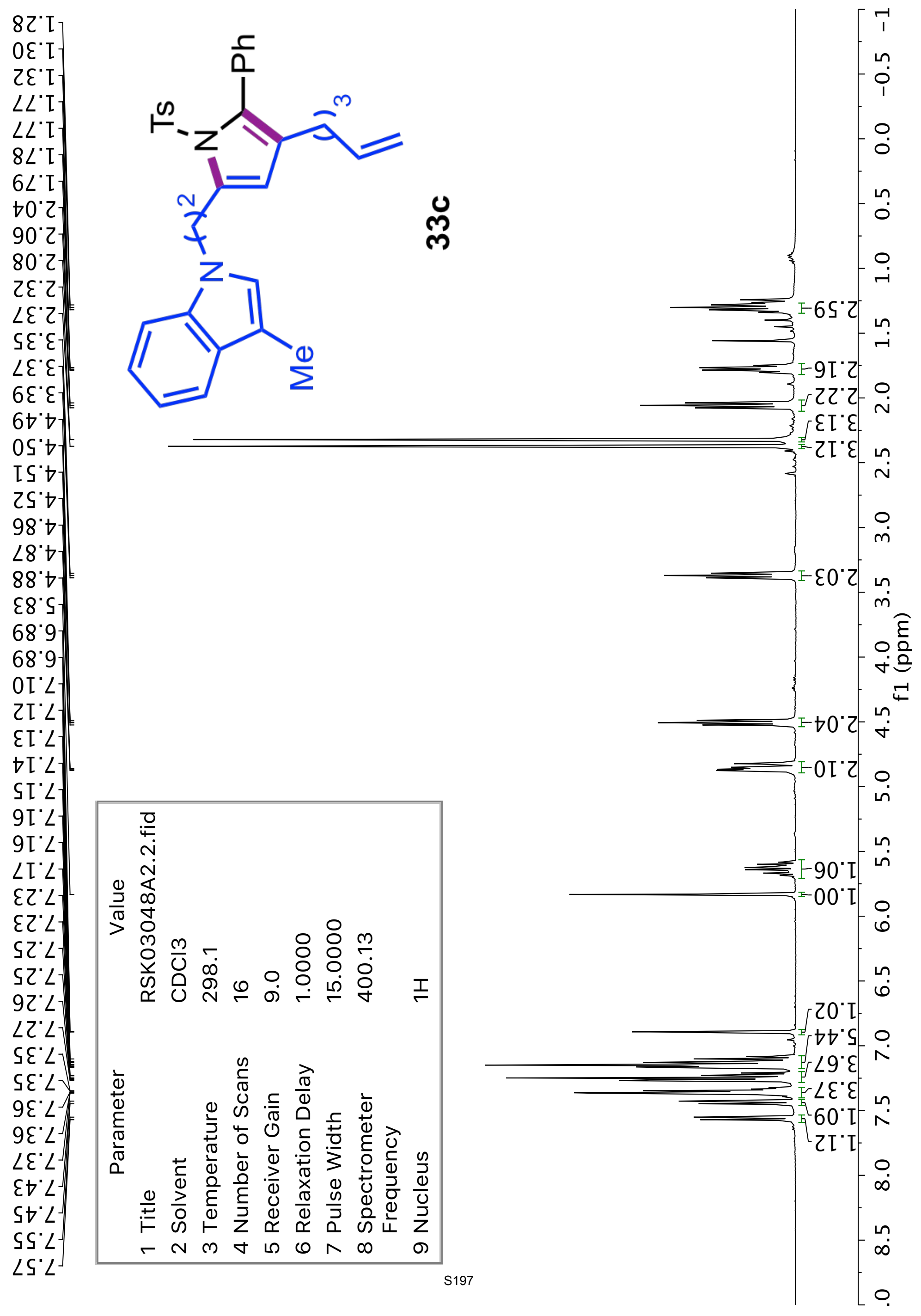


$\angle L{ }^{\circ}{ }^{-}$

$\varepsilon L ' I Z]$

OI'SZ

$82^{\circ} 62$ ᄂ

$\varepsilon t^{\prime} I \varepsilon-$

ZI' $\varepsilon \varepsilon^{\digamma}$
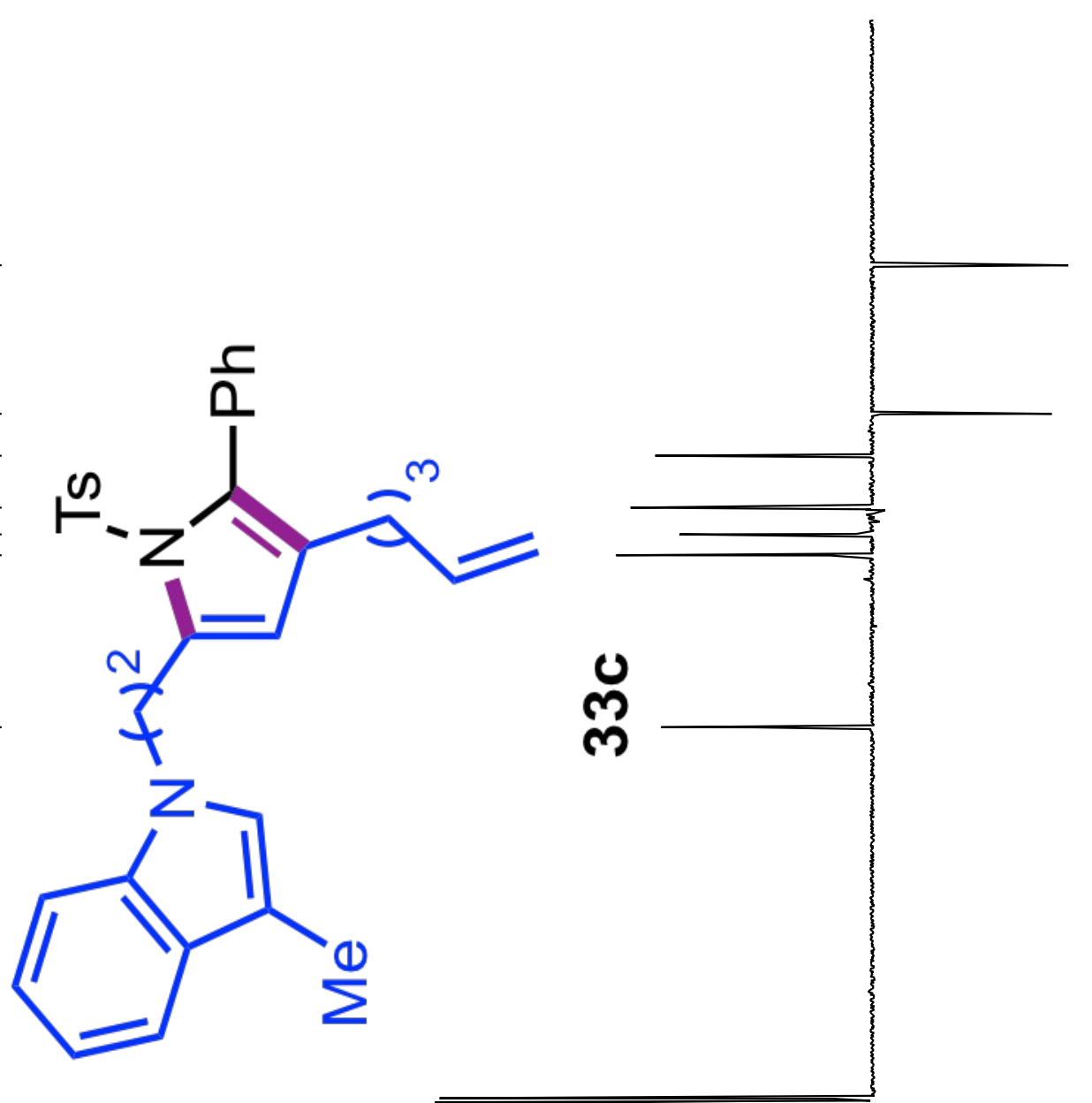

$96^{\circ} 9 t-$

$\angle \varepsilon^{\circ} 60 \mathrm{~T}$

I ${ }^{\circ} 0$ I I

$8 S^{\circ} \bullet \mathrm{II}$

29.9 I

$\angle S^{\circ} 8 \mathrm{II}$

$\varepsilon 00^{\circ} 6$ I I

$8 t^{\circ}$ LZL

$6 S^{\prime} S Z \mathrm{I}$

SS"9ZL ]E

$\left.0 t^{\circ} \angle Z \mathrm{I}\right]$

$20.82 \mathrm{I}$

$\checkmark \mathrm{I} \cdot 8 \mathrm{~L} \mathrm{I}$

$\angle L ' 8 Z I=$

2S.6ZI

$\angle L ' T E I$

โ0 $2 \varepsilon \mathrm{I}$

$6 \mathrm{~S}^{\circ} \varepsilon \varepsilon \mathrm{L}$

$96^{\circ} \varepsilon \varepsilon \mathrm{L}$

$\varepsilon \varepsilon^{\circ} 9 \varepsilon \mathrm{I}$

0t $9 \varepsilon \mathrm{I}$ -

$\angle S^{\circ} 8 \varepsilon$ 工 -

$8 \nabla^{\circ} \forall t \mathrm{I}$

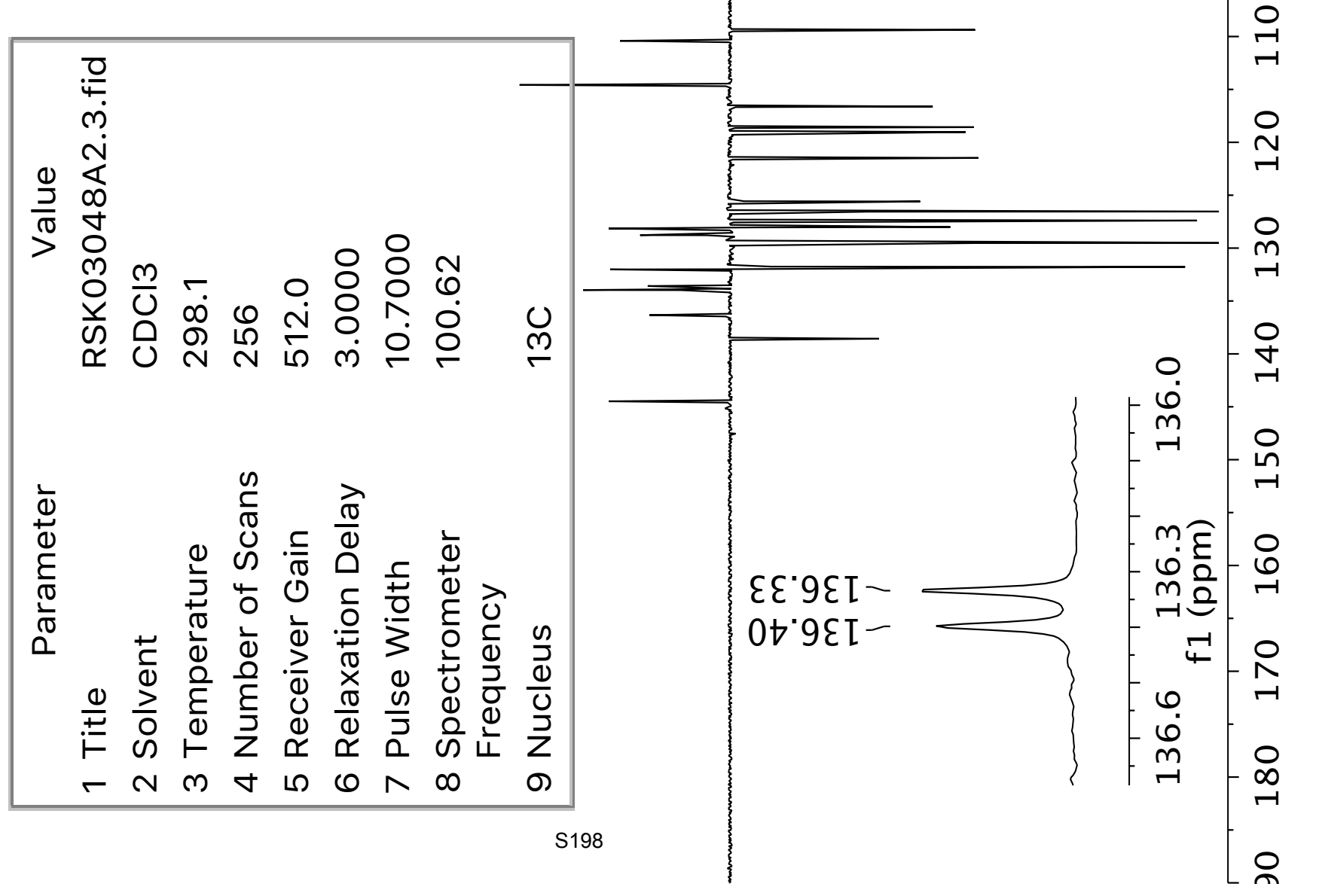


09' I-

$\left.\begin{array}{l}\angle 0^{\circ} \varepsilon \\ \succ I^{\circ} 9 \\ \varepsilon \varepsilon^{\circ} \angle \\ \varsigma \varepsilon^{\circ} \angle\end{array}\right]$

$9 \varepsilon^{\circ} L$

$8 \varepsilon^{\circ} L$

$8 \varepsilon^{\circ} L$

$6 \varepsilon^{\circ} \angle$

$0 \nabla^{\circ} L$

I $\nabla^{\circ} \angle$

$Z \nabla^{\circ} L$

$\varepsilon \nabla^{\circ} L$

$S \nabla^{\circ} L$

$S \nabla^{\circ} L$

$S t^{\circ} L$

$S \nabla^{\circ} L$

$9 t^{\circ} L$

$9 t^{\circ} L$

$\angle t^{\circ} \angle$

$\angle \nabla^{\circ} \angle$

$8 t^{\circ} L$

$8 t^{\circ} L$

$0 S^{\circ} \angle$

$\left.2 S^{\circ} \angle\right]$

$6 S^{\circ} \angle$

$\left[9^{\circ} L\right]$

$\varepsilon L ' L$

$\varepsilon L L J$

$\nabla L L$

$\nabla L L^{\prime} L$

$S L L$

$S L L^{\prime} L$
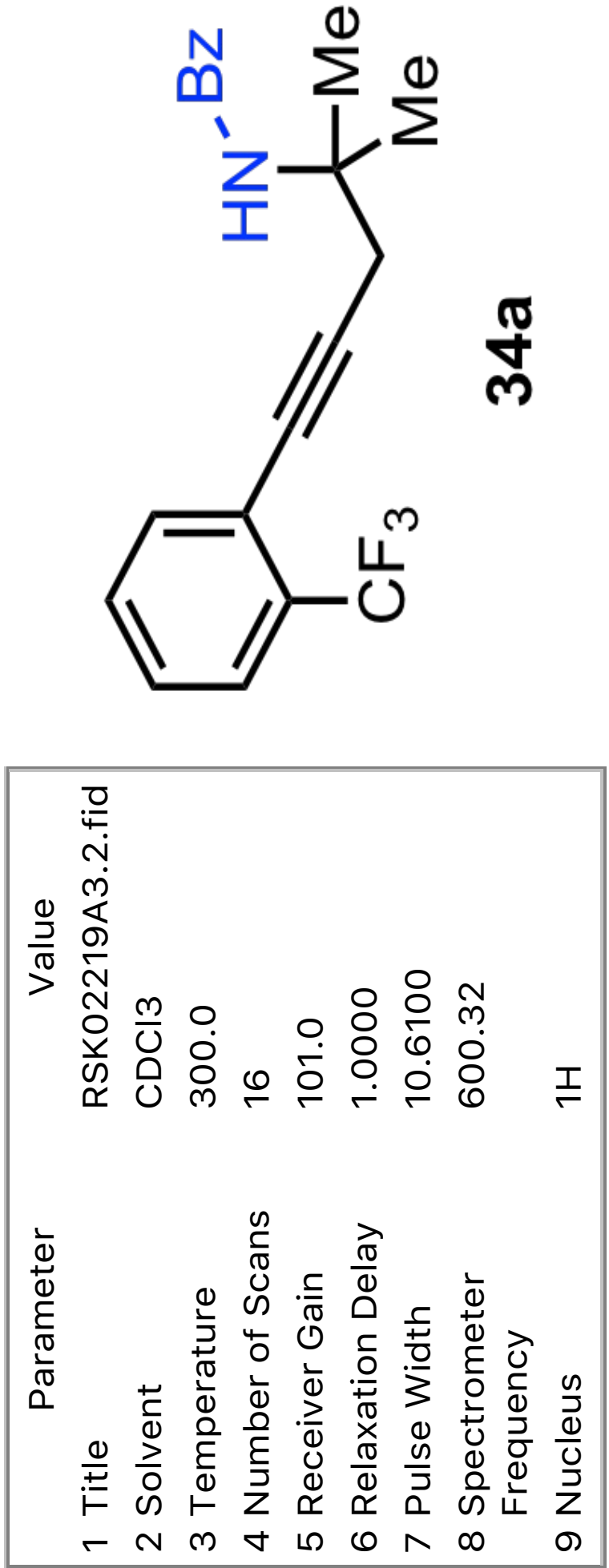


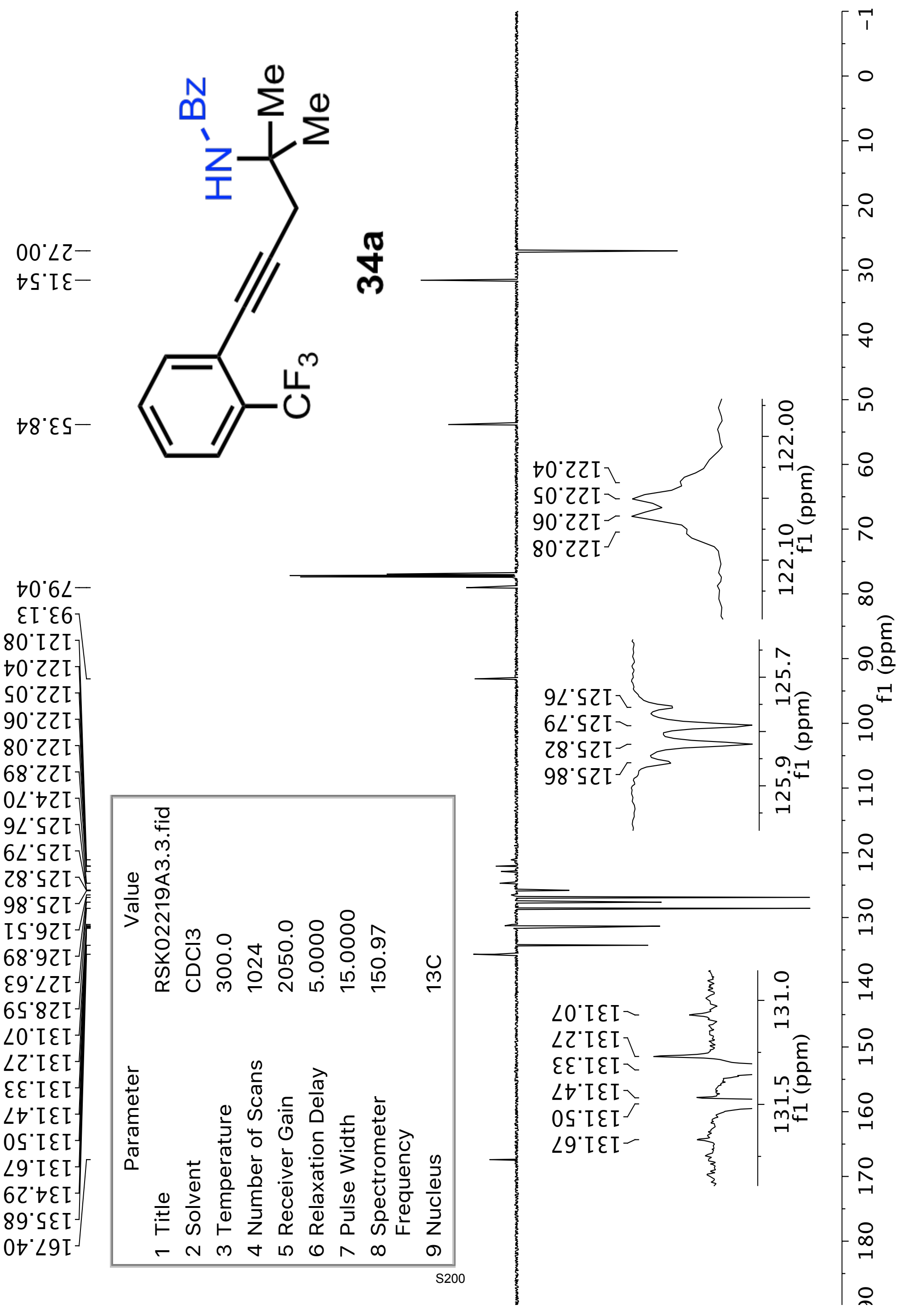




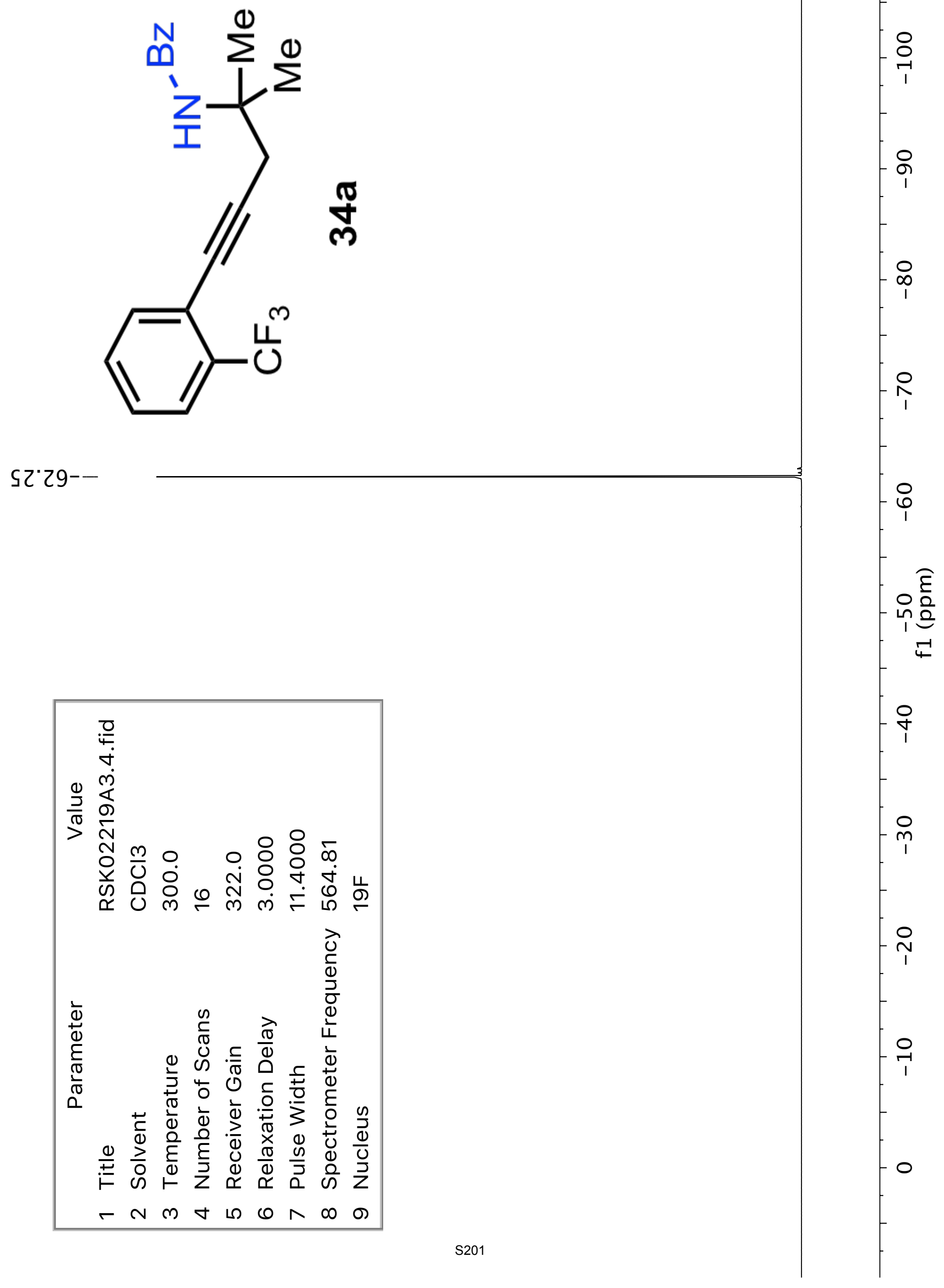


ss: 8 :

$20^{\circ} \varepsilon$

$\varepsilon$ L $\left.^{\circ} 9\right]$

$\neg 0^{\circ} \angle$

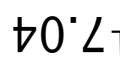

$\mathrm{SO}^{\circ} \mathrm{L}$

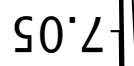

$\rightarrow I^{\circ} \angle$

$S I ' L$

9I' $\angle$

$9 I^{\prime} L$

$\angle I^{\circ} \angle$

$\angle I^{\circ} \angle$

$62^{\circ} \angle$

$62^{\circ} L$

$0 \varepsilon^{\circ} L$

$0 \varepsilon^{\circ} L$

I $\varepsilon^{\prime} L$

I $\varepsilon^{\circ} L$

$6 \varepsilon^{\circ} L$

$\mathrm{I} \nabla^{\circ} \mathrm{L}$

$2 \nabla^{\circ} L$

$2 \nabla^{\circ} L$

$\varepsilon \nabla^{\circ} L$

$\varepsilon \nabla^{\circ} L$

$9 t^{\circ} L$

$9 \nabla^{\circ} \angle$

$9 t^{\circ} \angle$

$\angle \nabla^{\circ} \angle$

$\angle D^{\circ} L^{\circ}$

$\nabla L L-1$

$\nabla L ' L$

$S L L$

$S \angle L$

$S L L$

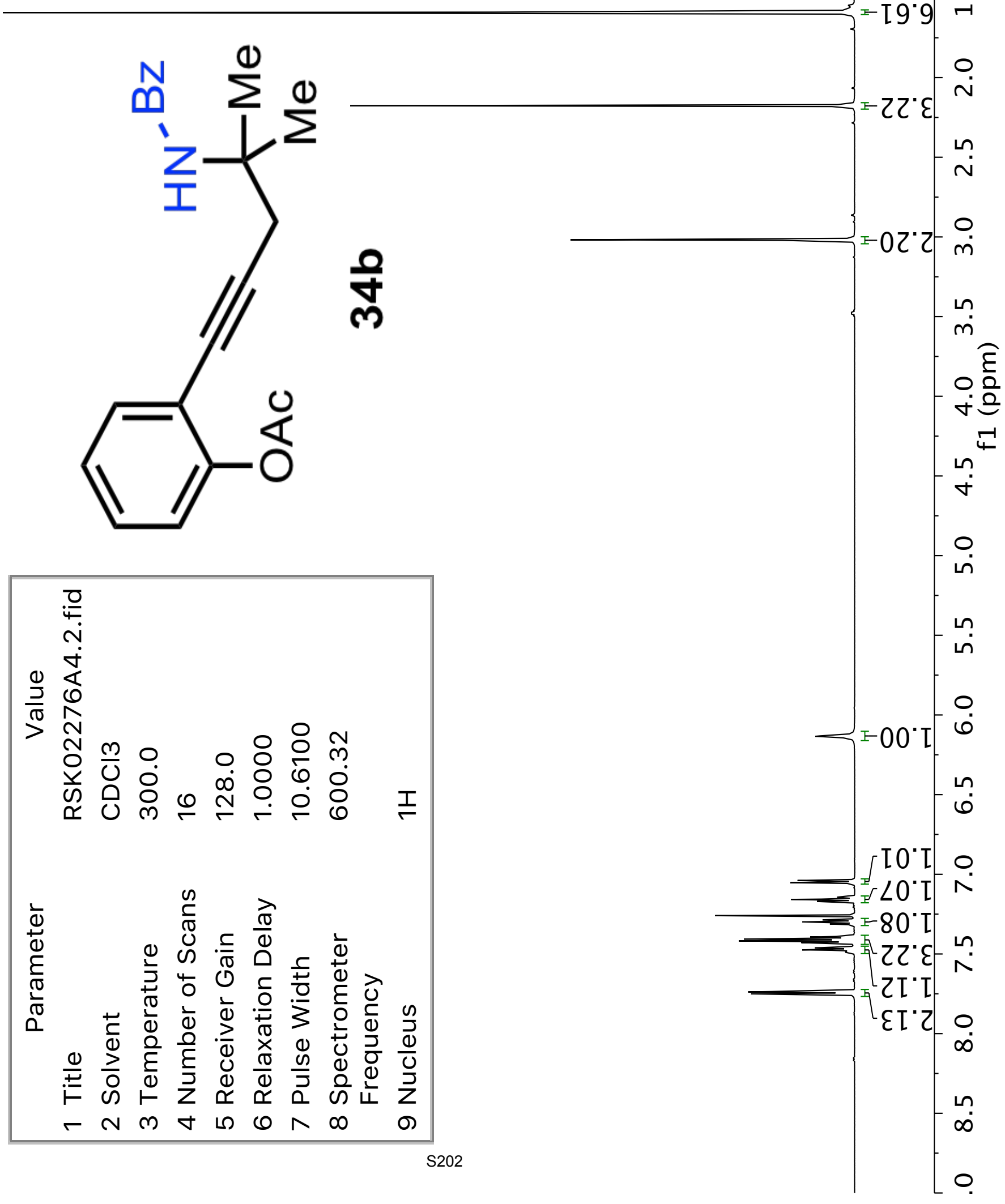




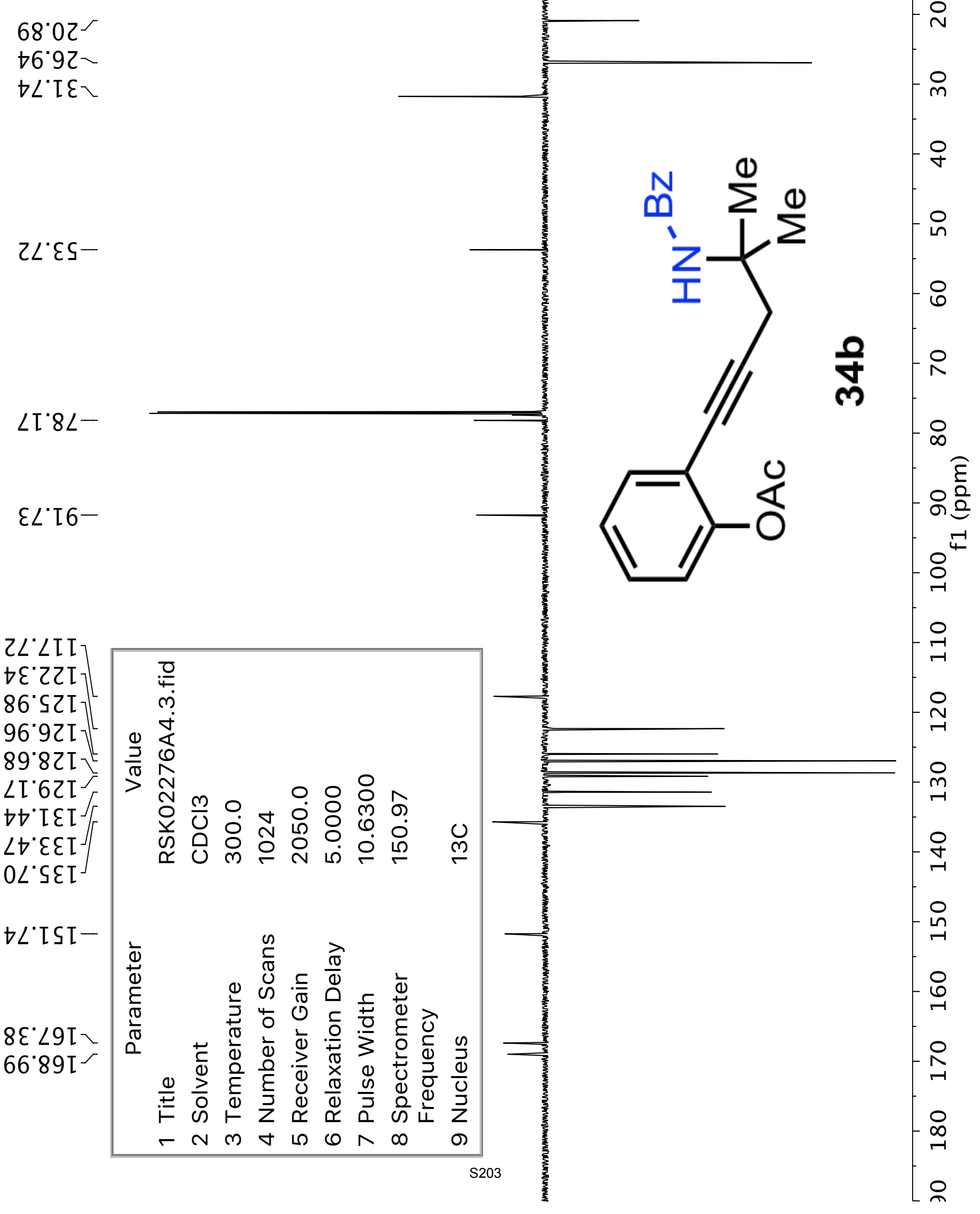




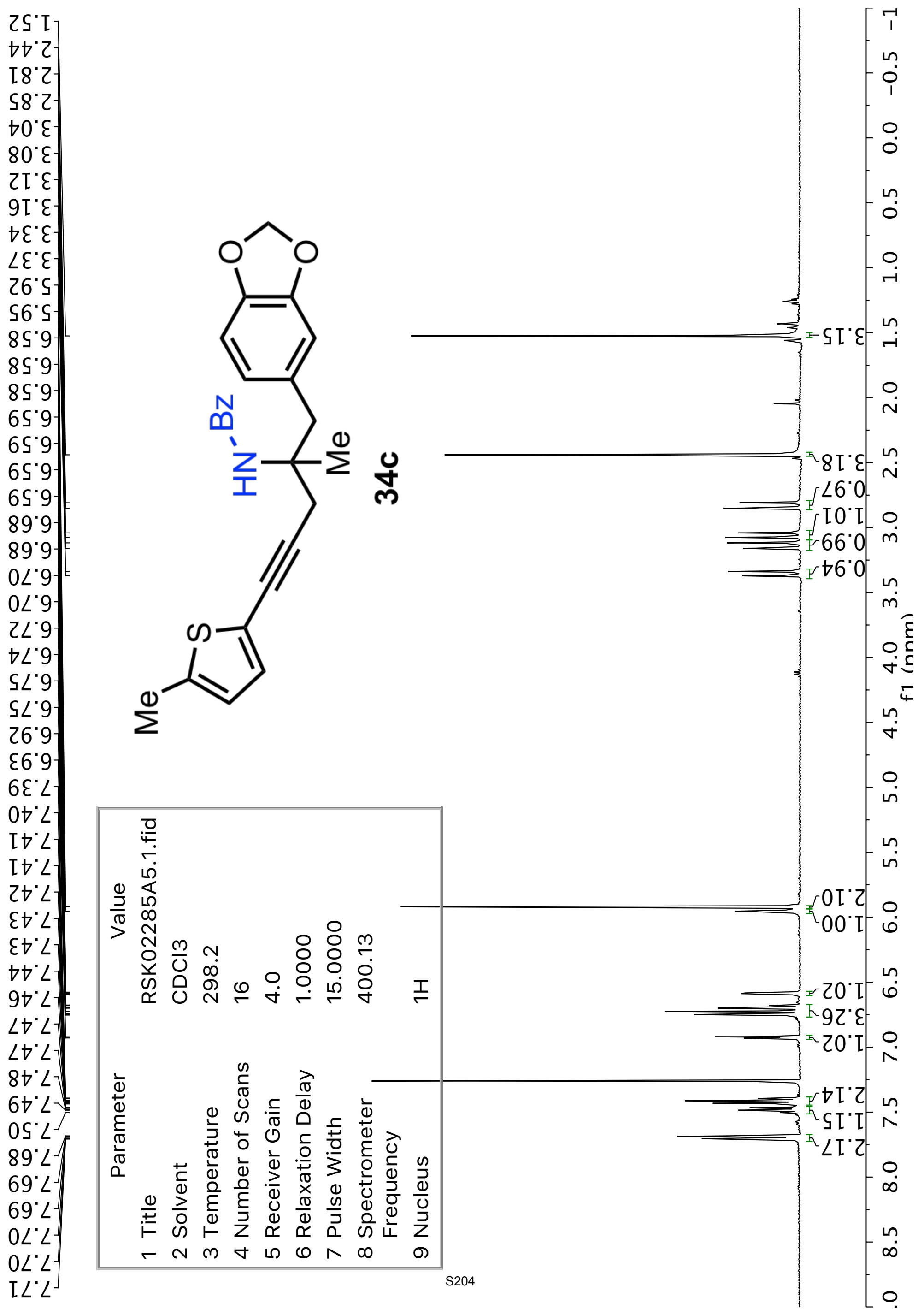




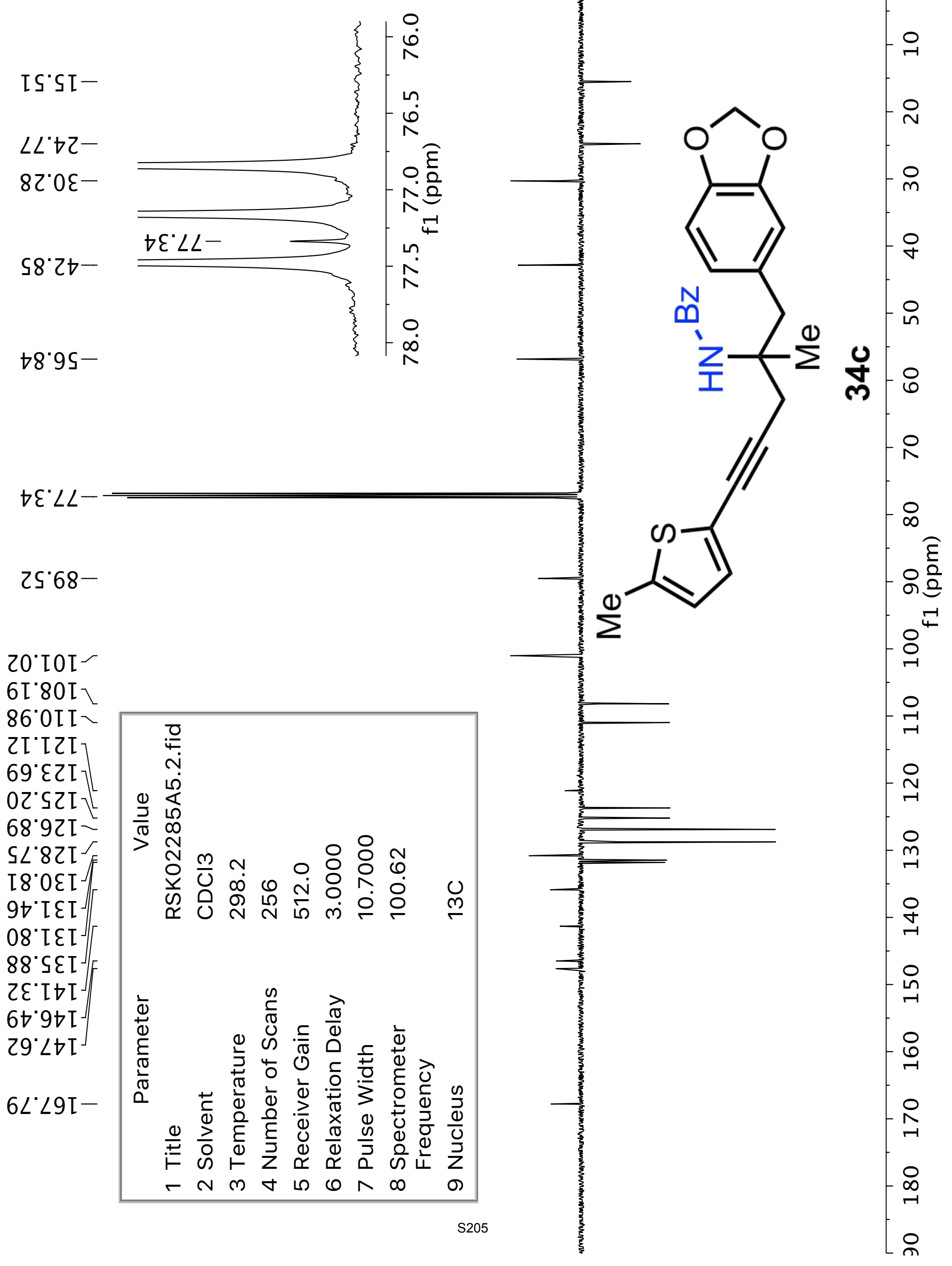


\$6: $:-$ $\varepsilon Z^{\prime} S$ $\varepsilon Z^{\prime} S$ $\nabla \tau^{\circ} s$ ธ6.9ธ6.9 96.9 $\angle 6^{\circ} 9$ $\angle 6^{\circ} 9$ $86^{\circ} 9$ $66^{\circ} 9$ I0 $\mathrm{L}$ $\mathrm{I}^{\circ} \mathrm{L}$ $20^{\circ} \mathrm{L}$ $\varepsilon 0^{\circ} \mathrm{L}$ $\mathrm{SO} \mathrm{L}^{\circ} \mathrm{L}$ $\mathrm{SO}^{\circ} \mathrm{L}$ $\mathrm{SO}^{\circ} \mathrm{L}$ $90^{\circ} \mathrm{L}$ $\angle 0^{\circ} \mathrm{L}$ $80^{\circ} \mathrm{L}$ $60^{\circ} \mathrm{L}$ $\varepsilon I^{\circ} L$ $\varepsilon[' L]$ SI' $L$ 9[' $\angle]$ $\angle I^{\circ} L$ $\angle I^{\circ} L$ $8 \mathrm{I}^{\circ} \mathrm{L}$ $6 I^{\prime} L$ $6 I^{\circ} L$ $6 \mathrm{I}^{\circ} \mathrm{L}$ $0 \varepsilon^{\circ} \angle$ ZE' $\angle$ ZE' $L$

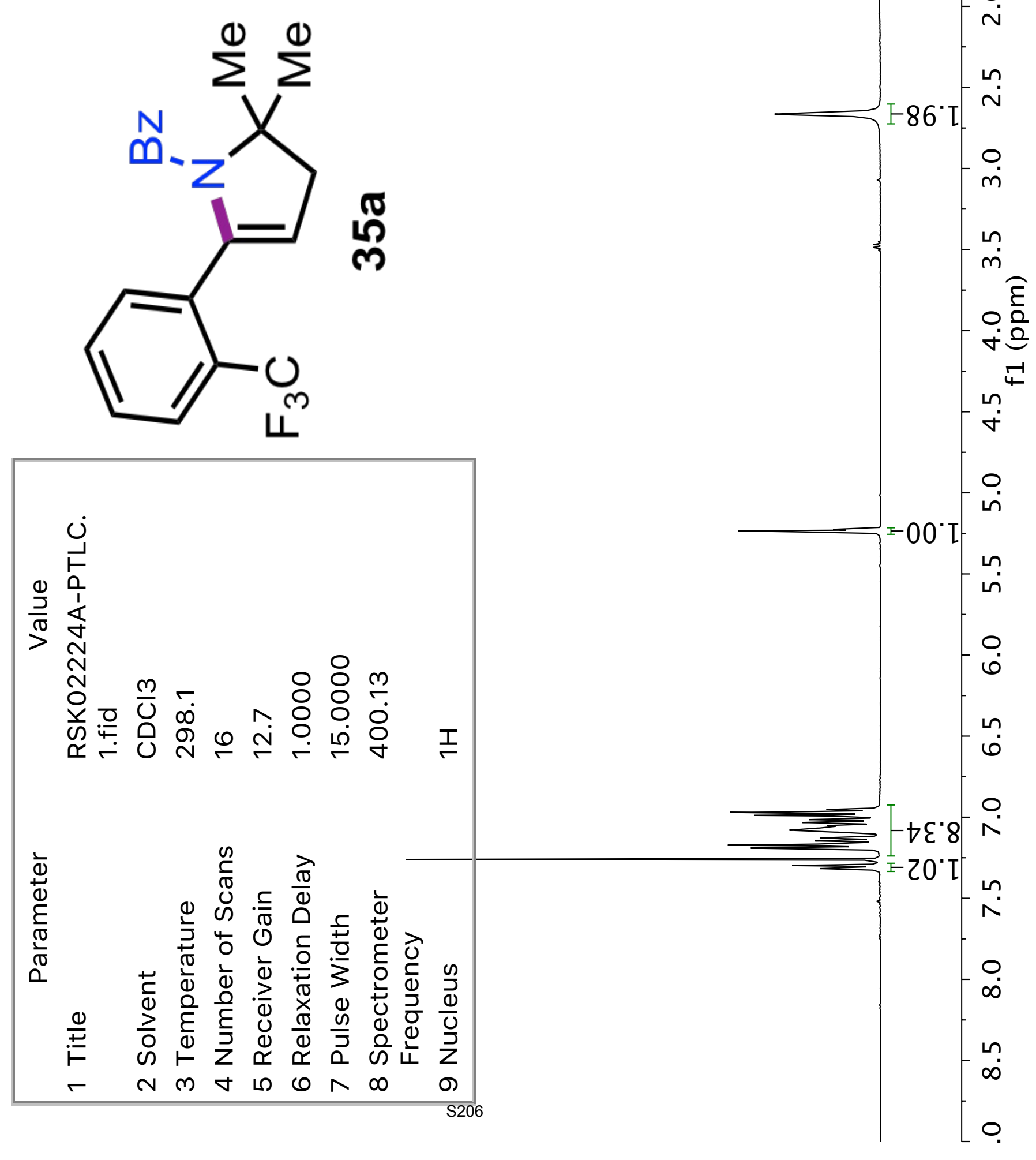




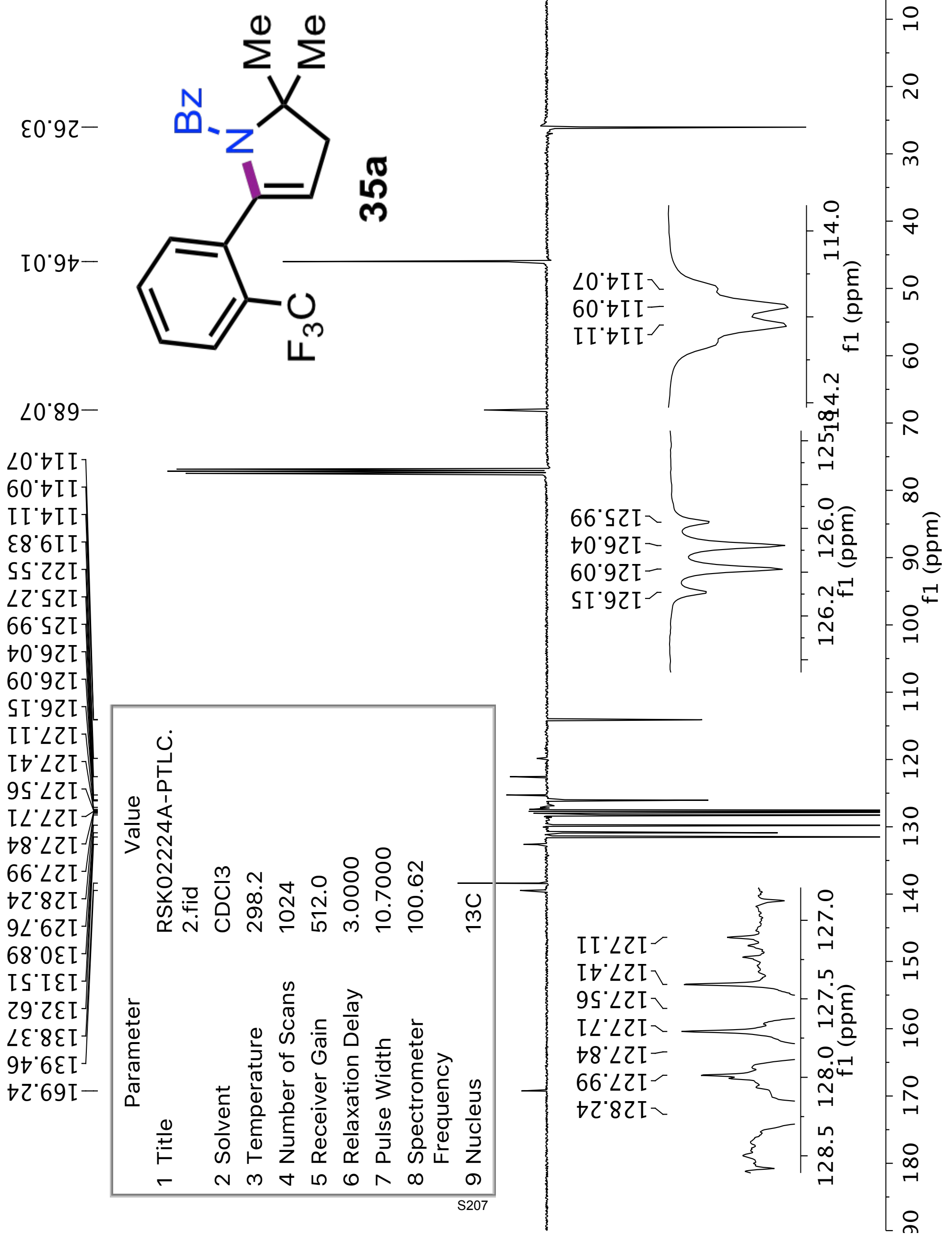




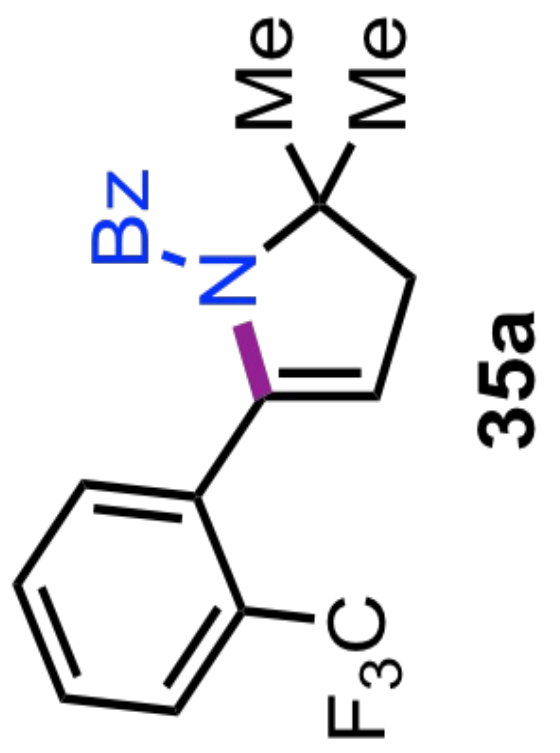

$8 t^{\circ} 8 s--$

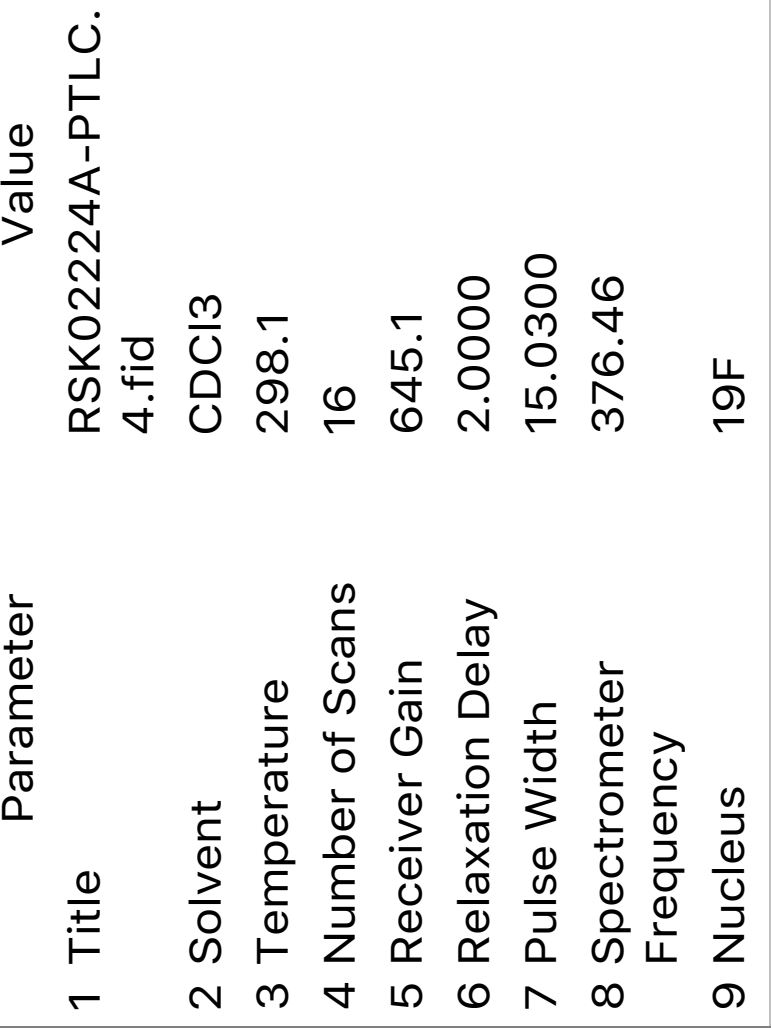

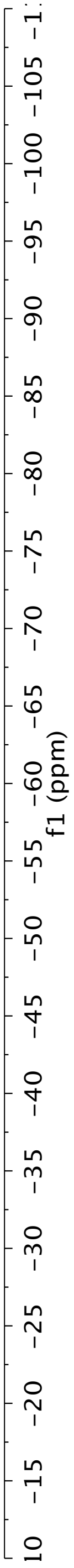




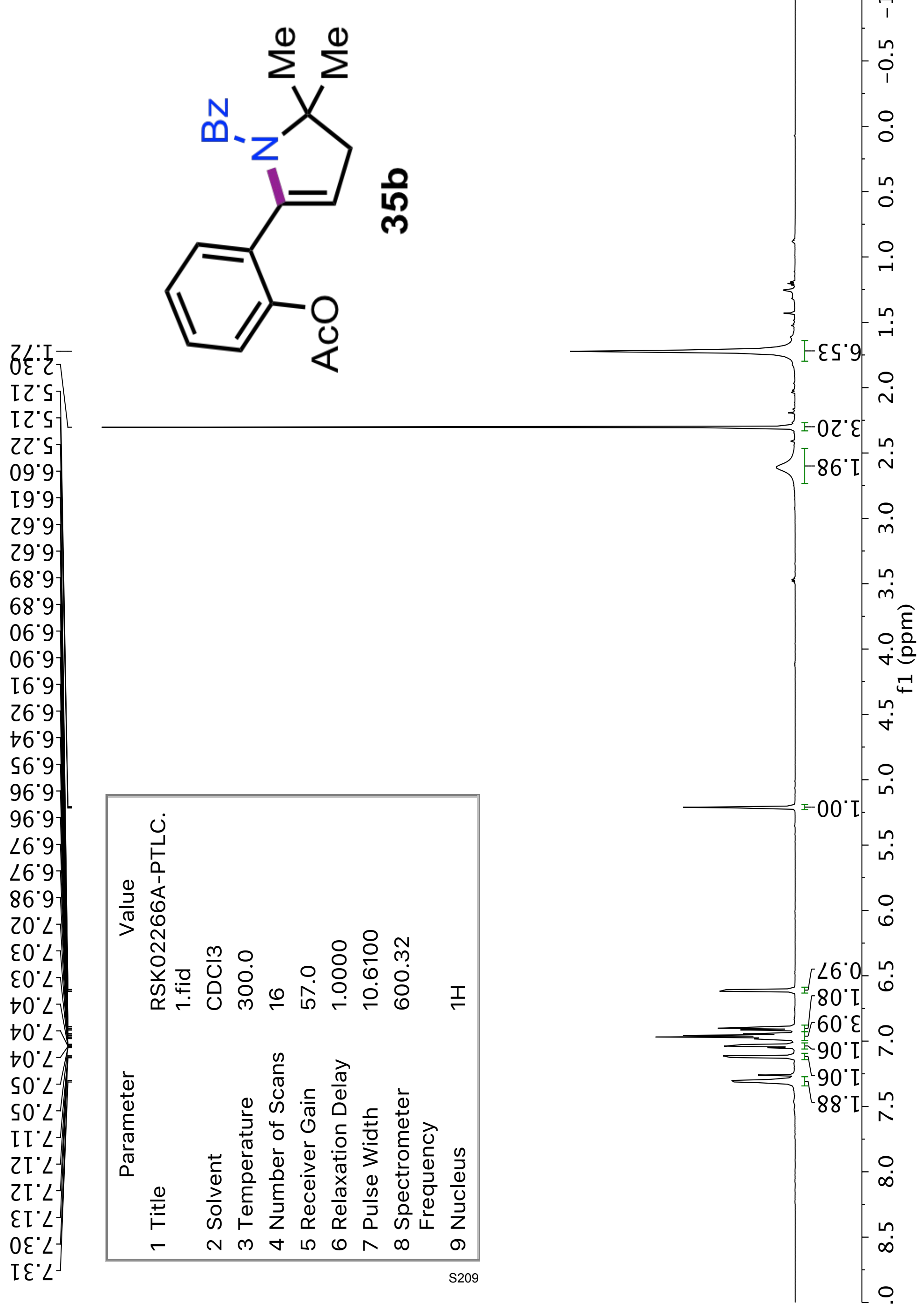


IE' IZ-

80.92-

$t Z^{\prime} S t-$

$2789-$

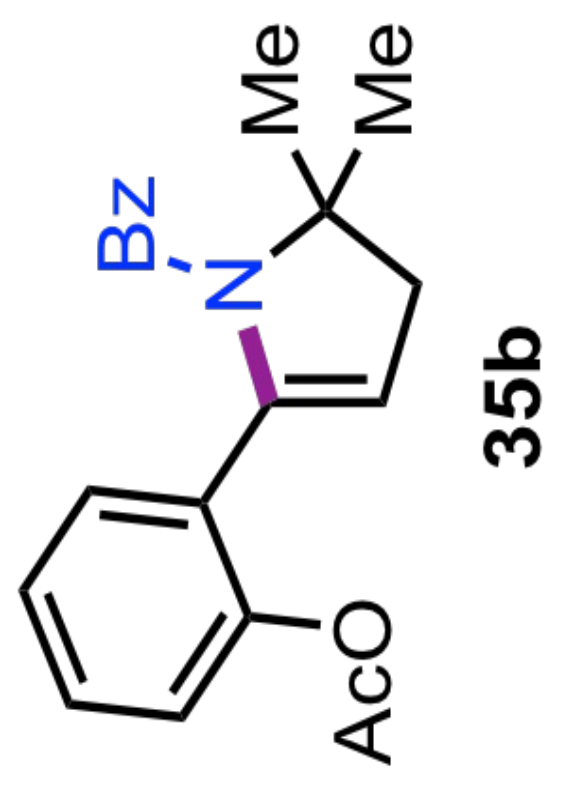

$0 L^{\prime} Z I I-$ $20.22 \mathrm{I}_{7}$ $8 \mathrm{~S}^{\circ} \mathrm{SZT}$. $\angle I^{\circ} \angle Z I Z$ $\forall \nabla^{\circ} \angle Z L^{\circ}$ $66.82 \mathrm{I}$ $00^{\circ} 62 \mathrm{I}$ $8 \mathrm{I}^{\circ} 0 \varepsilon \mathrm{I}$ $0 Z^{\circ} 0 \varepsilon \mathrm{I}$ $\angle \varepsilon^{\prime} \angle E\left[I^{-}\right.$ $\mathrm{ZL} 0 t \mathrm{I}]$ $\angle S^{\circ} 9 t{ }^{\circ}$ $\left.\begin{array}{l}\angle 88^{\circ} 89 \mathrm{I} \\ {[0.69 \mathrm{I}}\end{array}\right\}$
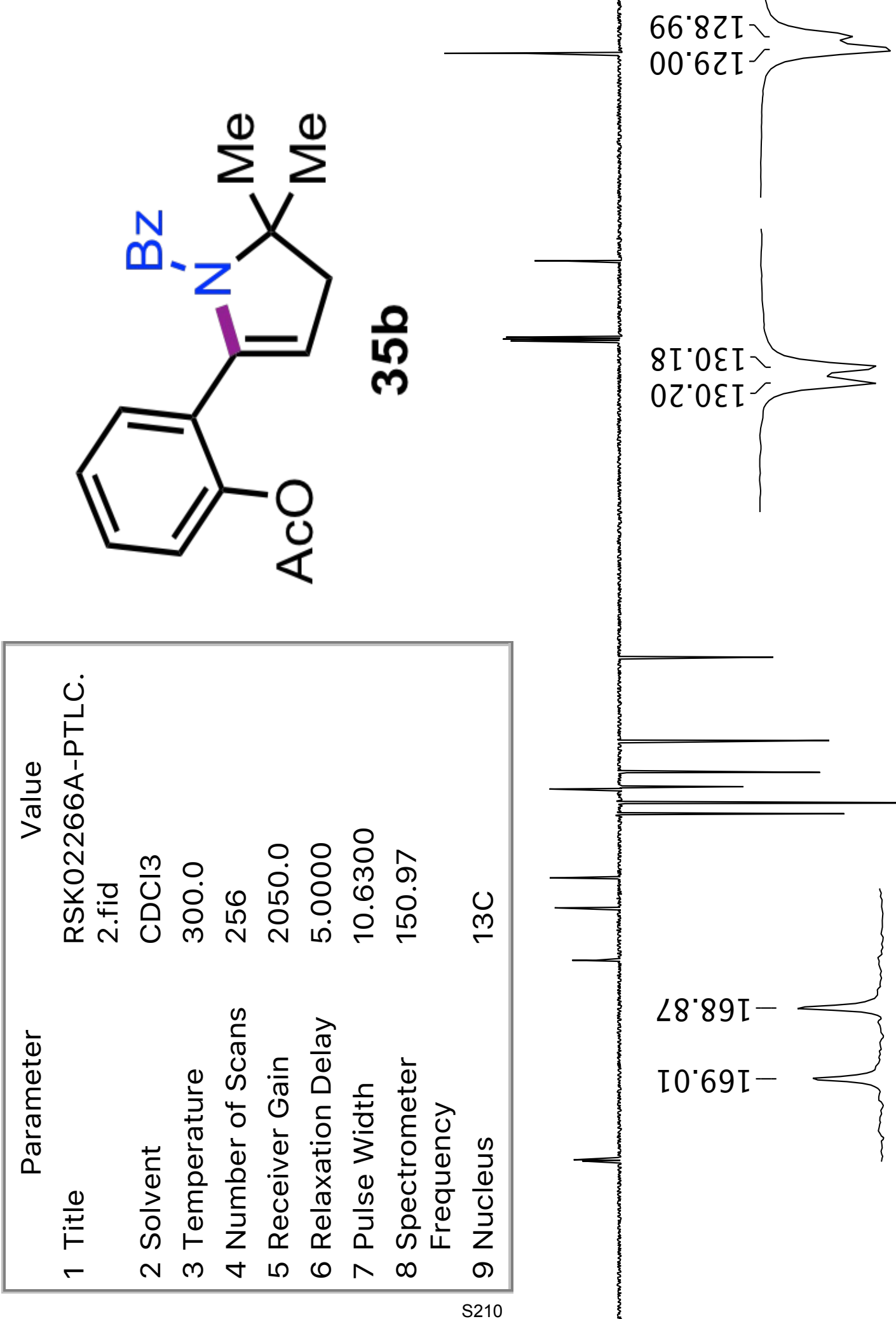
$00.62 \mathrm{I}^{-}$ 


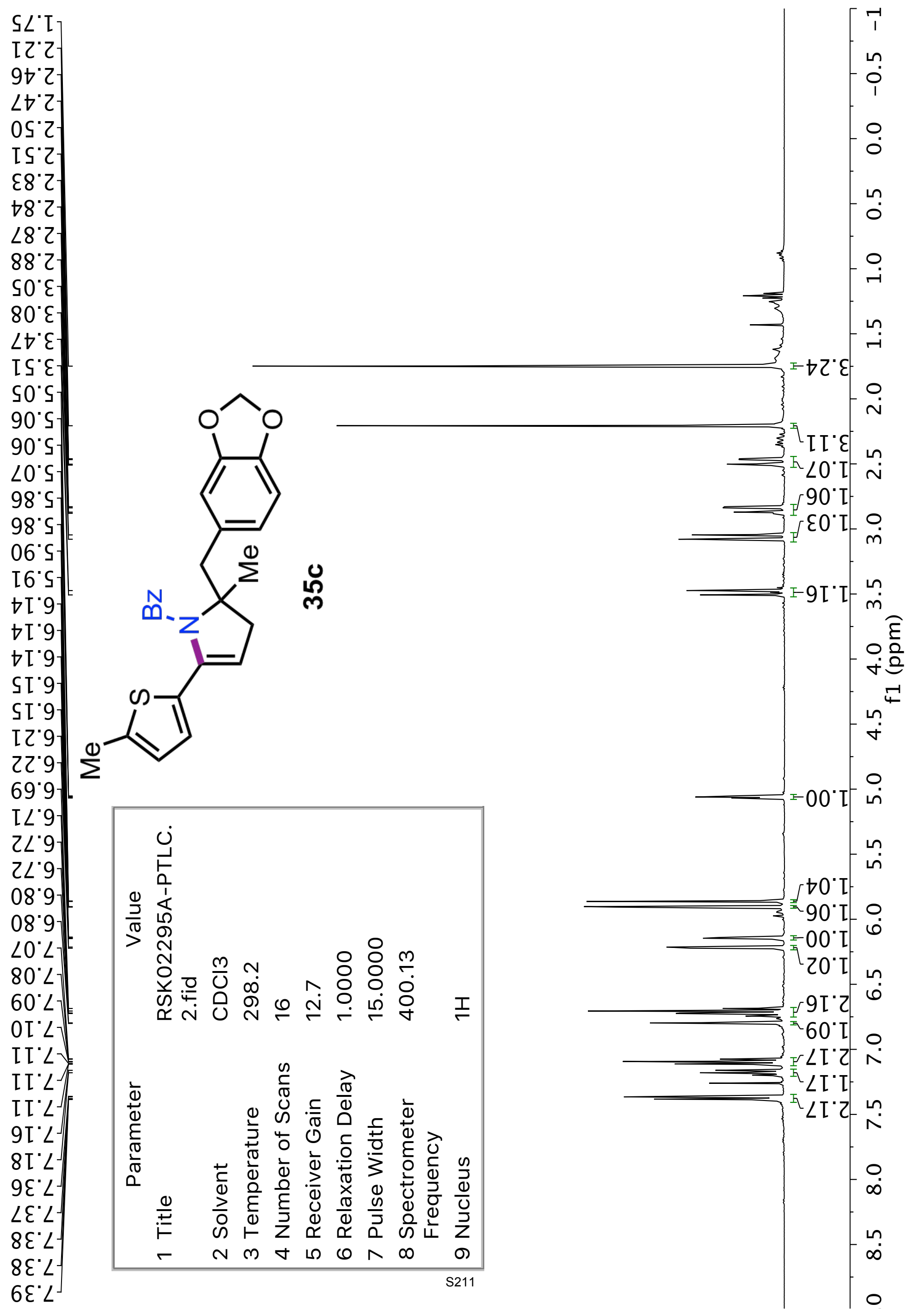




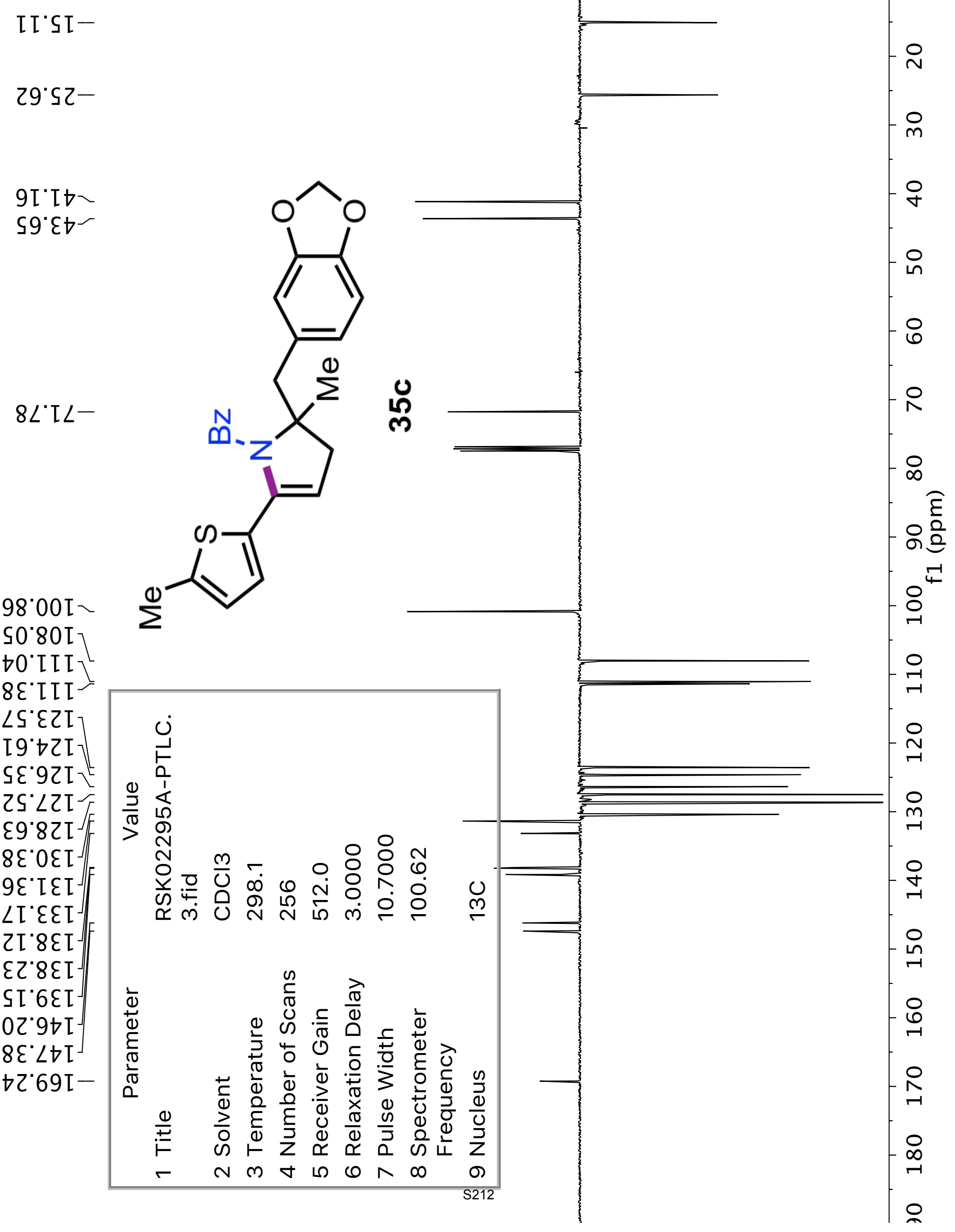

